

\section{STATUS PRAWNY OSÓB ŚWIADCZĄCYCH PRACĘ W RAMACH UMOWNEGO ZATRUDNIENIA NIETYPOWEGO}


留 


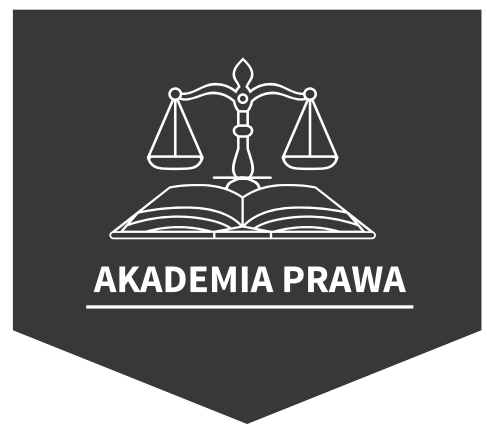

\section{STATUS PRAWNY \\ OSÓB ŚWIADCZACYCH PRACE \\ W RAMACH}

UMOWNEGO ZATRUDNIENIA NIETYPOWEGO

— Izabela Florczak - 
Izabela Florczak - Uniwersytet Łódzki, Wydział Prawa i Administracji

Katedra Prawa Ubezpieczeń Społecznych i Polityki Społecznej

90-033 Łódź, ul. Stefana Kopcińskiego 8/12

\author{
RECENZENT \\ Jakub Selina \\ REDAKTOR INICJUJĄCY \\ Monika Borowczyk \\ OPRACOWANIE REDAKCYJNE \\ Hanna Opala \\ SKŁAD I ŁAMANIE \\ Munda - Maciej Torz \\ PROJEKT OKŁADKI \\ Katarzyna Turkowska
}

Zdjęcie wykorzystane na okładce: @ Depositphotos.com/nevarpp

Stan prawny na dzień: 15 stycznia 2017 r.

(C) Copyright by Izabela Florczak, Łódź 2017

(c) Copyright for this edition by Uniwersytet Łódzki, Łódź 2017

\author{
Wydane przez Wydawnictwo Uniwersytetu Łódzkiego \\ Wydanie I. W.07934.17.0.M
}

Ark. wyd. 20,7; ark. druk. 19,75

ISBN 978-83-8088-657-5

e-ISBN 978-83-8088-658-2

https://doi.org/10.18778/8088-657-5

Wydawnictwo Uniwersytetu Łódzkiego

90-131 Łódź, ul. Lindleya 8

www.wydawnictwo.uni.lodz.pl

e-mail: ksiegarnia@uni.lodz.pl

tel. (42) 6655863 
Pamięci Taty dedykuje 



\section{Spis treści}

Wykaz skrótów $\quad 11$

$\begin{array}{ll}\text { Wstęp } & 13\end{array}$

ROZDZIAt I

Zatrudnienie typowe i umowne zatrudnienie nietypowe

1.1. Zatrudnienie typowe i umowne zatrudnienie nietypowe - uwagi terminologiczne 17

1.2. Rodzaje umownego zatrudnienia nietypowego 24

1.2.1. Uwagi wprowadzające $\quad 24$

1.2.2. Pracownicze umowne zatrudnienie nietypowe $\quad 25$

1.2.2.1. Umowa o pracę na czas określony 26

1.2.2.2. Umowa o pracę na czas wykonania określonej pracy, umowa o pracę w celu zastępstwa, umowa o pracę na okres próbny 32

1.2.2.3. Nietypowość miejsca świadczenia pracy. Zatrudnienie $w$ formie organizacyjnej telepracy 34

$\begin{array}{ll}\text { 1.2.2.4. Praca tymczasowa } & 38\end{array}$

1.2.3. Cywilnoprawne umowne zatrudnienie nietypowe 41

1.2.3.1. Umowa o pracę nakładczą 42

1.2.3.2. Zlecenie $\quad 43$

1.2.3.3. Umowa agencyjna $\quad 46$

1.2.3.4. Umowa o dzieło $\quad 47$

1.2.3.5. Umowy cywilnoprawne w zatrudnieniu tymczasowym 47

1.2.4. Podsumowanie 48

1.3. Prawne ograniczenia stosowania umownego zatrudnienia nietypowego 51

1.3.1. Uwagi wprowadzające 51

1.3.2. Prawne ograniczenia stosowania pracowniczego umownego zatrudnienia nietypowego 53

1.3.3. Prawne ograniczenia stosowania cywilnoprawnego umownego zatrudnienia $\begin{array}{ll}\text { nietypowego } & 61\end{array}$

$\begin{array}{ll}\text { 1.3.4. Podsumowanie } & 69\end{array}$ 
ROZDZIAt II

\section{Status prawny kandydatów do pracy w fazie nawiązywania stosunków umownego zatrudnienia nietypowego}

2.1. Wprowadzenie

2.2. Swoboda wyboru i kształtowania podstawy prawnej umownego zatrudnienia nietypowego

2.2.1. Uwagi wprowadzające

2.2.2. Zasada swobody umów jako wyznacznik wyboru i kształtowania umownego zatrudnienia nietypowego

2.2.3. Granice zasady swobody umów jako ograniczenia wyboru i kształtowania umownego zatrudnienia nietypowego

2.2.4. Treść i forma umowy mającej za przedmiot zatrudnienie nietypowe

2.3. Status prawny kandydatów przyjmowanych do pracy w ramach umownego zatrudnienia nietypowego

2.3.1. Uwagi wprowadzające

2.3.2. Ochrona danych osobowych kandydatów do pracy

2.3.3. Warunki dopuszczenia do pracy świadczonej w ramach umownego zatrudnienia nietypowego

2.3.4. Ochrona kandydatów do pracy przed dyskryminacją

\section{ROZDZIAt III}

\section{Status prawny osób świadczących pracę w ramach umownego} zatrudnienia nietypowego $\mathrm{w}$ okresie realizacji stosunku prawnego

\section{5}

3.1. Wprowadzenie

3.2. Status prawny osób świadczących pracę w ramach umownego zatrudnienia nietypowego wynikający z ich obowiązków

3.3. Status prawny osób świadczących pracę w ramach umownego zatrudnienia nietypowego wynikający z ich uprawnień

3.4. Odpowiedzialność stron umownego zatrudnienia nietypowego

3.4.1. Uwagi wprowadzające

3.4.2. Odpowiedzialność osób świadczących pracę w ramach umownego zatrudnienia nietypowego

3.4.3. Odpowiedzialność podmiotów zatrudniających za wykroczenia i przestępstwa związane ze stosunkiem umownego zatrudnienia nietypowego

3.5. Ubezpieczenia społeczne i ubezpieczenie zdrowotne osób świadczących pracę w ramach umownego zatrudnienia nietypowego

3.5.1. Uwagi wprowadzające

3.5.2. Podlegania ubezpieczeniom społecznym

3.5.3. Podleganie ubezpieczeniu zdrowotnemu 
ROZDZIAt IV

Status prawny osób świadczących pracę w ramach umownego zatrudnienia nietypowego w zakresie zbiorowych stosunków zatrudnienia

4.1. Wprowadzenie 209

4.2. Prawo do zrzeszania się w związkach zawodowych 210

4.3. Prawo do zawierania układów zbiorowych pracy i podleganie ich postanowieniom $\quad 218$

4.4. Prawo do uczestnictwa w zarządzaniu przedsiębiorstwem 226

4.5. Podsumowanie $\quad 230$

ROZDZIAt V

Status prawny osób świadczących pracę w ramach umownego zatrudnienia nietypowego $w$ fazie ustania stosunku prawnego

5.1. Wprowadzenie

5.2. Rozwiązanie nietypowego umownego stosunku zatrudnienia

5.3. Uprawnienia osób świadczących pracę nietypowo w przypadku wadliwego rozwiązania umowy

5.4. Szczególne uprawnienia i obowiązki osób zatrudnionych nietypowo związane z zakończeniem stosunku prawnego

5.5. Podsumowanie

Zakończenie

Bibliografia 



\section{Wykaz skrótów}

bhp

dyrektywa agencyjna

\section{EKS}

k.c.

k.k.

k.p.

k.p.c.

k.p.w.

k.w.

MOP

nowelizacja czerwcowa z 2015 r.

OSNC

OSNP

PIP

rozporządzenie w sprawie dokumentacji pracowniczej
- bezpieczeństwo i higiena pracy

- Dyrektywa Rady nr 86/653/EWG z dnia 18 grudnia 1986 r. w sprawie koordynacji ustawodawstw Państw Członkowskich odnoszących się do przedstawicieli handlowych działających na własny rachunek, Dz.U.EWG. L 382 z dnia 31 grudnia 1986, s. 17-21

- Europejska Karta Społeczna sporządzona w Turynie, 18 października 1961 r., Dz.U. z 1999 r., Nr 8, poz. 67 ze zm.

- Ustawa z dnia 23 kwietnia 1964 r. Kodeks cywilny, Dz.U. z 2016 r., poz. 380 - t.j. ze zm.

- Ustawa z dnia 6 czerwca 1997 r. Kodeks karny, Dz.U. z 2016 r., poz. 1137 - t.j.

- Ustawa z dnia 26 czerwca 1974 r. Kodeks pracy, Dz.U. z 2016 r., poz. 1666 - t.j.

- Ustawa z dnia 17 listopada 1964 r. Kodeks postępowania cywilnego, Dz.U. z 2016 r., poz. 1822 - t.j. ze zm.

- Ustawa z dnia 24 sierpnia 2001 r. Kodeks postępowania w sprawach o wykroczenia, Dz.U. z 2016 r., poz. 1713 - t.j.

- Ustawa z dnia 20 maja 1971 r. Kodeks wykroczeń, Dz.U. z 2015 r., poz. 1094 - t.j. ze zm.

- Międzynarodowa Organizacja Pracy

- Ustawa z dnia 25 czerwca 2015 r. o zmianie ustawy Kodeks pracy oraz niektórych innych ustaw, Dz.U. z 2015 r., poz. 1220

- Orzecznictwo Sądu Najwyższego. Izba Cywilna

- Orzecznictwo Sądu Najwyższego. Izba Pracy, Ubezpieczeń Społecznych i Spraw Publicznych

- Państwowa Inspekcja Pracy

- Rozporządzenie z dnia 28 maja 1996 r. w sprawie zakresu prowadzenia przez pracodawców dokumentacji w sprawach związanych ze stosunkiem pracy oraz sposobu prowadzenia akt osobowych pracownika, Dz.U. Nr 62, poz. 286 ze zm. 
rozp.pr.nakład.

TK

TSUE

u.e.r.z.

u.ik.

u.o.d.o.

u.s.u.s.

u.ś.z.f.ś.p.

u.u.s.w.p.

u.zw.grup.

u.Z.Z.

z.p.t.

$\mathrm{zd}$.
- Rozporządzenie z dnia 31 grudnia 1975 r. w sprawie uprawnień pracowniczych osób wykonujących pracę nakładczą, Dz.U. z 1976 r., Nr 3, poz. 19 ze zm.

- Trybunał Konstytucyjny

- Trybunał Sprawiedliwości Unii Europejskiej

- Ustawa z dnia 5 kwietnia 2002 r. o europejskich radach zakładowych, Dz.U. z 2012 r., poz. 1146 - t.j.

- Ustawa z dnia 7 kwietnia 2006 r. o informowaniu pracowników i przeprowadzaniu z nimi konsultacji, Dz.U. z 2006 r., $\mathrm{Nr} 79$, poz. 550 ze zm.

- Ustawa z dnia 29 sierpnia 1997 r. o ochronie danych osobowych, Dz.U. z 2016 r., poz. 922 - t.j.

- Ustawa z dnia 13 października 1998 r. o systemie ubezpieczeń społecznych, Dz.U. z 2016 r., poz. 963 - t.j. ze zm.

- Ustawa z dnia z dnia 27 sierpnia 2004 r. o świadczeniach z opieki zdrowotnej finansowanych ze środków publicznych, Dz.U. z 2016 r., poz. 1793 - t.j. ze zm.

- Ustawa z dnia 30 października 2002 r. o ubezpieczeniu społecznym z tytułu wypadków przy pracy i chorób zawodowych, Dz.U. z 2015 r., poz. 1242 - t.j. ze zm.

- Ustawa z dnia 13 marca 2003 r. o szczególnych zasadach rozwiązywania $\mathrm{z}$ pracownikami stosunków pracy z przyczyn niedotyczących pracowników, Dz.U. z 2016 r., poz. 1474 - t.j.

- Ustawa z dnia 23 maja 1991 r. o związkach zawodowych, Dz.U. z 2015 r., poz. 1881 - t.j.

- Ustawa z dnia 9 lipca 2003 r. o zatrudnianiu pracowników tymczasowych, Dz.U. z 2016 r., poz. 360 - t.j.

- zdanie 


\section{Wstęp}

Pojęcie „zatrudnienie nietypowe” nie jest prawnie zdefiniowane. Termin ten pochodzi z języka prawniczego i jest definiowany w piśmiennictwie a contrario do "zatrudnienia typowego". Wypracowany przez doktrynę prawa pracy model zatrudnienia typowego (umowa o pracę na czas nieokreślony, na podstawie której praca świadczona jest w pełnym wymiarze czasu pracy, w siedzibie pracodawcy i na jego rzecz) jest prezentowany w piśmiennictwie w sposób względnie jednolity. Powyższa definicja została przyjęta za punkt odniesienia w prowadzonych rozważaniach.

Punktem wyjścia dla istniejących opracowań dotyczących zagadnień zbieżnych z omawianymi w tej książce jest, w przeważającej części przypadków, założenie o konieczności dążenia do wzrostu roli zatrudnienia typowego. To przekonanie w konsekwencji prowadzi do wniosku o zasadności postulatu standaryzacji statusu prawnego ${ }^{1}$ wszystkich osób zatrudnionych, celem wypełnienia założeń sprawiedliwości społecznej. Miałoby to nastąpić poprzez zapewnienie wszystkim osobom świadczącym pracę uprawnień zarezerwowanych obecnie dla osób zatrudnionych typowo. Postulat ten realizowałoby stworzenie jednolitego prawa zatrudnienia $^{2}$ albo objęcie regulacjami właściwymi dla zatrudnienia typowego każdej pracy ludzkiej ${ }^{3}$. W tym kontekście wskazane wydaje się systemowe przedstawienie statusu prawnego osób świadczących pracę w ramach umownego zatrudnienia nietypowego. Taka analiza umożliwi określenie obszarów normatywnych wymagających ingerencji ustawodawcy celem unifikacji bądź tylko zbliżenia uregulowań prawnych kreujących status prawny wszystkich osób zatrudnionych $\mathrm{w}$ ramach zatrudnienia umownego (typowego i nietypowego). Mogłoby to na-

1 Pojęcie „status prawny” obejmuje w tym kontekście ogół przysługujących osobom zatrudnionym praw i ciążących na nich obowiązków ujmowanych w kontekście ogólnego otoczenia prawnego.

2 M. Gersdorf, Prawo zatrudnienia, Warszawa 2013, s. 169 i nast.

3 A.M. Świątkowski, Przedmiot stosunku pracy. Rozważania de lege lata $i$ de lege ferenda, [w:] L. Florek, Ł. Pisarczyk (red.), Wspótczesne problemy prawa pracy i ubezpieczeń społecznych. XVIII Zjazd Katedr i Zakładów Prawa Pracy i Ubezpieczeń Społecznych, Warszawa 2011, s. 48. 
stąpić poprzez wprowadzanie wspólnych standardów. Prowadzone rozważania pozwolą również dokonać oceny aktualności i zasadności unormowań różnicujących status prawny osób świadczących pracę.

W przeprowadzonych analizach przyjęte zostało założenie o potrzebie współistnienia różnych modeli zatrudnienia, co nie stoi na przeszkodzie, by dokonać krytycznej oceny niektórych obowiązujących konstrukcji prawnych, które różnicują status prawny osób świadczących pracę w ramach zatrudnienia umownego. Konieczność funkcjonowania w obrocie prawnym odmiennych modeli zatrudnienia może być uzasadniana uelastycznianiem prawa związanego $\mathrm{z}$ zatrudnieniem ${ }^{4}$. Powyższe stwierdzenie nie wyłącza podstaw do formułowania postulatów o racjonalności częściowej unifikacji statusu prawnego osób świadczących pracę poprzez zapewnienie im niezbędnego bezpieczeństwa socjalne$\mathrm{go}^{5}$. W związku $\mathrm{z}$ toczącym się $\mathrm{w}$ nauce prawa pracy dyskursem należy zatem odpowiedzieć na pytanie, czy społeczno-gospodarcze cele wyodrębnienia poszczególnych podstaw prawnych i form organizacyjnych umownego zatrudnienia nietypowego, istniejące na gruncie normatywnym, $w$ chwili dokonywania tego wyodrębnienia pozostają aktualne. To z kolei pozwoli określić, czy status prawny osób świadczących pracę spełnia obecnie te cele i czy powinien on być od nich uzależniany czy może, dla zapewnienia wszystkim jednakowych warunków zatrudnienia, należy dokonać jego ujednolicenia. Wydaje się, że konieczne jest obowiązywanie w systemie prawnym podstaw prawnych i form organizacyjnych umownego zatrudnienia, odpowiadających różnym celom społecznym i gospodarczym oraz w sposób zróżnicowany kreujących status prawny osób świadczących pracę. Umożliwia to stronom stosunku zatrudnienia dokonywanie wyboru o charakterze realnym ${ }^{6}$. Kompleksowe przedstawienie sytuacji prawnej osób zatrudnionych pozwoli dostrzec różnice w tym zakresie, uwarunkowane założeniami konstrukcyjnymi poszczególnych rodzajów umownego zatrudnienia nietypowego.

Przedmiotem monografii jest analiza prawnego zróżnicowania stosunków zatrudnienia, prowadząca do odmienności w sytuacji prawnej osób świadczących pracę na podstawie nietypowych stosunków umownych. Nie będą zatem poddane analizie pozaumowne stosunki zatrudnienia (powołanie, mianowanie, wybór oraz spółdzielcza umowa o pracę), gdyż o możliwości ich nawiązania przesądzają określone ustawowo okoliczności, nie zaś podmioty zatrudnienia.

4 A. Sobczyk, Różnicowanie praw (ochrony) zatrudnionych - wybrane kryteria i ich ocena, [w:] M. Bosak (red.), Funkcja ochronna prawa pracy a wyzwania wspótczesności, Warszawa 2014, s. 5.

5 U. Torbus, Ochrona pracowników w elastycznych formach zatrudnienia jako warunek stabilizacji w stosunkach pracy, [w:] M. Bosak (red.), op. cit., s. 56.

6 Zbytnie ujednolicenie statusu prawnego osób świadczących pracę mogłoby spowodować, że wybór ten byłby iluzoryczny, bowiem pomimo różnych organizacyjnych warunków świadczenia pracy status prawny wszystkich osób zatrudnionych byłby jednakowy. 
Punktem wyjścia dla zawartych w opracowaniu rozważań jest model sytuacji prawnej osoby zatrudnionej $w$ ramach zatrudnienia typowego. Odniesienie to jest czynione nie ze względu na powszechność zatrudnienia typowego, której istnienia nie przesądzam ${ }^{7}$, ale ze względu na systemowe wyodrębnienie. Zatrudnienie typowe jest zawsze odnośnikiem przy definiowaniu i opisywaniu różniących się od niego konstrukcji prawnych, których przedmiotem jest praca ludzka. Prowadzone analizy skupią się na przedstawieniu statusu prawnego osób świadczących pracę $\mathrm{w}$ ramach umownego zatrudnienia nietypowego, czyli na podstawie różnych rodzajów umów o pracę, w tym w organizacyjnej formie zatrudnienia pracowniczego, jaką jest telepraca. Obejmą one również szczególną, trójpodmiotową konstrukcję - pracę tymczasową oraz zatrudnienie cywilnoprawne. W obrębie zatrudnienia cywilnoprawnego omówiona zostanie sytuacja prawna osób zatrudnionych na podstawie umów o pracę nakładczą, umów zlecenia i umów o świadczenie usług, do których stosuje się przepisy o zleceniu, umów agencyjnych oraz umów o dzieło. Zasadność omówienia pozapracowniczych umownych podstaw prawnych zatrudnienia wynika z normatywnego zbliżenia do pracowniczego statusu prawnego osób świadczących pracę ${ }^{8}$. Co więcej, istniejące w tym zakresie różnice muszą zostać poddane analizie prawnej i ocenie zasadności obowiązywania.

Niniejsze opracowanie stanowi nieznacznie zmienioną wersję rozprawy doktorskiej obronionej na Wydziale Prawa i Administracji Uniwersytetu Łódzkiego w czerwcu 2016 r. Pragnę podziękować wszystkim, którzy przyczynili się do jej powstania. W sposób szczególny dziękuję mojemu Promotorowi, dr. hab. Mirosławowi Włodarczykowi, prof. nadzw. UŁ oraz Promotorowi Pomocniczemu - dr Magdalenie Paluszkiewicz. Za cenne uwagi dziękuję Recenzentom - dr hab. Monice Lewandowicz-Machnikowskiej i dr. hab. Krzysztofowi Walczakowi oraz Profesorom z Katedry Prawa Pracy Uniwersytetu Łódzkiego - dr hab. Teresie Wyce, prof. nadzw. UŁ i prof. zw. dr. hab. Zbigniewowi Góralowi. Za ogromne wsparcie dziękuję Mamie i Błażejowi.

Monografia uwzględnia stan prawny obowiązujący w chwili złożenia jej do druku, czyli w styczniu 2017 r.

7 Literatura z zakresu statystyki stosunków zatrudnienia wskazuje na spadek zainteresowania zatrudnieniem typowym. A. Kiersztyn, Prekariat i postawy obywatelskie Polaków, „Polityka Społeczna” 2004, nr 4, s. 13; Ł. Arendt, Wykorzystanie umów terminowych w Polsce w kontekście skutków światowego kryzysu gospodarczego, „Polityka Społeczna” 2014, nr 9, s. 12 i 14.

8 K.W. Baran, O systematyce i delimitacji niepracowniczych stosunków zatrudnienia. Z zagadnień prawa pracy i prawa socjalnego; Z. Kubot, T. Kuczyński (red.), Księga jubileuszowa Profesora Herberta Szurgacza, Warszawa 2011, s. 30 i literatura tam wskazana. 



\section{ROZDZIAt I \\ Zatrudnienie typowe i umowne zatrudnienie nietypowe}

\subsection{Zatrudnienie typowe i umowne zatrudnienie nietypowe - uwagi terminologiczne}

Celem prowadzenia rozważań stanowiących przedmiot niniejszego opracowania, czyli zagadnień dotyczących statusu prawnego osób świadczących pracę $\mathrm{w}$ ramach umownego zatrudnienia nietypowego, niezbędne jest wskazanie różnic pomiędzy stanowiącym punkt odniesienia $\mathrm{w}$ prowadzonej analizie zatrudnieniem typowym a umownym zatrudnieniem nietypowym. W związku z powyższym analizę rozpocząć należy od uwag o charakterze terminologicznym i pojęciowym.

Mianem zatrudnienia typowego określa się w literaturze zatrudnienie na podstawie umowy o pracę na czas nieokreślony, w wyniku zawarcia której praca świadczona jest w pełnym wymiarze czasu pracy, w pomieszczeniach pracodawcy i na jego rzecz ${ }^{1}$. W kontekście coraz częściej pojawiającego się poglądu, jakoby zatrudnienie dotąd uważane za typowe straciło swój charakter i w związku z tym wymagało nowej interpretacji², uznać należy, że w tym znaczeniu „typowość” nie

1 Z. Kubot, Szczególne formy zatrudnienia i samozatrudnienia, [w:] Z. Kubot (red.), Szczególne formy zatrudnienia, Wrocław 2000, s. 6; D. Makowski, Rozwój nietypowych form zatrudnienia w prawie państw Unii Europejskiej, [w:] H. Lewandowski, J. Sokołowski (red.), Pracodawcapracownik w procesie przemian gospodarki polskiej i integracji z Uniq Europejska, Łódź 2000, s. 71; A. Patulski, Koncepcja flexicurity a nietypowe formy zatrudnienia, czyli jak ograniczyć segmentyzację polskiego rynku pracy, [w:] A. Sobczyk (red.), Stosunki zatrudnienia w dwudziestoleciu spotecznej gospodarki rynkowej, Warszawa 2010, s. 361; J. Wratny, Przemiany stosunku pracy w III RP, „Praca i Zabezpieczenie Społeczne” 2012, nr 5, s. 4; J. Jończyk, Rodzaje i formy zatrudnienia, „Praca i Zabezpieczenie Społeczne” 2012, nr 6, s. 2. Typowość umowy o pracę na czas nieokreślony potwierdzona jest również w prawie unijnym. Por. B. Wagner, Niektóre elementy regulacji stosunku pracy w projekcie kodeksu pracy, „Praca i Zabezpieczenie Społeczne" 2008, nr 9, s. 7.

2 Z. Góral, Najnowsze tendencje w polskim prawie pracy na tle integracji europejskiej, „Prace Naukowe Wydziału Administracji. Szkoła Wyższa im. Pawła Włodkowica w Płocku. Zeszyty Naukowe" 2003, nr 26, s. 214; J. Wratny, Przemiany..., s. 5. 
implikuje „powszechności”. Stanowi ona jednak pewien punkt odniesienia ${ }^{3}$. Fakt coraz rzadszego zawierania stosunków prawnych kwalifikowanych jako „zatrudnienie typowe”, nazywane również „zatrudnieniem klasycznym”, nie przesądza o utracie typowego charakteru zatrudnienia przez umowę o pracę zawartą na czas nieokreślony, która obliguje pracownika do pracy w pełnym wymiarze czasu pracy, w pomieszczeniach pracodawcy i na jego rzecz. Typowość jest bowiem jedynie wyznacznikiem punktu odniesienia do prowadzonych analiz. Określenie cech zatrudnienia typowego pozwala w sposób negatywny wyodrębnić zatrudnienie nietypowe. Zatrudnienie nieposiadające wszystkich cech zatrudnienia typowego jest bowiem zatrudnieniem nietypowym.

Umowne zatrudnienie nietypowe należy podzielić na zatrudnienie $\mathrm{w}$ ramach stosunku pracy i poza nim. Do umownego zatrudnienia nietypowego poza stosunkiem pracy zaliczane są cywilnoprawne podstawy świadczenia pracy, w szczególności umowa o pracę nakładczą, zlecenie i umowy o świadczenie usług, do których stosuje się przepisy o zleceniu, umowa agencyjna i umowa o dzieło. Natomiast nietypowym umownym zatrudnieniem pracowniczym, a contrario do przedstawionych cech zatrudnienia typowego, będzie każde zatrudnienie powstałe na podstawie innej umowy niż umowa o pracę na czas nieokreślony, zobowiązująca pracownika do pracy w pełnym wymiarze czasu pracy, w siedzibie pracodawcy i na jego rzecz. Pracowniczym umownym zatrudnieniem nietypowym będzie zatem również zatrudnienie tymczasowe kreowane przez złożoną konstrukcję podmiotową (w przeciwieństwie do dwupodmiotowej więzi pracownik-pracodawca) $)^{5}$. Trafny wydaje się zaproponowany przez D. Makowskiego podział nietypowych stosunków zatrudnienia pracowniczego na zatrudnienie, którego nietypowość wynika z czasu obowiązywania umowy, wymiaru czasu pracy, trójstronnego charakteru zatrudnienia oraz miejsca wykonywania pracy ${ }^{6}$. Ostatnie kryterium pozwala uznać za pracownicze zatrudnienie nietypowe również formę organizacyjną zatrudnienia, jaką jest telepraca.

Powstanie i rozwój pracowniczego zatrudnienia nietypowego są postrzegane dwojako $^{7}$ - albo jako przejaw rozwoju prawa pracy stanowiący konsekwencję jego

3 B. Wagner, Terminowe umowy o pracę, Warszawa 1980, s. 89.

4 L. Mitrus, Kilka uwag o rozwiqzaniu za wypowiedzeniem umowy o pracę na czas określony, [w:] A. Sobczyk (red.), Stosunki zatrudnienia..., s. 247; J. Wratny, Przemiany..., s. 4.

5 D. Makowski, Rozwój..., s. 71. B. Wagner jako pracę nietypową, a contrario do pojęcia pracy typowej, uważa stosunki pracy, w których nie występują wszystkie cechy typologiczne. Por. B. Wagner, Jednolitość, wielopostaciowość czy ewolucja funkcji ochronnej prawa pracy - zatrudnienie typowe versus tymczasowe, [w:] A. Sobczyk (red.), Z problematyki zatrudnienia tymczasowego, https://sip-1lex-1pl-1004153yx0674.han3.lib.uni.lodz.pl/\#/monografia/ 369236017/15, pkt 3 (dostęp: 19.09.2017).

6 D. Makowski, Rozwój..., s. 75.

7 Z. Góral, Najnowsze tendencje..., s. 209. 
liberalizacji ${ }^{8}$, albo jako początek jego schyłku. Zbigniew Hajn zauważa, że rozwój zatrudnienia nietypowego prowadzi do osłabienia zbiorowej ochrony interesów pracowniczych ${ }^{10}$. Wniosek taki należy poprzeć faktem, że więź pracownika z pracodawcą w stosunkach zatrudnienia nietypowego ma charakter luźniejszy aniżeli w stosunkach zatrudnienia typowego, co wpływa na mniejszą identyfikację pracownika z miejscem pracy ${ }^{11}$. To z kolei powoduje m.in. zmniejszenie współczynnika uzwiązkowienia pracowników. Niezależnie od postrzegania rozkwitu zatrudnienia nietypowego jako naturalnej konsekwencji rozwoju prawa pracy czy też jako początku jego końca ${ }^{12}$, zjawisko to uznać należy za fakt ${ }^{13}$, którego następstwa wpływają na status prawny osób zatrudnionych. Zatrudnienie typowe uważane jest coraz częściej za anachroniczne ${ }^{14} \mathrm{i}$ ekonomicznie niekorzystne dla podmiotów zatrudniających $\mathrm{z}$ uwagi na nadmierne uprzywilejowanie pracowników $^{15}$. Z tego też powodu coraz powszechniej wybierane jest zatrudnienie nietypowe. Zgodnie $\mathrm{z}$ danymi Eurostatu ${ }^{16} \mathrm{w}$ latach $2003-2006$ odsetek zawieranych w Polsce umów terminowych, badany wśród wszystkich zawieranych umów o pracę, wzrósł z 19,4\% do 28,4\%. Forma organizacyjna umownego zatrudnienia pracowniczego - telepraca - jest wykorzystywana coraz częściej, choć jej praktyczne zastosowanie nie przybiera znaczących rozmiarów. Raport Polskiej Agencji Rozwoju Przedsiębiorczości wykazał, że w 2010 r. zatrudnianie częściowe $\mathrm{w}$ formie telepracy, czyli łączenie przez pracownika pracy w zakładzie pracy i poza nim, deklarowało $9,7 \%$ badanych pracodawców, natomiast wykorzystywanie telepracy uwzględniającej pracę wyłącznie poza zakładem - 3,2\% przed-

8 L. Florek, Granice liberalizacji prawa pracy, [w:] E. Bielak, H. Lewandowski (red.), Granice liberalizacji prawa pracy. Problemy zabezpieczenia społecznego. Materiaty z XIV Zjazdu Katedr (Zakładów) Prawa Pracy i Ubezpieczeń Społecznych, Łódź 2003, s. 12-13.

9 I. Boruta, W sprawie przyszłości prawa pracy, „Praca i Zabezpieczenie Społeczne” 2003, nr 4, s. 9.

10 Z. Hajn, Aspekty prawne relacji: pracownik - pracodawca w procesie przemian społeczno-gospodarczych i integracji europejskiej, [w:] H. Lewandowski, J. Sokołowski (red.), op. cit., s. 21.

11 A. Patulski, Koncepcja flexicurity..., s. 359.

12 Ten argument znajduje uzasadnienie w odniesieniu do wzrostu ilości zawieranych umów cywilnoprawnych, których przedmiotem jest zatrudnienie. To bowiem one mogłyby zastąpić w obrocie gospodarczym umowne zatrudnienie pracownicze. Pozostałe podstawy zatrudnienia nietypowego systemowo przynależą do prawa pracy, więc ich stosowanie nie świadczy o jego schyłku, a raczej o rozwoju.

13 B. Wagner, O swobodzie umowy o pracę raz jeszcze, [w:] M. Matey-Tyrowicz, L. Nawacki, B. Wagner (red.), Prawo pracy a wyzwania XXI wieku. Księga Jubileuszowa Profesora Tadeusza Zielińskiego, Warszawa 2002, s. 359.

$14 \mathrm{Na}$ istnienie takiego poglądu wskazał Z. Góral, Najnowsze tendencje..., s. 214.

15 J. Wojtyła, Dylematy ochronnej funkcji prawa pracy w stosunkach prawnych zatrudnienia, [w:] M. Seweryński, J. Stelina (red.), Wolność i sprawiedliwość w zatrudnieniu. Księga pamiq̨tkowa poświęcona Prezydentowi Rzeczypospolitej Polskiej Profesorowi Lechowi Kaczyńskiemu, Gdańsk 2012, s. 386.

16 Komisja Europejska, www.ec.europa.eu/eurostat/tgm/table.do?tab=table\&init=1\&language= en\&pcode=tesem110\&plugin=1 (dostęp: 2.01 .2017 ). 
siębiorców ${ }^{17}$. Badania przeprowadzone w 2012 r. przez Konfederację Lewiatan dowiodły, że około $10 \%$ mikro, małych i średnich przedsiębiorstw korzysta $\mathrm{z}$ telepracownikó ${ }^{18}$. Wzrasta również współczynnik stosowania zatrudnienia tymczasowego. Ilość zawieranych umów o pracę tymczasową wzrosła z 206665 w 2005 r. (z czego 62\% stanowiły umowy o prace, a 38\% umowy cywilnoprawne) do 799727 w 2015 r. (odpowiednio 48\% i 52\%) ${ }^{19}$. Zgodnie z danymi GUS w grupie osób, które równolegle nie pozostawały w stosunku pracy, w 2012 r. zawarto 546700 umów o dzieło i zleceń. W roku 2014 szacunkowa liczba osób, z którymi zawarta została umowa zlecenia lub umowa o dzieło, a które nie były zatrudnione w ramach stosunku pracy, wynosiła 1,1 miliona $^{20}$. Przedstawione dane jednoznacznie potwierdzają wzrastający udział umownego zatrudnienia nietypowego w ogólnej liczbie zawieranych umów, których przedmiotem jest zatrudnienie.

Przyjęcie założenia o istnieniu w polskim porządku prawnym domniemania bezterminowej (typowej) umowy o pracę skutkowałoby uznaniem, że zatrudnienie nietypowe jest wyjątkiem od zasady zatrudniania $w$ ramach zatrudnienia typowego. W kwestii tej niejednokrotnie wypowiadał się Sąd Najwyższy ${ }^{21}$, podkreślając, że w przypadku braku ustalenia w umowie o pracę jej rodzaju, przyjąć należy, że strony zawarły umowę bezterminową. Wniosek taki wypływa jednak nie $\mathrm{z}$ istnienia domniemania zawarcia umowy bezterminowej, a z przyjęcia, że gdyby strony miały zamiar wskazać termin końcowy umowy, poczyniłyby w niej odpowiednie zastrzeżenie. Wobec braku takiego zastrzeżenia uznać należy, że strony nie miały woli zawarcia umowy terminowej. Również gdyby strony miały zamiar wskazania miejsca pracy innego niż typowe (siedziba pracodawcy), albo wymiaru czasu pracy innego niż typowy, tudzież gdyby miały wolę ukształtowania stosunku pracy w jeszcze inny, nietypowy sposób, wyraziłyby ją w umowie. Brak stosownych postanowień umownych skłania do przyjęcia założenia, że strony umowy o pracę miały wolę ukształtowania jej w sposób typowy, czyli jako

17 Enterprise Europe Network, www.een.org.pl/index.php/rynki-zagraniczne-archiwum/ page/15/articles/telepraca-w-polskich-przedsiebiorstwach---wyniki-badan.html?page= 15\&articles=telepraca-w-polskich-przedsiebiorstwach---wyniki-badan\&blind_style=1 (dostęp: 2.01.2017).

18 Konfederacja Lewiatan, www.konfederacjalewiatan.pl/aktualnosci/2012/1/telepraca_nadal _niedoceniana (dostęp: 2.01.2017).

19 Dane dostępne: Wortal Publicznych Służb Zatrudnienia, www.psz.praca.gov.pl/-/181744raport-z-dzialalnosci-agencji-zatrudnienia-w-2006r-; www.psz.praca.gov.pl/documents/ 10828/2740811/Informacja\%20Agencje\%20Zatrudnienia\%202015.pdf/c6875f91-7996460c-84ec-b89a5c80011b?t=1462354092891 (dostęp: 2.01.2017).

20 Rocznik Statystyczny Pracy 2012, http://stat.gov.pl/obszary-tematyczne/roczniki-statystyczne/ roczniki-statystyczne/rocznik-statystyczny-pracy-2012,7,3.html; Rocznik Statystyczny Pracy 2015, http://stat.gov.pl/obszary-tematyczne/roczniki-statystyczne/roczniki-statystyczne/ rocznik-statystyczny-pracy-2015,7,4.html (dostęp: 2.01.2017).

21 Uchwała Sądu Najwyższego z dnia 10 września 1976 r., I PZP 48/76, OSNC 1977, Nr 4, poz. 65; Uchwała Sądu Najwyższego z dnia 21 listopada 1978 r., I PZP 28/78, OSNC 1979, Nr 5, poz. 92. 
umowę na czas nieokreślony, na podstawie której praca świadczona jest w pełnym wymiarze czasu pracy, w siedzibie pracodawcy oraz na jego rzecz. Dlatego też zatrudnienia nietypowego, w tym umownego, nie można postrzegać jako wyjątku od zasady zatrudniania w ramach zatrudnienia typowego.

Nie sposób omówić relacji zatrudnienia typowego i nietypowego bez uwzględnienia prawodawstwa Międzynarodowej Organizacji Pracy oraz Unii Europejskiej. Międzynarodowa Organizacja Pracy nie definiuje pojęć „zatrudnienie nietypowe” i „zatrudnienie typowe”, jednakże w wielu swoich aktach dąży do ochrony zatrudnienia osób pracujących w obrębie stosunków uważanych za nietypowe. Przykładami takich aktów są: konwencja z 1933 r. nr 39 dotycząca obowiązkowego ubezpieczenia na wypadek śmierci pracowników najemnych, zatrudnionych w przedsiębiorstwach przemysłowych i handlowych, w wolnych zawodach, jak również chałupników i pracowników gospodarstw domowych ${ }^{22}$, konwencja z 1994 r. nr 175 dotycząca pracy w niepełnym wymiarze czasu²3, konwencja z 1996 r. nr 177 dotycząca domowej pracy nakładczej ${ }^{24}$, konwencja z 1997 r. nr 181 dotycząca prywatnych biur pośrednictwa pracy ${ }^{25}$, zalecenie z 1994 r. nr 182 dotyczące pracy w niepełnym wymiarze czasu pracy ${ }^{26}$, zalecenie z 1996 r. nr 184 dotyczące domowej pracy nakładczej ${ }^{27}$ oraz zalecenie z 2011 r. nr 201 dotyczące pracowników domowych ${ }^{28}$. Międzynarodowa Organizacja Pracy (dalej: MOP) podjęła także działania, których celem miało być przyjęcie konwencji dotyczącej zatrudnienia cywilnoprawnego. Rozpoczęte w latach 90. XX w. prace nie zostały ukończone, gdyż ostatecznie na Konferencji Ogólnej w 1998 r. propozycja uchwalenia konwencji została odrzucona ${ }^{29}$. Głównym celem projektodawców konwencji i równolegle $\mathrm{z}$ nią opracowanego zalecenia ${ }^{30}$ było przyznanie osobom pracującym poza stosunkiem pracy uprawnień zbliżonych do pracowniczych. Były to również pierwsze akty, w których MOP wskazywała na istnienie, obok zatrudnienia pracowniczego, konstrukcyjnie zbliżonych do niego podstaw zatrudnienia poza stosunkiem pracy. Niepowodzenie prac nad konwencją i zaleceniem należy łączyć z bierną postawą organizacji pracodawczych, niezainteresowanych wprowadzeniem unormowań nakładających dodatkowe obciążenia finansowe na podmioty zatrudniające ${ }^{31}$.

22 Ratyfikowany tekst polski: Dz.U. z 1949 r., Nr 31, poz. 231.

23 Nieratyfikowana przez Polskę, tekst dostępny: MOP, www.mop.pl/doc/html/konwencje/ k175.html (dostęp: 2.01.2017).

24 Nieratyfikowana przez Polskę, tekst dostępny w zbiorze „ILOLEX” MOP.

25 Ratyfikowany tekst polski: Dz.U. z 2008 r., Nr 222, poz. 1448.

26 Tekst dostępny w zbiorze „ILOLEX” MOP.

27 Tamże.

28 Tamże.

29 A. Musiała, Zatrudnienie niepracownicze, Warszawa 2011, s. 236-241.

30 Tekst projektów konwencji i zalecenia: International Labour Organization, www.ilo.org/ public/english/standards/relm/ilc/ilc86/rep-v.htm (dostęp: 2.01.2017).

31 A. Musiata, Zatrudnienie..., s. 241. 
Spośród aktów prawnych MOP na uwagę zasługuje jeszcze zalecenie nr 198 z dnia 15 czerwca 2006 r., dotyczące stosunku pracy ${ }^{32}$. Jest to zalecenie samoistne, nie uzupełnia bowiem żadnej konwencji ${ }^{33}$. Nadrzędnym jego celem jest określenie istotnych cech stosunku pracy, bez podawania jego prawnej definicji, jako więzi zatrudnienia gwarantującej przyznanie osobom pracującym najszerszej ochrony oraz najliczniejszych praw. Przepisy zalecenia mają na celu przeciwdziałanie ukrywaniu rzeczywistej więzi pracowniczej pod postacią zatrudnienia cywilnoprawnego. Zalecenie wymienia cechy świadczące o istnieniu zatrudnienia na podstawie stosunku pracy (art. 13).

Prawodawstwo Unii Europejskiej w poszczególnych aktach prawnych ${ }^{34}$ wyróżnia i częściowo reguluje cztery rodzaje zatrudnienia nietypowego ${ }^{35}$. Należą do nich: zatrudnienie terminowe, umowa o pracę w niepełnym wymiarze czasu pracy, praca tymczasowa oraz telepraca ${ }^{36}$. Wspólnym biegunem konstrukcyjnym tych regulacji jest wyznaczanie granic i warunków pracy w ramach zatrudnienia nietypowego. Dzięki temu nie tylko spełniane jest założenie promowania zatrudnienia typowego, ale również konieczność zapewnienia osobom pracującym w różnych realiach organizacyjnych zbliżonych warunków pracy w zakresie chociażby bezpieczeństwa i higieny pracy.

Ważnym punktem odniesienia dla rozważań dotyczących podziału zatrudnienia na typowe i nietypowe jest projekt kodeksu pracy ${ }^{37}$, opracowany przez Komisję Kodyfikacyjną Prawa Pracy ${ }^{38}$. Pomimo że do tej pory projekt (będący efektem kil-

32 Recommendation concerning the employment relationship, International Latour Organization, http://www.ilo.org/dyn/normlex/en/f?p=NORMLEXPUB:12100:0::NO::P12100_INSTRUMENT_ ID:312535 (dostęp: 2.01.2017), w wersji polskiej: MOP, www.mop.pl/doc/html/zalecenia/ z198.html (dostęp: 2.01.2017).

33 A. Musiała, J. Jankowiak, Kiedy zatrudniony ma status pracownika, „Służba Pracownicza” 2007, nr 4, s. 17.

34 Warto wymienić: Dyrektywę Rady nr 91/383/EWG z dnia 25 czerwca 1991 r. uzupełniającą środki mające wspierać poprawę bezpieczeństwa i zdrowia w pracy pracowników pozostających w stosunku pracy na czas określony lub w czasowym stosunku pracy, Dz.U.EWG.L 206 z dnia 29 lipca 1991 r., s. 19-21; Dyrektywę Rady nr 97/81/WE z dnia 15 grudnia 1997 r. dotyczącą Porozumienia ramowego w sprawie pracy w niepełnym wymiarze godzin zawartego przez Europejską Unię Konfederacji Przemysłowych i Pracodawców (UNICE), Europejskie Centrum Przedsiębiorstw Publicznych (CEEP) oraz Europejską Konfederację Związków Zawodowych (ETUC), Dz.U.WE.L 14 z dnia 20 stycznia 1998 r., s. 9-14; Dyrektywę Rady nr 99/70/WE z dnia 28 czerwca 1999 r. dotyczącą Porozumienia ramowego w sprawie pracy na czas określony, zawartego przez UNICE, CEEP oraz ETUC, Dz.U.WE.L 175 z dnia 10 lipca 1999 r., s. 43-48.

35 Szczegółowe omówienie tej problematyki przedstawia M. Matey-Tyrowicz, Nietypowe formy zatrudnienia - dyrektywy i praktyka UE, [w:] K.W. Frieske (red.), Deregulacja polskiego rynku pracy, Warszawa 2003, s. 153-166.

36 J. Wratny, Przemiany..., s. 40.

37 Projekt kodeksu pracy i jego uzasadnienie: MPiPS, www.mpips.gov.pl/prawo-pracy/ projekty-kodeksow-pracy/ (dostęp: 2.01.2017).

38 Komisja Kodyfikacyjna powołana na podstawie rozporządzenia Rady Ministrów z dnia 30 sierpnia 2002 r. w sprawie powołania Komisji Kodyfikacyjnej Prawa Pracy (Dz.U. Nr 139, poz. 1167). 
kuletniej pracy uznanych przedstawicieli z zakresu nauki prawa pracy) nie został wdrożony, wymaga choćby wstępnej analizy z perspektywy przedstawionej w nim koncepcji zatrudnienia. Oprócz typowego stosunku pracy, którego definicję zawiera art. 44 projektu kodeksu pracy, wyróżnia on również nietypowe stosunki pracy. Do nietypowych stosunków pracy zaliczone zostały: praca tymczasowa, telepraca, staż zawodowy, zarządzanie zakładem pracy, praca nakładcza, stosunki pracy pracowników domowych i pracowników rodzinnych, a także spółdzielczy stosunek pracy ${ }^{39}$. Wobec tak obszernego wyliczenia nie sposób oprzeć się wrażeniu, że projektodawcy starali się maksymalnie rozszerzyć obowiązywanie choćby niektórych norm prawa pracy. Projekt kodeksu pracy nie definiuje pojęcia „nietypowe stosunki pracy”, posługując się nim w tytule księgi szóstej. W związku z powyższym niejasne jest, czy nietypowe stosunki pracy traktować należy jako rodzaj stosunku pracy (art. $1 \S 1$ projektu), czy też jako stosunki prawne inne niż stosunek pracy (art. $1 \$ 2$ projektu) ${ }^{40}$. Natomiast bez wątpienia nietypowe stosunki pracy mogą być kwalifikowane jako rodzaj umownego zatrudnienia nietypowego, którego zakres obejmuje zarówno zatrudnienie nietypowe w ramach stosunku pracy, jak i poza nim.

Jeżeli przyjąć, że nietypowe stosunki pracy są rodzajem stosunku pracy (art. 1 $\$ 1$ projektu), powstaje wątpliwość co do występowania w ich przypadku wszystkich cech stosunku pracy, które wymienia art. 44 projektu, a w szczególności podporządkowania. W nietypowych stosunkach pracy nie zawsze można odnaleźć cechy podporządkowania pracowniczego właściwe typowemu stosunkowi pracy. Dla przykładu: pracownik tymczasowy jest podporządkowany, ale nie wyłącznie swojemu pracodawcy, a przede wszystkim pracodawcy użytkownikowi, który, będąc uczestnikiem trójpodmiotowej relacji, nie jest stroną stosunku pracy ${ }^{41}$.

Arbitralne wydają się powody selekcji rodzajów nietypowych stosunków pracy uwzględnione w projekcie. Wątpliwości budzi włączenie do tego katalogu spółdzielczej umowy o pracę, przy pominięciu innych pozaumownych stosunków pracy, czyli powołania, mianowania i wyboru. Jedyna odrębność stosunku pracy powstałego na podstawie spółdzielczej umowy o pracę od stosunku pracy powstałego na podstawie umowy o pracę wynika z jego niesamodzielnego charakteru, który cechuje również pozostałe pozaumowne stosunki pracy ${ }^{42}$. Projektodawcy kodeksu pracy wyjaśniają w przygotowanym do niego uzasadnieniu, dlaczego włączono do niego pracę nakładczą, dotąd regulowaną pozakodeksowo ${ }^{43}$ i trak-

39 B. Wagner, Niektóre elementy..., s. 3.

40 T. Liszcz, Nietypowe stosunki pracy w Projekcie kodeksu pracy, [w:] Z. Niedbała, M. Skąpski (red.), Problemy zatrudnienia we wspótczesnym ustroju pracy. Księga jubileuszowa na 55-lecie pracy naukowej i dydaktycznej Profesora Włodzimierza Piotrowskiego, Poznań 2009, s. 141.

41 Ibidem, s. 142.

42 Ibidem, s. 143.

43 Rozporządzenie z dnia 31 grudnia 1975 r. w sprawie uprawnień pracowniczych osób wykonujących pracę nakładczą, Dz.U. z 1976 r., Nr 3, poz. 19 ze zm., dalej: rozp.pr.nakład. 
towaną jako rodzaj zatrudnienia cywilnoprawnego. Uznano, że status społeczny osób wykonujących pracę nakładczą jest na tyle zbliżony do statusu pracowników, że powinna ona znaleźć się w kodeksie pracy jako nietypowa forma zatrudnienia. Należy zauważyć, że obecnie, pomimo wielu uprawnień pracowniczych przyznanych wykonawcom pracy nakładczej (chałupnikom), ustawodawca różnicuje ich pozycję względem pracowników. Uprawnienia pracownicze można bowiem przyznać tylko podmiotom niebędącym pracownikami ${ }^{44}$, tak jak ma to miejsce $\mathrm{w}$ rozporządzeniu stanowiącym podstawę prawną do świadczenia pracy nakładczej. Pozakodeksowa regulacja pracy nakładczej jako zatrudnienia niepracowniczego w okresie gospodarczego zapotrzebowania na taki rodzaj zatrudnienia sprawdziła się w praktyce, dlatego włączanie jej do kodeksu pracy nie wydaje się konieczne.

Zgodnie $\mathrm{z}$ przyjętą powyżej terminologią $\mathrm{w}$ dalszej części rozważań status prawny osób świadczących pracę $\mathrm{w}$ ramach umownego zatrudnienia nietypowego zostanie przedstawiony $\mathrm{w}$ odniesieniu do statusu prawnego osób świadczących pracę $\mathrm{w}$ warunkach zatrudnienia typowego. Zanim jednak rozważania osiągną etap szczegółowej analizy, należy określić podstawowe cechy konstrukcyjne umownego zatrudnienia nietypowego, definiowanego w sposób negatywny w stosunku do zatrudnienia typowego, oraz określić założenia systemowe ich stosowania. Powyższe pozwoli dokonać oceny, czy zróżnicowanie statusu prawnego osób świadczących pracę $\mathrm{w}$ ramach umownego zatrudnienia nietypowego realizuje funkcje gospodarcze spełniane przez poszczególne rodzaje umownego zatrudnienia nietypowego.

\subsection{Rodzaje umownego zatrudnienia nietypowego}

\subsubsection{Uwagi wprowadzające}

Można wyróżnić wiele podstaw prawnych i form organizacyjnych zatrudnienia nietypowego odbiegających od przyjętego za typowe zatrudnienia na podstawie umowy o pracę na czas nieokreślony, w wyniku zawarcia której praca świadczona jest w pełnym wymiarze czasu pracy, w siedzibie pracodawcy i na jego rzecz. Rozważania ujęte w monografii dotyczą umownych rodzajów zatrudnienia nietypowego, które w sposób znaczący różnicują status prawny osób świadczących pracę oraz są w obrocie gospodarczym wykorzystywane w największym stopniu. Zostaną one przedstawione $\mathrm{z}$ uwzględnieniem podziału na rodzaje umowy o pracę, pracę w formie organizacyjnej telepracy, podstawę zatrudnienia wyróżniającą

44 W. Gujski, Praca nakładcza (chałupnicza), „Prawo Pracy” 1996, nr 7, s. 29-33. 
się szczególną konfiguracją podmiotową (pracę tymczasową) i cywilnoprawne podstawy zatrudnienia (umowę o pracę nakładczą, umowę zlecenia i umowy o świadczenie usług, do których stosuje się przepisy o zleceniu, umowę agencyjną oraz umowę o dzieło). Scharakteryzowanie poszczególnych rodzajów umownego zatrudnienia nietypowego pozwoli określić podstawowe cechy danych stosunków prawnych, co z kolei umożliwi prowadzenie dalszych rozważań dotyczących sytuacji prawnej osób zatrudnionych.

Wychodząc z założenia, że istotą stosunku prawnego jest społeczno-gospodarczy cel, który ma zostać osiągnięty przez zastosowanie prawa ${ }^{45}$, punktem wyjścia dla prowadzonych rozważań będzie określenie powyższego celu, jaki istniał w momencie wprowadzania do systemu prawa regulacji dotyczących poszczególnych rodzajów umownego zatrudnienia nietypowego. Aktualność tych celów potwierdzi zasadność ich systemowego wyodrębnienia, co z kolei może doprowadzić do wniosków o słuszności zróżnicowania kreowanych przez nie konstrukcji prawnych w obrębie statusu prawnego osób świadczących pracę. Stwierdzenie zmiany bądź zaniku pierwotnie istniejących społeczno-gospodarczych celów występowania w obrocie prawnym poszczególnych rodzajów umownego zatrudnienia nietypowego może z kolei uzasadniać stanowisko przeciwne. Postulowałoby ono konieczność dokonania przeobrażeń systemowych w zakresie modeli umownego zatrudnienia nietypowego, które dotyczyłyby w szczególności statusu prawnego osób świadczących pracę.

Punktem wyjścia do analizy umownego zatrudnienia nietypowego są podstawy zatrudnienia najbardziej zbliżone do zatrudnienia typowego, czyli rodzaje umów o pracę inne niż umowa o pracę na czas nieokreślony. Poza obszarem prowadzonej analizy znalazły się pozostałe podstawy nawiązania stosunku pracy (mianowanie, powołanie, wybór, spółdzielcza umowa o pracę). Są one ściśle reglamentowane przepisami prawa, dlatego nie mogą być wybierane przez strony zatrudnienia $\mathrm{w}$ dowolnych okolicznościach. Przedmiotem analiz zawartych w monografii są umowne podstawy zatrudnienia, ustawowo niereglamentowane.

\subsubsection{Pracownicze umowne zatrudnienie nietypowe}

Kodeks pracy w art. 25 przyjął klasyfikację „rodzajów umowy o pracę"46, zgodnie z którą należy dokonywać podziału umów o pracę, biorąc pod uwagę ich cechy rodzajowe. Wszystkie te umowy mają wspólne cechy determinujące możliwość włączenia ich do katalogu umów o pracę. Dodatkowo poszczególne rodzaje umów charakteryzują cechy konstrukcyjne, wyróżniające je jako określony rodzaj umowy

45 W. Ludwiczak, Umowa zlecenia, Poznań 1955, s. 30.

46 H. Lewandowski, Uwagi w sprawie podziału umowy o pracę na rodzaje, [w:] H. Lewandowski (red.), Studia z prawa pracy, Warszawa 1988, s. 176. 
o pracę ${ }^{47}$. Podział rodzajów umów o pracę jest dokonany ze względu na odmienność ich celów i funkcji. Każdy z rodzajów umów o pracę stanowi odrębną instytucję prawną, z właściwymi sobie celami i funkcjami ${ }^{48}$. Unormowania dotyczące poszczególnych umów o pracę odzwierciedlają to zróżnicowanie na gruncie regulacji szczegółowych, takich jak odmienność zakresu stosowania poszczególnych umów o pracę, odmienność ich treści czy sposobów i trybów rozwiązywania ${ }^{49}$. Powstanie stosunku pracy na podstawie rodzajowo różnych umów o pracę determinuje stosowanie modelowo odmiennych instytucji prawnych, które w inny sposób kształtują wzajemne relacje pracownika i pracodawcy. Jest to szczególnie widoczne w zakresie kreowania statusu prawnego osób zatrudnionych.

\subsubsection{Umowa o pracę na czas określony}

Jako pierwszą, obok umowy o pracę na czas nieokreślony, art. 25 k.p. wymienia umowę na czas określony. Umowa o pracę na czas określony zaliczana jest do terminowych umów o pracę. Terminowe umowy o pracę to takie, w których moment ustania stosunku pracy został $\mathrm{z}$ góry przez strony wyznaczony ${ }^{50} \mathrm{i}$ jest im znany ${ }^{51}$. Termin zakończenia trwania umowy o pracę na czas określony powinien być przez strony wyraźnie wskazany poprzez konkretną datę kalendarzową lub zdarzenie przyszłe ${ }^{52}$. To właśnie fakt konieczności określenia przez strony końcowego terminu zatrudnienia powoduje, że umowa o pracę na czas określony spełnia, jako podstawa zatrudnienia, funkcję stabilizacyjną ${ }^{53}$. Jednostronne odstąpienie od umowy zawartej na określony czas (poza okolicznościami nadzwyczajnymi) jest sprzeczne z jej naturą ${ }^{54}$. Strony umowy o pracę na czas określony, mając swobodę w oznaczaniu terminu jej wygaśnięcia, wyznaczają czasowe granice trwania stosunku pracy ${ }^{55}$. W założeniach systemowych umowa o pra-

47 Ibidem, s. 177.

48 B. Wagner, Zagadnienia na tle umowy o pracę na czas określony, „Praca i Zabezpieczenie Społeczne" 1975, nr 3, s. 32.

49 B. Wagner, Terminowe umowy..., s. 7.

50 Ibidem, s. 31.

51 H. Kasińska, Rozwiq̨zanie terminowych umów o pracę, „Praca i Zabezpieczenie Społeczne” 1980, nr 6, s. 19.

52 J. Pacho, Stosunek pracy i jego podmioty, [w:] R. Korolec, J. Pacho (red.), Nowe prawo pracy, Warszawa 1975, s. 83. Takie stanowisko prezentuje również Sąd Najwyższy: Orzeczenie Sądu Najwyższego z dnia 16 lutego 1952 r., Ł C 773/51, LEX nr 1673877; Orzeczenie Sądu Najwyższego z dnia 15 grudnia 1956 r., IV CR 35/56, LEX nr 118855. Odmiennie: B. Wagner, Terminowe umowy..., s. 21. Autorka uważa, że przy umowie o pracę na czas określony termin końcowy powinien być ściśle określony.

53 Z. Salwa, W sprawie rodzajów umowy o pracę i sposobie rozwiqzania umowy zawartej na okres wykonania określonej roboty, „Praca i Zabezpieczenie Społeczne” 1965, nr 7, s. 24.

54 J. Stelina, Nowa koncepcja umowy o pracę na czas określony, „Państwo i Prawo” 2015, nr 11, s. 46.

55 B. Wagner, Zagadnienia..., s. 24. 
cę na czas określony miała gwarantować trwanie stosunku pracy do momentu oznaczonego przez strony, dając zarówno pracownikowi, jak i pracodawcy poczucie stabilizacji ${ }^{56}$, stanowiące niezwykle ważny czynnik brany pod uwagę przy dokonywaniu wyboru podstawy prawnej zatrudnienia. Do nowelizacji czerwcowej z 2015 r. przedstawiony cel spełniały jednak tylko takie umowy o pracę na czas określony, w których strony nie przewidziały klauzuli wypowiadalności lub które nie mogły być wypowiedziane ${ }^{57}$. Klauzula wypowiadalności, zgodnie z art. 33 k.p., mogła być przez strony wprowadzona, gdy umowa została zawarta na czas przekraczający 6 miesięcy ${ }^{58}$. W sytuacji gdy strony przewidziały klauzulę wypowiadalności, ze względu na krótki, dwutygodniowy okres wypowiedzenia umowa o pracę na czas określony oznaczała stan niepewności co do trwania nawiązanego stosunku pracy ${ }^{59}$, niwecząc tym samym cele i funkcje tej podstawy zatrudnienia $^{60}$. Klauzula wcześniejszej wypowiadalności podważała cechy wyróżniające umowę o pracę na czas określony w systemie umów prawa pracy ${ }^{61}$, upodabniając ją do umowy o pracę na czas nieokreślony ${ }^{62}$. Stabilizacja zatrudnienia na podstawie umowy o pracę na czas określony występowała jedynie w przypadku gdy umowa nie zawierała klauzuli wcześniejszej wypowiadalności bądź zawarta była na okres do 6 miesięcy. W przypadku wprowadzenia do umowy na czas określony omawianej klauzuli, umowa ta traciła swój podstawowy walor, gwarantujący zatrudnienie do określonego czasu.

W związku z możliwością wprowadzenia do umowy o pracę na czas określony klauzuli umożliwiającej jej wcześniejsze wypowiedzenie powstawały dwie wątpliwości interpretacyjne. Pierwsza z nich dotyczyła czasu, w którym stosowna klauzula miałaby być wprowadzona. Stan prawny nie zawierał przepisu ograniczającego moment wprowadzenia takiej klauzuli do chwili zawierania umowy o pracę na

56 B. Wagner, Terminowe umowy..., s. 7-8, 38; A.M. Świątkowski, Kodeks pracy. Komentarz, Warszawa 2012, s. 191. Odmiennie: T. Romer, Kodeks pracy. Komentarz, Warszawa 2012, s. 240. Autorka wyraża pogląd, że to umowa o pracę na czas nieokreślony daje pracownikowi najdalej idącą gwarancję czasu trwania zatrudnienia. A. Górnicz-Mulcahy i M. Lewandowicz-Machnikowska podnoszą, że celem umów terminowych jest zagwarantowanie stronom pewności co do trwania zobowiązania przez oznaczony w umowie czas ze względu na interes stron w stabilizacji ustanowionego stosunku prawnego. A. Górnicz-Mulcahy, M. Lewandowicz-Machnikowska, Skutki prawne wypowiedzenia przez pracownika umowy na czas określony nieprzewidującej prawa do wypowiedzenia, „Monitor Prawa Pracy” 2012, nr 12, s. 628.

57 Zgodnie z art. 33 k.p. drugi z warunków dotyczył umów trwających do 6 miesięcy.

58 Istotą umowy o pracę na czas określony jest jej trwanie do momentu ustalonego wspólną wolą stron. Wcześniejsze rozwiązanie umowy o pracę, na mocy jednostronnej czynności, powinno być możliwe jedynie w nadzwyczajnych okolicznościach. M. Tomaszewska, [w:] K.W. Baran (red.), Kodeks pracy. Komentarz, Warszawa 2012, s. 252.

59 Ł. Pisarczyk, Terminowe umowy o pracę - szansa czy zagrożenie, „Praca i Zabezpieczenie Społeczne" 2006, nr 8, s. 3.

60 B. Wagner, Zagadnienia..., s. 31.

61 A. Górnicz-Mulcahy, M. Lewandowicz-Machnikowska, op. cit., s. 633.

62 Z. Salwa, W sprawie..., s. 24-25. 
czas określony, więc należało uznać, że mogła być ona przez strony wprowadzona również w trakcie trwania umowy ${ }^{63}$.

Druga wątpliwość dotyczyła wypowiedzenia umowy o pracę na czas określony, co do której strony przewiedziały taką możliwość w przypadku gdy wypowiedzenie miałoby nastąpić przed upływem sześciu miesięcy. Dokonanie wypowiedzenia w takich okolicznościach powodowało znaczne osłabienie nie tylko pozycji strony pracowniczej, ale i całej więzi stosunku pracy. Skoro ustawodawca zdecydował się wyznaczyć granicę, od której można było wprowadzać do umowy o pracę na czas określony klauzulę wypowiadalności, należało przyjąć, że jego intencją było, aby umowa o pracę na czas określony trwała co najmniej 6 miesięcy. Odmiennie w kwestii tej wypowiedział się Sąd Najwyższy, dopuszczając możliwość wypowiedzenia umowy o pracę na czas określony przed upływem 6 miesięcy w przypadku gdy strony wprowadziły do umowy stosowne postanowienie ${ }^{64}$. Stanowisku Sądu Najwyższego przyznać należy rację ${ }^{65}$. Nie było bowiem podstaw do nadinterpretacji przepisów kodeksu pracy celem jak najszerszej ochrony strony pracowniczej. Gdyby rzeczywistą intencją ustawodawcy było wprowadzenie możliwości wypowiedzenia umowy o pracę na czas określony, w której strony wprowadziły klauzulę wypowiadalności dopiero po upływie 6 miesięcy, stosowna regulacja zostałaby uwzględniona w kodeksie pracy. Przyjęcie takiego stanowiska powodowało, że większa była gwarancja stabilności zatrudnienia powstającego podczas zawierania umowy o pracę na czas określony krótszy niż 6 miesięcy, niż w przypadku umowy na czas określony dłuższy niż 6 miesięcy, dającej możliwość wcześniejszego wypowiedzenia ${ }^{66}$.

Ze stosowaniem umów o pracę na czas określony związane były jeszcze dwa zagadnienia warte rozważenia w tym miejscu opracowania: kauzalność umów o pracę na czas określony i ograniczenie czasowe w zakresie ich trwania. Kodeks pracy nie zawierał dyspozycji nakazującej uzasadnianie zawarcia umowy o pracę na czas określony zamiast umowy o pracę na czas nieokreślony. W związku $\mathrm{z}$ tym należało przyjąć istnienie akauzalnej koncepcji umowy o pracę ${ }^{67}$, co z kolei prowadziło do konstatacji, że umowy o pracę na czas określony mogły być zawierane na dowolnie długi okres. Skoro bowiem nie było obowiązku wskazywa-

63 B. Wagner, Terminowe umowy..., s. 97. Stanowisko to wyraził również Sąd Najwyższy w uchwale z dnia 14 czerwca 1994 r., I PZP 26/94, LEX nr 11847. Krytycznie do wskazanego orzeczenia odnióst się A. Tomanek, uznając, że dopuszczenie wprowadzenia klauzuli wcześniejszej wypowiadalności w trakcie trwania umowy pozostaje w sprzeczności z ratione legis umowy o pracę na czas określony. A. Tomanek, Glosa do uchwaty z 16 czerwca 1994 r., „Orzecznictwo Sądów Polskich” 1995, nr 9, poz. 184.

64 Uchwała Sądu Najwyższego z dnia 7 września 1994 r., I PZP 35/94, LEX nr 11877; Wyrok Sądu Najwyższego z dnia 30 września 2009 r., II PK 88/09, LEX nr 559938.

65 Odmiennie: M. Tomaszewska, op. cit., s. 254.

66 Z. Góral, [w:] K.W. Baran (red.), Kodeks pracy. Komentarz, Warszawa 2012, s. 254.

67 Ł. Pisarczyk, Terminowe umowy..., s. 6; M. Gersdorf, o przyczynowości zawarcia i rozwiqzania umowy na czas określony, [w:] A. Sobczyk (red.), Stosunki zatrudnienia..., s. 228. 
nia, dlaczego strony zawarły umowę o pracę na czas określony, tym bardziej nie można było stwierdzić, że umowa taka, zawarta na długi okres, jest sprzeczna z prawem. Ograniczanie możliwości zawierania długotrwałych umów o pracę na czas określony uznane zostało przez Sąd Najwyższy za celowe w orzeczeniach z 7 września 2005 r. $^{68}$ oraz z 25 października 2007 r. ${ }^{69}$. Na poparcie stanowiska Sądu Najwyższego można podnieść argument o gwarancyjnym charakterze przepisów prawa pracy czy też ograniczonych ramami zasady swobody umów możliwościach swobodnego kreowania stosunków prawnych ${ }^{70}$. Nie wydało się jednak słuszne ograniczanie możliwości zawarcia umowy o pracę na czas określony do bliżej nieokreślonego okresu (w przytoczonych orzeczeniach okresów siedmioletnich i dziesięcioletnich). W przypadku braku maksymalnego czasu trwania umowy o pracę na czas określony orzekanie, że czas trwania umowy jest zbyt długi, wydało się zmieniać rolę sądu z sądowniczej na ustawodawczą. Również wywodzenie z przepisów kodeksu pracy obowiązku istnienia obiektywnej przyczyny zawarcia umowy o pracę na czas określony nie pozostawało w zbieżności $\mathrm{z}$ ówczesnym stanem prawnym, nosząc znamiona nadinterpretacji ${ }^{71}$.

Zmiany w omawianym zakresie obowiązują od 22 lutego 2016 r. Nowelizacja czerwcowa z 2015 r. ostatecznie niweczy trwały charakter zatrudnienia terminowego poprzez uchylenie art. 33 k.p. Wydaje się, że w takim kształcie umowy o pracę na czas określony zawierane są nie po to, aby trwały określony czas, a po to, by nie trwały dłużej ${ }^{72}$. Zmieniona regulacja daje możliwość wypowiedzenia każdej umowy o pracę zawartej na czas określony bez istniejących przed jej wejściem w życie ograniczeń. Nowa konstrukcja umowy o pracę na czas określony wyłącza zasadę trwałości, cechującą zobowiązania terminowe $\mathrm{e}^{73}$. Na aprobatę zasługuje natomiast wprowadzenie maksymalnego 33-miesięcznego okresu trwania umowy o pracę na czas określony oraz ograniczenia do maksymalnie trzech takich umów.

68 Wyrok Sądu Najwyższego z dnia 7 września 2005 r., II PK 294/04, LEX nr 145435.

69 Wyrok Sądu Najwyższego z dnia 25 października 2007 r., II PK 49/07, LEX nr 464877. Potwierdzenie przyjętej linii orzeczniczej zawiera wyrok Sądu Najwyższego z dnia 5 czerwca 2014 r. uznający, że w obowiązującym stanie prawnym pracodawca mógł zawrzeć umowę o pracę na czas określony bez uzasadniania przyczyn jej zawarcia, jeżeli nie prowadziło to do obejścia prawa lub sprzeczności zawartej umowy z zasadami współżycia społecznego. Wyrok Sądu Najwyższego z dnia 5 czerwca 2014 r., I PK 308/13, LEX nr 1475061.

70 M. Myszka, Glosa do wyroku Sądu Najwyższego z 7 września 2005 r. (II PK 29/04) w sprawie niedopuszczalności zawierania długoterminowych umów o pracę na czas określony z możliwością ich wcześniejszego wypowiedzenia, „Praca i Zabezpieczenie Społeczne” 2006, nr 8, s. 32-36.

71 Stanowisko popierające konieczność interpretacji norm kodeksu pracy przez Sąd Najwyższy prezentuje M. Myszka, op. cit., s. 33.

72 K. Jaśkowski, Nowa umowa o pracę na czas określony, „Praca i Zabezpieczenie Społeczne” 2015, nr 11, s. 3.

73 J. Stelina, op. cit., s. 43. 
Od zasady automatyzmu prawnego zatrudnienia na czas nieokreślony w przypadku przekroczenia 33 miesięcy zatrudnienia bądź liczby trzech umów ustawodawca przewidział wyjątki, określone przez Jakuba Stelinę mianem „szczególnej umowy o pracę na czas określony"74. Należą do nich sytuacje, w których umowa o pracę na czas określony została zawarta w celu zastępstwa pracownika w czasie jego usprawiedliwionej nieobecności w pracy, wykonywania pracy o charakterze dorywczym lub sezonowym, wykonywania pracy przez okres kadencji albo w przypadku gdy pracodawca wskaże obiektywne przyczyny leżące po jego stronie ${ }^{75}$ oraz, co dotyczy wszystkich wskazanych wyjątków, jeżeli zawarcie umowy na czas określony w danym przypadku służy zaspokojeniu rzeczywistego okresowego zapotrzebowania i jest niezbędne w tym zakresie w świetle wszystkich okoliczności zawarcia umowy (art. $25^{1} \$ 4$ k.p. po nowelizacji). Wskazane rozwiązanie nie stanowi o kauzalności zawarcia umowy o pracę na czas określony. Pozwala jedynie stosować dłuższy czas trwania terminowego stosunku pracy bądź zawierać większą liczbę umów o pracę na czas określony. Wydaje się, że wskazane przez ustawodawcę powody umożliwiające przekroczenie 33 miesięcy zatrudnienia terminowego bądź liczbę trzech umów, czyli konieczność zaspokojenia rzeczywistego okresowego zapotrzebowania oraz niezbędność w świetle wszystkich okoliczności zawarcia umowy, są okolicznościami generalnie umożliwiającymi zawieranie umów o pracę na czas określony. Nie powinny one zatem uzasadniać wyjątkowego przekraczania ustawowych limitów, a raczej występować w przypadku zawierania wszystkich umów o pracę na czas określony. Brak istnienia powyższych przesłanek skłania bowiem do przyjęcia założenia, że strony powinny zawrzeć umowę o pracę na czas nieokreślony.

Przyjęta w polskim systemie prawnym konstrukcja zbliża okoliczności umożliwiające rozwiązywanie umowy o pracę na czas określony do zatrudnienia at-will ${ }^{76}$. Jedyną przesłanką ograniczającą możliwość rozwiązania umowy o pracę na czas określony jest naruszenie zasady równego traktowania w zatrudnieniu. W pozostałym zakresie pracodawca ma pełną dowolność w wypowiadaniu umowy o pracę zawartej na czas określony. Wyjątkiem jest przedłużenie trwania umowy do momentu porodu, w sytuacji gdyby umowa o pracę na czas określony

74 Autor wyróżnia zwykłą umowę o pracę na czas określony i umowę szczególną, zawartą w okolicznościach wskazanych w art. $25^{1} \S 4$ k.p. J. Stelina, op. cit., s. 45. K. Jaśkowski dokonuje podziału na umowy limitowane i umowy obiektywnie uzasadniane. K. Jaśkowski, op. cit., s. 3-6.

75 Konieczność wskazywania obiektywnych przesłanek usprawiedliwiających zawarcie każdej umowy terminowej wskazywał K. Walczak, Umowa na zastępstwo - czy można ja kwestionować ze względu na niezgodność z prawem europejskim?, „Monitor Prawa Pracy” 2005, nr 3, s. 63.

76 Ł. Pisarczyk, Terminowe umowy..., s. 4. Zgodnie z doktryną employment-at-will zwolnienie pracownika nie wymaga przedstawienia ze strony pracodawcy jakiegokolwiek powodu. Szczegółowe omówienie tej tematyki, wraz ze wskazaniem wyjątków od reguły at-will, przedstawit A. Rycak, Doktryna employment-at-will w prawie pracy w Stanach Zjednoczonych, „Praca i Zabezpieczenie Społeczne” 2008, nr 8, s. 8-17. 
rozwiązałaby się po upływie trzeciego miesiąca ciąży (art. $177 \$ 3$ k.p.). Podstawa zatrudnienia, jaką jest umowa o pracę na czas określony, która zgodnie ze swoim systemowym przeznaczeniem miała spełniać funkcję stabilizującą stosunek pracy poprzez zapewnienie jego stron o trwaniu do określonego momentu, nie spełnia w obecnym stanie prawnym powyższych założeń. Wprowadzając liberalne regulacje dotyczące możliwości rozwiązania umowy o pracę na czas określony ustawodawca przekreślił podstawowy jej cel - stabilizację zatrudnienia ${ }^{77}$. Pracownik, któremu pracodawca wadliwie wypowiedział umowę o pracę na czas określony, pozbawiony został ponadto, zgodnie z treścią art. $50 \$ 3$ k.p., prawa restytucji ${ }^{78}$. Przewidzianym przez kodeks pracy wyjątkiem od wyłącznego prawa do odszkodowania jest art. $50 \$ 5$ k.p. bądź wynikające z ustawy o związkach zawodowych ${ }^{79}$ prawo do skorzystania z uprawnień określonych w art. 45 k.p. Wskazany przepis stosowany jest wtedy odpowiednio, a pracownikowi przysługuje alternatywnie prawo pozostania w zatrudnieniu (jeśli umowa nie uległa jeszcze rozwiązaniu), prawo do przywrócenia do pracy albo prawo do odszkodowania.

Wprowadzenie limitu trwania lub zasady kauzalności zawierania umów o pracę na czas określony prowadzi do eliminowania zjawiska zawierania ich na długie okresy $^{80}$. W ujęciu systemowym uzasadnieniem zawarcia umowy o pracę na czas określony możne być istnienie perspektywy czasowej dla działań realizowanych przez pracodawcę przy udziale pracownika zatrudnionego na podstawie takiej umowy ${ }^{81}$. Zawieranie długoterminowych umów o pracę na czas określony zostałoby wyeliminowane przy rezygnacji z ustawowego dopuszczenia wypowiedzenia umowy o pracę na czas określony ${ }^{82}$ albo choćby wprowadzenia konieczności jego uzasadniania i konsultacji związkowej.

Umowa o pracę na czas określony jest chętnie wybieraną podstawą zatrudnienia pracowniczego ${ }^{83}$. Uzasadnieniem takiego stanu rzeczy nie jest jednak cel, w jakim umowa ta była wprowadzana do porządku prawnego, czyli stabilizacja zatrudnienia. Cel ten jest wprost przeciwny - łatwość rozwiązania stosunku pracy. Wobec braku konieczności uzasadniania zawarcia umowy o pracę na czas określony może być ona zawierana w takich samych warunkach jak umowa bezterminowa. Możliwość ta jest wykorzystywana na szeroką skalę. Pozostałe rodzaje umów o pracę, z których wszystkie zaliczyć należy do grupy umów terminowych, czyli umowa o pracę na czas wykonania określonej pracy, umowa o pracę zawarta w celu zastępstwa i umowa na okres próbny, zawierane są (były) w określonych

77 M. Gersdorf, o przyczynowości..., s. 228.

78 B. Wagner, O swobodzie..., s. 368.

79 Ustawa z dnia 23 maja 1991 r. o związkach zawodowych, Dz.U. z 2015 r., poz. 1881 - t.j.; dalej: u.z.z.

80 Ł. Pisarczyk, Terminowe umowy..., s. 7.

81 Ł. Pisarczyk, Różne formy zatrudnienia, Warszawa 2003, s. 69.

82 B. Wagner, O swobodzie..., s. 369.

83 Potwierdzają to dane statystyczne przedstawione na s. 19. 
okolicznościach faktycznych, zatem nie stanowią alternatywy dla umowy o pracę na czas nieokreślony. Umowy te w sposób wyraźny różnicują status prawny osób zatrudnionych na ich podstawie, spełniając odmienne założenia systemowe. W związku z nowelizacją czerwcową z 2015 r. umowy na czas wykonania określonej pracy i umowy w celu zastępstwa nieobecnego pracownika podczas jego usprawiedliwionej nieobecności przestały być osobnymi podtypami umów terminowych, o czym mowa będzie w dalszej części tekstu.

\subsubsection{Umowa o pracę na czas wykonania określonej pracy, umowa o pracę w celu zastępstwa, umowa o pracę na okres próbny}

Umowa o pracę na czas wykonania określonej pracy, usunięta z kodeksu pracy nowelizacją czerwcową z 2015 r., mogła być zawierana na okres realizacji oznaczonej $\mathrm{w}$ umowie pracy ${ }^{84}$, dając pewność zatrudnienia do czasu ukończenia wskazanych w umowie zadań. Gospodarczym celem umowy o pracę na czas wykonania określonej pracy było zawiązanie stosunku pracy na z góry określony czas, który nie mógł być ściśle oznaczony ${ }^{85}$. Przedmiotem umowy o pracę na czas wykonania określonej pracy było zarówno zatrudnienie trwające pewien okres, jak i wykonanie w tym okresie ściśle określonej pracy ${ }^{86}$. Umowa ta pozwalała na dostosowanie czasu trwania stosunku pracy do czasu realizacji zadania w sytuacji gdy zakładany termin końcowy ulegał wydłużeniu bądź skróceniu ${ }^{87}$. Ryzyko w zakresie długości trwania tego rodzaju umowy było wpisane w jej istotę ${ }^{88}$.

Umowa o pracę w celu zastępstwa była (do czasu usunięcia jej z kodeksu pracy nowelizacją czerwcową z 2015 r.) rodzajem umowy o pracę na czas określony ${ }^{89}$, zawieranej w szczególnych okolicznościach, a mianowicie w czasie usprawiedliwionej nieobecności innego pracownika ${ }^{90}$. Czas trwania takiej umowy był uzależniony od okoliczności dla niej zewnętrznych, czyli usprawiedliwionej nieobecności pracownika zastępowanego. Umowa ta miała szczególne przeznaczenie gospodarcze i walory praktyczne $\mathrm{w}$ postaci wypełnienia, poprzez ustanowienie zastępstwa ${ }^{91}$, niedoborów kadrowych powstałych w wyniku usprawiedliwionej

84 R. Sadlik, Umowa o pracę na czas wykonania określonej pracy, „Prawo Pracy” 2004, nr 4, s. 9. 85 Z. Salwa, W sprawie..., s. 26; S.W. Ciupa, Umowa o pracę zawierana na czas nieobecności (zastępstwo) pracownika, „Monitor Prawniczy” 2002, nr 24, s. 1118-1119.

86 B. Wagner, Terminowe umowy..., s. 35.

87 Ł. Pisarczyk, Różne formy..., s. 74.

88 H. Szewczyk, Charakter prawny umowy na czas wykonania określonej pracy, „Monitor Prawa Pracy" 2004, nr 8, s. 212.

89 Pogląd ten podzielił Sąd Najwyższy, zastrzegając ponadto, że przyczyny, dla których taka umowa była zawierana, były ograniczone do konieczności zastąpienia innego pracownika w czasie jego usprawiedliwionej nieobecności w pracy. Wyrok Sądu Najwyższego z dnia 4 października 2011 r., I PK 56/11, LEX nr 1107213.

90 Z. Kubot, Umowa o pracę na zastępstwo, „Praca i Zabezpieczenie Społeczne” 2003, nr 2, s. 17.

91 S.W. Ciupa, Umowa o pracę..., s. 1119; K. Walczak, Umowa na zastępstwo... 
nieobecności pracownika zastępowanego. Wykorzystywana mogła być w przypadku gdy przyczyna nieobecności usprawiedliwiała brak przebywania w pracy i jej wykonywania ${ }^{92}$. Był to zatem przykład umowy terminowej, której zakończenie warunkowało przyszłe zdarzenie pewne (koniec usprawiedliwionej nieobecności zastępowanego pracownika).

Celem sprawdzenia przydatności pracownika do określonej pracy strony stosunku pracy mogą zawrzeć umowę o pracę na okres próbny ${ }^{93}$. W okresie próby podmiot zatrudniający dokonuje weryfikacji posiadanych przez pracownika kwalifikacji ${ }^{94}$, a pracownik zapoznaje się z warunkami pracy ${ }^{95}$. Próba nie jest celem samym w sobie - $\mathrm{z}$ założenia poprzedza powstanie trwalszego stosunku pracy ${ }^{96}$ bądź uznanie nieprzydatności pracownika do pracy na określonym stanowisku. Jej celem jest wyeliminowanie przyczyn w postaci braku wymaganych kwalifikacji pracownika bądź niespełnienia jego oczekiwań związanych ze świadczoną pracą. Próba służy w przeważającej mierze pracodawcy, niwelując ryzyko osobowe. Jest jednak również pożyteczna dla pracownika, dając mu możliwość podjęcia świadomej decyzji dotyczącej wykonywania określonej pracy ${ }^{97}$.

Z powyższego wynika, że umowa o pracę na czas wykonania określonej pracy, umowa w celu zastępstwa oraz umowa na okres próbny zawierane były (w odniesieniu do dwóch pierwszych umów) i są (w odniesieniu do umowy na okres próbny) w szczególnych okolicznościach faktycznych - wykonania pracy, zastępstwa pracownika nieobecnego czy też sprawdzenia przydatności pracownika - spełniając określone gospodarczo cele. Poprzez zróżnicowanie sytuacji faktycznych, w których umowy te były (są) zawierane, w odmienny sposób kształtowany jest status prawny osób świadczących pracę. Obecnie obowiązujące regulacje w tym zakresie należy odnieść do nowelizacji czerwcowej z 2015 r.

Jednym z głównych celów nowelizacji czerwcowej kodeksu pracy z 2015 r. było ograniczenie nieuzasadnionego wykorzystywania umów o pracę na czas określony ${ }^{98}$. Ustawą nowelizacyjną dokonano zawężenia katalogu rodzajów umów o pracę, rezygnując z umowy na czas wykonania określonej pracy ${ }^{99}$ oraz z umowy na czas zastępstwa nieobecnego pracownika jako odrębnych podtypów umowy. Ustawodawca nie wyklucza możliwości zawierania jako umów o pracę na czas

92 S.W. Ciupa, op. cit., s. 1121.

93 B. Wagner, Terminowe umowy..., s. 36.

94 W. Radomski, Umowa o pracę na okres próbny i wstępny jako warunek zawarcia umowy na czas nieokreślony, „Praca i Zabezpieczenie Społeczne” 1975, nr 7, s. 19; Ł. Pisarczyk, Różne formy..., s. 64.

95 Z. Salwa, W sprawie..., s. 23-24.

96 B. Wagner, Zagadnienia..., s. 23.

97 H. Lewandowski, Instytucja próby w prawie pracy, Warszawa 1968, s. 7-8.

98 Uzasadnienie do projektu ustawy - zob. Sejm Rzeczpospolitej Polskiej, www.sejm.gov.pl/ Sejm7.nsf/druk.xsp?nr=3321 (dostęp: 3.01.2017).

99 K. Jaśkowski, op. cit., s. 2. 
określony umów klasyfikowanych przed nowelizacją jako umowy o pracę w celu zastępstwa ${ }^{100}$. Dodatkowo nowelizacją doprecyzowana została specyfika zatrudnienia na okres próbny, jaką jest sprawdzenie kwalifikacji pracownika i możliwości jego zatrudnienia w celu wykonywania określonego rodzaju pracy ${ }^{101}$.

\subsubsection{Nietypowość miejsca świadczenia pracy. Zatrudnienie w formie organizacyjnej telepracy}

Modyfikowanie miejsca świadczenia pracy jest kolejnym przejawem stosowania zatrudnienia nietypowego. Zgodnie $\mathrm{z}$ treścią art. 29 k.p. umowa o pracę określa miejsce wykonywania pracy. W praktyce najczęściej miejscem wykonywania pracy jest siedziba pracodawcy albo miejsce, w którym prowadzi on swoją działalność. Nie jest to jednak regułą, dlatego nie można stawiać znaku równości między miejscem pracy pracownika a siedzibą pracodawcy ${ }^{102}$. Mając na względzie, że kodeks pracy nie ogranicza możliwości wskazywania miejsca pracy do siedziby pracodawcy, należy przyjąć, że pracownik może świadczyć pracę $\mathrm{w}$ dowolnie wybranym miejscu, o ile oczywiście pozostaje w nim do dyspozycji pracodawcy ${ }^{103}$. Określenie miejsca świadczenia pracy determinuje stosowanie regulacji dotyczących m.in. podróży służbowej ${ }^{104}$ czy wypadku w drodze do pracy. Dlatego odpowiednie postanowienia zawarte $\mathrm{w}$ umowie o pracę mają dla jej stron istotne znaczenie. $W$ razie braku oznaczenia miejsca świadczenia pracy zastosowanie znajduje art. $454 \$ 2$ k.c. (w zw. z art. 300 k.p.), zgodnie z którym miejscem spełnienia świadczenia jest to, w którym dłużnik miał zamieszkanie lub siedzibę $\mathrm{w}$ chwili powstania zobowiązania. $\mathrm{W}$ takim przypadku miejscem świadczenia pracy będzie siedziba pracodawcy ${ }^{105}$. Możliwość świadczenia przez pracownika

100 Zachowane zostały przepisy bezpośrednio dotyczące umów o pracę na czas określony zawieranych w celu zastępstwa nieobecnego pracownika (art. $177 \S 3^{1}$ k.p.). Ustawodawca nie dopuszcza jednak dalszego stosowania zatrudnienia na czas wykonania określonej pracy. Powyższe nie wynika wprost ze znowelizowanych przepisów. Jednakże na s. 5 uzasadnienia do projektu ustawy wskazane zostało, że „pozostawienie dotychczasowych regulacji dotyczących umowy o pracę na czas wykonania określonej pracy może budzić uzasadnione wątpliwości w świetle zgodności z prawem unijnym, np. brak ograniczenia wielokrotnego zawierania tych umów. Nadal natomiast możliwe będzie zawieranie umów o pracę na czas określony w celu zastępstwa”. Zastosowanie zwrotu „nadal natomiast” sugeruje, że możliwość taka nie istnieje względem umów klasyfikowanych jako umowy o pracę na czas wykonania określonej pracy.

101 L. Mitrus, Projekt nowelizacji kodeksu pracy dotyczq̨cy umów terminowych, „Monitor Prawa Pracy" 2015, nr 6, s. 286-287.

102 Wyrok Sądu Najwyższego z dnia 1 kwietnia 1985 r., I PR 19/85, LEX nr 13556.

103 L. Florek, Prawne formy elastycznych form zatrudnienia, [w:] L. Machol-Zajda (red.), Elastyczne formy zatrudnienia sposobem na efektywność firm, Warszawa 2001, s. 31.

104 Wyrok Sądu Najwyższego z dnia 1 kwietnia 1985 r., I PR 19/85, zgodnie z którym wykonywanie przez pracownika pracy w uzgodnionym „,miejscu pracy”, innym niż siedziba pracodawcy, nie stwarza obowiązku wypłaty m.in. diet z tytułu podróży służbowej.

105 M. Tomaszewska, op. cit., s. 220-221. 
pracy w miejscu innym niż siedziba pracodawcy pozwala w pełni zagospodarować potencjał pracownika zgodnie z potrzebami pracodawcy. Określenie w umowie o pracę miejsca jej wykonywania innego niż siedziba pracodawcy nie rodzi dla pracownika żadnych istotnych konsekwencji, gdyż od samego początku wie on, gdzie będzie wykonywał obowiązki pracownicze.

Przykładem modyfikacji więzi zatrudnienia pracowniczego odnoszącej się do miejsca pracy jest telepraca. Jest to forma organizacyjna zatrudnienia pracowniczego przewidująca możliwość świadczenia przez pracownika pracy poza zakładem pracy. Polski ustawodawca uregulował tę formę organizacyjną zatrudnienia w kodeksie pracy ${ }^{106}$, co świadczy o jego przekonaniu o dość zbliżonym charakterze telepracy do typowego stosunku pracy ${ }^{107}$. Telepraca nie jest nowym rodzajem stosunku pracy, a jedynie jego bardziej elastyczną formą organizacyjną, która może zachowywać wszelkie cechy stosunku pracy ${ }^{108}$. Telepraca w warunkach określonych przez kodeks pracy może być zatem świadczona jedynie przez pracownika (telepracownika) w ramach stosunku pracy ${ }^{109}$. Przepisy dotyczące telepracy w większości realizują postanowienie europejskiego ramowego porozumienia w sprawie telepracy z dnia 16 lipca 2002 r. $^{110}$, zawartego na podstawie art. 139 Traktatu ustanawiającego Wspólnotę Europejską ${ }^{111}$. Na rozwój telepracy, który przypada na lata 60.-70. XX w. ${ }^{112}$, zdecydowany wpływ miał postęp w dziedzinie informatyki i łączności ${ }^{113}$, w szczególności możliwość komunikowania się

106 Ustawa z dnia 24 sierpnia 2007 r. o zmianie ustawy - Kodeks pracy oraz niektórych innych ustaw, Dz.U. Nr 181, poz. 1288.

107 M. Gersdorf, Zatrudnienie pracowników w formie telepracy, „Praca i Zabezpieczenie Spoteczne" 2008, nr 5, s. 9-10.

108 M. Tomaszewska, op. cit., s. 456.

109 Przed wprowadzeniem do kodeksu pracy przepisów dotyczących telepracy jej prawna kwalifikacja nie była możliwa. S.W. Ciupa rozważał, czy ta forma organizacyjna zatrudnienia powinna być zaliczana do nietypowych stosunków pracy, stosunków cywilnoprawnych czy w ogóle być traktowana jako nowy stosunek zatrudnienia z pogranicza prawa pracy i prawa cywilnego. S.W. Ciupa, Umowa o teleprace, „Monitor Prawa Pracy” 2005, nr 3, s. 77. Obecnie pewne jest, że telepraca, do której zastosowanie znajdą przepisy kodeksu pracy, może być świadczona wyłącznie jako forma organizacyjna w ramach stosunku pracy. A. Sobczyk, Telepraca w prawie polskim, Warszawa 2009, s. 35.

110 Porozumienie dostępne na stronie internetowej Confederation Syndicat European Trade Union, www.etuc.org/signature-european-framework-agreement-telework-brussels-16072002 (dostęp: 3.01.2017). Fakt realizacji postanowień Porozumienia szczegółowo opisany został w Opinii merytorycznej do rządowego projektu ustawy o zmianie ustawy - Kodeks Pracy oraz niektórych innych ustaw w szczególności w zakresie: społecznych skutków proponowanych regulacji prawnych, wpływu na rynek pracy (Druk Sejmowy nr 1684), www.orka. sejm.gov.pl/rexdomk5.nsf/Opwsdr?OpenForm\&1684 (dostęp: 3.01.2017).

111 Obecnie art. 155 Traktatu o Funkcjonowaniu Unii Europejskiej (Dz.U.C 326 z dnia 26 października 2012 r., s. 47-390).

112 D. Książek, Telepraca, „Praca i Zabezpieczenie Społeczne”, 2004, nr 7, s. 8.

113 D. Makowski, Praca tymczasowa jako nietypowa forma zatrudnienia, Warszawa 2006, s. 31;

L. Machol-Zajda, Telepraca - nowa forma zatrudnienia, [w:] K.W. Frieske, op. cit., s. 143. 
na odległość za pomocą Internetu. U podwalin telepracy leżą czynniki o charakterze drugoplanowym - dążenie do redukcji zapotrzebowania na paliwo wśród osób aktywnych zawodowo oraz zamiar aktywizacji osób niepełnosprawnych ${ }^{114}$. Telepraca spełnia zasadnicze funkcje $z$ dwóch perspektyw - pracowniczej i pracodawczej ${ }^{115}$. Ta forma organizacyjna zatrudnienia nie tylko umożliwia pracownikom łączenie obowiązków rodzinnych z zawodowymi ${ }^{116} \mathrm{czy}$ też aktywizuje osoby napotykające utrudnienia organizacyjne w wykonywaniu obowiązków pracowniczych $^{117}$ (osoby niepełnosprawne lub zamieszkujące miejsca oddalone od dużych aglomeracji) oraz ogranicza koszty i czas związane z dojazdami do pracy ${ }^{118}$. Jest ona korzystna również dla pracodawców poprzez znaczne ograniczanie kosztów organizacji miejsca pracy ${ }^{119}$ oraz liczby konfliktów w miejscu pracy ${ }^{120}$. Telepraca spełnia zatem swoje założenia systemowe zarówno poprzez pozytywne oddziaływanie na podmioty zatrudniane, jak i zatrudniające.

Tym, co wyróżnia telepracę jako nietypową formę organizacyjną umownego zatrudnienia pracowniczego, jest miejsce świadczenia pracy. Ustalane jest ono co najmniej także poza zakładem pracy ${ }^{121}$. Z powyższego wynika, że telepracownikiem będzie zarówno pracownik pracujący wyłącznie poza zakładem pracy (w swoim domu, w centrum telepracy, w innym miejscu), jak i pracownik łączący pracę w zakładzie pracy z pracą poza nim. Pojęcie „zakład pracy” należy w tym przypadku definiować szeroko, nie ograniczając go do znaczenia przedmiotowego. Pracą w zakładzie pracy będzie zatem również praca wykonywana przez

114 R. Depta, Teleworking jako alternatywna forma pracy w przyszłości, „Praca i Zabezpieczenie Społeczne" 1998, nr 4, s. 10; D. Książek, op. cit.

115 K. Zakrzewska-Szczepańska, Telepraca w Unii Europejskiej i w Polsce, „Służba Pracownicza” 2006, nr 4, s. 10.

116 L. Machol-Zajda, Telepraca..., s. 143. W skrajnych przypadkach praca w domu może powodować zatarcie granicy między życiem prywatnym a zawodowym, prowadząc do pracoholizmu. A. Pyszczak, Czy teleaktywność to szansa na pracę?, [w:] L. Machol-Zajda (red.), Elastyczne formy zatrudnienia sposobem na efektywność firm, Warszawa 2001, s. 91.

117 M. Gersdorf, Zatrudnienie pracowników..., s. 9.

118 A. Pyszczak, op. cit., s. 90-91; S. Driczynski, Elastyczność pojęcia czas pracy, Szczecin 2002, S. 141.

119 A. Mucha, Telepraca jako nowoczesna forma i organizacja zatrudnienia, „Radca Prawny” 2000, nr 5, s. 111; D. Książek, op. cit., s. 9; J. Wratny, Przemiany..., s. 5. Z ograniczeniem kosztów organizacji miejsc pracy związana jest cecha telepracy, która może być przez pracodawców postrzegana negatywnie - zmniejszenie możliwości kontrolnych nad pracownikiem. A. Pyszczak, op. cit., s. 91; D. Książek, op. cit., s. 11; D.E. Lach, Nowe formy zatrudnienia i zabezpieczenia społecznego w zakresie ochrony zdrowia, „Praca i Zabezpieczenie Społeczne" 2006, nr 5, s. 10.

120 A. Sobczyk, Telepraca..., s. 22.

121 Oznacza to, że świadczenie pracy poza zakładem pracy nie musi być stałe, ale musi występować przynajmniej częściowo, aby pracę można było zakwalifikować jako telepracę. D. Książek, op. cit., s. 9; M. Gersdorf, Zatrudnienie pracowników..., s. 10; J. Wiśniewski, Różnorodne formy zatrudnienia, Toruń 2012, s. 61-62. 
konsultanta w zakładzie pracy kontrahenta ${ }^{122}$. Telepraca nie jest zatem zjawiskiem jednolitym. Może bowiem obligować pracownika do pracy wyłącznie poza zakładem pracy (w domu, w centrum telepracy itp.), jak i łącznie wskazywać jako miejsce pracy zakład pracy i obszar poza nim ${ }^{123}$. Dodatkowym warunkiem uznania stosunku pracy za spełniający warunki formy organizacyjnej telepracy jest regularność pracy poza zakładem pracy (art. $67^{1} \$ 1$ k.p.). Wyłączone są zatem sytuacje okazjonalnego świadczenia pracy poza zakładem pracy ${ }^{124}$. Dodatkowo telepracę cechuje obowiązek przekazywania pracodawcy wyników pracy, w szczególności za pośrednictwem środków komunikacji elektronicznej (art. $67^{1} \$ 2$ k.p.). Miejsce świadczenia pracy jest ustalane przez strony stosunku pracy przy zawieraniu umowy o pracę przewidującej wykonywanie pracy w formie telepracy (art. $67^{7}$ W ZW. Z art. 29 k.p.) ${ }^{125}$. W trakcie trwania stosunku pracy zmiana warunków pracy na formę telepracy może nastąpić na mocy porozumienia stron, które powinno określać m.in. miejsce świadczenia pracy ${ }^{126}$. Porozumienie takie zawierane jest $\mathrm{z}$ inicjatywy pracownika lub pracodawcy.

Istotą telepracy, poza świadczeniem pracy co najmniej także poza zakładem pracy, jest wykorzystywanie środków komunikacji elektronicznej ${ }^{127}$. Telepraca, w rozumieniu kodeksu pracy, wykonywana być może wyłącznie przez telepracownika $^{128}$, czyli pracownika wykonującego pracę regularnie poza zakładem pracy z wykorzystaniem środków komunikacji elektronicznej, w szczególności tych, za pomocą których przekazuje on jej efekty. Wykorzystywanie środków komunikacji elektronicznej w procesie pracy różnicuje tę formę organizacyjną od typowego stosunku pracy. Środki komunikacji elektronicznej muszą być wykorzystywane $\mathrm{w}$ toku pracy w formie organizacyjnej telepracy, stanowiąc przy tym jeden ze sposobów przekazywania przez pracownika wyników pracy (art. $67 \$ 1$ i $\$ 2$ k.p.) ${ }^{129}$.

Warunki stosowania telepracy określa się w porozumieniu zawartym przez pracodawcę z zakładową organizacją związkową (art. $67^{6} \$ 1$ k.p.). W przypadku gdy u danego pracodawcy nie działają organizacje związkowe, warunki te zawiera

122 J. Wiśniewski, Różnorodne formy..., s. 65.

123 A. Mucha, op. cit., s. 109.

124 A. Sobczyk, Telepraca..., s. 25.

125 J. Wiśniewski, Różnorodne formy..., s. 64. Odmiennie: A.M. Świątkowski, Kodeks pracy..., s. 356-357. Autor uważa, że w przypadku telepracy strony stosunku pracy nie określają miejsca jej świadczenia.

126 J. Wiśniewski, Różnorodne formy..., s. 87.

127 Środkami komunikacji elektronicznej w rozumieniu ustawy z dnia 18 lipca 2002 r. o świadczeniu usług drogą elektroniczną (Dz.U. z 2016 r., poz. 1030 - t.j. ze zm.) są rozwiązania techniczne, w tym urządzenia teleinformatyczne i współpracujące z nimi narzędzia programowe, umożliwiające indywidualne porozumiewanie się na odległość przy wykorzystaniu transmisji danych między systemami teleinformatycznymi, a w szczególności poczta elektroniczna.

128 A. Sobczyk, Telepraca..., s. 24.

129 S.W. Ciupa, Zatrudnienie pracowników w formie telepracy według kodeksu pracy. Część 1, „Monitor Prawa Pracy” 2007, nr 11, s. 568. 
się w regulaminie telepracy, po uprzedniej konsultacji z przedstawicielem pracowników wyłonionym w trybie przyjętym u danego pracodawcy (art. $67^{6} \$ 4$ k.p.). Niezastosowanie wskazanej procedury nie powoduje jednak nieważności umów o pracę, na podstawie których praca ma być świadczona w formie telepracy, czy też uznania za niebyłe przekształcenia typowego stosunku pracy na tę formę organizacyjną. Jest to jedynie uchybienie natury formalnej ${ }^{130}$.

\subsubsection{Praca tymczasowa}

Zatrudnieniem pracowniczym charakteryzującym się modyfikacją najbardziej ingerującą w strukturę stosunku pracy ${ }^{131}$, a mianowicie w podstawową konfigurację pracownik-pracodawca, jest praca tymczasowa ${ }^{132}$. Konsekwencją tej ingerencji jest również zmiana względem typowego miejsca świadczenia pracy. Rozwój zatrudnienia tymczasowego, wykorzystywanego przy pracach cechujących się sezonowością i zmienną koniunkturą, przypada na lata 60. XX w. W założeniu systemowym praca tymczasowa nie tylko pozwala pracodawcom elastycznie reagować na zmieniającą się sytuację rynkową ${ }^{133}$, dostosowując strukturę zatrudnienia do aktualnego popy$\mathrm{tu}^{134}$. Korzystanie $\mathrm{z}$ pośrednictwa pracy $\mathrm{w}$ ramach zatrudnienia tymczasowego pozwala również obniżyć koszty rekrutacji pracowników ${ }^{135}$ oraz koszty związane z ich bieżącą obsługą kadrową. Jest to też forma pośrednictwa pracy ${ }^{136}$ mająca na celu przeciwdziałanie bezrobociu ${ }^{137}$. Na gruncie prawa polskiego powyższą tezę potwierdza fakt, że agencje pracy tymczasowej, jako agencje zatrudnienia, są instytucjami rynku pracy (zgodnie z art. 6 ust. 1 pkt 3 ustawy o promocji zatrudnienia i instytucjach rynku pracy ${ }^{138}$ ), których zadaniem jest m.in. łagodzenie skutków bezrobocia oraz aktywizacja zawodowa (art. 6 ust. 1 w zw. z art. 1 ust. 1 ww. ustawy) ${ }^{139}$. Zatrud-

130 J. Wiśniewski, Różnorodne formy..., s. 73.

131 J. Wratny, Przemiany..., s. 5.

132 Regulowana ustawą z dnia 9 lipca 2003 r. o zatrudnianiu pracowników tymczasowych, Dz.U. z 2016 r. poz. 360 - t.j., dalej: z.p.t.

133 A. Patulski, Doktrynalne aspekty zatrudnienia tymczasowego (wybrane aspekty), [w:] A. Sobczyk (red.), $Z$ problematyki..., pkt 1.

134 M. Moszyński, Praca tymczasowa - aspekty ekonomiczne i zatrudnieniowe, „Praca i Zabezpieczenie Społeczne" 2004, nr 10, s. 8.

135 Tamże, s. 9.

136 Ewolucję płatnego pośrednictwa pracy w obrębie zatrudnienia tymczasowego przedstawia M. Włodarczyk, Pośrednictwo pracy. Studium prawno-społeczne, Łódź 2002, s. 172-177. W początkowym okresie rozwoju płatnego pośrednictwa pracy jego rola nie była jednoznaczna. Zagadnienie to, z uwzględnieniem zmian w obrębie regulacji MOP, omawia D. Makowski, Praca..., s. 40-49.

137 J. Jończyk, Promocja zatrudnienia i przeciwdziałanie bezrobociu, „Praca i Zabezpieczenie Społeczne" 2004, nr 9, s. 3.

138 Ustawa z dnia 20 kwietnia 2004 r., Dz.U. z 2016 r., poz. 645 - t.j. ze zm.

139 M. Paluszkiewicz, Podmiotystosunku prawnego, [w:] M. Paluszkiewicz, Zatrudnienie tymczasowe w polskim prawie pracy. Konstrukcja i charakter prawny, rozdz. 2, pkt 2.1, https://sip-1lex-1pl-1004153yx0674.han3.lib.uni.lodz.pl/\#/monografia/369234447/15 (dostęp: 19.09.2017). 
nienie tymczasowe spełnia zatem zarówno funkcję uelastyczniania rynku pracy, jak i promowania zatrudnienia ${ }^{140}$.

Zatrudnienie tymczasowe charakteryzuje szczególna trójpodmiotowa więź. Cechą takiego zatrudnienia jest przeniesienie części uprawnień kierowniczych, wynikających ze stosunku pracy, na podmiot niebędący jego stroną, czyli pracodawcę użytkownika ${ }^{141}$, który jest odbiorcą pracy świadczonej przez pracownika tymczasowego. Regulacja zatrudnienia tymczasowego w krajowym porządku prawnym znajduje się w ustawie o promocji zatrudnienia i instytucjach rynku pracy, regulującej status i działalność agencji zatrudnienia świadczącej usługi pracy tymczasowej ${ }^{142}$, oraz w ustawie o zatrudnianiu pracowników tymczasowych. Zgodnie $\mathrm{z}$ art. 5 z.p.t. w zakresie nieuregulowanym odmiennie przepisami ustawy o zatrudnianiu pracowników tymczasowych i przepisami odrębnymi do agencji pracy tymczasowej, pracownika tymczasowego i pracodawcy użytkownika stosuje się przepisy prawa pracy dotyczące odpowiednio pracodawcy i pracownika, z uwzględnieniem ograniczeń wynikających z treści samej ustawy. Wskazana w tym przepisie „odpowiedniość” odnosi się nie tyle do reguł stosowania przepisów prawnych, co do podmiotów zatrudnienia. Względem pracownika tymczasowego stosuje się zatem przepisy prawa pracy dotyczące pracownika (z uwzględnieniem ograniczeń wynikających z treści samej ustawy), natomiast w stosunku do agencji pracy tymczasowej i pracodawcy użytkownika - przepisy dotyczące pracodawcy ( $z$ uwzględnieniem tych samych ograniczeń). Do relacji pracownika tymczasowego i agencji pracy tymczasowej przepisy te stosowane byłyby nawet w przypadku braku stosownego wskazania, skoro podmioty te są pracownikiem i pracodawcą w rozumieniu art. 2 i 3 k.p. Poczynione w art. 5 z.p.t. odniesienie dotyczy zatem raczej relacji pomiędzy pracownikiem tymczasowym a pracodawcą użytkownikiem jako podmiotem realizującym część uprawnień i obowiązków pracodawczych ${ }^{143}$.

Pracą tymczasową jest, od strony przesłanek o charakterze pozytywnym ${ }^{144}$, wykonywanie zadań o charakterze sezonowym, okresowym, doraźnym, których terminowe wykonanie przez pracowników zatrudnionych przez pracodawcę użytkownika nie byłoby możliwe lub których wykonanie należy do obowiązków nieobecnego

140 Promocja zatrudnienia byłaby dodatkowo spełniana, gdyby pracodawcy użytkownicy po zakończeniu korzystania z pracy pracowników tymczasowych zatrudniali ich jako pracowników regularnych. Nie są prowadzone badania, czy w tym zakresie praca tymczasowa spełnia swoje założenia. Informacja uzyskana z Centralnego Informatorium GUS w dniu 3.12.2015 r. (sygnatura pisma: GUS DI01.601.2443.15.MA).

141 A. Chobot, K. Pachciarek, Prawa i obowiqzzki agencji pracy tymczasowej i pracodawcy użytkownika wobec pracownika tymczasowego, „Praca i Zabezpieczenie Społeczne” 2005, nr 1, s. 26.

142 J. Wiśniewski, Różnorodne formy..., s. 136.

143 B. Wagner, Jednolitość..., pkt 4.

144 Negatywne przesłanki pracy tymczasowej wskazuje art. 8 z.p.t. Zostaną one omówione w podrozdz. 1.3. Prawne ograniczenia stosowania umownego zatrudnienia nietypowego. 
pracownika zatrudnionego przez pracodawcę użytkownika ${ }^{145}$ (art. 2 pkt 3 z.p.t.). Praca tymczasowa ma stanowić jedynie pewien przystanek, etap poprzedzający znalezienie zatrudnienia stałego, a ramy pracy tymczasowej są z góry określone ${ }^{146}$. Przy braku ustawowej definicji zarówno pracy sezonowej ${ }^{147}$, okresowej, jak i doraźnej należy odwołać się do powszechnego znaczenia wskazanych pojęćc ${ }^{148}$. Z uwagi na czasowe ograniczenie pracy tymczasowej agencja pracy tymczasowej zawiera z pracownikiem tymczasowym umowę o pracę na czas określony ${ }^{149}$. Możliwość skorzystania jedynie z tego rodzaju umowy o pracę potwierdza terminowy charakter zatrudnienia tymczasowego ${ }^{150}$. Umożliwia ono czasowe, zgodne z zapotrzebowaniem, korzystanie z pracy pracowników tymczasowych ${ }^{151}$, gwarantując prawidłową realizację założonego przez strony celu społeczno-gospodarczego ${ }^{152}$.

Cechą stosunku pracy wpływającą na szczególny status prawny osoby świadczącej pracę tymczasową jest podporządkowanie. Pracownik tymczasowy jest bowiem podporządkowany dwóm podmiotom - agencji pracy tymczasowej i pracodawcy użytkownikowi. Przepis art. 2 pkt 2 z.p.t. definiuje pracownika tymczasowego jako osobę wykonującą pracę pod kierownictwem pracodawcy użytkownika. Uprawnienia pracodawcy użytkownika obejmują jednak jedynie proces organizacji pracy (art. 14 ust. 1 z.p.t.). Należą do nich przykładowo uprawnienie do wyznaczania czasu pracy czy do wydawania poleceń związanych z pracą ${ }^{153}$. Konstrukcja ta nie pozbawia więzi zatrudnienia tymczasowego charakteru praw-

145 Warto zauważyć, że w przeciwieństwie do regulacji umowy o pracę w celu zastępstwa (art. 25 k.p. in fine w brzmieniu sprzed nowelizacji czerwcowej z 2015 r.), regulacja dotycząca pracy tymczasowej nie wymaga, aby nieobecność pracownika była usprawiedliwiona.

146 J. Wiśniewski, Różnorodne formy..., s. 136.

147 Zgodnie z wyrokiem Sądu Najwyższego z dnia 3 kwietnia 1986 r. (II URN 20/86) pracą sezonową jest praca wykonywana przez część roku, związana z określonym sezonem, w szczególności z porą roku. OSNC 1987, nr 2-3, poz. 45.

148 J. Wiśniewski, Różnorodne formy..., s. 136.

149 Nowelizacja czerwcowa z 2015 r., rezygnując z podtypu umowy terminowej, jakim jest umowa na czas wykonania określonej pracy, w art. 8 zmienita ustawę o zatrudnianiu pracowników tymczasowych. Ustawa w nowym brzmieniu zakłada, że praca tymczasowa może być świadczona jedynie na podstawie umowy o pracę na czas określony, a nie - jak w poprzednim stanie prawnym - również na podstawie umowy na czas wykonania określonej pracy.

150 B. Wagner, Jednolitość..., pkt 4.

151 M. Tiraboschi, O. Rymkevitch, The Regulation of Temporary Agency Work at European Union Level: Problems and Perspectives, [w:] T. Davulis, D. Petrylaite (red.), Labour and Social Security Law in the XXI Century: Challenges and Perspectives, Wilno 2007, s. 295-299.

152 M. Paluszkiewicz, Przedmiot stosunku prawnego między agencja pracy tymczasowej a pracodawca użytkownikiem, [w:] M. Paluszkiewicz, Zatrudnienie tymczasowe..., rozdz. 2, pkt 4, https://sip-1lex-1pl-1004153yx0674.han3.lib.uni.lodz.pl/\#/monografia/369234447/18 (dostęp: 19.09.2017).

153 A. Sobczyk, Art. 14, [w:] A. Sobczyk, Ustawa o zatrudnianiu pracowników tymczasowych. Komentarz, https://sip-1lex-1pl-1004153yx0674.han3.lib.uni.lodz.pl/\#/komentarz/587241503/38943 (dostęp: 19.09.2017). 
nopracowniczego. Nie ma bowiem przeszkód, aby pracodawca, czyli agencja pracy tymczasowej, przekazał część uprawnień kierowniczych innemu podmiotowi, czyli pracodawcy użytkownikowi ${ }^{154}$. Pracownik tymczasowy jest zatem zobowiązany do stosowania się do poleceń pracodawcy użytkownika, pomimo że nie łączy go $\mathrm{z}$ nim stosunek pracy oraz do uznania swojego podporządkowania względem pracodawcy, czyli agencji pracy tymczasowej ${ }^{155}$.

\subsubsection{Cywilnoprawne umowne zatrudnienie nietypowe}

Omówione dotychczas podstawy prawne i formy organizacyjne umownego zatrudnienia nietypowego łączył ich pracowniczy charakter. Przejście do omówienia cywilnoprawnych podstaw zatrudnienia ${ }^{156}$ (umowy o pracę nakładczą, umowy zlecenia i umów o świadczenie usług, do których stosuje się przepisy o zleceniu, umowy agencyjnej i umowy o dzieło) powoduje zmianę reżimu prawnego z prawa pracy na prawo cywilne.

Wspólną cechą umów prawa cywilnego związanych z zatrudnieniem jest to, że osoby świadczące pracę na ich podstawie wykonują ją samodzielnie zarówno w sensie organizacyjnym (nie są kierowane przez wydawanie im poleceń ${ }^{157}$ ), jak i majątkowym (dysponują środkami niezbędnymi do wykonania pracy, do której się zobowiązały ${ }^{158}$ ). Powyższe nie pozostaje w sprzeczności z faktem, że strony umowy, w zakresie zasady swobody umów, mogą dowolnie ukształtować treść łączącego je stosunku prawnego, zastrzegając na przykład, że to na podmiocie zlecającym wykonanie pracy ciążyć będzie obowiązek zapewnienia materiałów niezbędnych do wykonania pracy.

154 Z. Kubot, Kierownictwo pracodawcy wobec pracowników wypożyczonych, „Praca i Zabezpieczenie Społeczne” 2002, nr 4, s. 17; A. Reda, Pracodawca użytkownik jako podmiot prawa pracy, Poznań 2011, s. 87-88.

155 Warto zaznaczyć, że agencja pracy tymczasowej, posiadając status pracodawcy, dysponuje uprawnieniami kierowniczymi względem pracownika tymczasowego, o ile nie są to uprawnienia zarezerwowane dla pracodawcy użytkownika. A. Reda, Pracodawca..., s. 91 i nast. Przeciwnie: J. Stelina, Tradycyjna koncepcja stosunku pracy a stosunek pracy tymczasowej - potrzeba refleksji, pkt 5, [w:] A. Sobczyk (red.), Z problematyki zatrudnienia... Autor stwierdza, że w stosunku pracy tymczasowej kierownictwo zostaje „przypisane” pracodawcy użytkownikowi.

156 Zasadniczo w doktrynie powszechnie akceptowany jest pogląd o istnieniu zatrudnienia cywilnoprawnego. Wyjątkiem jest opinia J. Jończyka, który rezerwuje pojęcie „zatrudnienie” dla prawa pracy. J. Jończyk, Rodzaje i formy..., s. 2.

157 W. Balcerak, Sytuacja prawna ajentów w gospodarce uspołecznionej, „Praca i Zabezpieczenie Społeczne" 1975, nr 2, s. 15.

158 M. Piotrowski, [w:] Z. Niedbała (red.), Prawo pracy, Warszawa 2010, s. 102. Wyjątek stanowi regulacja dotycząca pracy nakładczej. Zgodnie bowiem z przepisem $\S 11$ rozp.pr.nakład. zasadniczo to na nakładcy spoczywa obowiązek dostarczenia przedmiotów niezbędnych do wykonania pracy. 
Umowy prawa cywilnego, których przedmiotem jest świadczenie pracy, są podstawą tzw. zatrudnienia cywilnoprawnego. Na potrzeby niniejszego opracowania do umów stosowanych w obrębie zatrudnienia cywilnoprawnego zaliczane będą umowy uregulowane w kodeksie cywilnym, których przedmiotem jest wykonywanie pracy (umowy zlecenia i umowy o świadczenie usług, do których stosuje się przepisy o zleceniu, umowy agencyjne, umowy o dzieło). Ponadto w ramach zatrudnienia cywilnoprawnego omówiona zostanie praca świadczona na podstawie umowy o pracę nakładczą ${ }^{159}$.

\subsubsection{Umowa o pracę nakładczą}

Rozporządzenie regulujące pracę nakładczą wydane zostało na podstawie art. 303 $\$ 1$ k.p. Nie jest ono źródłem prawa pracy w rozumieniu art. 9 k.p., który do „prawa pracy” zalicza co prawda akty wykonawcze, ale z zastrzeżeniem, że dotyczyć one muszą „praw i obowiązków pracowników i pracodawców”. Podmioty umowy o pracę nakładczą nie są pracownikiem i pracodawcą w rozumieniu kodeksu pracy, zatem ta podstawa zatrudnienia nie jest zatrudnieniem pracowniczym ${ }^{160}$. Dopuszczenie w art. 303 k.p. możliwości wydania rozporządzenia będącego podstawą wykonywania pracy nakładczej należy traktować jako przejaw ekspansji podmiotowej prawa pracy ${ }^{161}$. Poza pracą nakładczą pozostałe omawiane podstawy zatrudnienia cywilnoprawnego (umowy zlecenia i umowy, do których stosuje się przepisy o zleceniu, umowy agencyjne, umowy o dzieło) reguluje reżim kodeksu cywilnego.

Rozporządzenie regulujące pracę nakładczą nie wyjaśnia, na czym polega jej istota. Z kontekstu uregulowań wnioskować można, że natura tego stosunku prawnego opiera się na wykonaniu pracy ${ }^{162}$ przy użyciu surowców i maszyn powierzonych wykonawcy przez nakładcę. Praca może być wykonana w lokalu mieszkalnym wykonawcy. Wartość społeczna zatrudnienia nakładczego wyraża się w jego cechach, które nie mieszczą się w konstrukcji stosunku pracy ${ }^{163}$. Z tego punktu widzenia zatrudnienie nakładcze w założeniu systemowym umożliwia aktywizację zawodową osób, dla których praca w domu jest często jedyną możliwością podjęcia działalności zarobkowej ${ }^{164}$ (niepełnosprawnych lub opiekujących

159 Klasyfikację taką potwierdza wyrok Sądu Najwyższego z dnia 9 stycznia 2008 r. (III UK 76/07), który wskazuje na cywilnoprawny charakter pracy nakładczej. LEX nr 465905.

160 W. Szubert, Zakres podmiotowy i przedmiotowy kodeksu pracy, „Państwo i Prawo” 1974, nr 8-9, s. 11; T. Wyka, Regulacja umowy o pracę nakładczą na gruncie polskiego porządku prawnego, „Studia Prawno-Ekonomiczne” 1984, t. 33, s. 60.

161 S. Driczyński, [w:] K.W. Baran (red.), Kodeks pracy. Komentarz, Warszawa 2012, s. 1412.

162 Wykonawca rozliczany jest z efektu, stąd istotą pracy nakładczej jest wykonanie, a nie wykonywanie pracy.

163 T. Wyka, Regulacja..., s. 69.

164 R. Grzymkowski, Aktualne problemy oraz perspektywy rozwoju pracy nakładczej (II), „Praca i Zabezpieczenie Społeczne” 1970, nr 12, s. 20; F. Małysz, Chałupnictwo. Umowa i wynagradzanie, „Służba Pracownicza” 2006, nr 4, s. 12. 
się członkami rodziny), obniżając koszty związane z tworzeniem miejsca pracy. W gospodarce opartej głównie na wiedzy, a nie na wyrobie dóbr ${ }^{165}$, społeczna rola zatrudnienia nakładczego została przejęta przez telepracę.

Obecnie obowiązujący stan prawny nie uszczegóławia natury zatrudnienia nakładczego. W okresie rozwoju tej podstawy zatrudnienia istotę zatrudnienia nakładczego wskazywało rozporządzenie Przewodniczącego Komitetu Drobnej Wytwórczości z dnia 14 maja 1966 r. w sprawie określenia istotnych cech pracy nakładczej jako zatrudnienia wyłączonego spod działania prawa przemysłowego ${ }^{166}$. Zgodnie $\mathrm{z} \$ 1$ ww. aktu prawnego pracą nakładczą było zarobkowe wykonywanie przez osoby fizyczne na zlecenie i na rachunek jednostek gospodarki uspołecznionej (nakładców) czynności w zakresie wytwarzania artykułów, przedmiotów lub ich części z materiałów powierzonych przez nakładcę oraz w zakresie wykańczania, uszlachetniania, naprawy i konserwacji artykułów, przedmiotów lub ich części oraz w zakresie świadczenia innych usług. Pomimo nieuwzględnienia wskazanego wyliczenia w rozporządzeniu w sprawie uprawnień pracowniczych osób wykonujących pracę nakładczą, gospodarcza rola pracy wykonywanej w ramach zatrudnienia nakładczego pozostała niezmieniona.

Szereg uregulowań zatrudnienia nakładczego pokrywa się albo ma swoje odpowiedniki w przepisach dotyczących zatrudnienia pracowniczego ${ }^{167}$. Umowa o pracę nakładczą tworzy względnie trwałą więź między jej podmiotami. Dodatkowo, ponieważ wykonawca rozliczany jest z efektów swoich działań, a nie ze starannego działania, słuszne jest twierdzenie, że praca nakładcza łączy w sobie cechy umowy o pracę (ciągłość zatrudnienia) i umowy o dzieło (jako zobowiązanie rezultatu) $)^{168}$.

\subsubsection{Zlecenie}

Umowa zlecenia, tak jak umowa o pracę, jest umową starannego działania. Jednak cechy konstrukcyjne obu tych podstaw świadczenia pracy są różne, na co zwracano uwage już w literaturze sprzed wejścia w życie kodeksu cywilnego i kodeksu pracy. Roman Longchamps de Berier wywodził, że na gruncie kodeksu zobowiązań zlecenie odróżniało od umowy o pracę to, że umowę tę zawierano nie celem świadczenia pracy jako takiej, ale celem wykonania określonej czynności, załatwienia sprawy, którą powierza się przyjmującemu zlecenie. Przy umowie o pracę pracodawca posługuje się inną osobą, natomiast przy zleceniu dający zlecenie wyręcza się przyjmującym zlecenie. Autor wskazywał ponad-

165 Zatrudnienie nakładcze opiera się na wyrobie dóbr, uzupełniając produkcję odbywającą się w jednostkach podstawowych. R. Grzymkowski, Aktualne problemy oraz perspektywy rozwoju pracy nakładczej (I), „Praca i Zabezpieczenie Społeczne” 1970, nr 11, s. 12.

166 Dz.U. Nr 18, poz. 117.

167 W. Sanetra, Prawo pracy. Zarys wykładów, Białystok 1994, s. 54.

168 M. Gersdorf (red.), Zatrudnieni i zatrudniajacy na aktualnym rynku pracy, Warszawa 2012, s. 177. 
to na brak podporządkowania w przypadku zlecenia ${ }^{169}$. Stanisław Grzybowski w opracowaniu sporządzonym już pod rządami obecnego kodeksu cywilnego dowodził, że cechy charakterystyczne stosunku pracy nie znajdują żadnego odzwierciedlenia w zleceniu dokonania czynności faktycznych, uważając zagadnienie to za dalece bezsporne ${ }^{170}$. Co prawda, powyższy pogląd dotyczył umów o świadczenie usług, do których stosuje się przepisy o zleceniu, ale wydaje się, że zachowuje on swoją aktualność w relacji stosunku pracy do zlecenia unormowanego w art. 734 k.c.

Treścią umowy zlecenia jest staranna praca ludzka, która nie doznaje ucieleśnienia. Założonym przez strony wynikiem działań jest staranność $\mathrm{w}$ ich realizacji, a nie określony materialnie rezultat ${ }^{171}$. Pod rządami kodeksu zobowiązań umowa zlecenia spełniała funkcje zarówno jako umowa mająca za przedmiot czynności prawne, jak i czynności faktyczne ${ }^{172}$. Obecnie przedmiot zlecenia ogranicza się do wykonywania czynności prawnych, o czym mowa będzie dalej, co dodatkowo pomaga wyznaczyć granicę pomiędzy pracą świadczoną $\mathrm{w}$ ramach zlecenia i w ramach umowy o pracę. Pomimo że w kontekście językowym „zlecenie" wykonania określonej czynności wskazuje na nadrzędność podmiotu, który zleca względem podmiotu, który zlecenie przyjmuje, na gruncie obrotu cywilnoprawnego podmioty umowy zlecenia są sobie równe ${ }^{173}$. W związku z powyższym w umowie zlecenia nie występuje podporządkowanie przyjmującego zlecenie względem dającego zlecenie.

Zgodnie z art. 734 k.c. przyjmujący zlecenie, zawierając umowę zlecenia, zobowiązuje się do dokonania określonej czynności prawnej na rzecz dającego zlecenie. Umową zlecenia w ścisłym znaczeniu będzie umowa, na podstawie której przyjmujący zlecenie zobowiązany jest wykonać określoną czynność prawną ${ }^{174}$. Użycie przez ustawodawcę liczby pojedynczej nie wyklucza objęcia zleceniem większej, a nawet nieustalonej ilości czynności prawnych ${ }^{175}$. Umowy dotyczące wykonywania usług nie będą umowami zlecenia sensu stricto ${ }^{176}$. Zleceniem sensu stricto będzie umowa zawarta $\mathrm{w}$ warunkach określonych $\mathrm{w}$ art. 734 k.c. Zgodnie $\mathrm{z}$ dyspozycją art. 750 k.c. do nienazwanych umów o świadczenie usług stosuje się

169 R. Longchamps de Berier, Polskie prawo cywilne - zobowiq̨zania, Lwów 1939, Poznań 1999 (wydanie anastatyczne), s. 552.

170 S. Grzybowski, O przepisach kodeksu cywilnego dotyczących zlecenia, „Nowe Prawo” 1967, nr 10, s. 1279.

171 W. Ludwiczak, op. cit., s. 60-61, 144.

172 L. Ogiegło, Zlecenie, [w:] J. Rajski (red.), Prawo zobowiq̨zań - część szczegółowa, t. 7, Warszawa 2003, s. 437.

173 W. Ludwiczak, op. cit., s. 5-6.

174 K. Kołakowski, [w:] G. Bieniek (red.), Komentarz do kodeksu cywilnego. Księga trzecia. Zobowiqzania, t. 2, Warszawa 2007, s. 387.

175 S. Grzybowski, O przepisach..., s. 1281.

176 Potwierdzenia możliwości wyszczególnienia zlecenia sensu largo i sensu stricte dokonat Sąd Apelacyjny w Gdańsku w wyroku z dnia 16 lipca 2013 r., III AUa 379/13, LEX nr 1353683. 
przepisy o zleceniu ${ }^{177}$, stąd umowy takie często są nazywane zleceniem ${ }^{178}$. Zakres przedmiotowy usług, które mogą być przedmiotem omawianej umowy, jest zasadniczo nieograniczony ${ }^{179}$, stąd znacząca gospodarczo rola tego stosunku prawnego wydaje się niepodważalna. Norma z art. 750 k.c. ma charakter generalny. Znajduje zastosowanie w przypadku gdy umowa zobowiązuje jedną ze stron do świadczenia usług i jest to umowa nieuregulowana innymi przepisami ${ }^{180}$. Rozpowszechnienie w obrocie prawnym umów o świadczenie usług spowodowało osłabienie pierwotnego charakteru umowy zlecenia jako umowy pośrednictwa w dokonywaniu czynności prawnej o charakterze wykwalifikowanej usługi. Charakter zlecenia nie zanikł jednak zupełnie $\mathrm{z}$ uwagi na istnienie gospodarczej potrzeby funkcjonowania w obrocie prawnym umowy mającej za przedmiot dokonanie czynności prawnej.

Przepisy dotyczące zlecenia sensu largo, zatem zarówno zlecenia, jak i umowy o świadczenie usług, do której stosuje się przepisy o zleceniu, mają charakter dyspozytywny $^{181}$. Wyjątek stanowią jedynie art. $746 \$ 3$ k.c. i art. 751 k.c. w zw. $\mathrm{z}$ art. 119 k.c. Strony umowy zlecenia mogą zatem dowolnie ukształtować wszelkie kwestie z nim związane poza możliwością zrzeczenia się z góry uprawnienia do wypowiedzenia umowy z ważnych powodów. Nie mogą one również modyfikować ustawowych terminów dotyczących przedawnienia roszczeń wynikających z umowy zlecenia i umowy zawartej na jego warunkach.

Gospodarcza konieczność funkcjonowania w systemie prawnym umowy zlecenia wydaje się niepodważalna. Usankcjonowana w art. 750 k.c. możliwość zawierania umów nienazwanych, mających za przedmiot czynności faktyczne, $\mathrm{w}$ odniesieniu do których stosuje się przepisy o zleceniu, pełni funkcję klamry legislacyjnej spinającej szeroki katalog umów, mających istotne znaczenie praktyczne w warunkach gospodarki wolnorynkowej ${ }^{182}$. Zasadne jest zatem dalsze obowiązywanie w systemie umów związanych z zatrudnieniem zarówno zlecenia, jak i umów o świadczenie usług, do których stosuje się przepisy o zleceniu ${ }^{183}$.

177 P. Nazaruk, [w:] J. Ciszewski (red.), Kodeks cywilny. Komentarz, Warszawa 2013, s. 1222.

178 Ł. Pisarczyk, Różne formy..., s. 88. M. Gersdorf nazywa umowy takie quasi-zleceniem. M. Gersdorf, Prawo zatrudnienia..., s. 94.

179 W. Sośniak, Umowy o świadczenie usług z artykułu 750 kodeksu cywilnego, „Państwo i Prawo" 1981, nr 5, s. 64.

180 P. Nazaruk, op. cit., s. 1237. W obrocie prawnym umowy całkowicie nowe w stosunku do typów i rodzajów umów uregulowanych w przepisach prawnych w zasadzie nie występują, dlatego do kategorii umów nienazwanych zalicza się przede wszystkim umowy łączące w sobie cechy konstrukcyjne różnych stosunków prawnych. W. Sośniak, op. cit., s. 72.

181 P. Nazaruk, op. cit., s. 1222.

182 K. Kopaczyńska-Pieczniak, Art. 760, [w:] A. Kidyba (red.), Kodeks cywilny. Komentarz, t. 3: Zobowiq̨zania - część szczególna, https://sip-1lex-1pl-1004153yx0674.han3.lib.uni.lodz. pl/\#/komentarz/587286645/462838 (dostęp: 19.09.2017).

183 S. Grzybowski wskazywał na poważną rolę, jaką gospodarczo pełni zlecenie. Autor przedstawiał przykładowy katalog usług nim objętych: umowy o sprawowanie nadzoru inwestorskiego, umowy o prace geologiczne czy umowy stanowiące źródło stosunku prawnego dla akredytywy. S. Grzybowski, O przepisach..., s. 1285-1286. 


\subsubsection{Umowa agencyjna}

Umowa agencyjna ma zbliżony charakter do umowy zlecenia ${ }^{184}$. Agent zobowiązuje się dbać o interesy dającego zlecenie, ale nie jest mu podporządkowany w takim stopniu, w jakim ma to miejsce w przypadku stosunku pracy i relacji łączącej pracownika z pracodawcą. Szczególną cechą umowy agencyjnej jest to, że agent działa $\mathrm{w}$ ramach swojego przedsiębiorstwa, jako profesjonalista. Podmiotowość dającego zlecenie została również ograniczona. Może być nim jedynie przedsiębiorca (art. 758 k.c.). Wyjątek od powyższego stanowi art. $764^{9}$ k.c., obejmujący swoją dyspozycją sytuacje, $\mathrm{w}$ których umowę $\mathrm{z}$ agentem zawiera podmiot niebędący przedsiębiorcą. Przepis ten wyłącza stosowanie do takiej umowy przepisów dotyczących umowy agencyjnej o typowo handlowym charakterze ${ }^{185}$.

Umowa agencyjna, mając za przedmiot stałe pośrednictwo, należy do umów o świadczenie usług, których przedmiotem jest praca w znaczeniu ekonomicznym ${ }^{186}$. Obecny stan prawny umowy agencyjnej obowiązuje od 9 grudnia 2002 r. $^{187}$ Przeobrażenia, jakim została wówczas poddana regulacja kodeksu cywilnego, związane były z procesem integracji Polski z Unią Europejską ${ }^{188}$. Dzięki nim konstrukcja prawna umowy agencyjnej w pełni przystaje do profesjonalnego obrotu gospodarczego, dając przedsiębiorcom prowadzącym działalność handlową na szeroką skalę narzędzie prawne umożliwiające sprawną organizację świadczonych usług. Działalność agentów ułatwia przedsiębiorcom poszerzanie rynków zbytu swoich produktów przy jednoczesnym minimalizowaniu związanego z tym ryzyka finansowego ${ }^{189}$. Z samej istoty umowy agencyjnej wynika bowiem, że to agent ponosi materialne skutki realizacji umowy agencyjnej, nie mając roszczeń o zapłatę niewypracowanej prowizji ${ }^{190}$.

Konstrukcyjnie umowę agencyjną do umowy o pracę zbliża odpłatny charakter oraz stabilizacja, polegająca na trwałej współpracy pomiędzy agentem a dającym zlecenie. Współpraca ta polegać może bądź to na pośredniczeniu w zawieraniu umów, bądź na zawieraniu ich na rzecz dającego zlecenie ${ }^{191}$. Zgodnie z poglądem Sądu Najwyższego podobieństwo do stosunku pracy cechujące się m.in. ograniczonym podporządkowaniem ${ }^{192}$, określonym miejscem

184 E. Rott-Pietrzyk, Umowa agencyjna, [w:] J. Rajski (red.), op. cit., s. 497.

185 E. Rott-Pietrzyk, Dopuszczalność zastrzeżenia wypowiedzenia umowy agencyjnej na czas oznaczony, „Przegląd Prawa Handlowego” 2003, nr 10, s. 47.

186 I. Mycko-Katner, Umowa agencyjna, Warszawa 2012, s. 21-22.

187 Wtedy w życie weszła nowelizacja kodeksu cywilnego. Ustawa z dnia 26 lipca 2000 r. o zmianie ustawy - Kodeks cywilny, Dz.U. Nr 74, poz. 857.

188 Ł. Pisarczyk, Różne formy..., s. 92.

189 I. Mycko-Katner, op. cit., s. 37-38.

190 W. Balcerak, op. cit., s. 16.

191 P. Nazaruk, op. cit., s. 1248-1249.

192 Odmienny pogląd wyraża E. Rott-Pietrzyk. Jej zdaniem agent stosuje się jedynie do wskazówek dającego zlecenie, co ułatwia odróżnienie obu stosunków prawnych. Dający zlecenie może ingerować w działalność agenta jedynie w uzasadnionych okolicznościach. Autorka 
sprzedaży, określonymi zasadami powierzenia mienia czy też odpłatnością, ale nie powoduje automatycznego przekształcenia stosunku agencyjnego w stosunek pracy $^{193}$.

\subsubsection{Umowa o dzieło}

Stosunek prawny o odmiennym od omówionych charakterze powstaje w wyniku zawarcia umowy o dzieło. Umowa o dzieło jest bowiem umową rezultatu ${ }^{194}$, której przedmiotem jest rezultat starań przyjmującego zamówienie ${ }^{195}$, a nie samo staranie. Umowa o dzieło rozwijała się jako druga, obok sprzedaży, forma prawna wymiany dóbr i usług, aby w konsekwencji tego rozwoju stać się umową mającą za przedmiot wytworzenie dobra materialnego ${ }^{196}$. Gospodarczym celem, jaki ma zostać osiągnięty w wyniku realizacji umowy o dzieło, jest rezultat o charakterze samoistnym ${ }^{197}$. Przyjmujący zamówienie zobowiązuje się do osiągnięcia w przyszłości określonego rezultatu w zamian za wynagrodzenie ${ }^{198}$. Z tego względu dzieło podlega weryfikacji w zakresie istnienia wad fizycznych. Nieosiągnięcie umówionego rezultatu powoduje utratę roszczenia o wypłatę wynagrodzenia. Treścią umowy o dzieło jest świadczenie pracy i umiejętności, nieoparte na stosunku zależności wykonawcy od zamawiającego dzieło, które ma doprowadzić do osiągnięcia z góry określonego rezultatu. Rezultat ten ma charakter obiektywnie osiągalny. Ponoszenie materialnej odpowiedzialności za dostarczenie dzieła przez przyjmującego zamówienie pozwala wyznaczyć linię graniczną pomiędzy umową o pracę a umową o dzieło. Pracownik, w przeciwieństwie do przyjmującego zamówienie, nie ponosi odpowiedzialności kontraktowej, gdy świadczona przez niego praca nie spełnia oczekiwań pracodawcy ${ }^{199}$. Zasadność i konieczność funkcjonowania w obrocie prawnym umowy o wskazanym powyżej charakterze są bezsporne.

\subsubsection{Umowy cywilnoprawne w zatrudnieniu tymczasowym}

Odrębnym zagadnieniem z pogranicza prawa pracy i prawa cywilnego, związanym $z$ umownym zatrudnieniem nietypowym, jest zawarcie umowy cywilnoprawnej w ramach zatrudnienia tymczasowego. O możliwości skierowania do pracy tymczasowej na podstawie umowy prawa cywilnego stanowi art. 26 ust. 2 z.p.t. $\mathrm{Z}$ uwagi na to, że w ustępie 1 wskazany przepis reguluje sposób kierowania do

wskazuje, że agent, działający jako profesjonalista, jest podmiotem całkowicie samodzielnym. E. Rott-Pietrzyk, Umowa agencyjna, [w:] J. Rajski (red.), op. cit., s. 499.

193 Wyrok Sądu Najwyższego z dnia 16 stycznia 1979 r., I CR 440/78, LEX nr 5107.

194 M. Gersdorf, Prawo zatrudnienia..., s. 84.

195 K. Jędrej, [w:] J. Ciszewski (red.), Kodeks cywilny. Komentarz, Warszawa 2013, s. 1032.

196 A. Brzozowski, Odpowiedzialność przyjmujacego zamówienie za wady dzieła, Warszawa 1986, s. 22-23.

197 A. Brzozowski, Umowa o dzieło, [w:] J. Rajski (red.), op. cit., s. 329.

198 M. Gersdorf (red.), Zatrudnieni i zatrudniający..., s. 188.

199 K. Jędrej, op. cit., s. 1034; Ł. Pisarczyk, op. cit., s. 38; A. Brzozowski, Umowa..., s. 318, 320; W. Ludwiczak, op. cit., s. 62. 
pracy tymczasowej na podstawie umowy prawa cywilnego osób w wieku 1618 lat, w doktrynie pojawił się pogląd, jakoby możliwość zawarcia umowy prawa cywilnego, która staje się podstawą świadczenia pracy tymczasowej, ograniczała się jedynie do takich osób ${ }^{200}$. Jednakże, ponieważ kierowanie do wykonywania pracy tymczasowej osób niebędących pracownikami reguluje również art. 1 z.p.t, brak jest podstaw ograniczania możliwości zawierania umów cywilnoprawnych ${ }^{201}$ w ramach zatrudnienia tymczasowego do osób w wieku 16-18 lat. W przypadku zawarcia umowy cywilnoprawnej w ramach zatrudnienia tymczasowego zastosowanie mają przepisy prawa cywilnego oraz określone w art. 26 ust. 2 z.p.t. przepisy ustawy o zatrudnianiu pracowników tymczasowych dotyczące zakazu powierzania określonych prac (art. 8 z.p.t.), treści umowy (art. 9 z.p.t.) i obowiązków informacyjnych pracodawcy użytkownika (art. 23 z.p.t.) ${ }^{202}$.

\subsubsection{Podsumowanie}

Przedstawiona wstępna charakterystyka umownego zatrudnienia nietypowego wskazuje zarówno na zróżnicowanie konstrukcyjne w samym jego obrębie, jak i na odmienne cele społeczno-gospodarcze, jakie spełniać mają poszczególne stosunki prawne. Te różnice wpływają z kolei na to, że w założeniach modelowych różnią się między sobą podstawy prawne oraz formy organizacyjne umownego zatrudnienia nietypowego. Cel wprowadzenia do porządku prawnego określonej instytucji prawnej determinuje kreowaną w wyniku jej zastosowania sytuację prawną osoby zatrudnionej. Jedynie wniosek o braku aktualności powodów wprowadzenia do systemu prawnego poszczególnych stosunków mających za przedmiot umowne zatrudnienie nietypowe może uzasadniać postulaty w zakresie konieczności ingerencji legislacyjnej w ich wewnętrzną strukturę.

Wyodrębnienie w kodeksie pracy typów umów terminowych miało spełniać określone funkcje. Umowa o pracę zawarta na czas określony miała na celu zapewnienie trwania zatrudnienia przez z góry umówiony przez strony okres, a umowa o pracę na czas wykonania określonej pracy miała tworzyć stosunek pracy na czas, który nie może być ściśle oznaczony ${ }^{203}$. Natomiast podczas trwania stosunku pracy powstałego na podstawie umowy o pracę na okres próbny pracodawca miał dokonywać weryfikacji posiadanych przez pracownika kwalifikacji ${ }^{204}$, a pracownik zapoznawać się z warunkami pracy. W związku z nowelizacją czerwcową kodeksu pracy z 2015 r. wnioskować można, że ustawodawca uznał brak aktualności niektórych

200 D. Makowski, Praca..., s. 127-128.

201 A. Sobczyk, Zatrudnienie pracowników tymczasowych, „Praca i Zabezpieczenie Społeczne” 2004, nr 4, s. 35.

202 J. Wiśniewski, Różnorodne formy..., s. 228.

203 Z. Salwa, W sprawie..., s. 26.

204 W. Radomski, op. cit., s. 19; Ł. Pisarczyk, op. cit., s. 64. 
powyższych funkcji, spełnianych przez poszczególne rodzaje umów o pracę. Nowelizacja zaprzepaściła stabilizujący charakter umowy o pracę na czas określony, która, zgodnie ze stanem prawnym obowiązującym od 22 lutego 2016 r., może zostać wypowiedziana w każdym momencie. Ponadto ustawodawca nie uznał konieczności i zasadności dalszego obowiązywania podtypu umowy o pracę, jakim jest umowa na czas wykonania określonej pracy. Zmiana taka nie wydaje się słuszna, bowiem przy niektórych rodzajach prac istotne znaczenie dla ich wykonywania mają czynniki zewnętrzne, niemożliwe do określenia w chwili zawierania umowy, wpływające na długość okresu, w którym konieczne jest zatrudnianie pracownika. Nowelizacja dokonała uszczegółowienia gospodarczego celu podtypu umowy o pracę na czas określony - umowy na okres próbny. Jest nim sprawdzenie kwalifikacji pracownika i możliwości jego zatrudnienia w celu wykonywania określonego rodzaju pracy. Cel ten istnieje od początku obowiązywania umowy na okres próbny. Jego normatywne przełożenie w postaci dokładnego ustawowego doprecyzowania wydaje się współgrać ze społeczno-gospodarczym zapotrzebowaniem na ten rodzaj zatrudnienia. Potrzeby takie istnieją również w zakresie korzystania z umów, których celem jest zastępstwo nieobecnego pracownika podczas jego usprawiedliwionej nieobecności. Dokonana nowelizacją czerwcową z 2015 r. rezygnacja z odrębnego podtypu umowy terminowej (umowy o pracę w celu zastępstwa nieobecnego pracownika) nie wyklucza możliwości zatrudniania pracowników w celu zastępstwa nieobecnego pracownika na podstawie umowy o pracę na czas określony, której zakończenie związane będzie z powrotem zastępowanego pracownika.

Aktualność w zakresie realizowanych społeczno-gospodarczych funkcji zachowuje telepraca. Ta organizacyjna forma umownego zatrudnienia pracowniczego pozwala na wykorzystanie technologii umożliwiających porozumiewanie się na odległość celem zmniejszenia kosztów pracy oraz udostępnienia rynku pracy osobom $\mathrm{z}$ niego wykluczonym (np. niepełnosprawnym lub opiekującym się członkami rodziny).

Również aktualne są funkcje spełniane przez zatrudnienie tymczasowe - umożliwienie pracodawcom elastycznego reagowania na zmienną koniunkturę (zatrudnianie w okresach przejściowego zapotrzebowania na pracowników ${ }^{205}$ ) oraz ograniczenie kosztów związanych z rekrutacją i zatrudnianiem pracowników. Ponadto ten rodzaj zatrudnienia wydaje się istotny z punktu widzenia zapobiegania bezrobociu.

Niezbędne dla prawidłowego funkcjonowania gospodarki są wszystkie umowy zaliczane do zatrudnienia cywilnoprawnego - umowa o pracę nakładczą, umowa zlecenia wraz z umowami o świadczenie usług, do których stosuje się przepisy o zleceniu, umowa agencyjna oraz umowa o dzieło. Każda z nich spełnia odrębną funkcję, znajdując zastosowanie we właściwych dla swojej konstrukcji okolicznościach faktycznych. W związku z powyższym reżim prawny poszczególnych

205 D. Makowski, Praca..., s. 22. 
umów stanowiących podstawy zatrudnienia cywilnoprawnego w odmienny sposób reguluje status prawny osób świadczących pracę. Status ten jest również, ze względu na różnice systemowe, inny niż status pracowniczy. Poza pracą nakładczą, cywilnoprawne podstawy zatrudnienia nie zostały objęte dotąd ochroną właściwą dla prawa pracy, pomimo że w rzeczywistości ich wykonawcy mają podobny statusu społeczno-gospodarczy jak pracownicy ${ }^{206}$. Podobieństwo warunków wykonywania pracy na podstawie umów cywilnoprawnych i umów o pracę wynika nie tyle $\mathrm{z}$ regulacji prawnej, w wyniku stosowania której zbliżona zostaje sytuacja prawna osób zatrudnionych, co z praktyki ich wykorzystywania ${ }^{207}$. Teoretycznie łatwo odróżnić pracownicze podporządkowanie poleceniom pracodawcy od stosowania się do wskazówek podmiotu zatrudniającego w relacji opartej na konstrukcji umowy prawa cywilnego ${ }^{208}$. To z kolei umożliwia odróżnienie relacji prawnopracowniczej od cywilnoprawnej. Jednak często ta sama praca może być wykonywana w ramach pracowniczego podporządkowania, jak i poza nim, dlatego o kwalifikacji prawnej zatrudnienia świadczyć będą warunki realizacji umowy. Na możliwość istnienia pewnych cech podporządkowania i kierownictwa w stosunkach cywilnoprawnych, utrudniających odróżnienie go od zatrudnienia pracowniczego, uwagę zwrócił Sąd Najwyższy w wyroku z dnia 11 września 2013 r. $^{209}$

Wydaje się, że ewolucja regulacji dotyczących prawa związanego z zatrudnieniem powinna zmierzać raczej do wyodrębniania nowych, samodzielnych stosunków zobowiązaniowych, a nie w kierunku łączenia systemowo odrębnych stosunków prawnych w jedną kategorię pojęciową ${ }^{210}$. Dlatego też istniejące obecnie zróżnicowanie podstaw prawnych i form organizacyjnych umownego zatrudnienia nietypowego uważam za uzasadnione zarówno z perspektywy społecznego, jak i gospodarczego ich wykorzystywania ${ }^{211}$. Zatrudnienie nietypowe, w szczególności terminowe umowy o pracę, umożliwiają stymulowanie strukturą zatrudnienia w zależności od koniunktury gospodarczej, przy jednoczesnym zachowaniu

206 Z. Hajn, Aspekty prawne..., s. 23. Należy zgodzić się z poglądem, że zbliżenie do zatrudnienia pracowniczego przejawia się w obecnej sytuacji na rynku pracy głównie w taki sposób, że podmioty świadczące pracę na podstawie umowy prawa cywilnego, tak jak pracownicy, z reguły związane są tylko z jednym podmiotem zatrudniającym. J. Wratny, Przemiany..., s. 6.

207 Odmiennie: A. Patulski, Doktrynalne..., s. 365. Autor przedstawia tezę o zbliżeniu umów cywilnoprawnych do umowy o pracę na wielu płaszczyznach.

208 A. Chobot, Nowe formy zatrudnienia. Kierunki rozwoju i nowelizacji, Warszawa 1997, s. 181. Możliwość wskazywania sposobu wykonywania umowy zlecenia przedstawia S. Koczur, Differentia specifica „podporządkowania” właściwego dla stosunku pracy a umów cywilnoprawnych, „Monitor Prawa Pracy” 2015, nr 2, s. 68-69.

209 II PK 372/12, LEX nr 1474905.

210 Potrzebę takiej ewolucji w zakresie relacji pracy nakładczej i stosunku pracy postulowata T. Wyka, Regulacja..., s. 70. Wydaje się, że postulat ten zachowuje aktualność nie tylko względem wskazanej relacji, ale względem wszystkich umów związanych z zatrudnieniem nietypowym.

211 D. Makowski, Praca..., s. 19. 
miejsc pracy przez pracowników zatrudnionych na podstawie umowy o pracę na czas nieokreślony. Stosunki prawne realizujące odmienne funkcje różnicują status prawny osób objętych ich zakresem. Dalsze rozważania skupią się na przedstawieniu tego zróżnicowania z perspektywy osób świadczących pracę.

\subsection{Prawne ograniczenia stosowania umownego zatrudnienia nietypowego}

\subsubsection{Uwagi wprowadzające}

Wskazana w części poprzedzającej niniejszy podrozdział analiza w zakresie zasadności zachowania odrębności systemowej poszczególnych podstaw prawnych i form organizacyjnych umownego zatrudnienia nietypowego, spełniających różne funkcje społeczno-gospodarcze, zostanie uzupełniona o rozważania obejmujące zagadnienia związane $\mathrm{z}$ ograniczaniem możliwości ich stosowania. Regulacje obejmujące prawne sposoby takiego ograniczania wyznaczają ramy prawne, w których stosowanie umownego zatrudnienia nietypowego jest dopuszczalne. Przedstawienie ograniczeń prawnych pozwoli określić obszar, w którym ustawodawca dopuszcza występowanie umownego zatrudnienia nietypowego.

Zmierzając do pełnego, produktywnego zatrudnienia, zgodnie $\mathrm{z}$ dyspozycją art. 65 ust. 5 Konstytucji, ustawodawca dążyć powinien do promowania zatrudnienia długoterminowego, trwałego i zapewniającego jego stronom jak największą stabilizację, czyli zatrudnienia typowego, pożądanego zarówno przez osoby zatrudniane, jak i przez ustawodawcę. Polski porządek prawny nie zawiera norm nakazujących wybór zatrudnienia typowego ani takich, które nakazywałyby uzasadnianie zastępowania go zatrudnieniem nietypowym ${ }^{212}$. Istnieją jednak prawne ograniczenia stosowania umownego zatrudnienia nietypowego, których celem jest egzekwowanie obowiązującego prawa. Legislacyjna faworyzacja zatrudnienia typowego nie odnosi się do takich jego cech jak wymiar czasu pracy, miejsce świadczenia pracy oraz określenie beneficjenta pracy. W szczególności dotyczy ona ograniczeń w zakresie wyboru rodzaju umowy o pracę. Ustawodawca wprowadza mechanizmy prawne mające na celu wzrost współczynnika zawierania umów o pracę na czas nieokreślony, a nie zatrudnienia typowego w ogólności. Zasadniczo bowiem poza obszarem legislacyjnej ingerencji pozostaje organizacyjne ukształtowanie stosunku pracy, które może mieć wpływ na zaliczenie danej więzi do zatrudnienia typowego bądź nietypowego.

212 Jako granicę liberalizacji prawa pracy L. Florek podaje właśnie uzasadnianie zastępowania zatrudnienia tradycyjnego. L. Florek, Prawne formy..., s. 22. 
Osoby zatrudnione na innej podstawie bądź w innej formie organizacyjnej niż umowa o pracę na czas nieokreślony w wariancie typowym (praca świadczona w siedzibie pracodawcy, na jego rzecz, w pełnym wymiarze czasu pracy) często postrzegane są jako znajdujące się w gorszej sytuacji prawnej ${ }^{213}$ i faktycznej. W odniesieniu do sytuacji faktycznej powodem takiego poglądu jest słuszne przekonanie o braku ścisłego związku między osobą zatrudnioną i podmiotem zatrudniającym w przypadku istnienia więzi o charakterze przejściowym, doraźnym, która powoduje brak pewności zatrudnienia. $\mathrm{W}$ następstwie powstania relacji o nietrwałym charakterze podmiot zatrudniający nie ma bodźców nakłaniających go do inwestowania w rozwój osoby zatrudnionej, przez co utrzymane zostaje status quo dotyczące jej umiejętności ${ }^{214}$. Nietrwały charakter zatrudnienia oddziałuje negatywnie również na inne płaszczyzny życia, jak choćby brak zdolności kredytowej, uniemożliwiający otrzymanie środków z instytucji bankowych $^{215}$. Na sytuację prawną osób zatrudnionych wpływa szereg regulacji, w tym np. unormowania dotyczące możliwości wypowiedzenia umowy. W tym zakresie status prawny osób świadczących pracę jest korzystniejszy w umownym zatrudnieniu typowym aniżeli w zatrudnieniu nietypowym.

Przeciwnicy promowania zatrudnienia typowego wyrażają pogląd, że hamuje ono rozwój gospodarczy. Uważają zatrudnienie nietypowe (elastyczne) za motor napędzający wzrost efektywności przedsiębiorstw ${ }^{216}$. Istnieje również pogląd, że klasyczny stosunek pracy nie przystaje do współczesnych potrzeb gospodar$\mathrm{czych}^{217}$. Nie można jednak nie brać pod uwagę faktu, że gospodarkę napędzają konsumenci, którzy muszą mieć zapewnione stałe środki do życia, aby nabywać wytwarzane przez nią dobra. Pozbawieni pewnego zatrudnienia obywatele nie będą pożądanymi, z punktu widzenia gospodarki, konsumentami. Ich sytuacja prawna, powodująca brak pewności co do istnienia źródła utrzymania, będzie hamować decyzje związane $\mathrm{z}$ nabywaniem dóbr materialnych ${ }^{218}$. Dlatego również z powyższych względów promowane jest zatrudnienie typowe.

Nie oznacza to jednak, że odrębności dotyczące umownego zatrudnienia nietypowego w zakresie kształtowania stosunku prawnego, związane z jego społeczno-gospodarczymi celami, powinny zostać zniwelowane. W założeniach legislacyjnych, omówionych w poprzedniej części niniejszego rozdziału, rodzaje umownego zatrudnienia nietypowego mają spełniać określone funkcje. W zależności od rodzaju zatrudnienia nietypowego są one następujące:

213 A. Patulski, Doktrynalne..., s. 359.

214 Z. Góral, Najnowsze tendencje..., s. 226.

215 J. Wratny, Problemy ochrony pracowników w elastycznych formach zatrudnienia, „Praca i Zabezpieczenie Społeczne" 2007, nr 7, s. 3.

216 J. Wojtyła, op. cit., s. 385-386.

217 B. Wagner, Jednolitość..., pkt II.

218 Potwierdza to teoria wyboru konsumenta, która wymienia dochód jako jeden z czynników wpływający na to, czy konsument nabędzie określone dobro. M. Nasiłowski, System rynkowy: podstawy mikro- i makroekonomii, Warszawa 2011, s. 98 i nast. 
a) umożliwienie stosowania zatrudnienia terminowego w przypadku gdy możliwe jest określenie terminu końcowego pracy bądź zakresu jej wykonania (umowa o pracę na czas określony)

b) umowa na czas wykonania określonej pracy, obowiązująca w stanie prawnym sprzed nowelizacji czerwcowej z $2015 \mathrm{r}$.

c) umożliwienie zastąpienia nieobecnego pracownika podczas jego usprawiedliwionej nieobecności (umowa o pracę w celu zastępstwa nieobecnego pracownika, obowiązująca w stanie prawnym sprzed nowelizacji z 2015 r.)

d) umożliwienie świadczenia pracy poza zakładem pracy z wykorzystaniem środków komunikacji elektronicznej (telepraca)

e) umożliwienie korzystania z pracy osób zatrudnionych przez podmiot trzeci w przypadku wzmożonego zapotrzebowania na pracowników (zatrudnienie tymczasowe)

f) umożliwienie korzystania z organizacyjnie niepodporządkowanej pracy o rodzajowo różnym przedmiocie (zatrudnienie cywilnoprawne).

Ograniczanie stosowania umownego zatrudnienia nietypowego nie wyłącza zasadności jego wyboru w warunkach właściwych jego cechom.

Zatrudnienie typowe najpełniej realizuje postulat pełnego i produktywnego zatrudnienia $^{219}$, dlatego ustawodawca wprowadza ograniczenia stosowania podstaw prawnych i form organizacyjnych zatrudnienia nietypowego w warunkach właściwych zatrudnieniu typowemu. Ograniczenia te wpływają na status prawny osób zatrudnionych, nierzadko determinując konieczność wyboru konkretnej więzi zatrudnienia bądź przekształcając ją z mocy prawa. Konstrukcje prawne omówione zostaną zgodnie z przyjętą uprzednio systematyką, poczynając od poszczególnych rodzajów umów o pracę, przechodząc do formy organizacyjnej świadczenia pracy, jaką jest telepraca, poprzez pracę tymczasową, a kończąc rozważaniami dotyczącymi cywilnoprawnych podstaw zatrudnienia.

\subsubsection{Prawne ograniczenia stosowania pracowniczego umownego zatrudnienia nietypowego}

Dyrektywa nr 99/70/WE ${ }^{220}$ wprowadza regulacje, których celem jest zapobieganie nadużyciom związanym z zawieraniem następujących po sobie umów terminowych ${ }^{221}$. Zgodnie z klauzulą 5 pkt 1 wyżej wymienionej dyrektywy państwa

219 Sąd Najwyższy wskazał, że umowa o pracę zawarta na czas nieokreślony jest standardem prawa pracy. Wyrok z dnia 16 kwietnia 1998 r., III ZP 52/97, LEX nr 32575.

220 Dyrektywa Rady nr 99/70/WE z dnia 28 czerwca 1999 r. dotycząca Porozumienia ramowego w sprawie pracy na czas określony, zawartego przez Europejską Unię Konfederacji Przemysłowych i Pracodawców (UNICE), Europejskie Centrum Przedsiębiorstw Publicznych (CEEP) oraz Europejską Konfederację Związków Zawodowych (ETUC).

221 M. Matey-Tyrowicz, Nietypowe formy..., s. 158. 
członkowskie mogą wprowadzić jeden lub więcej spośród następujących środków służących zapobieganiu stosowania zatrudnienia terminowego:

a) obiektywne powody, uzasadniające odnowienie takich umów lub stosunków pracy

b) maksymalną łączną długość kolejnych umów o pracę lub stosunków pracy na czas określony

c) liczbę odnowień takich umów lub stosunków.

Zdaniem Jerzego Wratnego najpełniej dyrektywę realizowałaby regulacja dotycząca obowiązku uzasadniania, poprzez określenie obiektywnych powodów, zawarcia kolejnej umowy o pracę na czas określony ${ }^{222}$. Jednakże „obiektywne powody" mają, mimo warunku obiektywizmu, charakter ocenny i taka regulacja podlegałaby łatwej manipulacji. Poglądu Wratnego nie podziela Małgorzata Gersdorf, uważając, że wskazywanie przyczyny zarówno zawarcia, jak i rozwiązania umowy o pracę na czas określony przekreśla jej charakter związany z elastycznością zatrudnienia ${ }^{223}$.

W krajowym porządku prawnym postanowienia dyrektywy nr 99/70/WE ma realizować art. $25^{1}$ k.p. Zgodnie z normą art. $25^{1}$ k.p. w brzmieniu obowiązującym do 22 lutego 2016 r. zawarcie kolejnej umowy o pracę na czas określony było równoznaczne w skutkach prawnych z zawarciem umowy o pracę na czas nieokreślony, jeżeli strony uprzednio dwukrotnie zawarły umowę o pracę na czas określony na następujące po sobie okresy, o ile przerwa między rozwiązaniem poprzedniej a nawiązaniem kolejnej umowy o pracę nie przekroczyła jednego miesiąca ${ }^{224}$. Wprowadzone w 1996 r. ${ }^{225}$ regulacje w sposób znamienny wpłynęly na sytuację prawną osób zatrudnionych. Pomimo zawarcia umowy o pracę na czas określony, $\mathrm{w}$ przypadku ziszczenia się przesłanek wskazanych w art. $25^{1} \mathrm{k}$.p. umowa taka wywoływała skutki prawne równoznaczne z zawarciem umowy o pracę na czas nieokreślony. $Z$ uwagi na niewyeliminowanie problemu tzw. aneksowania umów, czyli przedłużania okresu ich obowiązywania w trakcie trwania stosunku pracy, w 2004 r. ustawodawca znowelizował wskazany przepis ${ }^{226}$, wprowadzając ograniczenie, zgodnie $\mathrm{z}$ którym uzgodnienie między stronami w trakcie trwania umo-

222 J. Wratny, Problemy ochrony..., s. 3.

223 M. Gersdorf, O przyczynowości..., s. 224. Stanowisko to jest zasadne jedynie przy uznaniu, że założeniem systemowym umowy o pracę na czas określony nie jest stabilizacja zatrudnienia do z góry ustalonego terminu.

224 Analogiczna regulacja prawa greckiego (przewidująca przerwę między umowami o pracę na czas określony w wymiarze 20 dni roboczych) uznana została przez Europejski Trybunał Sprawiedliwości za sprzeczną z dyrektywą nr 99/70/WE, jako niespełniająca wymogów jej implementacji (Wyrok Europejskiego Trybunału Sprawiedliwości z dnia 4 lipca 2006 r., C-212/04, Zb. Orz. 2006, 2. I-6057, pkt 84-85). L. Mitrus, Kilka uwag..., s. 258-259.

225 Ustawa z dnia 2 lutego 1996 r. o zmianie ustawy - Kodeks pracy oraz o zmianie niektórych ustaw, Dz.U. Nr 24, poz. 110.

226 Ustawa z dnia 14 listopada 2003 r. o zmianie ustawy - Kodeks pracy oraz o zmianie niektórych innych ustaw, Dz.U. Nr 213, poz. 2081. 
wy o pracę na czas określony dłuższego okresu wykonywania pracy na podstawie tej umowy uważane było za zawarcie, od dnia następującego po jej rozwiązaniu, kolejnej umowy o pracę na czas określony w rozumieniu ilości następujących po sobie umów, liczonej zgodnie $z$ art. $25^{1} \$ 1$ k.p. (art. $25^{1} \$ 2$ k.p.) ${ }^{227}$.

Przepis art. $25^{1}$ k.p. w sposób oczywisty ograniczał swobodę woli stron stosunku pracy w odniesieniu do możliwości wielokrotnego zawierania umów o pracę na czas określony, następujących niemalże bezpośrednio po sobie ${ }^{228}$. Miał on zastosowanie jedynie do umowy o pracę na czas określony. Nie dotyczył natomiast innych umów terminowych, pozostając w tym zakresie w sprzeczności ze wskazaną dyrektywą ${ }^{229}$. W zakresie nieobjęcia regulacją art. $25^{1} \mathrm{k}$.p. innych niż umowa na czas określony umów terminowych należy zauważyć, że umowa o pracę na okres próbny, zgodnie $\mathrm{z}$ art. 25 k.p., mogła być zawarta tylko raz w oparciu o te same okoliczności. Zatem z istoty tej podstawy zatrudnienia wynikał brak możliwości włączenia jej do hipotezy art. $25^{1} \mathrm{k}$.p. Umowy o pracę zawarte w celu zastępstwa nieobecnego pracownika i umowy o pracę zawarte w celu wykonywania pracy o charakterze dorywczym, sezonowym albo w celu wykonywania zadań realizowanych cyklicznie zostały wyłączone spod norm art. $25^{1} \$ 1$ k.p. w art. $25^{1} \$ 3$ k.p. Z wykładni gramatycznej art. $25^{1}$ k.p. wnioskować należało, że przepis ten odnosił się wyłącznie do umowy o pracę na czas określony, dlatego nie można było stosować go również w odniesieniu do umowy o pracę na czas wykonania określonej pracy. Zgodnie z art. 25 k.p. umowa o pracę na czas wykonania określonej pracy była odrębnym rodzajem umowy o pracę, której art. $25^{1}$ k.p. nie dotyczył ${ }^{230}$.

227 D.E. Lach wskazuje, że unormowania art. 251 k.p. pozostają w sprzeczności ze spełnianiem rzeczywistych potrzeb pracodawców i pracowników, tworząc fikcje prawne, które tychże potrzeb nie biorą pod uwagę. D.E. Lach, op. cit., s. 10.

228 Z. Góral, Swoboda nawiq̨zania stosunku pracy jako jedna z podstawowych zasad prawa pracy, [w:] Z. Niedbała, M. Skąpski (red.), op. cit., s. 65; A.M. Świątkowski, Kodeks pracy..., s. 152; M. Tomaszewska, op. cit., s. 208.

229 Zgodnie z klauzulą 3 pkt 1 dyrektywy nr 99/70/WE „pracownikiem zatrudnionym na czas określony” jest osoba, która „zawarła umowę o pracę lub stosunek pracy bezpośrednio między pracodawcą a pracownikiem, a termin wygaśnięcia umowy o pracę lub stosunku pracy jest określony przez obiektywne warunki, takie jak nadejście dokładnie określonej daty, wykonanie określonego zadania lub nastąpienie określonego wydarzenia”. Dyrektywa nie ogranicza stosowania regulacji nią objętych do umowy o pracę na czas określony. Dotyczy ona wszystkich umów terminowych. Ł. Pisarczyk, Terminowe umowy..., s. 5. W związku ze wskazaną sprzecznością Komisja Krajowa NSZZ „Solidarność” złożyła skargę do Komisji Europejskiej, www.solidarnosc.org.pl/images/files/dokumenty/eksperckie/ke/ Wniosek_umowy.pdf (dostęp: 3.01.2017). Pismem z 11 grudnia 2013 r. Komisja Europejska poinformowała Przewodniczącego Komisji Krajowej NSZZ „Solidarność, że w sprawie zarzutów zawartych w skardze skontaktowała się z władzami polskimi i wszczęła oficjalne postępowanie w sprawie uchybienia zobowiązaniom państwa członkowskiego. Jednocześnie Komisja oficjalnie wezwała władze polskie do usunięcia uchybień. Nowelizacja czerwcowa z 2015 r. wypełnia powyższe postulaty.

230 T. Romer, Kodeks..., s. 262. 
Pomimo że regulacja art. $25^{1}$ k.p. nie była doskonała (w wyniku jej stosowania powstawała wątpliwość interpretacyjna dotycząca pojęcia „miesiąc”, stosowania pomiędzy umowami o pracę umów cywilnoprawnych czy przedłużania czasu pomiędzy umowami do ponad jednego miesiąca ${ }^{231}$ ), uznać ją należy za słuszny krok ustawodawcy w kierunku niwelowania zatrudnienia pozornie krótkotrwałego. Pomiędzy stronami, które zawierały kolejną umowę o pracę na czas określony, powstaje względnie trwała więź, która powinna zostać przekształcona w zatrudnienie bezterminowe. Nowelizacja czerwcowa z 2015 r. dokonała zmiany brzmienia art. $25^{1} \mathrm{k}$.p. poprzez wprowadzenie limitu trwania zatrudnienia na podstawie umowy o pracę na czas określony w wysokości 33 miesięcy (bez względu na to, czy limit ten został osiągnięty w wyniku trwania jednej umowy, czy też jest efektem zsumowania okresów zatrudnienia, które nie muszą występować bezpośrednio po sobie) przy dodatkowym ograniczeniu łącznej liczby umów do trzech. W przypadku zatrudnienia na podstawie więcej niż trzech umów o pracę na czas określony bądź przez okres dłuższy niż 33 miesiące uważa się, że pracownik, odpowiednio od dnia następującego po tym okresie bądź od dnia zawarcia czwartej umowy o pracę na czas określony, jest zatrudniony na podstawie umowy o pracę na czas nieokreślony ${ }^{232}$. Poza regulacją art. $25^{1} \mathrm{k}$.p. pozostaje umowa na okres próbny, ale nowelizacją ustawodawca wprowadził inne ograniczenia stosowania umowy na okres próbny. Należą do nich:

- maksymalny, trzymiesięczny termin trwania okresu próby (tak jak w stanie prawnym sprzed nowelizacji)

- brak możliwości zawarcia kolejnej umowy na okres próbny w przypadku tego samego rodzaju pracy, chyba że miałoby to nastąpić po upływie co najmniej 3 lat od dnia rozwiązania bądź wygaśnięcia poprzedniej umowy o pracę.

W art. $25^{1}$ k.p., w treści obowiązującej od 22 lutego 2016 r., ustawodawca przewidział cztery przypadki wyłączające przekształcenie się umowy o pracę na czas określony w umowę o pracę na czas nieokreślony ${ }^{233}$. Pierwszy $\mathrm{z}$ nich dotyczy umowy zawartej w celu zastępstwa nieobecnego pracownika, drugi - prac o charakterze dorywczym lub sezonowym, trzeci - zatrudnienia w celu wykonywania pracy przez okres kadencji ${ }^{234}$, natomiast ostatnie wyłączenie stosowania art. $25^{1}$ k.p. związane jest z obiektywnymi przyczynami leżącymi po stronie pracodawcy, przy ograniczeniu ich zakresu do wymogów rzeczywistego zapo-

231 Możliwe sposoby obchodzenia normy art. 251 k.p. w stanie prawnym sprzed nowelizacji czerwcowej z 2015 r. przedstawia M. Rylski, Ochrona pracownika przed nadużywaniem terminowego zatrudnienia, „Praca i Zabezpieczenie Społeczne” 2014, nr 8, s. 3-4.

232 Do przekształcenia dochodzi z mocy prawa. L. Mitrus, Projekt nowelizacji..., s. 288.

233 Powyższe powoduje, że obecnie art. 251 k.p. stanowi kombinację wszystkich trzech środków przeciwdziałających nadużywaniu zatrudnienia terminowego przewidzianego przez dyrektywę nr 99/70/WE. J. Stelina, Nowa koncepcja umowy..., s. 42.

234 L. Mitrus, Projekt nowelizacji.... 
trzebowania i niezbędności zatrudnienia na czas określony. Zastosowanie przez ustawodawcę klauzul generalnych ${ }^{235}$ może zniweczyć założenia ustanowionych zmian, dając pracodawcom stosunkowo szeroki zakres swobody w ich stosowaniu $^{236}$. Powyższego nie zmienia fakt, że w przypadku skorzystania $\mathrm{z}$ dyspozycji art. $25^{1} \$ 4$ k.p. po nowelizacji pracodawca musi zawiadomić właściwego inspektora pracy (art. $25^{1} \$ 5$ k.p.). Nowelizacja czerwcowa z 2015 r. nie dokonała zmian w zakresie wyłączenia spod dyspozycji art. $25^{1} \mathrm{k}$.p. zatrudnienia tymczasowego, pozostawiając umowy o pracę tymczasową, niedające możliwości wcześniejszego wypowiedzenia, jedynymi umowami o pracę spełniającymi systemowe założenia umów terminowych w postaci trwania do oznaczonego momentu.

Regulacje dotyczące automatyzmu prawnego w przekształcaniu zatrudnienia w bezterminowe w sposób doniosły wpływają na sytuację prawną osób zatrudnionych w kontekście promowania zatrudnienia typowego. W pozostałych przypadkach, opisanych poniżej, sankcjonowane są przepisy wytyczające ramy prawne stosowania zatrudnienia nietypowego, w niektórych przypadkach ściśle związane z cechami konstrukcyjnymi omawianych stosunków prawnych. Dzięki temu, eliminując sytuacje patologiczne, ustawodawca wskazuje, w jakich okolicznościach umowne zatrudnienie nietypowe spełnia swoje społeczno-gospodarcze cele.

W odniesieniu do telepracy brak możliwości zastosowania tej formy organizacyjnej pracy w ramach jednostronnej decyzji uznać należy nie tyle za promowanie zatrudnienia typowego, ile za przejaw dwustronnie zobowiązującego charakteru stosunku pracy ${ }^{237}$. Dodatkowo jest to wyraz dobrowolności podejmowania telepracy oraz usankcjonowanie zasady wolności pracy wyrażonej w art. 10 k.p. ${ }^{238}$ Konstrukcja prawna zatrudnienia w formie telepracy w art. $67^{9} \mathrm{k}$.p. jednoznacznie przekreśla możliwość uznania za przyczyny rozwiązania stosunku pracy zarówno odmowę pracy w tej formie organizacyjnej, jak i wniosek pracownika o zaprzestanie wykonywania pracy w formie telepracy. Jest to potwierdzenie istnienia dobrowolności zarówno co do przyjęcia, jak i kontynuowania pracy w formie organizacyjnej telepracy ${ }^{239}$. Powyższe nie wyłącza prawa pracodawcy do wypowiedzenia umowy o pracę z przyczyn niedotyczących pracownika, którymi mogą być dla przykładu brak możliwości zapewnienia stanowiska pracy w systemie typowym czy brak racjonalności ekonomicznej w utrzymaniu typowego stanowiska pracy ${ }^{240}$.

235 Klauzulami takimi są choćby wymogi wskazania „obiektywnych przyczyn” czy „niezbędność zatrudnienia".

236 L. Mitrus, Projekt nowelizacji...; J. Stelina, Nowa koncepcja umowy..., s. 45. Stelina wskazuje, że niełatwe będzie ustalenie desygnatów tego pojęcia.

237 O dwustronnie zobowiązującym charakterze stosunku pracy: W. Szubert, O charakterze prawnym stosunku pracy, „Państwo i Prawo” 1964, nr 7, s. 81-96.

238 A.M. Świątkowski, Kodeks pracy..., s. 360.

239 M. Tomaszewska, op. cit., s. 465.

240 M. Gersdorf, Zatrudnienie pracowników..., s. 12; A. Sobczyk, Zakres przedmiotowy negatywnych przyczyn wypowiedzenia umowy o pracę, [w:] A.M. Świątkowski (red.), Ochrona praw 
Możliwe jest również wystąpienie przez każdą ze stron stosunku pracy, w terminie 3 miesięcy od dnia rozpoczęcia pracy w formie organizacyjnej telepracy, $\mathrm{z}$ wiążącym drugą stronę wnioskiem o zaprzestanie pracy w takiej formie (art. $67^{8} \$ 1$ k.p.). Wtedy w terminie ustalonym przez strony, nie dłuższym jednak niż 30 dni od dnia otrzymania wniosku, zostają przywrócone poprzednie warunki pracy. Oznacza to, że strony stosunku pracy mają 3 miesiące na sprawdzenie, czy forma organizacyjna telepracy jest dla nich odpowiednia. Powyższe potwierdza zasadę dobrowolności pracy w warunkach telepracy. Pracodawca, po upływie 3 miesięcy od dnia rozpoczęcia pracy w formie organizacyjnej telepracy, chcąc przywrócić poprzednie warunki pracy, może tego dokonać poprzez skorzystanie z wypowiedzenia warunków pracy (art. $67^{8} \$ 3$ k.p.).

Zatrudnienie tymczasowe, jako przejaw walki z bezrobociem poprzez promocję zatrudnienia, sporadycznie spełnia swoje zadanie, jakim jest znalezienie stałej pracy dla osób jej poszukujących ${ }^{241}$. W latach 2006-2007 iloraz szans ${ }^{242}$ przejścia $\mathrm{w}$ ciągu jednego roku $\mathrm{z}$ zatrudnienia tymczasowego do stałego w stosunku do szans pozostania w zatrudnieniu tymczasowym wynosił 0,5. Wartość ilorazu szans powyżej 1 wskazuje, że szansę taką uznać należy za znaczną ${ }^{243}$.

Jednym z mechanizmów wyznaczających ramy prawne zatrudnienia tymczasowego jest ograniczony katalog prac, jakie mogą być powierzone pracownikowi tymczasowemu (zgodnie z art. 2 pkt 3 z.p.t. i art. 8 z.p.t.). Dodatkowo są to regulacje wyłączające możliwość stosowania tego rodzaju zatrudnienia. W tym zakresie ograniczeniem podmiotowym jest zakaz wykonywania pracy tymczasowej przez pracownika pracodawcy użytkownika (art. 4 z.p.t.). Dotyczy to również sytuacji, w której pracownik wykonywałby rodzajowo inne prace na rzecz tego samego podmiotu w ramach stosunku pracy, jako dla pracodawcy, i w ramach stosunku pracy tymczasowej, jako dla pracodawcy użytkownika ${ }^{244}$. Główne ograniczenie w zakresie możliwości stosowania zatrudnienia tymczasowego wprowadzone zo-

człowieka w świetle przepisów prawa pracy i zabezpieczenia społecznego. Referaty i wystapienia zgłoszone na XVII Zjazd Katedr/Zakładów Prawa Pracy i Zabezpieczenia Społecznego, Kraków 7-9 maja 2009 r., Warszawa 2009, s. 282.

241 M. Gersdorf, Zatrudnieni i zatrudniający..., s. 14. M. Moszyński wskazuje tendencję, zgodnie z którą współczynnik ten rośnie współmiernie do długości pracy na rzecz danego pracodawcy użytkownika. M. Moszyński, op. cit., s. 11.

242 O pojęciu i zasadach obliczania ilorazu szans: B. Danieluk, Zastosowanie regresji logistycznej w badaniach eksperymentalnych, „Psychologia Społeczna” 2010, nr 5, s. 206.

243 Dane Komisji Europejskiej dostępne na stronie www.ec.europa.eu/employment_social/ eie/chap3-7-3_en.html (dostęp: 3.01.2017). Badania nie precyzują, czy zatrudnienie stałe zostało przez pracowników tymczasowych znalezione u pracodawców użytkowników, na rzecz których świadczyli pracę w ramach pracy tymczasowej. Tego typu badania (w zakresie kontynuacji zatrudnienia pracownika tymczasowego przez pracodawcę użytkownika po zakończeniu pracy tymczasowej) nie są prowadzone. Informacja uzyskana z Centralnego Informatorium GUS w dniu 3.12.2015 r. (sygnatura pisma: GUS DI01.601.2443.15.MA).

244 A. Patulski, Doktrynalne..., pkt 5. 
stało w art. 20 z.p.t. i dotyczy maksymalnego czasu trwania zatrudnienia tymczasowego pomiędzy konkretnymi podmiotami stosunku pracy tymczasowej, czyli pracownikiem tymczasowym i agencją pracy tymczasowej. Zgodnie ze wskazaną regulacją w okresie obejmującym 36 kolejnych miesięcy agencja pracy tymczasowej zatrudniająca pracownika tymczasowego może skierować tego pracownika do wykonywania pracy tymczasowej na rzecz jednego pracodawcy użytkownika przez okres nieprzekraczający łącznie 18 miesięcy. Wyjątek od powyższego wskazuje art. 20 ust. 2 z.p.t. stanowiący, że jeżeli pracownik tymczasowy wykonuje w sposób ciągły na rzecz danego pracodawcy użytkownika pracę tymczasową obejmującą zadania, których wykonanie należy do obowiązków nieobecnego pracownika zatrudnionego przez tego pracodawcę użytkownika, okres wykonywania pracy tymczasowej nie może przekroczyć 36 miesięcy. Ograniczenie długości trwania zatrudnienia tymczasowego związane jest z gospodarczym przeznaczeniem zatrudnienia tymczasowego jako zatrudnienia krótkotrwałego.

Ustawa o zatrudnianiu pracowników tymczasowych nie ustanawia sankcji za naruszenie ustawowych limitów trwania zatrudnienia tymczasowego. Nie ustanawia również fikcji prawnej, czy też domniemania istnienia zatrudnienia nietymczasowego w przypadku przekroczenia ustawowych terminów. W związku z powyższym należy przyjąć, że w przypadku przekroczenia limitów czasowych zatrudnienia tymczasowego, o którym wiedzę miała zarówno agencja pracy tymczasowej, jak i pracodawca użytkownik, pracownik tymczasowy dochodzić może ustalenia istnienia stosunku pracy nietymczasowej pomiędzy nim a pracodawcą użytkownikiem ${ }^{245}$.

Przedmiotowo stosowanie zatrudnienia tymczasowego zostało ograniczone w art. 8 z.p.t. Przepis ten wyznacza negatywne przesłanki stosowania zatrudnienia tymczasowego. Pracownikowi tymczasowemu nie można powierzyć pracy szczególnie niebezpiecznej, pracy na stanowisku, na którym jest zatrudniony pracownik pracodawcy użytkownika w okresie uczestniczenia tego pracownika w strajku oraz pracy na stanowisku, na którym w okresie ostatnich 3 miesięcy poprzedzających przewidywany termin rozpoczęcia wykonywania pracy tymczasowej przez pracownika tymczasowego był zatrudniony pracownik pracodawcy użytkownika, z którym został rozwiązany stosunek pracy z przyczyn niedotyczących pracowników. Wskazane ograniczenia mają odrębne uzasadnienia. Brak możliwości zatrudnienia w ramach stosunku pracy tymczasowej własnego pracownika chroni tego pracownika przed obchodzeniem przepisów o pracy w godzinach nadliczbowych. Pracodawca, chcąc uniknąć wypłaty dodatków za pracę w godzinach nadliczbowych, w razie zwiększonego zapotrzebowania mógłby korzystać z dodatko-

245 A. Sobczyk, Zatrudnienie pracowników..., s. 36; J. Wiśniewski, Różnorodne formy..., s. 139; M. Paluszkiewicz, Problem kwalifikacji prawnej pracy wykonywanej po uptywie terminu określonego w ustawie o zatrudnianiu pracowników tymczasowych, „Monitor Prawa Pracy" 2015, nr 11, s. 576; A. Reda-Ciszewska, Glosa do wyroku SN z dnia 1 kwietnia 2015 r., I PK 203/14, „Orzecznictwo Sądów Polskich” 2016, nr 1, poz. 8. Przeciwnie: Wyrok Sądu Najwyższego z dnia 1 kwietnia 2015 r., I PK 203/14, LEX nr 1710344. 
wej pracy swojego pracownika za pośrednictwem agencji pracy tymczasowej, do prac rodzajowo tożsamych bądź zbliżonych do wykonywanych w ramach podstawowego stosunku pracy. Brak szczególnej sankcji za naruszenia wskazanej regulacji nie umożliwia zastosowania sankcji ogólnej określonej w ustawie o promocji zatrudnienia i instytucjach rynku pracy, czyli wykreślenia z rejestru agencji pracy tymczasowej ${ }^{246}$. Pracodawca użytkownik w tym przypadku nie ponosi żadnych konsekwencji korzystania $\mathrm{z}$ dodatkowej pracy swojego pracownika za pośrednictwem agencji pracy tymczasowej.

Zakaz powierzania pracownikowi tymczasowemu pracy szczególnie niebezpiecznej uzasadniony jest gospodarczym przeznaczeniem zatrudnienia tymczasowego. Bezpośrednim dobrem chronionym tą regulacją jest zdrowie i życie pracownika tymczasowego, który pozbawiony jest możliwości zdobycia doświadczenia oraz odpowiedniego przygotowania się do wykonywania pracy szczególnie niebezpiecznej z uwagi na krótkotrwały z założenia charakter pracy tymczasowej ${ }^{247}$. Odnosząc się do regulacji zakazującej świadczenia pracy tymczasowej na stanowisku pracy pracownika uczestniczącego w strajku ${ }^{248}$, jako rationis legis wprowadzenia wskazanego zakazu uznać należy prawo pracownika do uczestnictwa w sporach zbiorowych. Zastąpienie pracownika na czas jego uczestnictwa w strajku przez pracownika tymczasowego zniechęca do udziału w strajku w obawie przed utratą stanowiska pracy. To z kolei niweczy efektywność strajku, niszcząc zbiorowe stosunki zatrudnienia. Ostatnie ograniczenie dotyczy zatrudniania pracownika tymczasowego na stanowisku, na którym uprzednio zatrudniony był pracownik, z którym rozwiązano stosunek pracy z przyczyn niedotyczących pracowników. Jednoznacznie wskazuje ono na konstrukcyjne ograniczenia zatrudnienia tymczasowego ${ }^{249}$. Czasowo, przez okres 3 miesięcy poprzedzających przewidywany termin rozpoczęcia wykonywania pracy tymczasowej, nieobsadzone stanowisko pracy pozostałe po pracowniku, z którym rozwiązano stosunek pracy z przyczyn go niedotyczących, nie może zostać powierzone pracownikom tym-

246 Przeciwnie: A. Sobczyk, art. 4, [w:] A. Sobczyk, Ustawa o zatrudnianiu pracowników tymczasowych. Komentarz, https://sip-1lex-1pl-1004153yx0cd3.han3.lib.uni.lodz.pl/\#/komentarz/587241493/38933 (dostęp: 19.09.2017) Argumentacja wskazana przez A. Sobczyka nie wydaje się uzasadniona. Ustawa o promocji zatrudnienia i instytucjach rynku pracy wśród przesłanek stanowiących podstawę wykreślenia z rejestru (art. 18m) nie wskazuje naruszenia przepisów ustawy o zatrudnianiu pracowników tymczasowych.

247 M. Paluszkiewicz, Zatrudnienie tymczasowe..., rozdz. II, pkt 5; M. Paluszkiewicz, Treść stosunku prawnego między agencja pracy tymczasowej a pracodawca użytkownikiem, [w:] M. Paluszkiewicz, Zatrudnienie tymczasowe w polskim prawie pracy, https://sip-1lex-1pl-1004153yx0674.han3.lib.uni.lodz.pl/\#/monografia/369234447/19 (dostęp: 19.09.2017).

248 Zagadnienie to omawia: A. Sobczyk, komentarz do art. 8 z.p.t., pkt 7-14, Ustawa o zatrudnianiu...

249 A. Sobczyk, komentarz do art. 8 z.p.t., pkt 18, op. cit. Autor bardzo szczegółowo omawia tę regulację z uwzględnieniem m.in. problematyki biegu trzymiesięcznego terminu oraz pojęcia „stanowisko pracy”, użytego w omawianej ustawie. 
czasowym. Tym samym pracodawca nie może rozwiązywać stosunków pracy ze swoimi pracownikami celem zatrudnienia na ich miejsce pracowników tymczasowych. Takie działanie byłoby korzystne dla pracodawcy w rachunku ekonomicznym, ale zdecydowanie godziłoby w postulat dążenia do kreowania trwałych stosunków zatrudnienia i uznawania zatrudnienia tymczasowego za drogę ku nim.

\subsubsection{Prawne ograniczenia stosowania cywilnoprawnego zatrudnienia nietypowego}

W związku z częstym zastępowaniem zatrudnienia pracowniczego zatrudnieniem cywilnoprawnym (a zwłaszcza umowami o świadczenie usług, do których stosuje się przepisy o zleceniu oraz umowami o dzieło), przy jednoczesnym zachowaniu warunków właściwych stosunkowi pracy, prawodawca wprowadził liczne regulacje mające na celu zapobieganie takim praktykom. Stworzył tym samym ramy konstrukcyjne wykorzystywania zatrudnienia cywilnoprawnego, związane z jego społeczno-gospodarczym przeznaczeniem jako zatrudnienia niezależnego. W pierwszej kolejności należy omówić regulację art. 22 k.p. Ostateczny kształt art. 22 k.p. osiągnął w 2002 r. Najpierw, w 1996 r. ${ }^{250}$ wprowadzono do niego $§ 1^{1}$, następnie $\mathrm{w}$ roku $2002^{251}$ dodano, potwierdzając istniejące ustalenia orzecznictwa i doktryny ${ }^{252}$, przepis $\$ 1^{2}$. Aby prawidłowo interpretować treść art. $22 \$ 1^{1}$ k.p., należy ją odnieść do art. $22 \$ 1$ k.p., który zawierając legalną definicję stosunku pracy, wskazuje jego cechy, określa treść, podmioty oraz wzajemne zobowiązania stron ${ }^{253}$. Przepis art. $22 \$ 1^{1}$ k.p. wprowadza regulację stanowiącą, że bez względu na nazwę zawartej przez strony umowy, zatrudnienie w warunkach określonych w poprzednim paragrafie jest zatrudnieniem na podstawie stosunku pracy. Cel wprowadzenia tej regulacji jest oczywisty - ma ona zapobiegać „ukrywaniu” rzeczywistych umów o pracę pod pozorem umów cywilnoprawnych ${ }^{254}$. Tym samym wprowadzono generalną zasadę, że niezależnie od tego, jak strony nazwały łączącą je umowę, zatrudnienie spełniające kryteria zawarte w art. $22 \$ 1$ k.p. jest zatrudnieniem pracowniczym (stosunkiem pracy $)^{255}$, zgodnie z zasadą falsa demonstratio non nocet. Samej kwalifikacji zatrudnienia można dokonać zarówno w fazie jego trwania, jak i ex post ${ }^{256}$.

250 Dz.U. Nr 24, poz. 110.

251 Ustawa z dnia 26 lipca 2002 r. o zmianie ustawy - Kodeks pracy oraz o zmianie niektórych innych ustaw, Dz.U. Nr 135, poz. 1146.

252 M. Gersdorf, Cechy charakterystyczne stosunku pracy po nowelizacji kodeksu pracy, „Praca i Zabezpieczenie Społeczne" 2002, nr 10, s. 20.

253 M. Tomaszewska, op. cit., s. 158.

254 Tamże, s. 165.

255 W. Gujski, Jeszcze o art. 22 \$ 11 k.p., „Prawo Pracy” 1996, nr 11, s. 33.

256 T. Liszcz, Prawna ochrona niepracowniczego zatrudnienia na podstawie umowy według projektu kodeksu pracy, [w:] A. Patulski, K. Walczak (red.), Jedność w różnorodności. Studia 
Działania ustawodawcy w zakresie przeciwdziałania nasilającemu się zjawisku obchodzenia przepisów prawa pracy nie zakończyły się na modyfikacjach art. 22 k.p. W roku 1996 dodano do kodeksu postępowania cywilnego przepisy dotyczące udziału inspektorów Państwowej Inspekcji Pracy w postępowaniu o ustalenie istnienia stosunku pracy oraz znowelizowano ustawę o Państwowej Inspekcji Pracy ${ }^{257}$. Intencją ustawodawcy nie było ograniczenie zawierania umów cywilnoprawnych, których przedmiotem jest świadczenie pracy i usług tam, gdzie umowy takie mogą, zgodnie z ich przeznaczeniem, znaleźć zastosowanie ${ }^{258}$. Zamiarem było jedynie wyeliminowanie sytuacji obchodzenia prawa poprzez „ukrywanie" rzeczywistej więzi pracowniczej.

Nowelizacje dokonane w latach 1996 i 2002 uznać należy za ukoronowanie działalności orzecznictwa i doktryny. Zasada identyfikacji umowy o pracę była bowiem od dawna obecna w literaturze i orzecznictwie Sądu Najwyższego (choćby w wyroku z dnia 2 grudnia 1975 r. $^{259}$ ). Jak słusznie zauważyli Zbigniew Góral i Henryk Lewandowski, dyspozycja z art. $22 \$ 1^{1}$ k.p. przyobleka jedynie w szatę tekstu prawnego to, co od dawna obowiązywało jako zasada praw$\mathrm{na}^{260}$. Dodatkowo jest to potwierdzenie reguły interpretacyjnej art. 65 k.c., która i tak znajdowała zastosowanie poprzez art. 300 k.p. Zgodnie z powyższą regułą o charakterze prawnym stosunku prawnego decyduje rzeczywista wola stron, a nie nazwa umowy ${ }^{261}$.

$\mathrm{Z}$ treści art. $22 \$ 1^{1}$ k.p. wynika, że dotyczy on sytuacji, w których umowa została nieprawidłowo przez strony nazwana („bez względu na nazwę zawartej umowy”), stąd w praktyce pojawić się mogą dwie wątpliwości. Po pierwsze, czy przepis ten obejmuje swoim zakresem również sytuacje gdy strony w ogóle nie zawarły żadnej umowy. Po drugie, czy stosuje się go w przypadku umów bez $n^{n a z w^{262}}$. Rozstrzygnięcie obu wątpliwości ma istotny wpływ na sytuację prawną osób zatrudnionych poprzez możliwość dokonania kwalifikacji ich zatrudnienia. Dyspozycja art. $22 \$ 1^{1}$ k.p. obejmuje swoim zakresem sytuacje, gdy strony nie zawarły pisemnie jakiejkolwiek umowy. Wynika to z faktu, że art. 22 k.p. nie stanowi o konieczności istnienia podstawy umownej (czy też aktu wyboru/powołania/ mianowania), aby powstał stosunek pracy. Umowa o pracę może bowiem zostać

z zakresu prawa pracy, zabezpieczenia społecznego i polityki społecznej. Księga pamiq̨tkowa dedykowana Profesorowi Wojciechowi Muszalskiemu, Warszawa 2009, s. 178.

257 Ustawa z dnia 6 marca 1981 r. o Państwowej Inspekcji Pracy, Dz.U. Nr 6, poz. 23 ze zm.

258 J. Wratny, Kodeks pracy. Komentarz, Warszawa 2005, s. 68.

259 Zgodnie z tym orzeczeniem zakwalifikowaniu umowy o świadczenie usług jako umowy o pracę nie stoi na przeszkodzie nazwa umowy, określająca ją jako umowę cywilnoprawną. Wyrok Sądu Najwyższego z dnia 2 grudnia 1975 r., I PRN 42/75, LEX nr 14292.

260 H. Lewandowski, Z. Góral, Przeciwdziałanie stosowaniu umów cywilnoprawnych do zatrudnienia pracowniczego, „Praca i Zabezpieczenie Społeczne” 1996, nr 12, s. 31.

261 M. Tomaszewska, op. cit., s. 165.

262 W. Gujski, Volenti non fit iniuria, „Prawo Pracy” 1996, nr 9, s. 21. 
zawarta w sposób dorozumiany poprzez dopuszczenie do pracy ${ }^{263}$. W przypadku braku pisemnej umowy o pracę kwalifikowany przez strony stosunek prawny jako umowa cywilnoprawna, na podstawie której świadczona jest praca w warunkach zatrudnienia pracowniczego, podlega dyspozycji art. $22 \$ 1^{1}$ k.p. Odnosząc się do drugiego z postawionych pytań, uznać trzeba, że o kwalifikacji prawnej umowy nie decyduje jej nazwa. Decydujące znaczenie ma natomiast treść umowy, a przede wszystkim sposób jej realizacji. Zatem tym bardziej w przypadku umowy bez nazwy łączącą strony więź badać należy z punktu widzenia praktycznego wykonywania pracy. W takiej sytuacji fakt nienazwania umowy pozostaje bez znaczenia przy stosowaniu art. $22 \$ 1^{1}$ k.p. Wprowadzenie do art. 22 k.p. przepisu $\$ 1^{1}$ spowodowało konieczność określenia, czy przepis ten stwarza prawne domniemanie istnienia stosunku pracy. Pogląd opowiadający się za przyjęciem takiego założenia jest mniejszościowy ${ }^{264}$. Dla potwierdzenia istnienia stosunku pracy niezbędny jest, mający charakter deklaratoryjny, wyrok ustalający jego istnienie. Sąd Najwyższy również opowiedział się za stanowiskiem, że art. $22 \$ 1^{1}$ k.p. nie stwarza prawnego domniemania zawarcia umowy o pracę ${ }^{265}$.

Kolejny przepis art. 22 k.p., czyli $\$ 1^{2}$, stanowi o niedopuszczalności zastępowania umowy o pracę umową cywilnoprawną, przy zachowaniu warunków wykonywania pracy określonych w art. $22 \$ 1$ k.p. Moim zdaniem regulacja art. $22 \$ 1^{2}$ k.p. jest zbędna. Uzasadnienie do projektu ustawy wprowadzającej regulację art. 22 $\$ 1^{2}$ k.p. wskazywało przepis ten jako środek mający przeciwdziałać tzw. samozatrudnieniu w zakresie możliwym do uregulowania przepisami prawa pracy ${ }^{266}$. W tym przypadku należy wskazać na podobieństwo, jakie występuje między art. $22 \S 1^{1}$ k.p. a art. $22 \S 1^{2}$ k.p. Teoretycznie pierwszy $z$ nich dotyczy zawarcia umowy pomiędzy stronami, które dotychczas nie były związane żadną umową.

263 H. Lewandowski, Z. Góral, op. cit., s. 31-32. Sankcjonowane jest uchylanie się od potwierdzenia umowy o pracę na piśmie. L. Florek, Ustawa i umowa w prawie pracy, Warszawa 2010, s. 64. W myśl art. 281 pkt 2 k.p. niepotwierdzenie na piśmie zawartej z pracownikiem umowy o pracę jest wykroczeniem przeciwko prawom pracownika i podlega karze grzywny od 1 tys. do 30 tys. zt.

264 G. Orłowski uważa, że przepis art. $22 \S 1^{1}$ k.p. to tzw. miękkie domniemanie. G. Orłowski, Umowa zlecenia a „miękkie domniemanie stosunku pracy”, „Monitor Prawa Pracy” 2007, $\mathrm{nr}$ 3, s. 134-136. A.M. Świątkowski wyraża pogląd o istnieniu w art. 22 § 1 k.p. domniemania zatrudnienia na podstawie umowy o pracę. W dalszej części wywodu autor wskazuje jednak, że art. $22 \S 1^{1}$ nie wprowadza domniemania zawarcia umowy o pracę. A.M. Świątkowski, Ochrona praw pracowniczych i socjalnych poprzez nawiqzanie stosunku pracy, [w:] A. Patulski, K. Walczak K. (red.), op. cit., s. 232-233. Brak podstaw do uznania art. 22 $\S 1^{1}$ k.p. za domniemanie istnienia stosunku pracy potwierdzają: Z. Góral, Najnowsze tendencje..., s. 211; Ł. Pisarczyk, Różne formy..., s. 41; T. Romer, Kodeks..., s. 199; M. Tomaszewska, op. cit., s. 165.

265 Wyrok z dnia 23 września 1998 r., II UKN 229/98, LEX nr 37516.

266 Projekt ustawy wrazzuzasadnieniem: orka.sejm.gov.pl/Druki4ka.nsf/\%28\$vAllByUnid\%29/ 69C42467A779EA5DC1256B8300461131/\$file/335.pdf, dostęp: 3.01.2017. 
Drugi miałby zastosowanie przy zastąpieniu umowy o pracę umową cywilnoprawną z zachowaniem dotychczasowych warunków świadczenia pracy. Brak jest uzasadnienia dla wprowadzenia art. $22 \$ 1^{2}$ k.p., gdyż zakres jego regulacji wyczerpany zostaje $\mathrm{w}$ art. $22 \$ 1^{1}$ k.p. ${ }^{267} \mathrm{~W}$ desygnatach stwierdzenia „bez względu na nazwę zawartej umowy” (art. $22 \$ 1^{1}$ k.p.) zawiera się niedopuszczalność „zastąpienia" umowy o pracę umową cywilnoprawną (art. $22 \S 1^{2}$ k.p.). Zastąpienie powoduje bowiem de facto zawarcie nowej umowy.

W obecnym stanie prawnym działają obok siebie trzy niezależne procedury przeciwdziałające „ukrywaniu” zatrudnienia pracowniczego pod pozorem zatrudnienia cywilnoprawnego. Ich celem nie jest, jak mogłoby się wydawać, ograniczanie możliwości stosowania umownego zatrudnienia cywilnoprawnego, a eliminowanie przypadków patologicznego stosowania go niezgodnie z prawem. Do procedur tych należą odpowiedzialność za wykroczenie popełnione przez pracodawcę lub podmiot działający w jego imieniu (art. 281 pkt 1 k.p., przy uwzględnieniu przepisów kodeksu wykroczeńn ${ }^{268}$ i kodeksu postępowania w sprawach o wykroczenia ${ }^{269}$ ), postępowanie w przedmiocie ustalenia istnienia stosunku pracy prowadzone przed sądem pracy oraz postępowanie mandatowe prowadzone przez inspektora pracy.

Wykroczenie stypizowane $\mathrm{w}$ art. 281 pkt 1 k.p. polega na zawarciu przez jego sprawcę umowy cywilnoprawnej w warunkach, w których zgodnie z art. 22 k.p., powinna być zawarta umowa o pracę. Wykroczenie to godzi $\mathrm{w}$ jedno $\mathrm{z}$ podstawowych praw pracownika - prawo do bycia podmiotem uprawnień przyznanych mu przez prawo ${ }^{270}$. Sprawcą wskazanego wykroczenia może być (rzekomy) pracodawca $^{271}$ lub osoba działająca w jego imieniu. Oznacza to, że w przypadku gdy zamiast pracodawcy działa osoba uprawniona do występowania w jego imieniu, odpowiedzialność ponosi sam pracodawca, pracodawca i osoba działająca w jego imieniu albo tylko osoba działająca $w$ imieniu pracodawcy.

Zgodnie z jednym z prezentowanych w literaturze poglądów dla bytu wykroczenia stypizowanego $\mathrm{w}$ art. 281 pkt 1 k.p. wystarczy wskazanie nieumyślności sprawcy $^{272}$. Drugi pogląd zakłada, że celem wprowadzonej regulacji było zapobie-

267 Z. Góral, Najnowsze tendencje..., s. 211.

268 Ustawa z dnia 20 maja 1971 r. Kodeks wykroczeń, Dz.U. z 2015 r., poz. 1094 - t.j. ze zm.; dalej: k.w.

269 Ustawa z dnia 24 sierpnia 2001 r. Kodeks postępowania w sprawach o wykroczenia, Dz.U. z 2016 r. poz. 1713 - t.j.; dalej: k.p.w.

270 J. Unterschütz, Karnoprawna ochrona praw osób wykonujących pracę zarobkowa, Warszawa 2010, s. 68.

271 Przed ustaleniem istnienia stosunku pracy nie można względem stron stosunku prawnego stosować nomenklatury właściwej dla stosunku pracy, zatem posługuję się w tych przypadkach dookreśleniem „,rzekomy”.

272 H. Lewandowski, Z. Góral, op. cit., s. 33; R. Celeda, [w:] L. Florek (red.), Kodeks pracy. Komentarz, Warszawa 2005, s. 1369; W. Kotowski, B. Kurzępa, Wykroczenia pozakodeksowe. Komentarz, Warszawa 2008, s. 612. 
żenie ukrywaniu stosunków zatrudnienia pracowniczego pod postacią zatrudnienia cywilnoprawnego, a takie ukrywanie może mieć miejsce tylko w przypadku gdy pracodawca (bądź osoba działająca w jego imieniu) działa umyślnie ${ }^{273}$. Zajmując stanowisko $\mathrm{w}$ tej sprawie, należy przyjąć, że skoro w przepisie brak słów „W celu obejścia ustawy”, to wykroczenie może być popełnione również nieumyślnie. Co więcej, byt wykroczenia, zgodnie z brzmieniem art. 1 k.w., powinien być oceniany przez pryzmat jego społecznej szkodliwości. Oceniając społeczną szkodliwość czynu, bierze się pod uwagę rodzaj i charakter naruszonego dobra, rozmiary wyrządzonej lub grożącej szkody, sposób i okoliczności popełnienia czynu, wagę naruszonych przez sprawcę obowiązków, postać zamiaru, motywację sprawcy, rodzaj naruszonych reguł ostrożności oraz stopień ich naruszenia (art. $47 \$ 6$ k.w.). Jeśli organ badający wykroczenie nie odnajdzie w nim znamion społecznej szkodliwości, pracodawca (lub osoba działająca w jego imieniu) nie poniesie konsekwencji niezawarcia umowy o pracę, pomimo spełnienia warunków zatrudnienia pracowniczego. Takie rozwiązanie daje możliwość uniknięcia bądź złagodzenia konsekwencji prawnych przy braku umyślności w działaniu.

Pokrzywdzony ma możliwość wystąpienia z wnioskiem o ukaranie w przypad$\mathrm{ku}$ popełnienia wykroczenia przeciwko prawom pracownika $\mathrm{z}$ art. 281 pkt 1 k.p. Zgodnie $\mathrm{z}$ art. $27 \$ 2$ k.p.w., jeśli w ciągu miesiąca od powiadomienia o wykroczeniu organu uprawnionego do występowania $\mathrm{w}$ tych sprawach $\mathrm{w}$ charakterze oskarżyciela, $\mathrm{w}$ tym przypadku inspektora pracy, pokrzywdzony nie zostanie powiadomiony o wniesieniu przez ten organ wniosku o ukaranie albo otrzyma zawiadomienie, że czynności wyjaśniające nie dostarczyły podstaw do jego wniesienia, może samodzielnie wystąpić z takim wnioskiem do właściwego sądu. O wniosku wniesionym przez pokrzywdzonego prezes sądu zawiadamia inspektora pracy, jako właściwego oskarżyciela publicznego (art. $27 \$ 4$ k.p.w.). Inspektor pracy ma prawo w ciągu 14 dni od otrzymania zawiadomienia o wniosku wniesionym przez pokrzywdzonego wnieść wniosek o ukaranie w sprawie o ten sam czyn wobec tej samej osoby. W takim przypadku wniosek inspektora pracy ma charakter wniosku publicznego, a wniosek pokrzywdzonego traktuje się jako oświadczenie o przyłączeniu do procesu w charakterze oskarżyciela posiłkowego ubocznego. Wymiar grożącej kary za popełnienie omawianego wykroczenia wynosi od 1 tys. do 30 tys. złotych. Wymierzając grzywnę w konkretnym stanie faktycznym, pod uwagę bierze się, zgodnie z art. $24 \$ 3$ k.w., dochody sprawcy, jego warunki osobiste i rodzinne, stosunki majątkowe, jak również możliwości zarobkowe.

W drugiej grupie praktycznych środków związanych z przeciwdziałaniem zawieraniu umów cywilnoprawnych kreujących faktyczną więź pracowniczą omówione zostaną uprawnienia Państwowej Inspekcji Pracy związane z ustalaniem istnienia

273 Pogląd taki za W. Sanetrą (J. Iwulski, W. Sanetra, Kodeks pracy. Komentarz, Warszawa 1999, s. 740) przedstawia M. Nałęcz, [w:] W. Muszalski (red.), Kodeks pracy. Komentarz, Warszawa 2001, s. 1290; T. Nycz, [w:] B. Wagner (red.), Kodeks pracy. Komentarz, Gdańsk 2004, s. 882. 
stosunku pracy i nakładaniem mandatów oraz odpowiadające im uprawnienia podmiotów zatrudnienia. Zadania Państwowej Inspekcji Pracy określa art. 10 pkt 1 ustawy o Państwowej Inspekcji Pracy ${ }^{274}$. W obrębie omawianego zagadnienia istotne znaczenie mają zadania wymienione w podpunkcie 11 powyższego przepisu. Są to prawa do wnoszenia powództw, a za zgodą osoby zainteresowanej - do uczestnictwa $\mathrm{w}$ postępowaniu przed sądem pracy $\mathrm{w}$ sprawach o ustalenie istnienia stosunku pracy. Znowelizowany w 1996 r. kodeks postępowania cywilnego ${ }^{275}$ umocował inspektorów pracy do wytaczania na rzecz obywateli powództw w sprawach o ustalenie istnienia stosunku pracy (art. $63^{1}$ k.p.c.). Inspektorzy pracy zyskali również możliwość wstępowania do toczących się spraw w tej materii. Jednakże, aby skorzystać z drugiego ze swoich uprawnień, muszą uzyskać zgodę powoda. Zgoda nie jest natomiast wymagana przy wytaczaniu takiego powództwa $\mathrm{z}$ własnej inicjatywy $\mathrm{y}^{276}$. Sąd Najwyższy uznał, że nie ma podstaw do twierdzenia, że brak zgody lub sprzeciw pracownika, na rzecz którego inspektor wytoczył powództwo, odbiera inspektorowi legitymację czynną ${ }^{277}$.W przypadku wystąpienia przez inspektora pracy z powództwem o ustalenie istnienia stosunku pracy sąd powinien zawiadomić stronę, na rzecz której wniesiono powództwo i doręczyć jej odpis pozwu. Osoba taka może wstąpić do sprawy w każdym jej stanie, stając się współuczestnikiem jednolitym ${ }^{278}$ (art. $56 \$ 1$ in fine k.p.c. w zw. $\mathrm{z}$ art. $63^{2}$ k.p.c.). Gdy inspektor pracy wstępuje, za zgodą powoda, do toczącego się postępowania, na mocy art. $63^{2}$ k.p.c. stosuje się do niego odpowiednio art. 60 k.p.c. Zgodnie z tym przepisem inspektor pracy może składać oświadczenia i zgłaszać wnioski, jakie uzna za celowe, oraz przytaczać fakty i dowody na ich potwierdzenie. W przedmiocie procesowej pozycji inspektora pracy w postępowaniu, do którego wstąpił za zgodą powoda, wypowiedział się Sąd Najwyższy ${ }^{279}$. W takim przypadku pozycja procesowa inspektora pracy jest szczególna - nie jest on ani stroną w ścisłym znaczeniu, ani współuczestnikiem, stając się uczestnikiem (podmiotem) postępowania.

Ostatnim środkiem sankcjonującym stosowanie zatrudnienia cywilnoprawnego w miejsce zatrudnienia pracowniczego jest możliwość nałożenia mandatu karnego. Inspektor pracy prowadzi postępowanie mandatowe w sprawach o wykroczenia przeciwko prawom pracownika ${ }^{280}$. Po przeprowadzeniu czynności wy-

274 Ustawa z dnia 13 kwietnia 2007 r. o Państwowej Inspekcji Pracy, Dz.U. z 2017 r. poz. 786 - t.j. ze zm.

275 Ustawa z dnia 17 listopada 1964 r. Kodeks postępowania cywilnego, Dz.U. z 2016 r. poz. 1822 - t.j. ze zm.; dalej: k.p.c.

276 R. Sadlik, Uprawnienia Inspekcji Pracy w ustalaniu stosunku pracy, „Prawo Pracy” 2000, nr 12, s. 26.

277 Wyrok Sądu Najwyższego z dnia 29 grudnia 1998 r., I PKN 494/98, LEX nr 36562.

278 R. Sadlik, op. cit., s. 26.

279 Wyrok Sądu Najwyższego z dnia 2 kwietnia 1998 r., I PKN 521/97, LEX nr 35307.

280 Wskazać należy, że uprawnień takich nie ma policja. H. Skwarczyński, Inspektor pracy w nowym postępowaniu w sprawach o wykroczenia, „Praca i Zabezpieczenie Społeczne” 2003, nr 9, s. 34. 
jaśniających ${ }^{281}$, stwierdziwszy popełnienie wykroczenia z art. 281 pkt 1 k.p., inspektor pracy nakłada grzywnę w drodze mandatu karnego (na podstawie art. 95 $\$ 3 \mathrm{w}$ zw. z art. $17 \$ 2$ k.p.w.). Wysokość nakładanej grzywny wynosi od $20 \mathrm{zł}$ do 2 tys. zł (art. 24 k.w., art. $96 \$ 1$ a k.p.w.). W przypadku recydywisty ${ }^{282}$ maksymalny wymiar grzywny to 5 tys. zł (art. $96 \$ 1$ b k.p.w.). Wymierzając grzywnę, inspektor pracy sam dokonuje kwalifikacji prawnej zatrudnienia, pomimo że faktycznie do kwalifikacji prawnej stosunku zatrudnienia umocowane są jedynie sądy ${ }^{283}$. Pomimo nałożenia na rzekomego pracodawcę mandatu, nadal będzie on pozostawał $\mathrm{z}$ osobą zatrudnioną w stosunku zatrudnienia cywilnoprawnego. Jeśli inspektor ponownie wymierzy grzywnę, a ukarany odwoła się do sądu karnego, to postępowanie zostanie umorzone jako prawomocnie zakończone co do tej samej osoby i tego samego czynu ${ }^{284}$. Zastosowanie kary mandatu, penalizując naruszanie norm prawnych, nie przekształca stosunku prawnego w stosunek pracy.

Pracodawca ma prawo odmówić przyjęcia mandatu od inspektora pracy (art. $97 \$ 2$ k.p.w.). W razie odmowy przyjęcia mandatu karnego przez pracodawcę inspektor pracy, który go nałożył, występuje do sądu z wnioskiem o ukaranie (art. 99 k.p.w.). Sąd rozpoznający sprawę, jeśli uzna winę pracodawcy, może utrzymać nałożoną przez inspektora pracy karę, a także nałożyć karę wyższą. Sąd może także uznać, że do wykroczenia nie doszło lub że nie ma uzasadnienia do nałożenia grzywny. Sąd, orzekając o bycie wykroczenia, nie jest związany decyzją inspektora pracy o ukaraniu mandatem.

Omówione powyżej rozbudowane w swojej strukturze środki przeciwdziałające stosowaniu umownego zatrudnienia cywilnoprawnego $\mathrm{w}$ warunkach właściwych zatrudnieniu pracowniczemu niekiedy umożliwiają określenie warunków właściwych dla stosowania jako podstawy zatrudnienia umów prawa cywilnego. Orzecznictwo dotyczące materii związanej z kwalifikacją prawną zatrudnienia doprecyzowuje zakres okoliczności, w których świadczona jest praca, kwalifikowanych jako poszczególne podstawy umownego zatrudnienia cywilnoprawnego ${ }^{285}$.

281 Rolą inspektora pracy jest nie tylko wymierzenie grzywny, ale również przeprowadzenie pełnych czynności wyjaśniających. T. Grzegorczyk, Kodeks postępowania w sprawach o wykroczenia, Warszawa 2008, s. 366.

282 W obrębie omawianej regulacji recydywistą jest osoba, która była ukarana co najmniej dwukrotnie za wykroczenie przeciwko prawom pracownika i w ciągu dwóch lat od ostatniego ukarania popełnia kolejne wykroczenie przeciwko prawom pracownika.

283 A. Sobczyk, Metody ograniczania umów cywilnoprawnych w stosunkach pracy - wątpliwości systemowe, „Praca i Zabezpieczenie Społeczne” 1997, nr 9, s. 36-37.

284 Zgodnie z art. 17 pkt 7 ustawy z dnia 6 czerwca 1997 r. Kodeks postępowania karnego, Dz.U. z 2016 r. poz. 1749 - t.j. ze zm.; stanowisko to prezentuje A. Sobczyk, Metody..., s. 37.

285 W większości kwalifikacja zatrudnienia cywilnoprawnego dokonywana jest w negacji do zatrudnienia prawnopracowniczego. Na uwagę zasługują takie orzeczenia jak: Wyrok Sądu Najwyższego z dnia 2 grudnia 1975 r., I PRN 42/75, LEX nr 14292; Uchwała Sądu Najwyższego z dnia 11 maja 1976 r., I PZP 18/76, LEX nr 12404; Wyrok Sądu Najwyższego z dnia 18 czerwca 1998 r., I PKN 191/98, LEX nr 36702; Wyrok Sądu Najwyższego z dnia 15 października 1999 r., 
Możliwość zatrudnienia tymczasowego na podstawie umowy prawa cywilnego została już w niniejszej pracy rozstrzygnięta jako dopuszczalna. To, co wymaga obecnie analizy, to zakres stosowania przepisów dotyczących przeciwdziałania stosowaniu umów cywilnoprawnych do zatrudnienia tymczasowego ${ }^{286}$. Ugruntowane w tym zakresie stanowisko doktryny ${ }^{287}$ potwierdził uchwałą $\mathrm{z}$ dnia 12 grudnia $2011 \mathrm{r}^{288}$ Sąd Najwyższy. Zgodnie z tym orzeczeniem art. $22^{1} \mathrm{k}$.p. znajduje zastosowanie $\mathrm{w}$ odniesieniu do zatrudnienia osób skierowanych do pracy tymczasowej na podstawie umowy prawa cywilnego. Za trafną należy uznać polemikę Anny Redy z treścią uzasadnienia do powyższej uchwały w części dotyczącej stanowiska sądu apelacyjnego ${ }^{289}$. Sąd apelacyjny założył, że umowy cywilnoprawne dotyczące pracy tymczasowej przyczyniają się do tworzenia miejsc pracy, a ich zawierania nie wyklucza dyrektywa $\mathrm{nr}$ 2008/104/WE ${ }^{290}$. Istotne jest, że umowy cywilnoprawne zawierane $\mathrm{w}$ celu świadczenia pracy tymczasowej powinny być poddane takiej samej analizie celowościowej, jak umowy cywilnoprawne zawierane zamiast umów o pracę. Kwestią wymagającą rozstrzygnięcia jest określenie podmiotu ponoszącego odpowiedzialność za zawarcie umowy cywilnoprawnej w warunkach zatrudnienia tymczasowego. We wskazanej powyżej uchwale Sąd Najwyższy stwierdzil, że powództwo o ustalenie istnienia stosunku pracy wytoczyć można jedynie przeciwko agencji pracy tymczasowej, nie zaś przeciwko pracodawcy użytkownikowi ${ }^{291}$. Stanowisko takie wydaje się o tyle kontrowersyjne, że wyłącza możliwość ustalenia istnienia stosunku pracy z podmiotem, który faktycznie realizuje uprawnienia kierownicze. $\mathrm{W}$ związku z przyjęciem takiego założenia ograniczenie odpowiedzialności nie powinno, moim zdaniem, dotyczyć agencji pracy tymczasowej również w zakresie odpowiedzialności za wykroczenie

I PKN 307/99, LEX nr 39667; Wyrok Sądu Najwyższego z dnia 3 listopada 2000 r., IV CKN 152/00, LEX nr 45451; Wyrok Sądu Najwyższego z dnia 9 stycznia 2008 r., III UK 73/07, LEX nr 356045; Wyrok Sądu Najwyższego z dnia 28 czerwca 2011 r., II PK 9/11, LEX nr 1044012; Wyrok Sądu Najwyższego z dnia 26 marca 2013 r., II UK 201/12, LEX nr 1341964; Wyrok Sądu Najwyższego z dnia 27 sierpnia 2013 r., II UK 26/13, LEX nr 1379926; Wyrok Sądu Najwyższego z dnia 18 września 2013 r., II UK 39/13, LEX nr 1378531.

286 Jest to zagadnienie o tyle istotne, że tylko w 2012 r. aż 63\% osób skierowanych do pracy przez agencje pracy tymczasowej stanowiły osoby zatrudnione na podstawie umów prawa cywilnego. Wyliczenia te, wykonane na podstawie danych Ministerstwa Pracy, przedstawita M. Paluszkiewicz, Agencje zatrudnienia po nowelizacji ustawy o promocji zatrudnienia $i$ instytucjach rynku pracy, „Praca i Zabezpieczenie Społeczne” 2014, nr 6, s. 13.

287 A. Sobczyk, Zatrudnienie pracowników..., s. 36; D. Makowski, Rozwój..., s. 129; A. Reda, Ochronne rozwiązania prawa pracy w zatrudnieniu tymczasowym, [w:] M. Seweryński, J. Stelina (red.), op. cit., s. 252; J. Wiśniewski, Różnorodne formy..., s. 229.

288 II UZP 6/11, LEX nr 951414.

289 A. Reda, Praca tymczasowa na podstawie umowy cywilnoprawnej, „Praca i Zabezpieczenie Społeczne" 2012, nr 9, s. 35-36.

290 Dyrektywa Parlamentu Europejskiego i Rady 2008/104/WE z dnia 19 listopada 2008 r. w sprawie pracy tymczasowej, Dz.U.WE.L. 327 z dnia 5 grudnia 2008 r., s. 9-14.

291 Przeciwnie: A. Reda, op. cit., s. 37. 
i odpowiedzialności mandatowej. W zależności od okoliczności, w jakich znajduje się konkretna osoba zatrudniona, mogłaby ona wnieść powództwo o ustalenie istnienia stosunku pracy z pracodawcą użytkownikiem, do którego została skierowana na podstawie umowy cywilnoprawnej, bądź też powództwo o ustalenie istnienia stosunku pracy tymczasowej opartego na podstawie umowy o pracę tymczasową z agencją pracy tymczasowej. Analogicznie do przedstawionych możliwości mógłby działać inspektor pracy, wymierzając sankcje karne lub wnosząc powództwo o ustalenie istnienia stosunku pracy. Jeżeli inspektor uznałby, że wykonywana praca ma cechy pracy tymczasowej, nałożyłby sankcje karne na agencję i wystąpił o ustalenie istnienia pracy tymczasowej pomiędzy osobą zatrudnioną a agencją. Jeśli natomiast uznałby, że powstała więź jest konstrukcyjnie zbliżona do klasycznego stosunku pracy, sankcje karne wymierzyłby przeciwko pracodawcy użytkownikowi i to jego oznaczyłby jako pracodawcę w powództwie o ustalenie istnienia stosunku pracy.

W rozporządzeniu dotyczącym przyznania uprawnień pracowniczych osobom wykonującym pracę nakładczą ustawodawca dodatkowo uszczegóławia możliwość stosowania tej cywilnoprawnej postawy zatrudnienia. Po pierwsze w $₫ 2$ pkt 2 wprowadza katalog umów, na podstawie których praca nakładcza może być świadczona. Do umów tych należy umowa na okres próbny, umowa na czas określony, umowa na czas wykonania określonej pracy i umowa na czas nieokreślony. Wskazany katalog jest jednak na tyle szeroki, że nie można uznać go za ograniczenie delimitujące możliwość świadczenia pracy nakładczej. Dodatkowo ustawodawca uszczegóławia możliwość świadczenia pracy na podstawie umowy o pracę nakładczą przedmiotowo. Pracą świadczoną na podstawie takiej umowy może być jedynie praca, którą da się określić ilościowo. To uszczegółowienie również nie ma charakteru zawężającego możliwość zawarcia umowy o pracę nakładczą. Wynika jedynie z istoty tej podstawy zatrudnienia ${ }^{292}$.

\subsubsection{Podsumowanie}

Ograniczenia stosowania umownego zatrudnienia nietypowego wyznaczają ramy prawne, w których zatrudnienie to może być stosowane. Uzasadnieniem wprowadzenia omówionych ograniczeń są zróżnicowane założenia systemowe, które spełniać ma umowne zatrudnienie nietypowe. To z kolei powoduje, że do różnych okoliczności faktycznych związanych ze świadczoną pracą wykorzystywane mogą

292 Pracą nakładczą są czynności związane z: a) wytwarzaniem artykułów, przedmiotów lub ich części z materiałów powierzonych przez nakładcę; b) wykańczaniem, uszlachetnianiem, naprawą i konserwacją artykułów, przedmiotów lub ich części oraz świadczeniem innych usług. Powyższe wynika z Rozporządzenia Przewodniczącego Komitetu Drobnej Wytwórczości w sprawie określenia istotnych cech pracy nakładczej jako zatrudnienia wyłączonego spod działania prawa przemysłowego. 
być inne podstawy prawne i formy organizacyjne umownego zatrudnienia nietypowego. Wybór zatrudnienia terminowego, w tym tymczasowego, jest dopuszczalny, o ile w rzeczywistości nie ma charakteru zatrudnienia typowego. Również wybór zatrudnienia cywilnoprawnego jest dopuszczalny, o ile w rzeczywistości nie są spełnione warunki powstania stosunku pracy. W takich przypadkach wprowadzone mechanizmy pozwalają na przekształcenie istniejącej umowy bądź ustalenie istnienia właściwego stosunku prawnego. Normom prawnym o charakterze ograniczającym podlegają sytuacje patologiczne, w których rodzajowo właściwe byłoby zawarcie umowy o pracę na czas nieokreślony (w przypadkach dotyczących eliminowania nadużywania zatrudnienia terminowego) bądź umowy o pracę (w przypadkach dotyczących eliminowania nadużywania zatrudnienia cywilnoprawnego). Automatyzm prawny w przekształceniu istniejącej więzi zatrudnienia oraz możliwość sądowego ustalenia jej istnienia wpływają na sytuację prawną osób zatrudnionych poprzez możliwość zmiany konstrukcji pierwotnie zawartego stosunku prawnego. 


\section{ROZDZIAŁ II \\ Status prawny kandydatów do pracy w fazie nawiązywania stosunków umownego zatrudnienia nietypowego}

\subsection{Wprowadzenie}

Faza nawiązywania stosunku umownego zatrudnienia nietypowego jest chronologicznie pierwszym etapem zatrudnienia, który podlega badaniu w odniesieniu do sytuacji prawnej osób świadczących pracę. W pierwszej kolejności na sytuację prawną kandydatów do pracy wpływają regulacje dotyczące wyboru i kształtowania podstaw prawnych umownego zatrudnienia nietypowego. Determinują one stosowanie właściwego reżimu prawnego kreującego status prawny osób zatrudnionych. Określenie zakresu swobody stron w wyborze i kształtowaniu umownego zatrudnienia nietypowego pozwoli ocenić, na ile regulacje prawne oddają do ich dyspozycji kwalifikowanie zatrudnienia. Konsekwencją tej kwalifikacji jest wyznaczenie ram prawnych statusu osoby świadczącej pracę. Na status prawny osób zatrudnionych wypływają również granice określające swobodę stosowania poszczególnych podstaw prawnych i form organizacyjnych umownego zatrudnienia nietypowego. Ograniczają one bowiem dowolność w zakresie dokonywanego wyboru podstawy prawnej zatrudnienia.

Status prawny osób świadczących pracę $\mathrm{w}$ ramach umownego zatrudnienia nietypowego zostanie przedstawiony $\mathrm{w}$ odniesieniu do fazy nawiązywania stosunku prawnego. Poczynione uwagi dotyczyć będą modelu ochrony danych osobowych kandydatów do pracy, warunków dopuszczenia ich do pracy oraz ochrony przed dyskryminacją. Celem uniknięcia powtórzeń w dalszej części pracy status prawny osób świadczących pracę związany z ochroną przed dyskryminacją zostanie przedstawiony również $\mathrm{w}$ odniesieniu do etapu trwania stosunku prawnego. Rezultatem przeprowadzonej analizy będzie określenie, czy i w jakim zakresie we wskazanych płaszczyznach status osób świadczących pracę jest zróżnicowany w zależności od podstawy prawnej i formy organizacyjnej umownego zatrudnienia nietypowego. Stwierdzenie istnienia tego zróżnicowania uzasadni konieczność dokonania oceny jego zasadności. 


\subsection{Swoboda wyboru i kształtowania podstawy prawnej umownego zatrudnienia nietypowego}

\subsubsection{Uwagi wprowadzające}

Kreując więź, której przedmiotem jest zatrudnienie umowne, podmioty stosunku prawnego muszą dokonać szeregu wyborów. Pierwszym z nich jest wybór kontrahenta ${ }^{1}$. Następnie dokonywana jest kwalifikacja zatrudnienia do właściwego reżimu prawnego. $\mathrm{W}$ obrębie badanych zagadnień obejmuje ona prawo pracy i prawo cywilne. W dalszej kolejności poprzez wybór konkretnego rodzaju umowy ${ }^{2}$ jej strony dokonują wyboru właściwej podstawy prawnej zatrudnienia. Na koniec dokonywany jest wybór sposobu realizacji umowy. W stosunkach pracy wymaga on daleko idącej konkretyzacji, obejmującej m.in. ustalenie organizacji pracy, w tym czasu i miejsca pracy. Sposób realizacji stosunków prawnych, których przedmiotem jest świadczenie pracy na podstawie umów prawa cywilnego, nie jest uszczegóławiany w takim samym stopniu, jak w przypadku pracy świadczonej w reżimie prawa pracy ${ }^{3}$. Powyższe nie wyłącza możliwości dookreślenia sposobu wykonania umowy zlecenia (art. 737 k.c.) czy umowy agencyjnej (art. 760 1 $\$ 1$ k.c.) lub uszczegółowienia innych okoliczności związanych $\mathrm{z}$ wykonaniem umów stanowiących podstawy prawne zatrudnienia cywilnoprawnego. Będą to $\mathrm{np}$. warunki dostarczania przedmiotów niezbędnych do wykonania umowy o pracę nakładczą czy umowy o dzieło ( $\$ 22$ ust. 2 rozp. pr. nakład.; art. 633 k.c.).

W tej części pracy zostaną przedstawione okoliczności dowodzące istnienia swobody dokonywania wyboru podstawy prawnej umownego zatrudnienia nietypowego i kreowania jego treści wraz z właściwymi jej ograniczeniami. Ograniczenia te wyznaczają ramy prawne stosowania umownego zatrudnienia nietypowego i nieodzownie powiązane są ze społeczno-gospodarczym przeznaczeniem poszczególnych jego rodzajów. Wpływają też na możliwość dokonania kwalifikacji stosunku prawnego, która determinuje stosowanie odpowiedniego reżimu prawnego kreującego sytuację osób świadczących pracę.

1 Z. Salwa, Kształtowanie treści umowy o pracę, „Praca i Zabezpieczenie Społeczne” 1993, nr 12, s. 3.

2 W ramach prawa pracy strony mogą dokonać wyboru w obrębie katalogu umów przewidzianego przez przepisy prawa pracy. Z. Salwa, Rola umowy o pracę w ksztattowaniu stosunku pracy, „Państwo i Prawo” 1977, nr 11, s. 27. Prawo pracy nie zna bowiem, wzorem prawa cywilnego, instytucji umów nienazwanych.

3 Dokonanie przez strony ustaleń w zakresie zbieżnym z cechami stosunku pracy (np. poprzez ustalenie czasu i miejsca pracy) może skutkować uznaniem łączącej strony więzi za stosunek pracy w ramach postępowania o ustalenie istnienia stosunku pracy. 
Międzynarodowa Organizacja Pracy (MOP) nie pozostaje obojętna na kwestie swobody kształtowania umownych stosunków zatrudnienia, choć aktem, którym reguluje omawianą tematykę, jest jedynie zalecenie. Zalecenie MOP nr 198 w ustępie 8 stanowi, że polityka krajowa dotycząca ochrony pracowników pozostających w stosunku pracy nie powinna ingerować w legalne stosunki cywilnoprawne i handlowe. Zatem dopóki stosunek umowny jest zgodny z prawem (np. nie narusza przepisów przeciwdziałających stosowaniu zatrudnienia cywilnoprawnego w miejsce zatrudnienia pracowniczego), strony mają swobodę w zakresie jego kształtowania. Mając na uwadze, że zalecenie jest aktem niewiążącym, jego rolę postrzegać należy jedynie przez pryzmat „przyjaznej” prawu międzynarodowemu wykładni przepisów krajowych, która stała się cechą kultury prawnej w Polsce ${ }^{4}$. Zalecenie nie wprowadza ograniczeń w zakresie swobody wyboru podstawy prawnej umownego zatrudnienia nietypowego, odsyłając w tym względzie do przepisów prawa krajowego.

\subsubsection{Zasada swobody umów jako wyznacznik wyboru i kształtowania umownego zatrudnienia nietypowego}

Wybór i kształtowanie podstaw prawnych umownego zatrudnienia nietypowego są ograniczone, jednakże zakres tych ograniczeń jest ściśle określony. Decyzje podejmowane $\mathrm{w}$ toku powstawania stosunku zatrudnienia, w tym umownego zatrudnienia nietypowego, są przejawem zasady autonomii woli, uważanej za jedną z podstawowych zasad prawa cywilnego ${ }^{5}$. W ramach autonomii woli, odnoszącej się do wszystkich rodzajów czynności prawnych ${ }^{6}$, system prawny daje podmiotom możliwość regulowania stosunków umownych według ich własnej woli za pomocą narzędzia, jakim jest czynność prawna ${ }^{7}$ Legislacyjnym wyrazem autonomii woli w kształtowaniu umów jest zasada swobody umów wyrażona w art. $353^{1}$ k.c. Do odpowiedniego stosowania tego przepisu w stosunkach pracy odsyła art. 300 k.p., stanowiący o ogólnej zasadzie stosowania do stosunku pracy kodeksu cywilnego w sprawach nieunormowanych przepisami prawa pracy, o ile nie są sprzeczne z jego zasadami. Prawo pracy ukształtowało się jako konsekwencja ograniczania zasady swobody umów na korzyść pracowników ${ }^{8}$. Jednym z ograniczeń tej zasady

4 A. Musiała, J. Jankowiak, Kiedy zatrudniony ma status pracownika, „Stużba Pracownicza” 2007, nr 4, s. 17.

5 Z. Radwański, Teoria umów, Warszawa 1977, s. 94.

6 P. Machnikowski, Swoboda umów według artykułu $353^{1}$ kodeksu cywilnego. Konstrukcja prawna, Warszawa 2005, s. 2.

7 Ibidem.

8 B. Wagner, Jednolitość, wielopostaciowość czy ewolucja funkcji ochronnej prawa pracy - zatrudnienie typowe versus tymczasowe, [w:] A. Sobczyk (red.), z problematyki zatrudnienia tymczasowego, pkt 2, https://sip-1lex-1pl-1004153yx0674.han3.lib.uni.lodz.pl/\#/monografia/369236017/15 (dostęp: 19.09.2017). 
na gruncie prawa pracy jest art. $18 \$ 1$ k.p., zgodnie z którym m.in. postanowienia umowne wprowadzone wolą stron nie mogą być dla pracownika mniej korzystne aniżeli unormowania, które wynikają z przepisów prawa pracy. Strony mogą więc ułożyć stosunek prawny jedynie w sposób korzystniejszy dla pracownika niż zostało to uregulowane w przepisach prawa pracy 9 .

Na gruncie prawa pracy autonomia woli stron urzeczywistniona zostaje mocą przepisów statuujących niektóre zasady prawa pracy. Przykładem jest zasada prawa do pracy wyrażona w art. 10 k.p. Zgodnie z nią każdy ma prawo m.in. do swobodnego wyboru pracy. Dotyczy to również wyborów dokonywanych w obrębie stosunku pracy ${ }^{10}$, np. wyboru rodzaju umowy o pracę. Druga płaszczyzna urzeczywistniająca zasadę autonomii woli stron $\mathrm{w}$ prawie pracy to zasada swobody nawiązania stosunku pracy (art. 11 k.p.). Działa ona na etapie zawiązywania więzi pracowniczej i kształtowania jej treści ${ }^{11}$. Zbigniew Góral przestawia stanowisko, zgodnie z którym istnieją różnice pomiędzy zasadą swobody umów z art. $353^{1}$ k.c. a zasadą swobody nawiązania stosunku pracy z art. 11 k.p. Autor wskazuje po pierwsze, że art. 11 k.p. nie odnosi się tylko do umownego stosunku pracy, ale również do jego pozaumownych rodzajów. Przepis art. $353^{1}$ k.c. obejmuje swoją hipotezą jedynie te stosunki prawne, które są umowami. Po drugie autor wymienia, że umowa o pracę jest jedną z wielu umów prawa pracy, obok choćby umowy o zakazie konkurencji. Przepis art. $353^{1}$ k.c. będzie miał zastosowanie do wszystkich umów prawa pracy, podczas gdy art. 11 k.p. znajdzie zastosowanie jedynie w stosunku do umowy o pracę. Góral stoi na stanowisku, że art. 11 k.p. dotyczy jedynie etapu nawiązywania stosunku pracy, podczas gdy art. $353^{1}$ k.c. dotyczy dodatkowo etapu jego trwania i rozwiązania. Analiza porównawcza treści norm art. $353^{1}$ k.c. i art. 11 k.p. potwierdza istotne różnice zakresów zasady swobody umów i zasady swobody nawiązania stosunku pracy.

W obrębie swobody umów ${ }^{12}$ należy wyróżnić kompleks instytucji związanych ze swobodą zawierania umów oraz swobodę w zakresie treści umowy. Swoboda zawierania umów wyraża się w swobodzie decyzji w kwestii zawarcia umowy, swobodzie wyboru kontrahenta, formy umowy i jej rozwiązania ${ }^{13}$. Przejawem zasady swobody umów w ujęciu prawa cywilnego jest również założenie, że strony

9 L. Florek, Granice liberalizacji prawa pracy, [w:] E. Bielak, H. Lewandowski (red.), Granice liberalizacji prawa pracy. Problemy zabezpieczenia społecznego. Materiały z XIV Zjazdu Katedr (Zakładów) Prawa Pracy i Ubezpieczeń Społecznych, Łódź 2003, s. 105.

10 Z. Góral, O kodeksowym katalogu zasad indywidualnego prawa pracy, Warszawa 2011, s. 106.

11 Tamże, s. 107.

12 T. Liszcz przedstawia taki sam katalog cech świadczących o obowiązywaniu zasady swobody umów na gruncie prawa pracy. T. Liszcz, Swoboda umów w prawie pracy, [w:] M. Seweryński, J. Stelina (red.), Wolność i sprawiedliwość w zatrudnieniu. Księga pamiątkowa poświęcona Prezydentowi Rzeczypospolitej Polskiej Profesorowi Lechowi Kaczyńskiemu, Gdańsk 2012, s. 177.

13 Z. Radwański, op. cit., s. 99-100. 
zawierające umowę są sobie równe ${ }^{14}$. Na gruncie unormowań prawa pracy zasada ta doznaje modyfikacji w kierunku uznania słabszej pozycji pracownika. Swoboda w zakresie treści umowy, której przedmiotem jest umowne zatrudnienie nietypowe, została szczególnie ograniczona na gruncie pracowniczych podstaw prawnych zatrudnienia. Zakres tych ograniczeń oraz uzasadnienie ich obowiązywania zostaną zaprezentowane w dalszej części.

Prezentując zasadę swobody umów w odniesieniu do statusu prawnego osób świadczących pracę w ramach umownego zatrudnienia nietypowego, w pierwszej kolejności należy wykazać swobodę stron w przedmiocie wyboru kontrahenta stosunku zatrudnienia. Zarówno przepisy kodeksu cywilnego, jak i kodeksu pracy zawierają w tym przedmiocie odpowiednie regulacje. Dotyczą one ograniczenia albo braku możliwości zawarcia żądanej przez strony umowy ze względu na zdolności psychofizyczne danego podmiotu - jego wiek albo stan psychiczny ${ }^{15}$. Na gruncie prawa pracy aktualizują się one w stosunku do wszystkich - typowych i nietypowych - umownych stosunków pracy. W tym zakresie inna od właściwej prawu pracy jest natomiast sytuacja prawna osób zatrudnionych na podstawie umów cywilnoprawnych.

Przepis art. $22 \$ 2$ k.p. wskazuje dolną granicę wieku dopuszczenia do zatrudnienia pracowniczego - 18 lat ${ }^{16}$. Możliwość zatrudnienia osób młodszych, między 16 a 18 rokiem życia, regulują przepisy działu 9 oraz szereg przepisów wykonawczych $^{17}$. Przepis art. $22 \$ 3$ k.p. pozwala osobom ograniczonym w zdolności do czynności prawnych nawiązać stosunek pracy, o ile nie sprzeciwia się to ich do-

14 E. Łętowska, Podstawy prawa cywilnego, Warszawa 1997, s. 27. W innym opracowaniu autorka stwierdza jednak, że zasada formalnej równości stron przestała być operacyjna. Wskazuje ona, że równość stron umowy jest mitem. E. Łętowska, Umowy - mitologia równości, [w:] S. Wronkowska, M. Zieliński (red.), Szkice z teorii prawa i szczegółowych nauk, Poznań 1990, s. 51, 56. Pogląd ten potwierdza A. Musiała, Problematyka kwalifikacji umowy o zatrudnienie jako umowy o pracę bądź umowy cywilnoprawnej o świadczenie usług, „Monitor Prawa Pracy" 2015, nr 1, s. 8.

15 Dodatkowo prawo pracy zawiera nakazy zatrudniania bądź statuuje zasadę pierwszeństwa w zatrudnieniu pewnych kategorii osób (m.in. art. $53 \S 5$ k.p., art. $66 \S 2$ k.p., art. 9 ust. 1 u.zw.grup.). Tematyka ta wykracza jednak poza zakres prowadzonych rozważań.

16 T. Romer, Kodeks pracy. Komentarz, Warszawa 2012, s. 201.

17 Rozporządzenie Rady Ministrów z dnia 28 maja 1996 r. w sprawie przygotowania zawodowego młodocianych i ich wynagradzania (Dz.U. z 2014 r., poz. 232 - t.j.); Rozporządzenie Ministra Pracy i Polityki Społecznej z dnia 5 grudnia 2002 r. w sprawie przypadków, w których wyjątkowo jest dopuszczalne zatrudnianie młodocianych, którzy nie ukończyli gimnazjum, osób niemających 16 lat, które ukończyły gimnazjum, oraz osób niemających 16 lat, które nie ukończyły gimnazjum (Dz.U. Nr 214, poz. 1808); Rozporządzenie Rady Ministrów z dnia 24 sierpnia 2004 r. w sprawie wykazu prac wzbronionych młodocianym i warunków ich zatrudniania przy niektórych z tych prac (Dz.U. Nr 200, poz. 2047); Rozporządzenie Ministra Edukacji Narodowej z dnia 15 grudnia 2010 r. w sprawie praktycznej nauki zawodu (Dz.U. Nr 244, poz. 1626); Rozporządzenie Ministra Edukacji Narodowej z dnia 13 grudnia 2016 r. w sprawie klasyfikacji zawodów szkolnictwa zawodowego (Dz.U. z 2016 r., poz. 2094). 
bru. W przeciwnym razie przedstawiciel ustawowy, za zgodą sądu, może stosunek pracy rozwiązać (art. $22 \S 3 \mathrm{zd}$. 2 k.p.). Prawo cywilne również zawiera regulacje dotyczące podmiotowego ograniczenia zawierania umów, w tym umów dotyczących zatrudnienia. Umowy, których przedmiotem jest świadczenie pracy (umowy o pracę nakładczą, umowy zlecenia, umowy o świadczenie usług, do których stosuje się przepisy o zleceniu, umowy agencyjne i umowy o dzieło), nie należą do umów powszechnie zawieranych w drobnych bieżących sprawach życia codziennego, dlatego nie mogą zostać zawarte przez osoby nieposiadające zdolności do czynności prawnych, czyli osoby ubezwłasnowolnione całkowicie bądź osoby do 13. roku życia (art. $12 \mathrm{i}$ art. $13 \$ 1$ k.c.). Osoby posiadające ograniczoną zdolność do czynności prawnych, czyli nieubezwłasnowolnione pomiędzy 13. a 18. rokiem życia i osoby ubezwłasnowolnione częściowo (art. 15 i art. $16 \$ 1$ k.c.) mogą zawrzeć umowę, której przedmiotem jest zatrudnienie. Jednak umowa taka dla swojej ważności wymaga zgody ich przedstawiciela ustawowego (art. 17 k.c.). $\mathrm{Z}$ przedstawionych unormowań wynika, że w obrębie zdolności do zawierania umów, których przedmiotem jest zatrudnienie, prawo cywilne kształtuje sytuację prawną osób zatrudnianych w sposób odmienny niż prawo pracy. Regulacja art. $22 \$ 3$ k.p., dotycząca osób ograniczonych w zdolności do czynności prawnych, nie wymaga bowiem zgody przedstawiciela ustawowego, aby nawiązany został stosunek pracy.

W ramach zatrudnienia umownego wybór kontrahenta nie pozostaje zbieżny $\mathrm{z}$ wyborem właściwego wykonawcy umowy w odniesieniu do wszystkich podstaw umownego zatrudnienia nietypowego. Nie powoduje to ograniczenia swobody umów w zakresie wyboru kontrahenta, a jedynie potwierdza konstrukcyjne zróżnicowanie poszczególnych podstaw umownego zatrudnienia nietypowego. Umowy o pracę zawsze mają osobisty charakter, zatem swoboda umów w zakresie wyboru wykonawcy umowy ogranicza się do wyboru pracownika. Odmienne $\mathrm{w}$ tym zakresie są regulacje właściwe prawu cywilnemu. $\mathrm{Z}$ istoty umowy o pracę nakładczą wynika, że wykonawca nie musi świadczyć pracy osobiście. Może on posłużyć się innymi osobami, w tym członkami rodziny, pozostającymi z nim we wspólnym gospodarstwie domowym ${ }^{18}$. Regulacja umowy zlecenia ustanawia możliwość wykonania go przez osobę trzecią (art. 738 k.c.). Przyjmujący zlecenie może powierzyć wykonanie zlecenia osobie trzeciej tylko wtedy, gdy wynika to $\mathrm{z}$ umowy lub ze zwyczaju albo gdy jest do tego zmuszony przez okoliczności.

18 Obecnie żaden przepis expressis verbis nie daje wykonawcy uprawnienia do wykonywania pracy nakładczej przy użyciu siły roboczej osób pozostających z nim we wspólnym gospodarstwie domowym. Uprawnienie takie wnioskować można z istoty pracy nakładczej, którą określało Rozporządzenie Przewodniczącego Komitetu Drobnej Wytwórczości w sprawie określenia istotnych cech pracy nakładczej jako zatrudnienia wyłączonego spod działania prawa przemysłowego, które w $\S 3$ dawało możliwość korzystania przez wykonawców z pomocy osób pozostających z nim we wspólnym gospodarstwie domowym. 
Natomiast zarówno umowa o dzieło, jak i umowa agencyjna ${ }^{19}$ nie są umowami o charakterze osobistym, co nie wyklucza możliwości zastrzeżenia stosownego postanowienia w ich treści. W sposób szczególny ograniczony został wybór osoby zatrudnianej w stosunku pracy tymczasowej. Agencja pracy tymczasowej zatrudnia pracownika tymczasowego w celu wykonywania pracy tymczasowej na rzecz i pod kierownictwem pracodawcy użytkownika (art. 2 pkt 2 z.p.t.). Krąg podmiotów, które mogą zostać zatrudnione w ramach umowy o pracę tymczasową został ograniczony w art. 4 z.p.t. Przepis ten statuuje zakaz zatrudniania na rzecz pracodawcy użytkownika osób pozostających z nim w stosunku pracy. Wskazana regulacja ogranicza swobodę umów w zakresie wyboru pracownika tymczasowego. Jej dodatkowym uzasadnieniem, poza wypełnianiem systemowych założeń zatrudnienia tymczasowego, jest promowanie zatrudnienia typowego oraz zapobieganie wykorzystywaniu zatrudnienia tymczasowego celem obchodzenia przepisów, m.in. o godzinach nadliczbowych, o czym była mowa w rozdziale pierwszym.

Wybór kontrahenta umowy związanej z zatrudnieniem dotyczy zarówno wyboru dokonywanego przez podmiot zatrudniany, jak i przez podmiot zatrudniający. Z perspektywy osoby zatrudnianej odzwierciedleniem swobody wyboru podmiotu, który ma pracę wykonać, jest zasada wolności pracy, urzeczywistniona w art. 65 ust. 1 Konstytucji oraz w art. 10 k.p. Zgodnie z nią każdy człowiek ma prawo decydowania o tym gdzie, jak, ale przede wszystkim dla kogo chce pracować. Powyższego nie wyłącza szczególna trójpodmiotowa więź zatrudnienia tymczasowego. Pracownik tymczasowy, dokonując wyboru kontrahenta, decyduje nie tylko o tym, kto będzie jego pracodawcą w rozumieniu art. 3 k.p., ale również o tym, kto będzie rzeczywistym odbiorcą pracy - pracodawcą użytkownikiem. Umowa o pracę tymczasową określa bowiem m.in. pracodawcę użytkownika (art. 13 ust. 1 z.p.t.). Związanie się jej treścią przez pracownika tymczasowego stanowi wyraz autonomii w zakresie decydowania o tym, na rzecz jakiego podmiotu będzie świadczona praca tymczasowa ${ }^{20}$.

Zasada wolności pracy jako wolności decydowania o spożytkowaniu własnej pracy, stosowana zarówno w obrębie zatrudnienia pracowniczego (art. 10 k.p.), jak i cywilnoprawnego, znajduje odbicie w wielu aktach prawa międzynarodowego, które zakazują pracy przymusowej ${ }^{21}$. Na tej płaszczyźnie, w celu wypełnienia zarówno standardów o charakterze ponadnarodowym, jak i konstytucyjnym, sta-

19 Podmiotowym ograniczeniem wyboru agenta jest konieczność posiadania przez niego statusu przedsiębiorcy.

20 W praktyce w przeważającej części przypadków możliwość decydowania o wyborze pracodawcy użytkownika, na rzecz którego ma być świadczona pracy, ogranicza się do przyjęcia bądź odrzucenia przez pracownika tymczasowego warunków zatrudnienia zaproponowanych przez agencję pracy tymczasowej.

21 Z. Góral, Swoboda doboru pracowników i wolność pracy, [w:] H. Lewandowski (red.), Polskie prawo pracy w okresie transformacji w oświetleniu prawa wspólnotowego, Warszawa 1997, s. 22. 
tus prawny wszystkich osób świadczących pracę w ramach umownego zatrudnienia nietypowego jest taki sam. Wszystkie one mają swobodę w zakresie decydowania, na czyją rzecz będą świadczyć pracę.

W dalszej kolejności, w ramach urzeczywistniania zasady swobody umów, strony umowy, której przedmiotem jest zatrudnienie, wybierają reżim prawny zatrudnienia $^{22}$. Dokonują one wyboru pomiędzy nietypowym umownym zatrudnieniem pracowniczym a zatrudnieniem cywilnoprawnym. O ile nie powstaje sprzeczność z regulacjami dotyczącymi przeciwdziałania stosowaniu umów cywilnoprawnych w miejsce zatrudnienia pracowniczego, strony mają swobodę dokonywania powyższego wyboru. Istnienie regulacji przeciwdziałających „ukrywaniu” zatrudnienia pracowniczego pod postacią umów cywilnoprawnych nie przekreśla ani nie ogranicza zasady swobody umów poprzez narzucanie zatrudnienia pracowniczego ${ }^{23}$. Przepisy zakazujące zawierania i realizowania umów cywilnoprawnych kreujących rzeczywistą więź pracowniczą mają na celu rozgraniczenie stosunków cywilnoprawnych od pracowniczych, czego konsekwencją jest objęcie ochroną właściwą prawu pracy wszystkich osób świadczących pracę w warunkach zatrudnienia pracowniczego. Wątpliwości budzi możliwość zawarcia umowy pracowniczej zawierającej elementy właściwe regulacjom prawa cywilnego i odwrotnie ${ }^{24}$. Umowa prawa pracy mogłaby zawierać elementy właściwe prawu cywilnemu, o ile nie mają one charakteru przeważającego i pozostają zgodne z przepisami prawa pracy. Ze względu na odrębności systemowe zatrudnienia prawnopracowniczego i cywilnoprawnego skatalogowanie takich elementów jest niezmiernie utrudnione. Umowę cywilnoprawną strony mogą wzbogacić o elementy właściwe prawu pracy (na przykład bezwzględny obowiązek osobistego wykonania umowy czy płatne przerwy w jej wykonywaniu), o ile jednak umowa zachowa swój pierwotnie założony charakter umowy cywilnoprawnej, a nie prawnopracowniczej. Przeważający

22 W rzeczywistości wyboru reżimu prawnego zatrudnienia i w konsekwencji konkretnej podstawy prawnej dokonuje podmiot zatrudniający, jako mający silniejszą pozycję negocjacyjną. Wybór dokonywany przez osobę mającą świadczyć pracę często ogranicza się do przyjęcia bądź odrzucenia zaproponowanych warunków.

23 B. Wagner, O swobodzie umowy o pracę raz jeszcze, [w:] M. Matey-Tyrowicz, L. Nawacki, B. Wagner (red.), Prawo pracy a wyzwania XXI wieku. Księga Jubileuszowa Profesora Tadeusza Zielińskiego, Warszawa 2002, s. 375; A. Góra-Błaszczykowska, Postępowanie w sprawach o ustalenie istnienia umowy o pracę - uwagi, „Monitor Prawa Pracy” 2005, nr 6, s. 153.

24 Stanowisko dotyczące możliwości zawierania umów cywilnoprawnych z elementami właściwymi prawu pracy poparła B. Wagner, O swobodzie umowy..., s. 375. W tej kwestii wypowiedział się Sąd Najwyższy, uznając, że umowa nie może mieć charakteru mieszanego umowy o pracę i umowy zlecenia. W samej treści uzasadnienia do wyroku Sąd Najwyższy wskazuje, że uznanie istnienia cech przeważających umowy o pracę albo umowy zlecenia powoduje prawną kwalifikację umowy (jako umowy o pracę bądź umowy zlecenia), wyłączając możliwość uznania jej mieszanego charakteru. Wyrok Sądu Najwyższego z dnia 23 stycznia 2002 r., I PKN 786/00, LEX nr 54890. 
stopień nasycenia cechami zatrudnienia pracowniczego jednoznacznie przesądzi o kwalifikacji prawnej zawartej umowy, bez względu na początkową wolę stron $^{25}$.

Kolejny etap realizacji zasady swobody umów w procesie zawierania umowy, której przedmiotem jest zatrudnienie nietypowe, stanowi wybór podstawy prawnej świadczenia pracy. Jeżeli strony zdecydują się na umowne zatrudnienie pracownicze ${ }^{26}$, wybór podstawy prawnej zatrudnienia, czyli rodzaju umowy o pracę, zasadniczo pozostawiony jest ich woli. Wyjątkami od tej zasady są regulacje art. $25^{1}$ k.p., art. 7 z.p.t. bądź też istnienie określonych prawem okoliczności. Okolicznościami tymi są, w odniesieniu do umowy o pracę na czas wykonania określonej pracy (obowiązującej w stanie prawnym sprzed nowelizacji czerwcowej z 2015 r.): urzeczywistniona praca podlegająca wykonaniu; w przypadku umowy o pracę w celu zastępstwa nieobecnego pracownika (obowiązującej w stanie prawnym sprzed nowelizacji czerwcowej z 2015 r.) - warunek w postaci usprawiedliwionej nieobecności pracownika; a w przypadku umowy o pracę na okres próbny - konieczność sprawdzenia przydatności pracownika do określonej pracy. Wybór rodzaju umowy o pracę determinuje cel, jaki strony chcą przez jej wykonywanie osiągnąć, w konsekwencji wpływając na realizację i sposób ustania stosunku pracy ${ }^{27}$. Umowa o pracę w celu zastępstwa, obowiązująca przed nowelizacją czerwcową z 2015 r., nie mogła być zawarta w dowolnych okolicznościach, a jedynie w razie potrzeby zastąpienia pracownika podczas jego usprawiedliwionej nieobecności. Umowa o pracę w celu wykonania określonej pracy musiała tę pracę określać, a w konsekwencji realizacji umowy praca ta musiała zostać urzeczywistniona. Celem weryfikacji przydatności pracownika do wykonywania określonego rodzaju pracy strony zawierają umowę o pracę na okres próbny.

Praca tymczasowa, zgodnie $\mathrm{z}$ art. 7 z.p.t., może być wykonywana jedynie na podstawie umowy o pracę na czas określony. Zatem podstawa prawna świadczenia pracy w ramach zatrudnienia tymczasowego została przez ustawodawcę ograniczona celem realizacji założenia o jego krótkotrwałym charakterze. Również przedmiot pracy tymczasowej został rodzajowo scharakteryzowany w ustawie o zatrudnianiu pracowników tymczasowych (art. 2 pkt 3 z.p.t.), o czym była już mowa. Powoduje to, że zatrudnienie tymczasowe może być stosowane jedynie w ściśle określonych okolicznościach.

25 Ł. Pisarczyk, Różne formy zatrudnienia, Warszawa 2003, s. 26. Nie znaczy to jednak, że wola stron przy kwalifikowaniu umowy w ogóle nie powinna być brana pod uwagę. Por.: Wyrok Sądu Najwyższego z dnia 27 maja 2010 r., II PK 354/09, LEX nr 598002.

26 W związku z tym, że poza obszarem zainteresowania pozostaje zatrudnienie pracownicze pozaumowne, nawiązywanie stosunku pracy na podstawie powołania, mianowania, wyboru i spółdzielczej umowy o pracę nie będzie omawianie.

27 Z. Salwa, Kształtowanie treści..., s. 4. 
Omówione ograniczenia, poza regulacją art. $25^{1}$ k.p. oraz art. 7 z.p.t. ${ }^{28}$, nie narzucają rodzaju umowy, a jedynie wskazują przesłanki, jakie muszą zostać spełnione dla zawarcia konkretnych umów o pracę. Przepisy prawa cywilnego nie ograniczają wyboru stron w zakresie rodzaju umowy stanowiącej podstawę stosunku prawnego, którego przedmiotem jest świadczenie pracy. Poprzez dopasowanie konkretnej więzi prawnej do określonych okoliczności faktycznych kwalifikują jedynie ów stosunek prawny jako określony ustawowo typ - umowę o pracę nakładczą, umowę zlecenia, umowę o świadczenie usług, do której stosuje się przepisy o zleceniu, umowę agencyjną czy umowę o dzieło.

W końcowej fazie powstawania stosunku zatrudnienia jego strony kształtują warunki organizacyjne świadczenia pracy. Decyzje dotyczące stron nie zawsze mogą zostać podjęte w pełni swobodnie. W przypadku zatrudnienia pracownika w celu zastępstwa nieobecnego pracownika podczas jego usprawiedliwionej nieobecności pracownik zastępujący musiał świadczyć pracę tego samego rodzaju co praca nieobecnego pracownika. Wynikało to z samej istoty tej podstawy umownego zatrudnienia nietypowego ${ }^{29}$. Praca pracownika zastępującego nie musiała być natomiast świadczona w tym samym wymiarze czasu pracy i za tym samym wynagrodzeniem, co praca świadczona przez pracownika zastępowanego ${ }^{30}$. Obecnie, w związku z nowelizacją czerwcową kodeksu pracy z 2015 r., powyższe uwagi należy odnieść do umowy zawieranej w warunkach art. $25^{1} \$ 4$ pkt 1 k.p. Na tym etapie kreowania stosunku nietypowego zatrudnienia umownego w obrębie stosunków prawnopracowniczych strony mogą dokonać wyboru formy organizacyjnej zatrudnienia w postaci telepracy. Decyzja o zastosowaniu telepracy należy zawsze do pracownika i pracodawcy, bez względu na to, czy podejmowana jest przy zawieraniu umowy o pracę czy w trakcie jej realizacji. Z uwagi na przedmiotowe ograniczenia możliwości wykonywania pracy w ramach telepracy (konieczność wykorzystania środków komunikacji elektronicznej w procesie pracy - art. $67^{5} \$ 1$ k.p.), wynikające $z$ samej jej istoty, warunki organizacyjne nie mogą być w tym przypadku kształtowane dowolnie. Muszą obejmować swoją treścią sposób i zakres wykorzystywania środków komunikacji elektronicznej.

Zakres swobody stron stosunku pracy w ustalaniu warunków pracy w zatrudnieniu tymczasowym rozłożony jest w innych proporcjach niż w zatrudnieniu typowym. Warunki zatrudnienia, takie jak rodzaj pracy, wymiar czasu pracy oraz miejsce wykonywania pracy nie są, zgodnie z art. 9 ust. 1 pkt 1, 4, 5 z.p.t., ustalane przez strony stosunku pracy (agencję pracy tymczasowej i pracownika tymczasowego). Uzgodnienia te zostają dokonane w umowie pomiędzy agencją a pra-

28 Dodatkowe ograniczenia występują np. w przypadku zatrudniania młodocianych czy zatrudnienia w służbie cywilnej. Por. Z. Góral, O kodeksowym katalogu..., s. 120.

29 M. Tomaszewska, Art. 25 k.p., pkt 10, [w:] K.W. Baran (red.), Kodeks pracy. Komentarz, https:// sip-1lex-1pl-1004153yx0674.han3.lib.uni.lodz.pl/\#/komentarz/587329041/490674 (dostęp: 19.09.2017).

30 Z. Kubot, Umowa o pracę na zastępstwo, „Praca i Zabezpieczenie Społeczne” 2003, nr 2, s. 20. 
codawcą użytkownikiem. Zatem czynnikiem wpływającym na kształt stosunku pracy tymczasowej są w tym przypadku uzgodnienia dokonywane przez agencję pracy tymczasowej z pracodawcą użytkownikiem, wskazywane następnie w umowie o pracę tymczasową (art. 13 ust. 1 pkt 1 z.p.t.) ${ }^{31}$. Wynika to $\mathrm{z}$ nietypowego, trójpodmiotowego charakteru zatrudnienia tymczasowego, jako więzi łączącej agencję pracy tymczasowej, pracodawcę użytkownika i pracownika tymczasowego. W przypadku gdyby umowa zawarta przez agencję pracy tymczasowej i pracodawcę użytkownika nie wskazywała warunków zatrudnienia pracownika tymczasowego, zasadniczo należy odwołać się do przepisów kodeksu pracy. Nieokreślenie wymiaru czasu pracy (wskazanego w art. 9 ust. 1 pkt 4 z.p.t. jako jedno z postanowień umowy pomiędzy agencją pracy tymczasowej a pracodawcą użytkownikiem) powoduje, że pracownik tymczasowy świadczy pracę w pełnym wymiarze czasu pracy. Natomiast nieokreślenie miejsca świadczenia pracy (czyli niewypełnienie dyspozycji art. 9 ust. 1 pkt 5 z.p.t.) skutkuje koniecznością ustalenia go w oparciu o rodzaj świadczonej pracy czy rodzaj i zakres terytorialny działalności pracodawcy użytkownika. Tym, co pozostaje w omawianym zakresie rozwiązaniem nietypowym, właściwym dla zatrudnienia tymczasowego, jest fakt, że o ostatecznym ustaleniu miejsca świadczenia pracy, dokonywanym w oparciu o art. 454 kc. w zw. z art. 300 k.p., decyduje siedziba pracodawcy użytkownika, a nie siedziba pracodawcy w rozumieniu art. 3 k.p., czyli agencji pracy tymczasowej ${ }^{32}$.

Z przedstawionej analizy wynika, że status prawny osób świadczących pracę na podstawie umownego zatrudnienia nietypowego jest zróżnicowany już w zakresie swobody zawierania umów i kształtowania ich treści. Zróżnicowanie to wynika $\mathrm{z}$ istoty poszczególnych podstaw prawnych umownego zatrudnienia nietypowego i uzasadnione jest ich odmiennym przeznaczeniem gospodarczym.

\subsubsection{Granice zasady swobody umów jako ograniczenia wyboru i kształtowania umownego zatrudnienia nietypowego}

Wyznacznikiem zasady swobody umów są jej ograniczenia wskazane $\mathrm{w}$ art. $353^{1}$ k.c. Swoboda stron w ułożeniu stosunku prawnego według ich uznania ograniczona jest w zakresie treści i celu tego stosunku warunkiem niesprzeciwiania się właściwościom (naturze) stosunku prawnego, ustawie oraz zasadom współżycia społecznego. Do wyznaczenia zakresu obowiązywania zasady swobody umów konieczne jest zatem określenie jej ograniczeń. Uzasadnieniem wpro-

31 M. Paluszkiewicz, Ogólna charakterystyka konstrukcji zatrudnienia tymczasowego w polskim prawie pracy, [w:] M. Paluszkiewicz, Zatrudnienie tymczasowe w polskim prawie pracy, https://sip-1lex-1pl-1004153yx0674.han3.lib.uni.lodz.pl/\#/monografia/369234447/12 (dostęp: 19.09.2017).

32 A. Piszczek, Odrębność podporządkowania pracownika w nietypowych umownych stosunkach pracy, Łódź 2016, s. 186. 
wadzenia ograniczeń zasady swobody umów jest potrzeba kontroli stosunków zobowiązaniowych przez państwo ${ }^{33}$. Strony, zawierając umowę, nie mogą mieć pełnej dowolności w kwestiach dotyczących jej treści. Często zdarza się bowiem, że siła negocjacyjna jednej strony jest znacznie słabsza niż drugiej, która mogłaby w takiej sytuacji swobodnie narzucić treść zawieranej umowy. Jest to szczególnie dostrzegalne w obrębie umów, których przedmiotem jest zatrudnienie. Wskazane $\mathrm{w}$ art. $353^{1}$ k.c. granice zasady swobody umów znajdują zastosowanie również na gruncie umownych stosunków prawnych, których przedmiotem jest świadczenie pracy. $\mathrm{Z}$ perspektywy badanych zagadnień istotne jest, że ograniczenia zasady swobody umów wyznaczają zakres swobody stron w kształtowaniu stosunków prawnych zatrudnienia nietypowego. Poniższe rozważania przedstawią ograniczenia zasady swobody umów aktualizujące się przy dokonywaniu przez podmioty zatrudnienia jego kwalifikacji prawnej jako zatrudnienia nietypowego. Omówione zostaną również ograniczenia w zakresie ustalania warunków świadczenia pracy. Wynikiem tej analizy będzie określenie granic wyboru i kształtowania poszczególnych typów umownego zatrudnienia nietypowego, różnicujących status prawny osób świadczących pracę.

Przepis art. $353^{1}$ k.c. nakazuje badanie zgodności z zasadą swobody umów nie tylko treści, ale i celu zobowiązania. Przez cel zobowiązania należy rozumieć stan rzeczy, który powinien zostać osiągnięty w następstwie wykonania zobowiązania $^{34}$. Zakres kompetencji stron w kształtowaniu treści umowy wyznaczony został na dwa sposoby. Po pierwsze, poprzez pozytywne unormowanie, że strony mogą „ułożyć stosunek prawny według swojego uznania”. Po drugie, przez negatywne określenie granic, poza które strony wykraczać nie mogą, czyli zakaz kształtowania stosunku zobowiązaniowego w sposób sprzeczny z właściwością (naturą) stosunku prawnego, ustawą lub zasadami współżycia społecznego ${ }^{35}$.

Pierwsza granica zasady swobody umów - właściwość (natura) stosunku zobowiązaniowego - nakazuje respektowanie ogólnych właściwości każdego stosunku zobowiązaniowego. Zgodnie z literaturą stosunek zobowiązaniowy powinien zapewnić stronom brak możliwości unicestwienia lub nadmiernego ograniczenia swobody stron przez porządek prawny oraz pewność w zakresie przysługujących im praw. Są to wartości, które nie wynikają wprost z przepisów prawa pozytywnego, a oceniane być powinny jako normy prawa naturalnego, obowiązujące samoistnie $^{36}$. Naturą stosunku prawnego są zarówno cechy charakterystyczne dla obowiązującego w polskim systemie prawnym modelu stosunku obligacyjnego, jak

33 Z. Radwański, A. Olejniczak, Zobowiq̨zania - część ogólna, Warszawa 2005, s. 126.

34 A. Olejniczak, Art. 353¹, [w:] A. Kidyba (red.), Kodeks cywilny. Komentarz, t. 3: Zobowiqzania - część ogólna, https://sip-1lex-1pl-1004153yx0674.han3.lib.uni.lodz.pl/\#/komentarz/ 587264116/167837 (dostęp: 19.09.2017).

35 P. Machnikowski, [w:] E. Gniewek (red.), Kodeks cywilny. Komentarz. Księga trzecia: Zobowiqzania, Warszawa 2006, s. 503.

36 Z. Radwański, A. Olejniczak, op. cit., s. 129. 
i cechy modelu określonego rodzaju zobowiązania ${ }^{37}$. Pojęcie ustawy jako drugiego czynnika ograniczającego zasadę swobody umów oznacza wszystkie źródła prawa powszechnie obowiązującego. Nie należy ustawy utożsamiać jedynie z kodeksem cywilnym. Ustawa w tym przypadku to nic innego jak prawo powszechnie obowiązujące. Zakaz ten dotyczy norm bezwzględnie wiążących i norm semiimperatywnych ${ }^{38}$. W przypadku norm względnie wiążących treść stosunku zobowiązaniowego może być, przy niewykraczaniu poza pozostałe granice zasady swobody umów, ukształtowana przez strony swobodnie ${ }^{39}$.

Ostatnią granicą zasady swobody umów są zasady współżycia społecznego. Przepis art. $58 \$ 2$ k.c. uznaje generalnie za dotknięte sankcją nieważności bezwzględnej czynności prawne sprzeczne z zasadami współżycia społecznego. Ponadto art. $353^{1}$ k.c., powołując się na to samo kryterium, ogranicza zasadę swobody umów. Granica swobody umów w postaci warunku niesprzeczności z zasadami współżycia społecznego, wskazana w art. $353^{1}$ k.c., pełni zatem funkcję ograniczającą swobodę kontraktową i wyznaczającą granicę wykonywania prawa podmiotowego ${ }^{40}$. Omawianie desygnatów pojęcia zasad współżycia społecznego nie wydaje się konieczne dla potrzeb dalszych rozważań. Dogłębna analiza tego pojęcia znacznie wykroczyłaby poza ramy niniejszego opracowania. Warto jednak wskazać uznaną w doktrynie definicję zasad współżycia społecznego zaproponowaną przez Stanisława Grzybowskiego. Autor ten pod pojęciem zasad współżycia społecznego rozumie szczególne reguły postępowania w życiu społecznym $^{41}$. W literaturze wskazuje się ponadto, że pojęcie zasad współżycia społecznego zastąpiło wcześniej używane przez ustawodawcę pojęcia dobrej wiary, dobrych obyczajów, uczciwego obrotu czy słuszności ${ }^{42}$.

$\mathrm{W}$ porównaniu z prawem cywilnym prawo pracy wyznacza sztywne ramy dotyczące treści oraz zakresu obowiązywania umów powstających w jego reżimie. Dowolność stron stosunku pracy w kwestii ustalania zakresu treści umowy, której przedmiotem jest zatrudnienie, została ograniczona w znacznym zakresie. Charakter prawny stosunku pracy określa art. 22 k.p., treść umowy o pracę - art. 29 k.p., warunki, jakie muszą zostać spełnione podczas podejmowania przez strony zatrudnienia pracowniczego decyzji o telepracy - art. $67^{6}$ k.p. i $67^{7}$ k.p., natomiast katalog postanowień, które muszą znaleźć się w poszczególnych umowach kreujących zatrudnienie tymczasowe (art. 9 ust. 1 z.p.t., art. 13 ust. 1 z.p.t.), zawiera

37 A. Olejniczak, op. cit., pkt 10.

38 Z. Radwański, A. Olejniczak, op. cit., s. 127.

39 E. Łętowska, op. cit., s. 115.

40 A. Brzozowski, M. Safjan, E. Skowrońska-Bocian, Witold Czachórski. Zobowiq̨zania. Zarys wyktadu, Warszawa 2002, s. 144.

41 S. Grzybowski, System prawa cywilnego, t. 1, Wrocław-Warszawa-Kraków-Gdańsk-Łódź 1985, s. 98.

42 R. Trzaskowski, Granice ksztattowania treści i celu umów obligacyjnych. Art. 353¹ k.c., Kraków 2005, s. 391 i literatura tam wskazana. 
ustawa o zatrudnianiu pracowników tymczasowych. Prawo pracy w znacznym stopniu ogranicza swobodę umów, która obowiązuje jedynie tam, gdzie przepisy prawa pracy nie nakazują określonego zachowania ${ }^{43}$. Strony umowy o pracę, w tym umów mających za przedmiot zatrudnienie nietypowe, mają swobodę w kształtowaniu poszczególnych jej elementów w sposób najpełniej realizujący ich interesy ${ }^{44}$. Swoboda ta jest odzwierciedleniem omówionych powyżej systemowych założeń wolności zarówno w kwestii decyzji o spożytkowaniu swojej pracy, jak i korzystania z cudzej pracy ${ }^{45}$.

Wybór umownej podstawy zatrudnienia nietypowego może zostać dokonany sprzecznie z pierwszą granicą zasady swobody umów, czyli z właściwościami (naturą) danego stosunku prawnego. W kontekście ograniczenia zasady swobody umów odnośnie warunku niesprzeczności z właściwościami (naturą) stosunku prawnego, spośród poszczególnych podstaw prawnych i form organizacyjnych umownego zatrudnienia nietypowego na samym początku omówiona zostanie umowa o pracę na czas określony. Określenie właściwości (natury) stosunku prawnego, jakim jest umowa o pracę na czas określony, w obecnym stanie prawnym stało się niemożliwe. Powoduje to trudności z wyznaczeniem ram swobody umów w zakresie odnoszącym się do właściwości (natury) stosunku prawnego. Powyższe wynika z zerwania, poprzez możliwość wcześniejszego wypowiedzenia, z systemowym wyodrębnieniem umowy o pracę na czas określony jako umowy stabilizującej zatrudnienie poprzez trwanie do oznaczonego przez strony momentu. Dodatkowymi czynnikami umożliwiającymi określenie natury stosunku prawnego powstającego w wyniku zawarcia umowy o pracę na czas określony są ustawowe limity jej trwania. Przed nowelizacją czerwcową z 2015 r. kodeks pracy nie zawierał regulacji w zakresie limitu trwania umowy. Powodowało to, że normatywne określenie właściwości (natury) stosunku prawnego (jako ograniczenia zasady swobody umów), powstającego w wyniku zawarcia umowy o pracę na czas określony, było znacznie utrudnione.

Właściwości (natura) pozostałych stosunków prawnych umownego pracowniczego zatrudnienia nietypowego mogą zostać określone poprzez odniesienie do ich istoty i celu społeczno-gospodarczego, jakie mają spełniać poszczególne podstawy zatrudnienia. Naturą umowy o pracę na czas wykonania określonej pracy było zatrudnienie trwające pewien okres oraz wykonanie w tym okresie ściśle określonej pracy ${ }^{46}$. Szczególną właściwością umowy o pracę w celu zastępstwa była moż-

43 D. Makowski, Praca tymczasowa jako nietypowa forma zatrudnienia, Warszawa 2006, s. 87; L. Florek, Swoboda umów w prawie pracy, [w:] M. Seweryński, J. Stelina (red.), Wolność isprawiedliwość w zatrudnieniu. Księga pamiątkowa poświęcona Prezydentowi Rzeczypospolitej Polskiej Profesorowi Lechowi Kaczyńskiemu, Gdańsk 2012, s. 252.

44 Z. Salwa, Rola umowy o pracę..., s. 25.

45 W rzeczywistości, o czym była już mowa, kształt zatrudnienia określa strona mająca silniejszą pozycję negocjacyjną, którą zazwyczaj jest podmiot zatrudniający.

46 B. Wagner, Terminowe umowy o pracę, Warszawa 1980, s. 35. 
liwość jej zawarcia jedynie podczas usprawiedliwionej nieobecności pracownika. Z kolei natura umowy o pracę zawartej na okres próbny związana jest z koniecznością weryfikacji kwalifikacji pracownika do wykonywania określonego rodzaju pracy. Zawarcie lub obowiązywanie wskazanych umów wbrew ich właściwościom (naturze) przekracza granice zasady swobody umów. Szczególną właściwością telepracy, jako formy organizacyjnej nietypowego umownego zatrudnienia pracowniczego, jest świadczenie pracy co najmniej także poza zakładem pracy ${ }^{47}, \mathrm{z}$ wykorzystaniem środków komunikacji elektronicznej oraz przekazywanie wyników pracy w szczególności za ich pośrednictwem (art. $67^{5}$ k.p.). Brak którejkolwiek ze wskazanych cech uniemożliwia zakwalifikowanie formy organizacyjnej świadczenia pracy jako telepracy. Dokonanie takiej kwalifikacji pomimo niespełnienia przesłanek określonych w art. $67^{5}$ k.p. pozostaje w sprzeczności z zasadą swobody umów, zarówno jako sprzeczność z naturą stosunku prawnego (stosunku pracy opartego o formę organizacyjną telepracy), jak i sprzeczność z drugą granicą zasady swobody umów - ustawą ${ }^{48}$. Kodeks pracy wskazuje wymienione powyżej przesłanki, jakie muszą zostać spełnione, aby zakwalifikować stosunek prawny jako telepracę. Ich brak uniemożliwia dokonanie kwalifikacji prawnej stosunku pracy jako spełniającego warunki wykonywania pracy $\mathrm{w}$ formie organizacyjnej telepracy. Powyższe stanowi ograniczenie zasady swobody umów w oparciu o przepisy prawa (ustawę). Jedną z właściwości (naturą) pracy tymczasowej jest zatrudnienie pracownika tymczasowego przez agencję pracy tymczasowej celem wykonywania na rzecz pracodawcy użytkownika pracy tymczasowej wskazanej w art. 2 ust. 3 z.p.t. Jeśli strony zatrudnienia tymczasowego ukrywają w ten sposób rzeczywistą trwałą więź zatrudnienia, na przykład poprzez kierowanie pracownika tymczasowego do tego samego pracodawcy użytkownika, ale przez inne, związane ze sobą, agencje pracy tymczasowej, wydaje się zachodzić sprzeczność takiego zachowania $\mathrm{z}$ czasową naturą zatrudnienia tymczasowego, a tym samym z zasadą swobody umów. Ograniczenie takie nie jest jednak uregulowane prawnie, stąd powszechne stało się obchodzenie limitów zatrudnienia tymczasowego poprzez kierowanie do pracy tego samego pracownika tymczasowego, ale przez różne agencje pracy tymczasowej ${ }^{49}$.

47 M. Gersdorf, Zatrudnienie pracowników w formie telepracy, „Praca i Zabezpieczenie Społeczne” 2008, nr 5, s. 10.

48 Krzyżowanie się granic zasady swobody umów - warunki niesprzeczności z naturą (właściwościami) stosunku prawnego oraz z ustawą - dostrzegł P. Machnikowski. Zakresowe krzyżowanie się obu granic autor tłumaczy tym, że kryterium natury zobowiązania, intuicyjnie kojarzone, może ułatwić uzasadnienie oceny przekroczenia granic swobody umów. Zob. P. Machnikowski, op. cit., s. 507-508.

49 Wprowadzenie sumowania okresów pracy tymczasowej z ramienia różnych agencji zakłada procedowana nowelizacja ustawy o zatrudnianiu pracowników tymczasowych. Projekt dostępny na stronie: MPiPS, www.mpips.gov.pl/bip/projekty-aktow-prawnych/projekty-ustaw/prawo-pracy/projekt-ustawy-o-zmianie-ustawy-o-zatrudnianiu-pracownikowtymczasowych-oraz-niektorych-innych-ustaw-/\#akapit4 (dostęp: 03.01.2017). 
Stosunki cywilnoprawne, których przedmiotem może być świadczenie pracy i które stanowią rodzaj umownego zatrudnienia nietypowego, mają zróżnicowane właściwości (naturę). Szczegółowo zagadnienia te były omawiane w rozdziale pierwszym, zatem w tym miejscu należy jedynie zasygnalizować pewne poczynione tam ustalenia. Właściwością pracy nakładczej jest wykonanie pracy przy użyciu surowców i maszyn powierzonych wykonawcy przez nakładcę. Praca ta może być wykonana w lokalu mieszkalnym wykonawcy. Szczególną właściwością umowy zlecenia jest staranność działań przyjmującego zlecenie, a także przedmiot umowy - dokonanie określonej czynności prawnej (art. 734 k.c.). Z uwagi na niejednolity przedmiot trudno jest określić naturę umów o świadczenie usług, które nie są uregulowane żadnymi przepisami (art. 750 k.c.). Właściwościami tych stosunków prawnych będą cechy niezarezerwowane dla innych typów umów. Szczególną właściwością umowy agencyjnej jest natomiast stałe pośrednictwo agenta przy zawieraniu umów na rzecz dającego zlecenie albo w jego imieniu (art. $758 \$ 1$ k.c.). Ostatnia spośród umów omawianych w obrębie umownego zatrudnienia nietypowego - umowa o dzieło - charakteryzuje się szczególnymi właściwościami w postaci jej określonego przedmiotu - rezultatu starań przyjmującego zamówienie ${ }^{50}$.

Weryfikacja właściwości (natury) konkretnego stosunku prawnego pozwala ocenić, czy jego kwalifikacja prawna dokonana przez strony pozostaje w zgodzie z zasadą swobody umów w kontekście niesprzeczności z właściwościami (naturą) stosunku prawnego mającego za przedmiot cywilnoprawne zatrudnienie nietypowe. To z kolei pozwala stosować właściwy reżim prawny kształtujący status prawny osoby świadczącej pracę.

Drugą granicą zasady swobody umów jest warunek niesprzeczności treści i celu stosunku prawnego z ustawą. Regulację prawną, zgodnie z którą umowa nie może być sprzeczna $\mathrm{z}$ ustawą, uszczegóławia, względem art. $353^{1}$ k.c., art. 22 $\$ 1^{1}$ i $\$ 1^{2}$ k.p. Dla przypomnienia - bowiem regulacja ta była już omawiana - wypada jedynie nadmienić, że w obrębie wskazanych przepisów (art. $22 \$ 1^{1}$ i $\$ 1^{2}$ k.p.) strony, zawierając umowę, której warunki są właściwe dla stosunku pracy, nie mają możliwości zakwalifikowania powstałego w wyniku tej umowy stosunku prawnego do reżimu prawa cywilnego. Dodatkowe ograniczenia zakazujące sprzeczności powstałej umowy z ustawą znaleźć można również na gruncie ustawy o zatrudnianiu pracowników tymczasowych. Nie jest bowiem dopuszczalne powierzenie pracownikowi tymczasowemu innej pracy niż wskazana w art. 2 ust. 2 z.p.t. oraz na czas dłuższy niż nią przewidziany (art. 20 z.p.t.). W przypadku naruszenia wskazanych przepisów należy przyjąć, że możliwe będzie ustalenie, że stosunek pracy ma bądź miał - w zależności od tego, czy nadal trwa - charakter nietymczasowy. Wola stron co do wyboru zatrudnienia jest nieograniczona tak długo, jak długo nie pozostaje sprzeczna z przepisami prawa ${ }^{51}$. Co więcej, pod ką-

50 K. Jędrej, [w:] J. Ciszewski (red.), Kodeks cywilny. Komentarz, Warszawa 2013, s. 1032.

51 Ł. Pisarczyk, Różne formy..., s. 26. 
tem zgodności z zasadą swobody umów i jej ograniczeniami zarówno na gruncie prawa cywilnego, jak i prawa pracy, oprócz badania samej treści umowy, badane jest również jej faktyczne wykonywanie ${ }^{52}$. Sprzeczność treści bądź celu stosunku prawnego mającego za przedmiot umowne zatrudnienie nietypowe $\mathrm{z}$ ustawą musi być badana wspólnie z właściwościami (naturą) danego stosunku prawnego, określonego właśnie przepisami prawa ${ }^{53}$. Niesprzeczność treści i celu stosunku prawnego mającego za przedmiot umowne zatrudnienie nietypowe z ustawą umożliwia zakwalifikowanie więzi zatrudnienia jako jego konkretnego typu i określenie normatywnego ukształtowania statusu prawnego osoby świadczącej pracę.

Ostatnią granicą swobody umów jest warunek niesprzeczności treści i celu stosunku prawnego z zasadami współżycia społecznego. W ramach wyboru i kształtowania podstaw umownego zatrudnienia nietypowego chronione są takie wartości jak wolność od presji ekonomicznej czy swoboda w zakresie decydowania o ukształtowaniu stosunku prawnego. Stosowanie presji ekonomicznej przez podmiot zatrudniający wobec podmiotu zatrudnianego w zakresie kształtowania treści umowy bądź wskazania podstawy zatrudnienia ${ }^{54}$ będzie złamaniem zasady uczciwego obrotu, stanowiącej jeden z przejawów zasady swobody umów ${ }^{55}$. Kwalifikacja prawna zatrudnienia bądź jego ukształtowanie dokonane sprzecznie z zasadami współżycia społecznego (np. poprzez wykorzystanie presji ekonomicznej) będzie pozostawało w sprzeczności z zasadą swobody umów.

\subsubsection{Treść i forma umowy mającej za przedmiot zatrudnienie nietypowe}

Wybór podstawy umownego zatrudnienia nietypowego wpływa na treść umowy oraz formę, w jakiej ma być ona zawarta. W treści umowy o pracę można wyróżnić kilka elementów. Pierwsza grupa to elementy strukturalne, bez których stosunek pracy nie powstanie. Należą do niej wszystkie elementy wskazane w art. 29 k.p. Spośród nich jedynie rodzaj pracy jest elementem przedmiotowo istotnym umowy o pracę ${ }^{56}$, bez którego nie może ona istniećs7. Stosunek pracy nie powstanie bowiem w przypadku braku wskazania rodzaju wykonywanej przez pracownika pracy ${ }^{58}$. Rodzaj pracy może być w umowie wskazany konkretnie, po-

52 M. Tomaszewska, op. cit., s. 166.

53 Por. przypis 48.

54 Zazwyczaj będzie to określenie podstawy cywilnoprawnej zamiast prawno-pracowniczej.

55 R. Trzaskowski, op. cit.

56 T. Zieliński, Prawo pracy. Zarys systemu. Część 2: Prawo stosunku pracy, Warszawa-Kraków 1986, s. 8.

57 H. Lewandowski, Uwagi o roli umowy we wspótczesnym prawie pracy, [w:] M. Matey-Tyrowicz, L. Nawacki, B. Wagner (red.), op. cit., s. 263-264.

58 F. Małysz, Treść i forma umowy o pracę, „Służba Pracownicza” 2009, nr 9, s. 5. 
przez określenie stanowiska albo poprzez wymienienie czynności bądź zespołu czynności, do wykonywania których pracownik będzie zobowiązany ${ }^{59}$. W tym zakresie szczególnie kształtował się sposób określania rodzaju pracy w umowie o pracę zawartej w celu zastępstwa nieobecnego pracownika, obowiązującej w stanie prawnym sprzed nowelizacji czerwcowej z 2015 r. Rodzajowo praca wykonywana przez pracownika zastępującego i zastępowanego musiała być bowiem tożsama ${ }^{60}$. Związane było to $\mathrm{z}$ istotą tej podstawy zatrudnienia jako spełniającej cel wypełnienia braków kadrowych. Obecnie, o czym była już mowa, w związku z nowelizacją czerwcową kodeksu pracy z 2015 r., powyższe uwagi należy odnieść do umowy zawieranej w warunkach art. $25^{1} \S 4$ pkt 1 k.p.

W przypadku telepracy i pracy tymczasowej stopień konkretyzacji rodzaju pracy musi być znaczący. Szczegółowe warunki wykonywania telepracy zostają określone $\mathrm{w}$ umowie o pracę, która jest świadczona w formie organizacyjnej telepracy (art. 67 $\$ 2$ k.p. w zw. $z$ art. $67^{5}$ k.p.). Przedmiot telepracy nie został przez ustawodawcę zawężony. Co prawda, nie każdy rezultat pracy świadczonej przez pracownika może być przekazany za pomocą środków komunikacji elektronicznej, jak wymaga tego art. $67^{5} \$ 2$ k.p., jednakże użycie w tym przepisie słów „w szczególności” świadczy o otwartym katalogu sposobów przekazywania wyników pracy. Przekazanie to może zatem nastąpić w formie bezpośredniej. Natomiast środki komunikacji elektronicznej, o których mowa $w$ art. $67^{5} \$ 1$ k.p. (np. poczta elektroniczna ${ }^{61}$ ), muszą być wykorzystywane przy wykonywaniu telepracy, ale niekoniecznie w zakresie przekazywania jej wyników. Powyższymi regulacjami nie tyle został zawężony rodzaj pracy, jaka może być wykonywana w formie organizacyjnej telepracy, ile dokonana jej konkretyzacja - konieczność wykorzystania w toku telepracy środków komunikacji elektronicznej. Umowa o pracę tymczasową, zgodnie $\mathrm{z}$ art. 13 ust. 1 pkt 1 z.p.t. $\mathrm{w}$ zw. z art. 9 ust. 1 pkt 1 z.p.t., musi konkretyzować rodzaj pracy, która ma być powierzona pracownikowi tymczasowemu. Stosowne ograniczenia w zakresie określania rodzaju pracy, jaki może zostać powierzony pracownikowi tymczasowemu, określa art. 2 pkt 3 z.p.t. Rodzaj pracy musi pozostawać w zbieżności z pracą o charakterze sezonowym, okresowym, doraźnym, pracą, której terminowe wykonanie przez pracowników zatrudnionych przez pracodawcę użytkownika nie byłoby możliwe lub której wykonanie należy do obowiązków nieobecnego pracownika zatrudnionego przez pracodawcę użytkownika. Drugą grupę tworzą podmiotowo doniosłe składniki umowy o pracę, czyli wprowadzone do niej zgodnie z wolą stron $i$ tej woli dowodzące ${ }^{62}$. Katalog tych postanowień jest otwarty, przez co pozostaje

59 Z. Salwa, Kształtowanie treści..., s. 4; H. Lewandowski, Uwagi..., s. 265.

60 S.W. Ciupa, Umowa o pracę zawierana na czas nieobecności (zastępstwo) pracownika, „Monitor Prawniczy” 2002, nr 24, s. 350.

61 M. Świerczyński, Art. 2, [w:] J. Gołaczyński (red.), Ustawa o świadczeniu usług droga elektronicznq. Komentarz, https://sip-1lex-1pl-1004153yx0674.han3.lib.uni.lodz.pl/\#/komentarz/587247059/44499 (dostęp: 19.09.2017).

62 T. Zieliński, op. cit., s. 6-7. 
bardzo szeroki. Strony umowy, o ile działają w granicach prawa, mają dowolność w zakresie kształtowania składników podmiotowo doniosłych umowy o pracę. Trzecią grupę stanowią składniki uzupełniające umowę ex lege. Zaliczane są do niej wszelkie uregulowania, które wynikają z mocy przepisów ${ }^{63}$. Strony umowy oraz data jej zawarcia wynikają z okoliczności zawarcia i wykonywania umowy. W ten sam sposób możliwe jest określenie rodzaju łączącej strony umowy. Brak odmiennych uregulowań umownych oraz okoliczności wynikających z jej faktycznego wykonywania umożliwia przyjęcie, że strony zawarły umowę o pracę na czas nieokreślony ${ }^{64}$. Termin rozpoczęcia pracy również wynika z okoliczności. Nie jest on jednak zawsze zbieżny z terminem nawiązania stosunku pracy. Nieokreślenie terminu nawiązania stosunku pracy, zgodnie z art. 26 k.p., powoduje przyjęcie, że jest nim dzień zawarcia umowy.

W przypadku braku odpowiednich postanowień umownych miejsce wykonywania pracy ustalone zostanie w sposób określony w art. 454 k.c., stosowanym zgodnie z art. 300 k.p., i będzie nim siedziba albo miejsce zamieszkania pracodawcy ${ }^{65}$. Z uwagi na istotę telepracy, którą jest świadczenie pracy co najmniej także poza zakładem pracy, miejscem pracy telepracownika nie może być wyłącznie siedziba zakładu pracy. Może on wykonywać pracę w swoim domu, co wynika $z$ art. $67^{14} \$ 2$ k.p., przy czym ustawodawca nie określa w sposób wyłączający, w jakich miejscach poza zakładem pracy pracownik może wykonywać pracę w tej formie. Słuszny wydaje się pogląd, zgodnie z którym ustalenie konkretnego miejsca świadczenia pracy w ramach telepracy następuje na mocy wspólnych uzgodnień pracownika i pracodawcy. Twierdzenie przeciwne wyłączałoby przede wszystkim możliwość uznania podporządkowania telepracownika co do miejsca pracy, ale również utrudniałoby stosowanie względem niego przepisów dotyczących chociażby podróży służbowej ${ }^{66}$. Brak umownego określenia miejsca pracy telepracownika nie daje możliwości zastosowania art. 454 k.c. w zw. z art. 300 k.p. Z istoty pracy świadczonej $\mathrm{w}$ formie telepracy wynika bowiem, że miejscem świadczenia pracy nie może być wyłącznie siedziba pracodawcy. W takim przypadku miejsce świadczenia pracy determinowane jest istotą pracy i powinno być określone $\mathrm{z}$ uwzględnieniem wszystkich okoliczności faktycznych świadczenia pracy w formie organizacyjnej telepracy ${ }^{67}$.

\section{Tamże.}

64 Jak wskazano w rozdziale I, gdyby strony miały zamiar określić termin końcowy umowy, poczynityby w niej odpowiednie zastrzeżenie. Wobec braku takiego zastrzeżenia uznać należy, że strony nie miały woli zawarcia umowy terminowej.

65 H. Lewandowski, Uwagi..., s. 269-270.

66 S. Duchna, M. Paluszkiewicz, Podporządkowanie telepracownika w stosunku pracy, „Zeszyty Prawnicze UKSW" 2013, vol. 13(1), s. 160-162.

67 J. Wiśniewski, Zatrudnienie pracowników w formie telepracy, Toruń 2007, s. 83; A. Piszczek, op. cit., s. 219. 
W przypadku pracy tymczasowej miejscem świadczenia pracy nie jest siedziba pracodawcy, czyli agencji pracy tymczasowej. Miejsce pracy ustalane jest przez agencję i pracodawcę użytkownika (art. 9 ust. 1 pkt 5 z.p.t.), a następnie uwzględniane $\mathrm{w}$ treści umowy o pracę tymczasową (art. 13 ust. 1 pkt 1 z.p.t. w zw. z art. 9 ust. 1 pkt 5 z.p.t.). Wobec braku określenia miejsca świadczenia pracy w umowie pomiędzy agencją pracy tymczasowej a pracodawcą użytkownikiem pod uwagę brane są okoliczności związane ze świadczeniem pracy. Ostatecznie, o czym była już mowa, o ustaleniu miejsca świadczenia pracy, dokonywanym w oparciu o art. 454 k.c. w zw. z art. 300 k.p., decyduje siedziba pracodawcy użytkownika ${ }^{68}$. Wobec braku odrębnego uregulowania jako obowiązujący przyjmuje się pełny wymiar czasu pracy ${ }^{69}$. Natomiast wynagrodzenie, w przypadku braku stosownego uregulowania $\mathrm{w}$ umowie, wypłacone powinno być w kwocie odpowiadającej rodzajowi wykonywanej pracy i kwalifikacjom pracownika (art. 78 k.p. ${ }^{70}$. Nie może być ono jednak niższe od minimalnego wynagrodzenia za pracę ani zupełnie pominięte (art. 84 k.p.). Określenie w umowie o pracę wysokości wynagrodzenia powinno ponadto obejmować wszystkie jego istotne składniki.

Ostatnia grupa postanowień to elementy autonomiczne, dodatkowe. Wśród nich wyróżnić można umowę o zakazie konkurencji czy umowę, w której powierza się pracownikowi mienie. Materia obejmująca swoim zakresem wskazane przykłady klauzul autonomicznych została szczegółowo uregulowana w odpowiednich przepisach prawa pracy i strony mogą ją modyfikować tylko w granicach dopuszczonych przez te przepisy ${ }^{71}$.

$\mathrm{Z}$ treścią umowy o pracę nieodzownie łączy się jej forma, wskazana w art. 29 $\$ 2$ k.p. Pisemna forma umowy o pracę nie została jednak zastrzeżona ad solemnitatem, co znaczy, że jej niezachowanie nie powoduje skutku nieważności czynności prawnej. W sytuacji zatrudnienia w ramach stosunku pracy per facta concludentia, bez umowy sporządzonej w formie pisemnej, osoba zatrudniona ma możliwość ustalenia istnienia stosunku pracy mocą wyroku sądu o charakterze deklaratywnym. W razie niezawarcia umowy na piśmie pracodawca jest zobowiązany, najpóźniej w dniu rozpoczęcia pracy, potwierdzić pracownikowi na piśmie ustalenia co do stron umowy, jej rodzaju oraz warunków. Brak wykonania powyższej dyspozycji stanowi wykroczenie stypizowane w art. 281 pkt 2 k.p. i podlega karze grzywny od tysiąca do 30 tys. zł.

Regulacja prawna związana $\mathrm{z}$ treścią nietypowych stosunków pracy różni się od regulacji przedstawionej w zakresie dotyczącym istoty poszczególnych ich podstaw prawnych i form organizacyjnych. Do stosunków pracy powstających wskutek zawarcia umów o pracę zastosowanie mają te same przepisy z modyfika-

68 A. Piszczek, op. cit., s. 186.

69 F. Małysz, Treść i forma..., s. 7.

70 Z. Salwa, Kształtowanie treści..., s. 6.

71 H. Lewandowski, Uwagi..., s. 272-273. 
cjami związanymi z właściwościami poszczególnych typów umownego pracowniczego zatrudnienia nietypowego. Treść umów terminowych musi wskazywać termin bądź okoliczności ich zakończenia, które pośrednio wynikają z warunków ich zawarcia. Zgodnie bowiem z treścią art. $25^{1} \$ 4$ k.p., wprowadzoną nowelizacją czerwcową z 2015 r., umowy o pracę na czas określony, przekraczające ustawowe limity, zawierane są w określonych okolicznościach, które muszą zostać powyższe w ich treści (zgodnie z art. $29 \$ 1^{1}$ k.p.) ${ }^{72}$. Dla przykładu umowa o pracę zawarta w celu zastępstwa nieobecnego pracownika podczas jego usprawiedliwionej nieobecności musi w swojej treści konkretyzować tego pracownika. Powyższe odnosi się zarówno do umów zawieranych przed nowelizacją czerwcową kodeksu pracy z 2015 r., jaki i (zgodnie z art. $29 \$ 1^{1}$ k.p.) do umów zawieranych w warunkach art. $25^{1} \$ 4$ pkt 1 k.p. Zatrudnienie w formie telepracy, bez względu na to, czy taka organizacja pracy zostaje wprowadzona przy zawieraniu umowy o prace, czy w trakcie jej trwania, zgodnie $z$ dyspozycją art. $67^{10} \$ 1$ k.p., wymaga dodatkowego określenia jednostki organizacyjnej pracodawcy, w skład której wejdzie telepracownik, oraz osoby lub organu odpowiedzialnych za współpracę z nim i uprawnionych do przeprowadzania kontroli w miejscu wykonywania pracy. Jeżeli strony, zawierając umowę o pracę, decydują się na formę pracy w ramach telepracy, powyższe postanowienia stanowią część składową informacji udzielanej pracownikowi w trybie przewidzianym w art. $29 \$ 3$ k.p. W razie zawierania porozumienia o świadczeniu pracy w formie organizacyjnej telepracy w czasie trwania stosunku pracy postanowienia te pracodawca musi przekazać pracownikowi najpóźniej w dniu rozpoczęcia pracy w formie telepracy (art. $67^{10} \$ 2$ k.p.).

Odmienną regulację, dotyczącą treści umowy o pracę, w porównaniu z tą znajdującą się w kodeksie pracy, zawiera ustawa o zatrudnianiu pracowników tymczasowych. Przepis art. 13 z.p.t. wskazuje elementy, jakie powinna określać umowa o pracę zawarta między agencją pracy tymczasowej a pracownikiem tymczasowym. Poza postanowieniami wymienionymi w art. 29 k.p. przepis ten wymienia konieczność określenia pracodawcy użytkownika oraz warunków wykonywania pracy na jego rzecz. Są to uregulowania wynikające z samej istoty pracy tymczasowej. Przepis art. 9 z.p.t. wskazuje natomiast ustalenia, które powinna zawierać umowa zawarta między pracodawcą użytkownikiem a agencją pracy tymczasowej. Ustalenia te obejmują swoim zakresem:

a) rodzaj pracy, która ma być powierzona pracownikowi tymczasowemu

b) wymagania kwalifikacyjne konieczne do wykonywania pracy, która ma być powierzona pracownikowi tymczasowemu

72 W tej sytuacji istotny jest status prawny umowy o pracę zawartej w warunkach wskazanych w art. $251 \S 4$ k.p. w przypadku odpadnięcia przyczyny uzasadniającej jej zawarcie. J. Stelina wskazuje, że w takiej sytuacji z dniem ustania powodu, o którym mowa w art. $25^{1} \S 4$ k.p., umowa o pracę przekształca się w zwykłą umowę o pracę na czas określony, o której mowa w art. $25^{1} \S 1$ k.p. J. Stelina, Nowa koncepcja umowy o pracę na czas określony, „Państwo i Prawo" 2015, nr 11, s. 49. 
c) przewidywany okres wykonywania pracy tymczasowej

d) wymiar czasu pracy pracownika tymczasowego

e) miejsce wykonywania pracy tymczasowej.

Jeżeli strony zatrudnienia $\mathrm{w}$ ramach umownego zatrudnienia nietypowego zawrą umowę cywilnoprawną, w odniesieniu do treści i formy umowy zastosowanie znajdą odpowiednie przepisy kodeksu cywilnego bądź rozporządzenia w sprawie uprawnień pracowniczych osób wykonujących pracę nakładczą. Ostatni ze wskazanych aktów w $\$ 2$ i $\$ 3$ precyzuje, jakie elementy musi zawierać umowa o pracę nakładczą. Elementy te to określenie rodzaju umowy i jej podstawowych warunków, a w szczególności rodzaju pracy i terminu jej rozpoczęcia oraz zasad wynagradzania. Dodatkowo w umowie o pracę nakładczą strony określają minimalną miesięczną ilość pracy, której wykonanie należy do obowiązków wykonawcy ( $\$ 3$ rozp. pr. nakład.). Umowa o pracę nakładczą powinna być zawarta $\mathrm{w}$ formie pisemnej ( $\$ 2$ ust. 1 rozp. pr. nakład.). Forma ta nie jest jednak zastrzeżona pod rygorem nieważności ${ }^{73}$. Również kodeks cywilny nie narzuca formy właściwej dla umów, które mogą być podstawą zatrudnienia. W tym zakresie jedynie przepis art. $758^{2}$ k.c. stanowi, że każda ze stron umowy agencyjnej może żądać od drugiej strony pisemnego potwierdzenia umowy, jej zmian lub uzupełnien ${ }^{74}$. Przepis ten ma charakter iuris cogentis.

Treść poszczególnych umów stanowiących podstawy cywilnoprawnego zatrudnienia nietypowego jest zróżnicowana. Essentialia negotii umowy zlecenia to określenie ( $w$ sposób względnie zindywidualizowany ${ }^{75}$ ) czynności prawnej, która ma zostać wykonana (art. 734 k.c.). Zlecenie może zakładać dokonanie więcej niż jednej czynności prawnej ${ }^{76}$. Umowy o świadczenie usług, o których mowa $\mathrm{w}$ art. 750 k.c., $\mathrm{z}$ racji nieuregulowania żadnymi przepisami, nie mają określonego zakresu swojej treści. Treść umowy agencyjnej wskazywać musi przedmiot stałego pośredniczenia (zawieranie umów na rzecz dającego zlecenie albo zawieranie ich w jego imieniu) oraz wynagrodzenie (art. 758 k.c.). Do istotnych składników umowy o dzieło należy określenie przedmiotu dzieła oraz wysokości wynagrodzenia (art. 627 k.c.). W porównaniu z umownym nietypowym zatrudnieniem pracowniczym ustawodawca daje stronom zatrudnienia cywilnoprawnego dalej idącą swobodę w zakresie ustalania treści umowy. Powyższe wpływa w sposób

73 F. Małysz, Chałupnictwo. Umowa i wynagradzanie, „Służba Pracownicza” 2006, nr 4, s. 13.

74 Powyższe zgodne jest z art. 13 ust 1 Dyrektywy Rady nr 86/653/EWG z dnia 18 grudnia 1986 r. w sprawie koordynacji ustawodawstw państw członkowskich odnoszących się do przedstawicieli handlowych działających na własny rachunek, Dz.U.EWG.L 382 z dnia 31 grudnia 1986 r., s. 17-21; dalej: dyrektywa agencyjna.

75 Oznacza to, że przedmiot umowy zlecenia nie musi, ale może zostać przez strony dookreślony w sposób dalece szczegółowy.

76 K. Kopaczyńska-Pieczniak, Art. 734 k.c., pkt 5, [w:] A. Kidyba (red.), Kodeks cywilny. Komentarz, t. 3: Zobowiqzzania - część szczególna, https://sip-1lex-1pl-1004153yx0674.han3.lib.uni. lodz.pl/\#/komentarz/587286617/462810 (dostęp: 19.09.2017). 
istotny na status prawny osób świadczących pracę. Potwierdzeniem takiej prawidłowości jest semiimperatywny charakter norm prawa pracy, w znaczący sposób ograniczający możliwość swobodnego kształtowania treści stosunku prawnego, niemający odpowiednika w przepisach prawa cywilnego.

\subsection{Status prawny kandydatów przyjmowanych do pracy w ramach umownego zatrudnienia nietypowego}

\subsubsection{Uwagi wprowadzające}

Konstrukcje prawne poszczególnych podstaw prawnych i form organizacyjnych umownego zatrudnienia nietypowego są zróżnicowane $\mathrm{z}$ uwagi na inne założenia systemowe, które mają realizować. Ze względu na to, że różne typy umownego zatrudnienia nietypowego spełniają odmienne społeczno-gospodarcze cele, o czym mowa była w pierwszym rozdziale, w konsekwencji związywania się nimi przez strony stosunku zatrudnienia, inaczej kształtuje się status prawny osób zatrudnianych. Zróżnicowanie to ujawnia się już na etapie powstawania stosunku prawnego. Przedstawienie sytuacji kandydatów przyjmowanych do pracy w fazie przygotowywania umowy o zatrudnienie i na etapie jej zawierania pozwoli rozpocząć kompleksową analizę statusu prawnego osób świadczących pracę w ramach umownego zatrudnienia nietypowego.

Poczynione uwagi będą obejmowały swoim zakresem status prawny kandydatów do pracy w odniesieniu do modelu ochrony ich danych osobowych, warunków, jakie muszą zostać spełnione przed dopuszczeniem do pracy oraz ochrony przed dyskryminacją. Analiza tych zagadnień pozwoli ocenić, czy status ten jest na wskazanych płaszczyznach zróżnicowany i czy zróżnicowanie to współgra z gospodarczo-społecznym przeznaczeniem poszczególnych stosunków prawnych umownego zatrudnienia nietypowego.

\subsubsection{Ochrona danych osobowych kandydatów do pracy}

Problematyka związana z ochroną danych osobowych pozostaje w obrębie zainteresowania zarówno teoretyków, jak i praktyków zajmujących się prawem. Ochrona danych osobowych jest składową szerszego dobra chronionego prawem, czyli prywatności. Prywatność sama w sobie nie może być zdefiniowana, gdyż jej granice 
każdorazowo uzależnione są od zindywidualizowanego położenia danej jednostki ${ }^{77}$. Prawo do prywatności jest chronione m.in. przez Powszechną Deklarację Praw Człowieka $^{78}$ (art. 12) oraz Europejską Konwencję o Ochronie Praw Człowieka i Podstawowych Wolności ${ }^{79}$ (art. 8). Na prywatność składają się: indywidualność, wolność, autonomia i poczucie bezpieczeństwa ${ }^{80}$. Ich naruszanie prowadzi do pozbawienia człowieka poczucia niezależności oraz szeroko rozumianej wolności osobistej. Rozważania tej części opracowania skupią się na prawie kandydatów do pracy do ochrony danych osobowych. Problematyka ta zostanie omówiona zarówno w kontekście fazy poprzedzającej zatrudnienie, jak i fazy związanej z zawieraniem umowy mającej za przedmiot zatrudnienie nietypowe. Zagadnieniem, które w niniejszej monografii wymaga najgłębszej analizy w obrębie normatywnym, nie są szczegółowe aspekty dotyczące ochrony danych osobowych w zatrudnieniu, a różnice w tej ochronie dotyczące poszczególnych podstaw prawnych i form organizacyjnych umownego zatrudnienia nietypowego, wpływające na status prawny osób zatrudnionych. Ujawniają się one szczególnie w fazie nawiązywania stosunku prawnego.

Na gruncie prawa krajowego główna regulacja dotycząca ochrony danych osobowych znajduje się w ustawie o ochronie danych osobowych ${ }^{81}$, choć podwaliny do tej ochrony daje już Konstytucja. W art. 51 Konstytucja wskazuje warunek ujawniania informacji dotyczących swojej osoby w postaci istnienia zobowiązującego do tego przepisu ustawy. W odniesieniu do ogółu obywateli przepisem zobowiązującym do ujawniania określonego katalogu danych osobowych jest właśnie ustawa z dnia 29 sierpnia 1997 r. o ochronie danych osobowych. W związku z powyższym obywatele mają prawo do nieujawniania swoich danych osobowych tak długo, jak długo nie zobowiązuje ich do tego przepis prawa ${ }^{82}$. Konieczność ujawnienia danych osobowych musi być uzasadniona interesem publicznym dla celów statystycznych, gospodarczych itp. ${ }^{83}$ Przepis art. 51 Konstytucji należy ponadto rozpatrywać

77 U. Jackowiak, Ochrona danych osobowych w prawie pracy, „Praca i Zabezpieczenie Społeczne" 1998, nr 7-8, s. 30.

78 Powszechna Deklaracja Praw Człowieka z dnia 10 grudnia 1948 r., United Nations, www. un.org/en/universal-declaration-human-rights/index.html (dostęp: 3.01.2017).

79 Konwencja o ochronie praw człowieka i podstawowych wolności z dnia 4 listopada 1950 r., zmieniona następnie Protokołami nr 3, 5 i 8 oraz uzupełniona Protokołem nr 2, Dz.U. z 1993 r., $\mathrm{Nr} 61$, poz. 284 ze zm.

80 H. Szewczyk, Ochrona dóbr osobistych w zatrudnieniu, Warszawa 2007, s. 341.

81 Ustawa z dnia 29 sierpnia 1997 r. o ochronie danych osobowych, Dz.U. z 2016 r. poz. 922 - t.j.; dalej: u.o.d.o.

82 E. Bielak-Jomaa, Ochrona danych osobowych bezrobotnych i poszukujacych pracy, [w:] T. Wyka, A. Nerka (red.), Ochrona danych osobowych podmiotów objętych prawem pracy i prawem ubezpieczeń społecznych, Warszawa 2012, s. 59.

83 P. Winczorek, Komentarz do Konstytucji Rzeczpospolitej Polskiej z 2 kwietnia 1997 r., Warszawa 2000, s. 69 i nast., za: A. Nerka, Problematyka zgody pracownika na przetwarzanie danych osobowych, [w:] T. Wyka, A. Nerka (red.), Granice ochrony danych osobowych w stosunkach pracy, Warszawa 2009, s. 71. 
w związku z brzmieniem art. 47 Konstytucji. Artykuł ten m.in. statuuje zasadę prawa do prywatności ${ }^{84}$, jednym z przejawów której, jak zostało już wskazane, jest właśnie ochrona danych osobowych. Zatem art. 51 Konstytucji może być uznany za konkretyzację ogólnej zasady ochrony prywatności, zawartej w art. 47 Konstytucji ${ }^{85}$.

Prawo pierwotne Unii Europejskiej reguluje ochronę danych osobowych Traktatem o Funkcjonowaniu Unii Europejskiej ${ }^{86}$. Kluczowy w tej materii jest art. 16 ust. 1, zgodnie z którym każda osoba ma prawo do ochrony dotyczących jej danych osobowych. Również Karta Praw Podstawowych Unii Europejskiej ${ }^{87}$ statuuje prawo do ochrony danych osobowych (art. 8). Dodatkowe standardy w tym zakresie wprowadzone zostały obowiązującą w ramach prawa wtórnego ${ }^{88}$ dyrektywą Parlamentu Europejskiego i Rady nr 95/46/WE w sprawie ochrony osób fizycznych w zakresie przetwarzania danych osobowych oraz swobodnego przepływu tych danych ${ }^{89}$. Najważniejszą regulacją dyrektywy są minimalne standardy ochrony danych osobowych. Dotyczą one udzielenia informacji o administratorze danych zbioru przed wyrażeniem zgody na ich dostarczenie, wyjątkowych przypadków przetwarzania danych bez zgody, zakazu automatycznego przetwarzania informacji, prawa do informacji o zbiorze danych, prawa do dokonywania zmian w zbiorze oraz prawa do wniesienia sprzeciwu wobec przetwarzania danych ${ }^{90}$. Powyższe standardy są w znacznym stopniu uregulowane w sposób szczegółowy, co nie zmienia faktu, że swoboda kształtowania prawa krajowego na gruncie omawianej dyrektywy jest relatywnie duża ${ }^{91}$. Ustawodawstwo Rady Europy również chroni dane osobowe. Konwencja Rady Europy nr $108^{92}$ nakłada na prawodawców państw członkowskich ${ }^{93}$ daleko idące zobowiązania w zakresie ochrony danych osobowych.

84 Ibidem.

85 H. Szewczyk, Ochrona dóbr..., s. 342.

86 Traktat o funkcjonowaniu Unii Europejskiej z dnia 26 października 2012 r., Dz.U.C 326 z dnia 26 października 2012 r., s. 47-390.

87 Karta zatwierdzona dnia 2 października 2000 r. na szczycie w Nicei (OJ 2000/c 364 of 18.12.2000), przyjęta przez Kartę Praw Podstawowych Unii Europejskiej z dnia 12 grudnia 2007 r., Dz.U.UE.C 2007 C 303.

88 T. Wyka, Propozycje zmian w prawie pracy w zakresie gromadzenia i przetwarzania danych osobowych kandydata na pracownika i pracownika, [w:] T. Wyka, A. Nerka (red.), Ochrona danych osobowych objętych prawem pracy i prawem ubezpieczeń społecznych. Stan obecny i perspektywy zmian, Warszawa 2012, s. 132.

89 Dyrektywa Parlamentu Europejskiego i Rady nr 95/46/EC z dnia 24 października 1995 r. w sprawie ochrony osób fizycznych w zakresie przetwarzania danych osobowych oraz swobodnego przepływu tych danych, Dz.U.EC.L 281 z dnia 23 listopada 1995 r., s. 31-50.

90 Szczegółowo kwestie te zostały omówione w: J. Barta, P. Fajgielski, R. Markiewicz, Ochrona danych osobowych, Kraków 2004, s. 91-93 oraz T. Wyka, Granice pozyskiwania danych osobowych dotyczących zdrowia pracownika, [w:] T. Wyka, A. Nerka (red.), op. cit., s. 91.

91 J. Barta, P. Fajgielski, R. Markiewicz, op. cit., s. 151.

92 Konwencja Rady Europy nr 108 z dnia 28 stycznia 1981 r. dotycząca ochrony osób w związku z automatycznym przetwarzaniem danych osobowych, Dz.U. z 2003 r., Nr 3, poz. 25.

93 J. Barta, P. Fajgielski, R. Markiewicz, op. cit., s. 70. 
Analiza ochrony danych osobowych osób zatrudnionych w ramach umownego zatrudnienia nietypowego rozpocznie się od przedstawienia więzi zatrudnienia pracowniczego. Zatrudnienie pracownicze zostanie omówione zbiorczo, bowiem ani rodzaj umowy o pracę, ani forma organizacyjna zatrudnienia nie mają znacznego wpływu na sytuację prawną osób zatrudnionych w zakresie sposobu ochrony danych osobowych, zarówno na etapie poprzedzającym zatrudnienie, jak i na etapie jego kreowania. Pewne odrębności w tych kwestiach przedstawione zostaną na koniec prezentowanego wątku.

Kodeks pracy zawiera regulację ochrony danych osobowych na etapie poprzedzającym zatrudnienie pracownicze. Do momentu wejścia w życie przepisów kodeksu pracy, normujących omawianą problematykę ${ }^{94}$, zarówno do etapu poprzedzającego zatrudnienie, jak i do etapu jego trwania zastosowanie miała ustawa o ochronie danych osobowych ${ }^{95}$. Obecnie ustawę tę stosuje się w odniesieniu do kwestii związanych ze stosunkiem pracy, nieuregulowanych w kodeksie pracy (art. $22^{1} \$ 5$ k.p.) ${ }^{96}$. Przepis art. $22^{1}$ k.p. zawiera katalog danych, których pracodawca ma prawo żądać od osoby ubiegającej się o zatrudnienie. Przyszły pracodawca, ponosząc ryzyko osobowe, jest zainteresowany poznaniem pełnego profilu kandydata na pracownika poprzez uzyskanie informacji o jego wykształceniu, umiejętnościach i kwalifikacjach ${ }^{97}$. Podstawą żądania danych osobowych $\mathrm{w}$ procesie rekrutacji pracowniczej jest art. $22^{1}$ k.p. oraz wydane na podstawie art. $298^{1}$ k.p. rozporządzenie $z$ dnia 28 maja 1996 r. w sprawie zakresu prowadzenia przez pracodawców dokumentacji w sprawach związanych ze stosunkiem pracy oraz sposobu prowadzenia akt osobowych pracownika ${ }^{98}$. Dane, których pracodawca ma prawo żądać ${ }^{99}$ od osoby ubiegającej się o zatrudnienie, to: imię (imiona) i nazwisko, imiona rodziców, data urodzenia, miejsce zamieszkania (adres do korespondencji), wykształcenie, przebieg dotychczasowego zatrudnienia ${ }^{100}$.

94 Dz.U. z 2003 r., Nr 213, poz. 2081.

95 T. Wyka, Propozycje zmian..., s. 133.

96 K. Walczak, Ochrona danych osobowych kandydata do pracy w trakcie rekrutacji, [w:] T. Wyka, A. Nerka (red.), op. cit., s. 83; T. Wyka, Propozycje zmian..., s. 130.

97 T. Wyka, Granice pozyskiwania..., s. 85.

98 Dz.U. Nr 62, poz. 286 ze zm.; dalej: rozporządzenie w sprawie dokumentacji pracowniczej.

99 „Żądanie” podania danych osobowych poprzedza etap ich przetwarzania, regulowany ustawą o ochronie danych osobowych. A. Kamińska-Pietnoczko, Dane osobowe w zatrudnieniu, „Monitor Prawa Pracy” 2015, nr 1, s. 12.

100 W tym miejscu powstać mogą wątpliwości dotyczące terminu „przebieg zatrudnienia”. Nie zostało bowiem sprecyzowane, czy chodzi jedynie o zatrudnienie w ramach stosunku pracy, czy o każde wykonywanie pracy. G. Spytek-Bandurska, Wybrane problemy pracodawców ze stosowaniem przepisów o ochronie danych osobowych, [w:] T. Wyka, A. Nerka (red.), Granice ochrony..., s. 27. W związku z powyższym wykładni kodeksu pracy dokonuje się łącznie z wykładnią rozporządzenia. Skoro okresy zatrudnienia mogą potwierdzać inne dokumenty niż świadectwa pracy, przyjąć należy, że pracodawca ma prawo żądać całościowej informacji o dotychczasowym zatrudnieniu bez ograniczania jej do uprzednich stosunków pracy. 
W celu ich uzyskania pracodawca może żądać od osoby ubiegającej się o zatrudnienie stosownych dokumentów. Ich wykaz określa rozporządzenie $\mathrm{w}$ sprawie zakresu prowadzenia przez pracodawców dokumentacji w sprawach związanych ze stosunkiem pracy oraz sposobu prowadzenia akt osobowych pracownika. Są to: kwestionariusz osobowy, świadectwa pracy z poprzednich miejsc pracy lub inne dokumenty potwierdzające okresy zatrudnienia, obejmujące okresy pracy przypadające w roku kalendarzowym, w którym pracownik ubiega się o zatrudnienie, dokumenty potwierdzające kwalifikacje zawodowe wymagane do wykonywania oferowanej pracy, w przypadku osoby ubiegającej się o zatrudnienie w celu przygotowania zawodowego - świadectwo ukończenia gimnazjum, orzeczenie lekarskie stwierdzające brak przeciwwskazań do pracy na określonym stanowisku oraz inne dokumenty, jeżeli obowiązek ich przedłożenia wynika $\mathrm{z}$ odrębnych przepisów. Osoba ubiegająca się o zatrudnienie pracownicze może dodatkowo, zgodnie z $\$ 1$ ust. 2 rozporządzenia w sprawie dokumentacji pracowniczej, przedłożyć dokumenty potwierdzające jej umiejętności i osiągnięcia zawodowe, świadectwa pracy z poprzednich miejsc pracy lub inne dokumenty potwierdzające okresy zatrudnienia, obejmujące okresy pracy przypadające $\mathrm{w}$ innym roku kalendarzowym niż ten, w którym ubiega się o zatrudnienie oraz dokumenty stanowiące podstawę do korzystania ze szczególnych uprawnień w zakresie stosunku pracy.

$\mathrm{Z}$ treści art. 19ga ustawy o promocji zatrudnienia i instytucjach rynku pracy wynika, że agencja pracy tymczasowej (jako agencja zatrudnienia) ma prawo żądać od osoby ubiegającej się o zatrudnienie złożenia oryginałów dokumentów. Skoro bowiem agencja pracy tymczasowej zobowiązana jest, na pisemny wniosek, do niezwłocznego zwrotu oryginałów dokumentów, w szczególności takich, które potwierdzają posiadane wykształcenie, kwalifikacje oraz doświadczenie zawodowe, uprzednio musi wejść $\mathrm{w}$ ich posiadanie. Wydaje się, że dysponowanie przez agencję pracy tymczasowej oryginałami dokumentów pracownika może powodować trudności w znalezieniu przez niego innego zatrudnienia ${ }^{101}$, nawet jeśli może on w każdym czasie żądać ich zwrotu. Uzasadnione byłoby wprowadzenie ustawowego nakazu natychmiastowego zwrotu oryginałów dokumentów pracownikowi tymczasowemu, który aktywizowałby się po zakończeniu procesu rekrutacji. Sprzyjałoby to możliwości znajdowania przez pracowników zatrudnienia nietymczasowego, czyli zatrudnienia spełniającego funkcję stabilizującą status zawodowy osób świadczących pracę. Prawodawca nie poprzestał na wskazaniu zamkniętego katalogu danych, których od osoby ubiegającej się o zatrudnienie ma prawo żądać pracodawca ${ }^{102}$. Wskazał również formę ich przekazywania.

101 M. Paluszkiewicz, Agencje zatrudnienia po nowelizacji ustawy o promocji zatrudnienia i instytucjach rynku pracy, „Praca i Zabezpieczenie Społeczne” 2014, nr 6, s. 11.

102 Wydawać się może, że katalog ten otwiera przepis art. $22^{1} \S 4$ k.p., zgodnie z którym pracodawca może żądać również innych danych osobowych. Wskazany przepis in fine ogranicza jednak prawo żądania innych danych od przepisu ustawy szczególnej, z której może wynikać obowiązek uzyskania dodatkowych danych (na przykład danych o niekaralności 
Zgodnie z art. $22^{1} \$ 3$ k.p. przekazanie danych następuje w formie oświadczenia woli kandydata na pracownika (bądź samego pracownika, o czym mowa będzie w dalszej części). Pracodawca ma ponadto możliwość żądania udokumentowania wskazanych danych.

Jedynymi danymi osobowymi, które nie podlegają ochronie, są podstawowe dane osobowe, czyli imię i nazwisko ${ }^{103}$. Do czasu używania ich zgodnie z regułami społecznymi, działania osób posługujących się nimi nie są bezprawne ${ }^{104}$. Katalog wskazany w art. $22^{1} \$ 1$ k.p. poszerza, względem danych podstawowych, katalog danych, które podlegają ujawnieniu i przetwarzaniu. Ma on jednak w dalszym ciągu charakter ściśle ograniczony. W związku z tym powstaje wątpliwość jeśli chodzi o możliwości przetwarzania dodatkowych danych kandydata na pracownika za jego zgodą. Dane osobowe są danymi identyfikującymi konkretną osobę albo umożliwiającymi jej identyfikację ${ }^{105}$. W związku z tym, że mają one również charakter osobopoznawczy ${ }^{106}$, ujawnianie ich poza katalog określony w kodeksie pracy bądź w przepisach odrębnych może nieść ze sobą określone konsekwencje. W szczególności podanie przez kandydata na pracownika danych o pochodzeniu etnicznym, rasowym, poglądach czy przekonaniach, jak również o statusie cywilnym czy rodzinnym, nawet jeśli dokonane za zgodą, zdaje się godzić nie tylko w zasadę poszanowania prawa do prywatności, ale również w zasadę niedyskryminacji i równego traktowania, o ile dane te zostaną wykorzystane jako podstawa decyzji dotyczącej zatrudnienia ${ }^{107}$. Dobrowolność wyrażenia takiej zgody jest znacznie ograniczona poprzez oczywistą zależność ekonomiczną osoby ubiegającej się o zatrudnienie od przyszłego pracodawcy ${ }^{108}$. Dodatkowym argumentem przemawiającym za tym, że zgoda kandydata na pracownika na udostępnienie innych niż ustawowo wskazane danych osobowych nie wyłącza bezprawności ich przetwarzania, jest wąski katalog danych, których pracodawca może żądać od osoby ubiegającej się o zatrudnienie oraz brak klauzuli umożliwiającej gromadzenie innych danych za zgodą osoby, której dotyczą. Zgoda na przetwarzanie danych osobowych jest dodatkową przesłanką, nieprzewidzianą przez ustawodawcę. W związku z tym nie ma podstaw do uznania możliwości wyrażenia przez kandydata na pracownika zgody na przetwarzanie danych osobowych ponad katalog wskazany w art. $22^{1} \$ 1$ k.p.

w przypadku ustawy o służbie cywilnej). Zamknięty charakter katalogu potwierdza A. Nerka, Problematyka zgody pracownika na przetwarzanie danych osobowych, [w:] T. Wyka, A. Nerka (red.), Granice ochrony danych osobowych w stosunkach pracy, Warszawa 2009. s. 78.

103 Wyrok Sądu Apelacyjnego w Gdańsku z dnia 15 marca 1996 r., I Acr 33/96, LEX nr 25507.

104 H. Szewczyk, Ochrona dóbr..., s. 359.

105 E. Bielak-Jomaa, op. cit., s. 65.

106 Wyrok Naczelnego Sądu Administracyjnego z dnia 28 listopada 2002 r., II SA 3389/01, LEX nr 241604.

107 G. Spytek-Bandurska, op. cit., s. 27.

108 A. Nerka, op. cit., s. 78. 
Znaczne ograniczenie katalogu danych osobowych, których można żądać w procesie rekrutacji pracowniczej, świadczy o wzmożonej i szczególnej ich ochronie. Dobrem, które ustawodawca stawia w tym przypadku na piedestale, jest nie tylko ochrona prawa do prywatności kandydata na pracownika, ale również ochrona przed dyskryminującą decyzją dotyczącą jego zatrudnienia. W związku z powyższym pogląd wyłączający możliwość udzielenia przez kandydata na pracownika zgody na uzyskanie przez pracodawcę danych poza ustawowy katalog zasługuje na aprobatę ${ }^{109}$.

Wskazana regulacja prawna ma zastosowanie do wszystkich rodzajów umownego zatrudnienia nietypowego. Wątpliwości o jej zupełności mogą się jedynie pojawić przy pracy tymczasowej. Ze swej natury praca tymczasowa powinna mieć charakter przejściowy. Nie znaczy to jednak, że do jej wykonywania nie są wymagane kwalifikacje oraz doświadczenie zawodowe potwierdzone odpowiednią dokumentacją ${ }^{110}$. Zgodnie z art. 9 pkt 2 z.p.t., agencja pracy tymczasowej i pracodawca użytkownik ustalają wymagania kwalifikacyjne konieczne do wykonywania pracy, która ma być powierzona pracownikowi tymczasowemu. Dzięki temu, rekrutując pracowników tymczasowych, agencja pracy tymczasowej wyłania tych, którzy spełniają wskazane przez pracodawcę użytkownika wymogi kwalifikacyjne. Przepisy prawa pracy nie definiują wprost pojęcia kwalifikacji. Kodeks pracy posługuje się nim jednak w rozdziale trzecim działu czwartego. Kwalifikacje zawodowe pracowników zawsze są powiązane z określonym rodzajem pracy, stanowiąc warunek do wykonywania pracy, do której pracownik się zobowiązał. Związane są również z możliwością pozostawania w zatrudnieniu na określonym stanowisku ${ }^{111}$. Kwalifikacje te to całokształt wiedzy i umiejętności posiadanych przez pracownika, niezbędnych do wykonywania pracy określonego rodzaju ${ }^{112}$, obejmujący wykształcenie oraz staż pracy ${ }^{113}$. Po-

109 Odmiennie: M. Głogowska, Dopuszczalność uzyskania informacji o karalności od kandydata na pracownika przez pracodawcę, [w:] A. Świątkowski (red.), Studia z zakresu prawa pracy i polityki społecznej, Kraków 2010, s. 149 oraz literatura tam wskazana; A. Kamińska-Pietnoczko, op. cit., s. 12-13.

110 Jak wskazano powyżej, agencja pracy tymczasowej może posiadać dokumentację kandydata na pracownika tymczasowego w oryginałach.

111 J. Jończyk, Prawo pracy, Warszawa 1994, s. 318. M. Włodarczyk, Art. 102, [w:] K.W. Baran (red.), Kodeks pracy. Komentarz, https://sip-1lex-1pl-1004153yx0674.han3.lib.uni.lodz. pl/\#/komentarz/587329148/490781 (dostęp: 19.09.2017).

112 Skoro za proces podnoszenia kwalifikacji uznaje się zdobywanie i uzupełnianie wiedzy i umiejętności, samą wiedzę i umiejętności uznać należy za kwalifikacje zawodowe, których poziom wzrasta poprzez czynności kategoryzowane jako podnoszenie kwalifikacji (kursy doszkalające, szkolenia). W ten sposób podnoszenie kwalifikacji zawodowych przedstawiają: W. Szubert, Zarys prawa pracy, Warszawa 1980, s. 203; M. Rylski, Podnoszenie kwalifikacji zawodowych przez pracowników na gruncie kodeksu pracy - teorie modelu legislacyjnego i ich konsekwencje prawne, cz. 2, „Praca i Zabezpieczenie Społeczne” 2015, nr 2, s. 2.

113 Ł. Pisarczyk, Obowiqzzek ułatwiania pracownikom podnoszenia kwalifikacji zawodowych, „Praca i Zabezpieczenie Społeczne” 2003, nr 4, s. 31. 
jęcia tego ustawodawca używa również w przepisach określających dopuszczalne wypadki powierzenia pracy innej niż umówiona (art. $42 \S 4$ k.p.), dlatego pomocna przy definiowaniu wymagań kwalifikacyjnych będzie analiza tej regulacji ${ }^{114}$. $\mathrm{W}$ wyroku z dnia 4 października $2000 \mathrm{r} \cdot{ }^{115}$ Sąd Najwyższy uznał, że pod pojęciem „kwalifikacji pracownika” $z$ art. $42 \$ 4$ k.p. należy rozumieć nie tylko przygotowanie zawodowe pracownika - jego formalne wykształcenie, zdobyte doświadczenie zawodowe i potrzebne umiejętności - ale także jego właściwości psychofizyczne, predyspozycje psychiczne oraz zdolności do wykonywania określonych czynności z punktu widzenia zdrowia fizycznego. Kandydat na pracownika na mocy dyspozycji $\$ 1$ ust. 1 pkt 3 rozporządzenia w sprawie dokumentacji pracowniczej zobowiązany jest przedstawić dokumenty potwierdzające kwalifikacje zawodowe, wymagane do wykonywania oferowanej pracy. Ponadto, zgodnie $\mathrm{z} \$ 1$ ust. 2 tego rozporządzenia, może on przedstawić dokumenty potwierdzające jego umiejętności. Jeśli kandydat na pracownika tymczasowego nie wykona powyższych czynności, pozbawi się możliwości weryfikacji swojej kandydatury przez agencję pracy tymczasowej pod kątem poszukiwanego przez pracodawcę użytkownika pracownika tymczasowego.

Przepis art. $22^{1}$ k.p. wymaga analizy z jeszcze jednej perspektywy. W swojej treści odwołuje się on bowiem do „osoby ubiegającej się o zatrudnienie”, a nie o zatrudnienie pracownicze. W związku z powyższym mogą powstać wątpliwości, czy ma on zastosowanie jedynie do zatrudnienia pracowniczego, czy również do zatrudnienia cywilnoprawnego ${ }^{116}$. Nieuzasadnione byłoby stosowanie regulacji kodeksu pracy do więzi zatrudnienia cywilnoprawnego, nawet w kontekście poprzedzającego go etapu, bez wyraźnego odesłania. Ilekroć ustawodawca dopuszcza możliwość stosowania przepisów prawa pracy do zatrudnienia cywilnoprawnego, wyraźnie to akcentuje (np. art. 304 k.p.). W rozpatrywanym przypadku brak jest takiego odesłania. W związku z powyższym wykładnia rozszerzająca, pomimo nieprecyzyjnej nomenklatury wskazanego przepisu, nie jest uzasadniona. Do osób ubiegających się o zatrudnienie cywilnoprawne zastosowanie będą miały przepisy ogólne dotyczące ochrony danych osobowych, znajdujące się w ustawie o ochronie danych osobowych. Przede wszystkim dane takie będą mogły być zbierane, utrwalane, przechowywane, opracowywane, zmieniane, udostępniane (czyli przetwarzane) jedynie za zgodą osoby, której dotyczą (art. 23 ust. 1 u.o.d.o. w zw. $\mathrm{z}$ art. 7 ust. 2 u.o.d.o.). Zgody nie wymaga jedynie przetwarzanie w zakresie usuwania danych. Nie ma zatem podstaw do stosowania kodeksu pracy do stosunków cywilnoprawnych $\mathrm{w}$ imię wyższego dobra, jakim jest ochrona pry-

114 A. Sobczyk, Art. 9, [w:] A. Sobczyk, Ustawa o zatrudnianiu pracowników tymczasowych. Komentarz, https://sip-1lex-1pl-1004153yx0cd3.han3.lib.uni.lodz.pl/\#/komentarz/ 587241498/38938 (dostęp: 19.09.2017).

115 Wyrok Sądu Najwyższego z dnia 4 października 2000 r., I PKN 61/00, LEX nr 46823.

116 Zob. K. Walczak, Ochrona danych..., s. 86. 
watności zatrudnianego ${ }^{117}$. Jego prywatność na gruncie obowiązujących regulacji chroni bowiem potrzeba uzyskania zgody na przetwarzanie danych osobowych. Odpowiedź na pytanie, czy ochrona ta jest wystarczająca, jest z perspektywy teoretycznoprawnej niemożliwa.

Drugim wątkiem, którego potrzeba omówienia była już sygnalizowana, jest ochrona danych osobowych w trakcie kreowania więzi umownego zatrudnienia nietypowego, ściśle powiązana $\mathrm{z}$ ochroną danych na etapie poprzedzającym jego powstawanie. Kodeks pracy w art. $22^{1} \$ 2$ zawiera katalog danych, o jakie może wnioskować pracodawca. W tym przypadku nie ulega wątpliwości, że przepis ten będzie miał zastosowanie jedynie do stosunku pracy. Ustawowy katalog danych, których pracodawca może żądać podczas trwania stosunku pracy, czego z reguły dokonuje bezpośrednio po podpisaniu umowy o pracę, został rozszerzony w stosunku do katalogu danych, których może on żądać od osoby ubiegającej się o zatrudnienie, o inne dane osobowe pracownika, a także imiona i nazwiska oraz daty urodzenia dzieci pracownika, jeżeli podanie takich danych jest konieczne ze względu na korzystanie przez pracownika ze szczególnych uprawnień przewidzianych $\mathrm{w}$ prawie pracy, oraz o numer PESEL. Zakres danych osobowych udostępnianych na żądanie pracodawcy na podstawie kodeksu pracy $\mathrm{w}$ trakcie trwania stosunku pracy tworzą zatem łącznie, poprzez katalog zamknięty ${ }^{118}$, dane wskazane w art. $22^{1} \$ 1$ i $\$ 2$ k.p. W pozostałym zakresie odnośnie do wszelkich czynności związanych $\mathrm{z}$ danymi osobowymi pracownika zastosowanie znajdzie ustawa o ochronie danych osobowych i wydane na jej podstawie przepisy wykonawcze. Innymi danymi osobowymi pracownika, jeżeli ich podanie jest konieczne ze względu na korzystanie przez pracownika ze specjalnych uprawnień, są na przykład dane pozwalające na korzystanie ze środków zakładowego funduszu świadczeń socjalnych ${ }^{119}$ czy z uprawnień związanych z rodzicielstwem. Aby móc prawidłowo wypełniać swoje obowiązki, pracodawca musi posiąść wskazane dane z początkiem zatrudnienia pracownika i weryfikować ich aktualność w trakcie trwania stosunku pracy.

Regulacja art. $22^{1} \$ 2$ k.p. ma zastosowanie do wszystkich stanowiących przedmiot niniejszej pracy podstaw umownego nietypowego zatrudnienia pracowniczego. Nie wydaje się jednak kompletna w odniesieniu do pracy tymczasowej. Wobec braku regulacji prawnej sposobu przepływu danych osobowych ${ }^{120}$ pomiędzy agencją pracy tymczasowej, czyli podmiotem, któremu pracownik tymczasowy udostępnia swoje dane, a pracodawcą użytkownikiem, czyli podmiotem, który również nimi dysponuje, choćby w zakresie prowadzenia ewidencji czasu

117 Ibidem, s. 82. T. Wyka wskazuje natomiast na konieczność uregulowania ochrony danych osobowych wykonawców umów cywilnoprawnych na poziomie zbliżonym do ochrony pracowniczej. T. Wyka, Propozycje zmian..., s. 142-143.

118 T. Wyka, Propozycje zmian..., s. 134.

119 A. Nerka, op. cit., s. 79.

120 Istnienie wskazanej luki zauważa T. Wyka. Zob. T. Wyka, Propozycje zmian..., s. 142. 
pracy, należy stosować przepisy ogólne ustawy o ochronie danych osobowych. Pierwotnym administratorem danych osobowych pracowników tymczasowych jest agencja pracy tymczasowej. Agencje zatrudnienia, w tym agencje pracy tymczasowej, zobowiązane są do przetwarzania posiadanych danych osobowych zgodnie z przepisami o ochronie danych osobowych (art. 19b ustawy o promocji zatrudnienia i instytucjach rynku pracy). Zgodnie z powyższym w zakresie przetwarzania danych osobowych agencja pracy tymczasowej zobowiązana jest do respektowania ustawy o ochronie danych osobowych ${ }^{121}$. Udostępnienie pracodawcy użytkownikowi danych pracownika tymczasowego, stanowiące jedną z czynności definiowanych w powyższej ustawie jako przetwarzanie danych, nie wymaga zgody pracownika tymczasowego ${ }^{122}$. Pracodawca użytkownik po powierzeniu mu danych osobowych przez agencję pracy tymczasowej na podstawie umowy staje się ich administratorem, decydując o celach i środkach przetwarzania ${ }^{123}$. Wykonując obowiązki nałożone na pracodawcę użytkownika przez ustawę o zatrudnianiu pracowników tymczasowych oraz umowę zawartą z agencją pracy tymczasowej, bez wątpienia pracodawca użytkownik będzie przetwarzał dane osobowe pracowników tymczasowych. Ze stanowiskiem tym zgodził się Generalny Inspektor Ochrony Danych Osobowych, uznając za administratora danych osobowych pracownika tymczasowego zarówno agencję pracy tymczasowej, jak i pracodawcę użytkownika, na którym spoczywają wszystkie obowiązki administratora danych osobowych określone w ustawie o ochronie danych osobowych ${ }^{124}$.

Na zakończenie warto wskazać tożsamość regulacji prawnych dotyczących rejestracji zbioru danych pracowników i osób zatrudnionych na podstawie umów cywilnoprawnych, ujednolicających status prawny osób świadczących pracę w ramach umownego zatrudnienia nietypowego. Do dnia 1 maja 2004 r., czyli do czasu wejścia w życie nowelizacji ustawy o ochronie danych osobowych ${ }^{125}$, na administratorach zbiorów danych osobowych osób świadczących pracę na podstawie

121 M. Paluszkiewicz, Art. 19(b), [w:] Z. Góral (red.), Ustawa o promocji zatrudnienia i instytucjach rynku pracy. Komentarz, https://sip-1lex-1pl-1004153yx0674.han3.lib.uni.lodz.pl/\#/ komentarz/587300374/508298 (dostęp: 19.09.2017).

122 Ogólny warunek przetwarzania danych osobowych, jakim jest zgoda osoby, której dane dotyczą, prezentuje P. Fajgielski. Zob. P. Fajgielski, Zgoda na przetwarzanie danych osobowych, [w:] G. Sibiga, X. Konarski (red.), Ochrona danych osobowych. Aktualne problemy inowe wyzwania, Warszawa 2007, s. 43.

123 W wyroku z dnia 30 stycznia 2002 r. (II SA 1098/01, LEX nr 50816) Naczelny Sąd Administracyjny orzekt, że administratorem danych osobowych nie jest każdy dysponent tych danych, a tylko ten, kto decyduje o celach i środkach ich przetwarzania.

124 Generalny Inspektor Danych Osobowych, Sprawozdanie z działalności Generalnego Inspektora Ochrony Danych Osobowych za rok 2004, www.giodo.gov.pl/plik/t/pdf/j/pl/id_p/727. pdf, s. 171-173 (dostęp: 2.01.2017).

125 Ustawa z dnia 22 stycznia 2004 r. o zmianie ustawy o ochronie danych osobowych oraz ustawy o wynagrodzeniu osób zajmujących kierownicze stanowiska państwowe, Dz.U. Nr 33, poz. 285. 
umów cywilnoprawnych ciążył obowiązek zgłaszania ich do rejestracji. W wyniku nowelizacji zmienione zostało brzmienie art. 43 ust. 1 pkt 4 u.o.d.o. Obecnie - tak jak w przypadku zbiorów danych pracowników - administratorzy takich zbiorów zwolnieni są z powyższego obowiązku, przez co na tej płaszczyźnie pozycja wszystkich osób zatrudnionych, bez względu na podstawę świadczonej pracy, została zrównana ${ }^{126}$. Obowiązek rejestracji zbioru danych osobowych osób zatrudnionych istnieje jedynie w przypadku wykorzystywania ich w innym celu niż związany z zatrudnieniem ${ }^{127}$.

W zakresie ochrony danych osobowych zarówno w procesie zawiązywania stosunku zatrudnienia umownego, jak i na etapie jego trwania sytuacja prawna osób ubiegających się o zatrudnienie pracownicze bądź pozostających już w stosunku pracy jest bardziej korzystna niż kształtujący się w równoległych warunkach status prawny osób zatrudnianych bądź zatrudnionych na niepracowniczej podstawie (umowy o pracę nakładczą, umowy zlecenia, umowy o świadczenie usług, do której stosuje się przepisy o zleceniu, umowy agencyjnej i umowy o dzieło). Regulacje prawa pracy, znajdujące zastosowanie do wszystkich podstaw umownego nietypowego zatrudnienia pracowniczego, przyznają szerszą ochronę danych osobowych niż przepisy ogólne, wynikające z ustawy o ochronie danych osobowych, stosowane względem osób zatrudnionych na podstawie umów prawa cywilnego. Uzasadnieniem takiego zróżnicowania jest systemowe założenie o formalnej równości stron stosunków cywilnoprawnych, skutkujące brakiem konieczności przyznania szczególnej ochrony jednej z nich (w omawianym przypadku osobie zatrudnianej). Konieczność taka występuje natomiast $\mathrm{w}$ stosunkach prawnopracowniczych, w których pracownik z systemowego założenia ma słabszą pozycję. Dodatkowo stosunki prawnopracownicze cechują się ścisłą współpracą ich podmiotów, w ramach której udostępniane dane osobowe mogłyby być wykorzystywane w sposób sprzeczny z prawem. Dlatego ich ochrona musi wykazywać większe standardy względem powszechnie obowiązującej ochrony danych osobowych.

\subsubsection{Warunki dopuszczenia do pracy świadczonej w ramach umownego zatrudnienia nietypowego}

Faza poprzedzająca umowne zatrudnienie nietypowe wiąże się z koniecznością spełnienia określonych prawem warunków. Wśród tych, które zostaną omówione, są wstępne badania lekarskie, przeszkolenie w zakresie bezpieczeństwa i higieny pracy, a także warunki zapewnienia osobom zatrudnianym środków ochrony in-

126 J. Barta, P. Fajgielski, R. Markiewicz, op. cit., s. 704-705.

127 A. Drozd, Ustawa o ochronie danych osobowych. Komentarz. Wzory pism i przepisy, Warszawa 2008, s. 291. 
dywidualnej oraz odzieży i obuwia roboczego, określanych łącznie mianem środków ochrony zdrowia prewencji bezpośredniej ${ }^{128}$. Dodatkowo omówione zostaną zagadnienia związane z zapewnianiem przedmiotów niezbędnych do świadczenia pracy. Nakazane prawem czynności poprzedzające każde zatrudnienie, $\mathrm{w}$ tym umowne zatrudnienie nietypowe, nie mogą być traktowane jako niesłusznie ograniczające możliwość swobodnego nawiązania stosunku zatrudnienia. Ponad wartością, jaką jest zdobycie i utrzymanie pracy, ustawodawca stawia zdrowie oraz bezpieczeństwo osób zatrudnianych ${ }^{129}$. Taka gradacja wartości wydaje się w pełni uzasadniona społecznie. Określenie zakresu obowiązków przeprowadzenia wstępnych badań lekarskich, przeszkolenia w zakresie bezpieczeństwa i higieny pracy oraz dostarczenia odzieży i obuwia roboczego w odniesieniu do umownego zatrudnienia nietypowego umożliwi przedstawienie statusu prawnego osób świadczących pracę z tych perspektyw.

Zgodnie z dyspozycją art. $229 \$ 1$ k.p. wstępnym badaniom lekarskim podlegają osoby przyjmowane do pracy. Aktualne orzeczenie lekarza, stwierdzające brak przeciwwskazań do pracy na określonym stanowisku, stanowi warunek sine qua non dopuszczenia pracownika przez pracodawcę do wykonywania pracy. $\mathrm{Na}$ każdym pracowniku, bez względu na warunki świadczonej pracy, spoczywa zatem obowiązek poddania się badaniom wstępnym, na pracodawcy natomiast obowiązek skierowania na nie pracownika, wyegzekwowania ich wykonania oraz, co wynika $z$ art. $229 \$ 6$ k.p., obowiązek ich opłacenia. Powyższe obowiązki pracodawcy należą do grupy obowiązków prewencji bezpośredniej o adresacie zindywidualizowanym, których wykonanie warunkuje dopuszczenie pracownika do pracy $^{130}$. Do ich realizacji stosuje się, poza kodeksem pracy, przepisy szczególne ${ }^{131}$. Mocą ustawy z dnia 7 listopada 2014 r. o ułatwieniu wykonywania działalności gospodarczej ${ }^{132}$ od 1 kwietnia 2015 r. zwolnienie z obowiązku badań wstępnych obejmuje swoim zakresem osoby:

a) przyjmowane ponownie do pracy u tego samego pracodawcy na to samo stanowisko lub na stanowisko o takich samych warunkach pracy w ciągu $30 \mathrm{dni}$ po rozwiązaniu lub wygaśnięciu poprzedniego stosunku pracy z tym pracodawcą (art. $229 \$ 1^{1}$ pkt 1 k.p.)

128 T. Wyka, Prawna ochrona zdrowia pracownika, [w:] H. Lewandowski (red.), Polskie prawo..., S. 81-82.

129 Ibidem, s. 73.

130 T. Wyka, Art. 229 k.p., pkt 3.4, [w:] K.W. Baran (red.), Kodeks pracy. Komentarz, https://sip-1lex-1pl-1004153yx0674.han3.lib.uni.lodz.pl/\#/komentarz/587329321/490969 (dostęp: 19.09.2017).

131 Rozporządzenie Ministra Zdrowia i Opieki Społecznej z dnia 30 maja 1996 r. w sprawie przeprowadzania badań lekarskich pracowników, zakresu profilaktycznej opieki zdrowotnej nad pracownikami oraz orzeczeń lekarskich wydawanych do celów przewidzianych w Kodeksie pracy, Dz.U. z 2016 r. poz. 2067 - t.j.

132 Dz.U. z 2014 r. poz. 1662. 
b) przyjmowane do pracy u innego pracodawcy na dane stanowisko w ciągu 30 dni po rozwiązaniu lub wygaśnięciu poprzedniego stosunku pracy, jeżeli przedstawią pracodawcy aktualne orzeczenie lekarskie stwierdzające brak przeciwwskazań do pracy $\mathrm{w}$ warunkach pracy opisanych $\mathrm{w}$ skierowaniu na badania lekarskie, a pracodawca ten stwierdzi, że warunki te odpowiadają warunkom występującym na danym stanowisku pracy, z wyłączeniem osób przyjmowanych do wykonywania prac szczególnie niebezpiecznych (art. 229 $\$ 1^{1}$ pkt 2 k.p.)

c) przyjmowane do pracy i pozostające jednocześnie $\mathrm{w}$ stosunku pracy $\mathrm{z}$ innym pracodawcą, jeżeli przedstawią pracodawcy aktualne orzeczenie lekarskie stwierdzające brak przeciwwskazań do pracy $\mathrm{w}$ warunkach pracy opisanych w skierowaniu na badania lekarskie, a pracodawca ten stwierdzi, że warunki te odpowiadają warunkom występującym na danym stanowisku pracy, z wyłączeniem osób przyjmowanych do wykonywania prac szczególnie niebezpiecznych (art. $229 \$ 1^{2}$ k.p. w zw. z art. $229 \$ 1^{1}$ pkt 2 k.p.).

$\mathrm{W}$ pozostałym zakresie ustawodawca wymaga poddania się przez osoby przyjmowane do pracy wstępnym badaniom lekarskim. W zatrudnieniu tymczasowym, w odniesieniu do wstępnych badań lekarskich, może powstać wątpliwość dotycząca warunków przeniesienia przez agencję pracy tymczasowej na pracodawcę użytkownika zobowiązania do ich przeprowadzenia. Wobec braku ustawowych ograniczeń pogląd o możliwości przekazania tego obowiązku wydaje się uzasadniony ${ }^{133}$. W takim przypadku należałoby jednak przyjąć istnienie obowiązku powiadomienia pracownika tymczasowego o przejęciu przez pracodawcę użytkownika obowiązku agencji pracy tymczasowej w zakresie skierowania na wstępne badania lekarskie. Brak stosownego powiadomienia skutkowałby niewiedzą pracownika tymczasowego o podmiocie, który ma skierować na badania wstępne i który ma te badania opłacić.

Redakcja art. $229 \$ 1$ pkt 1 k.p. może prowadzić do wniosku, że ma on zastosowanie również do pozapracowniczych podstaw zatrudnienia. Literalnie nakazuje on bowiem przeprowadzenie badań wstępnych wobec osób przyjmowanych do pracy. Nie ma jednak uzasadnienia dla zastosowania wykładni rozszerzającej wskazanego przepisu. W dalszej części posługuje się on bowiem nomenklaturą właściwą dla zatrudnienia pracowniczego. Ustawodawca celowo nie użył w stosunku do osoby podlegającej badaniom wstępnym określenia „pracownik”, bowiem osoba ta nie zawsze jest już pracownikiem. Poczynione w niniejszym rozdziale uwagi dotyczące etapu poprzedzającego zatrudnienie pozwalają zatem przyjąć, że przyszły pracownik (kandydat) jest w pierwszej kolejności „osobą

133 A. Chobot, K. Pachciarek, Prawa i obowiq̨zi agencji pracy tymczasowej i pracodawcy użytkownika wobec pracownika tymczasowego, „Praca i Zabezpieczenie Społeczne” 2005, nr 1, s. 25. 
ubiegającą się o zatrudnienie"134, następnie „osobą przyjmowaną do pracy”135. Nie jest uzasadnione przyjmowanie, że kosztami badań wstępnych osób, z którymi podmiot zatrudniający zawiera umowę cywilnoprawną, należy go obciążyć z mocy prawa ${ }^{136}$ i że badania takie w ogóle są konieczne. Dopuszczalne będzie natomiast umowne zobowiązanie osoby zatrudnianej do wykonania określonych badań lekarskich w trosce o jej bezpieczeństwo. Powyższe prowadzi do wniosku, że status prawny kandydatów przyjmowanych do pracy w ramach pracowniczego umownego zatrudnienia nietypowego jest w omawianym zakresie korzystniejszy niż status kandydatów przyjmowanych do pracy na podstawie umów prawa cywilnego. Osoby przyjmowane do pracy w charakterze pracowników mają bowiem ustawowo zapewnione prawo do skierowania i opłacenia badań wstępnych przez pracodawcę. Dzięki temu ich zdrowie i życie są lepiej chronione. Takie rozróżnienie nie wydaje się uzasadnione. $\mathrm{W}$ związku z powyższym racjonalne byłoby objęcie, przynajmniej w ograniczonym zakresie, osób przyjmowanych do pracy, która ma być świadczona $\mathrm{w}$ ramach zatrudnienia cywilnoprawnego, regulacjami zobowiązującymi do poddania się wstępnym badaniom lekarskim.

Ochrona pracy, przejawiająca się koniecznością zapewnienia bezpiecznych i higienicznych warunków pracy, w tym dokonania przeszkolenia przed dopuszczeniem do pracy, została uregulowana w ustawodawstwie międzynarodowym, europejskim oraz krajowym. Kilka aktów prawnych dotyczy czynności poprzedzających zatrudnienie i powstającego na tym etapie obowiązku zaznajomienia osoby zatrudnianej z przepisami i zasadami bezpieczeństwa i higieny pracy. Pierwszym z nich jest nieratyfikowana przez Polskę konwencja MOP z 1981 r. nr 155 dotycząca bezpieczeństwa, zdrowia pracowników i środowiska pracy ${ }^{137}$. Zgodnie z jej regulacjami (art. 5 lit. c) polityka krajowa powinna dążyć do organizowania szkoleń dla osób, które działają na rzecz osiągnięcia właściwego poziomu bezpieczeństwa i zdrowia. Z tak ogólnej regulacji konwencji, która musi znajdować zastosowanie w państwach członkowskich o różnych poziomach rozwoju cywilizacyjnego i gospodarczego ${ }^{138}$, można wysnuć wniosek o nacisku położonym na przeszkalanie w zakresie bezpieczeństwa i higieny pracy. Szczegółową regulację omawianego zagadnienia zawiera dyrektywa Rady nr 89/391/EWG z dnia 12 czerwca 1989 r. w sprawie wprowadzenia środków w celu poprawy bezpieczeństwa i zdrowia pracowników w miejscu pracy ${ }^{139}$. Po-

134 Na gruncie regulacji związanej z ochroną danych osobowych.

135 Na gruncie regulacji dotyczącej wstępnych badań lekarskich.

136 Przeciwnie: K. Zakrzewska-Szczepańska, Bhp zatrudnionych bez umowy o pracę, „Służba Pracownicza" 2006, nr 10, s. 36.

137 Konwencja z dnia 3 czerwca 1981 r. nr 155 dotycząca bezpieczeństwa, zdrowia pracowników i środowiska pracy; MOP, www.mop.pl/doc/html/konwencje/k155.html (dostęp: 3.01.2017).

138 A.M. Świątkowski, Europejskie prawo socjalne, Warszawa 1999, s. 266.

139 Dz.U.EWG.L 183 z dnia 29 czerwca 1989 r., s. 1-8. 
mimo że ma ona charakter ramowy, w art. 6 pkt 1 statuuje konkretny obowiązek pracodawcy m.in. w odniesieniu do przeprowadzania szkoleń z zakresu bezpieczeństwa i higieny pracy. Konkretyzację tego obowiązku na etapie przyjmowania pracownika do pracy zawiera natomiast art. 12 pkt 1 dyrektywy ${ }^{140}$. Uszczegóławiając procedurę przeprowadzania szkoleń, dyrektywa obciąża ich kosztami pracodawcę. Ponadto konkretyzuje, że szkolenia takie powinny odbywać się w czasie pracy.

Na gruncie krajowego porządku prawnego normy ogólne dotyczące ochrony pracy zawarte są w art. 24 Konstytucji. Prawo każdego do bezpiecznych i higienicznych warunków pracy zapewnia art. 66 Konstytucji. Regulacje prawa pracy ustanawiają obowiązek przeszkolenia pracownika w zakresie przepisów oraz zasad bezpieczeństwa i higieny pracy mocą art. $237^{3}$ k.p. Każdy pracodawca jest zobowiązany zapewnić każdemu pracownikowi szkolenie z zakresu bezpieczeństwa i higieny pracy ${ }^{141}$. Również $\mathrm{w}$ tym przypadku, podobnie jak w przypadku wstępnych badań lekarskich, potwierdzających brak przeciwwskazań do wykonywania pracy, oprócz kodeksu pracy zastosowanie znajdują przepisy szczególne. Rozporządzenie w sprawie szkoleń w dziedzinie bezpieczeństwa i higieny pracy $^{142}$ wymienia dwa rodzaje szkolen - wstępne i okresowe. Obszarem badawczym tej części pracy objęte są szkolenia wstępne.

Wypełnienie obowiązku odbycia przez pracownika szkolenia z zasad i przepisów bezpieczeństwa i higieny pracy ma za zadanie uchronić go oraz jego współpracowników przed konsekwencjami nieznajomości zasad i przepisów, mogącej prowadzić do wypadków przy pracy. Szkolenie wstępne ma charakter powszechny i jest adresowane do wszystkich pracowników przed dopuszczeniem do pracy. Tylko wyjątkowo pracodawca może odstąpić od obowiązku zapewnienia pracownikowi szkolenia wstępnego - jeśli pracownik podejmuje ponownie pracę na tym samym stanowisku, które zajmował u danego pracodawcy bezpośrednio przed nawiązaniem $\mathrm{z}$ nim kolejnej umowy o pracę (art. $237^{3} \$ 2$ zd. 2 k.p.). Realizacja obowiązku pracodawcy zapewnienia pracownikom szkoleń z zakresu bezpieczeństwa i higieny pracy wymaga spełnienia określonych powinności organizacyjnych, finansowych i formalnych. Należą do nich:

- obowiązek zapewnienia odpowiednich warunków lokalowych i wyposażenia dydaktycznego do odbycia szkolenia bądź zlecenie przeprowadzenia szkolenia uprawnionej jednostce organizacyjnej ( $\$ 5$ rozporządzenia w sprawie szkoleń w dziedzinie bezpieczeństwa i higieny pracy)

140 A.M. Świątkowski, Europejskie prawo..., s. 289.

141 Dodatkowo każdy pracodawca ma również obowiązek odbyć szkolenie z zakresu bezpieczeństwa i higieny pracy. Zob. T. Wyka, Art. $237^{3}$, [w:] K.W. Baran (red.), Kodeks pracy. Komentarz, https://sip-1lex-1pl-1004153yx0674.han3.lib.uni.lodz.pl/\#/komentarz/ 587329334/490982 (dostęp: 19.09.2017).

142 Rozporządzenie Ministra Gospodarki i Pracy z dnia 27 lipca 2004 r. w sprawie szkolenia w dziedzinie bezpieczeństwa i higieny pracy, Dz.U. Nr 180, poz. 1860 ze zm. 
- obowiązek zorganizowania szkolenia w czasie pracy i na koszt pracodawcy (art. $237^{3} \S 3$ k.p.)

- obowiązek wystawienia pracownikowi odpowiedniego zaświadczenia o ukończeniu szkolenia i włączenia go do akt osobowych ( $\$ 16$ rozporządzenia w sprawie szkoleń w dziedzinie bezpieczeństwa i higieny pracy).

Poprzez instytucję wstępnych szkoleń z zakresu bezpieczeństwa i higieny pracy ustawodawca chroni dobro najwyższej wartości - zdrowie i życie ludzkie. Zdrowie i życie wszystkich osób pracujących w ramach umownego zatrudnienia nietypowego nie są chronione jednakowo. Przepisy prawa pracy (kodeksu pracy i wskazanego rozporządzenia) mają zastosowanie do wszystkich podstaw zatrudnienia pracowniczego z pewnymi wyjątkami w obrębie pracy tymczasowej. Zgodnie bowiem $\mathrm{z}$ art. 9 ust. $2 \mathrm{a}$ z.p.t. to pracodawca użytkownik, nie agencja pracy tymczasowej, zobowiązany jest do przeprowadzania szkoleń z zakresu bezpieczeństwa i higieny pracy. Samo skierowanie pracownika tymczasowego do pracy u pracodawcy użytkownika nie zapewnia zatem o dopuszczeniu go do pracy. Dopiero po spełnieniu określonych wymogów, do których zalicza się obowiązek odbycia wstępnego szkolenia $\mathrm{z}$ zakresu bezpieczeństwa i higieny pracy, pracownik tymczasowy może rozpocząć pracęe $e^{143}$.

Obowiązek przeszkolenia osób zatrudnianych w ramach stosunków cywilnoprawnych nie został prawnie usankcjonowany ${ }^{144}$. Wynika to $\mathrm{z}$ faktu innych założeń systemowych pracy wykonywanej w ramach więzi właściwej prawu cywilnemu. Brak organizacyjnego podporządkowania osób świadczących pracę $\mathrm{w}$ ramach umownego zatrudnienia cywilnoprawnego nie wymaga bowiem konieczności prawnego sankcjonowania wstępnego szkolenia w zakresie bezpieczeństwa i higieny pracy. Osoby świadczące pracę niepodporządkowaną samodzielnie decydują o sposobie realizacji umowy. Tym samym ich status prawny jest odmienny od typowego w zakresie wstępnego przeszkolenia $\mathrm{z}$ bezpieczeństwa i higieny pracy. Wydaje się jednak, że korzystne byłoby uregulowanie obowiązku odbycia wstępnego przeszkolenia w zakresie bhp również w odniesieniu do zatrudnienia cywilnoprawnego. Życie i zdrowie wszystkich osób świadczących pracę powinny być chronione tak samo, bez względu na występujący w procesie realizacji umowy stopień zależności od podmiotu zatrudniającego.

W sposób szczególny uregulowane zostały dodatkowe warunki, jakie muszą zostać spełnione przed rozpoczęciem przez pracownika wykonywania pracy $\mathrm{w}$ formie organizacyjnej telepracy. Zgodnie z art. $67^{14} \S 4$ k.p. pierwszą kontrolę w zakresie bezpieczeństwa i higieny pracy wykonywanej przez telepracownika w jego domu

143 M. Paluszkiewicz, Treść stosunku prawnego między agencją pracy tymczasowej a pracodawcq użytkownikiem, [w:] M. Paluszkiewicz, Zatrudnienie tymczasowe w polskim prawie pracy, https://sip-1lex-1pl-1004153yx0674.han3.lib.uni.lodz.pl/\#/monografia/369234447/19 (dostęp: 19.09.2017).

144 A. Kolasa, Zdaniem Państwowej Inspekcji Pracy, „Praca i Zabezpieczenie Społeczne” 1999, nr 3, s. 45. 
pracodawca przeprowadza, na wniosek pracownika, przed rozpoczęciem wykonywania pracy. Konsekwencją braku wniosku telepracownika o przeprowadzenie takiej kontroli jest brak możliwości podjęcia przez niego pracy. Pracodawca nie może bowiem dopuścić telepracownika do pracy przed skontrolowaniem warunków bhp w miejscu jej wykonywania ${ }^{145}$. Wydaje się, że taka konstrukcja jest dyskusyjna. Racjonalne byłoby ukształtowanie omawianej kontroli zgodnie $\mathrm{z}$ art. $67^{14} \$ 1$ k.p. - kontrola byłaby przeprowadzana nie na wniosek, a za zgodą pracownika ${ }^{146}$.

Kolejnym omawianym w tej części pracy warunkiem dopuszczenia do pracy, wpływającym na status prawny osób świadczących pracę w ramach umownego zatrudnienia nietypowego, jest obowiązek dostarczenia im środków ochrony indywidualnej oraz odzieży i obuwia roboczego bądź innego rodzaju przedmiotów o zbliżonym charakterze ${ }^{147}$. W odniesieniu do zatrudnienia pracowniczego odpowiednie regulacje w przedmiocie dostarczania pracownikom środków ochrony indywidualnej oraz odzieży i obuwia roboczego zawiera rozdział 9 działu 10 kodeksu pracy. Regulacja ta nie różnicuje statusu prawnego osób zatrudnionych zależnie od podstawy umownego zatrudnienia nietypowego. Przepisy tego rozdziału mają charakter imperatywny, nakazując pracodawcy dostarczenie środków ochrony indywidualnej (art. $237^{6} \$ 1$ k.p.) oraz odzieży i obuwia roboczego (art. $237^{7} \$ 1$ k.p.), informowanie o sposobach posługiwania się środkami ochrony indywidualnej (art. $237^{6} \$ 1$ k.p. in fine), dopuszczenie do pracy jedynie takiego pracownika, który posiada wymagane środki ochrony indywidualnej oraz odzież i obuwie robocze (art. $237^{9} \$ 1$ k.p.), zapewnienie, aby powyższe przedmioty posiadały odpowiednie właściwości (ochronne i użytkowe) oraz zapewnienie ich prania, konserwacji, naprawy, odpylania i odkażania (art. $237^{9} \$ 2$ k.p.). Wreszcie pracodawca zobowiązany jest do stosowania określonych procedur względem środków ochrony indywidualnej oraz odzieży i obuwia roboczego, które uległy skażeniu środkami chemicznymi, promieniotwórczymi albo materiałami biologicznie zakaźnymi (art. $237^{10} \$ 1$ k.p.). Prawne usankcjonowanie powyższych obowiązków wynika z dbałości o zdrowie i życie pracowników. W tym zakresie status prawny wszystkich osób świadczących pracę $\mathrm{w}$ ramach umownego pracowniczego zatrudnienia nietypowego jest taki sam - wobec wszystkich tych

145 Przeciwnie: A. Sobczyk, Telepraca w prawie polskim, Warszawa 2009, s. 200.

146 M. Latos-Mitkowska, Art. $67^{14}$ [w:] M. Derlacz-Wawrowska, M. Latos-Miłkowska, Kodeks pracy. Komentarz w perspektywie europejskiej i międzynarodowej, https://sip-1lex-1pl-1004153yx0674.han3.lib.uni.lodz.pl/\#/komentarz/587713118/510558 (dostęp: 19.09.2017). Stanowisko o braku warunkowania możliwości rozpoczęcia świadczenia pracy przez telepracownika od przeprowadzenia pierwszej kontroli prezentuje A. Sobczyk. Zob. A. Sobczyk, Art. 67 ${ }^{14}$, [w:] A. Sobczyk (red.), Kodeks pracy. Komentarz, Warszawa 2014, s. 352.

147 Zazwyczaj obowiązek ten aktualizuje się z chwilą rozpoczynania świadczenia pracy, choć konieczność dostarczenia środków ochrony indywidualnej, odzieży i obuwia roboczego bądź innych, zbliżonych w przeznaczeniu przedmiotów, może powstać także w trakcie realizacji umowy, której przedmiotem jest zatrudnienie nietypowe. 
podmiotów pracodawcy mają takie same obowiązki. Wyjątkiem jest status prawny pracowników tymczasowych. Zgodnie z art. 9 ust. 2a z.p.t. to pracodawca użytkownik, a nie agencja pracy tymczasowej, dostarcza pracownikowi tymczasowemu środki ochrony indywidualnej oraz odzież i obuwie robocze. Przeniesienie na pracodawcę użytkownika obowiązku zarezerwowanego w kodeksie pracy dla pracodawcy $w$ rozumieniu art. 3 k.p. wynika $z$ faktu, że praca tymczasowa świadczona jest $\mathrm{z}$ wykorzystaniem środków i maszyn, których dysponentem jest właśnie pracodawca użytkownik. To on ma zatem najszerszą wiedzę w zakresie ich obsługi i niezbędnych ku temu przedmiotów. Również on zarządza procesem pracy i konkretyzuje sposób jej wykonywania, który może wiązać się z koniecznością wykorzystania środków ochrony indywidualnej, odzieży bądź obuwia roboczego.

Regulacje prawne nietypowego umownego zatrudnienia cywilnoprawnego nie ustanawiają konieczności zapewniania osobom zatrudnionym przez podmiot zatrudniający przedmiotów o przeznaczeniu tożsamym bądź zbliżonym do środków ochrony indywidualnej, odzieży bądź obuwia roboczego. Regulacja pracy nakładczej stanowi, że wobec braku odmiennych postanowień praca ta wykonywana jest przy użyciu surowców, materiałów, narzędzi, maszyn i urządzeń zapewnianych przez nakładcę ( $\$ 11$ ust. 1 rozp. pr. nakład.). Jednakże ustawodawca nie nałożył na nakładcę obowiązków o zbliżonym choćby charakterze do omówionych obowiązków ciążących na pracodawcy. W związku z powyższym wszystkie osoby świadczące pracę $\mathrm{w}$ oparciu o cywilnoprawne podstawy zatrudnienia umownego są zobligowane do samodzielnego organizowania swojej pracy poprzez zapewnienie przedmiotów o przeznaczeniu tożsamym bądź zbliżonym do środków ochrony indywidualnej, odzieży bądź obuwia roboczego. Wynika to z odrębności systemowej zatrudnienia cywilnoprawnego, które zakłada samodzielność nie tylko w zakresie sposobu wykonywania pracy, ale również organizowania procesu jej świadczenia.

Dodatkowe warunki, jakie muszą zostać spełnione przed rozpoczęciem świadczenia pracy, związane są z koniecznością zapewnienia osobom zatrudnionym przedmiotów niezbędnych do jej wykonywania. Ustawowo szczególne obowiązki w tym zakresie spoczywają, wobec braku odmiennej umowy, na podmiotach zatrudniających w ramach formy organizacyjnej telepracy i pracy nakładczej. Przepis art. $67^{11}$ k.p. nakłada na pracodawcę obowiązek:

a) dostarczenia telepracownikowi sprzętu niezbędnego do wykonywania pracy $\mathrm{w}$ formie telepracy, spełniającego wymagania określone w rozdziale IV działu 10 kodeksu pracy

b) ubezpieczenia sprzętu

c) pokrycia kosztów związanych z instalacją, serwisem, eksploatacją i konserwacją sprzętu

d) zapewnienia telepracownikowi pomocy technicznej i niezbędnego szkolenia w zakresie obsługi sprzętu. 
Dyskusyjne w tym zakresie jest, czy pracodawca powinien powyższe obowiązki ograniczyć do sprzętu rozumianego jako sprzęt komputerowy (komputer, drukarka, łącze internetowe itp.), czy też zobowiązany jest do dostarczenia i dokonywania dalszych czynności względem wyposażenia (biurka, krzesła itp.). Monika Latos-Miłkowska prezentuje, bez szczegółowego uzasadnienia, stanowisko o ograniczeniu obowiązków do sprzętu komputerowego ${ }^{148}$. Z kolei Arkadiusz Sobczyk argumentuje, że konieczność zapewnienia telepracownikowi również wyposażenia wynika choćby z obowiązku zapewnienia pracownikom pracującym przy monitorach ekranowych odpowiednich warunków pracy ${ }^{149}$. Drugie z zaprezentowanych stanowisk wydaje się uzasadnione. Przed określeniem warunków świadczenia pracy $\mathrm{w}$ formie organizacyjnej telepracy pracodawca może ustalić $\mathrm{z}$ pracownikiem stan posiadanego przez niego wyposażenia, uzyskując $\mathrm{w}$ ten sposób informację o konieczności jego uzupełnienia. W związku z powyższym wobec braku odmiennej umowy telepracownik powinien mieć zapewniony zarówno sprzęt, jak i wyposażenie niezbędne do świadczenia pracy, które w warunkach typowych pracodawca zapewniałby w zakładzie pracy.

Nakładca, wobec braku odmiennych postanowień umownych, dostarcza wykonawcy surówce, materiały lub inne przedmioty oraz narzędzia, maszyny i urządzenia niezbędne do wykonania pracy nakładczej. Ma on również obowiązek utrzymania ich w należytym stanie. Jedynie bieżąca konserwacja jest obowiązkiem wykonawcy ( $\$ 11$ ust. 1 rozp. pr. nakład.). Powyższy warunek sankcjonuje $\$ 11$ ust. 2 rozp. pr. nakład., zgodnie z którym, jeśli nakładca nie wykona swoich obowiązków, co uniemożliwi wykonawcy wykonanie miesięcznej ilości pracy, otrzyma ona wynagrodzenie obliczane jak za urlop wypoczynkowy, nie niższe niż wynagrodzenie najniższe. Uzasadnieniem istnienia takiej regulacji jest wynikający z istoty pracy nakładczej jej przedmiot w postaci wykonywania umowy z użyciem materiałów stanowiących własność nakładcy (montaż, naprawa itp.). Dlatego też jedynie w razie umownego zastrzeżenia nakładca zwolniony jest ze wskazanych obowiązków.

Status prawny osób mających świadczyć pracę $\mathrm{w}$ ramach umownego zatrudnienia nietypowego związany $z$ warunkami dopuszczenia do pracy jest wewnętrznie zróżnicowany. Omówione różnice wynikają z założeń systemowych poszczególnych rodzajów umownego zatrudnienia nietypowego. Obarczenie pracodawcy użytkownika obowiązkami przeprowadzenia szkolenia wstępnego z zakresu bhp oraz dostarczenia środków ochrony indywidualnej, odzieży i obuwia roboczego wynika ze szczególnego, trójstronnego charakteru zatrudnienia tymczasowego, w którym organizatorem procesu pracy jest właśnie pracodawca użytkownik.

148 M. Latos-Miłkowska, Art. 67 ${ }^{11}$, [w:] M. Derlacz-Wawrowska, M. Latos-Mitkowska, op. cit.

149 Zgodnie z Rozporządzeniem Ministra Pracy Polityki Socjalnej z dnia 1 grudnia 1998 r. w sprawie bezpieczeństwa i higieny pracy na stanowiskach wyposażonych w monitory ekranowe, Dz.U. Nr 148, poz. 973. A. Sobczyk, Art. 67"11, pkt 3, [w:] A. Sobczyk (red.), Kodeks pracy..., s. 343. 
Z kolei organizacyjna samodzielność świadczenia pracy w ramach zatrudnienia cywilnoprawnego wyłącza konieczność regulowania w sposób równy pracowniczemu statusu prawnego osób zatrudnionych w zakresie środków ochrony zdrowia prewencji bezpośredniej, stosowanych na etapie dopuszczania do pracy. Jeśli chodzi o konieczność wykonania wstępnych badań lekarskich oraz wstępnego przeszkolenia w zakresie bhp, racjonalne wydaje się jednak postulowanie objęcia regulacjami, choćby o zbliżonym charakterze, osób podejmujących zatrudnienie cywilnoprawne. Dzięki temu chronione byłyby, bez względu na rodzaj zatrudnienia, dobra o nadrzędnej wartości - zdrowie i życie.

\subsubsection{Ochrona kandydatów do pracy przed dyskryminacją}

Centralne umiejscowienie w aktualnym dyskursie nad prawem pracy ${ }^{150}$ oraz w regulacjach prawa pracy ${ }^{151}$ zagadnień związanych z równym traktowaniem i niedyskryminacją pracowników znajdzie odzwierciedlenie w analizie skutków wyboru zatrudnienia $\mathrm{z}$ perspektywy sytuacji prawnej osób zatrudnionych $\mathrm{w}$ ramach umownego zatrudnienia nietypowego. Zasada równego traktowania oraz zakaz dyskryminacji dotyczą zarówno etapu poprzedzającego umowne zatrudnienie nietypowe, jak i etapu jego trwania. Dlatego w celu uniknięcia powtórzeń uzasadnione jest kompleksowe omówienie powyższych zagadnień, dotyczące zarówno fazy nawiązywania, jak i trwania stosunku zatrudnienia. Tego rodzaju ujęcie zdaje się gwarantować klarowność rozważań. Prowadzona analiza pozwoli ocenić, na ile i z jakich przyczyn status prawny osób świadczących pracę w ramach umownego zatrudnienia nietypowego jest zróżnicowany w zakresie ochrony przed dyskryminacją.

Aktami prawnymi regulującymi materię związaną z ochroną przed dyskryminacją w zatrudnieniu na gruncie prawodawstwa Międzynarodowej Organizacji Pracy są m.in.: konwencja z 1951 r. nr 100, dotycząca jednakowego wynagrodzenia dla pracujących mężczyzn i kobiet za pracę jednakowej wartości ${ }^{152}$ oraz konwencja z 1958 r. nr 111 dotycząca dyskryminacji w zatrudnieniu oraz wykonywaniu zawodu ${ }^{153}$. Dodatkowo, nieratyfikowana przez Polskę konwencja z $1994 \mathrm{r}$. nr 175, dotycząca pracy w niepełnym wymiarze czasu ${ }^{154}$, gwarantuje osobom pracującym $\mathrm{w}$ niepełnym czasie pracy objęcie zakazem dyskryminacji w stopniu równym względem pracowników pełnoetatowych. Ustawodawstwo

150 Problem ten był sygnalizowany również w starszej literaturze. Por.: W. Sanetra, Zasada równego traktowania pracowników w kodeksie pracy, „Państwo i Prawo” 1977, nr 9, passim.

151 M.J. Zieliński, Zasada równego traktowania a zakaz dyskryminacji w prawie pracy, „Praca i Zabezpieczenie Społeczne" 2013, nr 8, s. 25.

152 Dz.U. z 1955 r., Nr 38, poz. 238.

153 Dz.U. z 1961 r., Nr 42, poz. 218.

154 MOP, www.mop.pl/doc/html/konwencje/k175.html (dostęp: 3.01.2017). 
Unii Europejskiej obfituje w przepisy traktujące o nakazie równego traktowania oraz zakazie dyskryminacji. Spośród licznych aktów prawnych można wymienić Traktat o funkcjonowaniu Unii Europejskiej, dyrektywę Rady nr 75/117/EWG z dnia 10 lutego 1975 r. w sprawie zbliżenia ustawodawstw państw członkowskich dotyczących stosowania zasady równości wynagrodzeń dla mężczyzn i kobiet ${ }^{155}$, dyrektywę Rady nr 76/207/EWG z dnia 9 lutego 1976 r. w sprawie wprowadzenia w życie zasady równego traktowania kobiet i mężczyzn w zakresie dostępu do zatrudnienia, kształcenia i awansu zawodowego oraz warunków pracy ${ }^{156}$, dyrektywę Rady nr 2000/43/WE z dnia 29 czerwca 2000 r. wprowadzającą w życie zasadę równego traktowania osób bez względu na pochodzenie rasowe lub etniczne ${ }^{157}$ czy dyrektywę Parlamentu Europejskiego i Rady nr 2006/54/WE z dnia 5 lipca 2006 r. w sprawie wprowadzenia w życie zasady równości szans oraz równego traktowania kobiet i mężczyzn w dziedzinie zatrudnienia i pracy ${ }^{158}$.

Rozważając omawiane zagadnienie z perspektywy prawa krajowego w pierwszej kolejności należy zwrócić uwagę na regulacje Konstytucji. Przepis art. 32 Konstytucji zapewnia obywatelom równość wobec prawa oraz równe traktowanie przez władze publiczne. Ustęp 2 powyższego przepisu gwarantuje zakaz dyskryminacji w życiu politycznym, społecznym i gospodarczym. Kolejny przepis - art. 33 ust. 2 odwołuje się m.in. do równego traktowania kobiet i mężczyzn w zakresie zatrudnienia i awansów, wynagrodzenia za pracę, zabezpieczenia społecznego oraz zajmowania stanowisk. Wskazana regulacja może wydawać się niekompletna, bowiem jako kryterium dyskryminacyjne wskazuje jedynie płeć. Jednak należy mieć na uwadze, że Konstytucja nie wyklucza możliwości rozszerzenia zakazanych kryteriów dyskryminacyjnych, a wskazuje jedynie pewne minimum regulacyjne. Przepisy konstytucyjne (zwłaszcza art. 33 ust. 2) mogą mieć zastosowanie zarówno do etapu poprzedzającego zatrudnienie, jak i do etapu jego trwania. Rozstrzygnięcia wymaga jedynie kwestia obszaru uregulowanego antydyskryminacyjnymi przepisami Konstytucji. Z pewnością dotyczą one stosunków zatrudnienia powstających w reżimie prawa pracy. Wątpliwości może natomiast budzić, czy regulacja ta powinna znajdować zastosowanie do zatrudnienia cywilnoprawnego. Ustawodawca posługuje się w Konstytucji pojęciem „zatrudnienie”, a nie „zatrudnienie pracownicze” czy „stosunek pracy”. Pojęcia konstytucyjne nie mogą być definiowane przez przepisy aktów prawnych niższego rzędu. Dlatego też znaczenia użytego w art. 33 ust. 2 Konstytucji pojęcia „zatrudnienie” poszukiwać należy na gruncie samej Konstytucji, a nie ustawodawstwa zwykłego. W art. 33 ust. 2 pojęcie zatrudnienia zostało połączone z pojęciem awansów. Z kolei

155 Dz.U.EWG.L 45 z dnia 19 lutego 1975 r., s. 19-20. Dyrektywa obowiązywała do 14 sierpnia $2009 \mathrm{r}$.

156 Dz.U.EWG.L 39 z dnia 14 lutego 1976 r., s. 40-42. Dyrektywa obowiązywała do 14 sierpnia $2009 \mathrm{r}$.

157 Dz.U.WE.L 180 z dnia 19 lipca 2000 r., s. 22-26.

158 Dz.U.WE.L 204 z dnia 26 lipca 2006 r., s. 23-36. 
pojęcie awansu jest związane z zatrudnieniem prawnopracowniczym. Awansowanie pracowników, jako uznanie ich zasług, jest typowe w zhierarchizowanej, wewnętrznie rozbudowanej strukturze właściwej prawu pracy. Skoro zatem ustawodawca konstytucyjny łączy $\mathrm{w}$ art. 33 ust. 2 pojęcie zatrudnienia $\mathrm{z}$ właściwym prawu pracy pojęciem awansów, przepis ten obejmuje swoim zakresem zatrudnienie pracownicze. Nie obejmuje natomiast zatrudnienia cywilnoprawnego. Norma art. 33 ust. 2 Konstytucji ustanawia nakaz równego traktowania kobiet i mężczyzn w zakresie zatrudnienia pracowniczego ${ }^{159}$. Taki wniosek nie wyłącza możliwości wprowadzenia regulacji antydyskryminacyjnych, obejmujących swoim zasięgiem zatrudnienie cywilnoprawne, jednak nie statuuje takiego obowiązku.

Konkretyzację norm konstytucyjnych zawiera regulacja kodeksu pracy ${ }^{160}$. Potrzeba wprowadzenia odpowiednich regulacji $\mathrm{w}$ tym zakresie związana była $\mathrm{z}$ dostosowywaniem prawa polskiego do norm Unii Europejskiej ${ }^{161}$. Do podstawowych zasad prawa pracy kodeks pracy zalicza zasadę równości pracowników (art. $11^{2}$ k.p.) oraz zasadę zakazu dyskryminacji (art. $11^{3}$ k.p.). Wspólnie regulacje te można określić jako ochronę przed dyskryminacją ${ }^{162}$. Już na tym etapie rozważań warto wskazać, że w przepisie art. $11^{3} \mathrm{k}$.p. ustawodawca zakazał dyskryminacji ze względu na zatrudnienie na czas określony lub nieokreślony albo w pełnym lub $\mathrm{w}$ niepełnym wymiarze czasu pracy. Zatem zarówno podstawa prawna świadczenia pracy, jak i organizacyjna struktura zatrudnienia pracowniczego nie mogą stanowić dyskryminującego zróżnicowania pracowników. Dodatkowo uszczegółowienie zasad niedyskryminacji i równego traktowania znajduje się w rozdziale IIa kodeksu pracy, zatytułowanym Równe traktowanie w zatrudnieniu. Pomimo że rozdział ten dotyczy zatrudnienia w ogólności, nie ma podstaw do stosowania wykładni rozszerzającej, umożliwiającej objęcie przepisami kodeksu pracy (którego zakres przedmiotowo-podmiotowy obejmuje prawa i obowiązki pracowników i pracodawców - art. 1 k.p.) zatrudnienia niepracowniczego ${ }^{163}$, w tym zatrudnienia cywilnoprawnego. Regulacja kodeksu pracy odnosząca się do równego traktowania i niedyskryminacji wydaje się być kompleksowa. Zgodnie z art. $18^{3 a} \mathrm{k}$.p. nakaz równego trak-

159 Przeciwnie: B. Banaszak, Konstytucja Rzeczypospolitej Polskiej. Komentarz, Warszawa 2009, s. 33. Autor uważa, że regulacja art. 33 ust. 2 Konstytucji obejmuje swoim zakresem również osoby zatrudnione w reżimie prawa cywilnego.

160 A. Sobczyk, Prawo pracy w świetle konstytucji RP, t. 2: Wybrane problemy i instytucje prawa pracy a konstytucyjne prawa i wolności człowieka, Warszawa 2013, s. 105.

161 Celem niniejszego opracowania nie jest szczegółowe omówienie ustawodawstwa Unii Europejskiej, dlatego kwestia ta, ze względu na swoją złożoność, zostanie jedynie zasygnalizowania.

162 Rozważanie dotyczące rozdzielności bądź zbieżności regulacji dotyczących zakazu dyskryminacji i nakazu równego traktowania przedstawia Z. Góral, O kodeksowym..., s. 155-156.

163 W. Szubert twierdzit, że kodeks pracy nie obejmuje swoim zakresem podmiotowym zatrudnienia charakteryzowanego obecnie jako cywilnoprawne, zawierając w art. 303 delegację do objęcia stosowaniem prawa pracy określonych grup podmiotów. W. Szubert, Zakres podmiotowy i przedmiotowy kodeksu pracy, „Państwo i Prawo” 1974, nr 8-9, s. 11-12. 
towania dotyczy już etapu nawiązywania stosunku pracy. W dalszej części przepis rozszerza nakaz równego traktowania na rozwiązanie oraz trwanie stosunku pracy, wskazując płaszczyzny ochrony oraz kryteria dyskryminacyjne. Kolejne przepisy (art. $18^{3 \mathrm{~b}} \$ 1$ k.p.) uszczegóławiają omawiane zagadnienie oraz pozwalają właściwie sklasyfikować niepożądane w sferze stosunków pracy zachowania. Kodeks pracy ustanawia również sankcje za naruszenie zasady równego traktowania (art. 18 ${ }^{3 \mathrm{~d}}$ ) oraz wskazuje, jakie okoliczności wyłączają możliwość stwierdzenia, że do naruszenia doszło (art. $18^{3 \mathrm{~b}} \$ 1$ in fine, $\$ 2-4$ k.p.).

Przepisy kodeksu pracy dotyczące niedyskryminacji i równego traktowania znajdują zastosowanie do wszystkich stosunków pracy. Obejmują zatem również wszystkie stosunki nietypowego umownego zatrudnienia pracowniczego. Dodatkowo art. $67^{15} \$ 1$ k.p. jest uzupełnieniem tej materii, zakazując mniej korzystnego traktowania telepracownika względem pracowników wykonujących podobną lub taką samą pracę poza telepracą. Norma ta dotyczy nawiązania i rozwiązania stosunku pracy, warunków zatrudnienia, awansowania oraz dostępu do szkoleń. Uzasadnione jest użycie przez ustawodawcę terminu „mniej korzystne traktowanie” w miejsce pojęcia „równe traktowanie”. Ze względu na specyfikę telepracy telepracownik nie może być traktowany tak samo (równo) jak pracownik wykonujący pracę w tradycyjny sposób. Wykonywanie pracy w formie organizacyjnej telepracy jest elementem istotnym, dopuszczającym częściowe różnicowanie sytuacji prawnej telepracownika względem pracownika typowego ${ }^{164}$. Jednak fakt wykonywania pracy w nietypowej formie organizacyjnej nie może być wyznacznikiem gorszej sytuacji pracownika. Dlatego też wskazana regulacja nie stanowi ustawowego superfluum. Postrzegać należy ją jako uszczegółowienie regulacji wymuszone odrębnościami związanymi z zatrudnieniem w formie telepracy. W pełni uzasadnione jest chronienie przed dyskryminacją i nierównym traktowaniem wszystkich pracowników. W odniesieniu do telepracy zakaz dyskryminacji i nakaz równego traktowania odnosić należy do porównywania sytuacji dwóch telepracowników oraz telepracownika i pracownika zwykłego. Natomiast zakaz mniej korzystnego traktowania odnosi się wyłącznie do sytuacji zestawienia warunków zatrudnienia pracownika i telepracownika.

Odmienną materię reguluje art. $67^{15} \$ 2$ k.p. Wskazana norma zakazuje dyskryminacji na dwóch płaszczyznach. Pierwszą z nich jest zakaz dyskryminacji, której podstawą byłoby podjęcie pracy w formie organizacyjnej telepracy. Drugą stanowi sytuacja określająca jako kryterium dyskryminacyjne odmowę podjęcia pracy $\mathrm{w}$ formie telepracy. Zakres podmiotowy pierwszego z przedstawionych kryteriów dyskryminacyjnych dotyczy pracowników, którzy byli zatrudnieni w warunkach typowych, a następnie podjęli pracę w formie organizacyjnej telepracy. Drugi z przypadków dotyczy pracowników zatrudnionych w warunkach typowych, którzy odmawiają podjęcia pracy w formie organizacyjnej telepracy ${ }^{165}$.

164 A. Sobczyk, Telepraca w prawie..., s. 129-130.

165 A. Sobczyk, Art. 67 ${ }^{15}$, pkt 6, [w:] A. Sobczyk (red.), Kodeks pracy..., s. 354. 
Również regulacja dotycząca pracy tymczasowej zawiera uszczegółowienie przepisów dotyczących ochrony przed dyskryminacją. Jej treść oparta jest o standardy wynikające $\mathrm{z}$ art. 5 dyrektywy Parlamentu Europejskiego i Rady nr 2008/104/WE z dnia 19 listopada 2008 r. w sprawie pracy tymczasowej. Antydyskryminacyjne regulacje dotyczące pracy tymczasowej znajdują się w ustawie o promocji zatrudnienia i instytucjach rynku pracy oraz w ustawie o zatrudnianiu pracowników tymczasowych. Pierwszy z wymienionych aktów prawnych $\mathrm{w}$ art. 19c zakazuje wszystkim agencjom zatrudnienia, nie tylko agencjom pracy tymczasowej, dyskryminacji wobec osób, dla których poszukują one zatrudnienia lub innej pracy zarobkowej. W procesie tym agencje zatrudnienia nie mogą kierować się takimi kryteriami jak płeć, wiek, niepełnosprawność, rasa, religia, pochodzenie etniczne, narodowość, orientacja seksualna, przekonania polityczne i wyznanie oraz przynależność związkowa.

Ustawa o zatrudnianiu pracowników tymczasowych w art. 15 ust. 1 odnosi się do porównywania sytuacji pracownika zatrudnionego przez pracodawcę użytkownika na takim samym lub podobnym stanowisku oraz pracownika tymczasowego (analogicznie regulacja art. $67^{15} \$ 1$ k.p. dotyczy relacji pracownik-telepracownik). Wskazany przepis zakazuje w okresie wykonywania pracy tymczasowej mniej korzystnego traktowania pracownika tymczasowego niż pracownika zatrudnionego przez pracodawcę użytkownika na takim samym lub podobnym stanowisku na określonych płaszczyznach. Płaszczyznami tymi są warunki pracy i inne warunki zatrudnienia. Punktem odniesienia dla porównywania warunków pracy i innych warunków zatrudnienia jest sytuacja prawna pracownika zatrudnionego przez pracodawcę użytkownika na takim samym lub podobnym stanowisku. Przepis art. 15 ust. 1 z.p.t. nie odnosi się do zakazu dyskryminacji, a do zakazu mniej korzystnego traktowania, które może mieć miejsce jedynie w przypadku porównywalnych, ale nie jednakowych sytuacji faktycznych (świadczenie pracy na tym samym bądź podobnym stanowisku). Warunki organizacyjne pracy świadczonej $\mathrm{w}$ ramach zatrudnienia tymczasowego narzucają pewne odmienności, które jednak nie mogą cechować się mniej korzystnym traktowaniem pracownika tymczasowego. W obrębie zatrudnienia tymczasowego działania dyskryminacyjne mogą mieć miejsce również w przypadku pracownika tymczasowego, którego potraktowano w sposób dyskryminujący względem pracownika regularnego, niepracującego na takim samym lub podobnym stanowisku ${ }^{166}$. W takim przypadku stosowane są przepisy ogólne dotyczące dyskryminacji w zatrudnieniu, uregulowane w kodeksie pracy. Przepisy kodeksu pracy znajdą zastosowanie również w przypadku dyskryminującego traktowania pracownika tymczasowego względem pracownika zatrudnionego przez pracodawcę użytkownika na takim samym lub podobnym stanowisku na

166 D. Dörre-Nowak, Zatrudnienie tymczasowe a regulacje dyskryminacyjne, pkt 2, [w:] A. Sobczyk (red.), Z problematyki... 
innych płaszczyznach niż warunki pracy i inne warunki zatrudnienia, wskazane jako kryteria dyskryminacyjne w art. 15 ust. 1 z.p.t.

Nie wydaje się uzasadnione wyłączenie kryterium dostępu do szkoleń jako kryterium umożliwiającego mniej korzystne traktowanie pracownika tymczasowego względem pracownika zatrudnionego przez pracodawcę użytkownika na takim samym lub podobnym stanowisku, w sytuacji gdy pracownik tymczasowy wykonuje pracę na rzecz pracodawcy użytkownika krócej niż 6 tygodni (art. 15 ust. 2 z.p.t.). Dyspozycja art. 15 ust. 2 z.p.t. nie będzie mogła zostać zastosowana, jeżeli pracodawca użytkownik w ogóle nie zatrudnia swoich pracowników bądź nie zatrudnia swoich pracowników na takim samym lub podobnym stanowisku jak stanowisko pracownika tymczasowego. Omawiana regulacja miała zapewne wyeliminować konieczność doszkalania przez pracodawców użytkowników pracowników tymczasowych pracujących na ich rzecz przez bardzo krótkie okresy. Jednak, skoro celem pracy tymczasowej jest m.in. ułatwienie znalezienia zatrudnienia stałego, ustawodawca powinien położyć szczególny nacisk na dostęp do szkoleń pracowników tymczasowych ${ }^{167}$. Biorąc dodatkowo pod uwagę fakt, że kodeks pracy nie dopuszcza przyjęcia jako kryterium dyskryminacyjnego zatrudnienia na czas określony ${ }^{168}$, brak jest uzasadnienia dla istnienia takiej regulacji. W omawianym przypadku należy stosować jako lex specialis ${ }^{169}$ ustawę o zatrudnianiu pracowników tymczasowych. Nie wydaje się jednak, aby współgrała ona $\mathrm{z}$ systemowymi założeniami zatrudnienia tymczasowego m.in. jako formy przeciwdziałającej bezrobociu. Podnoszenie kwalifikacji zawodowych jest zjawiskiem pożądanym, oddziałującym pozytywnie na stan gospodarki zarówno na poziomie jednostki, jak i na poziomie globalnym ${ }^{170}$. Dlatego też ustawodawca winien tworzyć regulacje sprzyjające podnoszeniu kwalifikacji przez pracowników tymczasowych.

Ważnymi aspektami regulacji antydyskryminacyjnych w obszarze pracy tymczasowej są zagadnienia związane z określeniem podmiotu odpowiedzialnego za naruszenie zakazu dyskryminacji oraz $\mathrm{z}$ wysokością odszkodowania. Zgodnie $\mathrm{z}$ art. 16 z.p.t. odpowiedzialność przed pracownikiem tymczasowym za działania

167 Już w starszej literaturze wskazywano na istotne znaczenie, jakie ma doszkalanie. Zob. K. Opolski, Społeczno-ekonomiczne aspekty doksztatcania i doskonalenia zawodowego, „Praca i Zabezpieczenie Społeczne” 1981, nr 5-6, passim.

168 D. Dörre-Nowak, op. cit., pkt 4.

169 Stanowisko o takiej relacji lex generalis-lex specialis wskazanych aktów prawnych (kodeksu pracy i ustawy o zatrudnianiu pracowników tymczasowych) prezentuje W. Sanetra, Praca tymczasowa - zatrudnienie czy pośrednictwo pracy, [w:] Z. Góral (red.), Z zagadnień wspótczesnego prawa pracy. Księga jubileuszowa Profesora Henryka Lewandowskiego, Warszawa 2009, s. 329.

170 M. Skąpski, Funkcje prawnej regulacji podnoszenia kwalifikacji zawodowych pracowników z zakres ich realizacji w Polsce, [w:] L. Florek, Ł. Pisarczyk (red.), Wspótczesne problemy prawa pracy i ubezpieczeń społecznych. XVIII Zjazd Katedr i Zakładów Prawa Pracy i Ubezpieczeń Społecznych, Warszawa 2011, s. 249. 
dyskryminacyjne pracodawcy użytkownika ponosi agencja pracy tymczasowej, z prawem restytucji do pracodawcy użytkownika. Nie znaczy to, że sama agencja pracy tymczasowej, jako pracodawca, nie może naruszyć przepisów antydyskryminacyjnych ${ }^{171}$. Podmiotem dopuszczającym się dyskryminacji pracownika tymczasowego może być pracodawca użytkownik bądź agencja pracy tymczasowej. Jednak pracownik tymczasowy dochodzi odszkodowania zawsze od swojego pracodawcy, czyli agencji pracy tymczasowej. W kwestii wysokości odszkodowania art. 16 z.p.t. odsyła do regulacji kodeksu pracy.

W dniu 14 lipca 2010 r. pełnomocnikowi Rzeczpospolitej Polskiej w postępowaniu przed organami sądowymi Unii Europejskiej i Trybunałem EFTA doręczono skargę przeciwko Rzeczypospolitej Polskiej ${ }^{172}$, złożoną przez Komisję Europejską do Europejskiego Trybunału Sprawiedliwości, w której Komisja Europejska zarzuciła Polsce m.in. niepełne i nieprawidłowe wdrożenie dyrektywy Rady nr 2000/43/WE. W związku z powyższym zaistniała konieczność niezwłocznego uregulowania kwestii ochrony przed dyskryminacją osób związanych więzią cywilnoprawną. Komisja Europejska w skardze podniosła, że przepisy dotychczas ustanowione świadczą o istnieniu środków nakazujących równe traktowanie jedynie w odniesieniu do pracowników oraz stosunku pracy, tym samym nie obejmują swoim działaniem zatrudnienia cywilnoprawnego. Komisja Europejska przedstawiła Polsce również zarzuty formalne dotyczące niewłaściwego lub niepełnego wdrożenia dyrektyw Rady Unii Europejskiej nr 2000/43/WE, 2000/78/WE ${ }^{173}$, 2004/113/WE ${ }^{174}$ oraz dyrektywy Parlamentu Europejskiego i Rady nr 2006/54/WE. W wyniku prac legislacyjnych uchwalono ustawę o wdrożeniu niektórych przepisów Unii Europejskiej w zakresie równego traktowania ${ }^{175}$. Obejmuje ona swoim zakresem wdrożenie dyrektyw Rady nr 86/613/EWG ${ }^{176}$, 2000/43/WE, 2000/78/WE, 2004/113/WE oraz dyrektywy Parlamentu Europejskiego i Rady Unii Europejskiej nr 2006/54/WE,

171 A. Sobczyk, Zatrudnienie pracowników tymczasowych, „Praca i Zabezpieczenie Społeczne” 2004, nr 4, s. 37.

172 Skarga wniesiona w dniu 7 lipca 2010 r. - Komisja Europejska przeciwko Rzeczypospolitej Polskiej, sygn. C-341/10, Dz.U.UE.C z dnia 25 września 2010 r.

173 Dyrektywa Rady nr 2000/78/WE z dnia 27 listopada 2000 r. ustanawiająca ogólne warunki ramowe równego traktowania w zakresie zatrudnienia i pracy, Dz.U.WE.L 303 z dnia 2 grudnia 2000 r., s. 16-22.

174 Dyrektywa Rady nr 2004/113/WE z dnia 13 grudnia 2004 r. wprowadzająca w życie zasadę równego traktowania mężczyzn i kobiet w zakresie dostępu do towarów i usług oraz dostarczania towarów i usług, Dz.U.W.L 373 z dnia 21 grudnia 2004 r., s. 37-43.

175 Ustawa z dnia 3 grudnia 2010 r. o wdrożeniu niektórych przepisów Unii Europejskiej w zakresie równego traktowania, Dz.U., Nr 254, poz. 1700 ze zm.

176 Dyrektywa Rady nr 86/613/EWG z dnia 11 grudnia 1986 r. w sprawie stosowania zasady równego traktowania kobiet i mężczyzn pracujących na własny rachunek, w tym w rolnictwie, oraz w sprawie ochrony kobiet pracujących na własny rachunek w okresie ciąży i macierzyństwa, Dz.U.EWG.L 359 z dnia 19 grudnia 1986 r., s. 56-58. 
a jej głównym celem jest, poza wdrożeniem wskazanych dyrektyw, uzupełnienie i wzmocnienie obowiązujących $\mathrm{w}$ polskim porządku prawnym norm chroniących przed dyskryminacją ${ }^{177}$.

Dokonując porównania obszaru regulacji przepisów antydyskryminacyjnych znajdujących się w kodeksie pracy oraz w ustawie o wdrożeniu niektórych przepisów Unii Europejskiej w zakresie równego traktowania, nie sposób nie zauważyć wielu zbieżności w katalogach kryteriów dyskryminacyjnych. Zbieżnymi kryteriami dyskryminacyjnymi w obu aktach są: płeć, wiek, niepełnosprawność, rasa, narodowość, pochodzenie etniczne, wyznanie, orientacja seksualna. W kodeksie pracy wymienione są ponadto przekonania polityczne, przynależność związkowa i rodzaj zatrudnienia. Natomiast w ustawie o wdrożeniu niektórych przepisów Unii Europejskiej w zakresie równego traktowania ustawodawca dodał do katalogu światopogląd. Przed omówieniem różnic w katalogach przyczyn dyskryminacyjnych wskazana być musi kluczowa różnica regulacji znajdującej się w kodeksie pracy oraz w omawianej ustawie. Artykuł $18^{3 a}$ k.p., statuujący katalog przyczyn, które mogą być podstawą działań dyskryminujących, a tym samym stanowić podstawę naruszenia zasady równego traktowania, poprzez użycie sformułowania „w szczególności”, przesądza o jego otwartym charakterze ${ }^{178}$. Natomiast katalog przyczyn wymienionych w ustawie wdrażającej przepisy Unii Europejskiej ma charakter zamknięty. Zatem katalog przyczyn, które uznane być mogą za dyskryminujące, został na gruncie ustawy ograniczony w porównaniu z odpowiednią regulacją znajdującą się w kodeksie pracy.

177 A. Ludera-Ruszel, Ustawa z dnia 3 grudnia 2010 r. o wdrożeniu niektórych przepisów Unii Europejskiej w zakresie równego traktowania jako przykład realizacji przez Polskę polityki równości Unii Europejskiej, „Analizy i Studia Europejskie” 2011, nr 1(7), s. 125.

$178 Z$ poglądem tym polemizuje M.J. Zieliński, Zasada równego traktowania a zakaz dyskryminacji w prawie pracy, „Praca i Zabezpieczenie Społeczne” 2013, nr 8, s. 27. Autor powołuje się na stanowisko Sądu Najwyższego, który, wyliczając kryteria dyskryminacyjne, pominął słowa „w szczególności”, co zdaniem autora implikuje zamknięty charakter katalogu przyczyn dyskryminacyjnych. Wyrok Sądu Najwyższego z dnia 10 września 1997 r., I PKN 246/97, LEX nr 32795. W dalszej części rozważań autor w kontrargumentacji podaje szereg innych orzeczeń Sądu Najwyższego. Wydaje się, że pogląd o zamkniętym charakterze katalogu przyczyn dyskryminacyjnych jest chybiony. Powszechnie przyjmuje się, że użycie przez (racjonalnego) ustawodawcę słów „w szczególności” otwiera katalog, który poddawany jest analizie. M.J. Zieliński podpiera rozważania powołaniem się na wyrok Sądu Najwyższego (z dnia 2 października 2012 r., II PK 82/12, LEX nr 1365774), zgodnie z którym otwarty katalog przyczyn dyskryminacyjnych wskazanych w art. $18^{3 a} \mathrm{k} . p$. kończy się na pierwszej części wyliczenia, czyli na słowach „a także bez względu na”. Pogląd ten uznaję za stuszny. Warto również zwrócić uwagę, że art. $18^{3 a} \S 2$ odnosi się do przyczyn dyskryminacji „wymienionych” w $\S 1$. Skoro katalog ma charakter otwarty, § 2 odnositby się tylko do wymienionych w $\S 1$ przyczyn, nie miałby natomiast zastosowania do przyczyn pominiętych z uwagi na otwarty charakter katalogu. A. Sobczyk, Prawo pracy w świetle konstytucji..., s. 120-121. 
W przedstawionym powyżej porównaniu kryteriów dyskryminacyjnych występują trzy różnice. Po pierwsze, kodeks pracy jako jedno z kryteriów wylicza przekonania polityczne, natomiast ustawa w swej treści stanowi o światopoglądzie. Przekonania polityczne z pewnością mieszczą się wśród desygnatów szerszego pojęcia, jakim jest światopogląd. Uzasadnienia wprowadzenia takiej rozbieżności w regulacjach doszukiwać należy się we wspomnianej różnicy charakterów katalogów kryteriów dyskryminacyjnych. Skoro kodeks pracy zawiera katalog otwarty, to mieszczą się w nim wszystkie pozostałe, poza przekonaniami politycznymi, desygnaty pojęcia światopogląd. Dwie pozostałe różnice rozpatrywać należy w odniesieniu do specyfiki zatrudnienia cywilnoprawnego. Wśród ustawowego katalogu przyczyn dyskryminacyjnych nie znalazły się przymioty bezpośrednio związane ze stosunkiem pracy (zatrudnienie na czas określony, nieokreślony, w pełnym lub niepełnym wymiarze czasu pracy) oraz przynależność związkowa. Osoby świadczące pracę na podstawie umów cywilnoprawnych mają ograniczoną możliwość tworzenia i przynależności do związków zawodowych ${ }^{179}$, zatem przyczyna ta może być podstawą naruszenia zasady równego traktowania $\mathrm{w}$ odniesieniu do zatrudnienia cywilnoprawnego. $\mathrm{W}$ związku z powyższym ustawodawca w art. 4 ust. 3 omawianej ustawy wskazał jako jeden $\mathrm{z}$ jej obszarów normatywnych stosowanie ustawy do przypadków przystępowania i działania w związkach zawodowych, organizacjach pracodawców oraz samorządach zawodowych, a także korzystania z uprawnień przysługujących członkom tych organizacji. Mimo wszystko nie zdecydował się uznać przynależności do związków zawodowych jako jednego z kryteriów dyskryminacyjnych. Jednak w związku z tym, że osoby wykonujące pracę na podstawie umowy agencyjnej, jeżeli nie są pracodawcami, mają prawo tworzyć i wstępować do związków zawodowych, a osoby wykonujące pracę nakładczą - wstępować do nich, nieunormowanie omówionych kwestii nie wydaje się uzasadnione. Ustawodawca uregulował przeciwdziałanie naruszeniom zasady równego traktowania w obrębie przystępowania i działania w związkach zawodowych. Wykluczył tym samym możliwość dyskryminującego procesu przyjmowania do związków zawodowych oraz realizowania uprawnień związkowych, pozostawiając poza regulacją fakt dyskryminowania kogoś z powodu jego przynależności bądź nieprzynależności do związku zawodowego. W mojej ocenie taka luka jest nieuzasadniona, gdyż to właśnie pominięta przez ustawodawcę płaszczyzna związana z przynależnością (bądź jej brakiem) do związku zawodowego może stanowić częstą przyczynę dyskryminacji.

Ustawa o wdrożeniu niektórych przepisów Unii Europejskiej w zakresie równego traktowania obejmuje swoim obszarem regulacyjnym warunki podejmowania i wykonywania działalności gospodarczej lub zawodowej, w tym w szcze-

179 O ile spełniają warunki przynależności oraz tworzenia związków zawodowych przewidziane w ustawie o związkach zawodowych. 
gólności w ramach stosunku pracy ${ }^{180}$ albo na podstawie umowy cywilnoprawnej (art. 4 pkt 2 omawianej ustawy). Natomiast obszarem wyłączonym spod regulacji ustawy są m.in.: sfera życia prywatnego i rodzinnego, treści zawarte w środkach masowego przekazu oraz swoboda wyboru strony umowy, o ile nie jest oparta na płci, rasie, pochodzeniu etnicznym lub narodowości. Uszczuplenie katalogu przyczyn dyskryminujących, mogących stanowić naruszenie zasady równego traktowania w zakresie swobody wyboru strony umowy, daje asumpt do twierdzenia, że swobody wyboru strony umowy nie ograniczają niewymienione kryteria (religia, wyznanie, światopogląd, niepełnosprawność, orientacja seksualna).

Na gruncie omawianej regulacji dopuszczenie się dyskryminacji bądź molestowania stanowi naruszenie zasady równego traktowania. Każdy, wobec kogo zasada równego traktowania została naruszona, ma prawo do odszkodowania (zgodnie z art. 13 ust. 1 ustawy). Na podstawie art. 24 k.c., stosowanego w związku $\mathrm{z}$ art. 13 ust. 2 ustawy, osoba, której dobro osobiste zostało naruszone poprzez działanie będące naruszeniem zasady równego traktowania, może żądać ponadto zaniechania działania, usunięcia jego skutków, zadośćuczynienia pieniężnego lub zapłaty odpowiedniej sumy pieniężnej na wskazany cel społeczny ${ }^{181}$. Jedną $\mathrm{z}$ różnic między regulacją dotyczącą równego traktowania zawartą w kodeksie pracy i w ustawie jest określenie w kodeksie pracy (art. $18^{3 \mathrm{~d}} \mathrm{k}$.p.) minimalnej sumy odszkodowania (minimalne wynagrodzenie ustalane na podstawie odrębnych przepisów). Ustawa nie określa granic odszkodowania. Wobec powyższego przy ustalaniu jego wysokości zastosowanie mają przepisy ogólne kodeksu cywilnego. Do postępowania w sprawach o naruszenie zasady równego traktowania, których podstawą jest ustawa o wdrożeniu niektórych przepisów Unii Europejskiej w zakresie równego traktowania, właściwym aktem prawnym w zakresie procedury jest kodeks postępowania cywilnego (zgodnie z brzmieniem art. 14 ustawy). Ma on zastosowanie również do spraw dotyczących naruszeń przepisów prawa pracy w zakresie zasady równego traktowania i niedyskryminacji. $\mathrm{W}$ ustawie (art. 3 pkt 2 in fine) ciężar dowodu przerzucony został na stronę pozwaną, zgodnie z antydyskryminacyjnymi regulacjami Unii Europejskiej ${ }^{182}$ (dyrektywa Rady nr 2000/43/WE, dyrektywa Rady nr 2000/78/WE). Analogicznie jak w odpowiedniej regulacji kodeksu pracy (art. $18^{3 \mathrm{~b}} \S 1$ in fine k.p. ${ }^{183}$, powód

180 Z treści art. 2 ustawy wynika, że przepisów rozdziałów 1 i 2 (przepisów ogólnych oraz dotyczących zasady równego traktowania i środków prawnych dla jej ochrony) nie stosuje się do pracowników w zakresie uregulowanym przepisami kodeksu pracy.

181 Analogicznie jak w przypadku naruszenia zasady równego traktowania w stosunku pracy. Tam przepisy kodeksu cywilnego znajdują odpowiednie zastosowanie na podstawie art. 300 k.p.

182 Z. Góral, O kodeksowym..., s. 164.

183 W kodeksie pracy reguła ta nie została wyrażona expressis verbis, należy ją jednak odczytywać $z$ art. $18^{3 b} \S 1$ in fine („chyba, że pracodawca udowodni, że kierował się obiektywnymi powodami”). Ibidem, s. 165. 
musi jedynie uprawdopodobnić fakt naruszenia zasady równego traktowania, natomiast to na pozwanym spoczywa obowiązek wykazania (udowodnienia), że naruszenia się nie dopuścił184.

Przedawnienie roszczeń wynikających z omawianej ustawy unormowane zostało poprzez wyznaczenie dwóch skorelowanych ze sobą terminów. Pierwszy z nich - a tempore scientiae - rozpoczyna swój bieg od powzięcia wiadomości o naruszeniu. Wynosi on 3 lata. Drugi - a tempore facti - to termin, który biegnie od zdarzenia stanowiącego naruszenie zasady równego traktowania i wynosi 5 lat. $\mathrm{W}$ równoległej sytuacji roszczenie pracownika $\mathrm{z}$ tytułu dyskryminacji przedawnia się w terminie 3 lat od wymagalności (art. 291 k.p.). W razie dochodzenia roszczeń z tytułu dyskryminacji początek biegu tego terminu nie może być z góry przesądzony. Jeśli dyskryminacja skutkowała rozwiązaniem stosunku pracy, bieg terminu przedawnienia następuje od momentu dowiedzenia się o szkodzie. Termin ten niekoniecznie jest zbieżny z momentem rozwiązania umowy o pracę $e^{185}$. $\mathrm{W}$ tym przypadku regulacja kodeksu pracy jest dla osoby świadczącej pracę bardziej korzystna niż regulacja omówionej ustawy, bowiem uprawnienie w zakresie dochodzenia roszczeń nie jest ograniczone terminem a tempore facti.

Dokonując porównania statusu prawnego pracowników zatrudnionych w ramach umownego zatrudnienia nietypowego i osób świadczących pracę na podstawie umów cywilnoprawnych, względem których naruszona została zasada równego traktowania i zakaz dyskryminacji, należy wywnioskować, że przyznana im ochrona nie jest tożsama. Ochrona przed działaniami dyskryminacyjnymi jest silniejsza w stosunkach pracy. Jest ona również zróżnicowana w przypadku telepracy i pracy tymczasowej celem dostosowania do odmiennych od typowych warunków świadczenia pracy. Stosunki nietypowego umownego zatrudnienia pracowniczego związane są ze stałą, a przede wszystkim bliską współpracą ich podmiotów, dlatego możliwość wystąpienia działań o charakterze dyskryminującym jest o wiele bardziej prawdopodobna niż w przypadku stosunków cywilnoprawnych. W związku z powyższym mechanizmy prawne służące ochronie przed dyskryminacją osób świadczących pracę w ramach umownego pracowniczego zatrudnienia nietypowego, zarówno na etapie powstawania, jak i trwania stosunku prawnego, są bardziej rozbudowane względem mechanizmów chroniących osoby zatrudnione na podstawie umów prawa cywilnego. Zatem na gruncie regulacji prawnych przeciwdziałających dyskryminacji należy uznać zasadność korzystniejszego statusu prawnego osób świadczących pracę w ramach umownego pracowniczego zatrudnienia nietypowego względem statusu prawnego osób świadczących pracę na podstawie umów właściwych reżimowi prawa cywilnego.

184 M. Gersdorf, Zatrudnienie pracowników..., s. 41-42.

185 Por. wyrok Sądu Najwyższego z dnia 3 lutego 2009 r., I PK 156/2008, „Monitor Prawa Pracy” 2009, $\mathrm{nr}$ 6, s. 311-314. 


\subsection{Podsumowanie}

Status prawny osób świadczących pracę w ramach umownego zatrudnienia nietypowego jest zróżnicowany już na etapie jego wyboru i kształtowania treści umowy. Swoboda stron w zakresie decydowania o podstawie prawnej umownego zatrudnienia nietypowego jest ograniczona regulacjami o charakterze ogólnym (zasadą swobody umów wyrażoną w art. $353^{1}$ k.c.). Ograniczenia te wynikają również z przepisów określających warunki, jakie muszą zostać spełnione, aby dany stosunek prawny mógł zostać nawiązany i być kontynuowany, bądź takich norm, które wyłączają możliwość dokonania kwalifikacji stosunku zatrudnienia. W związku z powyższym uzasadniony wydaje się pogląd, że zakres ograniczeń swobody stron w nawiązywaniu umownego zatrudnienia nietypowego wyznacza granice, w których strony stosunku prawnego mogą podejmować zamierzone działania.

Zróżnicowanie statusu prawnego osób świadczących pracę w ramach umownego zatrudnienia nietypowego występuje w zakresie modelu ochrony ich danych osobowych w fazie zawierania umowy. W tym względzie podmiotami posiadającymi szerszą ochronę są osoby ubiegające się o zatrudnienie pracownicze, a nie cywilnoprawne. W obrębie pracowniczych stosunków umownego zatrudnienia nietypowego w sposób szczególny kształtuje się ochrona danych osobowych pracowników tymczasowych. Powyższe związane jest z koniecznością dysponowania danymi osobowymi pracownika tymczasowego przez pracodawcę użytkownika, jako uczestnika trójpodmiotowej relacji zatrudnienia tymczasowego, niebędącego stroną umowy o pracę.

Dywersyfikacja statusu prawnego osób zatrudnianych w ramach umownego zatrudnienia nietypowego występuje również w zakresie warunków, jakie muszą zostać spełnione celem dopuszczenia ich do pracy. Więcej warunków musi zostać spełnionych, aby mogły powstać więzi o charakterze prawnopracowniczym aniżeli cywilnoprawnym. Osoby zatrudniane w ramach umownego zatrudnienia cywilnoprawnego nie podlegają obowiązkowi poddania się wstępnym badaniom lekarskim czy odbycia szkolenia wstępnego z zakresu bhp. Taki stan normatywny w sposób nieuzasadniony różnicuje ochronę zdrowia i życia w zależności od podstawy prawnej świadczenia pracy.

Zróżnicowanie statusu prawnego osób świadczących pracę w ramach umownego zatrudnienia nietypowego w zakresie warunków, jakie muszą zostać spełnione przed dopuszczeniem ich do pracy, wynika również z tego, że regulacje zatrudnienia tymczasowego przenoszą część obowiązków związanych z dopuszczeniem do pracy z pracodawcy (w rozumieniu art. 3 k.p.) na pracodawcę użytkownika. Pracownik tymczasowy zobowiązany jest do odbycia szkolenia wstępnego z zakresu bhp organizowanego przez pracodawcę użytkownika, a pracodawca użytkownik ma obowiązek takie szkolenie przeprowadzić, a także zapewnić środki ochrony indywidualnej oraz odzież i obuwie robocze (art. 14 ust. 2 pkt 1 z.p.t., 
art. 9 ust. 2a z.p.t.). W odniesieniu do zatrudnienia cywilnoprawnego omówione różnice wynikają z braku organizacyjnego podporządkowania świadczonej pracy i samodzielności w zakresie sposobu jej wykonywania ${ }^{186}$, a w odniesieniu do pracy tymczasowej - ze szczególnego, trójpodmiotowego charakteru zatrudnienia tymczasowego, w którym część obowiązków pracodawcy (w rozumieniu art. 3 k.p.) przejmuje pracodawca użytkownik.

Ostatnie poczynione $\mathrm{w}$ tym rozdziale uwagi dotyczą ochrony przed dyskryminacją osób zatrudnionych w ramach umownego zatrudnienia nietypowego. Wynikiem przeprowadzonej analizy jest wniosek o zróżnicowanej (w odniesieniu do zatrudnienia typowego) pozycji prawnej zarówno telepracowników, pracowników tymczasowych, jak i osób zatrudnionych w ramach umów prawa cywilnego. Zróżnicowanie to wynika ze specyfiki poszczególnych podstaw prawnych i form organizacyjnych umownego zatrudnienia nietypowego. Zakres ochrony telepracownika przed działaniami o charakterze dyskryminującym obejmuje zakaz mniej korzystnego traktowania telepracownika względem innych pracowników, niepracujących $w$ formie organizacyjnej telepracy (art. $67^{15} \$ 1$ k.p.), natomiast zakres ochrony przed dyskryminacją pracownika tymczasowego obejmuje zakaz mniej korzystnego traktowania pracownika tymczasowego względem pracowników pracodawcy użytkownika w ramach wyznaczonych przez art. 15 ust. 1 z.p.t. Powyższe regulacje związane są z systemowymi odrębnościami zarówno telepracy, jak i zatrudnienia tymczasowego. Status prawny osób świadczących pracę $\mathrm{w}$ ramach umownego zatrudnienia cywilnoprawnego w zakresie ochrony przed dyskryminacją uregulowany został w sposób odmienny od statusu pracowniczego. Różnice te, wpływające na mniej korzystną względem pracowniczej sytuację prawną osób zatrudnionych na podstawie umów prawa cywilnego, wynikają z innych założeń systemowych zatrudnienia powstającego w różnych reżimach prawnych. Strony umowy cywilnoprawnej pozostają w formalnej równości, dlatego też nie jest racjonalne przyznawania którejkolwiek z nich szerszych uprawnień w zakresie ochrony przed dyskryminacją.

Omówione regulacje różnią się nie tylko w obrębie odrębnych reżimów prawnych - prawa pracy i prawa cywilnego. Pozostają one zróżnicowane również wewnątrz danej gałęzi prawa w zależności od podstawy prawnej umownego zatrudnienia nietypowego. Konieczność obowiązywania w obrocie prawnym podstaw prawnych umownego zatrudnienia nietypowego, które w różny sposób normują wzajemne relacje swoich podmiotów, w tym status prawny osób zatrudnionych $\mathrm{w}$ fazie nawiązywania stosunku prawnego, wydaje się uzasadniona.

186 Nie wydaje się jednak, jak wskazano powyżej, aby te cechy zatrudnienia cywilnoprawnego wyłączały konieczność ochrony zdrowia i życia osób świadczących pracę. 


\section{Status prawny osób świadczących pracę $\mathbf{w}$ ramach umownego zatrudnienia nietypowego w okresie realizacji stosunku prawnego}

\subsection{Wprowadzenie}

Status prawny osób świadczących pracę w ramach umownego zatrudnienia nietypowego jest zróżnicowany w okresie realizacji umowy. Zróżnicowanie to obejmuje kilka płaszczyzn. W pierwszej kolejności występuje ono na gruncie obowiązków osób świadczących pracę. Zbadanie zakresu tych obowiązków, wynikających $\mathrm{z}$ unormowań poszczególnych podstaw prawnych i form organizacyjnych umownego zatrudnienia nietypowego, umożliwi dokonanie ich oceny pod względem zgodności z założeniami systemowymi rodzajów umownego zatrudnienia nietypowego. $Z$ wypełnianiem określonych powinności związane jest posiadanie przez osoby świadczące pracę uprawnień wynikających z realizacji umowy. Analiza statusu prawnego osób świadczących pracę w ramach umownego zatrudnienia nietypowego $\mathrm{z}$ perspektywy przysługujących im $\mathrm{w}$ związku $\mathrm{z}$ realizacją umowy uprawnień stanowi ważny punkt w prowadzonych wywodach. Oceny z punktu widzenia wypełniania społeczno-gospodarczych założeń poszczególnych rodzajów umownego zatrudnienia nietypowego wymagają odmienności w tym zakresie.

Realizacja umowy, której przedmiotem jest zatrudnienie nietypowe, różnicuje status prawny osób świadczących pracę również w obrębie odpowiedzialności jej stron. Odpowiedzialność podmiotu zatrudnionego wyznacza ramy prawne, w których jego działania uznawane są za zgodne z prawem. Ograniczenie tej odpowiedzialności może wynikać z odmiennego przeznaczenia różnych rodzajów umownego zatrudnienia nietypowego. Z kolei konieczność analizy zakresu odpowiedzialności podmiotów zatrudniających wydaje się uzasadniona z powodu wpływu, jaki wywiera ona na określenie podlegających prawnej ochronie obszarów związanych ze świadczeniem pracy przez osoby zatrudnione. Dalsza część rozważań obejmować będzie prezentację statusu prawnego osób świadczących pracę $\mathrm{w}$ ramach umownego zatrudnienia nietypowego $\mathrm{w}$ zakresie objęcia tych podmiotów ubezpieczeniami społecznymi i ubezpieczeniem zdrowotnym. Ewentualne różnice w statusie prawnym na tej płaszczyźnie podlegać będą ocenie z per- 
spektywy uzasadnienia ich występowania. Uzasadnieniem takim mogą być inne założenia systemowe poszczególnych podstaw prawnych i form organizacyjnych umownego zatrudnienia nietypowego, ich różne przeznaczenie społeczno-gospodarcze, a także odmienne warunki, w jakich świadczona jest praca.

\subsection{Status prawny osób świadczących pracę w ramach umownego zatrudnienia nietypowego wynikający z ich obowiązków}

Status prawny osób świadczących pracę w ramach umownego zatrudnienia nietypowego kształtuje ich obowiązki i uprawnienia. Zasadne jest dokonanie analizy obowiązków osób świadczących pracę w ramach umownego zatrudnienia nietypowego, które ukształtowane są odmiennie w zależności od podstawy świadczenia pracy i jej formy organizacyjnej. W niniejszej części przedstawione zostaną obowiązki osób świadczących pracę w ramach umownego zatrudnienia nietypowego wobec podmiotów zatrudniających ${ }^{1}$, które w sposób najbardziej znaczący wpływają na ich sytuację prawną. Zróżnicowanie obowiązków osób świadczących pracę $w$ ramach umownego zatrudnienia nietypowego jest nieodzownie związane z cechami konstrukcyjnymi poszczególnych podstaw prawnych i form organizacyjnych tego zatrudnienia oraz z ich społeczno-gospodarczym przeznaczeniem. Jest ono zatem $\mathrm{w}$ pełni uzasadnione równoległym współistnieniem zatrudnienia pracowniczego i cywilnoprawnego oraz poszczególnymi podstawami zatrudnienia w obrębie danej gałęzi prawa ${ }^{2}$. Ramy prawne obowiązków osób świadczących pracę często pozwalają zakwalifikować stosunek jako pracowniczy bądź cywilnoprawny ${ }^{3}$. Natomiast różnice w obowiązkach osób świadczących pracę w obrębie gałęzi prawa uzależnione są od warunków zatrudnienia nietypowego - rodzaju umowy i formy organizacyjnej świadczonej pracy.

1 Osoby zatrudnione mogą mieć również obowiązki np. wobec państwa. M. Święcicki, Prawo pracy, Warszawa 1968, s. 330. Te jednak nie będą przedmiotem rozważań.

2 Na przykład obowiązki pracowników tymczasowych ukształtowane w inny sposób niż obowiązki pracowników zatrudnionych typowo, co wynika z samej istoty zatrudnienia tymczasowego.

3 Pracownik wypetnia zobowiązanie świadczenia pracy w warunkach niespotykanych w stosunkach prawa cywilnego. Jego praca jest podporządkowana i zasadniczo odbywa się we współpracy z innymi pracownikami. Dodatkowo pracownik jest trwale związany z pracodawcą, co wynika z ciągłego charakteru stosunku pracy. Por.: M. Święcicki, op. cit., s. 333. 
Uregulowane w kodeksie pracy umowne podstawy zatrudnienia mają taki sam trzon obowiązków pracowniczych. Głównym obowiązkiem pracownika jest wykonywanie pracy podporządkowanej pracodawcy, co potwierdza art. $22 \$ 1$ k.p. Obowiązki pracownicze wymieniają również art. 100 k.p. oraz art. 211 k.p. Drugi z nich określa jako podstawowy obowiązek przestrzeganie przepisów oraz zasad bezpieczeństwa i higieny pracy.

W treści art. $100 \$ 1$ k.p. jako pierwszy obowiązek pracownika wskazana została powinność sumiennego i starannego wykonywania pracy, obejmująca swoim zakresem wszystkich pracowników, bez względu na podstawę świadczonej pracy. Analiza obowiązku wykonywania pracy sumiennie i starannie z perspektywy powinności osób świadczących pracę na podstawie umownego zatrudnienia nietypowego pozwoli ocenić, na ile i z jakich przyczyn poszczególne rodzaje tego zatrudnienia różnią się od siebie w zakresie kreowania statusu prawnego osób zatrudnionych. Oba przymioty (sumienność i staranność) bezpośrednio związane są z należytą jakością działań ${ }^{4}$. W przeciwieństwie do staranności ocenianej poprzez pryzmat jakości świadczonej pracy, sumienność może być badana jedynie na płaszczyźnie subiektywnego stosunku do wykonywanych czynności. Sumienność jest związana ze zindywidualizowanym podejściem pracownika do obowiązków ${ }^{5}$. Jako obowiązek pracowniczy jest ona odnoszona do zaangażowania pracownika w proces pracy. W przypadku zatrudnienia tymczasowego sumienność i staranność świadczenia pracy ocenia się w odniesieniu do zadań wykonywanych na rzecz pracodawcy użytkownika. Wynika to z samej istoty zatrudnienia tymczasowego, w ramach którego praca wykonywana jest na rzecz pracodawcy użytkownika (art. 2 pkt 3 z.p.t.). Pracownik tymczasowy jest zatem zobowiązany do sumiennego i starannego wykonywania pracy, której odbiorcą nie jest pracodawca w rozumieniu art. 3 k.p., jak ma to miejsce w typowym stosunku pracy. Powyższe nie pozostaje w sprzeczności z treścią art. 100 k.p., bowiem sumienność i staranność dotyczą wykonywania pracy jako takiej, bez wskazania jej rzeczywistego odbiorcy.

W zakresie obowiązków sumiennego i starannego wykonywania pracy odmiennie kształtuje się status prawny osób świadczących ją w ramach umownego zatrudnienia cywilnoprawnego. W zależności od rodzaju umowy stanowiącej jego podstawę w ramach świadczonej pracy osoba zatrudniona może być zobowiązana do starannego działania (zlecenie, umowa agencyjna) bądź osiągnięcia określonego rezultatu (dzieło, praca nakładcza). Obowiązek uzyskania określonego rezultatu nie wyłącza wskazanego w art. 355 k.c. obowiązku staranności dłużnika. Należyta staranność obliguje osobę świadczącą pracę do zachowania

4 J. Czerniak-Swędzioł, Pracowniczy obowiq̨zek ochrony interesów gospodarczych pracodawcy, Warszawa 2007, s. 50.

5 Z. Góral, Art. 100, [w:] K.W. Baran (red.), Kodeks pracy. Komentarz, https://sip-1lex-1pl-1004153yx0674.han3.lib.uni.lodz.pl/\#/komentarz/587329143/490776 (dostęp: 19.09.2017). 
minimalnego poziomu zaangażowania i dbałości o wykonanie zobowiązania ${ }^{6}$, bez względu na charakter łączącej strony umowy (jako umowy starannego działania czy umowy rezultatu). W odniesieniu do umowy agencyjnej, $\mathrm{z}$ uwagi na zastrzeżenie w art. 758 k.c., że aktywność agenta ma pozostawać w zakresie działalności jego przedsiębiorstwa, badając staranność wykonywanej pracy, należy odnieść się do treści art. $355 \$ 2$ k.c. Wzorzec należytej staranności agenta musi uwzględnić zwiększone oczekiwania dotyczące jego zawodowych kwalifikacji, wiedzy i praktycznych umiejętności skorzystania z niej

Staranność w ujęciu prawa cywilnego oceniania jest w sposób zobiektywizowany. W prawie pracy obiektywna ocena staranności dokonywana jest łącznie $\mathrm{z}$ jej zindywidualizowaną perspektywą oraz z subiektywnie badaną sumiennością. Należyta staranność $\mathrm{w}$ rozumieniu art. 355 k.c. powiązana jest z konkretnym typem stosunków zobowiązaniowych, stanowiących punkt odniesienia przy jej ocenie ${ }^{8}$. Indywidualne podejście podmiotu wykonującego zobowiązanie do jego realizacji, jego osobiste zaangażowanie i predyspozycje nie są przy tej ocenie uwzględniane w takim stopniu, jak ma to miejsce w stosunkach prawnopracowniczych' Wskazana różnica obowiązków osób świadczących pracę wynika z innego gospodarczego przeznaczenia zatrudnienia pracowniczego i zatrudnienia cywilnoprawnego. Celem zatrudnienia pracowniczego jest nie tylko osiąganie efektów pracy ludzkiej, ale też zorganizowanie sfery życia człowieka związanej z wykonywaniem pracy. $\mathrm{W}$ tym względzie prawo pracy respektuje fakt istnienia różnic $\mathrm{w}$ indywidualnych predyspozycjach pracowników. W stosunkach normowanych prawem cywilnym pierwszoplanową rolę odgrywa natomiast zobowiązanie jako takie. W odniesieniu do umów prawa cywilnego, których przedmiotem jest świadczenie pracy, najistotniejsze jest spełnienie określonego świadczenia. Prawo cywilne nie koncentruje się wokół regulowania wzajemnych relacji stron umów w zakresie tak daleko idącym jak prawo pracy. Tym bardziej nie stanowi jego cechy spersonalizowana perspektywa stosunków prawnych. Słuszne wydaje się stanowisko zarysowane przez Macieja Święcickiego jeszcze przed uchwaleniem kodeksu pracy, że zakresy obowiązku staranności pracownika i osoby zatrudnionej na podstawie umowy prawa cywilnego nie mogą być oceniane pod kątem ich wzmożoności. Obowiązek starannego świadczenia pracy podporządkowanej jest po prostu rodzajowo inny od staranności ocenianej w odniesieniu do umowy prawa cywilnego ${ }^{10}$.

6 A. Olejniczak, Art. 355, [w:] A. Kidyba (red.), Kodeks cywilny. Komentarz, t. 3: Zobowiq̨zania - część ogólna, https://sip-1lex-1pl-1004153yx0674.han3.lib.uni.lodz.pl/\#/komentarz/587264118/167839 (dostęp: 19.09.2017).

7 Wyrok Sądu Najwyższego z dnia 22 września 2005 r., IV CK 100/05, LEX nr 187120.

8 J. Czerniak-Swędzioł, op. cit., s. 69.

9 Sumienność w stosunkach prawa cywilnego jest częścią składową staranności, a nie cechą wykonywanego zobowiązania o równorzędnym do niej znaczeniu. O uwzględnianiu sumienności przy dokonywaniu oceny staranności pisze A. Olejniczak, op. cit.

10 M. Święcicki, op. cit., s. 347. 
Wskazane odmienności statusu prawnego osób świadczących pracę w ramach umownego zatrudnienia nietypowego względem zatrudnienia typowego, związane z obowiązkiem sumiennego i starannego wykonywania pracy, wynikają z różnych założeń systemowych poszczególnych rodzajów zatrudnienia nietypowego. Odmienności te zachodzą zwłaszcza w umownym zatrudnieniu cywilnoprawnym, w którym osobiste starania osoby świadczącej pracę nie są na tyle istotne, co rzeczywiście osiągnięty rezultat.

Osoby świadczące pracę w ramach umownego zatrudnienia nietypowego pozostają, w różnym zakresie i w odmienny sposób, związane poleceniami i wskazówkami, których udzielają im podmioty zatrudniające. Obowiązek stosowania się do nich nierzadko stanowi cechę konstrukcyjną umownego zatrudnienia nietypowego. $\mathrm{Z}$ istoty podporządkowania pracownika pracodawcy wynika obowiązek pracownika w postaci stosowania się do poleceń. Podporządkowanie pracownika względem pracodawcy jest cechą, która umożliwia odróżnienie więzi zatrudnienia pracowniczego od zatrudnienia niezależnego ${ }^{11}$. Osoby zatrudnione $\mathrm{w}$ ramach nietypowego zatrudnienia cywilnoprawnego są zobowiązane do przestrzegania porządku organizacyjnego procesu pracy w mniejszym stopniu aniżeli w stosunku pracy ${ }^{12}$. Nie są one związane poleceniami wydawanymi przez podmioty zatrudniające - ich obowiązki kształtować mogą jedynie wskazówki i wytyczne ${ }^{13}$. Zależność wykonawcy pracy świadczonej w wyniku zawarcia umowy prawa cywilnego od podmiotu zlecającego jej wykonanie nie obejmuje również pracowniczego obowiązku pozostawania w dyspozycji ${ }^{14}$. Powyższe wynika ze wskazywanej już wielokrotnie odrębności systemowej prawa pracy i prawa cywilnego. Praca świadczona w reżimie prawa cywilnego ma charakter organizacyjnie niezależny, czego skutkiem jest brak obowiązku osoby, która ją świadczy, wykonywania poleceń podmiotu zatrudniającego.

Nietypowość pracy świadczonej w formie organizacyjnej telepracy wynika m.in. z faktu wykonywania pracy regularnie poza zakładem pracy (art. $67^{5}$ $\$ 1$ k.p.). Ponieważ pracodawca nie ma możliwości sprawowania bieżącej kontroli nad pracownikiem, który świadczy pracę poza zakładem pracy, podporządkowanie telepracownika jest zakresowo mniejsze niż pracownika zatrudnionego typowo ${ }^{15}$. Nie oznacza to jednak, że telepracownik nie jest zobowiązany do świad-

11 A. Supiot, Zatrudnienie pracownicze i zatrudnienie niezależne, [w:] M. Seweryński (red.), Referaty na VI Europejski Kongres Prawa Pracy i Zabezpieczenia Społecznego, Warszawa 1999, s. 143.

12 S. Koczur, Differentia specifica „podporzqdkowania” właściwego dla stosunku pracy a umów cywilnoprawnych, „Monitor Prawa Pracy” 2015, nr 2, s. 68-73.

13 A. Chobot, Nowe formy zatrudnienia. Kierunki rozwoju i nowelizacji, Warszawa 1997, s. 181.

14 Z. Kubot (red.), Szczególne formy zatrudnienia, Wrocław 2000, s. 20; Z. Kubot, Pojęcie kierownictwa pracodawcy, [w:] M. Matey-Tyrowicz, L. Nawacki, B. Wagner (red.), Prawo pracy a wyzwania XXI wieku. Księga jubileuszowa Profesora Tadeusza Zielińskiego, Warszawa 2002, s. 242, 250.

15 L. Mitrus, Podporzqdkowanie pracownicze jako zmieniająca się cecha stosunku pracy, [w:] L. Florek, Ł. Pisarczyk (red.), Współczesne problemy prawa pracy i ubezpieczeń społecznych. XVIII Zjazd Katedr i Zakładów Prawa Pracy i Ubezpieczeń Społecznych, Warszawa 2011, s. 128. 
czenia pracy pod kierownictwem pracodawcy. Obowiązek ten realizowany jest $\mathrm{w}$ inny sposób, często wynikający z istoty telepracy, czyli poprzez wykorzystanie środków komunikacji elektronicznej.

W zakresie obowiązku podporządkowania w szczególny sposób ukształtowana jest sytuacja prawna pracownika tymczasowego. Uprawnienia do wyznaczania zadań w stosunku do pracownika tymczasowego ma podmiot niebędący stroną stosunku pracy, czyli pracodawca użytkownik (art. 2 pkt 1 z.p.t.). Pracownik tymczasowy zobowiązany jest do wykonywania pracy pod jego kierownictwem (art. 2 pkt 2 z.p.t.). Nie oznacza to jednak, że pracodawca użytkownik uzyskuje całość uprawnień kierowniczych właściwych pracodawcy. Pracownik tymczasowy jest zobowiązany do stosowania się do poleceń pracodawcy użytkownika w zakresie organizacji pracy. Prawa i obowiązki pracodawcze związane z organizacją pracy przyznaje pracodawcy użytkownikowi art. 14 ust. 1 z.p.t.

Status prawny osób świadczących pracę w ramach umownego zatrudnienia nietypowego zróżnicowany jest w zakresie obowiązku podporządkowania i zależności organizacyjnej względem podmiotu zatrudniającego. Samodzielność osoby świadczącej pracę w umownym zatrudnieniu cywilnoprawnym (czyli na podstawie umowy o pracę nakładczą, umowy zlecenia, umów, do których stosuje się przepisy o zleceniu, umowy agencyjnej i umowy o dzieło) wynika $\mathrm{z}$ jego niezależnej istoty. Zakres podporządkowania telepracownika wynika z cech telepracy i ograniczony jest świadczeniem pracy (wyłącznie bądź również) poza zakładem pracy. Natomiast pracownik tymczasowy jest podporządkowany zarówno agencji pracy tymczasowej, jak i pracodawcy użytkownikowi (w zakresie organizacji pracy). Wszystkie wskazane odrębności w statusie prawnym osób świadczących pracę w ramach umownego zatrudnienia nietypowego związane są ze społeczno-gospodarczymi założeniami poszczególnych jego rodzajów.

Jednym $\mathrm{z}$ obowiązków pracowników jest przestrzeganie ustalonego w zakładzie pracy czasu pracy (art. $100 \$ 2$ pkt 1 k.p.). Zbadanie, na ile obowiązek ten jest zróżnicowany zależnie od pracowniczej podstawy zatrudnienia nietypowego oraz na ile może aktualizować się w zatrudnieniu cywilnoprawnym, pozwoli przedstawić $\mathrm{z}$ tej perspektywy status prawny osób świadczących pracę w ramach umownego zatrudnienia nietypowego. Zbigniew Góral wymienia następujące elementy składowe obowiązku przestrzegania ustalonego czasu pracy: stawienie się punktualnie $\mathrm{w}$ miejscu wykonywania pracy ( $\mathrm{w}$ zakładzie pracy lub $\mathrm{w}$ innym miejscu wyznaczonym przez pracodawcę $e^{16}$ ), pozostawanie $\mathrm{w}$ dyspozycji przełożonych aż do pory zakończenia pracy, aktywna obecność w pracy polegająca na wykonywaniu umówionego rodzaju pracy, przestrzeganie przerw w pracy, przestrzeganie zasad usprawiedliwiania nieobecności w pracy, wykonywanie pracy w godzinach

16 W przypadku telepracownika może być to równoznaczne ze stawieniem się $\mathrm{w}$ centrum telepracy bądź zalogowaniem się do systemu umożliwiającego pracę zdalną. 
nadliczbowych ${ }^{17}$. Zakres ostatniego ze wskazanych obowiązków, tj. wykonywania pracy w godzinach nadliczbowych, krzyżuje się z zakresem obowiązku stosowania się do poleceń pracodawcy. Przy założeniu spełnienia przesłanek umożliwiających pracę w godzinach nadliczbowych (art. $151 \$ 1$ zd. 2 k.p.) obowiązek wykonywania pracy w godzinach nadliczbowych wynika $\mathrm{z}$ wymogu stosowania się do poleceń przełożonych, stanowiąc konsekwencję podporządkowania pracownika względem pracodawcy ${ }^{18}$.

Obowiązek przestrzegania ustalonego czasu pracy różnicuje status prawny pracowników zatrudnionych w formie organizacyjnej telepracy. Z uwagi na świadczenie pracy regularnie poza zakładem pracy możliwość ewidencjonowania i bieżącego nadzorowania czasu pracy telepracownika przez pracodawcę jest utrudniona. Strony w umowie o pracę, która przewiduje świadczenie pracy w formie organizacyjnej telepracy bądź w porozumieniu, o którym mowa w art. $67^{7}$ $\$ 3$ k.p., powinny ustalić, w jaki sposób pracownik potwierdza rozpoczęcie pracy, które umożliwia zweryfikowanie obowiązku przestrzegania ustalonego czasu pracy. Dokładne określenie sposobu ewidencjonowania czasu pracy telepracownika jest również konieczne w celu określenia, czy pracownik świadczył pracę w godzinach nadliczbowych bądź w porze nocnej ${ }^{19}$ oraz czy zachowane są wymagane przerwy w świadczeniu pracy [dobowe (art. 132 k.p.) i tygodniowe (art. 133 k.p.)]. W związku z powyższym status prawny telepracownika w zakresie obowiązku przestrzegania ustalonego czasu pracy powinien być dalece skonkretyzowany w umowie o pracę bądź w porozumieniu, o którym mowa w art. $67^{7} \$ 3$ k.p. ${ }^{20}$ Wobec braku możliwości wyznaczenia sztywnych ram czasowych do telepracy najkorzystniej jest stosować zadaniowy system czasu pracy, przerywany system czasu pracy bądź, na podstawie art. $140^{1} \$ 1$ i 2 k.p., elastyczny system czasu pracy ${ }^{21}$.

Pewne odrębności w zakresie obowiązku przestrzegania ustalonego czasu pracy, dowodzące nietypowego charakteru więzi zatrudnienia, istnieją w zatrudnieniu tymczasowym. Zgodnie $\mathrm{z}$ art. 9 ust. 1 pkt 4 z.p.t. wymiar czasu pracy jest elementem składowym umowy pomiędzy agencją pracy tymczasowej a pracodawcą użytkownikiem. Jego ustalenie determinuje właściwe postanowienia umowy o pracę tymczasową. W zakresie dalszych elementów składowych organiza-

17 Z. Góral, Art. 100, [w:] K.W. Baran (red.), Kodeks pracy. Komentarz, https://sip-1lex-1pl1004153yx0674.han3.lib.uni.lodz.pl/\#/komentarz/587329143/490776 (dostęp: 19.09.2017).

18 K. Stefański, Czas pracy, https://sip-1lex-1pl-1004153yx0674.han3.lib.uni.lodz.pl/\#/monografia/369276106/45 (dostęp: 19.09.2017).

19 Pora nocna określana jest względem strefy czasowej właściwej pracownikowi. A.M. Świątkowski, Telepraca - specyfika zatrudnienia na odległość, „Monitor Prawa Pracy” 2006, nr 7, s. 360.

20 W. Sanetra, Uwarunkowania instytucji czasu pracy, [w:] L. Florek (red.), Czas pracy, https://sip-1lex-1pl-1004153yx0674.han3.lib.uni.lodz.pl/\#/monografia/369223854/5 (dostęp: 19.09.2017).

21 J. Wiśniewski, Zatrudnienie pracowników w formie telepracy, Toruń 2007, s. 86; A. Sobczyk, Telepraca w prawie polskim, Warszawa 2009, s. 178-185. 
cji czasu pracy pracownik tymczasowy zobowiązany jest stosować się do zasad panujących u pracodawcy użytkownika. W relacji pracy tymczasowej obowiązek pracy $\mathrm{w}$ godzinach nadliczbowych związany jest $\mathrm{z}$ kierownictwem pracodawcy użytkownika, któremu pracownik tymczasowy jest podporządkowany w zakresie organizacji procesu pracy. Zatem podmiotem, wobec którego aktywizuje się obowiązek pracownika tymczasowego pracy w godzinach nadliczbowych, jest pracodawca użytkownik. Wynika to $\mathrm{z}$ faktu, że praca tymczasowa świadczona jest właśnie na jego rzecz (art. 2 pkt 2 z.p.t.).

Samodzielność organizacyjna osób świadczących pracę na podstawie umów prawa cywilnego wyłącza możliwość organizowania czasu ich pracy (w tym nakładania obowiązku pracy w godzinach nadliczbowych) przez podmioty zatrudniające. Niepodporządkowany charakter pracy świadczonej na podstawie umów prawa cywilnego czyni sprzecznym $z$ ich społeczno-gospodarczym przeznaczeniem wprowadzanie norm prawnych regulujących organizację procesu pracy, w tym norm dotyczących czasu pracy. Dlatego też osoby świadczące pracę na podstawie umów prawa cywilnego nie są zobowiązane do wykonywania czynności wykraczających poza zakres umowy, w szczególności nie są zobowiązane do pracy ponad uzgodnienia umowne w zbliżonych okolicznościach do wypełniających dyspozycje art. 151 k.p.

Analiza kolejnego obowiązku pracowniczego (przestrzegania regulaminu pracy i ustalonego w zakładzie pracy porządku - art. $100 \$ 2$ pkt 2 k.p.), związanego ze skooperowanym charakterem pracy świadczonej $\mathrm{w}$ ramach stosunku pracy $^{22}$, również umożliwi przedstawienie odmienności w statusie prawnym osób świadczących pracę $\mathrm{w}$ ramach umownego zatrudnienia nietypowego. Procesem organizacji pracy zarządza pracodawca w rozumieniu art. 3 k.p. bądź pracodawca użytkownik (art. 14 ust. 2 z.p.t.). W procesie tym uczestniczy wiele podmiotów, których działania muszą pozostawać ze sobą w zgodzie, celem osiągnięcia maksymalnej efektywności pracy. $Z$ istoty regulaminu pracy wynika, że umieszcza się $\mathrm{w}$ nim ustalenia mające służyć zapewnieniu prawidłowego przebiegu procesów pracy odbywających się w zakładzie pracy, które mają ponadto zmierzać do osiągnięcia celu wynikającego z zawarcia stosunku pracy ${ }^{23}$. Będą to zatem rygory dotyczące np. potwierdzania przybycia do pracy i obecności, zachowania czystości i porządku w miejscu pracy czy poddawania się przez pracowników osobistej kontroli przed rozpoczęciem pracy ${ }^{24}$.

W przypadku pracodawcy, u którego działa przynajmniej jedna zakładowa organizacja związkowa, jest on zobowiązany określić w porozumieniu z nią warunki stosowania telepracy (art. $67^{6} \$ 1$ k.p.). Jeśli u pracodawcy działa więcej zakłado-

22 Z. Góral, Art. 100, [w:] K.W. Baran (red.), Kodeks pracy. Komentarz...

23 M. Włodarczyk, [w:] K.W. Baran (red.), Zarys systemu prawa pracy, t. 1: Część ogólna prawa pracy, Warszawa 2010, s. 457.

24 W. Szubert, Zarys prawa pracy, Warszawa 1980, s. 169. 
wych organizacji związkowych, porozumienie zawierane jest z nimi wszystkimi (art. $67^{6} \$ 1$ in fine k.p.). Brak możliwości uzgodnienia treści porozumienia ze wszystkimi zakładowymi organizacjami związkowymi powoduje, że pracodawca uzgadnia jego treść z organizacjami reprezentatywnymi (art. $67^{6} \$ 2$ k.p.). Z uwagi na brak zawarcia porozumienia w terminie 30 dni od przedstawienia przez pracodawcę jego projektu, pracodawca określa warunki stosowania telepracy w regulaminie, uwzględniając uzgodnienia podjęte $\mathrm{z}$ zakładowymi organizacjami związkowymi w toku uzgadniania porozumienia (art. $67^{6} \$ 3$ k.p.). Jeśli natomiast u pracodawcy nie działają zakładowe organizacje związkowe, ustala on warunki stosowania telepracy po konsultacji z przedstawicielami pracowników wyłonionymi w trybie u niego przyjętym (art. $67^{6} \$ 4$ k.p.). Zarówno porozumienie, o którym mowa w art. $67^{6} \$ 1$ i 2 k.p., jak i regulamin, o którym mowa w art. $67^{6}$ $\$ 3$ i 4 k.p., powinny być przestrzegane przez telepracownika na mocy art. $100 \$ 1$ pkt 2 k.p. Nie wynika to $z$ obowiązku przestrzegania regulaminu, bowiem w tym zakresie przepis art. $100 \$ 1$ pkt 2 k.p. odnosi się do regulaminu pracy. Ponieważ jednak oba powyższe akty (porozumienie i regulamin telepracy) określają ustalony w zakładzie pracy porządek - w tym przypadku porządek w zakresie warunków stosowania telepracy - na tej podstawie powinny być przestrzegane przez telepracownika (art. $100 \$ 1$ pkt 2 k.p. in fine).

Warunkami stosowania telepracy, o których mowa w art. $67^{6}$ k.p., w przypadku braku konkretnego ustawowego wskazania, są cechy charakterystyczne telepracy. Będą to zatem: określenie miejsca wykonywania pracy (poza zakładem pracy), określenie zakresu (rodzaju) prac, które mogą być w tej formie wykonywane, określenie sytemu pracy i czasu pracy, regularnych okresów i formy kontaktu, kontroli wykonywania pracy przez telepracowników czy warunków przebywania telepracownika na terenie zakładu pracy ${ }^{25}$. Telepracownik jest ponadto zobowiązany do stosowania regulaminu pracy w zakresie, w jakim nie wyklucza tego istota telepracy i nie pozostaje to sprzeczne $z$ porozumieniem w sprawie telepracy bądź regulaminem telepracy, których zakres przedmiotowy uszczegóławia warunki stosowania telepracy. Wskazane odmienności wynikają z istoty telepracy jako formy świadczonej w szczególnych warunkach organizacyjnych. Określenie tych warunków jest uzależnione od konkretnych realiów - rodzaju wykorzystywanych środków komunikacji elektronicznej czy miejsca świadczenia telepracy. Dlatego też są one określane (w porozumieniu bądź regulaminie) zawsze gdy pracodawca stosuje tę formę organizacyjną zatrudnienia, bez odwołania do kryterium liczby zatrudnianych pracowników, jak w przypadku regulaminu pracy (art. $104 \$ 2$ k.p.) ${ }^{26}$.

25 M. Tomaszewska, Art. 676, [w:] K.W. Baran (red.), Kodeks pracy. Komentarz, https://sip-1lex-1pl1004153yx0674.han3.lib.uni.lodz.pl/\#/komentarz/587329092/490725 (dostęp: 19.09.2017).

26 M. Tomaszewska, Art. 676, [w:] K.W. Baran (red.), Kodeks pracy. Komentarz, Warszawa 2016, s. 501-502. Arkadiusz Sobczyk wskazuje, że redakcja art. $67^{6} \S 4$ k.p. uzasadnia przyjęcie, że obowiązek wprowadzenia regulacji w zakresie telepracy mają pracodawcy zatrudniający co najmniej trzech pracowników. Autor zauważa, że przedstawicieli pracowników powinno 
W odniesieniu do pracy tymczasowej stosowanie się do obowiązku przestrzegania regulaminu pracy i ustalonego w zakładzie pracy porządku obarcza pracownika tymczasowego głównie względem pracodawcy użytkownika ${ }^{27}$. Pracownik tymczasowy może być zobowiązany do przestrzegania regulaminu pracy i ustalonego w zakładzie pracy porządku również względem agencji pracy tymczasowej. W zakresie przejęcia przez pracodawcę użytkownika uprawnień kierowniczych związanych $\mathrm{z}$ organizacją procesu pracy pracownik tymczasowy musi przestrzegać porządku pracy (w tym regulaminu pracy) obowiązującego u pracodawcy użytkownika, jeśli ten jest zobowiązany do jego wydania. Natomiast w pozostałym zakresie, zarezerwowanym dla relacji pomiędzy pracownikiem tymczasowym a agencją pracy tymczasowej, pracownik tymczasowy musi przestrzegać porządku pracy ustalonego dla jej funkcjonowania.

Wskazywany już niejednokrotnie niezależny charakter pracy świadczonej w konsekwencji zawarcia umowy podlegającej reżimowi prawa cywilnego wyklucza obarczanie osoby zatrudnionej na takiej podstawie prawnej obowiązkiem przestrzegania porządku pracy ustalonego przez podmiot zatrudniający w zakresie właściwym prawu pracy. Nie jest to jednak tożsame z brakiem możliwości ustalenia przez strony określonych warunków organizacyjnych pracy. Istota pracy nakładczej, łącząca w sobie cechy niepodporządkowanej umowy prawa cywilnego i prawnopracowniczej ochrony osoby zatrudnionej, umożliwiła wprowadzenie do rozporządzenia w sprawie uprawnień pracowniczych osób wykonujących pracę nakładczą regulacji dotyczącej regulaminu pracy nakładczej ( $\$ 31$ rozp. pr. nakład.). Regulamin taki uzupełnia postanowienia umowy o pracę nakładczą ${ }^{28}$. Przedstawiony w ust. 2 powyższego przepisu katalog spraw normowanych regulaminem pracy nakładczej w zakresie obowiązków wykonawców obejmuje obowiązek odebrania surowców w wyznaczonym terminie i miejscu oraz dostarczenia wykonanych produktów i usług w wyznaczonym terminie i miejscu. Ponieważ jednak katalog ten ma charakter otwarty, możliwe jest unormowanie w regulaminie pracy nakładczej również innych obowiązków wykonawców.

Fakt zastosowania $\mathrm{w}$ rozporządzeniu $\mathrm{w}$ sprawie uprawnień pracowniczych osób wykonujących pracę nakładczą konstrukcji zbliżonej jedynie do prawnopracowniczego regulaminu pracy potwierdza odrębność systemową tej podstawy zatrudnienia. Również wskazany tam przykładowy katalog spraw, jakie mogą być uregulowane regulaminem i w konsekwencji stanowić obowiązki osoby zatrudnionej, potwierdza odmienny od pracowniczego charakter pracy nakładczej.

być co najmniej dwóch, wybranych przez gremium składające się z co najmniej jednego pracownika więcej. A. Sobczyk, Art. 676, [w:] A. Sobczyk (red.), Kodeks pracy. Komentarz, Warszawa 2014, s. 326.

27 M. Frączek, M. Łajeczko, Praca tymczasowa - pytania i odpowiedzi, „Służba Pracownicza” 2005, nr 2, s. 11.

28 T. Wyka, Zatrudnienie niepracownicze na podstawie umowy o pracę nakładcza, [w:] K.W. Baran (red.), System prawa pracy, t. 7: Zatrudnienie niepracownicze, Warszawa 2015, s. 203. 
Zakres podlegania przez pracownika obowiązkom wynikającym $\mathrm{z}$ regulaminu pracy i ustalonego porządku jest bowiem znacznie szerszy. Takie zróżnicowanie obowiązku przestrzegania porządku pracy wynika ze społeczno-gospodarczej potrzeby współistnienia $\mathrm{w}$ obrocie prawnym relacji o odmiennych charakterach. Możliwość wyboru podstawy umownego zatrudnienia nietypowego, w wyniku realizacji której osoba świadcząca pracę nie podlega ustalonemu porządkowi pracy, wydaje się konieczna. Nie każde warunki świadczenia pracy wymagają bowiem określania porządku pracy, pozostawiając osobie zatrudnionej swobodę $\mathrm{w}$ tym zakresie.

Zdrowie i życie ludzkie są dobrami o największej wartości, dlatego przepisy prawne chronią bezpieczeństwo i higienę wykonywanej pracy. Obowiązki osób świadczących pracę $w$ ramach umownego zatrudnienia nietypowego nie są $\mathrm{w}$ tym zakresie jednakowe. Obowiązek przestrzegania przez pracownika przepisów oraz zasad bezpieczeństwa i higieny pracy, poza ogólnym określeniem w art. $100 \$ 2$ pkt 3 k.p., wymieniony został w postaci skonkretyzowanego katalogu otwartego w art. 211 k.p., jako obowiązek o charakterze podstawowym. Treść art. $100 \$ 2$ pkt 3 k.p. zawiera ponadto obowiązek przestrzegania przepisów przeciwpożarowych. Zakwalifikowanie w kodeksie pracy jako podstawowych jedynie obowiązków z dziedziny bhp wskazanych w art. 211 świadczy o dostrzeganej przez ustawodawcę ich istotnej roli. Z punktu widzenia powinności obciążających obydwie strony stosunku pracy jest to dziedzina najistotniejsza, gdyż angażuje życie i zdrowie pracowników ${ }^{29}$. O szczególnej wadze przypisywanej ochronie zdrowia i życia ludzkiego świadczy ponadto rozszerzenie obowiązywania art. 211 k.p. na stosunki pozapracownicze oraz, o czym była już mowa, przyznanie prawa do bezpiecznych i higienicznych warunków pracy każdemu, nie tylko pracownikom (art. 66 ust. 1 Konstytucji). Zgodnie z $\$ 21$ rozp. pr. nakład., obowiązki wynikające $z$ art. 211 k.p. w odpowiednim zakresie obarczają również wykonawców pracy nakładczej. Na podstawie art. $304^{1}$ k.p. ciążą one też, $w$ zakresie określonym przez pracodawcę lub inny podmiot organizujący pracę, na osobach fizycznych wykonujących pracę na innej podstawie niż stosunek pracy w zakładzie pracy lub innym miejscu wyznaczonym przez pracodawcę lub przez inny podmiot organizujący pracę. Obowiązkami tymi, zgodnie $\mathrm{z}$ art. $304^{1} \mathrm{k}$.p., obciążone są również osoby prowadzące na własny rachunek działalność gospodarczą w zakładzie pracy lub w miejscu wyznaczonym przez pracodawcę lub inny podmiot organizujący pracę. Zakres podmiotowy art. $304^{1}$ k.p. jest rozbudowany i obejmuje cztery grupy podmiotów. Po pierwsze są to osoby fizyczne wykonujące pracę na innej podstawie niż stosunek pracy w zakładzie pracy bądź innym miejscu wyznaczonym przez pracodawcę. W takiej sytuacji jedna ze stron relacji stanowiącej źródło obowiązków osób zatrud-

29 T. Wyka, Art. 211, [w:] K.W. Baran (red.), Kodeks pracy. Komentarz, https://sip-1lex-1pl1004153yx0674.han3.lib.uni.lodz.pl/\#/komentarz/587329302/490950 (dostęp: 19.09.2017). 
nionych jest podmiotem prawa pracy. Chodzi tu o podmiot posiadający status pracodawcy, który, równolegle z zatrudnianiem pracowników, zatrudnia osoby w ramach zatrudnienia niepracowniczego. Drugi krąg podmiotów objętych omawianą regulacją (art. $304^{1}$ k.p.) stanowią osoby fizyczne wykonujące pracę na innej podstawie niż stosunek pracy w miejscu wyznaczonym przez podmiot organizujący pracę, niebędący pracodawcą. W tym przypadku oba wskazane podmioty są spoza prawa pracy. Trzecia grupa podmiotów objętych dyspozycją art. $304^{1}$ k.p. to osoby prowadzące w zakładzie pracy lub w innym miejscu wyznaczonym przez pracodawcę ${ }^{30}$ działalność gospodarczą na własny rachunek. One również są zobowiązane do przestrzegania przepisów bhp. Tak jak w pierwszym omówionym przypadku, również w tym jedna ze stron zobowiązania będącego podstawą obowiązku przestrzegania przepisów i zasad z zakresu bhp (pracodawca) jest podmiotem prawa pracy. Ostatnia grupa osób zatrudnionych, zobligowanych do stosowania norm art. 211 k.p. (w zw. z art. $304^{1}$ k.p.), to osoby prowadzące działalność gospodarczą na własny rachunek w innym niż zakład pracy miejscu wyznaczonym przez podmiot organizujący pracę, który nie jest pracodawcą. Poza tak szeroko określonym kręgiem podmiotów podlegających dyspozycji art. $304^{1}$ k.p. pozostają te osoby świadczące pracę w ramach zatrudnienia niepracowniczego, które całkowicie samodzielnie wyznaczają miejsce wykonywania pracy.

Zakres stosowania art. 211 k.p. do wymienionych grup osób zatrudnionych określa pracodawca lub innym podmiot organizujący pracę. Brak określenia przez pracodawcę lub inny podmiot organizujący pracę zakresu stosowania obowiązków wskazanych w art. 211 k.p. do nietypowego zatrudnienia cywilnoprawnego, uregulowanego w kodeksie cywilnym (umowy zlecenia, umowy o świadczenie usług, do której stosuje się przepisy o zleceniu, umowy agencyjnej i umowy o dzieło), wyłącza całkowicie konieczność przestrzegania przepisów z zakresu bhp przez osoby zatrudnione na podstawie tych umów ${ }^{31}$. Aby chronić zdrowie i życie każdej osoby świadczącej pracę, celowe byłoby wprowadzenie ustawowego obowiązku przestrzegania przepisów bhp wskazanych w kodeksie pracy odpowiednio do wszystkich umów stanowiących podstawę zatrudnienia cywilnoprawnego, tak jak ma to miejsce w odniesieniu do pracy nakładczej ( $\$ 21$ rozp. pr. nakład.). $\mathrm{W}$ obecnym stanie prawnym, jeśli pracodawca lub inny podmiot organizujący

30 Wyznaczanie miejsca świadczenia pracy, jako element podporządkowania, jest właściwe dla konstrukcji prawnopracowniczej i stanowi uzasadnioną podstawę do uznania więzi cywilnoprawnej za rzeczywisty stosunek pracy. Samo podporządkowanie odnośnie miejsca pracy nie przesądza o możliwości zakwalifikowania zatrudnienia jako stosunku pracy, ale stanowi w tym zakresie istotny argument. Przyjmując założenie racjonalności ustawodawcy, trzeba uznać, że omawiana norma art. $304^{1} \S 1$ k.p. znajduje zastosowanie tam, gdzie więź zatrudnienia nie traci cech cywilnoprawnych, pomimo wyznaczenia osobie fizycznej miejsca pracy.

31 Powyższe w związku z $\S 21$ rozp. pr. nakład. nie dotyczy umowy o pracę nakładczą. Do tej podstawy umownego zatrudnienia nietypowego art. 211 k.p. stosuje się bowiem odpowiednio. 
pracę nie określi zakresu stosowania art. 211 k.p., jego dyspozycja nie będzie aktualizowała się względem osób świadczących pracę w ramach umownego zatrudnienia cywilnoprawnego uregulowanego w kodeksie cywilnym.

Obowiązek przestrzegania norm związanych z bhp przez osoby świadczące pracę na podstawie umownego zatrudnienia cywilnoprawnego jest zasadniczo bezsankcyjny. Względem osoby zatrudnionej na podstawie umowy prawa cywilnego, która nie przestrzega zasad bhp, w razie określenia zakresu ich stosowania (art. $304^{1} \mathrm{kp}$. w zw. z art. 211 k.p.) można zastosować sankcję w postaci rozwiązania umowy z uwagi na nienależyte wykonanie zobowiązania. Przestrzeganie przepisów i zasad bhp uznać należy w takim przypadku za jeden $\mathrm{z}$ warunków należytego wykonania zobowiązania. Wydaje się, że właściwe byłoby przyznanie podmiotowi zatrudniającemu uprawnień do egzekwowania przestrzegania przepisów bhp poprzez np. możliwość nakładania kar pieniężnych. Brak podporządkowania w zakresie wykonywania pracy oraz niezależność organizacyjna, które cechują zatrudnienie cywilnoprawne, nie powinny wyłączać obowiązku stosowania przepisów z zakresu bhp. Nie ulega przy tym wątpliwości, że istnienie szczególnych sankcji za nieprzestrzeganie tych przepisów skłaniałoby osoby zatrudnione do ich respektowania.

Ze względu na specyfikę pracy świadczonej w formie organizacyjnej telepracy obowiązki przestrzegania przez telepracownika przepisów z zakresu bhp ukształtowane są w sposób nietypowy. Nietypowość ta ujawnia się względem pracy świadczonej poza zakładem pracy. Kodeks pracy nie wyłącza wobec telepracowników obowiązków przestrzegania bhp. Wydaje się zatem, że telepracownik zobligowany jest do stosowania przepisów z zakresu bezpieczeństwa i higieny pracy również wtedy, gdy świadczy pracę poza zakładem pracy - w centrum telepracy, w swoim domu bądź w innym miejscu. Ustawodawca uregulował jedynie kwestię kontroli bezpieczeństwa i higieny pracy względem pracownika świadczącego pracę w swoim domu (art. $67^{14} \$ 2$ pkt 3 k.p.). Mogłoby to sugerować, że $\mathrm{w}$ przypadku telepracy świadczonej poza zakładem pracy w miejscu innym niż dom telepracownika pracodawca nie ma możliwości dokonywania kontroli przestrzegania przez pracownika obowiązków w zakresie bhp. Wydaje się jednak, że w takiej sytuacji zastosowanie znajdują przepisy ogólne odnoszące się do uprawnień pracodawcy w zakresie przestrzegania przez pracownika bhp z uwzględnieniem art. $67^{14} \S 1$ k.p., uprawniające pracodawcę do kontroli świadczenia przez telepracownika pracy w miejscu jej wykonywania. Wątpliwości powstają w odniesieniu do możliwości kontroli przestrzegania warunków i zasad bhp świadczonej przez telepracownika pracy w miejscu, które nie jest jego domem i względem którego pracodawca nie ma uprawnień, by wejść. Słuszne byłoby założenie, że, celem wypełnienia obowiązków w zakresie bhp, telepraca musi być świadczona w domu telepracownika bądź w innym miejscu, do którego pracodawca ma tytuł prawny uprawniający do wstępu ${ }^{32}$. Jedynie wtedy pracodawca ma możliwość

32 A. Sobczyk, Telepraca w prawie..., s. 199-200. 
zweryfikowania, czy pracownik realizuje obowiązki w zakresie bhp. Z uwagi na to, że mir domowy telepracownika podlega ochronie, ustawodawca w sposób szczególny, mocą art. $67^{14} \S 2$ pkt 3 k.p., uregulował sposób przeprowadzania kontroli w zakresie bhp w domu telepracownika. Kontrola taka wymaga uprzedniej zgody telepracownika wyrażonej na piśmie, za pomocą środków komunikacji elektronicznej albo podobnych środków indywidualnego porozumiewania się na odległość. Wyrażenie zgody na każdą kolejną kontrolę należy interpretować raczej jako wspólne ustalenie z pracodawcą terminu przeprowadzenia kontroli, aniżeli jako zgodę na samo jej przeprowadzenie ${ }^{33}$.

Odrębności dotyczące obowiązków przestrzegania przepisów w zakresie bhp przez telepracowników wynikają z istoty tej formy organizacyjnej umownego zatrudnienia pracowniczego, która związana jest ze świadczeniem pracy również bądź wyłącznie poza zakładem pracy. Brak bieżącej kontroli pracodawcy nad sposobem wykonywania pracy, w tym nad przestrzeganiem zasad bhp, uzasadnia konieczność doraźnej weryfikacji wykonywania przez pracownika obowiązków $\mathrm{w}$ tym zakresie.

Obowiązek dbałości o dobro i interesy podmiotu zatrudniającego jest kolejnym czynnikiem wpływającym na status prawny osób świadczących pracę w ramach umownego zatrudnienia nietypowego $\mathrm{w}$ zakresie ich powinności. Odmienne ukształtowanie obowiązku dbałości o dobro i interesy podmiotu zatrudniającego związane jest $\mathrm{z}$ cechami poszczególnych podstaw prawnych i form organizacyjnych umownego zatrudnienia nietypowego, zwłaszcza w odniesieniu do stopnia zacieśnienia więzi zatrudnienia.

Respektowaniu uzasadnionego interesu pracodawcy służą obowiązki pracowników wymienione w art. $100 \$ 2$ pkt 4 k.p..$^{34}$ Należą do nich: obowiązek dbania o dobro zakładu pracy, ochrona jego mienia oraz obowiązek zachowania w tajemnicy informacji, których ujawnienie mogłoby narazić pracodawcę na szkodę. Powinności określone w art. $100 \$ 2$ pkt 4 k.p. ustanawiają szczególną zasadę lojalności pracownika względem pracodawcy. Z zasady tej wynika przede wszystkim obowiązek powstrzymania się pracownika od działań zmierzających do wyrządzenia pracodawcy szkody czy działań ocenianych jako podjęte na niekorzyść pracodawcy. Aby stwierdzić naruszenie wskazanych obowiązków, wystarczy wykazanie braku lojalności pracownika względem pracodawcy ${ }^{35}$. Norma wyrażona w art. $100 \$ 2$ pkt 4 k.p. dotyczy trzech powinności pracowniczych. Po pierwsze

33 M. Tomaszewska, Art. 67 ${ }^{14}$, [w:] K.W. Baran (red.), Kodeks pracy..., https://sip-1lex-1pl-1004153yx0674.han3.lib.uni.lodz.pl/\#/komentarz/587329100/490733 (dostęp: 19.09.2017). Przeciwnie: A. Sobczyk, Telepraca w prawie..., s. 192. Autor uważa, że zgodę wyraża się na cały okres zatrudnienia, a w jej treści zastrzec można, że konkretne terminy kontroli będą przez pracownika i pracodawcę ustalane wspólnie.

34 Z. Góral, Art. 100, [w:] K.W. Baran (red.), Kodeks pracy. Komentarz, https://sip-1lex-1pl1004153yx0674.han3.lib.uni.lodz.pl/\#/komentarz/587329143/490776 (dostęp: 19.09.2017).

35 Wyrok Sądu Najwyższego z dnia 2 marca 2011 r., II PK 204/10, LEX nr 817517. 
w art. $100 \$ 2$ pkt 4 k.p. ustawodawca wskazuje na pracowniczy obowiązek dbałości o dobro zakładu pracy; po drugie wymieniony został tam obowiązek ochrony mienia pracodawcy; po trzecie przepis ten wskazuje na obowiązek zachowania $\mathrm{w}$ tajemnicy informacji, których ujawnienie mogłoby narazić pracodawcę na szkodę. Pomimo że obowiązki wskazane jako drugi i trzeci stanowią przejaw obowiązku pierwszego (dbania o dobro pracodawcy), to wszystkie wymienione w omawianym przepisie regulacje są względem siebie samoistne i stanowią odrębną grupę obowiązków pracowniczych ${ }^{36}$.

Obowiązek dbania o dobro zakładu pracy aktualizuje się w sytuacjach kiedy przedmiotem ochrony jest dobro zakładu pracy w rozumieniu przedmiotowym ${ }^{37}$, nie zaś dobro pracodawcy. Często dobro zakładu pracy i dobro pracodawcy są zbieżne, nie jest to jednak regułą ${ }^{38}$. W sytuacji konfliktu dóbr pracodawcy i dóbr zakładu pracy pracownik zobowiązany jest do dbania o te drugie ${ }^{39}$. Dobrami zakładu pracy są środki materialne i niematerialne, które wpływają na jego rozwój, przyczyniają się do sprawnego funkcjonowania oraz niezakłóconego trybu i organizacji pracy ${ }^{40}$. Konkretyzacją zakresu obowiązków osób zatrudnionych w ramach umownego zatrudnienia nietypowego wynikającego z reżimu prawnego, w którym świadczą pracę, jest zakres obowiązku dbałości o dobro podmiotu zatrudniającego ${ }^{41}$. Zarówno w relacjach prawnopracowniczych, jak i cywilnoprawnych osoby zatrudnione zobowiązane są do powstrzymania się od wszelkich działań mogących szkodzić podmiotowi zatrudniającemu, co wynika z ogólnych zasad odpowiedzialności odszkodowawczej (art. 415 i nast. k.c.). W stosunkach cywilnoprawnych obowiązek ten ogranicza się jednak do szkody w rozumieniu art. 415 k.c. W jego zakres nie wchodzi obowiązek dbałości o dobro w zakresie aktualnym na gruncie stosunków pracy. Druga płaszczyzna obowiązku dbania o dobro podmiotu zatrudniającego - podejmowanie wszelkich niezbędnych działań $\mathrm{w}$ jego interesie i dla jego dobra ${ }^{42}$ - znajduje urzeczywistnienie jedynie w odniesieniu do obowiązków pracowników. Przykładem może być chociażby obowiązek czasowego wykonywania innego rodzaju pracy niż pierwotnie założony, powiązany z pracowniczym podporządkowaniem, czy obowiązek pracy w godzinach nad-

36 T. Kuczyński, O właściwościach pracowniczego obowiq̨zku dbałości o dobro zakładu pracy, „Praca i Zabezpieczenie Społeczne” 2004, nr 7, s. 2.

37 Wyrok Sądu Najwyższego z dnia 9 lutego 2006 r., II PK 160/05, LEX nr 212491; Wyrok Sądu Najwyższego z dnia 2 października 2012 r., II PK 56/12, LEX nr 1243024.

38 M. Skąpski, Pracowniczy obowiq̨zek dbatości o dobro zakładu pracy (art. 100 § 2 pkt 4 k.p.), „Praca i Zabezpieczenie Społeczne” 2001, nr 2, s. 14.

39 Ibidem, s. 16.

40 J. Czerniak-Swędzioł, op. cit., s. 82.

41 Na gruncie regulacji kodeksu pracy obszarem objętym tym obowiązkiem jest dobro zakładu pracy, o czym była już mowa.

42 Takie płaszczyzny obowiązku dbania o dobro zakładu pracy wskazuje J. Czerniak-Swędzioł, ibidem, s. 85. 
liczbowych ${ }^{43}$. Osoby świadczące pracę na podstawie umów prawa cywilnego nie są obarczone obowiązkami choćby o zbliżonym charakterze. Wyjątkiem w tym zakresie jest art. 760 k.c. zobowiązujący obie strony umowy agencyjnej, zatem również agenta, do wzajemnej lojalności. Czyni to umowę agencyjną umową zaufania $^{44}$. Względem agenta omawiany obowiązek wyraża się w powstrzymaniu się od wszelkich zachowań (działań czy zaniechań), które byłyby sprzeczne z interesami dającego zlecenie, co urzeczywistnia się poprzez zakaz zajmowania się przez niego działalnością konkurencyjną wobec dającego zlecenia w czasie trwania umowy agencyjnej czy dbanie o interesy dającego zlecenie ${ }^{45}$. W tym zakresie obowiązki agenta wykraczają poza zwykłe świadczenie usług.

Wskazanym $w$ dalszej kolejności obowiązkiem agenta jest m.in. istniejący w zakresie prowadzonych przez agenta spraw obowiązek podejmowania czynności potrzebnych do ochrony praw dającego zlecenie (art. $760^{1} \$ 1$ k.c. in fine). $\mathrm{W}$ związku z tym, że agent bądź pośredniczy w zawieraniu umów, bądź zawiera je w imieniu dającego zlecenie, do jego obowiązków należą m.in. czynności związane $\mathrm{z}$ badaniem sytuacji finansowej kontrahentó $w^{46}$. Obowiązkiem agenta nie jest zatem ochrona wszelkich dóbr dającego zlecenie, a jedynie ochrona jego praw pozostająca $\mathrm{w}$ związku z prowadzonymi sprawami. Poza umową agencyjną, która przejawia lojalnościowy charakter, pozostałe podstawy prawne umownego zatrudnienia cywilnoprawnego w swojej konstrukcji nie cechują się obowiązkiem dbania w sposób szczególny o dobro podmiotu zatrudniającego. Uzasadnieniem takiego stanu rzeczy wydaje się być specyfika współpracy stron w ramach umowy agencyjnej. Ponieważ agent działa w sposób zasadniczo ciągły, w imieniu bądź na rzecz dającego zlecenie, musi on zachować szczególną dbałość o jego dobro. Pozostałe umowy stanowiące podstawy zatrudnienia cywilnoprawnego, mając inne przeznaczenie gospodarcze, nie wymagają egzekwowania obowiązków osób zatrudnionych w zakresie dbałości o dobro podmiotu zatrudniającego.

Zatrudnienie tymczasowe w sposób szczególny reguluje status prawny osób świadczących pracę $\mathrm{w}$ ramach umownego zatrudnienia nietypowego w zakresie obowiązku dbania o dobro zakładu pracy. W związku $\mathrm{z}$ trójpodmiotowym charakterem tej więzi pracownik tymczasowy zobowiązany jest nie tylko do dbania o dobro zakładu pracy jako dobro agencji pracy tymczasowej, ale również do dbania o dobro zakładu pracy jako dobro pracodawcy użytkownika. Pracownik tymczasowy rzadko ma styczność z dobrami agencji pracy tymczasowej w znaczeniu materialnym. Tymi dobrami agencji pracy tymczasowej, wobec których pracownik

43 M. Święcicki, op. cit., s. 356; W. Szubert, Zarys prawa..., s. 172.

44 E. Rott-Pietrzyk, Dopuszczalność zastrzeżenia wypowiedzenia umowy agencyjnej na czas oznaczony, „Przegląd Prawa Handlowego” 2003, nr 10, s. 495.

45 K. Kopaczyńska-Pieczniak, Art. 760, [w:] A. Kidyba (red.), Kodeks cywilny. Komentarz, t. 3: Zobowiqzania - część szczególna, https://sip-1lex-1pl-1004153yx0674.han3.lib.uni.lodz. pl/\#/komentarz/587286645/462838 (dostęp: 19.09.2017).

46 Wyrok Sądu Najwyższego z dnia 11 grudnia 2007 r., II CSK 370/07, LEX nr 492169. 
tymczasowy zobowiązany jest do zachowania dbałości, będą więc w przeważającej większości dobra o charakterze niematerialnym ${ }^{47}$. Z kolei wobec dóbr pracodawcy użytkownika, jako uczestnika trójpodmiotowej relacji zatrudnienia tymczasowego, obowiązek ochrony dóbr dotyczyć będzie zarówno tych o charakterze materialnym, jak i niematerialnym. Powyższe wynika $z$ istoty i charakteru zatrudnienia tymczasowego jako relacji trzech podmiotów, w której przymioty właściwe pracodawcy w rozumieniu art. 3 k.p. podzielone są pomiędzy agencję pracy tymczasowej i pracodawcę użytkownika. W związku z art. 5 z.p.t. należałoby uznać, że $\mathrm{w}$ omawianym przypadku (ochrona dóbr pracodawcy) zastosowanie do relacji pracownika tymczasowego i pracodawcy użytkownika znajdą przepisy prawa pracy zobowiązujące pracownika do ochrony dóbr pracodawcy użytkownika.

Status prawny osób świadczących pracę w ramach umownego zatrudnienia nietypowego jest zróżnicowany również w odniesieniu do obowiązku dbania o mienie podmiotu zatrudniającego. Obowiązek ten został wymieniony w art. 100 $\$ 2$ pkt 4 k.p. jako jeden z obowiązków pracownika. Mieniem zakładu pracy, do dbałości o które zobowiązany jest pracownik, będą zatem aktywa zakładu pra$\mathrm{cy}^{48}$. Brakiem dbałości o mienie zakładu pracy będą zarówno sytuacje w sposób oczywisty naruszające mienie zakładu pracy (np. kradzież $\dot{2}^{49}$ ), jak i naruszające je w sposób pośredni (np. działania o charakterze zbliżonym jedynie do działań nieuczciwej konkurencji ${ }^{50}$ ). Częścią składową obowiązku dbania o mienie zakładu pracy jest niewątpliwie konieczność dochowania szczególnej troski w utrzymaniu go w jak najlepszym stanie ${ }^{51}$. Ta płaszczyzna ochrony mienia, wykraczająca poza powstrzymanie się od wyrządzania szkody, nie występuje na gruncie regulacji stosunków prawnych stanowiących podstawę umownego zatrudnienia cywilnoprawnego. Pracowniczy obowiązek dbałości o mienie zakładu pracy wykracza poza ogólne reguły związane z dbałością o cudzą własność i interesy. Nie jest on bowiem związany jedynie z obowiązkiem niewyrządzania szkody, ale również ze szczególną dbałością o to, aby żaden uszczerbek w mieniu pracodawcy nie powstał. Powyższa odrębność wynika $z$ innego charakteru prawnego stosunków prawnopracowniczych i cywilnoprawnych. Te pierwsze związane są z trwałą i bliską współpracą ich podmiotów, która nie cechuje stosunków stanowiących podstawę umownego zatrudnienia cywilnoprawnego.

W razie świadczenia pracy poza zakładem pracy, co jest warunkiem uznania organizacji pracy za telepracę, pracownik ma styczność z dobrami materialnymi pracodawcy w postaci dostarczonego mu przez pracodawcę sprzętu (art. $67^{11}$

47 Klasyfikację dóbr pracodawcy o charakterze materialnym i niematerialnym prezentuje J. Czerniak-Swędzioł, op. cit., s. 83 oraz R. Sadlik, Obowiqzek dbałości o dobro zakładu pracy i skutki jego naruszenia, „Monitor Prawa Pracy” 2015, nr 7, s. 357.

48 J. Czerniak-Swędziot, op. cit., s. 103.

49 Wyrok Sądu Najwyższego z dnia 12 sierpnia 1977 r., I PRN 97/77, LEX nr 14411.

50 Z. Góral, Art. 100, [w]: K.W. Baran (red.), Kodeks pracy. Komentarz...

51 M. Skąpski, Pracowniczy obowiq̨zek..., s. 14. 
$\$ 1$ k.p.). Stanowiący mienie pracodawcy sprzęt dostarczony telepracownikowi podlega obowiązkowi ochrony, o którym mowa w art. $100 \$ 2$ pkt 4 k.p.

Status prawny pracownika tymczasowego, związany $\mathrm{z}$ obowiązkiem ochrony mienia zakładu pracy, rozpatrywać należy przez pryzmat art. 5 z.p.t. Obowiązek ochrony mienia agencji pracy tymczasowej przez pracownika tymczasowego wynika ze stosowania do ich relacji przepisów prawa pracy. Zastosowanie do relacji pracownika tymczasowego i pracodawcy użytkownika przepisów prawa pracy dotyczących odpowiednio pracownika i pracodawcy skutkuje możliwością uznania, że pracownik tymczasowy zobowiązany jest do ochrony mienia pracodawcy użytkownika ${ }^{52}$. Pogląd ten wydaje się o tyle racjonalny, że to właśnie z tym mieniem pracownik tymczasowy ma bezpośrednią styczność. Wskazana nietypowość wynika $\mathrm{z}$ trójpodmiotowego charakteru zatrudnienia tymczasowego, który odmiennie od typowego rozkłada zakresy uprawnień i obowiązków jego uczestników.

W dalszej kolejności warto rozważyć, czy status prawny wszystkich osób świadczących pracę w ramach umownego zatrudnienia nietypowego jest tożsamy w zakresie obowiązków zachowania $\mathrm{w}$ tajemnicy informacji dotyczących podmiotu zatrudniającego, których ujawnienie mogłoby narazić go na szkodę. Względem pracowników obowiązek taki wynika $\mathrm{z}$ art. $100 \$ 2$ pkt 4 k.p. W tym przypadku zakres powyższego obowiązku nie ogranicza się do tajemnicy zakładu pracy. Oznacza to, że pracownik zobowiązany jest do zachowania w tajemnicy również tych informacji, które nie dotyczą zakładu pracy, a dotyczą pracodawcy, przy uwzględnieniu, że ich ujawnienie mogłoby narazić go na szkodę ${ }^{53}$. Warunkiem uznania niewypełnienia omawianego obowiązku jest sama możliwość powstania szkody zarówno materialnej, jak i niematerialnej ${ }^{54}$. Wobec braku ustawowej regulacji za tajemnicę uznać należy informacje wcześniej nieujawnione do publicznej wiadomości, niestanowiące elementu wiedzy ogólnej ${ }^{55}$.

Szczególny obowiązek telepracownika w zakresie nieujawniania wiedzy związany jest $z$ ochroną przekazywanych mu danych (art. $67^{12} \$ 2$ k.p.). Aby dokonać analizy tego obowiązku, w pierwszej kolejności należy rozgraniczyć pojęcia informacji (art. $100 \$ 2$ pkt 4 k.p.) i danych (art. $67^{12}$ k.p.). Informacja to proces interpretacji danych w oparciu o posiadaną wiedzę a priori w czasie. Dane mają

52 B. Wagner wskazuje, że art. 5 z.p.t., w zakresie stosowania do podmiotów zatrudnienia tymczasowego przepisów prawa pracy dotyczących odpowiednio pracownika i pracodawcy, należy odnieść do więzi pracownika tymczasowego i pracodawcy użytkownika. Do relacji agencji pracy tymczasowej i pracownika tymczasowego przepisy te znajdują zastosowanie w związku z tym, że podmioty te są pracownikiem i pracodawcą. B. Wagner, Jednolitość, wielopostaciowość czy ewolucja funkcji ochronnej prawa pracy - zatrudnienie typowe versus tymczasowe, [w:] A. Sobczyk (red.), Z problematyki zatrudnienia tymczasowego, https://sip-1lex-1pl-1004153yx0674. han3.lib.uni.lodz.pl/\#/monografia/369236017/15 (dostęp: 19.09.2017).

53 M. Skąpski, Pracowniczy obowiq̨zek..., s. 14-15.

54 R. Sadlik, Obowiq̨zek dbałości..., s. 359.

55 J. Czerniak-Swędziot, op. cit., s. 110-111. 
z założenia charakter subiektywny, podczas gdy informacje, będąc przetworzonymi przez konkretny podmiot danymi, są zindywidualizowane ${ }^{56}$. W związku z powyższym określony w art. $67^{12} \$ 2$ k.p. obowiązek telepracownika przestrzegania ochrony przekazywanych mu danych jest rodzajowo inny niż obowiązek zachowania w tajemnicy informacji, których ujawnienie mogłoby narazić pracodawcę na szkodę. Obowiązek ochrony przekazywanych telepracownikowi danych związany jest z istotą telepracy, w procesie której wykorzystywane są środki komunikacji elektronicznej. W jego zakresie mieszczą się takie czynności jak obowiązek stosowania kodów, korzystania tylko z określonych serwerów czy zakaz instalowania na sprzęcie oprogramowania innego niż wskazane przez pracodawcę ${ }^{57}$.

W odniesieniu do obowiązku zachowania w tajemnicy informacji, których ujawnienie mogłoby narazić pracodawcę na szkodę, w sposób odmienny ukształtowany jest status prawny pracowników tymczasowych. Nietypowość zatrudnienia tymczasowego wymaga, aby pracownik tymczasowy zachowywał w tajemnicy również te informacje, których ujawnienie mogłoby narazić na szkodę pracodawcę użytkownika. Podstawą do takiej ochrony będzie art. 5 z.p.t. W tym zakresie aktualne pozostają uwagi poczynione powyżej - do obowiązków pracownika tymczasowego względem pracodawcy użytkownika stosowane powinny być przepisy nakazujące zachowanie w tajemnicy informacji, których ujawnienie mogłoby narazić go na szkodę, dotyczące odpowiednio pracownika i pracodawcy.

Poza obowiązkiem zachowania tajemnicy, o którym mowa w art. $100 \$ 2$ pkt 4 k.p., pracownik zobowiązany jest do przestrzegania tajemnicy określonej w odrębnych przepisach (art. $100 \$ 2$ pkt 5 k.p.). Katalog takich tajemnic jest niezwykle szeroki ${ }^{58}$. W odniesieniu do statusu prawnego osób świadczących pracę $\mathrm{w}$ ramach umownego zatrudnienia nietypowego istotne wydaje się omówienie konstrukcji prawnej związanej z ochroną tajemnicy przedsiębiorstwa, która zakresowo często krzyżuje się z tajemnicą pracodawcy. Zgodnie z art. 11 ust. 4 ustawy z dnia 16 kwietnia 1993 r. o zwalczaniu nieuczciwej konkurencji ${ }^{59}$, aby określone informacje mogły zostać uznane za tajemnicę i poddane odpowiedniej ochronie, muszą spełniać kumulatywnie następujące przesłanki:

a) stanowić informacje techniczne, technologiczne, organizacyjne przedsiębiorstwa lub inne informacje posiadające wartość gospodarczą

b) pozostać nieujawnione do wiadomości publicznej

c) stanowić przedmiot niezbędnych działań przedsiębiorcy w celu zachowania ich poufności ${ }^{60}$.

56 M. Grabowski, A. Zając, Dane, informacja, wiedza - próba definicji, www.uci.agh.edu.pl/ uczelnia/tad/PSI9/2.rtf, s. 6 (dostęp 5.01.2017).

57 A. Sobczyk, Telepraca w prawie..., s. 165.

58 Próbę jego wskazania podejmuje J. Czerniak-Swędzioł, ibidem, s. 119-124.

59 Dz.U. z 2003 r., Nr 153, poz. 1503 - t.j. ze zm.

60 K. Róziewicz-Ładoń, Instytucjonalna ochrona konkurencji, [w:] K. Róziewicz-Ładoń, Postępowanie przed Prezesem Urzędu Ochrony Konkurencji i Konsumentów w zakresie przeciwdzia- 
Przekazanie, ujawnienie lub wykorzystanie takich informacji, a także nabycie ich od osoby nieuprawnionej, jeżeli zagraża to lub narusza interes przedsiębiorcy, stanowi czyn nieuczciwej konkurencji w rozumieniu ww. ustawy. W art. 11 ust. 4 ustawy o zwalczaniu nieuczciwej konkurencji krąg podmiotów odpowiedzialnych z tytułu wskazanego czynu nieuczciwej konkurencji został rozszerzony o osoby, które świadczyły pracę na podstawie stosunku pracy lub innego stosunku prawnego przez okres trzech lat od jego ustania, chyba że umowa stanowi inaczej albo ustał stan tajemnicy. Wskazana regulacja zrównuje w zakresie obowiązku zachowania tajemnicy przedsiębiorcy osoby zatrudnione, bez względu na rodzaj umownej podstawy zatrudnienia. W tym zakresie status prawny wszystkich osób świadczących pracę $\mathrm{w}$ ramach umownego zatrudnienia nietypowego jest taki sam. Społecznie uzasadnione jest bowiem, aby ochrona uczciwej konkurencji nie była uzależniona od podstawy prawnej świadczenia pracy.

Obowiązek przestrzegania zasad współżycia społecznego ma charakter ogólny, niezwiązany z żadnym konkretnym rodzajem więzi obligacyjnej. Jednakże ustawodawca dodatkowo zastrzegł, że obowiązkiem pracowniczym jest przestrzeganie w zakładzie pracy zasad współżycia społecznego (art. $100 \$ 2$ pkt 6 k.p.). Rozstrzygnięcie, czy obowiązek ten aktualizuje się względem wszystkich osób świadczących pracę $\mathrm{w}$ ramach umownego zatrudnienia nietypowego, pozwoli określić ich status prawny w tym zakresie. Nadanie charakteru prawnego obowiązkowi wynikającemu $\mathrm{z}$ zespołowej natury pracy świadczonej $\mathrm{w}$ ramach stosunku pracy podkreśla szczególną istotę relacji normowanych prawem pracy ${ }^{61}$. Obowiązek przestrzegania zasad współżycia społecznego w zakładzie pracy wykracza swoim zakresem zarówno poza obszar relacji międzypracowniczych (obejmując także relacje pomiędzy pracownikiem a pracodawcą $)^{62}$, jak i poza obszar ujęty ramami czasu i miejsca pracy ${ }^{63}$. Przyjmując przytaczany już w niniejszej pracy zakres pojęciowy zasad współżycia społecznego jako szczególnych reguł postępowania w życiu społecznym, należy zauważyć, że są nim objęte obie wskazane powyżej płaszczyzny. W relacjach prawa cywilnego, stanowiących podstawę umownego zatrudnienia cywilnoprawnego, wynikający z art. 5 i art. $354 \$ 1$ k.c. nakaz przestrzegania zasad współżycia społecznego również będzie dotyczył współpracy pomiędzy różnymi wykonawcami pracy, relacji pomiędzy osobą zatrudnioną i podmiotem zatrudniającym oraz relacji wykraczających poza zakres świadczonej pracy czy usług. Dodatkowe podkreślenie w art. $100 \$ 2$ pkt 6 k.p. konieczności przestrzegania w zakładzie pracy zasad współżycia społecznego daje asumpt do przyjęcia, że obowiązkowi temu ustawodawca przypisuje szczególną rolę, wykraczającą poza standardy przyjęte na gruncie regulacji prawa cywilnego.

tania praktykom ograniczającym konkurencję, https://sip-1lex-1pl-1004153yx0cd3.han3.lib. uni.lodz.pl/\#/monografia/369228613/5 (dostęp: 19.09.2017).

61 W. Szubert, Zarys prawa..., s. 174-175.

62 Z. Góral, Art. 100, [w:] K.W. Baran (red.), Kodeks pracy. Komentarz...

63 Wyrok Sądu Najwyższego z dnia 9 lipca 2008 r., I PK 2/08, LEX nr 531844. 
Pracownik tymczasowy zobowiązany jest do przestrzegania zasad współżycia społecznego w odniesieniu do podmiotowo rozumianego zakładu pracy jako agencji pracy tymczasowej ${ }^{64}$. Obowiązek pracownika tymczasowego przestrzegania zasad współżycia społecznego względem zakładu pracy pracodawcy użytkownika wynika, podobnie jak inne omawiane w tej części pracy obowiązki pracownika tymczasowego, $z$ art. 5 z.p.t. Zastosowanie do relacji pracownika tymczasowego i pracodawcy użytkownika przepisów prawa pracy dotyczących odpowiednio pracownika i pracodawcy umożliwia przyjęcie założenia, że względem pracownika tymczasowego obowiązek wynikający z art. $100 \$ 2$ pkt 6 k.p. dotyczy również zakładu pracy pracodawcy użytkownika. Występowanie w relacji zatrudnienia tymczasowego trzech podmiotów, wynikające $\mathrm{z}$ istoty tej podstawy umownego zatrudnienia nietypowego, uzasadnia takie rozłożenie obowiązków pracownika tymczasowego.

Niektóre regulacje prawne dotyczące rodzajów umownego zatrudnienia nietypowego ustanawiają szczególne obowiązki osób świadczących pracę, związane z charakterem prawnym poszczególnych relacji. Chodzi tu o obowiązek telepracownika przesyłania pracodawcy wyników swojej pracy, w szczególności za pomocą środków komunikacji elektronicznej (art. $67^{5} \$ 2$ k.p.). Jest on związany $\mathrm{z}$ istotą telepracy jako formy organizacyjnej zatrudnienia, w której wykorzystywane są środki komunikacji elektronicznej (art. $67^{5} \$ 1$ k.p.).

Szczególnym obowiązkiem przyjmującego zlecenie jest powinność udzielania dającemu zlecenie potrzebnych wiadomości o przebiegu sprawy, a po wykonaniu zlecenia lub po wcześniejszym rozwiązaniu umowy, złożenia mu sprawozdania (art. 740 k.c.). Powyższy obowiązek związany jest z charakterem prawnym umowy zlecenia. Ponieważ przyjmujący zlecenie działa w interesie dającego zlecenie, celem zaspokojenia tego interesu w jak najszerszym zakresie powinien na bieżąco informować dającego zlecenie o przebiegu sprawy, co z kolei umożliwia dającemu zlecenie udzielanie wskazówek w zakresie sposobu wykonywania umowy ${ }^{65}$. Wskazana odrębność uzasadniona jest zatem samą istotą stosunku prawnego powstającego w wyniku zawarcia umowy zlecenia. Zbliżony do omówionego jest obowiązek agenta wskazany w art. $760^{1} \$ 1$ k.c. dotyczący przekazywania wszelkich informacji mających znaczenie dla dającego zlecenie. Mogą to być np. informacje o pozyskanych klientach, o złożonych czy otrzymanych propozycjach zawarcia umowy, zaawansowaniu negocjacji prowadzonych w celu zawarcia umowy, o zawarciu umowy czy o odmowie bądź niemożliwości

64 Skoro zgodnie z wyrokiem Sądu Najwyższego I PK 2/08 obowiązek przestrzegania w zakładzie pracy zasad współżycia społecznego wykracza swoim zakresem poza miejsce pracy, pojęcie „zakład pracy” rozumieć należy w ujęciu podmiotowym, a nie przedmiotowym.

65 K. Kopaczyńska-Pieczniak, Art. 740 k.c., [w:] A. Kidyba (red.) Kodeks cywilny. Komentarz, t. 3: Zobowiq̨zania - część szczególna, https://sip-1lex-1pl-1004153yx0cd3.han3.lib.uni.lodz. pl/\#/komentarz/587286623/462816 (dostęp: 19.09.2017). 
jej zawarcia ${ }^{66}$. Również ten obowiązek wynika z samej istoty umowy agencyjnej. Dający zlecenie nie może być bowiem pozbawiony możliwości uzyskania informacji bezpośrednio go dotyczących.

Przedstawione obowiązki osób świadczących pracę w ramach umownego zatrudnienia nietypowego są zróżnicowane ze względu na charakter prawny oraz społeczno-gospodarcze przeznaczenie rodzajów zatrudnienia, przez co w sposób odmienny kształtują status prawny osób świadczących pracę. W tym zakresie w sposób najbardziej odbiegający od typowego ukształtowany został status prawny osób świadczących pracę w ramach formy organizacyjnej telepracy oraz na podstawie umowy o pracę tymczasową i cywilnoprawnych podstaw zatrudnienia umownego. Cechy poszczególnych rodzajów umownego zatrudnienia nietypowego determinują bowiem takie ukształtowanie obowiązków osób zatrudnionych, aby jak najpełniej realizowane były ich założenia systemowe.

\subsection{Status prawny osób świadczących pracę w ramach umownego zatrudnienia nietypowego wynikający $z$ ich uprawnień}

Status prawny osób świadczących pracę $\mathrm{w}$ ramach umownego zatrudnienia nietypowego jest ukształtowany w różny sposób w zakresie wynikającym $\mathrm{z}$ ich uprawnień. W pierwszej kolejności zróżnicowanie uprawnień uzależnione jest od reżimu prawnego, w ramach którego powstał stosunek zatrudnienia umownego. Zgodnie z zakreślonym obszarem badawczym poniższe rozważania będą przedstawiać uprawnienia osób zatrudnionych $\mathrm{w}$ reżimie prawa pracy i prawa cywilnego. W obrębie danej gałęzi prawa osobom zatrudnionym zostały przyznane różne uprawnienia w zależności od dokonanego przez strony wyboru rodzaju umowy bądź formy organizacyjnej świadczenia pracy. W sposób najbardziej istotny na status prawny osób świadczących pracę w ramach umownego zatrudnienia nietypowego wpływają uprawnienia związane $\mathrm{z}$ wynagrodzeniem za pracę, prawem do odpoczynku, bezpieczeństwem i higieną pracy, podnoszeniem kwalifikacji zawodowych, rodzicielstwem oraz ochroną zatrudnienia, dlatego też to one będą wchodziły w zakres prowadzonych rozważań. Dodatkowo, z uwagi na systemowe umiejscowienie wśród podstawowych zasad prawa pracy,

66 K. Kopaczyńska-Pieczniak, Art. 760¹, [w:] A. Kidyba (red.) Kodeks cywilny. Komentarz, t. 3: Zobowiq̨zania - część szczególna, https://sip-1lex-1pl-1004153yx0cd3.han3.lib.uni.lodz. pl/\#/komentarz/587286646/462839 (dostęp: 19.09.2017). 
omówione zostaną uprawnienia związane z zaspokajaniem potrzeb bytowych, socjalnych i kulturowych.

Dążenia wszystkich osób zatrudnionych są zbieżne ${ }^{67}$, ale przyznane im uprawnienia już nie. Oznacza to, że wszystkie osoby zatrudnione zmierzają do zaspokojenia tych samych potrzeb - zdobycia środków finansowych oraz realizacji kariery zawodowej, ale czynią to $\mathrm{w}$ innych uwarunkowaniach prawnych. Powyższe potrzeby osób zatrudnionych pozostają w zbieżności z potrzebami podmiotów zatrudniających. Im również, w pierwszej kolejności, zależy na zwiększaniu zysku ${ }^{68}$. Korzystając z wytworów pracy różnych grup osób zatrudnionych, podmioty zatrudniające muszą respektować przysługujące tym osobom uprawnienia, które są różne w zależności od podstawy prawnej i formy organizacyjnej umownego zatrudnienia nietypowego.

Skoro, jak wspomniano, głównym celem świadczenia pracy jest zdobycie środków umożliwiających zaspokajanie potrzeb socjalno-bytowych, rozważania dotyczące przedstawienia sytuacji prawnej osób świadczących pracę w ramach umownego zatrudnienia nietypowego rozpoczną się uwagami dotyczącymi wynagrodzenia za pracę. Taka analiza pozwoli określić zróżnicowanie statusu prawnego osób świadczących pracę i potwierdzić bądź zaprzeczyć istnieniu jego uzasadnienia w postaci zróżnicowanych założeń systemowych poszczególnych rodzajów zatrudnienia. Wynagrodzenie za pracę odgrywa istotną rolę z dwóch powodów. Jest jednym z głównych czynników zaspokajających potrzeby ludności oraz podstawowym bodźcem wzrostu wydajności pracy. Płaca pełni podwójną rolę: stanowi udział $\mathrm{w}$ dochodzie narodowym oraz wpływa na dynamikę jego wzrostu $^{69}$. Wynagrodzenie za pracę jest złożoną kategorią społeczną, prawną i ekonomiczną ${ }^{70}$, która w samym obrębie nauk prawnych występuje w różnych znaczeniach ${ }^{71}$. Ponieważ wynagrodzenie należne $z$ tytułu świadczenia pracy w ramach zatrudnienia umownego stanowi zazwyczaj główne źródło zaspokajania potrzeb osoby świadczącej pracę i jej rodziny ${ }^{72}$, przypisuje mu się funkcję alimentar-

67 I. Boruta, W sprawie przyszłości prawa pracy, „Praca i Zabezpieczenie Społeczne” 2003, nr 4, s. 10.

68 P. Prusinowski, Umowne podstawy zatrudnienia, Warszawa 2012, s. 29.

69 M. Święcicki, op. cit., s. 400.

70 J. Sokołowski, Wynagrodzenie jako element stosunków pracodawca-pracownik. Ewolucja i dostosowanie do standardów europejskich, [w:] H. Lewandowski, J. Sokołowski (red.), Pracodawca-pracownik w procesie przemian gospodarki polskiej i integracji z Uniq Europejskq, Łódź 2000, s. 157.

71 B. Wagner, Wynagrodzenie oraz inne świadczenia za pracę, „Prawo Pracy” 1997, nr 5, s. 1.

72 Za szerokim ujmowaniem wynagrodzenia osoby zatrudnionej jako źródła zaspokajania potrzeb rodziny przemawia art. 28 kodeksu rodzinnego i opiekuńczego (ustawa z dnia 25 lutego 1964 r., Dz.U. z 2015 r., poz. 2082 - t.j. ze zm.). Zgodnie z brzmieniem tego przepisu, jeżeli jeden z małżonków pozostających we wspólnym pożyciu nie spełnia ciążącego na nim obowiązku przyczyniania się do zaspokajania potrzeb rodziny, sąd może nakazać, ażeby wynagrodzenie za pracę albo inne należności przypadające temu małżonkowi były w całości lub 
ną (alimentacyjną) $)^{73}$. Wynagrodzenie jest ponadto odpowiednikiem wykonanej pracy należnym osobie zatrudnionej od podmiotu zatrudniającego ${ }^{74}$.

$\mathrm{Na}$ gruncie prawa tworzonego przez Międzynarodową Organizację Pracy uchwalono kilka konwencji, których przedmiotem jest płaca. Dość wskazać konwencję z dnia 30 maja 1928 r. nr 26 dotyczącą ustanowienia metod ustalania płac minimalnych ${ }^{75}$, konwencję z dnia 6 czerwca 1951 r. nr 99 dotyczącą metod ustalania płac minimalnych $\mathrm{w}$ rolnictwie ${ }^{76}$ oraz konwencje $\mathrm{z}$ dnia 3 czerwca $1970 \mathrm{r}$. nr 131 dotyczącą ustalania płac minimalnych, zwłaszcza w odniesieniu do krajów rozwijających się $e^{77}$. Warto wymienić także konwencję z dnia 8 czerwca $1949 \mathrm{r}$. nr 95 dotyczącą ochrony płacy $^{78}$. Sama definicja pojęcia płacy zawarta w art. 1 konwencji nr 95 budzi rozbieżności natury semantycznej. Zgodnie z polskim przekładem konwencji płacą jest wynagrodzenie lub zarobek należny na mocy pisemnej umowy pracownikowi od pracodawcy. Anglojęzyczna wersja konwencji nie posługuje się słowem „pracownik”. W wersji tej użyto słowa employed person, które powinno być tłumaczone nie jako pracownik, a raczej jako osoba zatrudniona. W związku z powyższym należałoby wyciągnąć wniosek, że konwencja nr 95 dotycząca ochrony płacy obejmuje swoimi regulacjami wszystkie osoby zatrudnione, nie tylko pracowników. Dodatkowo w art. 2 ust. 1 konwencja ta zakłada, że stosuje się ją do wszystkich osób, które otrzymują lub powinny otrzymywać płacę. Wyjątki od tej zasady mogą być wprowadzone w odniesieniu do osób, które pracują $\mathrm{w}$ takich okolicznościach i warunkach zatrudnienia, że stosowanie wszystkich lub niektórych postanowień konwencji nie byłoby możliwe i które nie są zatrudnione przy pracy fizycznej lub są zatrudnione przy usługach domowych lub podobnych zajęciach (art. 2 ust. 2). Konwencja nie ogranicza swojego zasięgu do więzi prawnopracowniczej. Jednakże na gruncie prawa polskiego przepisy chroniące wynagrodzenie osób zatrudnionych, takie jak przewidziane w konwen-

w części wypłacane do rąk drugiego małżonka. W odniesieniu do powyższego na potrzeby zaspokajania potrzeb rodziny powinno być przeznaczane każde wynagrodzenie, niezależnie od podstawy jego otrzymania i charakteru (periodycznego bądź jednorazowego). T. Sokotowski, Art. 28, [w:] H. Dolecki, T. Sokołowski (red.), Kodeks rodzinny i opiekuńczy. Komentarz, https://sip-1lex-1pl-1004153yx161d.han3.lib.uni.lodz.pl/\#/komentarz/587292531/152280 (dostęp: 19.09.2017).

73 M. Święcicki, op. cit., s. 403; K. Łapiński, Godziwe wynagrodzenie za pracę, „Monitor Prawa Pracy” 2011, nr 12, s. 633; M. Nowak, Wprowadzenie, [w:] M. Nowak, Wynagrodzenie za prace, https://sip-1lex-1pl-1004153yx0674.han3.lib.uni.lodz.pl/\#/monografia/369288048/4 (dostęp: 19.09.2017).

74 W. Szubert, Zarys prawa pracy..., s. 94.

75 MOP, www.mop.pl/doc/html/konwencje/k026.html (dostęp: 6.01.2017). Polska nie ratyfikowała dotychczas tej konwencji, ponieważ nie spełnia przewidzianych w niej kryteriów ustalania minimalnego wynagrodzenia za pracę. Ł. Kasprowicz, Sens i znaczenie wynagrodzenia minimalnego, „Praca i Zabezpieczenie Społeczne” 2013, nr 5, s. 14.

76 Dz.U. z 1977 r., Nr 39, poz. 176.

77 MOP, www.mop.pl/doc/html/konwencje/k131.html (dostęp: 6.01.2017).

78 Dz.U. z 1955 r., Nr 38, poz. 234. 
cji prawo do samodzielnego dysponowania wynagrodzeniem (art. 6) czy ochrona przed potrąceniami (art. 8), zostały w przeważającej większości ograniczone do praw pracowników. Ustawodawstwo unijne nie odnosi się bezpośrednio do kwestii związanych z wynagrodzeniem za pracę, bowiem z zakresu kompetencji Unii Europejskiej wyłączono problematykę wynagrodzeń pracowników. Nie oznacza to jednak zupełnego braku regulacji w tym zakresie, czego przykładem jest dyrektywa nr 2008/94/WE w sprawie ochrony pracowników na wypadek niewypłacalności pracodawcy ${ }^{79}$.

Analizę krajowego porządku prawnego rozpocząć należy od Konstytucji. Do problematyki związanej z wynagrodzeniem za pracę Konstytucja odnosi się w sposób bezpośredni jedynie w art. 65 ust. 4, gdzie wskazuje, że minimalną wysokość wynagrodzenia za pracę lub sposób jego ustalania określa ustawa. Konstytucja nie przesądza, czy minimalna wysokość wynagrodzenia dotyczy jedynie wynagrodzenia pracowniczego, czy każdego należnego za pracę ${ }^{80}$. Konkretyzację tego przepisu zawiera art. $10 \$ 2$ k.p., zgodnie z którym państwo określa minimalną wysokość wynagrodzenia za pracę ${ }^{81}$. Ponieważ kodeks pracy ma zastosowanie do pozapracowniczych stosunków zatrudnienia tylko w przypadku wyraźnego odesłania, przy jego braku w omawianej regulacji należy przyjąć, że przepis art. $10 \$ 2$ k.p. dotyczy jedynie minimalnego wynagrodzenia w sferze stosunków pracy. Uzupełnieniem tego przepisu jest art. 13 k.p. statuujący zasadę prawa do godziwego wynagrodzenia. Postulat godziwości wynagrodzenia pracowniczego

79 Dyrektywa Parlamentu Europejskiego i Rady nr 2008/94/WE z dnia 22 października 2008 r. w sprawie ochrony pracowników na wypadek niewypłacalności pracodawcy, Dz.U.WE.L 283 z dnia 28 października 2008 r., s. 36-42.

80 L. Florek, Konstytucyjne gwarancje uprawnień pracowniczych, „Państwo i Prawo” 1997, nr 11/12, s. 209. Przeciwnie: B. Banaszak, Konstytucja Rzeczypospolitej Polskiej. Komentarz, Warszawa 2009, s. 340; A. Sobczyk, Prawo pracy w świetle Konstytucji RP, t. 2: Wybrane problemy i instytucje prawa pracy a konstytucyjne prawa i wolności człowieka, Warszawa 2013, s. 39 i nast. Autorzy podkreślają, że konstytucyjna regulacja dotycząca minimalnego wynagrodzenia za pracę nie obejmuje jedynie pracowników. Moim zdaniem ustawodawca przesądził o zawężeniu kręgu podmiotów objętych regulacją dotyczącą minimalnego wynagrodzenia na gruncie aktów prawnych niższej rangi (kodeksu pracy i ustawy o minimalnym wynagrodzeniu za pracę), które muszą pozostawać zgodne z Konstytucją. Uznając ich zgodność, należy przyjąć, że sama Konstytucja ogranicza obowiązek ustalania minimalnego wynagrodzenia za pracę do więzi prawnopracowniczej.

81 Kontrowersje wokół powiązania godziwości wynagrodzenia z instytucją minimalnego wynagrodzenia przedstawia K. Walczak. Autor zauważa, że godziwe wynagrodzenie, w przeciwieństwie do wynagrodzenia minimalnego, ma jedynie charakter niesankcjonowanego postulatu. K. Walczak, Pojęcie płacy godziwej w ujęciu multidyscyplinarnym, [w:] G. Uścińska (red.), Prawo pracy. Refleksje i poszukiwania. Księga jubileuszowa Profesora Jerzego Wratnego, Warszawa 2013, s. 349-352. Ogólnikowość zwrotu „prawo do godziwego wynagrodzenia” wskazuje również Z. Góral. Autor w swoim opracowaniu wyprowadza desygnaty tego pojęcia z aktów prawa międzynarodowego i europejskiego. Z. Góral, O kodeksowym katalogu zasad indywidualnego prawa pracy, Warszawa 2011, s. 175-179. 
jest w szczególności realizowany poprzez ustalanie minimalnego wynagrodzenia, o czym stanowi zdanie drugie wskazanego przepisu. Uszczegółowienie sposobu ustalania wysokości minimalnego wynagrodzenia za pracę zawiera ustawa $\mathrm{z}$ dnia 10 października 2002 r. o minimalnym wynagrodzeniu za pracę ${ }^{82}$. Obowiązek kształtowania wynagrodzenia na poziomie równym co najmniej minimalnemu wynagrodzeniu dotyczy wszystkich stosunków pracy, bez względu na rodzaj umowy o pracę. Instytucja ta ma zapobiegać kształtowaniu wynagrodzeń na bardzo niskim poziomie ${ }^{83}$, co krytykowane jest przez przedstawicieli nauk ekonomicznych zajmujących się analizą gospodarczą rynku pracy ${ }^{84}$.

W zakresie najniższego wynagrodzenia, o którym mowa w $\$ 10$ ust. 2, wśród umów, które mogą być podstawą dla powstania stosunku zatrudnienia nietypowego, jedynie regulacja dotycząca pracy nakładczej odnosiła się do obowiązku zapewnienia wykonawcy określonego wynagrodzenia. Zgodnie z $\$ 3$ rozp. pr. nakład., jeśli praca nakładcza nie jest wyłącznym lub głównym źródłem utrzymania, ilość dostarczonej pracy powinna zapewniać wynagrodzenie na poziomie co najmniej $50 \%$ najniższego wynagrodzenia. Jeśli natomiast jest to dla wykonawcy jedyne lub główne źródło utrzymania, ilość pracy powinna być tak ustalona, aby wynagrodzenie za nią było równe co najmniej wysokości najniższego wynagrodzenia ${ }^{85}$. Wskazany przepis

82 Ustawa z dnia 10 października 2002 r. o minimalnym wynagrodzeniu za pracę. Dz.U. z 2017 r. poz. 847 - t.j. ze zm.

83 L. Florek, Wynagrodzenie za pracę w gospodarce rynkowej, [w:] B. Cudowski, J. Iwulski (red.), Z aktualnych zagadnień prawa pracy i zabezpieczenia społecznego. Księga Jubileuszowa Profesora Waleriana Sanetry, Białystok 2013, s. 109.

84 W. Jarzyński, A. Rzońca, P. Stolarczyk, W. Wojciechowski, Płaca minimalna zabija miejsca pracy, Analiza FOR 2011, nr 2, www.for.org.pl/pl/a/1861,Analiza-22011-Placa-minimalna-zabijamiejsca-pracy (dostęp: 6.01.2017). B. Godlewska-Bujok przedstawia dodatkowe negatywne skutki podwyższania minimalnego wynagrodzenia, wyliczając wpływ wzrostu jego wartości na sytuację różnych podmiotów. Jako przykład warto wskazać, że podwyższanie wysokości minimalnego wynagrodzenia powoduje wzrost kosztów egzaminów kwalifikacyjnych na aplikacje prawnicze, bowiem stanowi punkt odniesienia dla ich ustalania. B. Godlewska-Bujok, Płaca minimalna - druga strona medalu, „Praca i Zabezpieczenie Społeczne” 2007, nr 4, s. 11. Moim zdaniem nie jest to argument przemawiający za tym, aby minimalne wynagrodzenie określane było na niskim poziomie. Nie ma bowiem przeciwwskazań, aby zmienić regulacje dotyczące punktu odniesienia dla ustalania opłaty za ww. egzaminy, ustalając ją na poziomie np. części ułamkowej minimalnego wynagrodzenia. Ciekawy argument w dyskusji nad ustalaniem wysokości płacy minimalnej przedstawia M. Jerzak. Autorka zauważa, że jeśli różnica pomiędzy wysokością płacy minimalnej netto i zasitkiem dla bezrobotnych jest zbyt niska (w 2003 r. wynosita zaledwie 84,80 zt), bezrobotni nie dążą do podejmowania pracy. Z pewnością jest to argument świadczący raczej o potrzebie podwyższania płacy minimalnej, aniżeli o potrzebie redukowania wysokości zasitków dla bezrobotnych. M. Jerzak, Deregulacja rynku pracy w Polsce i Unii Europejskiej. ,Materiały i Studia NBP”, 2004, nr 176, s. 16.

85 M. Gersdorf, Prawo zatrudnienia, Warszawa 2013, s. 113. W związku z istnieniem tej regulacji wykonawca powinien złożyć nakładcy oświadczenie, czy świadczona przez niego praca nakładcza jest jego jedynym lub głównym źródłem utrzymania. Ł. Pisarczyk, Różne formy zatrudnienia, Warszawa 2003, s. 120. 
rozporządzenia $(\$ 3)$ w zakresie pojęcia najniższego wynagrodzenia odsyła w swojej treści do art. $77^{4}$ k.p., który został skreślony w 2002 r. ustawą wprowadzającą minimalne wynagrodzenie za pracę, znoszącą niezgodny z Konstytucją stan prawny ustalania najniższego wynagrodzenia aktem prawnym rangi niższej niż ustawa ${ }^{86}$. Przepis art. 25 ustawy o minimalnym wynagrodzeniu za pracę stanowi, że ilekroć $\mathrm{w}$ przepisach prawa jest mowa o „najniższym wynagrodzeniu za pracę pracowników", oznacza to kwotę 760 zł. Zatem najniższe wynagrodzenie wykonawców pracy nakładczej, o którym mowa w $\$ 3$ rozp. pr. nakład., wynosi 760 zł.

Ustawą z dnia 22 lipca 2016 r. o zmianie ustawy o minimalnym wynagrodzeniu za pracę oraz niektórych innych ustaw ${ }^{87}$ rozszerzono zakres obowiązku wypłaty wynagrodzenia w wysokości minimalnej na umowy zlecenia i umowy o świadczenie usług, do których stosuje się przepisy o zleceniu. Wynagrodzenie minimalne dla osób zatrudnionych na podstawie takich umów zostało określone według stawki godzinowej, której definicję zawiera art. 1 pkt 1a ustawy o minimalnym wynagrodzeniu za pracę. Wprowadzona regulacja precyzuje zakres podmiotowy oraz przedmiotowy stosowania minimalnego wynagrodzenia względem osób zatrudnionych na podstawie umów zlecenia i umów o świadczenie usług, do których stosuje się przepisy o zleceniu (art. 1 pkt $1 \mathrm{~b}$, art. $8 \mathrm{a}$ ust 1 , art. $8 \mathrm{~d}$ ust 1 ustawy o minimalnym wynagrodzeniu za pracę $\left.{ }^{88}\right)$. Prezentowany przed dokonaniem powyższej nowelizacji pogląd, że brak określenia minimalnego wynagrodzenia w stosunku do umów cywilnoprawnych (poza umową o pracę nakładczą) może prowadzić do wyzysku osób zatrudnionych na ich podstawie ${ }^{89}$, nie wydaje się słuszny. Swoboda kształtowania stosunków zobowiązaniowych jest jedną z podstawowych zasad prawa cywilnego. Przepisy kodeksu cywilnego zawierają wytyczne dla określania wynagrodzenia, o czym mowa będzie w dalszej części. Nie zrównują one jednak ochrony wynagrodzenia wszystkich osób zatrudnionych do poziomu właściwego prawu pracy. Jednakże zbyt niskie określenie wysokości wynagrodzenia może pozostawać sprzeczne z ustawą i właściwościami (naturą) danego stosunku prawnego (czyli z zasadą swobody umów - art. $353^{1}$ k.c.). Powściągliwość dotycząca obejmowania stosunków cywilnoprawnych, których przedmiotem jest praca (umowy zlecenia, umowy o świadczenie usług, do której stosuje się przepisy o zleceniu, umowy agencyjnej i umowy o dzieło), regulacją dotyczącą minimalnego wynagrodzenia spowodowana jest nie tyle wizją spadku

86 J. Wratny, Minimalne wynagrodzenie za prace - nowe regulacje prawne, „Praca i Zabezpieczenie Społeczne" 2003, nr 6, s. 2.

87 Dz.U. poz. 1265.

88 Omówienie wskazanych regulacji wykracza poza przedmiot niniejszego opracowania. Istotą problemu jest bowiem sam fakt rozszerzenia instytucji minimalnego wynagrodzenia na osoby niebędące pracownikami.

89 T. Liszcz, Nietypowe stosunki pracy w projekcie kodeksu pracy, [w:] Z. Niedbała, M. Skąpski (red.), Problemy zatrudnienia we współczesnym ustroju pracy. Księga jubileuszowa na 55-lecie pracy naukowej i dydaktycznej Profesora Włodzimierza Piotrowskiego, Poznań 2009, s. 145. 
podaży na pracę przy wprowadzeniu takiej regulacji ${ }^{90}$, ile dbałością o nieograniczanie ponad obecny stan prawny cywilistycznej zasady swobody umów. Obowiązującą ochronę wynagrodzenia w zakresie ustalania jego dolnego progu, uzależnioną od warunków zatrudnienia, uznać należy za wystarczającą i uzasadnioną odrębnościami systemowymi zatrudnienia cywilnoprawnego.

Już w pierwszym zdaniu uzasadnienia do projektu ustawy nowelizującej ustawę o minimalnym wynagrodzeniu za pracę wskazano, że wprowadzane zmiany mają na celu przeciwdziałanie nadużywaniu umów cywilnoprawnych oraz ochronę osób otrzymujących wynagrodzenie na najniższym poziomie ${ }^{11}$. Narzucając obowiązek ustalanie wynagrodzenia na poziomie minimalnej stawki godzinowej przy umowach zlecenia i umowach o świadczenie usług, do których stosuje się przepisy o zleceniu, ustawodawca zamierzał zminimalizować objawy problemu (nadużywanie zatrudnienia cywilnoprawnego $\mathrm{w}$ warunkach właściwych prawu pracy) zamiast przeciwdziałać przyczynie ${ }^{92}$. Brak jest $\mathrm{w}$ takim działaniu jakiejkolwiek racjonalności. Co więcej, wprowadzona regulacja godzi w zasady prawa cywilnego (zasadę swobody umów i zasadę ekwiwalentności świadczeńn ${ }^{93}$ oraz zaciera różnice pomiędzy zatrudnieniem pracowniczym a cywilnoprawnym. Zatarcie to wynika m.in. z konieczności ewidencjonowania godzin świadczenia pracy, która jest charakterystyczna dla stosunków o charakterze prawnopracowniczym $^{94}$ (art. 8b ust. 1-3 ustawy o minimalnym wynagrodzeniu za pracę). Na bardzo istotną dla omawianej materii kwestię zwraca uwagę Krzysztof Walczak ${ }^{95}$ : wprowadzona zmiana w sposób jednoznaczny faworyzuje jedną ze stron cywilnoprawnego stosunku zobowiązaniowego - podmiot zatrudniony. W żaden sposób nie został przez ustawodawcę wzięty pod uwagę interes podmiotu zatrudniającego. Powyższe, jak wskazuje Walczak, pozostaje w oczywistej sprzeczności z cywilistyczną zasadą równości stron. Biorąc powyższe argumenty pod uwagę,

90 A. Chobot przedstawia badania świadczące o tym, że powiązanie wzrostu minimalnego wynagrodzenia ze spadkiem popytu na pracę jest nieustalone bądź ustalone jako nikłe. A. Chobot, op. cit., s. 38-40. W związku z powyższym można przypuszczać, że również objęcie regulacją dotyczącą minimalnego wynagrodzenia grup dotąd nią nieobjętych pozostanie obojętne dla sytuacji na rynku pracy.

91 Rządowy projekt ustawy o zmianie ustawy o minimalnym wynagrodzeniu za pracę oraz niektórych innych ustaw dostępny na stronie: Sejm Rzeczpospolitej Polskiej, www.sejm.gov.pl/ sejm8.nsf/druk.xsp?nr=600 (dostęp: 6.01.2017).

92 J. Jasińska, P. Fik, O zmianie ustawy o minimalnym wynagrodzeniu za pracę, „Praca i Zabezpieczenie Społeczne" 2016, nr 9, s. 22.

93 K. Walczak, Wynagrodzenie minimalne w umowach zlecenia i o świadczenie usług-zagadnienia doktrynalne i praktyczne. Część 2, „Monitor Prawa Pracy” 2016, nr 9, s. 456.

94 J. Jasińska, P. Fik, op. cit. Co więcej, art. 8d ust. 1 ustawy o minimalnym wynagrodzeniu za pracę dopuszcza sytuacje, w których o miejscu i czasie wykonywania umowy decyduje wyłącznie podmiot zatrudniający. Decydowanie o czasie i miejscu świadczenia pracy przez podmiot zatrudniający jest cechą kierownictwa i odpowiada jej pracownicze podporządkowanie.

95 K. Walczak, Wynagrodzenie minimalne..., s. 456. 
jednoznacznie krytycznie odnoszę się do rozszerzenia konieczności ustalania wynagrodzenia na poziomie minimalnym na umowy, których przedmiotem jest wykonanie zlecenia bądź świadczenie usług.

Kształtowanie wysokości wynagrodzenia we wszystkich umownych stosunkach zatrudnienia pracowniczego odbywa się poprzez porozumienie jego stron. Ze względu na specyfikę zatrudnienia tymczasowego, polegającą na jej trójpodmiotowym charakterze, kształtowanie wynagrodzenia w tym przypadku dokonywane jest $\mathrm{w}$ sposób nietypowy. Zgodnie $\mathrm{z}$ art. 9 ust. 2 pkt 1 z.p.t. pracodawca użytkownik informuje agencję pracy tymczasowej o wynagrodzeniu za pracę, która ma być powierzona pracownikowi tymczasowemu, określonym w obowiązujących u niego przepisach o wynagradzaniu. Czynniki wpływające na wysokość wynagrodzenia generalnie określa pracodawca użytkownik, natomiast sama wysokość wynagrodzenia oraz zasady jego wypłacania określone są przez agencję pracy tymczasowej. Jest ona zainteresowana uzyskaniem informacji o szczegółowych zasadach ustalania wysokości wynagrodzenia za pracę tego samego rodzaju, obowiązujących u pracodawcy użytkownika. Związane jest to $\mathrm{z}$ wyrażonym w art. 15 u.z.p.t. zakazem dyskryminacji pracowników tymczasowych w zakresie warunków pracy i innych warunków zatrudnienia w stosunku do pracowników pracodawcy użytkownika zatrudnionych na takim samym lub podobnym stanowisku ${ }^{96}$. Wskazana nietypowość ustalania wysokości wynagrodzenia, wynikająca $\mathrm{z}$ charakteru zatrudnienia tymczasowego, nie wpływa na uprawnienia pracownika w zakresie jego otrzymywania. Podmiotem zobowiązanym do wyliczenia i wypłaty wynagrodzenia pozostaje bowiem pracodawca, czyli agencja pracy tymczasowej.

Zastrzeżenie odpłatności pracy jest konieczne do istnienia wszystkich umownych stosunków zatrudnienia nietypowego $\mathrm{z}$ wyjątkiem stosunku prawnego powstającego w wyniku zawarcia umowy zlecenia ${ }^{97}$. Ustawodawca w art. 735 k.c. dopuszcza ustalenie na podstawie umowy bądź okoliczności, że zlecenie wykonywane jest bez wynagrodzenia. Wtedy nie znajdą zastosowania przepisy dotyczące konieczności ustalania wynagrodzenia w wysokości minimalnej stawki godzinowej. Brak określenia wysokości wynagrodzenia w umowie o dzieło nie powoduje zawarcia tej umowy pod tytułem darmym. W takiej sytuacji zastosowanie znajduje bowiem art. 628 k.c., zgodnie z którym przyjmującemu zamówienie należy się zwykłe wynagrodzenie za dzieło danego rodzaju. W przypadku gdy określenie takiego wynagrodzenia również nie jest możliwe, ustala się je w odniesieniu do nakładu pracy i innych nakładów przyjmującego zamówienie ${ }^{98}$. Podobną regula-

96 M. Paluszkiewicz, Treść stosunku prawnego, [w:] M. Paluszkiewicz, Zatrudnienie tymczasowe w polskim prawie pracy, https://sip-1lex-1pl-1004153yx0674.han3.lib.uni.lodz.pl/\#/monografia/369234447/26 (dostęp: 19.09.2017).

97 Ł. Pisarczyk, Różne formy..., s. 22.

98 Tamże, s. 101. 
cję ustalania wysokości wynagrodzenia należnego agentowi zawiera art. $758^{1}$ k.c. Ustawodawca dostrzega konieczność warunkowania świadczonej pracy od uzyskiwanego wynagrodzenia ( $\mathrm{z}$ wyjątkiem przypadków umownego zastrzeżenia nieodpłatności zlecenia).

$\mathrm{Z}$ punktu widzenia omawianej tematyki istotne znaczenie ma również zróżnicowanie ochrony wynagrodzenia poszczególnych grup osób zatrudnionych. Ochronę wynagrodzenia rozpatrywać można z kilku perspektyw. Po pierwsze jako ochronę polegającą na ograniczeniu dokonywania potrąceń $z$ wynagrodzenia. Po drugie jako ochronę wynikającą z przepisów regulujących sposób i tryb wypłaty wynagrodzenia oraz ograniczających prawo do dysponowania nim. Po trzecie jako zachowanie prawa do wynagrodzenia pomimo nieświadczenia pracy. I wreszcie po czwarte jako grupę norm służących ochronie gwarancji wypłaty wynagrodzenia pomimo utraty płynności finansowej przez podmiot zatrudniający ${ }^{99}$.

Zakaz zrzeczenia się prawa do wynagrodzenia oraz brak możliwości przeniesienia prawa do wynagrodzenia na osobę trzecią są wyrazem ochrony wynagrodzenia w zakresie ograniczenia prawa do dysponowania nim. W przypadku umowy o pracę wyłączenie możliwości zrzeczenia się prawa do wynagrodzenia i przeniesienia go na inną osobę reguluje art. 84 k.p. Na podstawie $\$ 12$ ust. 4 rozp. pr. nakład. znajduje on zastosowanie również do tej podstawy świadczenia pracy $^{100}$. Gdy umowa zlecenia jest umową odpłatną i spełnione są przesłanki wypłaty wynagrodzenia na poziomie co najmniej minimalnej stawki godzinowej, przyjmujący zlecenie lub świadczący usługi nie może zrzec się prawa do takiego wynagrodzenia ani przenieść go na inną osobę (art. 8a ust 4 ustawy o minimalnym wynagrodzeniu za pracę). Odpłatność jest cechą umów o dzieło i umów agencyjnych, co nie wyłącza możliwości zrzeczenia się prawa do zastrzeżonego w umowie wynagrodzenia. W stosunkach cywilnoprawnych, które nie są objęte obowiązkiem wypłaty wynagrodzenia na poziomie wynagrodzenia w wysokości minimalnej stawki godzinowej, dopuszczalne jest przeniesienie wierzytelności na osobę trzecią, zatem dysponowanie prawem do wynagrodzenia jest nieograniczone. W takiej sytuacji zastosowanie znajduje art. 393 k.c. Przepis art. 8a ust 4 ustawy o minimalnym wynagrodzeniu za pracę, stanowiący,

99 Podobną klasyfikację przedstawia Z. Salwa. Nie wymienia jednak czwartej płaszczyzny ochrony, która nie istniała w ówczesnym stanie prawnym. Z. Salwa, Prawo pracy w PRL, Warszawa 1989, s. 237. J. Skoczyński w odniesieniu do treści rozdz. 2 kodeksu pracy wymienia cztery płaszczyzny ochrony wynagrodzenia tam przewidziane: zakaz zrzeczenia się przez pracownika prawa do wynagrodzenia i przeniesienia go na inną osobę; ograniczenie dopuszczalności umówienia wynagrodzenia w innej formie niż pieniężna; określenie czasu, miejsca i formy wypłaty wynagrodzenia; określenie granic dopuszczalności dokonywania potrąceń z wynagrodzenia. J. Skoczyński, Ochrona wynagrodzenia za pracę, „Praca i Zabezpieczenie Społeczne" 1997, nr 3, s. 17.

100 F. Małysz, Wybrane uprawnienia pracownicze osób wykonujących pracę nakładcza, „Polityka Społeczna" 2001, nr 8, s. 6. 
że przyjmujący zlecenie lub świadczący usługi nie może przenieść na inną osobę prawa do tego wynagrodzenia, określanego według minimalnej stawki godzinowej, ogranicza w sposób aksjologicznie nieuzasadniony swobodę dysponowania wynagrodzeniem przez osoby zatrudnione na podstawie umów zlecenia i umów o świadczenie usług.

Ograniczenie dokonywania potrąceń $\mathrm{z}$ wynagrodzenia za pracę, uważane za najważniejszy z mechanizmów chroniących wynagrodzenie pracownicze ${ }^{101}$, uregulowane zostało w kodeksie pracy poprzez wprowadzenie zamkniętego katalogu zobowiązań, które mogą być potrącane $\mathrm{z}$ wynagrodzenia za pracę oraz poprzez określenie maksymalnej procentowej wysokości potrąceń z wynagrodzenia wraz z określonym kwotowo progiem minimalnym kwoty wolnej od potrąceń. Doprecyzowanie przepisów prawa materialnego dotyczących ograniczenia potrąceń $\mathrm{z}$ wynagrodzenia zawiera kodeks postępowania cywilnego. Użyty w kodeksie pracy termin „potrącenie” nie dotyczy jedynie wierzytelności wzajemnych pracodawcy, lecz także innych należności ${ }^{102}$. Ochrona wynagrodzenia pracowniczego przed nadmiernym jego uszczupleniem na zaspokojenie różnych zobowiązań wynika z jego alimentarnej funkcji, zapewniającej dbałość o dobra samego pracownika, jak i jego rodziny. Zamknięty katalog zobowiązań, które mogą być potrącane $\mathrm{z}$ wynagrodzenia za pracę, wskazany został $\mathrm{w}$ art. 87 k.p. Po pierwsze wymienione zostały sumy egzekwowane na mocy tytułów wykonawczych na zaspokojenie świadczeń alimentacyjnych oraz na pokrycie innych należności ${ }^{103}$. W drugiej kolejności wskazano źródła potrąceń związane bezpośrednio ze stosunkiem pracy - zaliczki pieniężne udzielone pracownikowi ${ }^{104}$ oraz kary pieniężne. Inne potrącenia niż wymienione w art. 87 k.p. mogą być dokonane jedynie za zgodą pracownika wyrażoną na piśmie (art. 91 k.p.).

Maksymalne kwoty potrącenia uzależnione zostały od tego, jakich wierzytelności ono dotyczy. Zgodnie z regulacją art. $87 \$ 3$ k.p. przy egzekucji świadczeń alimentacyjnych potrącenia można dokonać do wysokości 3/5 wynagrodzenia. W razie egzekucji innych należności lub potrącania zaliczek pieniężnych kwotą wolną od potrąceń jest połowa wynagrodzenia. Jak już wspomniano, ustawodawca wprowadził dodatkowo minimalną kwotę wolną od potrąceń (art. 871 i $91 \$ 2$ k.p.). Pominięcie szczegółowej analizy tej materii wydaje się uzasadnione nadrzędnym celem, jakim jest przedstawienie głównych kierunków regulacji

101 M. Soćko, The Deduction from Remuneration for Work in the Polish Labour Code as One of Elements Remuneration-Protection System, „Praca i Zabezpieczenie Społeczne” 2014, nr 8, s. 19.

102 W. Szubert, Zarys prawa pracy..., s. 259. W. Jaśkiewicz, C. Jackowiak, W. Piotrowski, Prawo pracy w zarysie, Poznań-Gdańsk-Warszawa 1984, s. 345.

103 Nie wyłącza to sytuacji, w której wierzycielem egzekwowanej na mocy tytułu wykonawczego należności jest pracodawca. A. Matusiak-Wojnicz, P. Wojnicz, Egzekucyjne i nieegzekucyjne potracenia z wynagrodzeń, Wrocław 2012, s. 103.

104 Do zaliczek takich należy np. zaliczka na delegację. Ibidem, s. 32. 
prawnych kreujących sytuację prawną osób świadczących pracę w ramach umownego zatrudnienia nietypowego. Najistotniejsze wydaje się natomiast podkreślenie, że kodeks pracy, jako jedyne źródło prawa związanego z zatrudnieniem, zapewnia tak daleko idącą ochronę wynagrodzenia przed uszczupleniem jego wysokości poprzez dokonywanie potrąceń. Rozporządzenie dotyczące pracy nakładczej $\mathrm{w} \$ 12$ ust. 4 rozszerza przyznaną pracownikom ochronę przed potrąceniami na wykonawców pracy nakładczej ${ }^{105}$. Regulacja kodeksu pracy nie znajduje jednak zastosowania do umownego zatrudnienia cywilnoprawnego uregulowanego w kodeksie cywilnym ${ }^{106}$ (do umowy zlecenia i umów o świadczenie usług, do których stosuje się przepisy o zleceniu, umowy agencyjnej i umowy o dzieło). W związku z powyższym należałoby przyjąć, że art. $881 \$ 2$ i 3 k.p.c., znajdujący się w dziale zatytułowanym „Egzekucja $\mathrm{z}$ wynagrodzenia za pracę", który stanowi o możliwości prowadzenia egzekucji z wynagrodzenia "poza częścią wolną od potrąceń”, dotyczy wynagrodzenia należnego z tytułu umowy o pracę albo umowy o pracę nakładczą, a nie wynagrodzenia $\mathrm{z}$ tytułu wykonania umowy zlecenia, umowy agencyjnej i umowy o dzieło. Wniosek taki wynika $\mathrm{z}$ faktu, że regulacje obejmujące swoim zakresem umowę o pracę i umowę o pracę nakładczą są jedynymi, które ustanawiają ochronę przed egzekucją z całości wynagrodzenia za pracę. Analizując materię ochrony wynagrodzenia przed potrąceniami, istotne wydaje się jednak przedstawienie także regulacji art. 829 pkt 5 k.p.c., która pomimo znajdowania się w akcie prawnym dotyczącym procedury, w zakresie ograniczenia egzekucji zawiera normę o charakterze materialnoprawnym ${ }^{107}$. Przepis art. 829 pkt 5 k.p.c. dotyczy ograniczenia egzekucji z wynagrodzenia i obejmuje swoją regulacją kilka stanów faktycznych. Wskazana norma znajduje zastosowanie, kiedy dłużnik równolegle świadczy pracę na podstawie umowy o pracę albo umowy o pracę nakładczą i innej umowy prawa cywilnego. W takim stanie faktycznym należności ze stosunku pracy sumują się z należnościami z umowy cywilnoprawnej ${ }^{108} \mathrm{i}$ na tej podstawie, zgodnie z art. 835 k.p.c., oblicza się kwotę wolną od potrąceń. Po drugie art. 829 pkt 5 k.p.c. dotyczy sytuacji świadczenia przez dłużnika stałej pracy na podstawie umowy prawa cywilnego uregulowanej w kodeksie cywilnym, w wyniku zawarcia której otrzymuje on periodyczne wynagrodzenie. Wydaje się, że w takim przypadku zastosowanie znajdują również ograniczenia

105 M. Gersdorf, Prawo zatrudnienia..., s. 114.

106 A. Matusiak-Wojnicz, P. Wojnicz, op. cit., s. 164.

107 Zgodnie z tym przepisem nie podlegają egzekucji u dłużnika pobierającego periodyczną stałą płacę pieniądze w kwocie, która odpowiada niepodlegającej egzekucji części płacy za czas do najbliższego terminu wypłaty, a u dłużnika nieotrzymującego stałej płacy, pieniądze niezbędne dla niego i jego rodziny na utrzymanie przez dwa tygodnie.

108 H. Ciepła, Art. 829, [w:] H. Dolecki, T. Wiśniewski (red.), Kodeks postępowania cywilnego. Komentarz, t. 4. art. 730-1088, https://sip-1lex-1pl-1004153yx0674.han3.lib.uni.lodz.pl/\#/ komentarz/587310133/171035 (dostęp: 19.09.2017). 
egzekucji wynikające z kodeksu pracy ${ }^{109}$. Przepis art. $833 \$ 2$ k.p.c. in fine stanowi bowiem, że ograniczenie egzekucji przewidziane w przepisach kodeksu pracy stosuje się odpowiednio do wszystkich świadczeń powtarzających się, których celem jest zapewnienie utrzymania ${ }^{110}$. Ostatni stan faktyczny obejmuje swoją regulacją osoby zatrudnione na podstawie umowy prawa cywilnego, którym wynagrodzenie wypłacane jest jednorazowo. Wtedy kwotą wolną od potrąceń jest kwota dająca dłużnikowi i jego rodzinie możliwość utrzymania przez dwa tygodnie (art. 829 pkt 5 k.p.c. in fine) $)^{111}$.

Omówione regulacje nie zrównują sytuacji prawnej wszystkich osób świadczących pracę $\mathrm{w}$ ramach umownego zatrudnienia nietypowego $\mathrm{w}$ odniesieniu do ochrony wynagrodzenia przed potrąceniami, jednak w pewnym zakresie tę ochronę ujednolicają. Przepisy kodeksu postępowania cywilnego obejmują ochroną wynagrodzenie wszystkich osób świadczących pracę $\mathrm{w}$ ramach umownego zatrudnienia nietypowego. W odniesieniu do zatrudnienia pracowniczego kodeks postępowania cywilnego odsyła do reguł dotyczących potrąceń ustanowionych kodeksem pracy. Poprzez odesłanie w $\$ 12$ ust. 4 rozp. pr. nakład. reguły te znajdują odpowiednie zastosowanie do pracy nakładczej. Jeśli uregulowana w kodeksie cywilnym umowna podstawa zatrudnienia stanowi dla osoby świadczącej pracę źródło utrzymania, a wynagrodzenie wypłacane jest periodycznie, ochrona właściwa dla wynagrodzenia wypłacanego $\mathrm{z}$ tytułu świadczenia pracy $\mathrm{w}$ ramach stosunku pracy również znajduje zastosowanie w zakresie możliwości dokonywania potrąceń.

Status prawny osób świadczących pracę w ramach umownego zatrudnienia nietypowego w zakresie możliwości dokonywania potrąceń z wynagrodzenia za pracę jest zatem taki sam w odniesieniu do pracowników, wykonawców pracy nakładczej i osób świadczących pracę w ramach umowy zlecenia, umowy o świadczenie usług, do których stosuje się przepisy o zleceniu, umowy agencyjnej i umowy o dzieło, jeśli otrzymywane wynagrodzenie wypłacane jest periodycznie i stanowi dla osoby zatrudnionej źródło utrzymania. W tym kontekście inaczej uregulowana jest sytuacja prawna osób świadczących pracę w ramach umownego zatrudnienia cywilnoprawnego (umowy zlecenia, umowy o świadczenie usług, do której stosuje się przepisy o zleceniu, umowy agencyjnej i umowy o dzieło), jeśli wynagrodzenie nie jest otrzymywane periodycznie.

109 A. Matusiak-Wojnicz, P. Wojnicz, op. cit., s. 165. Potwierdzenie tego stanowiska zostało dokonane uchwałą siedmiu sędziów Sądu Najwyższego z dnia 17 grudnia 1981 r., III CZP 32/81, LEX nr 2746. Zgodnie z nią kwoty pobrane z tytułów wymienionych w art. $833 \S 2$ k.p.c. podlegają egzekucji z ograniczeniem wynikającym z odpowiedniego zastosowania art. 829 pkt 5 k.p.c.

110 Wskazać należy na niedookreśloność tego przepisu. Pojęcie utrzymania jest bowiem bardzo szerokie i subiektywne.

111 Regulację tę uznać należy za wielce niedoskonałą. Obiektywne określenie kwoty niezbędnej na dwutygodniowe utrzymanie jest niemożliwe. Dodatkowo, z uwagi na terminy płatności różnych zobowiązań, w poszczególnych okresach kwoty te mogą być różne. 
Uzasadnieniem takiego zróżnicowania jest fakt dostrzegania przez ustawodawcę konieczności ochrony przed potrąceniami wynagrodzenia, które służy utrzymaniu osoby świadczącej pracę. Warunku tego nie spełnia jedynie wynagrodzenie niewypłacane periodycznie.

Sposób i tryb wypłaty wynagrodzenia szczegółowo uregulowane zostały w kodeksie pracy. Przepisy kodeksu pracy mają na celu zapewnienie, że wynagrodzenie trafi do pracownika w określonym czasie i w określony sposób ${ }^{112}$. Regulacje dotyczące ochrony wynagrodzenia na tej płaszczyźnie mają zatem zastosowanie do wszystkich pracowniczych podstaw zatrudnienia. Spośród przepisów chroniących sposób i tryb wypłaty wynagrodzenia należy wskazać art. 85 k.p., regulujący termin wypłaty wynagrodzenia, oraz art. 86 k.p., dotyczący formy i sposobu wypłaty wynagrodzenia ${ }^{113}$. Zgodnie z $\$ 12$ ust. 4 rozp. pr. nakład., regulacja ta obejmuje również chałupników ${ }^{114}$. W stosunku do pozostałych osób zatrudnionych $w$ ramach zatrudnienia cywilnoprawnego (na podstawie umowy zlecenia, umowy o świadczenie usług, do której stosuje się przepisy o zleceniu, umowy agencyjnej i umowy o dzieło) przepisy kodeksu cywilnego nie regulują tej materii w sposób odrębny od ogólnych unormowań kodeksu cywilnego ${ }^{115}$. Wyjątkiem jest obowiązek wypłaty wynagrodzenia $\mathrm{w}$ formie pieniężnej $\mathrm{w}$ przypadku umów zlecenia i umów o świadczenie usług, które objęte są obowiązkiem wypłaty wynagrodzenia w wysokości co najmniej minimalnej stawki godzinowej (art. 8 a ust. 5 ustawy o minimalnym wynagrodzeniu za pracę). Wprowadzenie takiego ograniczenia w odniesieniu do formy wypłaty wynagrodzenia nie ma uzasadnienia w systemowym wyodrębnieniu cywilnoprawnych podstaw świadczenia pracy.

W relacjach prawnopracowniczych termin wypłaty wynagrodzenia został przez ustawodawcę szczegółowo określony w art. 85 k.p. Powinien on przypadać co najmniej raz w miesiącu, w stałym i z góry wyznaczonym terminie (art. $85 \$ 1$ k.p.). Wynagrodzenie płatne w cyklach miesięcznych wypłaca się z dołu, nie później niż 10 dnia następnego miesiąca kalendarzowego (art. $85 \$ 2$ k.p.). Jeśli dzień ustalony jako termin wypłaty wynagrodzenia jest wolny od pracy, wynagrodzenie powinno zostać wypłacone wcześniej (art. $85 \$ 3$ k.p.). Powyższe unormowania nie obowiązują w odniesieniu do umów prawa cywilnego, poza umową o pracę nakładczą ( $\$ 12$ ust. 4 rozp. pr. nakład.). Ustawodawca daje stronom umowy o dzieło swobodę wyboru terminu płatności. Jeśli strony nie postanowią inaczej, płatność jest należna w chwili oddania dzieła (art. 642 k.c.). W kodeksie cywilnym tak samo

112 Ostatnią zasadę wypłaty wynagrodzenia ustanawia art. $86 \S 3$ k.p. M. Soćko, op. cit, s. 15.

113 Formę i sposób wypłaty wynagrodzenia do przejawów jego ochrony zaliczali m.in.: W. Szubert, Zarys prawa pracy..., s. 259; W. Jaśkiewicz, C. Jackowiak, W. Piotrowski, op. cit., s. 343344; J. Wratny, Wynagrodzenie za pracę, [w:] R. Korolec, J. Pacho (red.), Nowe prawo pracy, s. 285-288.

114 M. Gersdorf, Prawo zatrudnienia..., s. 114.

115 W szczególności zastosowanie znajduje art. 454 k.c. dotyczący miejsca spełnienia świadczenia. 
uregulowana została kwestia odpłatności za zlecenie (art. 744 k.c.). Wyjątkiem w tym zakresie są umowy zlecenia i umowy o świadczenie usług, które w zakresie ustalania minimalnej stawki godzinowej objęte są regulacją ustawy o minimalnym wynagrodzeniu za pracę. Przepis art. 8 a ust. 6 ww. ustawy stanowi, że w przypadku umów zawartych na czas dłuższy niż 1 miesiąc wypłaty wynagrodzenia w wysokości wynikającej z wysokości minimalnej stawki godzinowej dokonuje się co najmniej raz w miesiącu. W zakresie zasadności takiej regulacji, stanowiącej powielenie uregulowań kodeksu pracy, w pełni podzielam stanowisko Krzysztofa Walczaka o jej niewspółmiernym do celu, nadmiernie ingerencyjnym w stosunki cywilnoprawne charakterze ${ }^{116}$.

Regulację prawa do wynagrodzenia prowizyjnego agenta zawiera art. $761^{3} \mathrm{k}$.c. Zgodnie z zasadą wyrażoną w art. $761^{3} \$ 1$ zd. 1 k.c. agent nabywa prawo do prowizji z chwilą zaistnienia jednej z alternatywnie wskazanych sytuacji: nadejścia terminu spełnienia świadczenia przez dającego zlecenie na rzecz klienta, faktycznego spełnienia na rzecz klienta świadczenia przez dającego zlecenie albo faktycznego spełnienia świadczenia przez klienta ${ }^{117}$. Dotyczy to przy tym tylko tych przypadków, gdy świadczenia zostały wykonane w całości, zgodnie z umową. Decydujące jest, które z tych zdarzeń nastąpiło wcześniej ${ }^{118}$. Swoboda stron w zakresie nabywania przez agenta prawa do prowizji ma charakter semiimperetywny - ogranicza się do unormowania tej kwestii w sposób bardziej korzystny dla agenta (art. $761^{3} \$ 3$ k.c. in fine). Roszczenie o zapłatę prowizji staje się natomiast wymagalne $\mathrm{z}$ upływem ostatniego dnia miesiąca następującego po kwartale, w którym agent nabył prawo do prowizji (art. $761^{3} \$ 3 \mathrm{zd}$. 1 k.c.). Również ta norma ma charakter semiimperatywny - strony mogą w umowie zastrzec unormowanie korzystniejsze dla agenta. W tym zakresie osoby świadczące pracę na podstawie umów prawa cywilnego (zlecenia, umowy o świadczenie usług, do której stosuje się przepisy o zleceniu, umowy agencyjnej i umowy o dzieło) nie mają, tak jak pracownik czy wykonawca pracy nakładczej, prawnie zagwarantowanej periodyczności wypłaty wynagrodzenia, która ma istotne znaczenie $\mathrm{z}$ punktu widzenia możliwości utrzymania.

Zachowanie prawa do wynagrodzenia pomimo nieświadczenia pracy przez pracownika jest przejawem ryzyka socjalnego i ryzyka technicznego, które ponosi pracodawca. W obrębie omawianych zagadnień ryzyko socjalne związane jest z sytuacjami, w których pracodawca dostarcza pracownikowi pracę, jednak ten z przyczyn leżących po jego stronie jej nie świadczy ${ }^{119}$. Natomiast ryzyko techniczne na płaszczyźnie ochrony wynagrodzenia dotyczy sytuacji odwrotnej - pracownik jest gotowy do świadczenia pracy, jednak z przyczyn leżących po stronie

116 K. Walczak, Wynagrodzenie minimalne..., s. 455.

117 Regulacja ta odpowiada art. 10 ust. 1 dyrektywy agencyjnej.

118 K. Kopaczyńska-Pieczniak, Art. 76133, [w:] A. Kidyba (red.), Kodeks cywilny. Komentarz, t. 3: Zobowiq̨zania - część szczególna, https://sip-1lex-1pl-1004153yx0cd3.han3.lib.uni.lodz. pl/\#/komentarz/587286652/462845 (dostęp: 17.09.2017).

119 P. Prusinowski, op. cit., s. 81-82. 
pracodawcy świadczyć jej nie może ${ }^{120}$. Ryzyko socjalne obejmuje m.in. prawo pracownika do wynagrodzenia pomimo czasowej niezdolności do pracy z powodu choroby, uregulowane w art. 92 k.p. W danym roku kalendarzowym przez pierwsze 33 dni niezdolności do pracy powstałej wskutek choroby (w odniesieniu do pracowników, którzy ukończyli 50 lat - 14 dni) pracownik zachowuje prawo do $80 \%$ wynagrodzenia (art. $92 \$ 1$ pkt 1 k.p.). Wynagrodzenie to wypłaca pracownikowi pracodawca. W związku z istnieniem takiego obowiązku pracodawca przybiera rolę podmiotu zabezpieczenia społecznego ${ }^{121}$, ponieważ świadczenie na rzecz pracownika nie ma charakteru wzajemnego ${ }^{122}$. Pracownik zachowuje prawo do $100 \%$ wynagrodzenia w przypadku nieświadczenia pracy wskutek wypadku w drodze do pracy lub z pracy albo choroby w czasie ciąży oraz w przypadku nieświadczenia pracy ze względu na poddanie się badaniom lekarskim związanym z transplantacją tkanek i narządów (art. $92 \$ 1$ pkt 2 i 3 k.p.).

Wykonawcom pracy nakładczej na podstawie $\$ 12$ ust. 5 rozp. pr. nakład. przysługują wszystkie uprawnienia wskazane w art. 92 k.p., w tym te omówione powyżej. Wyłącznie pracowników dotyczy natomiast zachowanie prawa do wynagrodzenia za okres poszukiwania pracy (art. 37 k.p.) czy z tytułu zaistnienia okoliczności rodzinnych bądź konieczności wypełnienia obowiązków pozapracowniczych (zgodnie z regulacją wydanego na podstawie art. $298^{2}$ k.p. rozporządzenia Ministra Pracy i Polityki Społecznej w sprawie sposobu usprawiedliwiania nieobecności w pracy oraz udzielania pracownikom zwolnien od pracy ${ }^{123}$ ). Pozostałe umowy prawa cywilnego (umowy zlecenia, umowy o świadczenie usług, do których stosuje się przepisy o zleceniu, umowy agencyjne i umowy o dzieło) nie zostały objęte ustawowym uprawnieniem osób świadczących pracę do zachowania prawa do wynagrodzenia pomimo nieświadczenia pracy. Związane jest to $\mathrm{z}$ istotą tych podstaw świadczenia pracy, w których ryzyko socjalne w omawianym zakresie spoczywa na podmiocie świadczącym pracę, a nie na podmiocie zatrudniającym.

Przestój, jako przejaw ryzyka technicznego, obejmuje swoim zakresem skutki zdarzeń leżących po stronie pracodawcy. Jeżeli pracownik był gotowy do wykonywania pracy, ale doznał przeszkód z przyczyn dotyczących pracodawcy, przysługuje mu wynagrodzenie w przypadku gdy przestój nie jest przez niego zawiniony (art. $81 \$ 1$ i 2 k.p.). Wynagrodzenie za czas przestoju obliczane jest zgodnie z wytycznymi zawartymi w art. 81 k.p. i przysługuje wszystkim pracownikom. Praca świadczona $\mathrm{w}$ formie organizacyjnej telepracy podlega regulacjom art. 81 k.p.

120 Ł. Pisarczyk, Konstrukcja i zakres ryzyka pracodawcy, „Praca i Zabezpieczenie Społeczne” 2003, nr 12, s. 5-6.

121 J. Wratny, Problemy regulacji wynagrodzenia za pracę de lege ferenda, „Praca i Zabezpieczenie Społeczne" 2013, nr 10, s. 5.

122 A. Sobczyk, Prawo pracy w świetle Konstytucji, t. 2..., s. 173.

123 Rozporządzenie Ministra Pracy i Polityki Socjalnej z dnia 15 maja 1996 r. w sprawie sposobu usprawiedliwiania nieobecności w pracy oraz udzielania pracownikom zwolnień od pracy, Dz.U. z 2014 r., poz. 1632 - t.j. 
Oznacza to, że telepracownik otrzymuje wynagrodzenie w przypadku gdy jest gotowy do wykonywania pracy, a doznał przeszkód z przyczyn dotyczących pracodawcy. Z uwagi na charakter świadczonej pracy w formie organizacyjnej telepracy warto wskazać wątpliwości związane z możliwością zakwalifikowania danego stanu faktycznego jako przestoju. Bez wątpienia przestojem będzie sytuacja, gdy pracownik typowy nie będzie mógł świadczyć pracy np. z powodu awarii sieci elektrycznej. W przypadku telepracy należałoby uznać, że awaria sieci elektrycznej czy też przerwa w dostawie Internetu są przestojem polegającym na zaburzeniu w funkcjonowaniu miejsca, w którym świadczona jest praca ${ }^{124}$. Pomimo że praca wykonywana jest poza zakładem pracy, ryzyko techniczne w dalszym ciągu obciąża pracodawcę.

Trójpodmiotowość zatrudnienia tymczasowego wymusza dookreślenie, kogo (agencję pracy tymczasowej czy pracodawcę użytkownika) dotyczyć mają okoliczności związane z przestojem, aby móc uznać jego zaistnienie. Wydaje się, że w przypadku skierowania pracownika tymczasowego do pracodawcy użytkownika niedostarczenie pracy przez pracodawcę użytkownika uprawnia do otrzymania wynagrodzenia za przestój, którego koszt obciąża pracodawcę użytkownika ${ }^{125}$. W relacji, jaką kreuje praca tymczasowa, obowiązek dostarczenia pracy ciąży na pracodawcy użytkowniku jako podmiocie, który ma pracę organizować (art. 14 ust. 1 z.p.t.). Niedostarczenie pracy wyłącza możliwość jej dalszej organizacji. W przypadku trwania stosunku pracy pomiędzy pracownikiem tymczasowym a agencją, w razie nieskierowania do pracodawcy użytkownika, przyczyny dotyczące przestoju leżą po stronie agencji. Nie można jednak w tym przypadku stwierdzić, że pracownik tymczasowy był gotowy do świadczenia pracy. Gotowość dotyczy bowiem relacji pracownik tymczasowy - pracodawca użytkownik ${ }^{126}$, a nie relacji pracownik tymczasowy - agencja pracy tymczasowej. Pracownik tymczasowy nie świadczy bowiem pracy na rzecz agencji, a na rzecz pracodawcy użytkownika. Niedostarczenie pracy przez agencję pracy tymczasowej nie uprawnia pracownika tymczasowego do wynagrodzenia przestojowego.

Spośród umów cywilnoprawnych, których przedmiotem może być świadczenie pracy, regulację o zbliżonym charakterze do omówionych, właściwych prawu

124 A. Sobczyk, Telepraca w prawie polskim..., s. 187.

125 Ł. Pisarczyk podnosi, że w przypadku wypłacania przez pracodawcę użytkownika stałego wynagrodzenia na rzecz agencji pracy tymczasowej, ryzyko z tytułu przestoju jest dla pracodawcy użytkownika największe. Ł. Pisarczyk, Praca tymczasowa a ryzyko pracodawcy, [w:] A. Sobczyk (red.), Z problematyki zatrudnienia tymczasowego, https://sip-1lex-1pl-1004153yx0674.han3.lib.uni.lodz.pl/\#/monografia/369236017/25 (dostęp: 19.09.2017).

126 Analogiczna sytuacja występuje w przypadku gdy pracodawca użytkownik rezygnuje z pracy pracownika tymczasowego. Również wtedy pracownik tymczasowy nie może pozostawać w gotowości do pracy względem agencji pracy tymczasowej. Por. A. Sobczyk, Art. 18, [w:] A. Sobczyk, Ustawa o zatrudnianiu pracowników tymczasowych, https://sip-1lex-1pl-1004153yx0674.han3.lib.uni.lodz.pl/\#/komentarz/587241507/38947 (dostęp: 19.09.2017). 
pracy, określa jedynie rozporządzenie w sprawie uprawnień pracowniczych osób wykonujących pracę nakładczą. W $\$ 11$ ust. 1 rozp. pr. nakład. ustanawia obowiązek nakładcy zapewnienia wykonawcy materiałów oraz sprzętu niezbędnego do wykonania pracy nakładczej. Jeśli strony umowy o pracę nakładczą nie wyłączą tego obowiązku i niewypełnienie go przez nakładcę spowoduje brak możliwości wykonania miesięcznej ilości pracy określonej w umowie, zgodnie z $\$ 11$ ust. 2 rozp. pr. nakład. wykonawcy przysługuje wynagrodzenie obliczane jak wynagrodzenie za urlop, którego wartość nie może jednak przekraczać wartości najniższego $^{127}$ wynagrodzenia ${ }^{128}$. W odniesieniu do podstaw umownego zatrudnienia cywilnoprawnego uregulowanych w kodeksie cywilnym (umowy zlecenia, umowy o świadczenie usług, do której stosuje się przepisy o zleceniu, umowy agencyjnej i umowy o dzieło) ryzyko związane z brakiem możliwości świadczenia pracy leży po stronie osoby świadczącej pracę. W związku z tym podmiot zatrudniający, o ile nic odmiennego nie wynika $z$ umowy, nie jest zobowiązany do wypłaty wynagrodzenia w przypadku samej tylko gotowości do świadczenia pracy.

Ostatnim elementem ochrony wynagrodzenia należnego $\mathrm{z}$ tytułu pracy świadczonej w ramach umownego zatrudnienia nietypowego jest ochrona gwarantująca wypłatę wynagrodzenia pomimo utraty płynności finansowej przez podmiot zatrudniający. Zgodnie z art. 10 ustawy z dnia 13 lipca 2006 r. o ochronie roszczeń pracowniczych w razie niewypłacalności pracodawcy ${ }^{129}$ pracownikiem objętym zasięgiem tej ustawy jest zarówno pracownik w rozumieniu kodeksu pracy, jak również wykonawca umowy o pracę nakładczą, agent oraz wykonawca zlecenia. Spośród wszystkich osób świadczących pracę w ramach umownego zatrudnienia nietypowego jedynie wykonawcy dzieła nie zostali objęci ustawą gwarantującą choćby częściowe zaspokojenie ich roszczeń w razie powstania stanu niewypłacalności podmiotu zatrudniającego. Wydaje się, że uzasadnieniem takiego stanu prawnego jest założenie o względnej trwałości pozostałych umownych stosunków zatrudnienia. Wynagrodzenie należne z tytułu ich wykonywania, stanowiące stałe źródło utrzymania osób świadczących pracę, musi być chronione w sposób wzmożony.

W przypadku zatrudnienia tymczasowego powstanie okoliczności w postaci stanu niewypłacalności pracodawcy użytkownika nie stanowi okoliczności umożliwiającej wypłatę wynagrodzenia z Funduszu Gwarantowanych Świadczeń Pracowniczych. Dopiero stan niewypłacalności agencji pracy tymczasowej daje pracownikom tymczasowym takie uprawnienie. Ryzyko niewypłacalności pracodawcy użytkownika ponosi agencja pracy tymczasowej, która jest zobowiązana do wypłaty wynagrodzenia pracownikom tymczasowym, zgodnie $\mathrm{z}$ art. 13 ust. 1 pkt 2 z.p.t. W tym zakresie status prawny pracowników tymczasowych nie jest od-

127 Por. uwagi dotyczące określania dolnego progu wynagrodzenia wykonawcy pracy nakładczej, s. 151.

128 Ł. Pisarczyk, Różne formy..., s. 121.

129 Dz.U. z 2016 r. poz. 1256 - t.j. 
mienny od typowego, bowiem ponoszą oni ryzyko niewypłacalności pracodawcy w rozumieniu art. 3 k.p.

W ramach ochrony wynagrodzenia w sposób szczególny ukształtowana została sytuacja prawna agenta. Może on zabezpieczyć swoje roszczenia względem dającego zlecenie poprzez skorzystanie z dyspozycji art. 763 k.c. Na podstawie tego przepisu agentowi przysługuje ustawowe prawo zastawu na rzeczach i papierach wartościowych dającego zlecenie.

W poglądach mających obecnie znaczenie historyczne szerokie uprawnienia pracowników związane z ochroną wynagrodzenia motywowano jego przeznaczeniem i funkcją społeczną. Wskazywano, że wynagrodzenie za pracę świadczoną w ramach stosunku pracy, w przeciwieństwie do wynagrodzenia za pracę wykonywaną na podstawie umów prawa cywilnego, jest z reguły jedynym źródłem utrzymania, służąc zaspokojeniu potrzeb pracownika i jego rodziny ${ }^{130}$. Poglądowi temu należy przyznać słuszność w odniesieniu do prawidłowości jego założenia (konieczności ochrony wynagrodzenia pracowniczego), jednak trafność jego uzasadnienia (wskazywanie wynagrodzenia jako jedynego źródła utrzymania) nie wydaje się wyczerpująco określona. Przede wszystkim trzeba bowiem zwrócić uwagę, że ochrona wynagrodzenia za pracę jest częścią składową nadrzędnej funkcji prawa pracy - funkcji ochronnej. Nie jest przy tym istotne, czy wynagrodzenie ze stosunku pracy jest dla pracownika jedynym czy głównym źródłem utrzymania. Słusznie przyjmuje się, że w stosunkach prawnopracowniczych pracownik jest stroną słabszą, stąd przyznanie jego wynagrodzeniu szerokiej ochrony wydaje się w pełni uzasadnione i racjonalne. Z kolei cechujące się formalną równością stron stosunki prawa cywilnego nie mogłyby faworyzować osoby świadczącej pracę poprzez nadmierną ochronę jej roszczeń. Wyjątek szerokiej ochrony wynagrodzenia w zatrudnieniu cywilnoprawnym, jaki stanowi praca nakładcza, zdaje się wynikać z samej idei tego rodzaju zatrudnienia. Skoro wykonawcy należy dostarczyć odpowiednią ilość pracy, tak aby osiągnął on określone przepisami wynagrodzenie, ustawodawca chroni wynagrodzenie stanowiące jedyny lub główny dochód zatrudnionego chałupnika. Systemowe założenia pozostałych stosunków prawa cywilnego stanowiących podstawę zatrudnienia umownego (umowy zlecenia, umowy o świadczenie usług, do których stosuje się przepisy o zleceniu, umowy agencyjnej i umowy o dzieło) nie uzasadniają aksjologicznie zrównania ochrony wynagrodzenia $\mathrm{z}$ regulacją właściwą dla stosunku pracy ${ }^{131}$.

130 W. Jaśkiewicz, C. Jackowiak, W. Piotrowski, op. cit., s. 321. W. Szubert uznawał wynagrodzenie za pracę za podstawę utrzymania pracownika i jego rodziny. W. Szubert, Zarys prawa pracy..., s. 258.

131 W odniesieniu do konieczności zapewnienia minimalnego wynagrodzenia za pracę przeciwny pogląd prezentują A. Sobczyk, Prawo pracy w świetle Konstytucji RP, t. 2..., s. 39; M. Skóra, Minimalne wynagrodzenie za pracę jako przejaw funkcji ochronnej prawa pracy, [w:] M. Bosak (red.), Funkcja ochronna prawa pracy a wyzwania współczesności, Warszawa 2014, s. 222. 
Obok wynagrodzenia za pracę uprawnieniem osób świadczących pracę w ramach umownego zatrudnienia nietypowego, które różnicuje ich status prawny w sposób znaczący i w związku z tym wymaga analizy w początkowej fazie rozważań, jest prawo do wypoczynku. Realizacja prawa do wypoczynku przebiega dwupłaszczyznowo - poprzez regulacje dotyczące czasu pracy oraz urlopów wypoczynkowych $^{132}$. Dlatego tematyka ta zostanie przedstawiona równolegle $z$ dwóch wskazanych perspektyw. Międzynarodowa Organizacja Pracy, normując regulacje dotyczące prawa do odpoczynku, również czyni to poprzez limitowanie czasu pracy oraz regulacje dotyczące urlopów. Już pierwsza konwencja MOP z 29 października 1919 r. ${ }^{133}$ podjęła kwestie związane z dzienną i tygodniową normą pracy. Spośród wielu konwencji MOP dotyczących prawa do wypoczynku można wymienić konwencję z dnia 25 października 1921 r. nr 14 dotyczącą odpoczynku tygodniowego w zakładach przemysłowych ${ }^{134}$, konwencję z dnia 14 czerwca 1935 r. nr 147 dotyczącą minimalnych norm na statkach handlowych ${ }^{135}$, konwencję z dnia 4 czerwca 1936 r. nr 52 dotyczącą corocznych płatnych urlopów ${ }^{136}$ czy konwencję z dnia 5 czerwca 1957 r. nr 106 dotyczącą cotygodniowego odpoczynku w handlu i w biurach ${ }^{137}$. Prawodawstwo Unii Europejskiej również nie pozostało obojętne na zagadnienia związane $\mathrm{z}$ prawem do wypoczynku. W tym zakresie wymienić należy dwa główne akty prawne - dyrektywę nr 93/104/EEC ${ }^{138}$ oraz dyrektywę nr 2003/88/WE ${ }^{139}$. Dyrektywa 2003/88/WE zastąpiła dyrektywę 93/104/EEC, zapewniając pracownikom okresy odpoczynku poprzez przyznanie im prawa do odpoczynku dobowego, tygodniowego i rocznego ${ }^{140}$.

$\mathrm{Na}$ gruncie krajowego porządku prawnego analizę statusu prawnego osób świadczących pracę $\mathrm{w}$ ramach umownego zatrudnienia nietypowego w odniesieniu do uprawnień związanych z wypoczynkiem rozpocząć należy od przy-

132 Z. Góral, O kodeksowym katalogu..., s. 179.

133 Konwencja MOP nr 1 dotycząca ograniczenia czasu pracy do ośmiu godzin dziennie i czterdziestu ośmiu godzin tygodniowo w zakładach przemysłowych, MOP, www.mop.pl/doc/ html/konwencje/k001.html (dostęp: 6.01.2017).

134 Dz.U. z 1925 r., Nr 54, poz. 384.

135 Dz.U. z 1997 r., Nr 72, poz. 454.

136 MOP, www.mop.pl/doc/html/konwencje/k052.html (dostęp: 6.01.2017).

137 MOP, www.mop.pl/doc/html/konwencje/k106.html (dostęp: 6.01.2017).

138 Dyrektywa Rady nr 93/104/WE z dnia 23 listopada 1993 r. dotycząca niektórych aspektów organizacji czasu pracy (Dz.U.WE.L 307 z dnia 13 grudnia 1993 r., s. 18-24) obowiązywała do 1 sierpnia 2004 r. Omówienie tej dyrektywy prezentują: L. Florek, Czas pracy i urlopy wypoczynkowe w prawie europejskim, „Praca i Zabezpieczenie Społeczne” 1999, nr 2, s. $12-$ 19; A.M. Świątkowski, Europejskie prawo socjalne, s. 207-230; H. Lewandowski, Zbliżenie polskiego indywidualnego prawa pracy do prawa wspólnotowego (Unii Europejskiej), [w:] H. Lewandowski, J. Sokołowski (red.), op. cit., s. 96-98.

139 Dyrektywa Parlamentu Europejskiego i Rady nr 2003/88/WE z dnia 4 listopada 2003 r. dotycząca niektórych aspektów organizacji czasu pracy, Dz.U.WE.L 299 z dnia 18 listopada 2003 r., s. 9-19.

140 Szerzej na ten temat: Z. Góral, O kodeksowym katalogu..., s. 181. 
bliżenia regulacji konstytucyjnych. Przepis art. 66 ust. 2 Konstytucji gwarantuje pracownikom ochronę w zakresie określonych w ustawie dni wolnych od pracy i corocznych płatnych urlopów oraz określenia maksymalnych norm czasu pracy. Co warte wskazania, art. 66 ust. 1 Konstytucji statuuje prawo do bezpiecznych i higienicznych warunków pracy, którego adresatem jest każdy ${ }^{141}$, natomiast art. 66 ust. 2 prawo do wypoczynku łączy ze statusem pracowniczym ${ }^{142}$. Wydaje się zatem, że o ile prawo do bezpiecznych i higienicznych warunków pracy jest niezależne od podstawy świadczenia pracy, o tyle prawo do wypoczynku jest ściśle związane z posiadaniem statusu pracowniczego. Ogólny charakter uregulowania konstytucyjnego w zakresie prawa do wypoczynku powoduje konieczność uszczegółowienia norm na poziomie ustaw zwykłych ${ }^{143}$. Na gruncie kodeksu pracy rozwinięcie regulacji konstytucyjnej zawiera art. 14, statuując zasadę prawa do wypoczynku jako jedną z podstawowych zasad prawa pracy. Normy prawne mające na celu zapewnienie realizacji tego prawa stanowią o czasie pracy, dniach wolnych od pracy oraz o urlopach wypoczynkowych ${ }^{144}$. Poza kodeksem pracy unormowania wymienionych elementów prawa do wypoczynku zawiera ustawa z 18 stycznia 1951 r. o dniach wolnych od pracy ${ }^{145}$.

Pracownikom tymczasowym, pomimo posiadania przez nich statusu pracowniczego, nie przyznano takich samych uprawnień. Istota pracy tymczasowej w postaci krótkotrwałości więzi zatrudnienia uniemożliwia stosowanie do pracowników tymczasowych wszystkich instytucji prawnych związanych z prawem do wypoczynku. Agencja pracy tymczasowej i pracodawca użytkownik mogą uzgodnić, że pracownik tymczasowy wykonujący pracę na rzecz pracodawcy użytkownika krócej niż 6 miesięcy będzie miał możliwość wykorzystania w całości lub w części urlopu wypoczynkowego (art. 10 ust. 1 z.p.t.). Ponieważ ustalenie między agencją a pracodawcą użytkownikiem udzielenia urlopu wypoczynkowego jest fakultatywne, w praktyce mogą zdarzyć się sytuacje nieudzielenia pracownikowi tymczasowemu urlopu w naturze, w przypadku gdy praca jest wykonywana krócej niż 6 miesięcy. Stanowi to istotny wyłom w zasadzie udzielania urlopu w ten właśnie sposób ${ }^{146}$. Jeśli pracownik tymczasowy pracował krócej niż 6 miesięcy i pracodawca użytkownik oraz agencja pracy tymczasowej nie zawarli porozumienia o udzieleniu urlopu, zamiast urlopu w naturze pracownikowi tymczasowemu przysługuje ekwiwalent. Obowiązek udzielenia pracownikowi tym-

141 L. Florek, Konstytucyjne gwarancje..., s. 210.

142 B. Banaszak zauważa, że nie ma podstaw do różnicowania podmiotowego zakresu art. 66 ust. 1 i 66 ust. 2 Konstytucji. B. Banaszak, op. cit., s. 344.

143 Z. Góral, O kodeksowym katalogu..., s. 182.

144 Ibidem.

145 Ustawa z dnia 18 stycznia 1951 r. o dniach wolnych od pracy, Dz.U. z 2015 r., poz. 90 - t.j.

146 A. Sobczyk, Art. 10, [w:] A. Sobczyk, Ustawa o zatrudnianiu pracowników tymczasowych. Komentarz, https://sip-1lex-1pl-1004153yx0674.han3.lib.uni.lodz.pl/\#/komentarz/587241499 /38939 (dostęp: 19.09.2017). 
czasowemu urlopu w naturze istnieje jedynie w przypadku wykonywania przez pracownika tymczasowego pracy na rzecz danego pracodawcy użytkownika przez okres 6 miesięcy bądź dłuższy ${ }^{147}$, przy czym należy dopuścić kumulowanie następujących po sobie okresów pracy ${ }^{148}$. Z uwagi na trójpodmiotową konstrukcję zatrudnienia tymczasowego i fakt, że pracodawcą jest agencja pracy tymczasowej, urlopu udziela agencja, natomiast obowiązkiem pracodawcy użytkownika jest umożliwienie jego wykorzystania ${ }^{149}$. Uzależnienie obowiązku udzielenia urlopu od co najmniej sześciomiesięcznego okresu wykonywania pracy na rzecz danego pracodawcy użytkownika różnicuje pozycję prawną pracowników tymczasowych względem pozostałych pracowników. Długość trwania konkretnego stosunku pracy na gruncie kodeksu pracy ma wpływ jedynie na prawo do urlopu wypoczynkowego w przypadku pierwszej pracy i tylko w pierwszym roku kalendarzowym (art. 153 k.p.). W każdym innym przypadku, nawet przy bardzo krótkiej umowie terminowej, pracownik nabywa prawo do urlopu proporcjonalnie do jej długości w danym roku kalendarzowym od pierwszego dnia pracy. Wydaje się jednak, że takie zróżnicowanie statusu prawnego pracowników tymczasowych podyktowane jest uwzględnieniem całokształtu uwarunkowań systemowych zatrudnienia tymczasowego. Musi ono uwzględniać interesy wszystkich trzech podmiotów danej relacji. Obarczenie pracodawcy użytkownika korzystającego z pracy pracownika tymczasowego przez względnie krótki czas (krócej niż 6 miesięcy) koniecznością uwzględnienia $\mathrm{w}$ organizacji procesu pracy jego nieobecności spowodowanej urlopem wypoczynkowym godziłoby w racjonalność stosowania zatrudnienia tymczasowego. Tym samym wydaje się, że ustawodawca wyważył interesy wszystkich podmiotów. Po pierwsze nie zamknął drogi umożliwiającej ustalenie, że urlop będzie przysługiwał nawet takiemu pracownikowi tymczasowemu, który pracuje krócej niż 6 miesięcy (art. 10 ust. 1 z.p.t.). Dodatkowo usankcjonował obowiązek udzielenia urlopu w naturze przy wykonywaniu pracy na rzecz pracodawcy użytkownika przez okres dłuższy (art. 10 ust. 2 z.p.t.).

Pracownikowi tymczasowemu przysługuje urlop wypoczynkowy w wymiarze dwóch dni za każdy miesiąc pozostawania w dyspozycji danego pracodawcy użytkownika bądź więcej niż jednego pracodawcy użytkownika (art. 17 z.p.t.). Wskazana regulacja stanowi wyłom w kodeksowym unormowaniu udzielania urlopu co do zasady w oparciu o staż pracy. Zatem z materialnego punktu widzenia sytuacja prawna pracownika tymczasowego różni się od sytuacji prawnej pracownika zatrudnionego na umownych podstawach stosunku pracy uregulowanych w ko-

147 A. Daszczyńska, Prawo pracownika tymczasowego do wypoczynku, pkt 4.1, [w:] A. Sobczyk (red.), Z problematyki zatrudnienia tymczasowego, https://sip.lex.pl/\#/monografia/369236017/5 (dostęp: 19.09.2017).

148 A. Sobczyk, Art. 10, [w:] A. Sobczyk, Ustawa o zatrudnianiu pracowników tymczasowych. Komentarz, https://sip-1lex-1pl-1004153bj6de6.han3.lib.uni.lodz.pl/\#/komentarz/587241499/ 38939 (dostęp: 19.09.2017).

149 A. Daszczyńska, op. cit. 
deksie pracy. Wymiar urlopu tego ostatniego wynosi 20 dni przy zatrudnieniu trwającym krócej niż 10 lat i 26 dni przy zatrudnieniu przez co najmniej 10 lat (art. $154 \$ 1$ k.p.). Pracownik tymczasowy może w danym roku kalendarzowym, przy spełnieniu przesłanek określonych w art. 17 z.p.t., wykorzystać maksymalnie 24 dni urlopu. Jeżeli jest to pracownik posiadający staż pracy krótszy niż 10 lat, ustawa o zatrudnianiu pracowników tymczasowych reguluje jego sytuację prawną w sposób korzystniejszy niż kodeks pracy (pracownik taki „zyskuje” cztery dni urlopu w roku kalendarzowym). Przeciwnie - pracownik, którego staż pracy wynosi co najmniej 10 lat, przy zastosowaniu regulacji ustawy o zatrudnianiu pracowników tymczasowych "traci” 2 dni urlopu względem uprawnień wynikających z kodeksu pracy. Jest to szczególnie niekorzystne dla osób, które świadczą pracę tymczasową przez bardzo długie okresy na rzecz różnych pracodawców użytkowników bądź z ramienia różnych agencji pracy tymczasowej. Wydaje się jednak, że skoro założeniem systemowym jest krótkotrwałość zatrudnienia tymczasowego, takie zróżnicowanie nie godzi w interesy pracowników tymczasowych.

Sytuacja prawna pracownika tymczasowego związana z prawem do urlopu jest nietypowa również dlatego, że zgodnie $\mathrm{z}$ art. 17 ust. 1 z.p.t. nabywa on prawo do urlopu zawsze $\mathrm{z}$ dołu, po każdym miesiącu pozostawania $\mathrm{w}$ dyspozycji danego pracodawcy użytkownika. Oprócz pierwszego urlopu pracownik zatrudniony typowo nabywa uprawnienia urlopowe z góry. Wydaje się, że uzasadnieniem takiego stanu prawnego jest specyfika zatrudnienia tymczasowego, które powinno być stosowane w okresie wzmożonego zapotrzebowania na pracowników, mającego co do zasady charakter przejściowy. Typowe umowne zatrudnienie pracownicze koncentruje się natomiast na długotrwałym charakterze więzi stosunku prawnego, w który wpisuje się prawo do wykorzystania urlopu również przed przepracowaniem okresu, za jaki on przysługuje (z góry) ${ }^{150}$.

Badając prawo do wypoczynku pracowników tymczasowych w kontekście przepisów dotyczących czasu pracy, nie ma podstaw do uznania, że kwestia ta została uregulowana odmiennie niż stanowi o tym kodeks pracy. Ustawa o zatrudnianiu pracowników tymczasowych nie zawiera bowiem żadnych dodatkowych uregulowań tej materii. Przepisy dotyczące norm czasu pracy czy okresów odpoczynku (dobowego i tygodniowego), mające wpływ na sytuację prawną osób zatrudnionych, znajdują zastosowanie również w stosunku do pracowników tymczasowych (zgodnie z art. 5 z.p.t.).

Spośród umów cywilnoprawnych, których przedmiotem może być świadczenie pracy, jedynie regulacja pracy nakładczej zawiera unormowania dotyczące prawa do wypoczynku. Nie znaczy to, że kształtując stosunki prawne w oparciu o pozostałe umowy stanowiące podstawę zatrudnienia cywilnoprawnego (umowę zlecenia, umowę o świadczenie usług, do której stosuje się przepisy o zlece-

150 A. Sobczyk, Interes pracodawcy i pracownika w zatrudnieniu tymczasowym, „Monitor Prawa Pracy" 2011, nr 5, s. 304. 
niu, umowę agencyjną czy umowę o dzieło) strony nie mogą wprowadzić takich postanowień. Mają taką możliwość, o ile nie naruszają zasady swobody umów oraz przepisów przeciwdziałających i zwalczających stosowanie umów cywilnoprawnych $\mathrm{w}$ miejsce zatrudnienia pracowniczego (poprzez uregulowanie łączącej je więzi w sposób ukrywający rzeczywiście istniejący stosunek pracy) ${ }^{151}$. Wykonawcom pracy nakładczej przysługuje, właściwe dla stosunku pracy ${ }^{152}$, prawo do corocznego, nieprzerwanego i płatnego urlopu wypoczynkowego. Prawo to zapewnione jest wykonawcom, którzy otrzymują wynagrodzenie w wysokości równej co najmniej połowie wynagrodzenia najniższego ( $\$ 14$ rozp. pr. nakład.). Wymiar ich urlopu oblicza się tak samo jak wymiar urlopu pracownika. Wynosi on, w zależności od stażu pracy, 20 albo 26 dni. Dodatkowo do pracy nakładczej odpowiednio zastosowanie znajdują przepisy art. $162-167$ oraz 171 k.p. (\$16 ust. 1 rozp. pr. nakład. $)^{153}$.

W kontekście prawa do wypoczynku związanego z organizacją czasu pracy sytuacja prawna wszystkich pracowników, bez względu na podstawę prawną i formę organizacyjną zatrudnienia, jest taka sama. Każdy pracownik ma prawo do przerw w pracy oraz do dobowego i tygodniowego odpoczynku w granicach zagwarantowanych przepisami prawa pracy. Wyjątkami od konieczności zastosowania norm dotyczących odpoczynku dobowego są ograniczenia o charakterze podmiotowym (art. $132 \$ 1$ pkt 1 k.p.) i przedmiotowym (art. $132 \$ 1$ pkt 2 k.p.). Znajdują one zastosowanie również do odpoczynku dobowego przy uwzględnieniu dodatkowych okoliczności wynikających z dyspozycji art. $133 \$ 3$ k.p. ${ }^{154}$

Podobnych uprawnień nie posiadają osoby świadczące pracę na podstawie umów prawa cywilnego. Osoby te same organizują proces pracy oraz czas, jaki na nią przeznaczają ${ }^{155}$. Potwierdzeniem powyższego jest nie tylko brak zapewnionych ustawowo okresów odpoczynku, ale również brak odpowiedników istniejących w zatrudnieniu pracowniczym możliwości dostosowania organizacji pracy do nagłych potrzeb podmiotu zatrudniającego. W stosunku pracy możliwością taką jest wydanie polecenia obligującego do pracy w godzinach nadliczbowych. Niepodporządkowany charakter pracy świadczonej na podstawie umów prawa cywilnego czyni sprzecznym $\mathrm{z}$ ich społeczno-gospodarczym przeznaczeniem

151 Z. Kubot, Urlop wypoczynkowy w zatrudnieniu niepracowniczym typu cywilnoprawnego, „Praca i Zabezpieczenie Społeczne” 2002, nr 9, s. 31.

152 M. Gersdorf, Prawo zatrudnienia..., s. 115.

153 F. Małysz, Wybrane uprawnienia pracownicze osób wykonujących pracę nakładcza, ,Polityka Społeczna" 2001, nr 8, s. 7.

154 K. Stefański, Okresy odpoczynku w kodeksie pracy, „Praca i Zabezpieczenie Społeczne” 2006, nr 1, s. 27-28.

155 W zakresie przepisów dotyczących okresów odpoczynku funkcja ochronna prawa pracy często "chroni pracownika przed nim samym”, ustawowo narzucając np. okresy odpoczynku czy zakazy pracy w godzinach nadliczbowych. J. Loga, Uwagi na tle projektu zmiany kodeksu pracy, „Praca i Zabezpieczenie Społeczne” 1981, nr 5/6, s. 15. 
wprowadzanie norm prawnych regulujących organizację procesu pracy, w tym norm dotyczących czasu pracy. Przyznanie pracownikowi czasu wolnego (czy to $\mathrm{w}$ postaci przerw w pracy, czy w postaci urlopu) służy zapewnieniu mu czasu na realizację własnych spraw oraz regenerację sił ${ }^{156}$. Ponieważ pracownik jest podporządkowany pracodawcy w zakresie czasu pracy, to właśnie zapewnienie mu czasu wolnego, podlegającego samodzielnemu planowaniu pozwala na realizację jego indywidualnych potrzeb ${ }^{157}$. Podporządkowanie takie nie występuje w stosunkach zatrudnienia cywilnoprawnego. Przyjmujący zlecenie, agent czy wykonawca dzieła nie są uzależnieni w wykonywanych czynnościach od harmonogramów pracy w sposób równy pracowniczemu podporządkowaniu, dlatego też mogą dowolnie planować czas wykonywania czynności, uwzględniając swoje prywatne potrzeby. W związku z powyższym nie wydaje się słuszne twierdzenie, że obowiązkowym prawem do urlopu obciążona jest praca, a nie pracownik podporządkowany, który to pogląd daje argument do przyjęcia, że prawo do urlopu powinno być prawem wszystkich osób zatrudnionych ${ }^{158}$. Prawo do wypoczynku w ogólności powinno być prawem wszystkich osób zatrudnionych pracujących w podobnych warunkach, a warunki pracy wykonywanej na podstawie umowy prawa cywilnego są z natury rzeczy odmienne od pracy w ramach stosunku pracy. Osoby zatrudnione w reżimie prawa cywilnego mogą tak ukształtować warunki wynagrodzenia, aby zabezpieczyć swój byt nawet w okresach nieświadczenia pracy z powodu wypoczynku bądź realizowania innych potrzeb. Nie ma przy tym konieczności ustawowego zapewniania im tego prawa ${ }^{159}$.

Kolejnym wymagającym omówienia zagadnieniem, związanym ze zróżnicowaniem uprawnień osób zatrudnionych na etapie realizacji zatrudnienia, są regulacje dotyczące ochrony życia i zdrowia w zakresie bezpiecznych i higienicznych warunków pracy. W rozdziale drugim monografii zostały omówione unormowa-

156 W. Dyląg, Prawo do odpoczynku jako przejaw funkcji ochronnej prawa pracy, [w:] M. Bosak (red.), Funkcja ochronna prawa pracy a wyzwania wspótczesności, Warszawa 2014, s. 32.

157 Również normy ograniczające możliwość pracy w godzinach nadliczbowych czy w niedziele i święta oraz ustanawiające konieczność kompensaty tej pracy czasem wolnym bądź dodatkowym wynagrodzeniem realizują zamiar ustawodawcy przyznania pracownikom czasu pozostawionego do ich swobodnej dyspozycji.

158 Odmiennie: A. Sobczyk, Prawo pracy w świetle Konstytucji RP, t. 1: Teoria publicznego i prywatnego indywidualnego prawa pracy, Warszawa 2013, s. 208. Pogląd odmienny prezentuje również M. Skąpski. Autor argumentuje, że faktyczne podobieństwo pracy w ramach zatrudnienia pracowniczego i cywilnoprawnego powoduje konieczność objęcia wszystkich tych osób choćby zbliżonym prawem do wypoczynku. M. Skąpski, Funkcje regulacji czasu pracy wobec idei równości i sprawiedliwości, „Annales Universitatis Mariae Curie-Skłodowska”, 2015, vol. 62(2), s. 28. Należy mieć jednak na uwadze, że w sytuacji faktycznego zbliżenia warunków zatrudnienia cywilnoprawnego do zatrudnienia pracowniczego prawdopodobnie jest ono zatrudnieniem pracowniczym, do którego strony, sprzecznie z prawem, zastosowały umowę cywilnoprawną.

159 Przeciwnie: M. Gersdorf, Prawo zatrudnienia..., s. 189. 
nia dotyczące obowiązku zapewnienia bezpiecznych i higienicznych warunków pracy $\mathrm{w}$ fazie nawiązywania stosunku zatrudnienia. $\mathrm{W}$ tym miejscu wskazane zostaną naturalne konsekwencje zawarcia umowy o zatrudnienie związane $\mathrm{z}$ realizacją uprawnień osób zatrudnionych do pracy w warunkach bezpieczeństwa i higieny.

Fakt, że wiele regulacji $\mathrm{MOP}^{160}$ dotyczy materii związanej z bezpiecznymi i higienicznymi warunkami pracy, potwierdza istotną rolę, jaką przypisuje się temu aspektowi zatrudnienia. Spośród aktów prawa unijnego uregulowanie prawa do bezpiecznych i higienicznych warunków pracy statuuje dyrektywa 89/391/EWG ${ }^{161}$, wspominana już przy omawianiu warunków dopuszczania do pracy. Dyrektywa posługuje się pojęciem worker, tłumaczonym w wersji polskiej jako pracownik. W związku z tym powstaje wątpliwość co do określenia zakresu podmiotowego stosowania dyrektywy na gruncie krajowego porządku prawnego. Dyrektywa wskazuje, że osoba, którą określa się jako worker jest zatrudniona przez pracodawcę. W pojęciu tym mieszczą się osoby prowadzące szkolenia i stażyści, z wyłączeniem pomocy domowych (art. 3 lit. a). Zatem regulacje dyrektywy można interpretować na dwa sposoby. Pierwszy z nich ograniczy obowiązek zapewniania bezpiecznych i higienicznych warunków pracy tylko do tych podmiotów, które mają status pracownika, przy jednoczesnym rozszerzeniu zakresu wypełnienia obowiązków wynikających z dyrektywy na osoby zatrudnione poza stosunkiem pracy. Druga interpretacja ograniczy obowiązek zapewniania bezpiecznych i higienicznych warunków pracy jedynie do obowiązku pracodawcy względem pracownika. Wydaje się, że to pierwsza interpretacja jest właściwa. Skoro bowiem ten sam podmiot zatrudnia osoby na podstawie różnych stosunków prawnych (pracowniczych i cywilnoprawnych), nieuzasadnione byłoby zapewnianie bezpiecznych i higienicznych warunków pracy jedynie części osób świadczących pracę. Wszystkie osoby zatrudnione pracują dla osiągnięcia wspólnego celu, a ich działania często pozostają skooperowane. Brak konieczności zapewnienia przez pracodawcę bezpiecznych i higienicznych warunków pracy osobom zatrudnionym na podstawie umów prawa cywilnego skutkowałby zawsze brakiem możliwości zapewnienia pracownikom tych warunków w stopniu zadowalającym. Wydaje się, że takie właśnie założenie przyjął również prawodawca krajowy, skoro art. 66 Konstytucji stanowi, że każdemu przysługuje prawo do bezpiecznych i higienicznych warunków pracy. Bezpieczeństwo i higiena pracy wiążą się z ochroną zdrowia, przy czym nie można rozróżniać zdrowia pracowniczego i niepracow-

160 Jak szacuje T. Wyka, MOP wydała ponad 40 konwencji dotyczących tej materii. T. Wyka, Ochrona zdrowia i życia pracownika jako element treści stosunku pracy, Warszawa 2003, s. 70 .

161 Z. Góral, O kodeksowym katalogu..., s. 189. Analizę postanowień dyrektywy nr 89/391/EWG przeprowadził A.M. Świątkowski. Zob. A.M. Świątkowski, Europejskie prawo socjalne, Warszawa 1999, s. 275 i nast. 
niczego ${ }^{162}$. Zdrowie wszystkich osób świadczących pracę powinno być chronione jednakowo. Przepis art. 66 Konstytucji rozgranicza w ust. 1 uprawnienie do bhp (przysługujące każdemu) i w ust. 2 uprawnienie do wypoczynku (przysługujące pracownikom) ${ }^{163}$.

Na gruncie kodeksu pracy skorelowany z uprawnieniem pracownika obowiązek zapewnienia przez pracodawcę bezpiecznych i higienicznych warunków pracy został uznany za jedną z podstawowych zasad prawa pracy (art. 15). Kodeks pracy w art. 15 ogranicza, względem regulacji konstytucyjnej, jego zakres podmiotowy do więzi pracodawca-pracownik. Jednak, o czym mowa będzie w dalszej części, ograniczenie to zostaje w przeważającym stopniu zniesione w przepisach szczegółowych dotyczących bhp, stanowiąc realizację konstytucyjnej zasady zapewniania każdemu bezpiecznych i higienicznych warunków pracy. O ciężarze rodzajowym uprawnienia pracownika do pracy w bezpiecznych i higienicznych warunkach świadczy choćby fakt, że nierealizowanie przez pracodawcę obowiązków w tym zakresie może prowadzić do rozwiązania przez pracownika stosunku pracy bez wypowiedzenia ${ }^{164}$ (art. 55 $\$ 1^{1}$ k.p.). Rozbudowana w kodeksie pracy regulacja dotycząca uprawnień pracownika związanych z bhp znajduje zastosowanie do wszystkich pracowników, bez względu na rodzaj umowy o pracę i formę organizacyjną zatrudnienia, z uwzględnieniem odrębności wynikających ze specyfiki telepracy i pracy tymczasowej. Regulacja pracy w formie organizacyjnej telepracy w art. $67^{17} \mathrm{k}$.p. rozróżnia telepracę wykonywaną w domu pracownika i poza nim. Ustawa nie reguluje sposobu zapewniania bhp telepracownikowi, gdy świadczy on pracę poza domem ${ }^{165}$. Wydaje się zatem, że w takiej sytuacji pracownik uprawniony jest do bezpiecznych i higienicznych warunków pracy na zasadach ogólnych stosowanych wobec pracowników wykonujących pracę poza zakładem pracy ${ }^{166}$. Potwierdza to wyrażoną w niniejszej pracy tezę, że telepraca powinna być świadczona w miejscach, do których pracodawca ma swobodny wstęp. W przeciwnym razie nie może zapewnić pracownikowi bezpiecznych i higienicznych warunków pracy, co powoduje, że pracownik nie może w pełni korzystać z przysługujących mu w tym zakresie uprawnień.

162 J. Jończyk, Prawo pracy, Warszawa 1994, s. 341.

163 A. Sobczyk, Prawo pracy w świetle Konstytucji RP, t. 1: Teoria publicznego i prywatnego indywidualnego prawa pracy, Warszawa 2013, s. 170; T. Wyka, Konstytucyjne prawo każdego do bezpiecznych i higienicznych warunków pracy a zatrudnienie na innej podstawie niż stosunek pracy oraz praca na własny rachunek - uwagi de lege ferenda, [w:] J. Stelina, A. Wypych-Żywicka (red.), Człowiek, obywatel, pracownik. Studia z zakresu prawa pracy. Księga jubileuszowa Profesor Urszuli Jackowiak, „Gdańskie Studia Prawnicze” 2007, t. 17, s. 333 i nast.

164 T. Wyka, Prawna ochrona zdrowia pracownika, [w:] H. Lewandowski (red.), Polskie prawo pracy w okresie transformacji w oświetleniu prawa wspólnotowego, Warszawa 1997, s. 80 i nast.

165 Pracodawca jest zobowiązany zapewnić bezpieczne i higieniczne warunki pracy na zasadach ogólnych w sytuacji gdy telepracownik świadczy część obowiązków w jego siedzibie.

166 A. Sobczyk, Art. 67 ${ }^{17}$, [w:] A. Sobczyk (red.), Kodeks pracy. Komentarz..., s. 357. 
Gdy telepracownik świadczy pracę w swoim domu, stosuje się do niego przepisy kodeksu pracy w zakresie bhp z ograniczeniami wskazanymi w art. $67^{17}$ k.p. ${ }^{167}$ Pierwszą grupę obowiązków, których pracodawca nie musi wykonywać względem telepracownika świadczącego pracę w swoim domu, stanowią obowiązki wykraczające poza zakres wynikający z rodzaju i warunków wykonywanej pracy, a więc przede wszystkim te, które w swojej treści odnoszą się do ich wykonywania na terenie zakładu pracy ${ }^{168}$. Drugą grupę wyłączeń stanowią przepisy wskazane w treści omawianego przepisu. Po pierwsze wobec telepracownika pracodawca nie ma obowiązku dbałości o bezpieczny i higieniczny stan pomieszczeń i wyposażenia technicznego, a także o sprawność środków ochrony zbiorowej i ich stosowanie zgodnie z przeznaczeniem (art. 212 pkt 4 k.p.). Po drugie względem pracy świadczonej w formie telepracy zastosowania nie znajdują przepisy rozdziału 3 działu 10 kodeksu pracy, dotyczące obowiązków pracodawcy w zakresie przebudowy pomieszczeń pracy oraz zapewnienia odpowiednich do wykonywania danej pracy pomieszczeń. Po trzecie pracodawca nie jest względem telepracownika zobowiązany do wypełnienia dyspozycji art. 233 k.p., czyli zapewnienia urządzeń higieniczno-sanitarnych oraz niezbędnych środków higieny osobistej.

Ponieważ istotą telepracy jest praca wyłącznie bądź także poza zakładem pracy, w zakresie prawa do bezpiecznych i higienicznych warunków pracy mogą powstać trudności w ustalaniu okoliczności wypadku przy pracy telepracownika. O zaistniałym wypadku telepracownik powinien, o ile umożliwia mu to stan zdrowia, niezwłocznie powiadomić pracodawcę i umożliwić mu sporządzenie protokołu powypadkowego ${ }^{169}$. W przeciwnym razie pracownik może stracić prawo do świadczeń z tytułu ubezpieczeń społecznych. Wprowadzenie wskazanych odrębności wydaje się w pełni uzasadnione. Ze względu na specyfikę telepracy, gdyby na pracodawcy ciążyły obowiązki wyłączone mocą art. $67^{17}$ k.p., nie tylko musiałby on kontrolować stan higieny domu pracownika, ale także, w niektórych przypadkach, dokonywać jego przebudowy czy konserwacji. Decydując się na pracę w formie telepracy w domu, pracownik wie, w jakich warunkach będzie pracował i nie może żądać od pracodawcy ich poprawy. W zakresie bezpieczeństwa i higieny pracy minimalizowanie ryzyka związanego ze świadczeniem pracy w domu należy zatem w przeważającej części do obowiązków telepracownika, a nie wyłącznie do obowiązków pracodawcy, skorelowanych z uprawnieniami pracownika ${ }^{170}$. Zarówno zapewnianie bezpieczeństwa i higieny pracy, jak i ich kontrolowanie w przypadku

167 Warto wskazać, że ograniczenia te wynikają z samej istoty telepracy świadczonej w domu. Ustawodawca w treści art. $67^{17}$ k.p. wskazał, że pracodawca realizuje obowiązki dotyczące bhp w zakresie „wynikającym z rodzaju i warunków wykonywanej pracy”, wyłączając te, które i tak nie są objęte obszarem rodzaju i warunków wykonywanej pracy. A. Sobczyk, Telepraca w prawie polskim..., s. 210.

168 A. Sobczyk (red.), Kodeks pracy. Komentarz..., s. 357-358.

169 Ibidem, s. 223.

170 A. Sobczyk, Telepraca w prawie..., s. 168-169. 
tej formy organizacyjnej umownego zatrudnienia nietypowego jest bardzo utrudnione i wymaga bliskiego współdziałania pracownika i pracodawcy. Jakakolwiek ingerencja pracodawcy w bhp telepracownika pracującego w domu wiąże się bowiem $z$ wkroczeniem w jego sferę prywatną. Ponieważ jednak ingerencja ta, chroniąc życie i zdrowie jako dobra najwyższej wartości, pozostaje w zbieżności z interesem pracownika, należy uznać ją za konieczną.

Również uzasadnione wydają się odrębności w zakresie uprawnień dotyczących obowiązku zapewnienia bezpiecznych i higienicznych warunków pracy świadczonej w ramach zatrudnienia tymczasowego. Przepis art. 14 ust. 2 pkt 1 z.p.t. wskazuje, że to na pracodawcy użytkowniku, czyli podmiocie niebędącym stroną stosunku pracy, ciąży obowiązek zapewnienia pracownikowi tymczasowemu bezpiecznych i higienicznych warunków pracy. Ponieważ został on wskazany w katalogu obowiązków pracodawcy użytkownika jako pierwszy, należy mu przypisać szczególną wartość ${ }^{171}$. Regulacja art. 9 ust. 2a z.p.t. stanowi dodatkowo, jakie powinności związane z bezpieczeństwem i higieną pracy spoczywają na pracodawcy użytkowniku. Należą do nich: dostarczenie pracownikowi tymczasowemu odzieży i obuwia roboczego oraz środków ochrony indywidualnej, zapewnienie napojów i posiłków profilaktycznych, przeprowadzenie szkolenia w zakresie bezpieczeństwa i higieny pracy, ustalenie okoliczności i przyczyny wypadku przy pracy, przeprowadzenie oceny ryzyka zawodowego oraz informowanie o tym ryzyku.

Uprawnienia osób świadczących pracę w ramach cywilnoprawnego zatrudnienia umownego w zakresie bhp są zróżnicowane. Jednakowe uprawnienia przysługują osobom świadczącym pracę w ramach umowy zlecenia, umowy o świadczenie usług, do której stosuje się przepisy o zleceniu, umowy agencyjnej oraz umowy o dzieło. Najszersze przysługują natomiast wykonawcom pracy nakładczej. Prawodawca zdecydował się przyznać część uprawnień w zakresie bezpieczeństwa i higieny osobom zatrudnionym na podstawie umów prawa cywilnego. Dokonał przy tym rozszerzenia stosowania jego przepisów na stosunki cywilnoprawne, umiejscawiając w nim właściwą regulację. Przepis art. $304 \$ 1$ k.p. zobowiązuje pracodawcę do zapewnienia bezpiecznych i higienicznych warunków pracy osobom fizycznym wykonującym pracę w zakładzie pracy lub innym miejscu wyznaczonym przez pracodawcę na innej podstawie niż stosunek pracy. Dokonując analizy powyższej regulacji, bezsporny staje się fakt szerszego definiowania pracy aniżeli jedynie przedmiotu działania pracownika w ramach stosunku pracy. Praca może być bowiem świadczona również poza stosunkiem pracy przez osoby fizyczne. W zakresie objęcia osób fizycznych dyspozycją art. $304 \$ 1$ k.p. odsyła on do art. $207 \$ 2$ k.p. Pracodawca jest wobec takich osób zobowiązany do:

a) organizowania pracy w sposób zapewniający bezpieczne i higieniczne warunki pracy

171 A. Reda, Pracodawca użytkownik jako podmiot prawa pracy, Poznań 2011, s. 94. 
b) zapewniania przestrzegania w zakładzie pracy przepisów oraz zasad bezpieczeństwa i higieny pracy, wydawania poleceń usunięcia uchybień w tym zakresie oraz kontrolowania wykonania tych poleceń

c) reagowania na potrzeby w zakresie zapewnienia bezpieczeństwa i higieny pracy oraz dostosowywania środków podejmowanych w celu doskonalenia istniejącego poziomu ochrony zdrowia i życia pracowników, biorąc pod uwagę zmieniające się warunki wykonywania pracy

d) zapewnienia rozwoju spójnej polityki zapobiegającej wypadkom przy pracy i chorobom zawodowym, uwzględniającej zagadnienia techniczne, organizację pracy, warunki pracy, stosunki społeczne oraz wpływ czynników środowiska pracy

e) uwzględniania ochrony zdrowia młodocianych, kobiet w ciąży lub karmiących dziecko piersią oraz zatrudnionych niepełnosprawnych w ramach podejmowanych działań profilaktycznych

f) zapewniania wykonania nakazów, wystąpień, decyzji i zarządzeń wydawanych przez organy nadzoru nad warunkami pracy

g) zapewniania wykonanie zaleceń społecznego inspektora pracy ${ }^{172}$.

Uprawnienia osób świadczących pracę w ramach umownego zatrudnienia cywilnoprawnego nie są realizowane przez obowiązek informacyjny w zakresie zagrożeń dla życia i zdrowia związanych z warunkami wykonywania pracy (art. $207^{1} \$ 1$ pkt 1 k.p.), obowiązek informacyjny w zakresie podjętych działań ochronnych i zapobiegawczych (art. $207^{1} \$ 1$ pkt 2 k.p.), obowiązek informacyjny dotyczący wskazania pracowników wyznaczonych do udzielania pierwszej pomocy oraz do wykonywania działań w zakresie zwalczania pożarów i ewakuacji pracowników (art. $207^{1} \$ 1$ pkt 3 k.p.), obowiązek zapewnienia im środków niezbędnych do udzielania pierwszej pomocy (art. $209^{1} \$ 1$ pkt 1 k.p.), obowiązek wyznaczania pracowników do udzielania pierwszej pomocy i wykonywania działań w zakresie zwalczania pożarów i ewakuacji pracowników (art. $209^{1} \$ 1$ pkt 2 k.p.), obowiązek zapewnienia łączności z zewnętrznymi służbami wyspecjalizowanymi w zakresie udzielania pierwszej pomocy, ratownictwa medycznego oraz ochrony przeciwpożarowej (art. $209^{1} \$ 1$ pkt 3 k.p.), obowiązek niezwłocznego poinformowania o zagrożeniach zdrowia lub życia oraz obowiązek podjęcia działań w celu zapewnienia odpowiedniej ochrony (art. $209^{2} \$ 1$ pkt 1 k.p.), obowiązek dostarczenia instrukcji umożliwiających w przypadku bezpośredniego zagrożenia przerwanie pracy i oddalenie się z miejsca zagrożenia w miejsce bezpieczne (art. $209^{2} \$ 1$ pkt 2 k.p.). Wydaje się, że powyższe obowiązki podmiotów zatrudniających, skorelowane z uprawnieniami osób świad-

172 Pomimo że ustawodawca przesądzit o stosowaniu regulacji art. $207 \S 2$ k.p. wprost (T. Wyka, Konstytucyjne prawo każdego..., s. 337), z perspektywy relacji cywilnoprawnej została ona przeze mnie dostosowana językowo do warunków zatrudnienia cywilnoprawnego poprzez zmianę nomenklatury, przy zachowaniu pozostałych elementów. 
czących pracę, są nieodzownie związane $\mathrm{z}$ faktem organizowania procesu pracy przez pierwszy z nich. Dlatego w stosunkach prawnopracowniczych podmiot zatrudniający zobowiązany jest do zapewnienia bezpiecznych i higienicznych warunków pracy we wszystkich wskazanych aspektach. Z tego samego powodu - braku organizowania procesu pracy w stosunkach cywilnoprawnych - obowiązki podmiotów zatrudniających zostały, zgodnie z powyższym wyliczeniem, ograniczone, przez co zmniejszeniu uległy również uprawnienia osób świadczących pracę w zakresie możliwości dochodzenia ich realizacji.

Dodatkowo rationis legis ograniczenia stosowania przepisów w zakresie bezpieczeństwa i higieny pracy względem osób fizycznych świadczących pracę na innej podstawie niż stosunek pracy jedynie do treści art. $207 \$ 2$ k.p. jest fakt, że obowiązek zapewniania bezpiecznych i higienicznych warunków pracy (art. 15 k.p.) jest podstawową zasadą prawa pracy ${ }^{173}$. Rozszerzanie jej obowiązywania w całości na podmioty nieobjęte prawem pracy byłoby nieuzasadnioną ingerencją w rozdzielność gałęziową prawa pracy i prawa cywilnego. Warunkiem objęcia obowiązkiem zapewnienia bhp w zakresie regulacji art. $207 \$ 2$ k.p. jest świadczenie przez osobę fizyczną pracy w zakładzie pracy lub w miejscu wyznaczonym przez pracodawcę. W związku z powyższym, jeśli miejsce pracy osoby fizycznej pokrywa się z miejscem uznawanym za zakład pracy w znaczeniu przedmiotowym, podmiot zatrudniający zobowiązany jest do wypełnienia dyspozycji art. $207 \$ 2$ w zw. z art. $304 \$ 1$ k.p. ${ }^{174}$ Wątpliwość interpretacyjna powstaje przy badaniu zakresu podmiotowego umożliwiającego stosowanie art. $207 \$ 2$ k.p. względem osób fizycznych nieposiadających statusu pracownika, które wykonują pracę w miejscu wyznaczonym przez pracodawcę. W tym zakresie aktualne pozostają uwagi poczynione przy okazji omawiania obowiązków osób zatrudnionych ${ }^{175}$. Wart rozważenia wydaje się postulat Teresy Wyki w zakresie rozszerzenia zakresu obowiązywania art. $304 \$ 1$ k.p. na te stosunki zatrudnienia cywilnoprawnego, w których osoba zatrudniona sama decyduje o miejscu świadczenia pracy, ale świadczy ją za pomocą środków podmiotu zatrudniającego ${ }^{176}$. Dostosowanie tych środków do warunku bezpieczeństwa i higieny powinno stanowić obowiązek podmiotu zatrudniającego, a nie osoby zatrudnianej, zwłaszcza w przypadku urządzeń o skomplikowanej budowie technologicznej.

Na zakończenie rozważań dotyczących uprawnień osób świadczących pracę $\mathrm{w}$ ramach umownego zatrudnienia nietypowego, badanych $\mathrm{z}$ perspektywy bezpieczeństwa i higieny pracy, omówiona zostanie regulacja pracy nakładczej. Prze-

173 Z. Góral, O kodeksowym katalogu..., s. 190-191.

174 T. Wyka, Konstytucyjne prawo każdego...., s. 336.

175 Patrz przypis 30, rozdz. 2.

176 T. Wyka, Bezpieczeństwo i ochrona zdrowia w zatrudnieniu niepracowniczym typu cywilnoprawnego, [w:] Z. Kubot (red.), Szczególne formy zatrudnienia..., s. 171. 
pis $₫ 21$ ust. 1 rozp. pr. nakład. stanowi, że praca nakładcza powinna być wykonywana $\mathrm{z}$ zachowaniem przepisów i zasad bhp. Uprawnienia wykonawcy związane są z obowiązkami nakładcy, do których należą:

a) przejawianie troski o bezpieczne i higieniczne warunki wykonywania pracy ${ }^{177}$

b) wydawanie poleceń usuwania stwierdzonych w zakresie bhp uchybień

c) kontrolowanie wykonania wyżej wymienionych poleceń

d) współdziałanie przy wykonywaniu zarządzeń i zaleceń wydawanych przez organy nadzoru nad warunkami pracy.

Dodatkowo uprawnienia wykonawcy pracy nakładczej w zakresie bhp konkretyzuje $\$ 22$ rozp. pr. nakład. Zgodnie z jego treścią, jeżeli praca wykonywana jest w mieszkaniu wykonawcy, nie może być szkodliwa dla zdrowia jego lub jego współmieszkańców ( $\$ 22$ ust. 1 rozp. pr. nakład.). Regulacja ta rozszerza zakres troski o bhp na osoby trzecie względem umowy o pracę nakładczą. Jeśli natomiast praca wykonywana jest w pomieszczeniach nakładcy, zastosowanie znajdują przepisy działu 10 kodeksu pracy ( $\$ 22$ ust. 3 rozp. pr. nakład.). Są to szczególne uprawnienia wykonawców skorelowane z obowiązkami nakładców, związane z wykonywaniem pracy nakładczej w domu. Środki służące do wykonania pracy (surowce, materiały, maszyny i inne urządzenia techniczne), dostarczone przez nakładcę, powinny odpowiadać wymaganiom bezpieczeństwa i higieny pracy ( $\$ 22$ ust. 2 rozp. pr. nakład.). O szerokim zastosowaniu do pracy nakładczej przepisów kodeksu pracy dotyczących bhp świadczy katalog wskazany w $\$ 23$ rozp. pr. nakład. Wymienione tam przepisy kodeksu pracy ${ }^{178}$ stosuje się odpowiednio do pracy nakładczej. Zatrudnienie chałupnicze zbliża, w zakresie bezpieczeństwa i higieny pracy, ochronę osób zatrudnionych do ochrony właściwej dla stosunku pracy, przy zachowaniu odrębności wynikających ze specyfiki pracy nakładczej. Wydaje się to pozostawać w zgodzie z systemowymi założeniami pracy nakładczej jako podstawy zatrudnienia z pogranicza prawa pracy i prawa cywilnego.

Ponieważ konieczne jest takie kształtowanie warunków każdego zatrudnienia, które umożliwia przeciwdziałanie ryzyku związanemu ze świadczeniem pracy, ustawodawca rozszerzył właściwe zatrudnieniu pracowniczemu uprawnienia osób świadczących pracę w ramach umownego zatrudnienia nietypowego w zakresie bhp na osoby zatrudnione na podstawie umów prawa cywilnego. Jest to uzasadnione zarówno aspektem społecznym, jak i pragmatycznym ${ }^{179}$, zgodnie z zasadą „lepiej zapobiegać niż zwalczać”. Koszty zwalczania następstw wypad-

177 Przejawianie troski o bhp uznać należy za obowiązek o mniejszym ciężarze rodzajowym aniżeli obowiązek zapewnienie bezpiecznych i higienicznych warunków pracy właściwy dla stosunku pracy i rozszerzony w art. $304 \S 1$ k.p. na stosunki cywilnoprawne. Ibidem, s. 175.

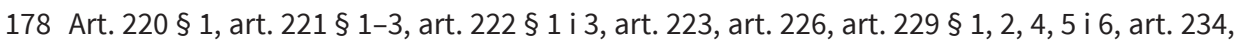
art. 235 , art. $237^{3}$, art. $237^{4} \mathrm{i}$ art. $237^{6} \S 1$ i 3 k.p.

179 T. Wyka, Bezpieczeństwo i ochrona zdrowia..., s. 165. 
ków przy pracy i chorób zawodowych mogą przewyższać nakłady poniesione na środki prewencyjne służące zachowaniu bezpieczeństwa i higieny pracy.

Analiza zróżnicowania statusu prawnego osób świadczących pracę w ramach umownego zatrudnienia nietypowego dokonana być może również w odniesieniu do ich uprawnień w zakresie podnoszenia kwalifikacji. Jest to uprawnienie pracowników stanowiące jedną z podstawowych zasad prawa pracy (art. 17 k.p.). Nie ma ono roszczeniowego charakteru. Informacyjnie wskazać można akty prawa międzynarodowego regulujące tę materię. Są to konwencje MOP z dnia 5 czerwca 1974 r. nr $140^{180}$ i z dnia 4 czerwca 1975 r. nr $142^{181}$. Natomiast akty prawa unijnego nie odnoszą się bezpośrednio do kształtowania obowiązku umożliwiania pracownikowi podnoszenia kwalifikacji, a jedynie wskazują na obowiązek równego traktowania w tym zakresie (dyrektywa nr 2000/78/WE).

Na gruncie zatrudnienia pracowniczego normy dotyczące uprawnień pracowników do podnoszenia kwalifikacji zawodowych ustanawiają przepisy art. 102$103^{6}$ k.p. Podnoszenie kwalifikacji zawodowych zdefiniowane zostało jako zdobywanie lub uzupełnianie wiedzy i umiejętności przez pracownika, następujące z inicjatywy pracodawcy lub za jego zgodą (art. $103^{1}$ k.p.). W określonych okolicznościach pracownikowi przysługuje urlop szkoleniowy albo zwolnienie z całości lub części dnia pracy. Obie te nieobecności traktowane są jako usprawiedliwione i pełnopłatne. Jeśli natomiast pracownik zdobywa lub uzupełnia wiedzę w innym trybie, pracodawca może mu przyznać zwolnienie z całości lub części pracy bez zachowania prawa do wynagrodzenia bądź urlop bezpłatny. Jak już wskazano, regulacje te mają charakter nieroszczeniowy. Pracodawca zobligowany jest jedynie do „ułatwienia” pracownikowi podnoszenia kwalifikacji zawodowych, co uznać należy za nakazywanie mu przyjęcia pewnej postawy, która znajduje swój wyraz w sposobie traktowania pracownika dokształcającego się ${ }^{182}$.

W zakresie uprawnień pracowników do podnoszenia kwalifikacji zawodowych nietypowo unormowany został status prawny pracowników tymczasowych. Ponieważ zgodnie z art. 15 ust. 1 z.p.t. pracownik tymczasowy nie może być traktowany w sposób mniej korzystny niż pracownicy zatrudnieni przez pracodawcę użytkownika, należałoby przyjąć, że to samo dotyczy dostępu pracowników tymczasowych do organizowanych przez pracodawcę użytkownika szkoleń w zakresie podnoszenia kwalifikacji zawodowych. Jednak zgodnie z art. 15 ust. 2 z.p.t. dyspozycją taką są objęci jedynie pracownicy tymczasowi wykonujący pracę na rzecz pracodawcy użytkownika przez okres co najmniej sześciotygodniowy. A contrario pracownicy tymczasowi wykonujący pracę na rzecz pracodawcy użyt-

180 Konwencja nr 140 dotycząca płatnego urlopu szkoleniowego, Dz.U. z 1979 r., Nr 16, poz. 100. 181 Konwencja nr 142 dotycząca roli poradnictwa i ksztatcenia zawodowego w rozwoju zasobów ludzkich, Dz.U. z 1979, Nr 29, poz. 164.

182 Ł. Pisarczyk, Obowiqzzek ułatwiania pracownikom podnoszenia kwalifikacji zawodowych, „Praca i Zabezpieczenie Społeczne” 2003, nr 4, s. 31. 
kownika przez okres krótszy nie muszą być uwzględnieni w planie szkoleniowym. Taki stan prawny uzasadniony jest istotą pracy tymczasowej jako zatrudnienia o krótkotrwałym, przejściowym charakterze. Dodatkowym argumentem na jego uzasadnienie jest fakt, że pracodawcy użytkownicy nie są zainteresowani inwestowaniem w pracowników, którzy pracują dla nich krótkotrwale ${ }^{183}$. Nie wydaje się jednak, o czym była już mowa w rozdziale drugim, aby regulacja art. 15 ust. 2 z.p.t. w pełni realizowała założenie o istotnej roli dokształcania, jako czynnika sprzyjającego spadkowi bezrobocia i wzrostowi gospodarczemu.

Z punktu widzenia osób świadczących pracę istotne są uprawnienia związane $\mathrm{z}$ rodzicielstwem. Ich posiadanie warunkuje możliwość opieki nad dzieckiem na różnych etapach jego rozwoju. Są one zróżnicowane względem osób świadczących pracę $\mathrm{w}$ ramach umownego zatrudnienia nietypowego w zależności od reżimu prawnego zatrudnienia. Prawo pracy gwarantuje wszystkim pracownikom, niezależnie od podstawy umownego zatrudnienia nietypowego, uprawnienia związane $\mathrm{z}$ rodzicielstwem o rozbudowanej strukturze. Nie są to jedynie uprawnienia przysługujące po narodzinach dziecka, ale także te przysługujące pracownicom $\mathrm{w}$ okresie ciąży, jak ochrona przed pracą $\mathrm{w}$ godzinach nadliczbowych, w porze nocnej (art. $178 \$ 1$ k.p.) bądź zakaz wykonywania określonych prac (art. 179 k.p.). Uprawnienia rodziców związane są z kolei z koniecznością opieki nad dzieckiem nowo narodzonym bądź, w przypadku adopcji, nowo przyjętym do rodziny. Uprawnienia związane z rodzicielstwem obejmują swoim zakresem również opiekę nad dzieckiem w okresie dzieciństwa - jednemu z rodziców przysługują 2 dni pełnopłatnego zwolnienia od pracy w przypadku wychowywania dziecka do 14 roku życia (art. 188 k.p.). W związku z nowelizacją kodeksu pracy z 24 lipca 2015 r. od 2 stycznia 2016 r. uprawnienie to obejmuje 16 godzin albo $2 \mathrm{dni}^{184}$. Przyznając uprawnienia związane $\mathrm{z}$ rodzicielstwem, prawo pracy spełnia potrzeby osób pracujących, posiadających dzieci ${ }^{185}$, pozwalając wypełniać obowiązki wobec nich.

W pełnym zakresie powyższe uprawnienia nie przysługują osobom wykonującym pracę na podstawie umów prawa cywilnego. To w konsekwencji powoduje, że nie wszystkim dzieciom przysługują jednakowe uprawnienia do „bycia zaopiekowanymi” ${ }^{186}$. Istniejące regulacje nie przewidywały możliwości dzielenia się uprawnieniami związanymi z opieką nad dzieckiem w przypadku gdy jedno $\mathrm{z}$ rodziców dziecka posiadało status pracownika, drugie natomiast było objęte

183 M. Moszyński, Praca tymczasowa - aspekty ekonomiczne i zatrudnieniowe, „Praca i Zabezpieczenie Społeczne" 2004, nr 10, s. 10.

184 Ustawa z dnia 24 lipca 2015 r. o zmianie ustawy - Kodeks pracy oraz niektórych innych ustaw, Dz.U. z 2015 r., poz. 1268.

185 I. Boruta, Podmioty prawa do urlopu wychowawczego i innych „rodzicielskich” praw pracowniczych, „Praca i Zabezpieczenie Społeczne” 1997, nr 2, s. 34.

186 A. Sobczyk, Prawo dziecka do opieki rodziców jako uzasadnienie dla urlopu i zasitku macierzyńskiego, „Praca i Zabezpieczenie Społeczne” 2015, nr 9, s. 16. 
ubezpieczeniem społecznym w razie choroby i macierzyństwa na innej podstawie niż stosunek pracy. Powyższe było jednym z powodów nowelizacji kodeksu pracy dokonanej mocą ustawy z 24 lipca 2015 r. ${ }^{187}$ Przepis art. $175^{1}$ k.p. wprowadza definicje ułatwiające określenie zakresu podmiotowego stosowania przepisów $\mathrm{o}$ uprawnieniach związanych z rodzicielstwem. Ubezpieczoną - matką dziecka, zgodnie $\mathrm{z}$ art. $175^{1}$ pkt 1 k.p., jest matka dziecka niebędąca pracownicą, objęta ubezpieczeniem społecznym $\mathrm{w}$ razie choroby i macierzyństwa zgodnie $\mathrm{z}$ ustawą o systemie ubezpieczeń społecznych ${ }^{188}$. Ustawa ta $\mathrm{w}$ art. 11 wskazuje, poprzez odesłanie do art. 6 ust. 1 pkt 2, 4, 5, 8, 10, podmioty objęte takim ubezpieczeniem dobrowolnie. W zakresie omawianych zagadnień istotne jest, że są to osoby wykonujące pracę nakładczą (pkt 2) oraz osoby wykonujące pracę na podstawie umowy agencyjnej lub umowy zlecenia albo innej umowy o świadczenie usług, do której zgodnie z kodeksem cywilnym stosuje się przepisy dotyczące zlecenia, jeżeli nie są one uczniami gimnazjów, szkół ponadgimnazjalnych, szkół ponadpodstawowych lub studentami, do ukończenia 26 lat (pkt $2 \mathrm{w}$ zw. $\mathrm{z}$ art. 6 ust. 4). Wskazany katalog podmiotów odnosi się również do sformułowanej w art. $175^{1}$ pkt 2 k.p. definicji ubezpieczonego - ojca dziecka ${ }^{189}$. Spośród osób świadczących pracę $w$ ramach umownego zatrudnienia cywilnoprawnego obecnie jedynie wykonawcy umowy o dzieło nie są objęci regulacją kodeksu pracy w zakresie uprawnień związanych z rodzicielstwem, bowiem osoby te nie są objęte ubezpieczeniem społecznym $w$ razie choroby i macierzyństwa.

$\mathrm{W}$ zatrudnieniu nakładczym, zgodnie z $\$ 18$ ust. 1 rozp. pr. nakład., kobiecie wykonującej pracę nakładczą przysługuje urlop macierzyński w wymiarze i na zasadach określonych w kodeksie pracy. Dodatkowo $\$ 18$ ust. 2 rozp. pr. nakład. nakazuje do pracy nakładczej odpowiednie stosowanie przepisów art. 181-184 i 185 $\$ 1$ k.p. W związku z powyższym do pracy nakładczej znajdą zastosowanie m.in. przepisy dotyczące urlopu wychowawczego czy uprawnień związanych z przyjęciem przez pracownika dziecka na wychowanie. Ponieważ jednak przepis $\$ 18$ ust. 1 rozp. pr. nakład. przyznaje prawo do urlopu macierzyńskiego wyłącznie kobiecie, wydaje się, że wskazane do odpowiedniego stosowania przepisy kodeksu pracy dotyczą również wyłącznie kobiet wykonujących pracę nakładczą. Ponieważ na gruncie kodeksu pracy mężczyznom przyznano szereg uprawnień związanych z urlopami rodzicielskimi, wydaje się, że mężczyźni wykonujący pracę nakładczą również powinni z nich korzystać. Kobiety wykonujące pracę nakładczą w okresie ciąży objęto ponadto ochroną $\mathrm{w}$ zakresie zakazu wykonywania prac wzbronionych kobietom w ciąży ( $\$ 20$ rozp. pr. nakład.).

187 Uzasadnienie do projektu ustawy: http://orka.sejm.gov.pl/Druki7ka.nsf/0/BD8D1DA496E82AFEC1257E21003718F3/\%24File/3288.pdf, s. 14, (dostęp: 6.01.2017).

188 Ustawa z dnia 13 października 1998 r., Dz.U. z 2016 r. poz. 963 - t.j. ze zm.

189 Celowo w rozważaniach pomijam zagadnienia związane z możliwością sprawowania opieki nad dzieckiem przez innych członków rodziny. Są to bowiem uprawnienia o charakterze pochodnym. 
Rozszerzanie uprawnień związanych z rodzicielstwem na osoby niebędące pracownikami, ubezpieczone w zakresie ubezpieczenia chorobowego, obejmuje kilka stanów faktycznych. Po pierwsze chodzi o sytuacje, w których pracownica wykorzystuje część urlopu macierzyńskiego, przez okres pozostały do końca jego trwania osobistą opiekę nad dzieckiem sprawować ma ubezpieczony - ojciec dziecka, który w tym celu przerywa działalność zarobkową (art. $180 \$ 4$ pkt 2; $\$ 6$ pkt 2; $\$ 10$ pkt 2 k.p.). Po drugie urlop macierzyński przysługuje pracownikom-ojcom, pomimo że matka dziecka nie posiadała statusu pracowniczego, ale podlegała ubezpieczeniu w zakresie ubezpieczenia chorobowego (art. $180 \$ 5$, $\S 7, \S 11, \S 12, \S 13$ k.p.). Zarówno pracownik - ojciec wychowujący dziecko, jak i pracownik inny członek najbliższej rodziny mają na mocy art. $180 \$ 15$ k.p. prawo do skorzystania z urlopu bądź zasiłku macierzyńskiego nawet w przypadku gdy matka nie była objęta ubezpieczeniem. Ponieważ, zgodnie z art. $182^{\text {lf }}$ k.p., do urlopu rodzicielskiego stosuje się odpowiednio przepisy art. $180 \$ 6-12$ k.p., ubezpieczony - ojciec dziecka ma uprawnienie do zasiłku macierzyńskiego za okres niewykorzystanego przez pracownicę urlopu rodzicielskiego (w okolicznościach wskazanych w art. $180 \$ 10$ pkt 2 k.p.), zaś pracownik - ojciec wychowujący dziecko będzie mógł skorzystać z tego urlopu rodzicielskiego, gdy ubezpieczona - matka dziecka nie wykorzysta całości zasiłku macierzyńskiego za okres urlopu rodzicielskiego, zgodnie z art. $180 \$ 7, \S 11, \S 12, \S 13$ k.p.

Ochrona związana z rodzicielstwem nie powinna ograniczać się jedynie do stosunków zatrudnienia pracowniczego. Dlatego zmiany w tym zakresie uznać należy za społecznie uzasadnione. Prawo powinno wspierać wszystkie osoby posiadające dzieci ${ }^{190}$. Dobrem ogólnospołecznym jest stworzenie rodzicom prawnie przyjaznych warunków do posiadania dzieci i opieki nad nimi, a przepisy prawa zatrudnienia są w tym przypadku jedną z części składowych szerokiego rozwiązania systemowego w ramach polityki społecznej. W tym przypadku rozszerzenie instytucji właściwych dla prawa pracy na stosunki cywilnoprawne uzasadnione jest ochroną wyższych dóbr - dobra dziecka i rodzicielstwa. Nie ma przy tym znaczenia fakt, że obecnie sami pracownicy rzadziej niż kiedyś korzystają z uprawnień rodzicielskich ${ }^{191}$. Inną kategorią prawną jest bowiem posiadanie określonych uprawnień, a inną rzeczywiste korzystanie z nich.

190 Przed nowelizacją prawo wspierało w tym zakresie głównie zatrudnionych posiadających status pracowników. Omówienie tego zagadnienia przedstawiła I. Boruta, op. cit., s. 34.

191 Zgodnie z Rocznikiem Statystycznym Rzeczpospolitej Polskiej 2014 różnica pomiędzy przeciętną liczbą wypłacanych świadczeń z tytułu opieki nad dzieckiem w okresie korzystania z urlopu wychowawczego zmalała ze 140 tys. w 2005 r. do 68,5 tys. w roku 2013. Oznacza to zmniejszoną liczbę osób korzystających z urlopu wychowawczego uprawniającego do świadczeń z tytułu opieki nad dzieckiem. Główny Urząd Statystyczny, www.stat.gov.pl/obszary-tematyczne/roczniki-statystyczne/roczniki-statystyczne/rocznik-statystyczny-rzeczypospolitej-polskiej-2014,2,9.html, s. 289 (dostęp: 6.01.2017). 
Warto wskazać na jeszcze jedną regulację kreującą sytuację prawną osób świadczących pracę w ramach umownego zatrudnienia nietypowego z perspektywy ich uprawnień. Wiąże się ona $\mathrm{z}$ przestrzeganiem prawa zatrudnienia, a konkretnie z uprawnieniami kontrolnymi Państwowej Inspekcji Pracy. Do obowiązków PIP należy przede wszystkim nadzór i kontrola przestrzegania prawa pracy (art. 1 ustawy o PIP). Z przywołanego przepisu in fine wynika, że Państwowa Inspekcja Pracy sprawuje nadzór i kontrolę również nad przestrzeganiem przepisów dotyczących legalności innej pracy zarobkowej. Przepis art. 10 ust. 1 pkt 3 ustawy o PIP potwierdza ten stan rzeczy. Pojęcia „zatrudnienie i inna praca zarobkowa” definiowane powinny być w odniesieniu do ustawy o promocji zatrudnienia i instytucjach rynku pracy ${ }^{192}$. Zgodnie $\mathrm{z}$ art. 2 ust. 11 tej ustawy inną pracą zarobkową jest wykonywanie pracy lub świadczenie usług na podstawie umowy prawa cywilnego. Jednak do 1 stycznia 2017 r. ustawa o Państwowej Inspekcji Pracy nie stanowiła o jej nadzorze i kontroli nad świadczeniem umów przynależnych reżimowi prawa cywilnego. Dotyczyła ona jedynie kontroli legalności tego rodzaju zatrudnienia. W zakresie wykraczającym poza obszar prawa pracy Państwowa Inspekcja Pracy mogła badać jedynie legalność zatrudnienia cywilnoprawnego. Ustawa z dnia 22 lipca 2016 r. o zmianie ustawy o minimalnym wynagrodzeniu za pracę oraz niektórych innych ustaw znowelizowała przepis art. 13 ustawy o PIP poprzez dodanie w pkt. 5 możliwości dokonywania kontroli wobec przedsiębiorców albo innych jednostek organizacyjnych, na rzecz których w ramach prowadzonej przez te podmioty działalności jest wykonywane zlecenie lub są świadczone usługi przez przyjmującego zlecenie lub świadczącego usługi. Kontrola taka obejmuje swoim zakresem wypłacanie wynagrodzenia w wysokości wynikającej $\mathrm{z}$ wysokości minimalnej stawki godzinowej.

Z przytoczonych w niniejszym rozdziale uwag wynika, że część przepisów prawa pracy znajduje zastosowanie do pozapracowniczych stosunków zatrudnienia cywilnoprawnego. Przestrzeganie tych norm może kontrolować inspektor PIP, co dodatkowo potwierdza, w odniesieniu do bhp, redakcja art. 10 ust 2 pkt 1 i art. 13 pkt 1 ustawy o PIP ${ }^{193}$. Inspektor PIP nie ma natomiast kompetencji kontrolnych w zakresie np. terminowości wypłacania wynagrodzenia osobie

192 D. Makowski, Nowa ustawa o Państwowej Inspekcji Pracy, „Praca i Zabezpieczenie Społeczne" 2007, nr 6, s. 16.

193 W odniesieniu do przedmiotu analizy istotne jest, że art. 10 ust. 2 pkt 1 ustawy o PIP wskazuje, że do jej zadań należy nadzór i kontrola zapewnienia bezpiecznych i higienicznych warunków pracy osobom fizycznym wykonującym pracę na innej podstawie niż stosunek pracy oraz w miejscu wyznaczonym przez pracodawcę lub przedsiębiorcę, niebędącego pracodawcą, na rzecz którego taka praca jest świadczona. Natomiast zgodnie z art. 13 pkt 1 ww. ustawy kontroli PIP w zakresie bezpieczeństwa i higieny pracy podlegają pracodawcy oraz niebędący pracodawcami przedsiębiorcy i inne jednostki organizacyjne, na rzecz których jest świadczona praca przez osoby fizyczne, bez względu na podstawę świadczenia tej pracy. 
zatrudnionej na podstawie umowy prawa cywilnego. Kontroli podlega bowiem jedynie przestrzeganie przepisów prawa pracy. Jeśli przepisy prawa pracy obejmują swoim zakresem zatrudnienie cywilnoprawne (jak w przypadku bhp), to kompetencje Inspektora Pracy dotyczą kontroli ich przestrzegania. Ponieważ rozporządzenie w sprawie uprawnień pracowniczych osób wykonujących pracę nakładczą nie stanowi źródła prawa pracy, inspektor pracy może kontrolować warunki wykonywania pracy nakładczej tylko w zakresie objętym normą art. 13 pkt 1 ustawy o PIP oraz w odniesieniu do regulacji odsyłających do przepisów prawa pracy. Uprawnienia Inspekcji Pracy nie sięgają tam, gdzie rozporządzenie samodzielnie kreuje sytuację podmiotów pracy nakładczej, nie odsyłając do uregulowań prawa pracy.

W zakresie możliwości nadzoru nad przestrzeganiem prawa korzystniej unormowana została sytuacja prawna osób świadczących pracę w ramach zatrudnienia pracowniczego aniżeli cywilnoprawnego. Wydaje się, że powodem takiego stanu rzeczy jest odrębność systemowa prawnopracowniczych i cywilnoprawnych podstaw zatrudnienia. Założenie o słabszej pozycji pracowników względem pracodawców uzasadnia wzmożoną dbałość ustawodawcy o ochronę ich praw.

Uprawnieniem, które warto wskazać w końcowej fazie rozważań, jest obowiązek zaspokajania przez podmiot zatrudniający potrzeb bytowych, socjalnych i kulturalnych osób świadczących pracę w ramach umownego zatrudnienia nietypowego. Jest ono istotne nie tyle ze względu na obwarowanie jego niewykonania sankcjami ${ }^{194}$, ile ze względu na normatywne umiejscowienie go pośród podstawowych zasad prawa pracy (art. 16 k.p.). Wydaje się zatem, że ustawodawca przypisuje mu istotną rolę, przynajmniej w odniesieniu do zatrudnienia pracowniczego. W art. 94 pkt 8 k.p. zaspokajanie, w miarę posiadanych środków, socjalnych potrzeb pracowników zostało wskazane jako jeden $\mathrm{z}$ obowiązków pracodawcy. Bez wątpienia uprawnienie pracowników dotyczące zaspokajania przez pracodawcę, stosownie do możliwości i warunków, potrzeb bytowych, socjalnych i kulturalnych dotyczy wszystkich pracowników, bez względu na rodzaj zawartej umowy o pracę lub jej formę organizacyjną. Pomimo to ustawodawca zdecydował się $\mathrm{w}$ art. $67^{16} \mathrm{k}$.p. określić, że pracodawca umożliwia telepracownikowi m.in. korzystanie z zakładowych obiektów socjalnych i prowadzonej działalności socjalnej. W tym zakresie telepracownik nie może być traktowany inaczej niż ogół pracowników. Ponieważ telepracownik jest, z istoty pracy wykonywanej wyłącznie bądź także poza zakładem pracy, pozbawiony możliwości bieżącego korzystania z obiektów socjalnych i prowadzonej działalności socjalnej, ustawodawca podkreślił w art. $67^{16}$ k.p., że jego uprawnienia w tym zakresie nie są ograniczone. Uszczegółowieniem uprawnień pracowników w omawianym kontekście jest ustawa z dnia 4 marca 1994 r. o zakładowym funduszu świad-

194 Zasadniczo bezsankcyjny charakter omawianego przepisu potwierdził Sąd Najwyższy w wyroku z dnia 15 lipca 1987 r., I PRN 25/87, LEX nr 13048. 
czeń socjalnych ${ }^{195}$. Na gruncie przepisów prawa pracy jej stosowanie w obrębie omawianej tematyki może powodować wątpliwości w odniesieniu do pracy tymczasowej. Wątpliwości te dotyczą zakresu podmiotowego objętego wskazaną regulacją. Skoro jednak obowiązek zaspokajania potrzeb bytowych, socjalnych i kulturalnych został przez ustawodawcę zakwalifikowany jako jedna z podstawowych zasad prawa pracy, nie wydaje się uzasadnione obarczanie nim pracodawcy użytkownika ${ }^{196}$.

Umowy cywilnoprawne (umowa o pracę nakładczą ${ }^{197}$, umowa zlecenia, umowy o świadczenie usług, do których stosuje się przepisy o zleceniu, umowa agencyjna i umowa o dzieło) ze względu na swoją odrębność systemową nie są objęte uprawnieniem osób świadczących pracę do zaspokajania przez podmioty zatrudniające ich potrzeb bytowych, socjalnych i kulturalnych. Wydaje się, że takie zróżnicowanie statusu prawnego osób świadczących pracę w ramach umownego zatrudnienia nietypowego jest uzasadnione. Inne założenia systemowe, które nie wiążą się z wielopłaszczyznowymi powiązaniami podmiotów stosunku zatrudnienia, jak ma to miejsce w zatrudnieniu pracowniczym, wydają się uzasadniać brak uprawnień osób świadczących pracę w ramach umownego zatrudnienia cywilnoprawnego do zaspokajania przez podmiot zatrudniający ich potrzeb bytowych, socjalnych i kulturowych.

Uprawnienia osób świadczących pracę w ramach umownego zatrudnienia nietypowego są wewnętrznie zróżnicowane. Wynika to (w odniesieniu do relacji prawnopracowniczych i cywilnoprawnych) z odrębnych założeń systemowych oraz (w odniesieniu do telepracy i zatrudnienia tymczasowego) ze szczególnych warunków świadczenia pracy. Wydaje się, że w przeważającej większości obowiązujące odmienności są uzasadnione. Forma organizacyjna umownego zatrudnienia pracowniczego - telepraca, z uwagi na fakt świadczenia pracy wyłącznie bądź także poza zakładem pracy, wymusza odmienne regulacje w zakresie bezpieczeństwa i higieny pracy. To na tej płaszczyźnie sytuacja prawna telepracownika najbardziej różni się od sytuacji pracownika zatrudnionego typowo. Zatrudnienie tymczasowe, w którym obowiązki pracodawcy wykonują dwa podmioty, warunkuje inne niż typowe rozłożenie ich zakresu w odniesieniu do podmiotu odpowiedzialnego za zapewnienie bezpieczeństwa i higieny pracy. To z kolei wpływa na uprawnienia pracowników tymczasowych. Z natury krótkotrwały charakter

195 Ustawa z dnia 4 marca 1994 r. o zakładowym funduszu świadczeń socjalnych, Dz.U. z 2016 r., poz. 800 - t.j. ze zm.

196 A. Sobczyk, Zatrudnienie pracowników tymczasowych, „Praca i Zabezpieczenie Społeczne” 2004, nr 4, s. 39.

197 Przepis $\S 13$ rozp. pr. nakład. stanowit, że nakładca powinien przejawiać troskę o zaspokajanie bytowych, socjalnych i kulturalnych potrzeb wykonawców pracy nakładczej. Został on jednak skreślony Rozporządzeniem Rady Ministrów z dnia 28 maja 1996 r., zmieniającym rozporządzenie w sprawie uprawnień pracowniczych osób wykonujących pracę nakładczą, Dz.U. Nr 60, poz. 280. 
pracy tymczasowej zdaje się również uzasadniać odmienne od typowych regulacje związane $z$ urlopem wypoczynkowym oraz uprawnieniami do podnoszenia kwalifikacji zawodowych. Natomiast niezależny charakter pracy świadczonej na podstawie umów prawa cywilnego (umowy zlecenia, umów o świadczenie usług, do których stosuje się przepisy o zleceniu, umowy agencyjnej i umowy o dzieło) czyni niezbędnym odmienne od typowego ukształtowanie sytuacji prawnej osób świadczących pracę w obrębie ich uprawnien. Osoby te korzystają z ochrony wynagrodzenia $\mathrm{w}$ stopniu mniejszym aniżeli pracownicy. Wydaje się, że powinny one mieć natomiast zapewnione bezpieczne i higieniczne warunki pracy w stopniu zbliżonym do gwarancji pracowniczych. Zdrowie wszystkich osób świadczących pracę ma bowiem taką samą wartość.

Nieprzyznanie prawa do wypoczynku osobom zatrudnionym na podstawie umowy zlecenia, umów o świadczenie usług, do których stosuje się przepisy o zleceniu, umowy agencyjnej i umowy o dzieło jest konsekwencją braku ich podporządkowania co do czasu pracy. Skutkuje to samodzielnym organizowaniem przez osoby zatrudnione okresów pracy i odpoczynku. W odniesieniu do tej kategorii podmiotów dobrym kierunkiem zmian legislacyjnych wydaje się natomiast uwzględnienie ich $\mathrm{w}$ kręgu podmiotów, którym prawo przyznaje uprawnienia związane z rodzicielstwem. Świadczenie pracy niepodporządkowanej nie wyklucza bowiem potrzeby i konieczności sprawowania osobistej opieki nad dzieckiem. $\mathrm{W}$ zakresie uprawnień osób świadczących pracę $\mathrm{w}$ ramach cywilnoprawnego zatrudnienia umownego odmiennie ukształtowana jest sytuacja prawna osób wykonujących pracę nakładczą. Przyznanie im szerokich uprawnień w obrębie ochrony wynagrodzenia, prawa do wypoczynku czy uprawnień związanych z rodzicielstwem odzwierciedla właściwości tej podstawy zatrudnienia stanowiącej kompromis pomiędzy interesami osoby świadczącej pracę a jej (pracy) niepodporządkowanym charakterem.

\subsection{Odpowiedzialność stron umownego zatrudnienia nietypowego}

\subsubsection{Uwagi wprowadzające}

Konieczność omówienia odpowiedzialności stron umownego stosunku zatrudnienia nietypowego wynika $\mathrm{z}$ faktu, że wpływa ona na ukształtowanie pozycji prawnej osób świadczących pracę $\mathrm{w}$ ramach umownego zatrudnienia nietypowego. Odpowiedzialność tę kreują unormowania dotyczące odpowiedzialności osób świadczących pracę oraz odpowiedzialności podmiotów zatrudniających. To wła- 
śnie regulacje dotyczące tej ostatniej kwestii umożliwiają określenie uprawnień przysługujących osobom zatrudnionym w zakresie dochodzonych roszczeń i realizacji praw. Wskazują one również krąg podmiotów odpowiedzialnych za przestrzeganie przepisów o charakterze karnoprawnym, konkretyzując przy tym podlegające ochronie wartości. Przyznanie określonych praw osobom świadczącym pracę $\mathrm{w}$ ramach umownego zatrudnienia nietypowego pociąga za sobą powstanie obowiązków ich realizacji przez podmioty zatrudniające oraz odpowiedzialności za ich niewykonanie. Analiza zakresu odpowiedzialności zarówno osób zatrudnionych w ramach umownego zatrudnienia nietypowego, jak i podmiotów je zatrudniających pozwoli określić ewentualne różnice w ich sytuacji prawnej, które następnie będą poddane ocenie z punktu widzenia systemowych uwarunkowań i zasadności.

\subsubsection{Odpowiedzialność osób świadczących pracę w ramach umownego zatrudnienia nietypowego}

Odpowiedzialność osób świadczących pracę w ramach umownego zatrudnienia nietypowego związana jest z zakresem nałożonych na nie obowiązków. W warunkach zatrudnienia pracowniczego jest to odpowiedzialność porządkowa i materialna ${ }^{198}$. Odpowiedzialność materialną, właściwą dla stosunku pracy, ponoszą również wykonawcy pracy nakładczej ${ }^{199}$. Natomiast osoby świadczące pracę na podstawie pozostałych umów prawa cywilnego (umowy zlecenia, umów o świadczenie usług, do których stosuje się przepisy o zleceniu, umowy agencyjnej i umowy o dzieło) podlegają odpowiedzialności cywilnej z tytułu deliktu (art. 415 k.c.) oraz z tytułu niewykonania bądź nienależytego wykonania zobowiązania (art. 471 i nast. k.c.). Ponieważ wszystkie osoby świadczące pracę podlegają takiej samej odpowiedzialności karnej, ta płaszczyzna regulacji nie wymaga omówienia, bowiem nie różnicuje pozycji prawnej osób zatrudnionych.

Celem regulacji prawnych dotyczących pracowniczej odpowiedzialności porządkowej (art. 108-113 k.p.) jest przeciwdziałanie występowaniu przejawów braku dyscypliny wśród pracowników ${ }^{200}$. Odpowiedzialność ta nie ma charakteru

198 Dodatkowo należy wymienić odpowiedzialność dyscyplinarną, która występuje w zatrudnieniu pracowniczym pozaumownym. Wyraźne rozgraniczenie odpowiedzialności porządkowej i dyscyplinarnej potwierdza Z. Góral, Odpowiedzialność porządkowa pracowników w świetle najnowszego orzecznictwa sq̨dowego, „Praca i Zabezpieczenie Społeczne” 2002, nr 11, s. 31-32.

199 Przepis § 30 rozp. pr. nakład. odsyła do stosowania względem pracy nakładczej art. 114127 k.p., czyli całości regulacji dotyczącej pracowniczej odpowiedzialności materialnej.

200 M. Święcicki, op. cit., s. 364. W. Szubert wskazywał ponadto, że odpowiedzialność porządkowa stanowi dolegliwość moralną bądź materialną, pozwalającą pracodawcy reagować na uchybienia pracownika. W. Szubert, Zarys prawa pracy..., s. 176. 
kompensacyjnego ${ }^{201}$. Pracownicy ponoszą odpowiedzialność porządkową $\mathrm{w}$ formie kar porządkowych (sankcji) w sytuacji niedopełnienia określonych w kodeksie pracy obowiązków o charakterze porządkowym ${ }^{202}$. Do tych obowiązków należą: przestrzeganie ustalonej organizacji i porządku w procesie pracy, przestrzeganie przepisów dotyczących bezpieczeństwa i higieny pracy, przestrzeganie przepisów przeciwpożarowych, a także przestrzeganie przyjętego sposobu potwierdzania przybycia i obecności w pracy oraz usprawiedliwiania nieobecności (art. $108 \$ 1$ k.p.). Dodatkowo do norm o charakterze porządkowym kodeks pracy zalicza zakaz opuszczania pracy bez usprawiedliwienia, zakaz stawienia się do pracy w stanie nietrzeźwości oraz zakaz spożywania alkoholu w czasie pracy (art. 108 $\$ 2$ k.p.). Stosownie do rodzaju naruszenia i stopnia winy pracodawca może zastosować karę upomnienia bądź nagany, a w przypadku przekroczeń porządkowych wymienionych w art. $108 \$ 2$ k.p. - nałożyć na pracownika karę pieniężną.

Pracownicza odpowiedzialność porządkowa jest jednolicie ukształtowana dla wszystkich osób świadczących pracę w ramach umownego stosunku pracy, bez względu na jego podstawę prawną i formę organizacyjną. W przypadku zatrudnienia $\mathrm{w}$ formie telepracy telepracownika obowiązują takie same jak w przypadku zatrudnienia typowego obowiązki o charakterze porządkowym, jednak weryfikacja ich realizacji jest znacznie trudniejsza. Dla przykładu, pracodawca ma ograniczoną możliwość stwierdzenia, czy telepracownik stawił się do pracy w stanie nietrzeźwości. Jeśli telepracownik świadczy pracę w domu, kontrola w tym zakresie odbywa się za jego uprzednią zgodą, której może w danym momencie nie wyrazić (art. $67^{14} \$ 1$ pkt 3 k.p.). Natomiast w przypadku świadczenia pracy poza zakładem pracy w miejscu innym niż dom pracownika pracodawca może co prawda dokonać kontroli w każdym momencie, jednakże w praktyce nie zawsze dysponuje odpowiednimi możliwościami organizacyjnymi. Nie ulega wątpliwości, że znacznie łatwiej jest kontrolować pracownika świadczącego pracę w zakładzie pracy.

Pewne trudności w wymierzaniu kar porządkowych mogą również zaistnieć w przypadku pracy tymczasowej. W literaturze wskazuje się, że podmiotem, który ocenia fakt przekroczenia porządkowego i jego ciężar rodzajowy jest pracodawca użytkownik. Natomiast podmiotem uprawnionym do nałożenia kary porządkowej jest agencja pracy tymczasowej jako pracodawca ${ }^{203}$. Dlatego też w celu nało-

201 W. Sanetra, Kilka uwag o pojęciu odpowiedzialności w prawie pracy, „Praca i Zabezpieczenie Społeczne" 2007, nr 11, s. 4.

202 W. Jaśkiewicz, C. Jackowiak, W. Piotrowski, op. cit., s. 269. J. Nowacki wskazywał, że odpowiedzialność porządkowa uzupełnia działania kierownictwa zakładu pracy w zakresie organizacji pracy oraz środków zachęty. J. Nowacki, Odpowiedzialność pracownika za naruszenie porządku i dyscypliny pracy, [w:] R. Korolec, J. Pacho (red.), op. cit., s. 473.

203 M. Paluszkiewicz, Wnioski, [w:] M. Paluszkiewicz, Zatrudnienie tymczasowe w polskim prawie pracy, https://sip-1lex-1pl-1004153yx0cd3.han3.lib.uni.lodz.pl/\#/monografia/369234447/33 (dostęp: 17.09.2017). Przeciwnie: D. Makowski, Praca tymczasowa jako nietypowa forma 
żenia kary porządkowej na pracownika tymczasowego pracodawca użytkownik powinien powiadomić agencję pracy tymczasowej o fakcie popełnienia przez pracownika tymczasowego przekroczenia porządkowego. Następnie agencja pracy tymczasowej powinna zbadać okoliczności rzekomego przekroczenia porządkowego i, przy uznaniu ich zasadności, wysłuchać pracownika w trybie art. 109 k.p. Dopiero wtedy agencja pracy tymczasowej uprawniona jest do nałożenia kary porządkowej. Wątpliwości mogą natomiast powstać w przypadku badania podmiotu objętego hipotezą art. 109 k.p. w części dotyczącej powzięcia wiadomości o naruszeniu obowiązku pracowniczego przez pracownika tymczasowego. Chwila ta rozpoczyna bowiem bieg dwutygodniowego terminu a tempore scientae do nałożenia kary porządkowej. Ponieważ podmiotem uprawnionym do nałożenia kary porządkowej jest agencja pracy tymczasowej, to jej dotyczy hipoteza omówionej normy w przypadku naruszenia obowiązków o charakterze porządkowym przez pracownika tymczasowego. Opieszałość pracodawcy użytkownika w powiadomieniu agencji pracy tymczasowej o zaistnieniu takiego zdarzenia nie wyłącza możliwości ukarania pracownika tymczasowego karą porządkową, o ile stanie się to nie później niż po dwóch tygodniach od powzięcia przez agencję wiadomości o naruszeniu i nie później niż 3 miesiące od zdarzenia (art. $109 \$ 1$ k.p.).

Odpowiedzialność porządkowa jest właściwa dla zatrudnienia pracowniczego i nie obejmuje swoim zakresem umów zawieranych w reżimie prawa cywilnego ${ }^{204}$. Zatrudnienie cywilnoprawne nie wymaga dbałości o dyscyplinę organizacyjną, bowiem w obrębie autonomii działania osoba zatrudniona powinna się w tym względzie dyscyplinować samodzielnie. Jednak w pewnym obszarze regulacja ta nie wydaje się wystarczająca. Skoro bowiem osoby świadczące pracę na podstawie umów prawa cywilnego mogą ją świadczyć w kooperacji z pracownikami i skoro pracodawca (lub inny podmiot organizujący pracę) ma względem nich obowiązek zapewnienia bezpiecznych i higienicznych warunków pracy (któremu odpowiada obowiązek przestrzegania przepisów bhp - art. $304^{1}$ k.p.), brak możliwości egzekwowania od wszystkich osób świadczących pracę w ramach umownego zatrudnienia nietypowego przestrzegania przepisów dotyczących bhp nie wydaje się uzasadniony odrębnościami systemowymi poszczególnych podstaw zatrudnienia.

zatrudnienia, Warszawa 2006, s. 120-122. Autor zauważa, że nakładanie kar porządkowych związane jest z organizowaniem procesu pracy, co należy do zadań pracodawcy użytkownika. Przyjęcie takiego stanowiska stwarza jednak, zdaniem samego jego autora, pewne problemy interpretacyjne. Pracodawca użytkownik, nakładając karę porządkową i tak musiałby w nieokreślonym zakresie współdziałać z agencją pracy tymczasowej jako dysponentem akt osobowych pracownika tymczasowego, w których umieszcza się odpis zawiadomienia o nałożeniu kary (art. 110 k.p. in fine). Druga wątpliwość dotyczy wpływu z kar porządkowych. Ustawodawca, nierozstrzygając, który z podmiotów pracy tymczasowej może nakładać kary porządkowe, pozostawit lukę prawną w zakresie przeznaczenia środków uzyskanych z ich nałożenia (art. 108 § 4 k.p.). Nie wiadomo bowiem, czy środki te miatyby poprawiać warunki bhp u pracodawcy użytkownika, czy w agencji pracy tymczasowej.

204 E. Staszewska, Odpowiedzialność pracownicza, Warszawa 2013, s. 18. 
Osoba świadcząca pracę na podstawie umowy prawa cywilnego swoim działaniem bądź zaniechaniem, powodującym naruszenie przepisów bhp, może nie tylko wyrządzić szkodę sobie, ale również innym osobom, z którymi pracuje, w tym pracownikom. Wobec braku możliwości egzekwowania od wszystkich osób zatrudnionych obowiązku przestrzegania przepisów bhp, pracodawca ma ograniczoną możliwość realizacji swojego obowiązku w postaci zapewnienia bezpieczeństwa i higieny pracy. Jego pełna realizacja ma bowiem miejsce tylko wtedy, gdy podmiot odpowiedzialny za zapewnienie bhp ma środki, aby wymagać zachowania bezpieczeństwa i higieny pracy od wszystkich osób pracujących razem, bez względu na podstawę prawną tej pracy. Brak wynikających bezpośrednio z przepisów prawa możliwości egzekwowania przestrzegania przepisów bhp od osób świadczących pracę w reżimie prawa cywilnego nie wyłącza możliwości umownego zastrzeżenia obowiązku ich przestrzegania oraz sankcji za jego niewypełnienie. Wprowadzenie do umowy takich postanowień pozostaje $\mathrm{w}$ zbieżności nie tylko $\mathrm{z}$ interesem podmiotu zatrudniającego oraz zatrudnianych przez niego pracowników, ale również z interesem osoby, której dotyczy obowiązek i jego sankcjonowanie. Powyższe mobilizuje ją bowiem do przestrzegania norm prawnych chroniących przede wszystkim jej zdrowie i życie. Jeśli do umowy zostaną wprowadzone odpowiednie postanowienia zobowiązujące do przestrzegania określonych przepisów i zasad w zakresie bhp (art. $304^{1}$ k.p. w zw. art. 211 k.p.), nieprzestrzeganie ich przez osobę świadczącą pracę na podstawie umowy prawa cywilnego może w konsekwencji doprowadzić do jej rozwiązania albo do powstania odpowiedzialności odszkodowawczej za nienależyte wykonanie zobowiązania na podstawie art. 471 k.c. ${ }^{205}$

Drugi rodzaj odpowiedzialności pracowników świadczących pracę $\mathrm{w}$ ramach podstaw umownych - odpowiedzialność materialna - w zakresie uregulowanym w kodeksie pracy znajduje zastosowanie zarówno do zatrudnienia pracowniczego, jak i do zatrudnienia na podstawie umowy o pracę nakładczą ( $\$ 30$ rozp. pr. nakład.). $Z$ uwagi na zasadność nieobciążania pracownika ryzykiem działalności pracodawcy oraz alimentarną funkcję wynagrodzenia za pracę wprowadzono do regulacji kodeksu pracy inną od właściwej prawu cywilnemu odpowiedzialności odszkodowawczej - odpowiedzialność za szkodę powstałą przy świadczeniu pracy. Jej podstawowymi cechami są ograniczenie zakresu odpowiedzialności (art. 119 k.p.) oraz przerzucenie ciężaru dowodu (art. 116 k.p. ${ }^{206}$. Wskazane odrębności w sposób zdecydowanie korzystniejszy kreują sytuację prawną pracow-

205 Nienależytym wykonaniem zobowiązania jest każda sytuacja, gdy świadczenie zostanie spełnione, lecz nie będzie ono prawidłowe, gdyż odbiega od świadczenia wymaganego. Niezaspokojenie interesu wierzyciela w sposób wynikający z treści zobowiązania umożliwia stwierdzenie, że zobowiązanie zostało wykonane w sposób nienależyty. A. Rzetecka-Gil, Art. 471, [w:] A. Rzetecka-Gil, Kodeks cywilny. Komentarz. Zobowiqzzania-część szczególna, https://sip-1lex-1pl-1004153yx0cd3.han3.lib.uni.lodz.pl/\#/komentarz/587362348/159788 (dostęp: 17.09.2017).

206 W. Jaśkiewicz, C. Jackowiak, W. Piotrowski, op. cit., s. 279-280. 
ników, aniżeli w odpowiednich okolicznościach kształtuje się sytuacja prawna osób świadczących pracę na podstawie umów prawa cywilnego (zlecenia, umów o świadczenie usług, do których stosuje się przepisy o zleceniu, umowy agencyjnej i umowy o dzieło). Pracownik ponosi odpowiedzialność jedynie za działania zawinione (art. 114 k.p.). W przypadku winy umyślnej powstała w wyniku działania pracownika szkoda podlega pełnej kompensacji (art. 122 k.p.). A contrario do art. 122 k.p. należy stwierdzić, że ograniczona odpowiedzialność, o której stanowi art. 119 k.p., dotyczy tylko szkody nieumyślnej. W razie wyrządzenia szkody, której skutki regulowane są przepisami prawa cywilnego, dla wysokości odszkodowania nie ma znaczenia umyślność. Osoba świadcząca pracę na podstawie umowy prawa cywilnego, poza umową o pracę nakładczą, przy braku okoliczności wyłączających winę będzie zatem odpowiadała w pełnej wysokości zarówno za lekkomyślność, jak i za niedbalstwo ${ }^{207}$.

Odstępstwa w regulacji dotyczącej pracowniczej odpowiedzialności majątkowej ustawodawca wprowadził $\mathrm{w}$ ramach zatrudnienia tymczasowego. Zgodnie z art. 19 z.p.t. odpowiedzialnością w zakresie naprawienia szkody wyrządzonej przez pracownika tymczasowego pracodawcy użytkownikowi obciążona jest agencja pracy tymczasowej. Agencja odpowiada jednak przed pracodawcą użytkownikiem na zasadach określonych w kodeksowej regulacji dotyczącej pracowniczej odpowiedzialności materialnej. Jeśli agencja pracy tymczasowej poniesie wskazaną odpowiedzialność, ma prawo żądać od pracownika tymczasowego równowartości wypłaconego odszkodowania (art. 19 ust. 2 z.p.t.). Powodem wprowadzenia rozwiązania umożliwiającego żądanie zwrotu równowartości wypłaconego odszkodowania jest fakt, że odpowiedzialność materialna dotyczy zawsze relacji pracodawca-pracownik. Pracodawca użytkownik nie jest podmiotem tej relacji, choć ma niezaprzeczalny wpływ na jej kształt. Agencja pracy tymczasowej może przy tym, wbrew swojemu interesowi, przyjąć na siebie pełną odpowiedzialność za szkodę wyrządzoną przez pracownika tymczasowego. Pomimo to odpowiedzialność pracownika tymczasowego względem agencji pozostanie ograniczona zgodnie z zasadami odpowiedzialności materialnej przewidzianymi w kodeksie pracy (art. 19 ust. 1 z.p.t. $)^{208}$.

Powierzenie mienia pracownikowi tymczasowemu przez pracodawcę użytkownika nie jest uregulowane w sposób szczegółowy w przepisach ustawy o zatrudnianiu pracowników tymczasowych. W związku z powyższym uznać należy, że w ramach świadczenia pracy tymczasowej możliwe jest powierzanie pracownikowi tymczasowemu mienia na zasadach przewidzianych przez art. 124-127 k.p. Zdaniem Mag-

207 Por. uwagi dotyczące winy w prawie cywilnym: M. Serwach, Wina jako zasada odpowiedzialności cywilnej oraz okoliczność zwalniająca z obowiq̨zku naprawienia szkody, „Wiadomości Ubezpieczeniowe" 2009, nr 1, s. 86.

208 M. Raczkowski, Ustawa o zatrudnianiu pracowników tymczasowych. Komentarz, Warszawa 2013, s. 65. 
daleny Paluszkiewicz powierzenie mienia powoduje zmianę treści stosunku pracy, zatem z umowy zawartej pomiędzy agencją pracy tymczasowej a pracodawcą użytkownikiem powinno wynikać uprawnienie tego ostatniego do powierzenia mienia pracownikowi tymczasowemu ${ }^{209}$. Konieczność umownego uregulowania pomiędzy agencją a pracodawcą użytkownikiem warunków powierzania mienia pracownikowi tymczasowemu dostrzega również Arkadiusz Sobczyk ${ }^{210}$.

Przepis art. 19 z.p.t. dotyczy jedynie szkody wyrządzonej pracodawcy użytkownikowi przez pracownika tymczasowego. Nie obejmuje swoim zakresem szkody wyrządzonej osobie trzeciej. W tym przypadku podmiotem odpowiedzialnym w pierwszej kolejności będzie agencja pracy tymczasowej ${ }^{211}$. Nie podzielam przy tym poglądu, jakoby odpowiedzialność za szkodę wyrządzoną osobie trzeciej ponosił pracodawca użytkownik w ramach odpowiedzialności za szkodę wyrządzoną przez osobę, której powierzyło się wykonanie czynności (art. 429 k.c.) ${ }^{212}$. Ponoszenie przez pracodawcę użytkownika winy w wyborze jest obarczone wadą - wyboru pracownika tymczasowego dokonuje bowiem agencja pracy tymczasowej, kierując się jedynie wskazówkami doboru przedstawionymi przez pracodawcę użytkownika. Proces poszukiwania podmiotu odpowiedzialnego za szkodę wyrządzoną osobie trzeciej przez pracownika tymczasowego jest utrudniony. Wydaje się, że w tym przypadku zastosowanie znajdzie art. 5 z.p.t., który odsyła, w zakresie nieuregulowanym $\mathrm{w}$ ustawie, do przepisów prawa pracy dotyczących odpowiednio pracownika i pracodawcy. Skoro ustawa o zatrudnianiu pracowników tymczasowych nie reguluje odpowiedzialności pracownika tymczasowego za szkodę wyrządzoną osobie trzeciej przy wykonywaniu obowiązków pracowniczych, należy do odpowiedzialności tej stosować przepisy dotyczące pracownika. W tym przypadku będzie to art. 120 k.p. Dariusz Makowski dostrzega mankamenty tego rozwiązania. Autor zauważa, że podmiotem kierującym procesem pracy pracownika tymczasowego jest pracodawca użytkownik, więc to on ma wpływ na wykonywanie przez pracownika tymczasowego obowiązków pracowniczych. W dalszej części autor ten wskazuje na możliwość obarczenia pracodawcy użytkownika odpowiedzialnością za szkodę wyrządzoną osobie trzeciej na zasadzie określonej w art. 430 k.c. ${ }^{213}$ Interpretacja ta wydaje się o tyle dyskusyjna, że dotyczy podmiotów, które powierzyły wykonywanie określonych czynności. W stosunku zatrudnienia tymczasowego powierzenie to następuje łącznie - najpierw poprzez skierowanie do pracy

209 M. Paluszkiewicz, Treść stosunku prawnego, [w:] M. Paluszkiewicz, Zatrudnienie tymczasowe w polskim prawie pracy, https://sip-1lex-1pl-1004153yx0674.han3.lib.uni.lodz.pl/\#/monografia/369234447/31 (dostęp: 19.09.2017).

210 A. Sobczyk, Art. 19, [w:] A. Sobczyk, Ustawa o zatrudnianiu pracowników tymczasowych. Komentarz, https://sip-1lex-1pl-1004153yx0674.han3.lib.uni.lodz.pl/\#/komentarz/587241508/38948 (dostęp: 19.09.2017).

211 Zgodnie z art. 120 k.p. za szkodę taką odpowiada pracodawca.

212 M. Raczkowski, op. cit., s. 65-66.

213 D. Makowski, Praca tymczasowa..., s. 119-120. 
tymczasowej, którego dokonuje agencja pracy tymczasowej, a następnie poprzez konkretyzację obowiązków, której dokonuje pracodawca użytkownik. Moim zdaniem w rozpatrywanej sytuacji nie ma konieczności stosowania przepisów kodeksu cywilnego na zasadach wskazanych w art. 300 k.p. Prawo pracy obarcza odpowiedzialnością za szkodę wyrządzoną osobie trzeciej, w granicach wskazanych w art. 120 k.p., pracodawcę. Jako pracodawca agencja pracy tymczasowej ponosi ryzyko związane $\mathrm{z}$ doborem pracowników tymczasowych ${ }^{214}$.

Poza chałupnikami ( $\$ 30$ rozp. pr. nakład.) osoby świadczące pracę na podstawie umów prawa cywilnego nie są ustawowo objęte ograniczeniem odpowiedzialności materialnej, odpowiadając za delikty oraz niewykonanie bądź nienależyte wykonanie zobowiązania na zasadach ogólnych. Unormowania dotyczące umowy o dzieło ustanawiają szczególną odpowiedzialność przyjmującego zamówienie za wadliwe wykonanie dzieła (art. 636 i 637 k.c.). Odpowiedzialność ta związana jest $\mathrm{z}$ charakterem umowy o dzieło jako umowy rezultatu.

Zróżnicowanie pozycji prawnej osób świadczących pracę w ramach umownego zatrudnienia nietypowego na płaszczyźnie odpowiedzialności materialnej wydaje się uzasadnione. Zwiększona, względem pracowniczej, odpowiedzialność, właściwa stosunkom prawa cywilnego, jest pochodną braku podporządkowania oraz odmiennych założeń systemowych. Pełna odpowiedzialność materialna w odniesieniu do stosunków pracy byłaby poważnym zagrożeniem dla alimentarnej funkcji wynagrodzenia za pracę, którego wysokość często nie wystarczyłaby na pokrycie pełnej szkody. Ponieważ podobną funkcję, o czym była już mowa, spełnia wynagrodzenie należne osobom świadczącym pracę w ramach pracy nakładczej, również ta podstawa umownego zatrudnienia nietypowego ogranicza odpowiedzialność materialną osób zatrudnionych. Przedstawione odmienności występujące w odpowiedzialności pracowników tymczasowych wynikają ze szczególnego, trójpodmiotowego charakteru zatrudnienia tymczasowego, który determinuje konieczność współuczestnictwa wszystkich jego podmiotów w ustalaniu zakresu odpowiedzialności materialnej pracowników tymczasowych i jej sankcjonowania.

\subsubsection{Odpowiedzialność podmiotów zatrudniających za wykroczenia i przestępstwa związane ze stosunkiem umownego zatrudnienia nietypowego}

Konieczność omówienia odpowiedzialności podmiotów zatrudniających za wykroczenia i przestępstwa wynika z faktu, że bezpośrednio z nią skorelowane są instytucje prawne kształtujące sytuację prawną osób świadczących pracę w ramach umownego zatrudnienia nietypowego. Zróżnicowanie odpowiedzialności

214 M. Paluszkiewicz, Treść stosunku prawnego... 
podmiotów zatrudniających determinuje zróżnicowanie statusu prawnego osób świadczących pracę. Analizę zagadnienia należy rozpocząć od odpowiedzialności, jakiej podlega pracodawca. Kształtują ją zarówno przepisy prawa pracy, jak i przepisy innych gałęzi prawa, w tym w szczególności prawa karnego ${ }^{215}$. Wśród przepisów prawa pracy wiodącą rolę pełnią przepisy działu 13 kodeksu pracy. Przewidzianej w nich odpowiedzialności za wykroczenia podlegają wszyscy pracodawcy ${ }^{216}$, bez względu na podstawę zatrudnienia czy jego formę organizacyjną. Odpowiedzialność ta dotyczy przestrzegania przepisów prawa pracy wobec wszystkich podmiotów nim objętych - również tych, które nie są podmiotami prawa pracy.

Przepis art. $283 \$ 1$ k.p. rozszerza odpowiedzialność za nieprzestrzeganie przepisów bhp poza podmiotowy obszar prawa pracy. Z jego treści wynika, że nieprzestrzeganie przepisów dotyczących bezpieczeństwa i higieny pracy w stosunku do podmiotów innych niż pracownicy skutkuje odpowiedzialnością przewidzianą w tym przepisie. Sankcjonowanie nieprzestrzegania przepisów bhp jest zatem tożsame względem obowiązku istniejącego $\mathrm{w}$ stosunku do wszystkich osób zatrudnionych, bez względu na umowną podstawę zatrudnienia. Poprzez taką regulację podmioty odpowiedzialne za zapewnienie bezpiecznych i higienicznych warunków pracy w zakresie prewencji ogólnej podlegają jednakowemu oddziaływaniu norm prawnych ${ }^{217}$. W konsekwencji zrównuje to sytuację prawną osób świadczących pracę w ramach umownego zatrudnienia nietypowego (bez względu na jego podstawę) w odniesieniu do obowiązków zapewnienia im bezpiecznych i higienicznych warunków pracy. Pozostała odpowiedzialność, przewidziana mocą przepisów prawa pracy, jest ściśle związana ze stosunkiem pracy oraz relacją pracownik-pracodawca, zatem nie znajduje zastosowania do nietypowego zatrudnienia umownego innego niż pracownicze.

Ustawa o zatrudnianiu pracowników tymczasowych w części zawierającej

215 Przepisy działu XXVIII kodeksu karnego (ustawa z dnia 6 czerwca 1997 r., Dz.U. z 2016 r. poz. 1137 - t.j.; dalej: k.k.) wskazują na uregulowanie w nim odpowiedzialności za przestępstwa związane z wykonywaniem pracy zarobkowej, dlatego też regulacja ta wymaga dokładniejszego omówienia. Podmioty zatrudniające mogą ponosić również odpowiedzialność na innych płaszczyznach (za przestępstwa, wykroczenia czy też odpowiedzialność o charakterze administracyjnym bądź cywilnym), ale jest to odpowiedzialność o charakterze ogólnym, która nie wpływa na zróżnicowanie sytuacji prawnej osób zatrudnionych.

216 Odpowiedzialności tej podlegają również osoby działające w imieniu pracodawcy, osoba obciążona określonymi obowiązkami (art. 281 k.p.), osoba odpowiedzialna za stan bezpieczeństwa i higieny pracy w zakładzie pracy albo osoba kierująca pracownikami (art. 283 k.p.). Z. Salwa, Podmioty odpowiedzialne za wykroczenia przeciwko prawom pracownika, „Praca i Zabezpieczenie Społeczne” 2001, nr 8, s. 21.

217 Celem prewencji ogólnej jest w tym przypadku zarówno odstraszający wpływ wymiaru kary, jak i umacnianie przekonania o nieopłacalności popełniania czynu zabronionego i o nieuchronności konsekwencji karnych. Takie generalne aspekty prewencji ogólnej wskazał Sąd Najwyższy w wyroku z dnia 10 września 1963 r., Rw 911/63, LEX nr 1674067. 
przepisy karne reguluje jedynie odpowiedzialność pracodawcy użytkownika. $\mathrm{Na}$ gruncie odpowiedzialności, jaką ponosi pracodawca w stosunku do agencji pracy tymczasowej, stosuje się, mocą art. 5 z.p.t., regulacje prawa pracy dotyczące pracodawcy. Dodatkowo odpowiedzialność agencji zatrudnienia normuje ustawa o promocji zatrudnienia i instytucjach rynku pracy. Odpowiedzialność ta jest ściśle związana ze świadczeniem usług w zakresie pracy tymczasowej.

Interesy osób świadczących pracę w ramach umownego zatrudnienia nietypowego są chronione lepiej dzięki istnieniu specjalnego rodzaju odpowiedzialności dotyczącej konieczności przestrzegania przepisów prawa pracy przez podmioty zatrudniające. Jest ona najszersza w odniesieniu do pracodawców, dlatego najskuteczniej egzekwowane są obowiązki przestrzegania przepisów prawa pracy w stosunku do nich. Obowiązki te, głównie o charakterze organizacyjno-porządkowym (jak obowiązek potwierdzenia umowy na piśmie czy przestrzegania norm czasu pracy), pozostają ściśle skorelowane z więzią prawnopracowniczą, która jest, z założenia systemowego, relacją dwóch nierównych sobie podmiotów: ekonomicznie silniejszego pracodawcy i słabszego, wymagającego wzmożonej ochrony, pracownika. Rozbudowane konsekwencje nieprzestrzegania przepisów prawa pracy mają na celu nie tylko działanie sankcjonujące, ale również prewencyjne, poprzez skłonienie pracodawców do zachowań zgodnych z prawem ${ }^{218}$.

Nowelizacja ustawy o minimalnym wynagrodzeniu za pracę wprowadziła w art. 8e odpowiedzialność przedsiębiorców albo osób działających w ich imieniu bądź innych jednostek organizacyjnych za niewypłacanie przyjmującemu zlecenie lub świadczącemu usługi wynagrodzenia za każdą godzinę wykonania zlecenia lub świadczenia usług w wysokości równej co najmniej minimalnej stawce godzinowej. Orzekanie w sprawach o takie czyny następuje, zgodnie $\mathrm{z}$ art. 8f, w trybie przepisów kodeksu postępowania w sprawach o wykroczenia. Karą, jaka może zostać wymierzona, jest grzywna w wysokości od 1000 zł do 30000 zł. Penalizacja nieprzestrzegania norm ustawowych jest naturalną konsekwencją wprowadzenia ich do systemu prawnego. Nie wpływa wszakże na jednoznacznie negatywną ocenę rozszerzania instytucji minimalnego wynagrodzenia na stosunki cywilnoprawne, o czym była już mowa.

Odpowiedzialność karną za przestępstwa przeciwko prawom osób wykonujących pracę zarobkową statuuje kodeks karny. Tytuł rozdziału XXVIII k.k. sugeruje, że dotyczy on praw wszystkich osób wykonujących pracę zarobkową, nie tylko pracowników. Mimo to redakcja przepisów tego rozdziału nie potwierdza w sposób jednoznaczny tej tezy. Co prawda stypizowane tam przestępstwa do-

218 Choć, jak dowodzą doświadczenia Państwowej Inspekcji Pracy, nieprzestrzeganie przepisów skutkujące koniecznością zapłaty kary finansowej jest dla pracodawców często bardziej opłacalne ekonomicznie niż stosowanie przepisów prawa pracy. T. Zając, Z doświadczeń kontrolnych Państwowej Inspekcji Pracy, „Praca i Zabezpieczenie Społeczne” 2001, nr 1, s. 3. 
tyczą nieprzestrzegania przepisów prawa pracy i ubezpieczeń społecznych (a te mogą obejmować również osoby zatrudnione, które nie są pracownikami), jednak w hipotezach niektórych przepisów (odnosi się to do art. 218 i 220 k.k.) ustawodawca posłużył się dodatkowo właściwymi dla stosunku pracy zwrotami - pracodawca, pracownik i stosunek pracy ${ }^{219}$. Przepis art. 218 k.k. sankcjonuje złośliwe lub uporczywe naruszanie prawa pracownika wynikającego ze stosunku pracy lub ubezpieczenia społecznego przez osobę wykonującą czynności w sprawach z zakresu prawa pracy i ubezpieczeń społecznych. Z kolei hipoteza normy art. 220 k.k. obejmuje osoby odpowiedzialne za bezpieczeństwo i higienę pracy, które nie dopełniają wynikającego z tego faktu obowiązku i przez to narażają pracownika na bezpośrednie niebezpieczeństwo utraty życia albo ciężkiego uszczerbku na zdrowiu.

Słuszne wydaje się zatem stanowisko Sądu Najwyższego, zgodnie z którym przepisy rozdziału XXVIII należy badać w kontekście ich zindywidualizowanego charakteru ${ }^{220}$. Zakres ochrony udzielanej dobru prawnemu przez określoną normę prawa karnego ustalany być musi przede wszystkim $\mathrm{z}$ uwzględnieniem znaczenia pojęć, których użyto dla sprecyzowania znamion czynu zabronionego ${ }^{221}$. Sankcjonowanie popełnienia przestępstw przeciwko prawom osób wykonujących pracę zarobkową ma na celu ochronę zasadniczo wszystkich tych osób, chyba że konkretna norma ogranicza katalog podmiotów chronionych do pracowników. Takie ograniczenie występuje w dwóch przepisach (art. 218 i 220 k.k.).

Szeroka ochrona pracowników wynika z rozbudowanej odpowiedzialności za wykroczenia i przestępstwa skierowane przeciwko nim. W takim zakresie nie znajduje ona zastosowania do osób zatrudnionych na podstawie umów prawa cywilnego. W tym względzie status prawny wszystkich pracowników, zarówno tych świadczących pracę $\mathrm{w}$ ramach zatrudnienia typowego, jak i nietypowego, jest taki sam. Wzmożona ochrona dóbr pracowniczych daje, przynajmniej w założeniu teoretycznym, większą pewność co do przestrzegania prawa mającego tę ochronę zapewniać. Dzięki temu, na poziomie ochrony bezpośrednio związanej z zatrudnieniem, status prawny pracowników, w tym pracowników zatrudnionych nietypowo, kształtuje się w sposób korzystniejszy aniżeli status prawny osób świadczą-

219 Osobnym zagadnieniem, wykraczająca poza ramy niniejszego opracowania, jest możliwość ustalenia przez sąd karny istnienia stosunku pracy, co dawałoby podstawy do skazania za przestępstwa z rozdziału XXVIII. Problematykę tę omawiają: S. Koczur, Ustalenie istnienia stosunku pracy przez sq̨d karny - wokót zastrzeżeń interpretacyjnych na gruncie art. 220 KK, „Monitor Prawa Pracy” 2013, nr 11, s. 573-577; T. Wrocławska, O znaczeniu wyroku sqdu karnego w postępowaniu w sprawach z zakresu prawa pracy na przykładzie wybranych instytucji prawa pracy, [w:] G. Uścińska (red.), Prawo pracy. Refleksje i poszukiwania..., s. 443-445.

220 Uchwała Sądu Najwyższego z dnia 15 grudnia 2005 r., I KZP 34/05, LEX nr 164200.

221 Stanowisko to potwierdza K. Pawlak, Przestępstwo z art. 218 \& 1a kodeksu karnego jako podstawa prawno karnej ochrony praw pracowniczych, „Biuletyn Koła Naukowego Prawa Pracy”, z. 7 (specjalny), Łódź 2013, s. 190. 
cych pracę na podstawie umów prawa cywilnego. Wydaje się, że uzasadnieniem takiego stanu rzeczy jest systemowe założenie o konieczności szczególnej ochrony pracy ludzkiej świadczonej przez podmioty ekonomicznie słabsze w warunkach podporządkowania.

\subsection{Ubezpieczenia społeczne i ubezpieczenie zdrowotne osób świadczących pracę w ramach umownego zatrudnienia nietypowego}

\subsubsection{Uwagi wprowadzające}

Konieczność przeprowadzenia analizy statusu prawnego osób świadczących pracę w ramach umownego zatrudnienia nietypowego z perspektywy sfery ubezpieczeń społecznych i ubezpieczenia zdrowotnego podyktowana jest dwoma kwestiami. Po pierwsze są to zagadnienia o dużym znaczeniu społecznym. Po drugie ewolucja normatywna dokonywana w tym zakresie odzwierciedla faktycznie zachodzące zmiany w zatrudnieniu. Przedstawienie rozwiązań modelowych ${ }^{222} \mathrm{w}$ zakresie podlegania przez osoby świadczące pracę $\mathrm{w}$ ramach umownego zatrudnienia nietypowego ubezpieczeniom społecznym i ubezpieczeniu zdrowotnemu pozwoli ocenić, na ile modele te się od siebie różnią oraz czy zróżnicowanie to jest prawnie uzasadnione. W zakresie objętym tą częścią rozważań nie występują istotne różnice w statusie prawnym osób zatrudnionych pośród poszczególnych grup pracowników, dlatego uwagi skoncentrują się na przedstawieniu sytuacji prawnej pracowników jako ubezpieczonych i odniesieniu do niej sytuacji prawnej w zakresie podlegania ubezpieczeniom społecznym i ubezpieczeniu zdrowotnemu osób świadczących pracę na podstawie poszczególnych umów prawa cywilnego.

Zabezpieczenie społeczne stanowi system rozwiązań mających na celu ochronę każdego człowieka na wypadek utraty bezpieczeństwa socjalnego. Jest to system zagwarantowanych prawem (w tym Konstytucją - art. 67) świadczeń służących pokryciu potrzeb spowodowanych określonymi zdarzeniami, spełnianych przez zobowiązane do tego instytucje. Kategoria zabezpieczenia społecznego

222 W związku z takim ujęciem tematu poza obszarem analizy pozostają zagadnienia o charakterze szczegółowym, takie jak zbieg tytułu ubezpieczeń (poza kilkoma poczynionymi w treści wywodu uwagami), wysokość składek ubezpieczeniowych, wysokość świadczeń czy okres podlegania ubezpieczeniom. 
uważana jest na gruncie prawa organizacji międzynarodowych (ONZ, MOP, Rada Europy) za jedno z praw człowieka ${ }^{223}$. Ponieważ prawo do zabezpieczenia społecznego jest prawem wszystkich obywateli ${ }^{224}$, powinno być ono przyznane w jednakowym zakresie wszystkim osobom świadczącym pracę w takich samych warunkach. Teza taka wyklucza konieczność objęcia regulacjami zabezpieczenia społecznego $\mathrm{w}$ jednakowym zakresie osób świadczących pracę w sposób ciągły i podporządkowany oraz osób świadczących pracę w postaci niezależnych, niepowtarzalnych, jednostkowych czynności. Druga grupa, co do zasady, w zakresie zabezpieczenia społecznego nie jest obejmowana przymusem ubezpieczeniowym ${ }^{225}$, co nie wyklucza przyznania jej dobrowolności w przystępowaniu do ubezpieczeń. Do zakresu objętego zabezpieczeniem społecznym zalicza się ubezpieczenia społeczne ${ }^{226}$. Ubezpieczenie zdrowotne stanowi natomiast odrębny od ubezpieczeń społecznych system, powołany do ochrony zdrowia i życia ludzkiego, pozostający jednak z nim w ścisłym powiązaniu ${ }^{227}$. Zasady podlegania ubezpieczeniom społecznym i ubezpieczeniu zdrowotnemu ulegały zmianom na przestrzeni obowiązywania regulacji dotyczących tej sfery normatywnejej ${ }^{228}$ W związku z rozszerzaniem możliwości dobrowolnego przystąpienia do ubezpieczeń społecznych ich konstrukcja coraz bardziej odchodzi od formy opartej na aktywności zawodowej ${ }^{229}$ na rzecz modelu związanego z zamieszkaniem. Stopniowo zwiększany jest również zakres ubezpieczeń obowiązkowych. Jednak w dalszym ciągu status prawny poszczególnych grup osób świadczących pracę nie jest jednakowy.

223 K. Antonów, Przedmiotowe, konstytucyjne i procesowe przesłanki uznania prawa zabezpieczenia społecznego za odrębna gałąź prawa, [w:] A. Patulski, K. Walczak (red.), Jedność w różnorodności. Studia z zakresu prawa pracy, zabezpieczenia społecznego i polityki społecznej. Księga pamiątkowa dedykowana Profesorowi Wojciechowi Muszalskiemu, Warszawa 2009, s. 293. Przeciwnie: B. Wagner, Prawo do zabezpieczenia społecznego w Konstytucji RP, [w:] A. Patulski, K. Walczak (red.), op. cit., s. 347. Autorka zalicza prawo do zabezpieczenia społecznego do podmiotowych praw obywatelskich, a nie do praw człowieka.

224 Ibidem.

225 M. Krajewski, Dobrowolne ubezpieczenie emerytalne i rentowe na gruncie art. 7 i 10 ustawy o systemie ubezpieczeń społecznych, „Praca i Zabezpieczenie Społeczne” 2014, nr 5, s. 10.

226 T. Bińczycka-Majewska, Konstrukcja zabezpieczenia ryzyka starości w nowym systemie prawnym, [w:] T. Bińczycka-Majewska (red.), Konstrukcje prawa emerytalnego, Kraków 2004, s. 38, 42.

227 G. Szyburska-Walczak, Ubezpieczenia społeczne. Repetytorium, Warszawa 2012, s. 24, 27.

228 Ewolucję podlegania ubezpieczeniom społecznym przez zleceniobiorców przedstawia I. Sierocka, Umowa zlecenia i umowa o dzieło w systemie ubezpieczeń społecznych, „Monitor Prawa Pracy" 2015, nr 7, s. 344.

229 Na konieczność istnienia związku ubezpieczenia z pracą wskazywał W. Szubert, Ubezpieczenia społeczne. Zarys systemu, Warszawa 1987, s. 49. 


\subsubsection{Podleganie ubezpieczeniom społecznym}

W regulacjach dotyczących ubezpieczeń społecznych określone zdarzenia chronione są konkretnymi rodzajami ubezpieczeń społecznych, wymienionymi w art. 1 u.s.u.s. Są to: ubezpieczenie emerytalne (w przypadku dożycia określonego wieku), ubezpieczenie rentowe (w razie powstania trwałej niezdolności do pracy, śmierci żywiciela rodziny), ubezpieczenie chorobowe (w przypadku czasowej niezdolności do pracy wywołanej chorobą i w przypadku macierzyństwa) oraz ubezpieczenie wypadkowe (w przypadku niezdolności do pracy wywołanej wypadkiem przy pracy bądź chorobą zawodową) ${ }^{230}$. Określenie, w jakim stopniu sytuacja prawna osób świadczących pracę w ramach umownego zatrudnienia nietypowego, ale na różnych jego podstawach, jest do siebie zbliżona na płaszczyźnie podlegania ubezpieczeniom społecznym, umożliwi ocenę regulacji prawnych $\mathrm{w}$ tym zakresie. To bowiem one pozwalają najlepiej zaobserwować zjawisko zbliżania się sytuacji prawnej poszczególnych grup osób świadczących pracę w ramach umownego zatrudnienia nietypowego ${ }^{231}$.

W nurcie unifikacji sytuacji prawnej pracowników i osób świadczących pracę na podstawie umów cywilnoprawnych ${ }^{232} \mathrm{w}$ miarę rozwoju zatrudnienia niezależnego zaczęto dostrzegać konieczność objęcia ubezpieczeniami społecznymi osób zatrudnionych na umownych podstawach niepracowniczych ${ }^{233}$. Stosunek pracy, bez względu na jego konstrukcję wewnętrzno-organizacyjną, zawsze rodzi obowiązek odprowadzania składek w odniesieniu do wszystkich rodzajów ubezpieczenia społecznego. Dlatego też odpowiednie zakwalifikowanie zatrudnienia jako pracownicze bądź cywilnoprawne ma doniosłe konsekwencje właśnie na gruncie prawa ubezpieczeń społecznych. Reformy systemu ubezpieczeniowego coraz bardziej zbliżają regulacje dotyczące poszczególnych podstaw zatrudnienia, jednak różnice w sytuacji prawnej poszczególnych osób świadczących pracę są wciąż zauważalne ${ }^{234}$. Obejmując coraz szersze grupy osób zatrudnionych uprawnieniami związanymi z podleganiem ubezpieczeniom społecznym, prawodawca reaguje na dokonujące się zmiany systemowe związane $\mathrm{z}$ paradygmatem pracy ${ }^{235}$, chroniąc (w zakresie podlegania ubezpieczeniom społecznym) każdą pracę człowieka, a nie

230 G. Szyburska-Walczak, op. cit., s. 24-25.

231 A. Supiot, op. cit., s. 155.

232 P. Prusinowski, op. cit., s. 31, za: L. Florek, Kodyfikacyjne problemy prawa pracy, „Państwo i Prawo" 2007, nr 11, s. 10.

233 Pierwotne regulacje prawne mające za przedmiot ubezpieczenia społeczne nie wywoływały wątpliwości związanych z kręgiem ich adresatów. Obejmowały one swoim zakresem wszystkie osoby zatrudnione, co wynikało z praktycznego braku różnorodności w podstawach zatrudnienia. D.E. Lach, Nowe formy zatrudnienia i zabezpieczenia społecznego w zakresie ochrony zdrowia, „Praca i Zabezpieczenie Społeczne” 2006, nr 5, s. 12.

234 Ł. Pisarczyk, Różne formy..., s. 44, 137.

235 I. Boruta, W sprawie przyszłości..., s. 5. 
tylko pracę wykonywaną $\mathrm{w}$ warunkach ścisłego podporządkowania i organizacyjnej zależności. Zasady sprawiedliwości społecznej nakazują bowiem zapewnienie wszystkim obywatelom takiego samego bądź zbliżonego statusu socjalnego, bez względu na to, w jakim reżimie prawnym świadczą pracę ${ }^{236}$. W tym właśnie celu, na gruncie przepisów ubezpieczeniowych, rozszerzono, względem prawnopracowniczej, definicję pracownika (art. 8 ust. 2a u.s.u.s.), czyli osoby podlegającej zasadniczo obowiązkowo wszystkim ubezpieczeniom społecznym ${ }^{237}$. W zakresie regulacji prawa ubezpieczeń społecznych umowy agencyjne, zlecenia, umowy o świadczenie usług, do których stosuje się przepisy o zleceniu oraz umowy o dzieło zrównują osoby świadczące pracę na ich podstawie $\mathrm{w}$ statusie prawnym $\mathrm{z}$ pracownikiem w rozumieniu kodeksu pracy, jeżeli osoby te są związane z podmiotem zatrudniającym stosunkiem pracy bądź praca wykonywana $\mathrm{w}$ ramach umowy prawa cywilnego świadczona jest na rzecz ich pracodawcy ${ }^{238}$. W przypadku gdy umowa cywilnoprawna zawarta jest $\mathrm{z}$ podmiotem trzecim, a jedynie świadczona na rzecz pracodawcy, składki ubezpieczeniowe z jej tytułu odprowadza pracodawca ${ }^{239}$.

Zakres podlegania ubezpieczeniom emerytalnemu i rentowemu wyznacza art. 6 i następne u.s.u.s. Spośród podmiotów, których dotyczą niniejsze rozważania, obowiązkowymi ubezpieczeniami emerytalnym i rentowym zostali objęci pracownicy (w rozumieniu kodeksu pracy), z wyłączeniem prokuratoró ${ }^{240}$, osoby wykonujące pracę nakładczą oraz osoby wykonujące pracę na podstawie umowy agencyjnej lub umowy zlecenia albo innej umowy o świadczenie usług, do której zgodnie z kodeksem cywilnym stosuje się przepisy dotyczące zlecenia ${ }^{241}$ (art. 6 ust. 1 pkt 1-2, 4 u.s.u.s.).

Według obowiązującego do końca 2015 r. stanu prawnego w przypadku zbiegu obowiązkowych tytułów ubezpieczenia emerytalnego i rentowego z uwagi na wykonywanie pracy nakładczej, wykonywanie pracy na podstawie umowy agencyjnej lub umowy zlecenia albo innej umowy o świadczenie usług, do której zgodnie z kodeksem cywilnym stosuje się przepisy dotyczące zlecenia ${ }^{242}$, tytułem

236 R.A. Tokarczyk, Filozofia prawa w perspektywie prawa natury, Białystok 1996, s. 160 i nast., za: A. Chobot, op. cit., s. 195.

237 Odrębność definicji pracownika na gruncie prawa pracy i prawa ubezpieczeń społecznych potwierdził Sąd Najwyższy w wyroku z dnia 24 marca 2015 r., II UK 184/14, LEX nr 1710359.

238 J. Skoczyński, Zmiany regulacji obowiq̨zku ubezpieczeń społecznych z tytułu świadczenia pracy na podstawie cywilnoprawnych umów o świadczenie usług, „Praca i Zabezpieczenie Społeczne" 2000, nr 2, s. 23.

239 Tak względem umowy o dzieło orzekł Sąd Najwyższy Uchwałą z dnia 2 września 2009 r., II UZP 6/09, LEX nr 514221.

240 Powyższe dotyczy również sędziów. Zgodnie z art. 91 § 9 Ustawy z dnia 27 lipca 2001 r. Prawo o ustroju sądów powszechnych. Dz.U. z 2016 r., poz. 2062 - t.j. ze zm.

241 Z ostatniej grupy art. 6 ust. 4 u.s.u.s. wyłącza uczniów gimnazjów, szkół ponadgimnazjalnych, szkół ponadpodstawowych lub studentów do ukończenia 26 lat.

242 Zbieg ten dotyczy również innych podmiotów wymienionych w art. 6 ust. 1 pkt 5-6 i 10 u.s.u.s., ale ten zakres podmiotowy nie jest przedmiotem niniejszych rozważań. 
ubezpieczeniowym był ten, który powstał najwcześniej (art. 9 ust. 2 u.s.u.s.) $)^{243}$, przy czym obowiązek ubezpieczeniowy w tym zakresie stwarzało wykonywanie umowy, a nie samo jej zawarcie ${ }^{244}$. Od 1 stycznia $2016 \mathrm{r}^{245} \mathrm{w}$ przypadku powyższego zbiegu istnieje dodatkowa możliwość dobrowolnego objęcia ubezpieczeniami emerytalnym i rentowym także z pozostałych, wszystkich lub wybranych tytułów. Ubezpieczony ma również możliwość zmiany tytułu ubezpieczeń. Istotnym zastrzeżeniem nowelizacji jest wskazanie w art. 9 ust. 2c u.s.u.s., że osoba, o której mowa w art. 6 ust. 1 pkt 4 u.s.u.s. (w zakresie omawianej tematyki katalog ten wystarczy ograniczyć do osób wykonujących pracę na podstawie umowy agencyjnej lub umowy zlecenia albo innej umowy o świadczenie usług, do której zgodnie z kodeksem cywilnym stosuje się przepisy dotyczące zlecenia), której podstawa wymiaru składek na ubezpieczenia emerytalne i rentowe w danym miesiącu jest niższa od minimalnego wynagrodzenia, spełniająca warunki do objęcia obowiązkowo ubezpieczeniami emerytalnym i rentowym $z$ innych tytułów, podlega obowiązkowo powyższym ubezpieczeniom również z tych tytułów. Zasady tej nie stosuje się, jeżeli łączna podstawa wymiaru składek z tytułu wykonywania pracy na podstawie umowy, o której mowa w art. 6 ust. 1 pkt 4 u.s.u.s., lub z innych tytułów, osiąga kwotę minimalnego wynagrodzenia (art. 9 ust. 2c u.s.u.s. in fine). Agent lub przyjmujący zlecenie, którego wynagrodzenie jest niższe niż wynagrodzenie minimalne, wykonujący jednocześnie pracę w oparciu o inne umowy stanowiące tytuły ubezpieczeniowe, ex lege podlega ubezpieczeniom emerytalnemu i rentowemu także na ich podstawie do łącznej kwoty co najmniej minimalnego wynagrodzenia ${ }^{246}$. Zatem punktem odniesienia do objęcia obowiązkowym ubezpieczeniem emerytalnym i rentowym od 1 stycznia 2016 r. jest wysokość minimalnego wynagrodzenia za pracę bez względu na to, czy obejmuje ona jeden tytuł ubezpieczeniowy, czy jej osiągnięcie będzie możliwe po zsumowaniu kilku tytułów.

243 Wyjątek w tym zakresie stanowi art. 9 ust. 2a u.s.u.s. Zgodnie z nim osoba, o której mowa w art. 6 ust. 1 pkt 4 u.s.u.s. - prowadząca jednocześnie pozarolniczą działalność, o której mowa w art. 8 ust. 6 pkt 1 u.s.u.s. - podlega obowiązkowo ubezpieczeniom emerytalnemu i rentowemu z tytułu tej działalności, jeżeli z tytułu wykonywania umowy agencyjnej lub umowy zlecenia albo innej umowy o świadczenie usług, do której zgodnie z kodeksem cywilnym stosuje się przepisy dotyczące zlecenia, oraz współpracy przy wykonywaniu tych umów podstawa wymiaru składek na ubezpieczenia emerytalne i rentowe jest niższa od obowiązującej tę osobę najniższej podstawy wymiaru składek dla osób prowadzących pozarolniczą działalność. Może ona dobrowolnie, na swój wniosek, być objęta ubezpieczeniami emerytalnym i rentowym również z tytułu, o którym mowa w art. 6 ust. 1 pkt 4 u.s.u.s.

244 Wyrok Sądu Najwyższego z dnia 17 czerwca 2008 r., I UK 402/07, OSNP 2009, nr 21-22, poz. 297.

245 Zmianę wprowadziła ustawa z dnia 23 października 2014 r. o zmianie ustawy o systemie ubezpieczeń społecznych oraz niektórych innych ustaw, Dz.U. z 2014 r., poz. 1831.

246 I. Sierocka, Ubezpieczenie społeczne osób świadczących pracę na podstawie umów prawa cywilnego, [w:] A. Bieliński, A. Giedrewicz-Niewińska, M. Szabłowska-Juckiewicz (red.), Elastyczne formy zatrudnienia i organizacji czasu pracy, Warszawa 2015, s. 103. 
Osoby wykonujące pracę na podstawie umowy o dzieło zawartej z innym podmiotem niż ich pracodawca i nieświadczonej na jego rzecz nie są objęte obowiązkowymi ubezpieczeniami emerytalnym i rentowym. Mogą one jednak przystąpić do tych ubezpieczeń dobrowolnie ${ }^{247}$. Uprawnienie takie przyznaje im art. 7 u.s.u.s. ${ }^{248}$

Ubezpieczenie chorobowe $\mathrm{w}$ stosunku do pracowników (w rozumieniu kodeksu pracy), za wyjątkiem prokuratorów i sędziów, ma charakter obligatoryjny (art. 11 ust. 1 u.s.u.s. w Zw. Z art. 6 ust. 1 pkt 1 u.s.u.s.) ${ }^{249}$. Spośród osób świadczących pracę na podstawie umów prawa cywilnego ubezpieczeniu chorobowemu dobrowolnie, na swój wniosek podlegają osoby wykonujące pracę nakładczą i pracę na podstawie umowy agencyjnej lub umowy zlecenia albo innej umowy o świadczenie usług, do której zgodnie z kodeksem cywilnym stosuje się przepisy dotyczące zlecenia. Warunkiem, jaki musi zostać spełniony, aby wymienione osoby podlegały ubezpieczeniu chorobowemu, jest obowiązkowe podleganie przez nie ubezpieczeniom emerytalnym i rentowym (art. 11 ust. 2 u.s.u.s. w zw. z art. 6 ust. 1 pkt 2 i 4 u.s.u.s.). Ubezpieczeniu temu nie podlegają zatem wykonawcy umowy o dzieło.

Ubezpieczeniem wypadkowym objęte są wszystkie osoby podlegające ubezpieczeniom emerytalnemu i rentowemu (art. 12 ust. 1 u.s.u.s. $)^{250}$. Dotyczy to zarówno

247 Ibidem, s. 98.

248 Rationis legis wprowadzenia od 1 stycznia 2013 r. możliwości dobrowolnego ubezpieczenia emerytalnego i rentowego oraz jego negatywne konsekwencje przedstawia M. Krajewski, op. cit., s. 9-15.

249 W tym miejscu warto zauważyć, że przepisy ustawy z dnia 25 czerwca 1999 r. (Dz.U. z 2016 r., poz. 372 - t.j. ze zm.) o świadczeniach pieniężnych z ubezpieczenia społecznego w razie choroby i macierzyństwa, poprzez unifikację statusu prawnego wszystkich podlegających jej podmiotów, dokonują faktycznego zróżnicowania ich sytuacji. W zakresie nabycia prawa do zasitku chorobowego art. 4 powyższej ustawy stanowi, że prawo to ubezpieczony nabywa po upływie 30 dni nieprzerwanego ubezpieczenia chorobowego - jeżeli podlega obowiązkowo temu ubezpieczeniu (ust. 1). Do okresów ubezpieczenia chorobowego wlicza się poprzednie okresy ubezpieczenia chorobowego, jeżeli przerwa między nimi nie przekroczyła 30 dni lub była spowodowana urlopem wychowawczym, urlopem bezpłatnym albo odbywaniem czynnej służby wojskowej przez żołnierza niezawodowego (ust. 2). W zakresie ubezpieczenia chorobowego pracowników tymczasowych, których praca ma zasadniczo charakter krótkotrwały, nabycie prawa do zasiłku chorobowego może zostać znacznie przesunięte w czasie w razie konieczności sumowania okresów ubezpieczenia. W. Koczur, Zasiłek chorobowy jako świadczenie z tytułu czasowej niezdolności do pracy pracowników tymczasowych, [w:] A. Sobczyk (red.), z problematyki...

250 Wyjątek stanowią: 1) bezrobotni pobierający zasiłek dla bezrobotnych lub świadczenie integracyjne; 2) posłowie do Parlamentu Europejskiego, o których mowa w art. 1 ust. 1 ustawy o uposażeniu posłów do Parlamentu Europejskiego wybranych w Rzeczypospolitej Polskiej; 3) osoby wykonujące pracę nakładczą; 4) żołnierze niezawodowi pełniący czynną służbę wojskową, z wyłączeniem żołnierzy pełniących służbę kandydacką; 5) osoby przebywające na urlopach wychowawczych lub pobierające zasiłek macierzyński albo zasitek w wysokości zasitku macierzyńskiego; 6) osoby pobierające świadczenia socjalne wypłacane w okresie urlopu oraz osoby pobierające zasiłek socjalny wypłacany na czas przekwalifi- 
osób, które podlegają obowiązkowo ubezpieczeniom emerytalnemu i rentowemu, jak i tych, które przystąpiły do nich dobrowolnie w ramach dyspozycji art. 7 u.s.u.s. ${ }^{251}$ Ustawa systemowa nie przewiduje możliwości dobrowolnego przystąpienia do ubezpieczenia wypadkowego ${ }^{252}$.

Pojęcie wypadku przy pracy określa ustawa o ubezpieczeniu społecznym z tytułu wypadków przy pracy i chorób zawodowych ${ }^{253}$. Przepis art. 3 ust. 1 u.u.s.w.p., definiujący wypadek przy pracy, obejmuje swoim zakresem sytuacje faktyczne, gdy zdarzenie będące wypadkiem przy pracy ma bezpośredni związek z zatrudnieniem pracowniczym. Chodzi bowiem o nagłe zdarzenia, wywołane przyczyną zewnętrzną, zaistniałe podczas lub w związku z wykonywaniem przez pracownika zwykłych czynności lub poleceń przełożonych, podczas lub w związku z wykonywaniem przez pracownika czynności na rzecz pracodawcy, nawet bez polecenia czy też w czasie pozostawania pracownika w dyspozycji pracodawcy $\mathrm{w}$ drodze między siedzibą pracodawcy a miejscem wykonywania obowiązku wynikającego ze stosunku pracy. Również art. 3 ust. 2 u.u.s.w.p. związany jest bezpośrednio ze świadczeniem pracy w warunkach stosunku pracy ${ }^{254}$. Przepis art. 3 ust. 3 pkt 6 u.u.s.w.p. stanowi, że za wypadek przy pracy uważa się również nagłe zdarzenie wywołane przyczyną zewnętrzną, powodujące uraz lub śmierć, które nastąpiło $\mathrm{w}$ okresie ubezpieczenia wypadkowego $\mathrm{z}$ danego tytułu podczas wykonywania pracy na podstawie umowy agencyjnej, umowy zlecenia lub umowy o świadczenie usług, do której zgodnie z kodeksem cywilnym stosuje się przepisy dotyczące zlecenia. Wydawałoby się, że wskazane regulacje (art. 3 ust. 1 i ust. 3 u.u.s.w.p.) mają charakter synchronizacyjny - nie rozróżniają one sytuacji prawnej osób świadczących pracę na różnych podstawach umownego zatrudnienia nietypowego ${ }^{255}$. Trzeba jednak mieć na uwadze, że znaczna większość okoliczności stanowiących

kowania zawodowego i poszukiwania nowego zatrudnienia, a także osoby pobierające wynagrodzenie przysługujące w okresie korzystania ze świadczenia górniczego albo w okresie korzystania ze stypendium na przekwalifikowanie, wynikające z odrębnych przepisów lub układów zbiorowych pracy; 7) osoby pobierające świadczenie szkoleniowe wypłacane po ustaniu zatrudnienia; 8) osoby podlegające dobrowolnym ubezpieczeniom emerytalnemu i rentowym (art. 7 u.s.u.s.).

251 P. Kostrzewa, Art. 12, [w:] P. Kostrzewa, Ustawa o systemie ubezpieczeń społecznych. Komentarz, https://sip-1lex-1pl-1004153yx0cd3.han3.lib.uni.lodz.pl/\#/komentarz/587704619 /502059 (dostęp: 19.09.2017).

252 G. Szyburska-Walczak, op. cit., s. 81.

253 Ustawa z dnia 30 października 2002 r., Dz.U. z 2015 r. poz. 1242 - t.j. ze zm., dalej: u.u.s.w.p.

254 Zgodnie z tym przepisem na równi z wypadkiem przy pracy, w zakresie uprawnienia do świadczeń określonych w ustawie, traktuje się wypadek, któremu pracownik uległ: 1) w czasie podróży służbowej w okolicznościach innych niż określone w ust. 1, chyba że wypadek spowodowany został postępowaniem pracownika, które nie pozostaje w związku z wykonywaniem powierzonych mu zadań; 2) podczas szkolenia w zakresie powszechnej samoobrony; 3) przy wykonywaniu zadań zleconych przez działające u pracodawcy organizacje związkowe.

255 P. Prusinowski, op. cit., s. 32. 
wypadek przy pracy, wskazanych zarówno w art. 3 ust. 1, jak i ust. 2 u.u.s.w.p., ma nieodzowny związek z zatrudnieniem pracowniczym, a jednocześnie nie ma z cechami zatrudnienia cywilnoprawnego. Na gruncie omawianej ustawy zróżnicowanie sytuacji prawnej osób świadczących pracę w różnych reżimach prawnych wynika z odmiennego charakteru wykonywanych czynności. Sytuacje te różnicuje sama konstrukcja podporządkowanego zatrudnienia pracowniczego i niepodporządkowanego zatrudnienia cywilnoprawnego. Omówiony stan prawny respektuje odmienne założenia systemowe pracy podporządkowanej i niezależnej. Różnicą w sytuacji prawnej pracowników (w rozumieniu kodeksu pracy) i pozostałych osób uprawnionych w zakresie podlegania ubezpieczeniu wypadkowemu jest to, że zasiłek wyrównawczy przysługuje jedynie pracownikom. Wynika to z redakcji art. 6 ust. 1 pkt 3 u.u.s.w.p. ${ }^{256}$

Z przedstawionych rozważań dotyczących sytuacji prawnej osób świadczących pracę $\mathrm{w}$ ramach umownego zatrudnienia nietypowego odnoszącej się do sfery podlegania ubezpieczeniom społecznym wynika, że zbliżony do pracowniczego status mają wszystkie osoby zatrudnione, poza wykonawcami umów o dzieło. Jest to związane z brakiem ciągłości zatrudnienia opartego na tej podstawie $^{257}$. Popularyzacja stosowania umów o dzieło związana jest z częstym świadczeniem pracy $\mathrm{w}$ ramach jednorazowych usług wykonywanych niezależnie. Wobec powyższego wykonawcy dzieła nie powinni być pozbawieni możliwości choćby dobrowolnego przystąpienia do ubezpieczeń społecznych ${ }^{258}$. Brak obligatoryjnego objęcia ubezpieczeniem chorobowym oraz możliwość dobrowolnego przystępowania do niego przez wszystkie osoby świadczące pracę w ramach umów prawa cywilnego, poza wykonawcami umów o dzieło, wynika z różnorodnego charakteru i okoliczności poszczególnych podstaw zatrudnienia cywilnoprawnego. Pozostawienie osobie świadczącej pracę możliwości podjęcia decyzji w tym zakresie umożliwia racjonalną, zindywidualizowaną i opartą o kryterium możliwości finansowych ocenę konkretnej sytuacji ${ }^{259}$. Powyższe prowadzi do wniosku, że wykonawcy umowy o dzieło powinni mieć możliwość dobrowolnego przystąpienia do ubezpieczenia chorobowego po oszacowaniu przez nich swoich możliwości finansowych.

256 P. Prusinowski, op. cit.

257 M. Krajewski, op. cit., s. 10.

258 I. Sierocka, Ubezpieczenie społeczne... Powyższy postulat zdaje się pozostawać w zbieżności z założeniem, że z ubezpieczeń społecznych powinny korzystać podmioty przyczyniające się do tworzenia dochodu narodowego. Zob. W. Jaśkiewicz, C. Jackowiak, W. Piotrowski, op. cit., s. 458. Osoby świadczące pracę na podstawie umów prawa cywilnego spełniają powyższy warunek.

259 A. Jabłoński, Prawo do zasitku chorobowego osoby wykonującej równocześnie pracę w ramach kilku tytułów ubezpieczeniowych, [w:] Z. Kubot, T. Kuczyński (red.), Z zagadnień prawa pracy i prawa socjalnego. Księga jubileuszowa Profesora Herberta Szurgacza, Warszawa 2011, s. 705. 


\subsubsection{Podleganie ubezpieczeniu zdrowotnemu}

Status prawny osób świadczących pracę w ramach umownego zatrudnienia nietypowego nie jest jednakowy w odniesieniu do podlegania ubezpieczeniu zdrowotnemu. Zgodnie z art. 2 Ustawy z dnia 27 sierpnia 2004 r. o świadczeniach $z$ opieki zdrowotnej finansowanych ze środków publicznych ${ }^{260}$ do korzystania ze świadczeń opieki zdrowotnej ${ }^{261}$ finansowanych ze środków publicznych na zasadach określonych w ustawie mają prawo osoby objęte powszechnym - obowiązkowym i dobrowolnym ubezpieczeniem zdrowotnym. Katalog podmiotów objętych dobrowolnym ubezpieczeniem zdrowotnym wskazuje art. 66 u.ś.z.f.ś.p. W zakresie omawianych zagadnień są to pracownicy (w rozumieniu ustawy o systemie ubezpieczeń społecznych ${ }^{262}$ ), osoby wykonujące pracę nakładczą oraz osoby wykonujące pracę na podstawie umowy agencyjnej lub umowy zlecenia ${ }^{263}$ albo innej umowy o świadczenie usług, do której stosuje się przepisy kodeksu cywilnego o zleceniu (u.ś.z.f.ś.p., art. 66 ust. 1 pkt 1 lit. a, d, e), które spełniają warunki do nabycia statusu ubezpieczonych zgodnie $\mathrm{z}$ art. 3 u.ś.z.f.ś.p. Tym samym, spośród osób świadczących pracę, których status prawny jest $\mathrm{w}$ niniejszej monografii omawiany, jedynie osoby zatrudnione na podstawie umów o dzieło nie podlegają obowiązkowemu ubezpieczeniu zdrowotnemu. Mogą one natomiast, przy spełnieniu warunku zamieszkiwania na terenie Rzeczpospolitej Polskiej, przystąpić do tego ubezpieczenia dobrowolnie

260 Dz.U. z 2016 r. poz. 1793 - t.j. ze zm., dalej: u.ś.z.f.ś.p.

261 Zgodnie z art. 5 pkt 34 u.ś.z.f.ś.p. świadczeniami opieki zdrowotnej są świadczenia zdrowotne (zgodnie z art. 5 pkt 40 u.ś.z.f.ś.p. są to działania służące profilaktyce, zachowaniu, ratowaniu, przywracaniu lub poprawie zdrowia oraz inne działania medyczne wynikające z procesu leczenia lub przepisów odrębnych regulujących zasady ich udzielania), świadczenia zdrowotne rzeczowe (zgodnie z art. 5 pkt 37 u.ś.z.f.ś.p. są to związane z procesem leczenia leki, wyroby medyczne, w tym wyroby medyczne będące przedmiotami ortopedycznymi, i środki pomocnicze) i świadczenia towarzyszące (zgodnie z art. 5 pkt 38 u.ś.z.f.ś.p. są to zakwaterowanie i adekwatne do stanu zdrowia wyżywienie w szpitalu lub w innym przedsiębiorstwie podmiotu leczniczego wykonującego działalność leczniczą w rodzaju stacjonarne i całodobowe świadczenia zdrowotne w rozumieniu przepisów o działalności leczniczej, usługi transportu oraz transportu sanitarnego, a także zakwaterowanie poza przedsiębiorstwem podmiotu leczniczego, jeżeli konieczność jego zapewnienia wynika z warunków określonych dla danego świadczenia gwarantowanego).

262 W przypadku zastosowania konstrukcji uznającej za pracownika osobę świadczącą pracę na postawie umowy prawa cywilnego zawartej z podmiotem trzecim, ale na rzecz pracodawcy, obowiązkiem odprowadzania składek na ubezpieczenie zdrowotne z tytułu umowy cywilnoprawnej obarczony jest pracodawca. Wyrok Sądu Apelacyjnego w Białymstoku, z dnia 1 lipca 2014 r., III AUa 13/14, LEX nr 1493712.

263 Ubezpieczeniu zdrowotnemu (ani ubezpieczeniom społecznym) nie podlega zleceniobiorca wykonujący zlecenie pod tytułem darmym. A. Sidorko, Ubezpieczenie zdrowotne zleceniobiorców, „Służba Pracownicza” 2010, nr 4, s. 11. 
(art. 68 ust. 1 u.ś.z.f.ś.p.) ${ }^{264}$. Aby wykonawca dzieła, nieposiadający tytułu określonego w art. 66 ust. 1 u.ś.z.f.ś.p., uprawniającego do ubezpieczenia zdrowotnego, został nim objęty, musi wnieść jednorazową opłatę (art. 68 ust. 7 u.ś.z.f.ś.p.), której wysokość uzależniona jest od okresu przerwy w ubezpieczeniu zdrowotnym i w opłacaniu składek (art. 68 ust. 8 u.ś.z.f.ś.p.). Osoba ubiegająca się o dobrowolne ubezpieczenie zdrowotne składa w wybranym oddziale wojewódzkim Narodowego Funduszu Zdrowia (NFZ) wniosek, podpisując następnie z NFZ umowę dobrowolnego ubezpieczenia zdrowotnego. Umowa zawierana jest na czas nieokreślony i ma charakter umowy adhezyjnej ${ }^{265}$.

Zróżnicowanie sytuacji prawnej osób świadczących pracę w ramach umownego zatrudnienia nietypowego w zakresie podlegania ubezpieczeniu zdrowotnemu wydaje się uzasadnione. Możliwość podlegania mu mają wszystkie osoby świadczące pracę $^{266}$. Brak trwałej więzi pomiędzy podmiotami umowy o dzieło uzasadnia brak obowiązkowego ubezpieczenia zdrowotnego, dając możliwość przystąpienia do niego w sposób dobrowolny. W takiej sytuacji okres ubezpieczenia nie jest uzależniony od wykonania umowy o charakterze jednorazowym, a związany jest z obowiązywaniem umowy zawartej pomiędzy wykonawcą umowy o dzieło a NFZ.

\subsection{Podsumowanie}

Przeprowadzona w tej części opracowania analiza wydaje się jednoznacznie wskazywać, że status prawny osób świadczących pracę w ramach umownego zatrudnienia nietypowego jest zróżnicowany na wszystkich omówionych płaszczyznach - w zakresie obowiązków i uprawnień osób świadczących pracę, ich odpowiedzialności, odpowiedzialności podmiotów zatrudniających oraz w zakresie podlegania ubezpieczeniom społecznym i ubezpieczeniu zdrowotnemu. Odmienności dotyczące kreowania statusu prawnego osób świadczących pracę w okresie realizacji stosunku prawnego, $\mathrm{w}$ ramach poszczególnych podstaw prawnych i form organizacyjnych umownego zatrudnienia nietypowego, są uzależnione od ich społeczno-gospodarczego przeznaczenia. Ponieważ rodzaje umów o pracę, jako podstawy umownego zatrudnienia pracowniczego, mają tożsame społeczno-gospodarcze przeznaczenie, w ramach omówionych w niniejszej części zagad-

264 A. Sidorko, Art. 68, [w:] A. Pietraszewska-Macheta (red.), Ustawa o świadczeniach zdrowotnych finansowanych ze środków publicznych. Komentarz, https://sip-1lex-1pl1004153yx0cd3.han3.lib.uni.lodz.pl/\#/komentarz/587259973/521174 (dostęp: 19.09.2017).

265 Ibidem.

266 Pod warunkiem spełnienia przesłanek określonych w art. 3 i art. 68, ust. 1 u.ś.z.f.ś.p. 
nień status prawny pracowników nie jest zróżnicowany w zależności od rodzaju umowy o pracę (poza umową zawieraną w ramach zatrudnienia tymczasowego).

W odniesieniu do pracy świadczonej w formie organizacyjnej telepracy odmienności statusu prawnego telepracowników związane są z faktem, że praca ta jest wykonywana również bądź wyłącznie poza zakładem pracy. Powoduje to, że ukształtowanie zarówno obowiązków, jak i uprawnień telepracowników jest odmienne od typowego. Powyższe jest widoczne zwłaszcza na płaszczyźnie omówionych w toku wywodu obowiązków i uprawnień stron stosunku pracy związanych z bezpieczeństwem i higieną pracy.

Zatrudnienie tymczasowe, ukształtowane jako więź trójpodmiotowa, spełniające szczególne założenia systemowe, w sposób mu właściwy wpływa na status prawny osób świadczących pracę w okresie realizacji stosunku prawnego. Konstrukcja ta wymusza podzielenie obowiązków pracownika tymczasowego na obowiązki, które musi wykonywać względem agencji pracy tymczasowej i obowiązki, których musi przestrzegać względem pracodawcy użytkownika. Zatrudnienie tymczasowe w sposób odmienny od zatrudnienia typowego reguluje również uprawnienia pracownicze. Do uczynienia zadość obowiązkowi ich zapewnienia zobowiązana jest agencja pracy tymczasowej oraz pracodawca użytkownik. W tym względzie szczególnie unormowany został tryb udzielania urlopu wypoczynkowego pracownikowi tymczasowemu oraz jego wymiar. Omówione w tym zakresie regulacje związane są nie tylko z trójpodmiotowym charakterem pracy tymczasowej, ale również z jej względną krótkotrwałością. I choć w tym kontekście nie budzą zastrzeżeń, wydaje się jednak, że mogłyby rodzić pewne wątpliwości z punktu widzenia zasady równego traktowania.

Zróżnicowanie statusu prawnego osób świadczących pracę w ramach cywilnoprawnego zatrudnienia umownego na omówionych w tej części monografii płaszczyznach wynika w przeważającej mierze $\mathrm{z}$ faktu podlegania innemu reżimowi prawnemu. Wydaje się przy tym uzasadnione obejmowanie osób nieposiadających statusu pracowniczego pewnymi instytucjami prawnymi właściwymi prawu pracy - regulacjami związanymi z bezpiecznymi i higienicznymi warunkami pracy czy ochroną rodzicielstwa. Dbałość o interesy o najwyższej wartości nie powinna być warunkowana podstawą świadczenia pracy, obejmując, choćby w zbliżonym zakresie, wszystkie osoby świadczące pracę. Niemniej jednak niepodporządkowany charakter umownego zatrudnienia cywilnoprawnego nie wymaga, aby stosunki prawne powstające w wyniku zawarcia umów właściwych prawu cywilnemu ujednolicały z prawem pracowniczym status prawny osób świadczących pracę na etapie realizacji stosunku prawnego. Systemowe założenie prawa cywilnego o formalnej równości stron nie czyni koniecznym dla przykładu przyznawania osobom świadczącym pracę ochrony wynagrodzenia bądź ograniczonej odpowiedzialności materialnej, jak ma to miejsce w stosunkach prawnopracowniczych. Z kolei samodzielność organizacyjna procesu pracy powoduje, że zapewnianie okresów odpoczynku nie jest, jak w przypadku zatrudnienia pracowniczego, uregulowane 
ustawowo. Skoro bowiem podmiot zatrudniający nie ma możliwości wyznaczania czasu pracy, nie może być zobowiązany do zapewniania okresów jej nieświadczenia (okresów odpoczynku bądź urlopów o charakterze wypoczynkowym).

Podstawy prawne umownego zatrudnienia cywilnoprawnego nie kreują w sposób jednolity statusu prawnego osób świadczących pracę $\mathrm{w}$ okresie realizacji umowy. Najbardziej zbliżony do pracowniczego status prawny, w zakresie omówionym w niniejszym rozdziale, posiadają wykonawcy pracy nakładczej. Wynika to z przyznania im licznych uprawnień. Pozostałe podstawy prawne umownego zatrudnienia cywilnoprawnego (umowa zlecenia, umowy o świadczenie usług, do których stosuje się przepisy o zleceniu, umowa agencyjna i umowa o dzieło) konstrukcyjnie inaczej niż prawo pracy kształtują sytuację prawną osób zatrudnionych. Konkretna podstawa prawna umownego zatrudnienia cywilnoprawnego dodatkowo dostosowuje normy wpływające na status prawny osób zatrudnionych w okresie realizacji umowy zależnie od charakteru stosunku prawnego, jego cech konstrukcyjnych oraz społeczno-gospodarczego przeznaczenia. Powyższe wynika w przeważającej mierze ze stopnia trwałości więzi umownego zatrudnienia cywilnoprawnego. W najszerszej mierze trwałość ta przejawia się w stosunku prawnym powstającym $w$ wyniku zawarcia umowy agencyjnej. Stąd status prawny agenta w fazie realizacji umowy jest szczególny zarówno w zakresie jego obowiązków (np. obowiązek lojalności - art. 760 k.c.), jak i uprawnień (np. prawo do wynagrodzenia prowizyjnego nawet po zakończeniu umowy - art. $761^{1}$ k.c.).

Umowa zlecenia w konstrukcji stanowionej normą art. 734 k.c. dotyczy co prawda zobowiązania do dokonania jednostkowej czynności prawnej, jednak powyższe nie stoi na przeszkodzie, aby objętych było nią więcej czynności prawnych ${ }^{267}$. W związku z powyższym zlecenie powstające zarówno w oparciu o art. 734 k.c., jak i umowy o świadczenie usług, o których mowa w art. 750 k.c., tworzą więź względnie trwałą. To z kolei uzasadnia wprowadzenie do przepisów regulujących tę podstawę umownego zatrudnienia cywilnoprawnego norm w sposób szczególny regulujących status prawny osób świadczących pracę w okresie realizacji umowy, jak choćby ustanowiony treścią przepisu art. 740 k.c. obowiązek udzielania informacji o przebiegu sprawy ${ }^{268}$.

Istotą umowy o dzieło jest jej realizacja poprzez dokonanie jednostkowej czynności - wykonania oznaczonego dzieła (art. 627 k.c.). Powoduje to, że stosunek prawny powstający $\mathrm{w}$ wyniku zawarcia takiej umowy ma z zasady charakter nietrwały, a przyjmujący zamówienia nierzadko działa $\mathrm{z}$ wykorzystaniem przedmio-

267 S. Grzybowski, o przepisach kodeksu cywilnego, „Nowe Prawo” 1967, nr 10, s. 1281.

268 Literalne brzmienie art. 740 k.c. nawiązuje do umowy zlecenia, której przedmiotem jest dokonanie określonej czynności prawnej. W tym kontekście przyjmujący zlecenie udziela informacji np. o negocjacjach prowadzonych celem zawarcia umowy. W odniesieniu do umowy zlecenia, której przedmiotem będzie czynność faktyczna, wypełnienie obowiązku określonego w art. 740 k.c. będzie obejmowało udzielanie informacji o wykonywaniu tej czynności. 
tów i materiałów stanowiących własność zamawiającego (art. 633 k.c.). Wskazane okoliczności wpływają na ukształtowanie statusu prawnego osoby zatrudnionej w fazie realizacji stosunku prawnego w sposób dalece odmienny od statusu prawnego osób zatrudnionych w ramach umownego zatrudnienia typowego. Skutkują one również (o czym była mowa w niniejszym rozdziale) całkowitym, uznawanym przeze mnie za nieuzasadnione, wyłączeniem przyjmujących zamówienie wykonania umowy o dzieło spod możliwości przystąpienia do ubezpieczenia chorobowego. Podleganie ubezpieczeniom społecznym przez przyjmujących zamówienie wykonania umowy o dzieło jest ograniczone $\mathrm{z}$ racji epizodycznego i nietrwałego charakteru prawnego tej podstawy umownego zatrudnienia cywilnoprawnego. Powyższe nie stanowi jednak przyczyny, która uniemożliwiałaby przyznanie wykonawcom umów o dzieło możliwości dobrowolnego przystępowania do ubezpieczenia chorobowego.

Rozbudowana struktura rozdziału oraz wielość poruszanych w nim wątków wymusiła ograniczenie poczynionych uwag podsumowujących jedynie do wybranych aspektów wpływających na status prawny osób świadczących pracę w ramach umownego zatrudnienia nietypowego w okresie realizacji umowy. Wydaje się przy tym uzasadnione wskazanie, że w zakresie przeprowadzonej analizy zdecydowana większość instytucji różnicujących status prawny osób świadczących pracę $\mathrm{w}$ ramach umownego zatrudnienia nietypowego w okresie realizacji umowy uzasadniona jest społeczno-gospodarczym przeznaczeniem poszczególnych podstaw prawnych i form organizacyjnych umownego zatrudnienia nietypowego. 



\section{Status prawny osób świadczących pracę $\mathbf{w}$ ramach umownego zatrudnienia nietypowego w zakresie zbiorowych stosunków zatrudnienia}

\subsection{Wprowadzenie}

Status prawny osób świadczących pracę w ramach umownego zatrudnienia nietypowego kreują, poza regulacjami dotyczącymi indywidualnych stosunków zatrudnienia, również unormowania obejmujące swoim zakresem zbiorowe stosunki zatrudnienia. W związku z tym uzasadnione jest przeprowadzenie analiz na płaszczyźnie związanej z prawem osób świadczących pracę do zrzeszania się w związkach zawodowych, prawem do zawierania układów zbiorowych pracy i do obejmowania ich postanowieniami oraz prawem w zakresie uczestnictwa w zarządzaniu przedsiębiorstwem. $Z$ perspektywy badanego tematu doniosłe znaczenie ma możliwość dochodzenia praw oraz zapewnienie ochrony interesów wszystkim osobom świadczącym pracę $\mathrm{w}$ ramach umownego zatrudnienia nietypowego ${ }^{1}$. Pewne jest przy tym, że zbiorowe interesy osób zatrudnionych są chronione najlepiej w przypadku rozbudowanej możliwości organizowania się przez nie w tym właśnie celu². Formą takiego zorganizowania, która wydaje się najbardziej zakorzeniona w prawie pracy, są związki zawodowe ${ }^{3}$. Realizują one funkcję ochronną zbiorowego prawa pracy, polegającą na zabezpieczaniu interesów ludzi pracy rozumianych w szerokim kontekście, bez ograniczenia do osób posiadających status

1 Rozgraniczeniu pojęć „ochrona interesów” i „ochrona praw” uwagę poświęca L. Florek, Prawna ochrona pracowników, Warszawa 1990, s. 41 i nast.

2 A.M. Świątkowski wskazuje, że nawet wobec braku ustawowych możliwości zrzeszania się w związkach zawodowych, prawo takie, jako naturalne prawo człowieka, przysługuje wszystkim obywatelom, bez względu na podstawę świadczonej pracy. A.M. Świątkowski, Prawo do wolności zrzeszania się i uprawnień pokrewnych, „Monitor Prawa Pracy” 2015, nr 9, s. 455 i nast. Jednak nie sposób nie zauważyć, że brak ustawowej regulacji prawa zrzeszania się w związkach zawodowych w stosunku do niektórych grup społecznych w praktyce uniemożliwia im pełne korzystanie z prawa do zrzeszania się w związkach zawodowych.

3 J. Stelina, Zwiq̨zki zawodowe w systemie zbiorowej reprezentacji zatrudnionych - stan obecny i kierunki zmian, [w:] A. Wypych-Żywicka, M. Tomaszewska, J. Stelina (red.), Zbiorowe prawo pracy XXI wieku, Gdańsk 2010, s. 148 i 156. 
pracowniczy ${ }^{4}$. Zobowiązaniowy charakter stosunku pracy nie wyklucza możliwości korzystania z mechanizmów regulujących sytuację prawną osób zatrudnionych na poziomie zbiorowym ${ }^{5}$, a wręcz wymusza ich stosowanie. To właśnie mechanizmy zbiorowe, głównie działalność związków zawodowych, zapewniają lepszą ochronę interesów indywidualnych ${ }^{6}$. Wolność związkowa, uznawana za jedno z podstawowych praw człowieka ${ }^{7}$, powinna być $\mathrm{w}$ ramach prawa stanowionego realizowana w jak największym zakresie wobec możliwie najszerszej grupy osób. Zbadanie, na ile wszystkie osoby świadczące pracę w ramach umownego zatrudnienia nietypowego mogą korzystać z uprawnień do zrzeszania się w związkach zawodowych, pozwoli dokonać oceny wypełnienia przez porządek prawny konieczności zapewniania praw związkowych wszystkim osobom zatrudnionym. Przedstawienie statusu prawnego osób zatrudnionych $\mathrm{w}$ ramach umownego zatrudnienia nietypowego $\mathrm{w}$ zakresie prawa do zawierania układów zbiorowych pracy i podlegania ich postanowieniom umożliwi określenie różnic w sytuacji prawnej poszczególnych grup zatrudnionych. Zostaną one ocenione z perspektywy społecznego lub gospodarczego uzasadnienia występowania. W końcowej części niniejszego rozdziału zostaną zaprezentowane uwagi dotyczące statusu prawnego osób świadczących pracę w ramach umownego zatrudnienia nietypowego, związanego $\mathrm{z}$ prawem do uczestnictwa $\mathrm{w}$ zarządzaniu przedsiębiorstwem. Względnie szerokie uprawnienia pracowników w tym zakresie kształtują się w sposób nietypowy w odniesieniu do zatrudnienia tymczasowego. Co więcej, uprawnień choćby zbliżonych do pracowniczych nie posiada żadna grupa osób zatrudnionych na podstawie umów prawa cywilnego. Przedstawienie obowiązujących regulacji umożliwi dokonanie ich oceny z uwzględnieniem odniesienia do wypełnienia społecznych i gospodarczych celów poszczególnych rodzajów umownego zatrudnienia nietypowego.

\subsection{Prawo do zrzeszania się w związkach zawodowych}

Prawo tworzenia i działania w związkach zawodowych zapewnia art. 12 Konstytucji. Pochodną tego prawa jest wyrażone w art. 59 ust. 1 prawo zrzeszania

4 K.W. Baran, Zbiorowe prawo pracy, Kraków 2002, s. 18.

5 G. Goździewicz, Wptyw działań zbiorowych na indywidualne stosunki pracy, [w:] H. Lewandowski (red.), Polskie prawo pracy w okresie transformacji w oświetleniu prawa wspólnotowego, Warszawa 1997, s. 95.

6 B. Cudowski, Reprezentacja praw i interesów pracowniczych w sporach zbiorowych pracy, [w:] H. Lewandowski (red.), Polskie prawo pracy..., s. 309.

7 L. Florek, M. Seweryński, Międzynarodowe prawo pracy, Warszawa 1988, s. 120. 
się w związkach zawodowych ${ }^{8}$. Prawo to może być ograniczone tylko w zakresie związania umową międzynarodową (art. 59 ust. 4). Na gruncie prowadzonych rozważań bez znaczenia są wyłączenia możliwości wstępowania i tworzenia związków zawodowych przez takie grupy zatrudnionych jak sędziowie czy pracownicy $\mathrm{NIK}^{9}$. Istotne są natomiast inne wyłączenia, które zostaną omówione poniżej, powodujące zróżnicowanie statusu prawnego osób świadczących pracę $\mathrm{w}$ ramach umownego zatrudnienia nietypowego.

Aktami prawnymi MOP dotyczącymi problematyki tworzenia i wstępowania do związków zawodowych są: konwencja z dnia 17 czerwca 1948 r. nr 87 dotycząca wolności związkowej i ochrony praw związkowych ${ }^{10}$, konwencja z dnia 8 czerwca 1949 r. nr 98 dotycząca stosowania zasad prawa organizowania się i rokowań zbiorowych ${ }^{11}$ oraz konwencja z dnia 7 czerwca 1978 r. nr 151 dotycząca ochrony prawa organizowania się i procedury określania warunków zatrudnienia w służbie publicznej ${ }^{12}$. Prawo tworzone przez Radę Europy odwołuje się do uprawnień z zakresu zbiorowego prawa pracy w Europejskiej Karcie Społecznej ${ }^{13}$. W art. 5 gwarantuje ona pracownikom (w tekście oryginalnym użyto słowa workers $^{14}$ ) prawo do tworzenia organizacji dla ochrony ich interesów ekonomicznych i społecznych oraz wstępowania do tych organizacji. Prawodawstwo Unii Europejskiej w zakresie zbiorowego prawa pracy jest rozwinięte jedynie szczątkowo w aktach prawa pierwotnego oraz Karcie Praw Podstawowych Unii Europejskiej.

Artykuł 1 ustawy z dnia 23 maja 1991 r. o związkach zawodowych definiuje, że związki zawodowe są samorządnymi organizacjami ludzi pracy. Pomimo szerokiego zakresu desygnatów pojęcia „ludzie pracy”, ustawodawca zdecydował o zamknięciu katalogu podmiotów do niego zaliczanych ${ }^{15}$. Przepis art. 2 u.z.z. zapewnia prawo tworzenia i wstępowania do związków zawodowych wszystkim pracownikom, bez względu na podstawę stosunku pracy. Każdy pracownik, niezależnie od rodzaju podpisanej umowy o pracę oraz szczególnej organizacyjnej formy, ma takie same, nieograniczone prawa w zakresie tworzenia i wstępowania

8 L. Florek, Pojęcie i zakres wolności zwiq̨zkowej, [w:] A. Wypych-Żywicka, M. Tomaszewska, J. Stelina (red.), op. cit., s. 72.

9 Analizę tego zagadnienia przedstawia J. Skoczyński, Reprezentacja praw i interesów pracowników służby publicznej, [w:] G. Goździewicz (red.), Reprezentacja praw i interesów pracowniczych, Toruń 2001, s. 261 i nast.

10 Dz.U. z 1958 r., Nr 29, poz. 125.

11 Dz.U. z 1958 r., Nr 29, poz. 126.

12 Dz.U. z 1994 r., Nr 22, poz. 78.

13 Europejska Karta Społeczna sporządzona w Turynie 18 października 1961 r., Dz.U. z 1999 r., $\mathrm{Nr}$ 8, poz. 67 ze zm.

14 W odniesieniu do prawa polskiego ograniczenie zakresu podmiotowego Europejskiej Karty Społecznej wynika z tłumaczenia słowa „workers” jako „pracownicy”.

15 J. Unterschütz, Wybrane problemy ograniczenia swobody koalicji w świetle prawa międzynarodowego i konstytucji RP, „Praca i Zabezpieczenie Społeczne”, 2013, nr 10, s. 22. 
do związków zawodowych ${ }^{16}$. Jedyne wątpliwości w tej kwestii mogą powstać w obrębie prawa koalicji przyznanego pracownikom tymczasowym ${ }^{17}$. Należy wnioskować, że korzystają oni z pełni praw związkowych. Skoro bowiem art. 5 z.p.t. odsyła do stosowania przepisów prawa pracy, to odesłanie to dotyczy również norm zbiorowego prawa pracy ${ }^{18}$. Realizacja prawa pracowników tymczasowych w kontekście prawa koalicji w związkach zawodowych odbywa się na płaszczyźnie pracownik-pracodawca, tj. pracownicy tymczasowi - agencja pracy tymczasowej. Nie została natomiast uregulowana kwestia możliwości przyznania prawa koalicji pracownikom tymczasowym u pracodawcy użytkownika, a ponieważ to właśnie $\mathrm{z}$ tym podmiotem pracownicy tymczasowi związani są poprzez faktyczne wykonywanie pracy na jego rzecz, uzasadniony mógłby wydawać się postulat umożliwienia im wstąpienia do związku zawodowego działającego u pracodawcy użytkownika na zasadach gwarantowanych chałupnikom ${ }^{19}$. Argumentem wskazującym na zasadność przyznania pracownikom tymczasowym prawa wstępowania do związku zawodowego działającego u pracodawcy użytkownika nie może być jedynie fakt wykonywania pracy na jego rzecz ${ }^{20}$. Praca tymczasowa jest szczególną konstrukcją prawną i właśnie poprzez ten pryzmat powinno się badać problematykę związaną z prawem koalicji pracowników tymczasowych. Skoro bowiem związek zawodowy powołany jest do reprezentowania i obrony praw, interesów zawodowych i socjalnych ludzi pracy (art. 1 u.z.z.), w sposób najlepszy postulat ten mógłby spełniać związek bezpośrednio organizacyjnie związany z pracownikiem tymczasowym, czyli związek zawodowy działający u pracodawcy użytkownika. Działalność związku zawodowego obejmuje sprawowanie kontroli nad przestrzeganiem prawa pracy oraz uczestniczenie w nadzorze nad przestrzeganiem zasad bezpieczeństwa i higieny pracy (art. 23 ust. 1 u.z.z.). Jeśli względem pracowników tymczasowych działania te miałby podejmować związek działający w agencji pracy tymczasowej, ich faktyczna realizacja mogłaby być utrudniona. Odmiennym od zaproponowanego rozwiązaniem mogłoby być przyznanie pracownikom tymczasowym uprawnień do zakładania organizacji związkowych o charakterze międzyzakładowym. W takiej sytuacji wynegocjowane z pracodawcami (agencjami pracy tymczasowej) rozwiązania pracodawcy użytkownicy musieliby respektować na mocy umowy zawieranej z agencją pracy tymczasowej.

16 K.W. Baran, Komentarz do ustawy o zwiqzzkach zawodowych, art. 2, [w:] K.W. Baran, Zbiorowe prawo pracy. Komentarz, https://sip.lex.pl/\#/komentarz/587710503/507943 (dostęp: 19.09.2017).

17 A. Reda, Pracodawca użytkownik..., s. 109 i nast.

18 K.W. Baran, Zatrudnienie tymczasowe a zbiorowe prawo pracy, [w:] A. Sobczyk (red.), Z problematyki zatrudnienia tymczasowego, https://sip.lex.pl/\#/monografia/369236017/5 (dostęp: 19.09.2017).

19 J. Wratny, Problem ochrony pracowników w elastycznych formach zatrudnienia, „Praca i Zabezpieczenie Społeczne" 2007, nr 7, s. 5.

20 Przeciwnie: A. Reda, Pracodawca użytkownik..., s. 111-112. 
Dodatkowym argumentem na potwierdzenie konieczności przyznania pracownikom tymczasowym prawa koalicji w związku zawodowym działającym u pracodawcy użytkownika jest fakt, że stroną zbiorowych stosunków pracy powinien być podmiot mający faktyczny wpływ na decyzje dotyczące procesu pra$\mathrm{cy}^{21}$. W omawianym przypadku jest to pracodawca użytkownik, nie agencja pracy tymczasowej. Klauzula art. 5 z.p.t., nakazując stosowanie względem podmiotów zatrudnienia tymczasowego przepisów prawa pracy dotyczących odpowiednio pracownika i pracodawcy, umożliwia dostosowanie norm zbiorowego prawa pracy do realiów pracy tymczasowej22. Ustawa o związkach zawodowych nie uzależnia członkostwa $\mathrm{w}$ związku zawodowym od pozostawania $\mathrm{w}$ stosunku pracy z pracodawcą, u którego ten związek działa ${ }^{23}$, zatem nie ma prawnych przeszkód, aby pracownicy tymczasowi mogli wstępować do związku działającego u pracodawcy użytkownika, nawet jeśli, z uwagi na dużą fluktuację zatrudnienia, stosunkowo rzadko będą tym zainteresowani ${ }^{24}$. Nie jest to jednak argument na poparcie stanowiska, że prawo takie nie powinno zostać im zagwarantowane. Inną kategorią jest bowiem przyznanie prawa, a inną korzystanie $\mathrm{z}$ niego.

W zakresie dotyczącym uprawnień koalicyjnych osób zatrudnionych na podstawie umów cywilnoprawnych należy zwrócić uwagę na rozgraniczenie prawa tworzenia i wstępowania do związków zawodowych, wpływające na zróżnicowanie ich statusu prawnego. Pomimo że prawo zrzeszania się w związkach zawodowych na tle przepisów konstytucyjnych nie zostało ograniczone jedynie do pracowników ${ }^{25}$, z praw tych, na podstawie ustawy o związkach zawodowych, nie mogą w pełni korzystać wszystkie osoby świadczące pracę w ramach umów prawa cywilnego ${ }^{26}$. Spośród osób zatrudnionych na cywilnoprawnych podstawach oba wskazane uprawnienia (do tworzenia i wstępowania do związków zawodowych) posiadają jedynie wykonawcy umowy agencyjnej, pod warunkiem że sami nie są pracodawcami (art. 2 ust. 1 u.z.z.). Wykonawcom pracy nakładczej przyzna-

21 K. Walczak, Równość czy równowaga w zbiorowych stosunkach pracy, [w:] A.M. Świątkowski (red.), Ochrona praw człowieka w świetle przepisów prawa pracy i zabezpieczenia społecznego. Referaty i wystąienia zgłoszone na XVII Zjazd Katedr/Zakładów Prawa Pracy i Zabezpieczenia Społecznego, Kraków 7-9 maja 2009 r., Warszawa 2009, s. 255.

22 K.W. Baran, Zatrudnienie tymczasowe...

23 Ograniczenie takie wynika jednak często ze statutów związkowych.

24 J. Wratny podaje jako jedną z przyczyn spadku uzwiązkowienia właśnie pracę tymczasową jako podstawę niesprzyjającą wstępowaniu do związków zawodowych. J. Wratny, Zwiq̨zki zawodowe $i$ inne formy przedstawicielstwa pracowniczego, „Monitor Prawa Pracy” 2013, nr 12, s. 633.

25 Z. Hajn, Prawo zrzeszania się w związkach zawodowych - prawo pracowników, czy prawo ludzi pracy?, [w:] A. Wypych-Żywicka, M. Tomaszewska, J. Stelina (red.), op. cit., s. 179.

26 Stuszna wydaje się uwaga o nieadekwatności tego katalogu. Uprawnienia związane z prawem koalicji nie przysługują bowiem najliczniejszym grupom zatrudnionym na podstawie umów cywilnoprawnych - osobom pracującym w ramach umów zleceń i umów o dzieło. Zob. M. Gersdorf, Prawo zatrudnienia..., s. 188. 
no prawo do wstępowania do związków zawodowych, wyłączając względem tych podmiotów możliwość ich tworzenia. Prawo to jest dodatkowo ograniczone do możliwości wstąpienia do związku zawodowego działającego w zakładzie pracy, z którym wykonawcy pracy nakładczej nawiązali umowę o pracę nakładczą (art. 2 ust. 2 u.z.z.).

W związku z powyższą regulacją z 28 lipca 2011 r. Niezależny Samorządny Związek Zawodowy „Solidarność” złożył skargę do Międzynarodowej Organizacji Pracy, zarzucając polskiemu rządowi naruszenie międzynarodowych standardów prawa pracy (konwencji nr 87, 98 i $135^{27}$ ) poprzez przyznanie prawa do zrzeszania się w związkach zawodowych tylko wybranym kategoriom osób ${ }^{28}$. Ustawodawstwu polskiemu zarzucono nieefektywną ochronę przed dyskryminacją w zakresie możliwości przynależności do związków zawodowych. NSZZ „Solidarność" wysunął szereg argumentów na poparcie swojego stanowiska. Pierwszy z nich wskazywał, że polska wersja konwencji MOP nr 87 używa słowa „pracownicy” dla przetłumaczenia angielskiego słowa workers. Podniesiono zarzut, że zdefiniowane w kodeksie pracy pojęcie „pracownicy” jest znaczeniowo węższe od pojęcia workers (zatrudnieni/pracujący). Skarżący wskazali, że wszystkie podmioty świadczące odpłatną pracę powinny mieć prawo do założenia związków zawodowych i przynależności do nich zgodnie z ich wyborem oraz że nie powinno istnieć rozróżnienie oparte na rodzaju zatrudnienia. Drugim zarzutem NSZZ „Solidarność" była arbitralność ustawodawcy dotycząca kręgu podmiotów, którym przyznano pełne bądź ograniczone prawo koalicji w związkach zawodowych.

Zdaniem NSZZ „Solidarność" w polskim ustawodawstwie naruszona została również konwencja $\mathrm{nr} 135$, stanowiąca, że termin „reprezentacja pracujących” odnosi się nie tylko do członków związków zawodowych, ale również do osób, którym przyznano takie prawo w ustawodawstwie krajowym. Tylko pracownicy, w rozumieniu kodeksu pracy, korzystają z pełnej ochrony, którą gwarantują zakładowe organizacje związkowe. Podniesiono również, że ograniczoną względem pracowniczej ochronę przyznano chałupnikom, którym ochrona przed wypowiedzeniem i rozwiązaniem stosunku pracy nakładczej przysługuje tylko w przypadku gdy są członkami zarządu tej organizacji ( $\$ 5$ rozp. pr. nakład.). Pracownikom ochrona taka przysługuje nawet $\mathrm{w}$ przypadku gdy nie są członkami zakładowej organizacji związkowej, a związek zawodowy wyraził zgodę na ich obronę (art. $23^{2}$ k.p.). W ostatnim z zarzutów wskazana została dyskryminująca pozycja osób świadczących pracę na podstawie umowy agencyjnej, których prawo do tworzenia i wstępowania do związków zawodowych zostało uwarunkowane nieposiadaniem równolegle statusu pracodawcy. Odpowiedzią na skargę były

27 Konwencja z dnia 2 czerwca 1971 r. dotycząca ochrony przedstawicieli pracowników w przedsiębiorstwach i przyznania im ułatwień, Dz.U. z 1977 r., Nr 39, poz. 178.

28 NSZZ „Solidarność”. Komisja Krajowa, www.solidarnosc.org.pl/images/files/zalaczniki/ Skarga_MOP_www_.PDF (dostęp: 18.01.2017). 
spotkania partnerów społecznych w dniach 14-16 maja 2014 r. ${ }^{29}$, których przedmiotem było sprawozdanie Misji Międzynarodowej Organizacji Pracy ${ }^{30}$. Postulaty wysunięte przez Misję MOP nie pozostawiają wątpliwości w zakresie konieczności rozszerzenia uprawnień koalicyjnych na osoby zatrudnione na podstawie umów prawa cywilnego. Rozszerzenie to nie musiałoby jednak mieć charakteru zupełnego. Nadrzędnym celem jest przyznanie wszystkim osobom pracującym prawa do organizowania się i możliwości prowadzenia dialogu społecznego.

Kwestionowana pod względem zgodności ze standardami MOP regulacja zdaje się nie posiadać uzasadnienia, a wybory ustawodawcy przybierają formę legislacyjnej dowolności. Trudno oprzeć się wrażeniu, że ustawodawca według swego uznania przyznał pewnym grupom podmiotów uprawnienia, ograniczając je albo całkowicie wyłączając w przypadku innych grup ${ }^{31}$. Przyznano uprawnienia osobom zatrudnionym na podstawie umów agencyjnych (o ile nie zatrudniają pracowników), które są przecież umowami cywilnoprawnymi ${ }^{32}$, a nie przyznano takich uprawnień np. wykonawcom dzieła, pomimo że prawa oraz interesy zawodowe i socjalne tych osób również powinny podlegać ochronie ${ }^{33}$ zgodnie $\mathrm{z}$ art. 1 u.z.z. Na obronę takiej regulacji racjonalny mógłby być argument, że agent zazwyczaj pozostaje w stałej współpracy z podmiotem zatrudniającym, natomiast wykonawca dzieła nie. Nie jest to jednak zasada, stąd prawa związane ze zrzeszaniem się w związkach zawodowych powinny być jednakowe względem wszystkich osób zatrudnionych w ramach cywilnoprawnego zatrudnienia umownego.

Przepisy zawężające prawo do zrzeszania się w związkach zawodowych do wybranych grup osób zatrudnionych na podstawie umów prawa cywilnego zostały wyrokiem Trybunału Konstytucyjnego z dnia 2 czerwca 2015 r. ${ }^{34}$ uznane za niezgodne $\mathrm{z}$ art. 12 Konstytucji. W komunikacie wydanym po ogłoszeniu powyższego wyroku Trybunał wskazał, że podmiotem wolności zrzeszania się w związku zawodowym są pracownicy, ale w konstytucyjnym rozumieniu tego pojęcia. Status pracownika powinien być oceniany przez odwołanie się do kryterium wykonywania pracy zarobkowej, a nie definicji znajdującej się w kodeksie pracy ${ }^{35}$. W uzasadnieniu do powyższego wyroku Trybunał Konstytucyjny sformułował trzy przesłanki wyznaczające ramy prawne konstytucyjnego rozumienia pojęcia „pracownik”, o któ-

29 Przebieg pomocy technicznej ze strony MOP przedstawia E. Podgórska-Rakiel, Konieczność nowelizacji prawa polskiego w kwestii wolności zwiq̨zkowych z perspektywy Międzynarodowej Organizacji Pracy, „Monitor Prawa Pracy” 2014, nr 10, s. 510-514.

30 NSZZ „Solidarność”. Komisja Krajowa, www.solidarnosc.org.pl/images/files/zalaczniki/ Pomoc_techniczna_MOP.pdf (dostęp: 18.01.2017).

31 Z. Hajn, op. cit., s. 176-177.

32 D. Wojciechowska, Związki zawodowe w firmie, Gdańsk 2004, s. 8.

33 J. Unterschütz, Wybrane problemy..., s. 24.

34 K 1/13, Dz.U. z 2015 r., poz. 791.

35 Trybunał Konstytucyjny, http://trybunal.gov.pl/rozprawy/komunikaty-prasowe/komunikaty-po/art/8073-zasady-tworze nia -zwiazkow-zawodowych/ (dostęp: 17.08.2015). 
rym mowa w art. 59 ust. 1 Konstytucji. Pojęcie to obejmuje wszystkie osoby, które po pierwsze wykonują określoną pracę zarobkową, po drugie pozostają w stosunku prawnym z podmiotem, na rzecz którego ją świadczą, oraz po trzecie mają takie interesy zawodowe związane z wykonywaniem pracy, które mogą być grupowo chronione. Konsekwencją wyroku Trybunału Konstytucyjnego są prace legislacyjne mające na celu zmianę ustawy o związkach zawodowych ${ }^{36}$. Uzasadnienie do projektu zmiany ustawy o związkach zawodowych wskazuje, że prace nad nią zmierzają do objęcia pełnym prawem koalicji związkowej, czyli prawem tworzenia i wstępowania do organizacji związkowych, wszystkich osób świadczących osobiście pracę za wynagrodzeniem, bez względu na podstawę zatrudnienia. Nowelizowane przepisy zakładają, że pracownikiem jest każdy, kto wykonuje określoną pracę zarobkową na rzecz innego podmiotu w ramach łączącego go $\mathrm{z}$ tym podmiotem stosunku prawnego. Nowelizacja ma na celu umożliwienie tworzenia i wstępowania do związków zawodowych w szczególności osobom wykonującym pracę na podstawie umów cywilnoprawnych. Ponadto $\mathrm{w}$ ramach definicji osoby wykonującej pracę zarobkową zakłada się rozszerzenie uprawnienia do tworzenia związków zawodowych na osoby wykonujące pracę nakładczą, które dotychczas posiadały jedynie uprawnienie do wstępowania do związków zawodowych działających już w zakładzie pracy. Pełne prawo koalicji związkowej będzie przysługiwało zatem wszystkim osobom wykonującym pracę zarobkową. Projektowane zmiany nie są oceniane jednoznacznie ${ }^{37}$. $\mathrm{Z}$ ferowaniem ostatecznych wniosków dotyczących rozszerzenia zakresu podmiotowego prawa koalicji należy jednak poczekać do ustalenia ostatecznego brzmienia znowelizowanej ustawy o związkach zawodowych.

Przyznanie uprawnień koalicyjnych wiąże się z rzeczywistym wykonywaniem zadań przez związki zawodowe, czyli ochroną indywidualnych i zbiorowych interesów zatrudnionych. Prawo do zrzeszania się służy ochronie interesów zbiorowych, które realizowane są przez inne prawa zbiorowe ${ }^{38}$. Związki zawodowe w zakresie zbiorowych praw pracowniczych mają prawo m.in. do prowadzenia rokowań zbiorowych $\mathrm{z}$ pracodawcą $\mathrm{w}$ celu zawarcia układu zbiorowego pracy,

36 Projekt dostępny na stronie: Ministerstwo Pracy i Polityki Społecznej, https://www.mpips. gov.pl/bip/projekty-aktow-prawnych/projekty-ustaw/dialog-spoleczny/projekt-ustawyo-zmianie-ustawy-o-zwiazkach-zawodowych-oraz-niektorych-innych-ustaw/\#akapit3 (dostęp: 18.01.2017).

37 K.W. Baran wskazuje, że rozszerzenie pełnego prawa koalicji wydaje się zbyt rozległe. K.W. Baran, Refleksje o zakresie prawa koalicji w projekcie nowelizacji ustawy o zwiqzkach zawodowych, „Monitor Prawa Pracy” 2016, nr 6, s. 289. P. Grzebyk zwraca uwagę m.in. na mankamenty regulacji uzależniającej prawo koalicji od długości trwania okresu zatrudnienia na podstawie umowy cywilnoprawnej. P. Grzebyk, Osoby wykonujq̨ce pracę zarobkowq a wolność koalicji. Uwagi na marginesie projektu zmieniającego ustawę o zwiqzzkach zawodowych z 22 marca 2016 r., „Praca i Zabezpieczenie Społeczne” 2016, nr 5, s. 6.

38 M. Kurzynoga, Prawo do wszczęcia sporu zbiorowego oraz prawo do akcji zbiorowych osób zarobkowo wykonujących pracę niebędących pracownikami, „Monitor Prawa Pracy” 2014, nr 12, s. 623. 
wszczynania i prowadzenia sporu zbiorowego pracy, organizowania strajku, akcji protestacyjnych czy uzgadniania treści regulaminów ${ }^{39}$. Konsekwencją nieposiadania prawa tworzenia i przynależności do związków zawodowych przez osoby zatrudnione niewskazane $\mathrm{w}$ art. 2 u.z.z. jest pozbawienie ich reprezentacji związkowej w wymienionych aspektach ${ }^{40}$.

Ważnym punktem odniesienia w rozważaniach dotyczących aktualnej dyskusji nad prawem pracy, również w zakresie prawa koalicji w związkach zawodowych, są projekty kodeksu pracy i zbiorowego kodeksu pracy. W art. 7 jako jedną z zasad zbiorowego prawa pracy projekt zbiorowego kodeksu pracy wymienia prawo zrzeszania się w związkach zawodowych. Prawo to dotyczy jedynie pracowników. Jednakże w części bezpośrednio poświęconej związkom zawodowym projekt przyznaje prawo koalicji w związkach zawodowych szerszej grupie podmiotów. $\mathrm{Z}$ art. 15 projektu zbiorowego kodeksu pracy wynika, że osoby niebędące pracodawcami, ale wykonujące pracę zarobkową (czyli na przykład zleceniobiorcy, wykonawcy dzieła czy chałupnicy) mają prawo przynależności do organizacji pracowniczych. Regulacja ta stanowi przełomową i postępową propozycję $\mathrm{w}$ dyskusji nad rozszerzeniem prawa koalicji w związkach zawodowych na podmioty zatrudnione w ramach cywilnoprawnych podstaw zatrudnienia umownego.

Sytuację prawną osób zatrudnionych w zakresie prawa koalicji w związkach zawodowych reguluje również ustawa $\mathrm{z}$ dnia 3 grudnia $2010 \mathrm{r}$. o wdrożeniu niektórych przepisów Unii Europejskiej w zakresie równego traktowania. Przepis art. 4 ust. 3 ww. ustawy stanowi, że stosuje się ją w zakresie przystępowania i działania w związkach zawodowych, organizacjach pracodawców oraz samorządach zawodowych, a także $\mathrm{w}$ zakresie korzystania $\mathrm{z}$ uprawnień przysługujących członkom tych organizacji. Z art. 4 ust. 2 ustawy o wdrożeniu niektórych przepisów Unii Europejskiej w zakresie równego traktowania wynika, że ustawa ma zastosowanie do warunków podejmowania i wykonywania działalności gospodarczej lub zawodowej na podstawie umowy cywilnoprawnej, stąd należałoby wnioskować, że ustawa uznaje możliwość przystępowania i działalności w związkach zawodowych osobom świadczącym pracę na podstawie umów cywilnoprawnych. W odniesieniu do prawa koalicji w związkach zawodowych omawiana ustawa reguluje jednak tylko aspekty związane z równym traktowaniem. Nie przyznaje ona natomiast prawa koalicji. Aktem szczegółowym dotyczącym prawa koalicji jest ustawa o związkach zawodowych, która nie daje możliwości tworzenia i wstępowania do

39 E. Wronikowska, P. Nowik, Zbiorowe prawo pracy, Warszawa 2008, s. 9-10.

40 B. Cudowski, Reprezentacja zatrudnionych w sporach zbiorowych pracy (de lege lata $i$ de lege ferenda), [w:] A. Wypych-Żywicka, M. Tomaszewska, J. Stelina (red.), op. cit., s. 241. K.W. Baran wskazuje, że osoby świadczące pracę w ramach umownego zatrudnienia obligacyjnego, nie mając prawa do zrzeszania się w związkach zawodowych, zgodnie z dyrektywą a fortiori, nie mogą brać udziału w akcjach protestacyjnych. K.W. Baran, Zbiorowe prawo pracy a zatrudnienie niepracownicze, [w:] K.W. Baran (red.), System prawa pracy, t. 7: Zatrudnienie niepracownicze, Warszawa 2015, s. 690. 
związków zawodowych wszystkim osobom zatrudnionym na podstawie umów cywilnoprawnych. Obszarem obowiązywania ustawy o wdrożeniu niektórych przepisów Unii Europejskiej w zakresie równego traktowania objęte są jedynie te podmioty, którym mocą ustawy o związkach zawodowych przyznano prawo tworzenia bądź wstępowania do związków zawodowych.

Z przedstawionej analizy statusu prawnego osób świadczących pracę $\mathrm{w}$ ramach umownego zatrudnienia nietypowego w zakresie prawa do zrzeszania się w związkach zawodowych wynika, że status ten jest zróżnicowany w zależności od podstawy zatrudnienia. O ile nie różni się on w zakresie kształtowania statusu prawnego pracowników (wszyscy mają bowiem pełne prawo koalicji), o tyle umowne podstawy zatrudnienia cywilnoprawnego przyznają osobom świadczącym pracę uprawnienia w zakresie okrojonym (wykonawcy pracy nakładczej, agenci) bądź nie przyznają ich w ogóle (przyjmujący zlecenie i osoby zatrudnione na podstawie umów o świadczenie usług, do których stosuje się przepisy o zleceniu, wykonawcy umowy o dzieło). Taka dyferencjacja nie wydaje się uzasadniona społecznym przeznaczeniem poszczególnych podstaw zatrudnienia. W odniesieniu do prawa do zrzeszania się w związkach zawodowych i innych praw z nim związanych nadrzędną rolę pełni bowiem konieczność przyznania pełni praw wszystkim osobom świadczącym pracę $\mathrm{w}$ ramach umownego zatrudnienia nietypowego.

\subsection{Prawo do zawierania układów zbiorowych pracy i podleganie ich postanowieniom}

Oprócz prawa koalicji w związkach zawodowych w obrębie zagadnień związanych ze zbiorowymi stosunkami pracy status prawny osób świadczących pracę $\mathrm{w}$ ramach umownego zatrudnienia nietypowego zostanie przedstawiony $\mathrm{w}$ kontekście prawa do zawierania układów zbiorowych pracy i podlegania ich postanowieniom. Układy zbiorowe pracy stanowią skuteczny instrument ochrony pracowników, znajdujący zastosowanie przede wszystkim w dążeniu do poprawy warunków płacy i pra$\mathrm{cy}^{41}$, dlatego podleganie ich postanowieniom wywiera istotny wpływ na sytuację prawną określonych grup podmiotów. Układy zbiorowe pracy cedują na partnerów społecznych część monopolu państwa w kształtowaniu warunków pracy, stwarzając najlepsze gwarancje oddziaływania zbiorowego na stosunki pracy ${ }^{42}$.

41 W. Sanetra, Konstytucyjne prawo do rokowań, „Praca i Zabezpieczenie Społeczne” 1998, nr 12, s. 4; L. Florek, Znaczenie układów zbiorowych pracy, [w:] Z. Góral (red.), Układy zbiorowe pracy w stulecie urodzin Profesora Wacława Szuberta, Warszawa 2013, s. 49.

42 G. Goździewicz (red.), Reprezentacja praw..., s. 98, 100. 
Problematyka związana z układami zbiorowymi pracy wykracza poza obszar prawodawstwa krajowego. Międzynarodowa Organizacja Pracy w odniesieniu do rokowań wydała konwencje z dnia 8 marca 1949 r. nr 98, z dnia 3 czerwca 1981 r. nr $154^{43}$ oraz zalecenia $\mathrm{z}$ dnia 6 czerwca $1951 \mathrm{r}$. nr $91^{44}$ i z dnia 3 czerwca $1981 \mathrm{r}$. $\mathrm{nr} 163^{45}$. Odmienność regulacji prawnych państw członkowskich w zakresie układów zbiorowych pracy nie dała możliwości stworzenia uniwersalnych norm na poziomie Unii Europejskiej. Nie znaczy to jednak, że ustawodawstwo unijne nie kładzie nacisku na dialog społeczny ${ }^{46}$.

Prezentacja krajowych unormowań rozpoczęta zostanie od Konstytucji. W art. 87 Konstytucji w katalogu źródeł prawa nie zostały wymienione układy zbiorowe pracy. Konstytucyjne podstawy do zawierania układów zbiorowych pracy znajdują się natomiast w art. 59 ust. 2. W zgodności z regulacją konstytucyjną pozostaje kodeks pracy. Układy zbiorowe pracy są, zgodnie z brzmieniem art. 9 $\$ 1$ k.p., źródłami prawa pracy. Nie mają one natomiast charakteru powszechnego - wiążą co do zasady strony, które układ zawarły ${ }^{47}$. Wśród podmiotów uprawnionych do zawierania układów zbiorowych pracy Konstytucja wymienia związki zawodowe oraz pracodawców i ich organizacje. Wszyscy pracownicy będących stroną układu pracodawców mają równe prawo do bycia objętymi postanowieniami układu zbiorowego pracy zawartego przez właściwą organizację związkową ${ }^{48}$. Powodem wyłączenia spod obowiązywania układu nie może być zatem ani forma organizacyjna zatrudnienia, ani tym bardziej rodzaj umowy o pracę, na podstawie której pracownik jest zatrudniony. Tego typu wyłączenia stanowiłyby przejaw dyskryminacji.

Regulacje dotyczące zawierania oraz obowiązywania układów zbiorowych pracy stosuje się do wszystkich pracowników. W tym zakresie w sposób szczególny przedstawia się status prawny pracowników tymczasowych ${ }^{49}$. Prawo do rokowań pracowników zatrudnianych przez agencje pracy tymczasowej

43 Konwencja nr 154 dotycząca popierania rokowań zbiorowych, MOP, www.mop.pl/doc/html/ konwencje/k154.html (dostęp: 18.01.2017).

44 Zalecenie nr 91 dotyczące układów zbiorowych, MOP, www.mop.pl/doc/html/zalecenia/ z091.html (dostęp: 18.01.2017).

45 Zalecenie nr 163 dotyczące popierania rokowań zbiorowych, MOP, www.mop.pl/doc/html/ zalecenia/z163.html (dostęp: 18.01.2017).

46 Szerzej problematykę tę omawia A.M. Świątkowski, Europejskie prawo socjalne, Warszawa 1999, s. 445-462.

47 G. Goździewicz, Układy zbiorowe pracy jako źródto prawa pracy, [w:] Z. Góral (red.), Układy zbiorowe pracy w stulecie..., s. 77-78.

48 Wyjątek stanowi możliwość wyłączenia spod obowiązywania układu jakiejś grupy pracowników (art. 239 § 1 k.p.).

49 M. Paluszkiewicz wskazuje, że w Polsce brak jest praktyki układowej w zatrudnieniu tymczasowym, co nie wyklucza konieczności omówienia tego zagadnienia. M. Paluszkiewicz, Układy zbiorowe pracy w zatrudnieniu tymczasowym, [w:] Z. Góral (red.), Układy zbiorowe pracy w stulecie..., s. 248. 
gwarantuje konwencja MOP z dnia 3 czerwca 1997 r. nr 181 ${ }^{50}$. Na gruncie prawa krajowego brakuje stosownej regulacji uszczegóławiającej tę problematykę. W związku z powyższym powstaje wątpliwość, czy art. 5 z.p.t. daje możliwość stosowania przepisów dotyczących układów zbiorowych pracy do podmiotów pracy tymczasowej ${ }^{51}$. Jeśli przyjąć takie założenia za Magdaleną Paluszkiewicz ${ }^{52}$, należy rozróżnić kilka możliwości faktycznego stosowania przepisów dotyczących układów zbiorowych pracy do zatrudnienia tymczasowego. Autorka wskazuje, że ponadzakładowy układ zbiorowy pracy mógłby zostać zawarty wyłącznie przez organizacje zrzeszające agencje pracy tymczasowej albo przez te organizacje oraz pracodawcó ${ }^{53}$. Obejmowałby on swoim zakresem tylko pracowników tymczasowych bądź wszystkich pracowników zatrudnianych przez stronę pracodawczą układu. Możliwa jest przy tym sytuacja, w której pracownicy tymczasowi wstępowaliby do ponadzakładowej organizacji związkowej działającej u pracodawcy użytkownika. Jednak z uwagi na krótkotrwały charakter pracy tymczasowej działania takie pozbawione są większego znaczenia prawnego. W kontekście analizy zakładowych układów zbiorowych pracy Paluszkiewicz wskazuje na możliwość zawarcia układu, którego stroną byłaby agencja pracy tymczasowej. Podaje tym samym w wątpliwość możliwość zawarcia układu przez pracodawcę użytkownika. Zwraca bowiem uwagę na fakt, że strona układu zbiorowego pracy musi posiadać status pracodawcy, zatem nie każdy pracodawca użytkownik będzie mógł być stroną układu ${ }^{54}$. Co więcej, o ile relacja pomiędzy agencją pracy tymczasowej a pracownikiem tymczasowym może być względnie trwała (jeżeli pracownik tymczasowy kierowany jest do pracy tymczasowej przez jedną agencję, ale do różnych pracodawców użytkowników), o tyle relacja pomiędzy pracownikiem tymczasowym a pracodawcą użytkownikiem ma $\mathrm{z}$ natury pracy tymczasowej charakter krótkotrwały. Dlatego tworzenie układu na tej płaszczyźnie nie wydaje się racjonalne. Prawną możliwość wyklucza dodatkowo brak więzi stosunku pracy pomiędzy pracodawcą użytkownikiem a pracownikiem tymczasowym. Układ zbiorowy pracy obowiązujący u pracodawcy użytkownika może natomiast pośrednio wpływać na sytuację pracownika tymczasowego. Skoro bowiem na gruncie dyspozycji art. 15 z.p.t. pracownicy tymczasowi nie mogą być traktowani mniej korzystnie niż pracownicy pracodawcy użytkownika pracujący na takim samym bądź podobnym stanowisku, wszelkie uprawnienia pracowników pracodawcy użytkownika

50 Konwencja nr 181 dotycząca prywatnych biur pośrednictwa pracy, Dz.U. z 2008 r., Nr 222, poz. 1448.

51 M. Paluszkiewicz, Układy zbiorowe pracy..., s. 250.

52 Ibidem, s. 250-259.

53 Autorka wskazuje przy tym, że trwałe związanie agencji pracy tymczasowej i pracodawcy użytkownika wspólnym układem zbiorowym pracy może budzić wątpliwości w kontekście obchodzenia przepisów służących promowaniu zatrudnienia nietymczasowego.

54 M. Paluszkiewicz, Układy zbiorowe pracy..., s. 254. 
wynikające z układu zbiorowego pracy znajdą zastosowanie do pracowników tymczasowych ${ }^{55}$. Rozwiązanie takie wydaje się najbardziej korzystne, bowiem pracownicy pracodawcy użytkownika mają silniejszą pozycję negocjacyjną niż pracownicy tymczasowi.

Warunkiem, jaki musi spełniać układ zbiorowy pracy, aby mógł zostać zaliczony do źródeł prawa pracy, jest określanie praw i obowiązków pracowników i pracodawców, czyli stron stosunku pracy ${ }^{56}$. W związku z powyższym powstaje wątpliwość, czy układem zbiorowym pracy obowiązującym u pracodawcy użytkownika można objąć pracowników tymczasowych, czyli osoby niebędące pracownikami tego pracodawcy, skoro jego postanowienia mają dotyczyć relacji stricte związanych z przymiotem „bycia pracownikiem”. Założenie, że pracownicy tymczasowi mogą być objęci układem, stwarza kolejne wątpliwości: kto negocjuje dla nich układ, czy sami mają zdolność układową oraz jakie postanowienia układu mogą ich dotyczyć. Wydaje się, że postulowane w poprzedniej części niniejszego rozdziału przyznanie pracownikom tymczasowym prawa koalicji w związku zawodowym o charakterze międzyzakładowym rozwiązałoby powyższe wątpliwości. $\mathrm{W}$ takiej sytuacji pracownicy tymczasowi samodzielnie negocjowaliby $\mathrm{z}$ agencjami pracy tymczasowej treść układu zbiorowego pracy, któremu następnie by podlegali. W zakresie zobowiązań nałożonych na pracodawcę użytkownika mocą układu zbiorowego pracy nie byłby on ich adresatem wprost. Jego obowiązki musiałyby natomiast wynikać z treści umowy zawieranej przez agencję pracy tymczasowej z pracodawcą użytkownikiem. Jedynie w takim przypadku postanowienia układu zbiorowego pracy byłyby w rzeczywistości realizowane.

Przepis artykułu $239 \$ 2$ k.p., rozszerzając zakres obowiązywania kodeksu pra$\mathrm{cy}^{57}$, umożliwia objęcie postanowieniami układu zbiorowego pracy, obok emerytów i rencistów, osób świadczących pracę na innej podstawie niż stosunek pracy. Dyspozycja zawarta we wskazanym przepisie rodzi wiele pytań i wątpliwości, głównie ze względu na swoją lakoniczność i brak szczegółowych wytycznych co do sposobu obejmowania tych podmiotów układem zbiorowym pracy. Określenie kręgu podmiotów, które mogą być objęte układem zbiorowym pracy w ramach dyspozycji art. $239 \$ 2$ k.p., jako osoby świadczące pracę na innej podstawie niż stosunek pracy, wydaje się mieć w tym miejscu znaczenie kluczowe. W związku z tym wyróżnić można dwa warianty:

a) objęcie układem zbiorowym pracy osób zatrudnionych na podstawie umów cywilnoprawnych (umowy o pracę nakładczą i umowy agencyjnej),

55 A. Reda, Pracodawca użytkownik..., s. 115.

56 G. Goździewicz, Charakter porozumień zbiorowych w prawie pracy, „Praca i Zabezpieczenie Społeczne" 1998, nr 3, s. 19.

57 K.W. Baran, O zakresie podmiotowym nauki prawa pracy na tle niepracowniczych stosunków zatrudnienia, [w:] L. Florek, Ł. Pisarczyk (red.), Wspótczesne problemy prawa pracy i ubezpieczeń społecznych. XVIII Zjazd Katedr i Zakładów Prawa Pracy i Ubezpieczeń Społecznych, Warszawa 2011, s. 441. 
którym przyznano prawo koalicji i które są reprezentowane przez związek zawodowy ${ }^{58}$

b) objęcie układem zbiorowym pracy wszystkich osób zatrudnionych na podstawie umów cywilnoprawnych bez względu na to, czy mają one prawo koalicji i czy są reprezentowane przez związek zawodowy ${ }^{59}$.

Wobec nieuregulowania wskazanej kwestii w kodeksie pracy można uznać (choć pogląd ten pozostaje w zdecydowanej mniejszości), że skoro układy zbiorowe pracy są instytucją prawa pracy i przez tę gałąź prawa są regulowane, to brak jest podstaw do twierdzenia, że przepisy dają możliwość objęcia ich postanowieniami innych niż pracownicy osób świadczących pracę, jeśli nie posiadają one prawa koalicji. W przeciwnym razie część osób, które byłyby objęte układem, nie miałaby żadnego wpływu na jego treśćc ${ }^{60}$. Twierdzenie takie zawężałoby jednak znacznie zakres podmiotowy obowiązywania układów zbiorowych pracy i pośrednio godziło w ideę związków zawodowych jako organizacji ludzi pracy. Kompromisowym rozwiązaniem jest uznanie, że osoby nieposiadające prawa koalicji, zatrudnione na innej podstawie niż stosunek pracy (zleceniobiorcy, wykonawcy dzieła, agenci będący pracodawcami) są, mocą odpowiedniego porozumienia ze związkiem zawodowym, podmiotami pośrednio reprezentowanymi przez związek zawodowy ${ }^{61}$. Każdorazowo o zakresie podmiotowym układu decyduje wola zawierających go stron. Nie można odmówić im możliwości przyznania określonym podmiotom (np. wszystkim osobom zatrudnionym na podstawie umów cywilnoprawnych) uprawnień wynikających z treści układu ${ }^{62}$, zwłaszcza że ograniczenia takiego nie ustanawiają przepisy prawa pracy. Wobec powyższego wydaje się uzasadnione twierdzenie, że na mocy dyspozycji art. $239 \$ 2$ k.p. postanowieniami układu zbiorowego pracy mogą być objęte wszystkie osoby zatrudnione na postawie umów prawa cywilnego bez względu na to, czy posiadają one prawo koalicji.

58 Takie rozwiązanie uznaje K. Kolasiński, Prawo pracy znowelizowane, Toruń 1996, s. 256.

59 Taką możliwość potwierdzają: K. Jaśkowski, Układy zbiorowe pracy, Warszawa 1994, s. 14; J. Stelina, [w:] U. Jackowiak i in. (red.), Kodeks pracy z komentarzem, Gdynia 2004, s. 791; T. Liszcz, Prawo pracy, Warszawa 2008. s. 47; K.W. Baran, [w:] B. Wagner (red.), Kodeks pracy 2011. Komentarz, Gdańsk 2011, s. 1083; J. Piątkowski, [w:] K.W. Baran (red.), Kodeks pracy. Komentarz, Warszawa 2012, s. 1180-1181; K. Rączka, [w:] M. Gersdorf, K. Rączka, M. Raczkowski (red.), Kodeks pracy. Komentarz, Warszawa 2012, s. 991; H. Tulwin, [w:] A. Patulski, G. Orłowski (red.), Kodeks pracy 2012. Komentarz dla praktyków, Gdańsk 2012, s. 922.

60 J. Unterschütz, Wybrane problemy..., s. 24-25.

61 W. Sanetra podkreśla, że układ zbiorowy pracy jest porozumieniem zawierającym przepisy adresowane zasadniczo wyłącznie do podmiotów bezpośrednio lub pośrednio reprezentowanych przez strony układu, które go zawarły. W. Sanetra, Strony układu zbiorowego pracy po nowelizacji kodeksu pracy, „Praca i Zabezpieczenie Społeczne” 1995, nr 2, s. 2.

62 Z. Salwa, Zakres podmiotowy i przedmiotowy układów zbiorowych pracy, „Praca i Zabezpieczenie Społeczne" 1994, nr 12, s. 5; E. Wronikowska, [w:] E. Wronikowska, P. Nowik (red.), Zbiorowe prawo pracy, Warszawa 2008, s. 78. 
Analizowane zagadnienie wymaga również, poza przedstawieniem go od strony podmiotowej, prezentacji strony przedmiotowej. Układ zbiorowy pracy składa się $\mathrm{z}$ postanowień normatywnych i obligacyjnych. Postanowienia normatywne mają charakter ogólny i wchodzą w skład indywidualnych umów o pracę ${ }^{63}$. Dotyczą one bezpośrednio stosunków pracy. Postanowienia obligacyjne określają wzajemne zobowiązania stron związane z obowiązywaniem, przestrzeganiem i realizacją postanowień normatywnych (np. sposobu załatwiania spraw spornych czy podporządkowania z góry ustalonym skutkom nieprzestrzegania układu) ${ }^{64}$. Jeżeli uznać, że część normatywna nie może dotyczyć osób zatrudnionych na innej podstawie niż stosunek pracy (gdyż ma dotyczyć uprawnień i obowiązków stron stosunku pracy), to bezcelowe byłoby objęcie osób zatrudnionych na innej podstawie niż stosunek pracy (na podstawie umowy prawa cywilnego) jedynie częścią obligacyjną. Przy takim założeniu art. $239 \$ 2$ k.p. byłby normą pustą, bowiem nigdy nie można byłoby objąć postanowieniami układu zbiorowego pracy osób zatrudnionych na podstawie umów cywilnoprawnych. Właściwe wydaje się rozumienie dyspozycji art. $239 \$ 2$ k.p. jako możliwości objęcia osób zatrudnionych na innej podstawie niż stosunek pracy uprawnieniami stanowiącymi odpowiedniki instytucji właściwych dla stosunku pracy ${ }^{65}$. Nie mogą to być natomiast postanowienia dotyczące bezpośrednio stosunku pracy ${ }^{66}$. W szczególności mogłyby to być natomiast postanowienia dotyczące nagradzania pracy wyróżniającej się czy przyznawania odpowiedników deputatów, sposobu wypłaty wynagrodzenia albo informowania osób zatrudnionych o zmianach organizacyjnych procesu pracy. Zakres stosowania postanowień układu zbiorowego pracy w stosunku do osób zatrudnionych na podstawie umów cywilnoprawnych musi zostać w układzie dokładnie określony ${ }^{67}$. Osoby świadczące pracę na innej podstawie niż stosunek pracy mogą być objęte jedynie takimi postanowieniami układu, które zachowują względem nich aktualność ${ }^{68}$. Układ zbiorowy pracy nie może być zawarty wyłącznie dla osób niebędących pracownikami, gdyż, jak już wskazano, nie jest on zawierany „dla” tych podmiotów. Osoby takie mogą być objęte postanowieniami układu, które pierwotnie zostały do niego wprowadzone jako określenie uprawnień pracowniczych, albo postanowieniami im odpowiadającymi.

Zgodnie z dyspozycjami przepisów art. 18 i $241^{13} \mathrm{k}$.p. postanowienia zarówno umów o pracę, jak i innych niż układy zbiorowe pracy źródeł prawa pracy, mniej

63 Z. Fenichel, Prawo pracy. Komentarz, Kraków-Warszawa 1939, s. 530, za: J. Wratny, Zakres przedmiotowy układów zbiorowych pracy w świetle przepisów prawa pracy, [w:] J. Wratny (red.), Układy zbiorowe pracy w demokratycznym ustroju pracy. Studium z zakresu prawa pracy, Warszawa 1997, s. 17-18.

64 W. Szubert, Układy zbiorowe pracy, Warszawa 1960, s. 224.

65 A.M. Świątkowski, Kodeks pracy. Komentarz, Warszawa 2010, s. 1082-1083.

66 Ibidem; J. Piątkowski, [w:] K.W. Baran (red.), Kodeks pracy. Komentarz...

67 H. Tulwin, [w:] A. Patulski, G. Orłowski (red.), op. cit.

68 K. Rączka, [w:] M. Gersdorf, K. Rączka, M. Raczkowski (red.), Kodeks pracy... 
korzystne dla pracowników, zastępowane są przez bardziej korzystne, wynikające $\mathrm{z}$ postanowień układowych. Osoby zatrudnione na podstawie umów prawa cywilnego nie korzystają z ochrony stworzonej przez te regulacje. Rozszerzanie zasady automatyzmu prawnego dotyczącej stosowania postanowień korzystniejszych względem osób zatrudnionych na innej podstawie niż stosunek pracy naruszałoby zasadę formalnej równości stron w stosunkach cywilnoprawnych, godząc w podstawowe założenia tej gałęzi prawa.

Wobec nieistnienia szczegółowych regulacji dotyczących obowiązywania układów zbiorowych pracy względem osób zatrudnionych na innej podstawie niż stosunek pracy przyjmuje się, że należy do nich odpowiednio stosować przepisy dotyczące pracowników ${ }^{69}$. Z uwagi na brak ustawowego ograniczenia oraz fakt, że przepis art. $239 \$ 2$ k.p., umożliwiający objęcie postanowieniami układu zbiorowego pracy osoby wykonujące pracę na innej podstawie niż stosunek pracy, znajduje się w części kodeksu pracy dotyczącej ogólnych przepisów o układach zbiorowych pracy, należy wnioskować, że osoby takie mogą być objęte postanowieniami zarówno zakładowego, jak i ponadzakładowego układu zbiorowego pracy. W obu sytuacjach odpowiednie zastosowanie w stosunku do nich będą miały przepisy dotyczące objęcia pracowników postanowieniami układów zbiorowych pracy.

W razie objęcia postanowieniami układu zbiorowego pracy osób zatrudnionych na innej niż stosunek pracy podstawie powstaje konieczność określenia procedury dochodzenia przez nie wykonania przez podmiot zatrudniający zobowiązań nałożonych przez ten układ. Aby objęcie postanowieniami układu zbiorowego pracy było skuteczne, umowa stanowiąca podstawę zatrudnienia cywilnoprawnego powinna przewidywać określone postanowienie. Nieprzestrzeganie postanowień układu zbiorowego pracy uprawnia osobę zatrudnioną do dochodzenia roszczeń z tytułu niewykonania bądź nienależytego wykonania umowy. Roszczenia te będą mogły być dochodzone na drodze sądowej w postępowaniu zwykłym, a nie w odrębnym postępowaniu w sprawach z zakresu prawa pracy. Z postępowania odrębnego mogą korzystać jedynie podmioty prawa pracy, czyli w tym przypadku - posiadające status pracowników.

Status prawny osób świadczących pracę w ramach umownego zatrudnienia cywilnoprawnego w zakresie podlegania postanowieniom układu zbiorowego pracy został ukształtowany w sposób nietypowy względem statusu pracowniczego. Wydaje się jednak, że powyższe różnice uzasadnione są odrębnościami systemowymi zatrudnienia cywilnoprawnego. W przypadku wypełnienia postulatu przyznania wszystkim osobom świadczącym pracę na podstawie umów prawa cywilnego jednakowych praw $\mathrm{w}$ zakresie prawa koalicji $\mathrm{w}$ związkach zawodowych ich status w obrębie możliwości zawierania układów zbiorowych pracy i podlegania ich postanowieniom byłby także zrównany.

69 K. Jaśkowski, Nowa regulacja układów zbiorowych pracy, „Prawo Pracy” 1998, nr 1, s. 5. 
Ustawą z dnia 9 listopada $2000 \mathrm{r}^{70}$ wprowadzono do kodeksu pracy istotne zmiany dotyczące regulacji związanych z obowiązywaniem układów zbiorowych pracy względem osób zatrudnionych na innej podstawie niż stosunek pracy. Wskazana nowelizacja uchyliła obowiązujące dotąd w kodeksie pracy przepisy - art. $241^{20} \mathrm{~W}$ zW. $\mathrm{z}$ art. $241^{29}$. Wymienione przepisy dotyczyły obowiązywania układu zbiorowego pracy w przypadku podziału bądź połączenia zakładu pracy, czyli w przypadku zmian po stronie pracodawczej. Stały się one zbędne po wprowadzeniu przepisu art. $241^{8}$ k.p. ${ }^{71}$ Obecnie kodeks pracy nie rozróżnia połączenia i podziału zakładu pracy, określając wszelkie zmiany po stronie pracodawczej mianem „przejścia zakładu pracy” (art. $23^{1}$ k.p.). W przypadku przejścia zakładu pracy bądź jego części na innego pracodawcę nowy pracodawca wstępuje w miejsce dotychczasowego i zobowiązany jest stosować przepisy układu zbiorowego pracy względem pracowników nim objętych w okresie jednego roku od dnia przejścia (art. $23^{1} \mathrm{~W} \mathrm{zw} . \mathrm{z}$ art. $241^{8} \$ 1 \mathrm{k}$.p.). Ma w tym przypadku zastosowanie zasada automatyzmu prawnego - nowy pracodawca nie musi zawierać nowych układów zbiorowych pracy z pracownikami zatrudnionymi przez dotychczasowego pracodawcę. Odmienna jest sytuacja osób zatrudnionych na podstawie umów prawa cywilnego. W przypadku tych stosunków zatrudnienia automatyzm prawny, dotyczący wstąpienia nowego podmiotu zatrudniającego w pozycję dotychczasowego (art. $23^{1}$ k.p.), nie znajduje zastosowania ${ }^{72}$. Nowy pracodawca musi zawrzeć nowe umowy z osobami zatrudnionymi na podstawie umów prawa cywilnego ${ }^{73}$.

Nierozbudowana regulacja prawna dotycząca możliwości objęcia postanowieniami układu zbiorowego pracy osób świadczących pracę na innej podstawie niż stosunek pracy uzasadniona może być głównie faktem nikłego zainteresowania samych osób zatrudnionych korzystaniem z przyznanego uprawnienia. Z uwagi na brak trwałego związku z podmiotem zatrudniającym osoby te nie wstępują do związków zawodowych i w konsekwencji nie prowadzą rokowań układowych ${ }^{74}$. Powyższe uwarunkowania nie stanowią jednak przeszkody do analizy teoretycz-

70 Ustawa z dnia 9 listopada 2000 r. o zmianie ustawy - Kodeks pracy oraz niektórych innych ustaw, Dz.U. Nr 107, poz. 1127.

71 H. Tulwin, [w:] A. Patulski, G. Orłowski (red.), op. cit., s. 1040-1041 i 1083.

72 W. Sanetra, [w:] J. Iwulski, W. Sanetra (red.), Kodeks pracy. Komentarz, Warszawa 2011, s. 1230; H. Tulwin, [w:] A. Patulski, G. Orłowski (red.), op. cit., s. 980.

73 W. Sanetra, [w:] J. Iwulski, W. Sanetra (red.), Kodeks pracy..., s. 1230; J. Piątkowski, [w:] K.W. Baran (red.), Kodeks pracy. Komentarz..., s. 1219; H. Tulwin, [w:] A. Patulski, G. Orłowski (red.), op. cit., s. 980. Do czasu zmiany przepisów kodeksu cywilnego, która nastąpiła w 2003 r., słuszne było twierdzenie, że nabywca nie musi względem osób zatrudnionych składać oświadczeń woli o przejęciu. Obowiązywała wtedy zasada, że nabywając przedsiębiorstwo, nabywa się zarówno aktywa, jak i pasywa. Por. Ł. Pisarczyk, Przejście zakładu pracy na innego pracodawcę, Warszawa 2002, s. 121.

74 M. Seweryński, Uwagi o przyszłości układów zbiorowych pracy, [w:] Z. Góral (red.), Układy zbiorowe pracy w stulecie..., s. 90. 
noprawnej. Jeśli bowiem uprawnieniami koalicyjnymi zostaną objęte wszystkie osoby zatrudnione, wszystkie one powinny mieć prawo do negocjowania, zawierania i bycia objętymi układami zbiorowymi pracy. Co więcej, możliwość objęcia regulacjami układowymi osób nieposiadających statusu pracowniczego umożliwia związkom zawodowym wpływ na kształtowanie standardów ochrony tej grupy osób świadczących pracę ${ }^{75}$. Wydaje się to zjawiskiem społecznie pożądanym. Status prawny osób świadczących pracę w ramach umownego zatrudnienia nietypowego w zakresie prawa do zawierania układów zbiorowych pracy i podlegania ich postanowieniom jest pochodną prawa koalicji w związkach zawodowych. Przyznanie tego prawa wszystkim osobom świadczącym pracę $\mathrm{w}$ ramach umownego zatrudnienia nietypowego umożliwi im zawieranie układów zbiorowych pracy i podleganie ich postanowieniom.

\subsection{Prawo do uczestnictwa w zarządzaniu przedsiębiorstwem}

Zbiorowe stosunki zatrudnienia wpływają na status prawny osób świadczących pracę również w zakresie ich prawa do uczestnictwa w zarządzaniu przedsiębiorstwem (zakładem pracy). Nadrzędną funkcją pozazwiązkowego przedstawicielstwa pracowników jest partycypacja w zarząadzaniu procesem pracy oraz jej organizacją w celu dbania o interesy pracowników ${ }^{76}$, stąd prawo do przynależności do niego posiadają wszyscy pracownicy, bez względu na umowną podstawę zatrudnienia. Głównym pozazwiązkowym przedstawicielstwem są rady pracowników, tworzone na podstawie ustawy o informowaniu pracowników i przeprowadzaniu z nimi konsultacji ${ }^{77}$, uchwalonej w wyniku implementacji dyrektywy nr 2002/14/WE ${ }^{78}$. W przedsiębiorstwach państwowych tworzone są przedstawicielstwa pracowników w postaci ogólnego zebrania pracowników przedsiębiorstwa oraz rad pracowniczych $^{79}$. Charakter doraźny, na potrzeby konkretnej sytuacji, ma forma

75 Z. Kubot, Szczególne formy zatrudnienia, Wrocław 2000, s. 30.

76 J. Wratny, Związki zawodowe i inne formy przedstawicielstwa pracowniczego, „Monitor Prawa Pracy" 2013, nr 12, s. 633.

77 Ustawa z dnia 7 kwietnia 2006 r. o informowaniu pracowników i przeprowadzaniu z nimi konsultacji, Dz.U. Nr 79, poz. 550 ze zm., dalej: u.ik.

78 Dyrektywa Parlamentu Europejskiego i Rady nr 2002/14/WE z dnia 11 marca 2002 r. ustanawiająca ogólne ramowe warunki informowania i przeprowadzania konsultacji z pracownikami we Wspólnocie Europejskiej, Dz.U.WE L 80 z dnia 23 marca 2002 r., s. 29-34.

79 Powoływane na podstawie ustawy z dnia 25 września 1981 r. o samorządzie załogi przedsiębiorstwa państwowego, Dz.U. z 2015 r., poz. 1543 - t.j. 
przedstawicielstwa pracowników powoływanych w trybie przyjętym u danego pracodawcy w konkretnym celu ${ }^{80}$. Dodatkowo pracownicy mogą wchodzić w skład europejskiej rady zakładowej ${ }^{81}$ czy przedstawicielstwa pracowników w spółkach europejskich. Działalność ta umożliwia pracownikom, w ramach realizacji prawa do informacji i konsultacji, wywieranie wpływu na decyzje podejmowane w podmiotach gospodarczych, przez które są zatrudnieni ${ }^{82}$. Uprawnienia związane $\mathrm{z}$ prawem do uczestnictwa w zarządzaniu przedsiębiorstwem w różnym zakresie przysługują poszczególnym grupom osób świadczących pracę w ramach umownego zatrudnienia nietypowego. Określenie tego zakresu pozwoli przedstawić sytuację prawną osób zatrudnionych, związaną z możliwością współuczestniczenia w działalności organizacyjnej przedsiębiorstwa.

Rady pracowników, działające w oparciu o ustawę o informowaniu pracowników i przeprowadzaniu z nimi konsultacji, uprawniają pracowników do współzarządzania zakładem pracy ${ }^{83}$. Uprawnienia do informacji i konsultacji w ramach działalności rad pracowników mają wszyscy pracownicy, bez względu na podstawę zatrudnienia i organizację procesu pracy. Uprawnienie takie posiadają również pracownicy tymczasowi, zatrudnieni przez agencje pracy tymczasowej. Obowiązek utworzenia rady pracowników spoczywa wówczas na agencji pracy tymczasowej ${ }^{84}$. Duża zmienność w zakresie struktury zatrudnienia pracowników tymczasowych może powodować liczne komplikacje nie tylko w kwestii ustalania liczby zatrudnionych pracowników ${ }^{85}$, od której uzależniony jest obowiązek utwo-

$80 \mathrm{~Np}$. w celu zawieszenia stosowania przepisów prawa pracy (art. $9^{1} \S 2$ k.p.); ustalenia treści regulaminu telepracy (art. $67^{6} \S 4$ k.p.) czy ustalenia przedłużonego okresu rozliczeniowego w trybie art. $150 \S 3$ pkt 2 k.p.

81 Powoływane na podstawie ustawy z dnia 5 kwietnia 2002 r. o europejskich radach zakładowych, Dz.U. 2012, poz. 1146 - t.j., wydanej w oparciu o dyrektywę Parlamentu Europejskiego i Rady nr 2009/38/WE z dnia 6 maja 2009 r. w sprawie ustanowienia europejskiej rady zakładowej lub trybu informowania pracowników i konsultowania się z nimi w przedsiębiorstwach lub w grupach przedsiębiorstw o zasięgu wspólnotowym, Dz.U.WE L 22 z dnia 16 maja 2009 r., s. 28-44.

82 G. Goździewicz, Pozycja prawna podmiotów w zbiorowym prawie pracy, [w:] A.M. Świątkowski (red.), Ochrona praw człowieka..., s. 226.

83 A. Dubowik, Rady pracowników i związki zawodowe jako reprezentanci zbiorowych interesów pracowników na szczeblu zakładowym, [w:] Z. Hajn (red.), Zwiq̨zkowe przedstawicielstwo pracowników zakładu pracy, Warszawa 2012, s. 219.

84 M. Gładoch, Ustawa o informowaniu pracowników i przeprowadzaniu z nimi konsultacji. Komentarz, Toruń 2007, s. 42.

85 Dyrektywa nr 2008/104/WE w art. 7 ust. 1 stanowi, że pracowników tymczasowych uwzględnia się, na warunkach określonych prawem wewnętrznym, przy ustalaniu liczby pracowników obligującej do utworzenia organów przedstawicielstwa pracowników. Ustawodawca unijny preferuje, aby pracowników tymczasowych zaliczyć do progu zatrudnienia w agencji pracy tymczasowej. Możliwość zaliczenia ich do puli zatrudnionych przez pracodawcę użytkownika przyznaje alternatywnie. L. Mitrus, Ochrona pracowników tymczasowych w świetle prawa unijnego a prawo polskie, [w:] A. Sobczyk (red.), z problematyki... 
rzenia rady pracowników, ale też wyboru członków rady. Pracownicy tymczasowi nie są wliczani do liczby osób zatrudnionych u pracodawcy użytkownika oraz nie korzystają z czynnego i biernego prawa wyborczego do rady pracowników działającej u pracodawcy użytkownika ${ }^{86}$. Wynika to $\mathrm{z}$ faktu, że pracownik tymczasowy posiada status pracowniczy w związku z zatrudnieniem w ramach stosunku pracy, który powstaje $\mathrm{w}$ relacji $\mathrm{z}$ agencją pracy tymczasowej, a nie $\mathrm{z}$ pracodawcą użytkownikiem. Sformułowanie postulatu włączenia pracowników tymczasowych do ogólnej liczby pracowników zatrudnianych przez pracodawcę użytkownika wymagałoby doprecyzowania. Często bowiem pracownicy tymczasowi kierowani są do pracodawcy użytkownika na bardzo krótkie okresy (nawet kilkudniowe), więc i w tym przypadku zmienność w zakresie ich liczby jest znaczna.

Największy wpływ na sytuację prawną pracowników tymczasowych ma pracodawca użytkownik dyktujący warunki wykonywania pracy. Natomiast katalog informacji przekazywanych radzie pracowników i z nią konsultowanych nie wydaje się mieć pierwszoplanowego znaczenia dla pracowników tymczasowych, świadczących pracę względnie krótko. Są to bowiem informacje dotyczące funkcjonowania pracodawcy jako takiego, nie zaś spraw bieżących, istotnych dla pracowników tymczasowych. Jeśli zatem przyjąć postulat kwalifikowania pracowników tymczasowych do liczby zatrudnionych u pracodawcy użytkownika oraz przyznać im bierne i czynne prawo wyborcze do rady pracowników działającej u pracodawcy użytkownika, należałoby uzależnić to prawo od minimalnego okresu skierowania pracownika tymczasowego do pracy na rzecz konkretnego pracodawcy użytkownika. Rozwiązanie takie powodowałoby co prawda różnice w sytuacji prawnej pracowników tymczasowych i pracowników stałych (ta druga kategoria nie jest różnicowana ze względu na długość zatrudnienia, zatem do ogólnej liczby zatrudnionych liczy się także pracowników wykonujących pracę np. na podstawie umowy o pracę na czas określony, zawartej na bardzo krótki okres), ale z uwagi na szczególny charakter pracy tymczasowej wydaje się uzasadnione. Pracownicy tymczasowi z pewnością są zainteresowani posiadaniem wiedzy na temat stanu, struktury i przewidywanych zmian zatrudnienia oraz działań mających na celu utrzymanie poziomu zatrudnienia czy mogących powodować istotne zmiany w organizacji pracy lub w podstawach zatrudnienia (art. 13 ust. 1 pkt 2 i 3 u.ik.). Przy braku włączenia pracowników tymczasowych do ogólnej liczby pracowników utworzenie rady pracowników w świetle art. 1 ust. 2 u.ik mogłoby nie być konieczne, co spowodowałoby brak obowiązku informowania pracowników o powyższych okolicznościach. Jeśli natomiast u pracodawcy użytkownika działa już rada pracowników, powinien on, na podstawie art. 14 ust. 1. w zw. $\mathrm{z}$ art. 13 u.ik., skonsultować z nią chęć skorzystania z pracy pracowników tymczasowych. Jest to bowiem działanie powodujące zmiany struktury zatrudnienia oraz organizacji pracy ${ }^{87}$.

86 A. Reda, Pracodawca użytkownik...., s. 118-119.

87 L. Mitrus, op. cit. 
Uprawnień związanych z funkcjonowaniem rad pracowników (w zakresie ustalania liczby osób zatrudnionych oraz czynnego i biernego prawa wyborczego) nie mają osoby zatrudnione na podstawie umów prawa cywilnego. Zatrudnienie to ma $\mathrm{z}$ założenia systemowego charakter niepodporządkowany i incydentalny, więc nie jest konieczne informowanie i konsultowanie przez podmiot zatrudniający szczegółów funkcjonowania jego przedsiębiorstwa. Dlatego też nie wydaje się konieczne rozszerzanie prawa do uczestnictwa w zarządzaniu przedsiębiorstwem względem wszystkich osób świadczących pracę w ramach umownego zatrudnienia cywilnoprawnego. $Z$ uwagi na swoje założenia systemowe omawiane regulacje powinny objąć zatrudnienie nakładcze i stosunek prawny powstający w wyniku zawarcia umowy agencyjnej. Tak jak zatrudnienie prawnopracownicze, cechują się one ciągłością i bliską współpracą podmiotów. Cechy te wydają się uzasadniać postulat przyznania wykonawcom pracy nakładczej i agentom choćby części uprawnień pracowniczych związanych z informowaniem i konsultacją.

Możliwość powołania do życia europejskiej rady zakładowej spełnia postulat konieczności objęcia wszystkich obywateli Unii Europejskiej zatrudnionych na jej obszarze uprawnieniem do informowania przez pracodawców o decyzjach w sprawach, które ich dotyczą, a są podejmowane przez pracodawców mających siedzibę $\mathrm{w}$ innym państwie członkowskim ${ }^{88}$. Utrudnieniem dla przedstawicielstwa pracowniczego jest podejmowanie decyzji przez pracodawcę mającego siedzibę w innym państwie ${ }^{89}$. Obowiązująca na gruncie polskiego porządku prawnego ustawa o europejskich radach zakładowych ${ }^{90}$ różnicuje uprawnienia pracowników zatrudnionych w ramach zatrudnienia nietypowego w zależności od wymiaru czasu pracy, w jakim pracują. Zgodnie $\mathrm{z}$ art. 3 ust. 2 u.e.r.z., dokonując wyliczenia liczby pracowników, niezbędnego do ustalenia wynikających z ustawy obowiązków, pod uwagę bierze się osoby zatrudnione na podstawie stosunku pracy, po przeliczeniu na pełny wymiar czasu pracy. Zatem pracownik zatrudniony nietypowo ( $w$ niepełnym wymiarze czasu pracy) liczony jest $\mathrm{w}$ stosunku do wymiaru czasu pracy, w którym pracuje. Zgodnie $\mathrm{z}$ art. 2 ust. 2 dyrektywy nr 2009/38/WE przy obliczaniu liczby zatrudnionych bierze się pod uwagę pracowników zatrudnionych $\mathrm{w}$ niepełnym wymiarze godzin, pracujących $\mathrm{w}$ ciągu ostatnich dwóch lat. Istotą prawa do współuczestnictwa w zarządzaniu przedsiębiorstwem jest możliwość posiadania realnego wpływu na proces organizacji przebiegu pracy i strukturę zatrudnienia przez osoby świadczące pracę. $Z$ tego względu wydaje się uzasadnione, że uprawnień w zakresie informacji i konsultacji nie przyznano osobom zatrudnionym na podstawie umów prawa cywilnego. Specyfika tego zatrudnienia, organizacyjnie niezależnego i krótkotrwałego, nie wymaga ingerowania osób świadczących pracę w działalność podmiotów zatrud-

88 A.M. Świątkowski, Europejskie prawo socjalne..., s. 475-476.

89 L. Florek, Europejskie prawo pracy i ubezpieczeń społecznych, Warszawa 1996, s. 85.

90 Dalej: u.e.r.z. 
niających. Brak organizacyjnych powiązań pomiędzy działalnością podmiotów wymienionych umów cywilnoprawnych wyłącza taką konieczność, co nie dezaktualizuje przywoływanego już niejednokrotnie postulatu o konieczności przyznania wszystkim osobom świadczącym pracę w ramach umownego zatrudnienia nietypowego prawa koalicji w związkach zawodowych. Rola przedstawicielstwa związkowego jest jednak inna niż podmiotów powołanych do uczestnictwa w zarządzaniu zakładem pracy. Tym niemniej nie wydaje się uzasadnione całkowite pozbawienie wykonawców pracy nakładczej oraz agentów prawnie usankcjonowanej możliwości współuczestnictwa w zarządzaniu przedsiębiorstwem. Stopień zależności gospodarczej wykonawcy pracy nakładczej od nakładcy (przejawiający się choćby obowiązkiem zapewnienia minimalnej ilości pracy) oraz względna trwałość zatrudnienia powstającego w wyniku zawarcia umowy o pracę nakładczą uzasadniają postulat o konieczności przyznania osobom świadczącym pracę na ich podstawie choćby zbliżonych do pracowniczych uprawnień związanych ze współuczestnictwem w zarządzaniu przedsiębiorstwem. Powyższa uwaga wydaje się aktualna również $\mathrm{w}$ odniesieniu do stosunku zatrudnienia powstającego $\mathrm{w}$ wyniku zawarcia umowy agencyjnej.

\subsection{Podsumowanie}

Status prawny osób świadczących pracę w ramach umownego zatrudnienia nietypowego w zakresie zbiorowych stosunków zatrudnienia nie jest jednolity, a kolektywna ochrona praw i interesów osób zatrudnionych nie jest obecnie dostateczna $^{91}$. Z pełni praw do zrzeszania się w związkach zawodowych, zawierania i podlegania układom zbiorowym pracy, jak i uczestnictwa w zarządzaniu przedsiębiorstwem korzystają pracownicy. Jednakże z uwagi na szczególny charakter zatrudnienia tymczasowego, w którym odbiorcą pracy jest podmiot niebędący pracodawcą $\mathrm{w}$ rozumieniu art. $3 \mathrm{k} . \mathrm{p}$., pracownicy tymczasowi nie mają możliwości korzystania $\mathrm{z}$ praw związanych ze zbiorowymi stosunkami zatrudnienia w sposób umożliwiający pełną i skuteczną ochronę ich interesów. Obowiązujące konstrukcje prawne, dotyczące zarówno zrzeszania się w związkach zawodowych, układów zbiorowych pracy, jak i udziału w zarządzaniu przedsiębiorstwem, zdają się nie odpowiadać realiom zatrudnienia tymczasowego. Celem zmiany takiego stanu rzeczy zasadne wydaje się postulowanie przyznania szerszych uprawnień na wskazanych płaszczyznach w zakresie relacji pracowników tymczasowych i pra-

91 Z. Hajn, Regulacja pozycji prawnej pracownika i pracodawcy a funkcje prawa pracy, „Praca i Zabezpieczenie Społeczne" 2000, nr 10, s. 6. 
codawców użytkowników (jak choćby wliczanie pracowników tymczasowych do liczby pracowników pracodawcy użytkownika, od której zależy obowiązek powołania rady pracowników).

W zakresie zbiorowych stosunków zatrudnienia w sposób fragmentaryczny i wybiórczy unormowane zostały uprawnienia osób zatrudnionych na podstawie umów prawa cywilnego. Nie wydaje się, aby racjonalność takiego stanu rzeczy potwierdzała odrębność systemową zatrudnienia cywilnoprawnego. Dlatego też zasadne jest, postulowane w treści niniejszego rozdziału, objęcie osób zatrudnionych na podstawie umów prawa cywilnego nieograniczonym prawem do zrzeszania się w związkach zawodowych oraz do zawierania układów zbiorowych pracy i podlegania ich postanowieniom. Nie wydaje się przy tym konieczne rozszerzanie uprawnień związanych z uczestnictwem w zarządzaniu przedsiębiorstwem w jednakowym stopniu na wszystkich zatrudnionych w ramach umów prawa cywilnego. Mogłoby to natomiast mieć miejsce w stosunku do osób stale współpracujących z podmiotami zatrudniającymi (wykonawców pracy nakładczej, agentów). 



\section{ROZDZIAt V \\ Status prawny osób świadczących pracę $\mathbf{w}$ ramach umownego zatrudnienia nietypowego $\mathrm{w}$ fazie ustania stosunku prawnego}

\subsection{Uwagi wprowadzające}

Ostatnim etapem zatrudnienia jest ustanie stosunku prawnego. Status prawny osób świadczących pracę w ramach umownego zatrudnienia nietypowego jest w tym zakresie zróżnicowany. Przedstawienie zagadnień związanych z fazą ustawania stosunku prawnego gwarantuje zachowanie kompletności prowadzonych rozważań. Uprzednio zostały bowiem omówione etapy nawiązywania i realizacji stosunku zatrudnienia. Faza ustania stosunku prawnego na gruncie prowadzonych rozważań związana jest ze statusem prawnym osób świadczących pracę w ramach umownego zatrudnienia nietypowego:

a) przy rozwiązywaniu umowy

b) w razie wadliwego rozwiązania umowy

c) w zakresie ich statusu prawnego związanego ze szczególnymi obowiązkami i uprawnieniami na etapie ustawania stosunku prawnego.

Przedstawione poniżej rozważania będą prowadzone właśnie w oparciu o trzy wymienione płaszczyzny. Ich analiza pozwoli wskazać różnice $\mathrm{w}$ statusie prawnym poszczególnych grup osób świadczących pracę, które poddane będą następnie ocenie w kwestii zasadności ich występowania z perspektywy społeczno-gospodarczego przeznaczenia poszczególnych rodzajów umownego zatrudnienia nietypowego oraz zróżnicowania w zakresie istniejących podstaw zatrudnienia.

\subsection{Rozwiązanie nietypowego umownego stosunku zatrudnienia}

Status prawny osób świadczących pracę w ramach umownego zatrudnienia nietypowego przy rozwiązywaniu umowy w przeważającej mierze kreują regulacje prawne związane z ochroną trwałości zatrudnienia. Ochrona ta polega na wpro- 
wadzeniu prawnych ograniczeń w zakresie swobodnego wypowiadania i rozwiązywania bez wypowiedzenia umów dotyczących zatrudnienia ${ }^{1}$. Jednym z głównych przejawów ochronnej funkcji prawa pracy jest ochrona trwałości stosunku pracy, dlatego ochrona trwałości zatrudnienia przybiera najszerszą formę właśnie na gruncie przepisów tej gałęzi prawa, spełniając systemowe założenia stabilizacji zatrudnienia. Ma ona różne wymiary w zależności od przyjętego kryterium. Określa się ją zatem mianem ochrony powszechnej oraz ochrony szczególnej czy też ochrony przed wypowiedzeniem lub ochrony przed rozwiązaniem stosunku pracy bez wypowiedzenia. Przyczyn uznania przez ustawodawcę konieczności wzmożonej ochrony interesów pracowniczych na tej płaszczyźnie jest kilka. Do głównych zaliczyć należy alimentarną funkcję wynagrodzenia za pracę. Skoro bowiem wynagrodzenie za pracę ma zapewniać pracownikowi i jego rodzinie warunki do życia, nie można bezzasadnie, uznaniowo oraz natychmiastowo pozbawiać pracowników tej korzyści płynącej ze świadczenia pracy. Również koncepcja prawa naturalnego, w kontekście prawa człowieka do pracy, postuluje ochronę trwałości stosunku pracy². Pracodawcy, dyktujący popyt na zatrudnienie, wskazują jednak, że czynniki ograniczające swobodę rozwiązywania umów, których przedmiotem jest zatrudnienie, hamują ich sprawność dostawcząa ${ }^{3}$ czyli wpływają na ograniczenie rozwoju gospodarczego oraz są przyczyną bezrobocia ${ }^{4}$. Z powo-

1 Tak samo ochronę trwałości stosunku pracy określa G. Goździewicz. Zob. G. Goździewicz, Przemiany w zakresie ochrony trwałości stosunku pracy w Polsce - wybrane zagadnienia, [w:] G. Goździewicz (red.), Ochrona trwałości stosunku pracy w społecznej gospodarce rynkowej, Warszawa 2010, s. 18. Nie można przy tym odnosić pojęcia ochrony trwałości stosunku pracy jedynie do regulacji zatrudnienia typowego. Skoro bowiem pozostałe regulacje prawne dotyczące umów o pracę, nie tylko umowy o pracę zawartej na czas nieokreślony, przewidują określone ograniczenia wypowiadania i rozwiązywania stosunków pracy, pojęcie ochrony trwałości stosunku pracy obejmuje je wszystkie. E. Wronikowska słusznie wskazuje, że w tradycyjnym modelu zatrudnienia, w którym zatrudnienie bezterminowe ma charakter typowy, regulacje ochronne pozostałych umów o pracę nie są niezbędne, bowiem umowy te zawierane są na określony z góry okres. W takiej sytuacji nie jest konieczne wprowadzanie ochrony przed wypowiedzeniem, bowiem zatrudnienie trwa do momentu zakończenia umowy. Jednak w obecnym stanie praktycznego wykorzystywania umów terminowych konieczność wprowadzenia odpowiednich regulacji zaistniała również względem stosunków pracy powstających na podstawie tych umów. E. Wronikowska, Terminowe umowy o pracę a ochrona trwałości stosunku pracy, [w:] G. Goździewicz (red.), Reprezentacja praw..., s. 188 i nast. Konieczność ta wynika dodatkowo z dostosowywania polskiego prawa do standardów Unii Europejskiej, o czym mowa będzie w dalszej części rozdziału.

2 J. Loga, Formy ochrony trwatości stosunku pracy, [w:] H. Lewandowski (red.), Studia z prawa pracy, Warszawa 1988, s. 190.

3 J. Wojtyła, Dylematy ochronnej funkcji prawa pracy w stosunkach prawnych zatrudnienia, [w:] M. Seweryński, J. Stelina (red.), Wolność i sprawiedliwość w zatrudnieniu. Księga pamiątkowa poświęcona Prezydentowi Rzeczypospolitej Polskiej Profesorowi Lechowi Kaczyńskiemu, Gdańsk 2012, s. 385.

4 A. Dral, Problemy liberalizacji, deregulacji i uelastyczniania ochrony trwałości stosunku pracy w polskim prawie, „Praca i Zabezpieczenie Społeczne” 2009, nr 5, s. 12. W dalszym toku 
du odrębności systemowej, która skutkuje innym przeznaczeniem gospodarczym podstaw umownego zatrudnienia cywilnoprawnego, ochrona trwałości tego rodzaju zatrudnienia nie jest uregulowana w sposób odbiegający od ogólnych standardów prawa cywilnego związanych z możliwością rozwiązywania umów. Pewne odrębności występują jedynie w pracy nakładczej, o czym mowa będzie w dalszej części rozdziału. Wydaje się, że zróżnicowanie sytuacji prawnej osób świadczących pracę w ramach umownego zatrudnienia nietypowego na etapie kończącym stosunek prawny najlepiej ukaże kolejne omówienie instytucji związanych z rozwiązaniem umowy. Zostaną one przedstawione z perspektywy konkretnego stosunku umownego zatrudnienia nietypowego.

W prawodawstwie Międzynarodowej Organizacji Pracy, dając wyraz uznaniu wagi omawianej tematyki, uregulowano ochronę przed wypowiedzeniem umowy o pracę oraz rozwiązaniem jej bez wypowiedzenia konwencją nr $158 \mathrm{z}$ dnia 2 czerwca 1982 r. dotyczącą rozwiązania stosunku pracy z inicjatywy pracodawcy ${ }^{5}$ oraz zaleceniami: nr 119 z dnia 5 czerwca 1963 r. dotyczącym rozwiązania stosunku pracy z inicjatywy pracodawcy ${ }^{6}$, nr 143 z dnia 2 czerwca 1971 r. dotyczącym ochrony przedstawicieli pracowników w przedsiębiorstwach i przyznania im ułatwień $^{7}$ i nr 166 z dnia 2 czerwca 1982 r. dotyczącym rozwiązania stosunku pracy $\mathrm{z}$ inicjatywy pracodawcy ${ }^{8}$. Zalecenie $\mathrm{nr} 166$ zastąpiło zalecenie $\mathrm{nr} 119$. Wymienione akty prawne odwołują się w swojej treści zarówno do warunków wypowiedzenia umowy o pracę (np. konieczność określenia przyczyny), jak i katalogu przyczyn, które nie mogą stanowić podstawy wypowiedzenia i rozwiązania umowy ${ }^{9}$.

Konstytucyjne podstawy ochrony trwałości zatrudnienia zawiera art. 24, statuujący zasadę ochrony pracy przez państwo. Przepis ten dotyczy każdej pracy, więc nie wyklucza możliwości ochrony stron zatrudnienia pozapracowniczego, w tym cywilnoprawnego ${ }^{10}$. Pewne jest jednak, że najszersza ochrona powinna być i jest przyznana podmiotom uważanym za ekonomicznie słabsze, czyli pracownikom. Pozycja prawna osób zatrudnionych na podstawie umów prawa cywilnego z zało-

wypowiedzi autor wskazuje, że nie ma dowodów na to, iż rezygnacja z ochrony trwałości stosunku pracy spowoduje spadek bezrobocia.

5 Konwencja nr 158 dotycząca rozwiązania stosunku pracy z inicjatywy pracodawcy, MOP, www.mop.pl/doc/html/konwencje/k158.html (dostęp: 21.01.2017).

6 Zalecenie nr 119 dotyczące rozwiązania stosunku pracy z inicjatywy pracodawcy, MOP, www. mop.pl/doc/html/zalecenia/z119.html (dostęp: 21.01.2017).

7 Zalecenie $\mathrm{nr} 143$ dotyczące ochrony przedstawicieli pracowników w przedsiębiorstwach i przyznania im ułatwień, MOP, www.mop.pl/doc/html/zalecenia/z143.html (dostęp: 21.01.2017).

8 Zalecenie nr 166 dotyczące rozwiązania stosunku pracy z inicjatywy pracodawcy, MOP, www. mop.pl/doc/html/zalecenia/z166.html (dostęp: 21.01.2017).

9 Szczegółową analizę wymienionych aktów prawnych MOP przeprowadza L. Florek, Konstytucyjne i prawnomiędzynarodowe podstawy ochrony trwatości stosunku pracy, [w:] G. Goździewicz (red.), Reprezentacja praw..., s. 47-52.

10 L. Florek, Konstytucyjne gwarancje uprawnień pracowniczych, „Państwo i Prawo” 1997, nr 11-12, s. 197; tenże, Konstytucyjne i prawnomiędzynarodowe..., s. 42. 
żenia systemowego jest formalnie równa z pozycją prawną podmiotów zatrudniających. Dlatego też nie jest konieczne przyznawanie szczególnej ochrony trwałości stosunku pracy osobom zatrudnionym na podstawie umów cywilnoprawnych.

Stanowiący punkt odniesienia do prowadzenia niniejszych rozważań kodeks pracy w art. 30 jako pierwszy sposób rozwiązania umowy o pracę wymienia porozumienie stron. Nie bez powodu ustawodawca wybrał taką kolejność regulowania omawianej materii. Rozwiązanie umowy o pracę na mocy zgodnego oświadczenia woli obu stron stosunku pracy jest skorelowane z zasadą wyrażoną w art. 11 k.p. Skoro bowiem nawiązanie stosunku pracy wymaga zgodnego oświadczenia pracownika i pracodawcy, to również rozwiązanie powinno nastąpić w taki sposób ${ }^{11}$. Przepisy nie ograniczają woli stron w zakresie porozumienia rozwiązującego umowę o pracę ${ }^{12}$. Ponadto porozumienie stron może być zawarte przez podmioty stosunku zatrudnienia bez względu na to, czy praca ma charakter prawnopracowniczy czy cywilnoprawny. W zatrudnieniu nakładczym możliwość taką potwierdza przepis $₫ 4$ ust. 1 rozp. pr. nakład. Nie ma również znaczenia rodzaj podpisanej umowy o zatrudnienie, bowiem w ten sposób można rozwiązać każdą z nich ${ }^{13}$. Przedstawiona analiza wskazuje, że status prawny osób świadczących pracę w ramach umownego zatrudnienia nietypowego $\mathrm{w}$ zakresie możliwości rozwiązania umowy na mocy porozumienia stron jest jednakowy, choć - w zależności od reżimu prawnego, któremu podlega stosunek zatrudnienia - uregulowany innymi przepisami.

Drugim sposobem rozwiązania umowy o pracę jest oświadczenie jednej ze stron z zachowaniem okresu wypowiedzenia (art. $30 \$ 1$ pkt 2 k.p.). Warunki, jakie muszą zostać spełnione, aby rozwiązanie umowy o pracę z zachowaniem okresu wypowiedzenia uznać za skuteczne i prawidłowe, stanowią ramy ochronne kreujące sytuację prawną poszczególnych osób zatrudnionych w ramach umownego zatrudnienia nietypowego. Do momentu wejścia w życie nowelizacji czerwcowej z 2015 r. rozwiązanie umowy o pracę za wypowiedzeniem mogło być zastosowane w przypadku umowy o pracę na okres próbny oraz umowy o pracę na czas nieokreślony (art. 32 $\$ 1$ k.p.). Ustawodawca dopuszczał możliwość rozwiązania umowy o pracę na czas określony, ale tylko w przypadku gdy umowa taka trwała dłużej niż 6 miesięcy oraz gdy strony wprowadziły odpowiednie postanowienie w jej treści (art. 33 k.p.). Względem umowy zawartej w celu zastępstwa nieobecnego pracownika rozwiąza-

11 L. Florek, Rozwiq̨zanie i wygaśnięcie stosunku pracy, [w:] M. Matey-Tyrowicz, T. Zieliński (red.), Prawo pracy RP w obliczu przemian, Warszawa 2006, s. 172.

12 T. Romer, Rozwiqzanie umowy o prace (art. 30-61), „Prawo Pracy” 1996, nr 2, s. 7.

13 Przepis $\S 4$ ust. 1 rozp.pr.nakład. wskazuje możliwość rozwiązania umowy o pracę nakładczą w każdym czasie. Regulacje dotyczące pozostałych umów stanowiących podstawy zatrudnienia cywilnoprawnego (zlecenia sensu largo, umowy o dzieło, umowy agencyjnej) nie wymieniają porozumienia stron jako jednego ze sposobów rozwiązania umowy. Jednak nawet w przypadku niewprowadzenia przez strony do treści umowy możliwości jej rozwiązania na mocy porozumienia stron należy uznać, że strony mogą, poprzez zgodne oświadczenie woli, w każdym czasie postanowienie to odwołać i rozwiązać umowę. 
nie umowy za wypowiedzeniem doprecyzowywał art. $33^{1}$ k.p. Spośród rodzajów umów o pracę uregulowanych w kodeksie pracy brak możliwości rozwiązania umowy za wypowiedzeniem dotyczył umowy na czas wykonania określonej pracy oraz umowy o pracę na czas określony krótszy niż 6 miesięcy oraz dłuższej, co do której strony nie przewidziały możliwości wypowiedzenia ${ }^{14}$.

Nowelizacja czerwcowa kodeksu pracy z 2015 r. wprowadziła zmiany w zakresie przepisów dotyczących wypowiadania umów o pracę. Zostaną one omówione zgodnie $\mathrm{z}$ tokiem wywodu. W odniesieniu do możliwości rozwiązania umowy o pracę za wypowiedzeniem nowy stan normatywny unifikuje sytuację prawną wszystkich pracowników, dopuszczając możliwość rozwiązania za wypowiedzeniem każdej umowy o pracę. Konieczność dokonania zmian w tym zakresie wyniknęła z rozstrzygnięcia dokonanego przez Trybunał Sprawiedliwości Unii Europejskiej w wyroku C-38/14 ${ }^{15}$, o czym mowa będzie przy prezentacji warunków wypowiadania umów związanych z zatrudnieniem. Zgodnie z brzmieniem art. 32 k.p. nadanym nowelizacją czerwcową z 2015 r. każda ze stron umowy o pracę ma możliwość jej rozwiązania za wypowiedzeniem. Rozwiązanie za wypowiedzeniem staje się przez to typowym i normalnym sposobem jednostronnego zakończenia każdej umowy ${ }^{16}$. Konsekwencją powyższej zmiany jest wykreślenie art. 33 i $33^{1}$ k.p. Możliwość wypowiedzenia każdej umowy o pracę zawartej na czas określony niweczy jej systemowe założenie, jakim jest trwanie do określonego w umowie momentu. Kierunek zmian obrany przez ustawodawcę nie wydaje się zatem odpowiedni.

Zgodnie ze stanem prawnym sprzed nowelizacji wypowiedzenie umowy terminowej mogło być uzależnione od określonych okoliczności. Ustawodawca dopuszczał bowiem odstępstwa od wskazanych powyżej uregulowań w razie zaistnienia przyczyn niezależnych od pracownika. Przepis art. $41^{1} \$ 2$ k.p. umożliwiał rozwiązanie za dwutygodniowym wypowiedzeniem umów o pracę na czas określony lub na czas wykonania określonej pracy w razie ogłoszenia upadłości lub likwidacji pracodawcy. W takim przypadku wypowiedzeniu podlegały wszystkie umowy o pracę na czas określony, nawet te, w stosunku do których w przepisach rangi lex generalis ustawodawca nie przewidział takiej możliwości (umowy, których okres trwania nie przekraczał 6 miesięcy oraz umowy, których okres trwania przekraczał 6 miesięcy, ale strony nie wprowadziły do treści umowy klauzuli umożliwiającej jej wcześniejsze wypowiedzenie $)^{17}$.

14 Nie dotyczy to możliwości rozwiązania ww. umów bez wypowiedzenia, na mocy porozumienia stron albo w razie ogłoszenia upadłości lub likwidacji pracodawcy, którym w zatrudnieniu tymczasowym jest agencja pracy tymczasowej.

15 Wyrok Trybunału Sprawiedliwości Unii Europejskiej z dnia 13 marca 2014 r., C-38/13, Dz.U.UE.C 135 z dnia 5 maja 2014 r., s. 13.

16 L. Mitrus, Projekt nowelizacji kodeksu pracy dotyczący umów terminowych, „Monitor Prawa Pracy" 2015, nr 6, s. 289.

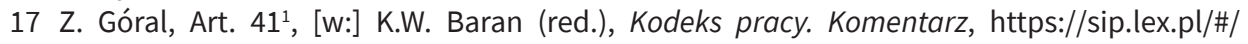
komentarz/587329059/490693 (dostęp: 19.09.2017). 
Drugi wyjątek wprowadzała ustawa z dnia 13 marca 2003 r. o szczególnych zasadach rozwiązywania z pracownikami stosunków pracy z przyczyn niedotyczących pracowników ${ }^{18}$. Zakres przedmiotowy regulacji art. 5 ust. 7 u.zw.grup. również, podobnie jak art. $41^{1} \$ 2$ k.p., dotyczył wszystkich umów o pracę na czas określony (bez względu na ich długość oraz wprowadzoną do treści umowy możliwość wypowiedzenia ${ }^{19}$ ) oraz umów na czas wykonania określonej pracy. Wskazana regulacja dawała możliwość ich rozwiązania przez każdą ze stron za dwutygodniowym wypowiedzeniem w razie wypowiadania pracownikom stosunków pracy w ramach zwolnienia grupowego. W wyniku wprowadzonej nowelizacją czerwcową z 2015 r. możliwości rozwiązania za wypowiedzeniem każdej umowy o pracę uchylone zostały obie omówione regulacje. W art. $41^{1}$ k.p. uchylony został $\$ 2$, natomiast w ustawie o szczególnych zasadach rozwiązywania z pracownikami stosunków pracy z przyczyn niedotyczących pracowników uchylony został art. 5 ust. 7.

Sytuacja prawna pracowników tymczasowych w zakresie możliwości wypowiedzenia umowy o pracę jest kreowana inaczej. Do umowy o pracę tymczasową zawartej na czas określony można wprowadzić postanowienie o jej wcześniejszym rozwiązaniu za wypowiedzeniem (art. 13 ust. 2 z.p.t). Możliwość rozwiązania umowy o pracę tymczasową za wypowiedzeniem nie jest zatem zasadą. Powyższe wynika z ogólnego założenia, że umowa o pracę tymczasową rozwiązuje się z upływem terminu, na który została zawarta, a nie poprzez rozwiązanie poprzedzone okresem wypowiedzenia ${ }^{20}$. W tym przypadku ustawodawca nie wprowadził ograniczenia w postaci minimalnego czasu trwania umowy, do której strony mogą wprowadzić klauzulę wcześniejszej wypowiadalności ${ }^{21}$, jak miało to miejsce w przypadku regulacji dotyczącej umów o pracę na czas określony. Przed nowelizacją czerwcową z 2015 r. umowa na czas wykonania określonej pracy zawarta w ramach pracy tymczasowej, tak jak w przypadku pracy o charakterze nietymczasowym, nie mogła być rozwiązana za wypowiedzeniem. Z uwagi na rezygnację z tego podtypu umowy, dokonaną nowelizacją czerwcową z 2015 r., zmianie uległa treść art. 13 ust. 2 z.p.t. W związku z tym, że podtyp umów o pracę na czas wykonania określonej pracy nie jest już wyodrębniony, dyspozycją art. 13 z.p.t. objęte są wszystkie umowy o pracę tymczasową, którymi mogą być jedynie umowy o pracę

18 Dz.U. z 2016 r. poz. 1474 - t.j.; dalej: u.zw.grup.

19 W stosunku do umowy o pracę, do której strony nie wprowadziły klauzuli wypowiadalności, możliwość rozwiązania za dwutygodniowym wypowiedzeniem (przy spełnieniu warunków ustawy o szczególnych zasadach rozwiązywania z pracownikami stosunków pracy z przyczyn niedotyczących pracowników) potwierdził Sąd Najwyższy w wyroku z dnia 4 grudnia 2008 r., II PK 137/08, LEX nr 469931.

20 M. Raczkowski, Ustawa o zatrudnianiu pracowników tymczasowych. Komentarz, Warszawa 2013, s. 62.

21 B. Wagner, Jednolitość, wielopostaciowość czy ewolucja funkcji ochronnej prawa pracy - zatrudnienie typowe versus tymczasowe, [w:] A. Sobczyk (red.), Z problematyki zatrudnienia tymczasowego, https://sip-1lex-1pl-1004153yx0674.han3.lib.uni.lodz.pl/\#/monografia/369236017/15 (dostęp: 19.09.2017). 
na czas określony. Przepis art. 13 z.p.t. stanowi wyłom od wprowadzonej nowelizacją zasady możliwości wypowiedzenia każdej umowy o pracę. Umowa o pracę tymczasową może być rozwiązana za wypowiedzeniem tylko w przypadku gdy strony w jej treści zawrą taką możliwość. Zatem co do zasady, wobec braku odmiennych postanowień umowa o pracę tymczasową jest umową niewypowiadalną. Powoduje to, że w zakresie możliwości rozwiązania umowy za wypowiedzeniem status prawny pracownika tymczasowego jest korzystniejszy aniżeli status prawny pracowników zatrudnionych na podstawie umów uregulowanych w kodeksie pracy. Brak powodów do przypisywania ustawodawcy przypadkowości w ustanowieniu takich rozbieżności wymusza przyjęcie założenia, że pozostawienie w ustawie o zatrudnianiu pracowników tymczasowych zasady o niewypowiadalnym charakterze umów o pracę tymczasową było działaniem celowym. W związku z powyższym obecny stan prawny powoduje, że trwałość zatrudnienia osób świadczących pracę na podstawie umów o pracę tymczasową, w których nie przewidziano klauzuli wcześniejszej wypowiadalności, jest większa aniżeli pracowników zatrudnionych na podstawie umów o pracę na czas określony.

Umowy cywilnoprawne będące podstawą zatrudnienia mogą zostać rozwiązane na mocy wypowiedzenia dokonanego przez jedną ze stron. Umowa o pracę nakładczą może być rozwiązana za wypowiedzeniem w przypadku gdy jest umową na okres próbny lub na czas nieokreślony ( $\$ 4$ ust. 2 rozp.pr.nakład.). A contrario, za wypowiedzeniem nie można rozwiązać umowy o pracę nakładczą zawartej na czas określony i na czas wykonania określonej pracy. Umowa zlecenia może zostać wypowiedziana zarówno przez dającego (art. $746 \$ 1$ k.c.), jak i przez przyjmującego zlecenie (art. $746 \$ 2$ k.c.). Regulacja prawna dotycząca zlecenia ustanawia ponadto brak możliwości zrzeczenia się prawa do wypowiedzenia zlecenia $\mathrm{z}$ ważnych powodów (art. $746 \$ 3$ k.c.). Podstawę prawną wypowiedzenia umowy agencyjnej stanowi art. $764^{1}$ k.c. i art. $764^{2}$ k.c. Odstapienie od umowy o dzieło przez zamawiającego normują przepisy art. 631 k.c., 635 k.c., 636 k.c. oraz 644 k.c. Powyższe uregulowania zostaną omówione w dalszej części wywodu. W tym miejscu wskazać jednak należy, że odstąpienie od umowy, przewidziane $\mathrm{w}$ regulacji dotyczącej umowy o dzieło, nie jest tożsame z jej wypowiedzeniem. Wypowiedzenie prowadzi do przerwania stosunku wynikającego z umowy ze skutkami dotyczącymi wyłącznie niewykonanych elementów zobowiązania (a zatem do rozwiązania tego stosunku ex nunc). Odstąpienie wywiera natomiast skutek ex tunc ${ }^{22}$. Powyższe nie wyklucza wprowadzenia do treści umowy o dzieło możliwości jej wypowiedzenia ${ }^{23}$.

22 G. Kozieł, Art. 635, [w:] Kodeks cywilny. Komentarz, t. 3: Zobowiq̨zania - część szczególna, https://sip-1lex-1pl-1004153bj6de6.han3.lib.uni.lodz.pl/\#/komentarz/587286493/462685 (dostęp: 19.09.2017).

23 G. Koziet, Art. 644, [w:] A. Kidyba (red.), Kodeks cywilny. Komentarz, t. 3: Zobowiq̨zania - część szczególna, https://sip-1lex-1pl-1004153bj6de6.han3.lib.uni.lodz.pl/\#/komentarz/587286502/ 462695 (dostęp: 19.09.2017). 
Z przedstawionych regulacji jedynie te odnoszące się do umowy o pracę nakładczą i umowy agencyjnej zakładają konieczność upływu okresu wypowiedzenia pomiędzy oświadczeniem o wypowiedzeniu a rozwiązaniem umowy ( $\$ 4$ ust. 2 i 3 rozp.pr.nakład.; art. $764^{1}$ k.c.). Umowa zlecenia ulega natychmiastowemu (bez zachowania właściwego dla stosunku pracy okresu wypowiedzenia) rozwiązaniu z chwilą dojścia oświadczenia woli o jej wypowiedzeniu (art. 61 k.c.), chyba że strony w jej treści zawrą postanowienie odmienne. Powyższe dotyczyć będzie również umowy o dzieło, w której strony przewidziały możliwość wypowiedzenia.

Okres wypowiedzenia, upływający od złożenia oświadczenia woli o wypowiedzeniu umowy do jej rozwiązania, umożliwia stronom stosunku prawnego zamknięcie bieżących spraw. W odniesieniu do uregulowanych kodeksowo podstaw prawnych umownego zatrudnienia cywilnoprawnego powyższe aktualizuje się w przypadku umowy agencyjnej. W prawie pracy instytucja okresu wypowiedzenia dodatkowo chroni trwałość z natury stabilnego stosunku zatrudnienia. Z tego też powodu konieczność zachowania okresu wypowiedzenia przeniesiona została na grunt regulacji pracy nakładczej, łączącej właściwą prawu pracy ochronę zatrudnienia $\mathrm{z}$ jego niepodporządkowanym charakterem.

Przedstawiając sytuację prawną osób świadczących pracę w ramach umownego zatrudnienia nietypowego z perspektywy rozwiązania umowy za wypowiedzeniem, za punkt wyjścia przyjęto regulację typową, czyli warunki wypowiedzenia umowy o pracę na czas nieokreślony. Jako pierwszy z nich warto wskazać konieczność uzasadniania decyzji o wypowiedzeniu. Uznając element ten za środek służący stabilizacji zatrudnienia, trzeba dodatkowo przyznać, że ma on niezaprzeczalny walor w postaci szanowania godności pracownika ${ }^{24}$. Decyzja pracodawcy o rozwiązaniu umowy o pracę musi mieć swoje podstawy, które pracownik poznaje poprzez jej uzasadnienie. Konieczność spełnienia warunku uzasadnienia wypowiedzenia umowy o pracę poprzez podanie przyczyny wynika z treści art. 30 $\$ 4$ k.p. i jest przykładem szczególnej ochrony, jaką ustawodawca przypisuje trwałości zatrudnienia typowego ${ }^{25}$. Przyczyna podana przez pracodawcę jako uzasadnienie dla wypowiedzenia może być ogólna, zwłaszcza w przypadku gdy pracownik miał świadomość istnienia konkretnych zarzutów dotyczących jego sposobu wykonywania pracy ${ }^{26}$. Ustawodawca celowo nie skatalogował przyczyn wypowiedzenia umowy o pracę zawartej na czas nieokreślony ${ }^{27}$. Wobec braku możli-

24 H. Lewandowski, Granice liberalizacji prawa pracy, [w:] E. Bielak, H. Lewandowski (red.), Granice liberalizacji prawa pracy. Problemy zabezpieczenia społecznego. Materiały z XIV Zjazdu Katedr (Zakładów) Prawa Pracy i Ubezpieczeń Społecznych, Łódź 2003, s. 33.

25 Z. Salwa, Wypowiedzenie umowy o pracę w kodeksie pracy, „Państwo i Prawo” 1974, nr 8-9, s. 21.

26 Wyrok Sądu Najwyższego z dnia 24 lutego 1998 r., I PKN 538/97, LEX nr 34664.

27 Wyjątkiem jest regulacja art. 196 k.p. Przepis ten dotyczy zatrudniania młodocianych, czyli problematyki wykraczającej poza ramy opracowania, dlatego zagadnienie to nie będzie omawiane. 
wości stworzenia katalogu o charakterze wyczerpującym posłużenie się klauzulą generalną wydaje się bardziej odpowiednie ${ }^{28}$. Nie znaczy to jednak, że przyczyna wypowiedzenia umowy zawartej na czas nieokreślony nie musi mieć charakteru rzeczywistego, konkretnego i obiektywnego ${ }^{29}$.

Umowa o pracę na czas nieokreślony jest jedyną spośród umów o pracę, której wypowiedzenie wymaga uzasadnienia. Strony pozostałych umów mogą zawrzeć $\mathrm{w}$ umowie postanowienie, zgodnie z którym wypowiedzenie będzie wymagało uzasadnienia. Postanowienie takie nie narusza art. 18 k.p. tylko w przypadku gdy chroni interes pracownika, czyli obliguje pracodawcę do uzasadniania wypowiedzenia. Jeśli bowiem to pracownik musiałby wskazać powody wypowiadania umowy o pracę, odpowiednie postanowienie statuujące taki obowiązek, jako mniej korzystne niż przepisy prawa pracy, mocą art. $18 \$ 2$ k.p. byłoby nieważne. Brak konieczności uzasadnienia ${ }^{30}$ wypowiedzenia przeczy idei zatrudnienia terminowego $\mathrm{w}$ postaci pewności co do trwania stosunku prawnego do oznaczonego terminu, powodując nieuzasadnioną dysproporcję pomiędzy daleko idącą ochroną pracownika przed wypowiedzeniem umowy o pracę na czas nieokreślony a swobodą wypowiadania umów o pracę na czas określony ${ }^{31}$. Zróżnicowanie statusu prawnego pracowników w kontekście wymogu uzasadniania wypowiedzenia umowy o pracę nie zostało uznane za niezgodne z konstytucyjną zasadą

28 G. Goździewicz, Przemiany w zakresie..., s. 22.

29 Wyrok Sądu Najwyższego z dnia 25 listopada 1997 r., I PKN 385/97, LEX nr 33568; Wyrok Sądu Najwyższego z dnia 4 grudnia 1997 r., I PKN 419/97, LEX nr 33895; Wyrok Sądu Najwyższego z dnia 14 października 2004 r., I PK 697/03, LEX nr 149347. W odniesieniu do telepracy brak zgody pracownika na zmianę warunków wykonywania pracy w przypadku określonym w art. $67^{7} \S 3$ k.p., a także zaprzestanie wykonywania pracy w formie telepracy w warunkach określonych w art. $67^{8}$ k.p. same w sobie nie mogą stanowić przyczyny uzasadniającej wypowiedzenie umowy o pracę. Nie stoi to jednak na przeszkodzie wypowiedzeniu umowy o pracę z przyczyny braku możliwości zapewnienia stanowiska pracy w siedzibie przedsiębiorstwa we wskazanych powyżej przypadkach. M. Gersdorf, Zatrudnianie pracowników w formie telepracy, „Praca i Zabezpieczenie Społeczne” 2008, nr 5, s. 12; A. Sobczyk, Zakres przedmiotowy negatywnych przyczyn wypowiedzenia umowy o pracę, [w:] A.M. Świątkowski (red.), Ochrona praw człowieka w świetle przepisów prawa pracy i zabezpieczenia społecznego. Referaty i wystąienia zgłoszone na XVII Zjazd Katedr/ Zakładów Prawa Pracy i Zabezpieczenia Społecznego, Kraków 7-9 maja 2009 r., Warszawa 2009, s. 278 i nast.

30 Potrzebę wprowadzenie uzasadnienia wypowiedzenia takiej umowy postuluje E. Wronikowska, Terminowe umowy, s. 194 i nast. Autorka podkreśla, że projekt kodeksu pracy częściowo spełnia to wymaganie w art. 82, zgodnie z którym wobec odmiennego postanowienia w umowie pracodawca ma obowiązek uzasadniania wypowiedzenia umowy o pracę zawartej na czas określony. Warunek ten nie ma jednak charakteru obligatoryjnego, dlatego można domniemywać, że pracodawca wykorzystując przewagę ekonomiczną, często wprowadzałaby do umowy o pracę postanowienie wyłączające go.

31 H. Kasińska, Rozwiq̨zanie terminowych umów o pracę, „Praca i Zabezpieczenie Społeczne” 1980, nr 6, s. 26-27. 
równości ${ }^{32}$. Na gruncie ustawodawstwa unijnego w wyroku C-38/13 Trybunał Sprawiedliwości Unii Europejskiej ${ }^{33}$ nie uznał wprost niezgodności tego zróżnicowania $\mathrm{z}$ Porozumieniem ramowym w sprawie pracy na czas określony, stanowiącym załącznik do dyrektywy Rady nr 99/70/WE ${ }^{34}$. Trybunał odniósł się w wyroku jedynie do długości okresu wypowiedzenia jako przesłanki różnicującej pozycję pracowników. Tego zagadnienia dotyczyło bowiem pytanie prejudycjalne. Skoro jednak Trybunał uznał, że warunki wypowiedzenia umów o pracę na czas określony i nieokreślony powinny być takie same, tożsamość tę należałoby odnieść również do wymogu uzasadniania wypowiedzenia umowy o pracę ${ }^{35}$. W wyroku C-38/13 TSUE zaliczył do warunków zatrudnienia długość okresu wypowiedzenia, która nie powinna być różnicowana w zależności od rodzaju umowy o pracę (pkt 35 wyroku). W związku z powyższym coraz bardziej zyskuje na znaczeniu postulat rozszerzenia obowiązku uzasadniania wypowiadania umów o pracę względem umów zawartych na czas określony ${ }^{36}$. Uzasadnianie wypowiedzenia umowy jest bowiem również jednym z warunków zatrudnienia, który nie powinien być różnicowany w zależności od rodzaju umowy o pracę.

Żadna z konstrukcji umów cywilnoprawnych, na podstawie których może być świadczona praca, nie wprowadza konieczności uzasadniania jej wypowiedzenia. Również wypowiedzenie umowy o pracę nakładczą, świadczoną $\mathrm{w}$ ramach umowy zawartej na czas nieokreślony, nie wymaga uzasadnienia ${ }^{37}$. Nie stoi to jednak na przeszkodzie takiemu ukształtowaniu stosunku prawnego, które będzie uwzględniało konieczność uzasadnienia wypowiedzenia umowy. W związku z tym, że w stosunkach cywilnoprawnych, spełniających odmienne od stosunków prawnopracowniczych cele gospodarcze, strony uznawane są za równe, umowa może przewidywać konieczność uzasadnienia wypowiedzenia zarówno przez osobę świadczącą pracę, jak i przez podmiot zatrudniający.

Status prawny osób świadczących pracę $\mathrm{w}$ ramach umownego zatrudnienia nietypowego w odniesieniu do konieczności uzasadniania przez podmiot za-

32 Wyrok Trybunału Konstytucyjnego z dnia 2 grudnia 2008 r., P 48/07, Dz.U. Nr 219, poz. 1409. Trybunat stwierdzit, że pracownicy zatrudnieni na podstawie umów o pracę na czas określony nie należą do tej samej klasy co pracownicy zatrudnieni na podstawie umów o pracę na czas nieokreślony, co uniemożliwia ich porównywanie. Por. A. Sobczyk, Różnicowanie praw (ochrony) zatrudnionych - wybrane kryteria i ich ocena, [w:] M. Bosak (red.), Funkcja ochronna prawa pracy a wyzwania wspótczesności, Warszawa 2014, s. 5-6.

33 Dalej: TSUE.

34 Treści wyroku przedstawia P. Bocianowski, Konieczne zmiany w polskim kodeksie pracy w zakresie umów na czas określony - wyrok Trybunału Sprawiedliwości UE z 13 marca 2014 r. w sprawie C-38/13, „Praca i Zabezpieczenie Społeczne” 2014, nr 4, passim.

35 Zrównanie uprawnień pracowników dotyczyć powinno także konsultacji związkowej wypowiedzenia umowy o pracę.

36 Na tendencję do postulowania takich zmian wskazuje G. Goździewicz, Przemiany w zakresie..., s. 37.

37 Ł. Pisarczyk, Różne formy zatrudnienia, Warszawa 2003, s. 120. 
trudniający decyzji o wypowiedzeniu umowy jest tożsamy. Żadna z omawianych podstaw umownego zatrudnienia nietypowego nie wymaga takiego uzasadnienia. Brak obowiązku uzasadniania wypowiedzenia terminowych umów o pracę nie wydaje się usprawiedliwiony ich społeczno-gospodarczym przeznaczeniem. Wręcz przeciwnie - osłabia trwałość zatrudnienia terminowego, którego systemowym przeznaczeniem jest trwanie do określonego momentu. Terminowe umowy o pracę, jeśli w ogóle, powinny być wypowiadane w nadzwyczajnych okolicznościach. Brak stabilizacji zatrudnienia, wynikający z możliwości wypowiedzenia umowy bez istnienia przyczyny, ujemnie wpływa na stosunek pracownika do wypełnianych obowiązków ${ }^{38}$, co de facto pozostaje w sprzeczności również z interesem pracodawcy. Stabilizacją zatrudnienia są zatem zainteresowane obie strony.

Zamiar wypowiedzenia ${ }^{39}$ umowy o pracę zawartej na czas nieokreślony pracodawca musi skonsultować $\mathrm{z}$ reprezentującą pracownika zakładową organizacją związkową (art. 38 k.p.). Konsultacja ta ma postać społecznej kontroli zasadności wypowiedzenia umowy o pracę $e^{40}$. Z racji tego, że stanowisko zakładowej organizacji związkowej w postaci zgłoszenia umotywowanych zastrzeżeń nie jest wiążące, pracodawca nie musi uwzględniać go w ostatecznej decyzji o wypowiedzeniu umowy. Pracodawca jest jednak związany procedurą wypowiedzenia, której jednym z elementów jest konsultacja związkowa ${ }^{41}$. Obowiązek pracodawcy konsultacji zamiaru rozwiązania umowy o pracę za wypowiedzeniem jest korzystny dla sytuacji prawnej pracownika ${ }^{42}$, natomiast w kontekście spadku uzwiązkowienia konsultacja ma marginalne znaczenie. Można jej bowiem przypisać walor

38 A. Walas, Problemy ustawowego uregulowania stosunku pracy, „Praca i Zabezpieczenie Społeczne" 1963, nr 5, s. 8.

39 W związku z konsultacją samego zamiaru przypisuje się jej przymiot uprzedniości względem samego wypowiedzenia. T. Romer, Rozwiqzanie umowy o pracę..., s. 10.

40 A. Rycak, Zwiq̨zkowa reprezentacja uprawnień pracowniczych w rozwiq̨zaniu umów o praca, [w:] G. Goździewicz (red.), Reprezentacja praw i interesów pracowniczych, Toruń 2001, s. 175.

41 M. Seweryński, Ochrona pracowników przed rozwiqzzaniem umowy o pracę według projektu kodeksu pracy, [w:] G. Goździewicz (red.), Reprezentacja praw..., s. 143.

42 Na tym etapie prowadzonych rozważań powstaje wątpliwość co do trybu, w którym pracodawca ma zwracać się do zakładowej organizacji związkowej o przedstawienie listy osób przez nią reprezentowanych. Rozwiewając te wątpliwości, Sąd Najwyższy stwierdzit, że zamierzając wypowiedzieć umowę o pracę zawartą na czas nieokreślony, pracodawca powinien o tym zamiarze powiadomić zakładową organizację związkową, wnosząc przy tym o określenie, czy pracownik, któremu chce wypowiedzieć stosunek pracy, jest przez tę organizację reprezentowany. $W$ ten sposób pracodawca miałby czynić zadość obowiązkowi wskazanemu w art. 38 § 1 k.p. w zw. z art. $23^{2}$ k.p. oraz art. 30 ust. $2^{1}$ u.z.z. Wyrok Sądu Najwyższego z dnia 21 kwietnia 1999 r., I PKN 36/99, LEX nr 37100. Wybranie takiego wariantu, w którym pracodawca wskazuje imiennie, kogo dotyczy zamiar wypowiedzenie umowy o pracę, prowadzi do oczywistych nadużyć w postaci natychmiastowego obejmowania ochroną przez zakładowe organizacje związkowe wskazanych przez pracodawcę pracowników. Szerzej na ten temat A. Rycak, Zwiq̨zkowa reprezentacja..., s. 180 i nast. 
istotności w przypadku powszechnego i obowiązkowego charakteru ${ }^{43}$. Powyższe nie zmienia faktu, że poza pracownikami zatrudnionymi na podstawie umowy o pracę na czas nieokreślony status prawny pozostałych osób świadczących pracę $\mathrm{w}$ ramach umownego zatrudnienia nietypowego jest taki sam. Podmiot zatrudniający nie ma obowiązku konsultacji zamiaru wypowiedzenia umowy z reprezentującą osobę zatrudnioną zakładową organizacją związkową. Zróżnicowanie statusu prawnego osób świadczących pracę $\mathrm{w}$ ramach umownego zatrudnienia nietypowego względem zatrudnienia typowego nie wydaje się uzasadnione. Podstawa prawna zatrudnienia nie wpływa bowiem na uzasadnienie braku społecznej kontroli zamiaru wypowiedzenia. Wprowadzenie tego obowiązku, jako obowiązku powszechnego, mogłoby ponadto przynieść wzrost poziomu uzwiązkowienia.

Formalnym warunkiem złożenia oświadczenia woli o wypowiedzeniu umowy jest zachowanie odpowiedniej formy. Zgodnie z art. $30 \S 3$ k.p. oświadczenie woli o wypowiedzeniu umowy o pracę powinno być złożone na piśmie. Niezachowanie powyższej formy nie skutkuje nieważnością dokonanej czynności. Jest natomiast równoznaczne z jej wadliwością, dającą podstawy do wystąpienia na drogę sądową z odpowiednimi roszczeniami. Dodatkowo oświadczenie składane przez pracodawcę musi zawierać pouczenie o przysługującym pracownikowi prawie do odwołania od niego do sądu pracy (art. $30 \$ 5$ k.p.). Żadna z regulacji prawnych dotyczących cywilnoprawnych podstaw świadczenia pracy nie ustanawia dla skuteczności wypowiedzenia zachowania formy pisemnej ${ }^{44}$, co nie wyłącza powinności jej zachowania w przypadku gdy sama umowa taką formę miała (art. $77 \$ 2$ k.c.). Pouczenie o możliwości dochodzenia swoich roszczeń przed sądem również nie jest wymagane na gruncie umów, których przedmiotem jest zatrudnienie cywilnoprawne. Zróżnicowanie statusu prawnego osób świadczących pracę we wskazanym zakresie uzasadnione jest założeniem, że pracownik wymaga ochrony wzmożonej, obejmującej konieczność wskazania mu drogi dochodzenia swoich prac, względem ochrony powszechnie obowiązującej w obrocie prawnym, obejmującej konieczność wskazywania pracownikowi drogi dochodzenia swoich praw.

Sytuacja prawna osób świadczących pracę w ramach umownego zatrudnienia nietypowego jest zróżnicowana również w odniesieniu do okresów wypowiedzenia. Okres wypowiedzenia umowy o pracę zawartej na czas określony i nieokreślony uzależniony jest od stażu pracy i wynosi odpowiednio: 2 tygodnie, jeśli pracownik był zatrudniony u danego pracodawcy krócej niż 6 miesięcy, 1 miesiąc, jeżeli pracownik był zatrudniony co najmniej 6 miesięcy oraz 3 miesiące, jeśli pracownik był zatrudniony co najmniej 3 lata (art. $36 \$ 1$ k.p.). Istotne jest przy

43 J. Piątkowski, Udział zwiq̨zku zawodowego w rozwiq̨zaniu stosunku pracy - niedoskonatości regulacji prawnej, [w:] G. Goździewicz (red.), Reprezentacja praw..., s. 140 i literatura tam wskazana.

44 Powyższe dotyczy również umowy o pracę nakładczą. 
tym, że do zakładowego stażu pracy, od którego zależy okres wypowiedzenia, wlicza się wszystkie okresy pozostawania w zatrudnieniu u danego pracodawcy bez względu na to jak długo trwał stosunek pracy, którego dotyczy wypowiadana umowa o pracę. Również następstwo prawne prowadzące do kontynuacji zatrudnienia nie przerywa biegu okresu, od którego zależy długość okresu wypowiedzenia (art. $36 \$ 2$ k.p.). W stanie prawnym zmienionym nowelizacją czerwcową z 2015 r. spośród wypowiadalnych umów o pracę regulacje dotyczące umów o pracę na czas określony oraz umowy zawartej w celu zastępstwa nie różnicowały długości okresu wypowiedzenia w zależności od stażu zakładowego. W pierwszym przypadku zawsze wynosił on 2 tygodnie (art. 33 k.p.), w drugim jedynie 3 dni (art. $33^{1}$ k.p.). Nowelizacja czerwcowa z 2015 r. ujednolica regulacje związane z okresami wypowiedzenia umów o pracę. Do umów o pracę na czas określony zastosowanie znajduje art. 36 k.p. Tym samym rozszerzeniu uległy obowiązujące dotąd jedynie w stosunku do umów bezterminowych przepisy dotyczące długości okresów wypowiedzenia ${ }^{45}$. Ustawodawca pozostawił natomiast odmienną regulację dotyczącą okresu wypowiedzenia umowy o pracę na okres próbny. Okres ten nie jest uzależniony od stażu zakładowego, ale od czasu trwania konkretnego stosunku prawnego. Umowa o pracę zawarta na okres próbny rozwiązuje się zatem po upływie okresu wypowiedzenia, który wynosi 3 dni robocze, jeśli okres próby nie przekracza dwóch tygodni, 1 tydzień, jeśli okres próby przekracza 2 tygodnie oraz 2 tygodnie, jeśli okres ten wynosi 3 miesiące (art. 34 k.p.).

W zakresie długości okresu wypowiedzenia w sposób odmienny ukształtowana jest sytuacja prawna pracowników tymczasowych. Ustawa o zatrudnianiu pracowników tymczasowych różnicuje okres wypowiedzenia umowy zawartej na czas określony. Przed nowelizacją czerwcową z 2015 r. stanowiło to wyłom w zasadzie braku wpływu okresu zatrudnienia na długość okresu wypowiedzenia umowy o pracę zawartej na czas określony. Przepis art. 13 ust. 2 z.p.t. ustanawia dwie długości okresów wypowiedzenia. Trzydniowy okres wypowiedzenia stosowany jest w przypadku umowy o pracę tymczasową zawartej na okres nieprzekraczający dwóch tygodni, natomiast tygodniowy okres wypowiedzenia - w razie umowy o pracę tymczasową zawartej na okres dłuższy niż dwa tygodnie. Systemowym założeniem pracy tymczasowej jest jej krótkotrwały charakter, a zatrudnienie tymczasowe wykorzystywane jest w przejściowych okresach wzmożonego zapotrzebowania, dlatego regulacja ta daje możliwość szybkiego zrezygnowania z pracy pracownika tymczasowego ${ }^{46}$. W związku z art. 18 ust. 2 z.p.t. pracodawca użytkownik może zrezygnować z pracy pracownika tymczasowego przed upływem okresu wykonywania pracy tymczasowej, zawiadamiając o tym fakcie agencję pracy tymczasowej. Obowiązek dokonania tego zawiadomienia z uwzględnieniem

45 L. Mitrus, op. cit., s. 290.

46 M. Pędziwiatr, Uprawnienia kierownicze w stosunkach pracy tymczasowej, „Praca i Zabezpieczenie Społeczne" 2008, nr 5, s. 18. 
okresu wypowiedzenia nie jest zastrzeżony pod żadnym rygorem. Pracodawca użytkownik powinien uwzględnić obowiązujący strony umowy o pracę tymczasową okres wypowiedzenia jedynie „w miarę możliwości”. Powyższe powoduje, że pracownik tymczasowy może zakończyć pracę na rzecz pracodawcy użytkownika przed końcem okresu wypowiedzenia.

Spośród uregulowanych w kodeksie cywilnym umów stanowiących podstawę zatrudnienia cywilnoprawnego (umowy zlecenia, umów o świadczenie usług, do których stosuje się przepisy o zleceniu, umowy agencyjnej i umowy o dzieło), których przedmiotem może być świadczenie pracy, jedynie regulacja prawna umowy agencyjnej normuje kwestie związane $\mathrm{z}$ okresami wypowiedzenia ${ }^{47}$. Przepis art. $764^{1}$ k.c. statuuje zasadę, zgodnie z którą umowa zawarta na czas nieoznaczony może być wypowiedziana $\mathrm{z}$ miesięcznym wyprzedzeniem $\mathrm{w}$ pierwszym roku trwania, $\mathrm{z}$ dwumiesięcznym wyprzedzeniem $\mathrm{w}$ drugim roku trwania oraz $\mathrm{z}$ trzymiesięcznym wyprzedzeniem w trzecim i kolejnych latach trwania. Powyższa regulacja pozostaje zbieżna $\mathrm{z}$ art. 15 ust. 2 dyrektywy agencyjnej. Możliwe jest umowne przedłużenie wskazanych terminów z uwzględnieniem warunku $\mathrm{w}$ postaci co najmniej równego terminu wypowiedzenia ustalonego dla dającego zlecenie i agenta. Dodatkowo każdorazowe wydłużenie okresu wypowiedzenia dla agenta powoduje takie samo wydłużenie dla dającego zlecenie $\left(764^{1} \$ 2\right.$ k.c.). Strony umowy agencyjnej nie mogą skrócić ustawowo przewidzianych okresów wypowiedzenia. Postanowienie takie byłoby nieważne ${ }^{48}$ pomimo zgodnej woli obu stron umowy. Powyższe podyktowane jest założeniem o gospodarczym przeznaczeniu umowy agencyjnej, jako umowy o charakterze ciągłym, gwarantującej względną trwałość stosunku prawnego.

Umowa agencyjna może być zawarta również na czas oznaczony. W takiej sytuacji jej treść może przewidywać możliwość wcześniejszego wypowiedzenia, pod warunkiem że będzie ona ograniczona do wskazanych w treści umowy okoliczności. Tylko takie uregulowanie wzajemnych relacji, wskazujące warunki, jakie muszą zaistnieć, aby umowa mogła zostać wypowiedziana przed przewidywaną datą zakończenia, nie narusza natury umowy terminowej jako umowy trwającej do umówionego momentu ${ }^{49}$.

Regulacja umowy o pracę nakładczą ustanawia $\mathrm{w} \$ 4$ rozp.pr.nakład. dwutygodniowy okres wypowiedzenia dla umowy zawartej na okres próbny. Rozporządzenie w sprawie uprawnień pracowniczych osób wykonujących pracę nakładczą nie różnicuje również okresu wypowiedzenia umowy o pracę nakładczą zawartej na czas nieokreślony. Okres ten wynosi zawsze 1 miesiąc, bez względu na długość

47 W przypadku pozostałych umów właściwe postanowienia mogą zostać wprowadzone przez strony do ich treści. Ł. Pisarczyk, Różne formy..., s. 91.

48 Ibidem, s. 97.

49 E. Rott-Pietrzak, Dopuszczalność zastrzeżenia wypowiedzenia umowy agencyjnej na czas oznaczony, „Przegląd Prawa Handlowego” 2003, nr 10, s. 49-50. 
trwania umowy. Rozporządzenie nie przewiduje, aby za wypowiedzeniem można było rozwiązać umowę o pracę nakładczą zawartą na czas określony bądź na czas wykonania określonej pracy. Umowy te uznać należy zatem za niewypowiadalne, przez co stabilizujące status prawny wykonawcy pracy nakładczej. Wydaje się, że zasadne byłoby, o czym była już mowa, istnienie odpowiedniej regulacji w zatrudnieniu prawnopracowniczym. To bowiem jego trwałość powinna być najszersza.

Kolejną płaszczyzną, na której przedstawiona zostanie sytuacja prawna osób zatrudnionych w ramach umownego zatrudnienia nietypowego, jest sposób obliczania terminu wypowiedzenia. W braku odmiennej regulacji do stosunku pracy stosuje się art. 61 k.c. (w zw. z art. 300 k.p.). Zatem oświadczenie woli o wypowiedzeniu należy uznać za złożone, w chwili gdy doszło do drugiej strony w taki sposób, że mogła się z nim zapoznać5 ${ }^{50}$. Pracownicze podstawy zatrudnienia ustanawiają wspólną regulację w zakresie terminu wypowiedzenia oznaczonego w tygodniach lub miesiącach (art. $30 \$ 2^{1}$ k.p.). Na jej podstawie okres wypowiedzenia umowy obejmujący tydzień kończy się zawsze w sobotę, natomiast okres wypowiedzenia obejmujący miesiąc, kończy się w ostatnim dniu miesiąca. Regulacja ta znajdzie zastosowanie również $\mathrm{w}$ stosunku do rozwiązania umowy o pracę tymczasową za jednotygodniowym wypowiedzeniem (art. 13 ust. 2 pkt 2 z.p.t.). W związku z powyższym powstaje wątpliwość, czy wskazane w kodeksie pracy okresy wypowiedzenia są okresami minimalnymi, czy też nie. Jeśli przyjąć, że są to okresy minimalne, okres wypowiedzenia trwa od momentu dojścia oświadczenia woli o wypowiedzeniu w taki sposób, że druga strona mogła się z nim zapoznać, do końca okresu obliczanego zgodnie z art. $30 \$ 2^{1}$ k.p. Przyjęcie założenia przeciwnego (czyli że określone w kodeksie pracy okresy wypowiedzenia nie są okresami minimalnymi) powoduje, że długość okresu wypowiedzenia oblicza się poprzez odniesienie długości jego trwania do daty końcowej ${ }^{51}$. Kodeks pracy nie reguluje kwestii związanej z okresem wypowiedzenia wyznaczonym w dniach, należy więc w takim przypadku odwołać się do przepisów kodeksu cywilnego. Okres wypowiedzenia zakończy się zatem ostatniego dnia bez uwzględniania dnia, w którym oświadczenie woli o wypowiedzeniu zostało złożone (art. 111 k.c. w ZW. z art. 300 k.p. $)^{52}$.

Jeśli strony nie postanowią inaczej, umowa agencyjna, tak jak umowa o pracę, której termin wypowiedzenia określany jest w miesiącach, rozwiązuje się na ko-

50 L. Florek, Rozwiq̨zanie i wygaśnięcie..., s. 174.

51 Szczegółową analizę tego zagadnienia wraz z przedstawieniem szerokiej argumentacji za stanowiskiem krytycznym wobec koncepcji minimalnych okresów wypowiedzenia w kodeksie pracy prezentuje M. Rylski, O powszechnym rozumieniu okresów wypowiedzenia i sposobach ich obliczania - krytycznie. Część I, „Monitor Prawa Pracy” 2015, nr 6, passim; tenże, O powszechnym rozumieniu okresów wypowiedzenia i sposobach ich obliczania - krytycznie. Część II, „Monitor Prawa Pracy” 2015, nr 7, passim.

52 L. Florek, Rozwiq̨zanie i wygaśnięcie..., s. 177. Dotyczy to również rozwiązania umowy o pracę tymczasową za trzydniowym wypowiedzeniem. 
niec miesiąca (art. 764ำ 3 k.c.). Regulacje dotyczące umów zleceń i umów o dzieło nie konkretyzują terminów wypowiedzenia, ale stosowne postanowienia w tym zakresie mogą być wprowadzone do wskazanych umów wolą stron. Wobec braku takich postanowień, do obliczania terminów należy stosować przepisy kodeksu cywilnego (art. 111 i nast. k.c.). Regulację kodeksu cywilnego dotyczącą terminu oznaczonego w tygodniach należy również zastosować do wypowiedzenia umowy o pracę nakładczą zwartej na okres próbny. Dwutygodniowy okres wypowiedzenia skończy się w dniu odpowiadającym nazwą terminowi, w którym okres wypowiedzenia zaczął biec (art. 112 k.c.). Natomiast w przypadku umowy o pracę nakładczą zawartej na czas nieokreślony, okres wypowiedzenia kończy się ostatniego dnia miesiąca kalendarzowego ( $\$ 4$ ust. 3 zd. 2 rozp.pr.nakład.).

Określanie sposobu obliczania terminu wypowiedzenia nie powoduje zróżnicowania statusu prawnego osób świadczących pracę w ramach umownego zatrudnienia nietypowego w sposób mniej bądź bardziej korzystny. Regulacje te mają natomiast charakter systematyzujący i z tej perspektywy są bez wątpienia istotne.

Jako kolejny sposób rozwiązania umowy o pracę art. 30 k.p. wymienia rozwiązanie umowy bez wypowiedzenia. Natychmiastowe rozwiązanie umowy, której przedmiotem jest umowne zatrudnienie nietypowe, będzie następną perspektywą, z której omówiona zostanie sytuacja prawna osób zatrudnionych. Kodeks pracy statuuje różne okoliczności zakończenia stosunku pracy w ten sposób. Po pierwsze wskazuje na możliwość rozwiązania stosunku pracy bez wypowiedzenia z winy pracownika (art. 52); po drugie stanowi o możliwości rozwiązania umowy o pracę bez winy pracownika (art. 53) i po trzecie daje pracownikowi możliwość rozwiązania umowy o pracę bez wypowiedzenia z powodów niezależnych od pracodawcy (art. $55 \$ 1$ ) oraz z powodów zależnych od pracodawcy (art. $55 \$ 1^{1}$ ). Możliwości te dotyczą rozwiązania bez wypowiedzenia każdego rodzaju umowy o pracę.

Pracownik tymczasowy może rozwiązać umowę o pracę bez wypowiedzenia $\mathrm{w}$ trybie art. $55 \S 1^{1}$ k.p. w razie ciężkiego naruszenia obowiązków pracodawcy, czyli agencji pracy tymczasowej. Również ciężkie naruszenie przez pracodawcę użytkownika obowiązków wobec pracownika tymczasowego uprawnia tego drugiego do rozwiązania umowy bez wypowiedzenia w trybie art. $55 \$ 1^{1}$ k.p. ${ }^{53}$ $\mathrm{W}$ przypadku zaistnienia okoliczności uregulowanych hipotezą normy z art. 55 $\$ 1$ k.p. (wydania orzeczenia lekarskiego stwierdzającego szkodliwy wpływ wykonywanej pracy na zdrowie pracownika), to pracodawca użytkownik, w poro-

53 A. Reda, Pracodawca użytkownik jako podmiot prawa pracy, Poznań 2011, s. 85. K. Łapiński, Rozwiqzanie umowy o pracę bez zachowania okresu wypowiedzenia, [w:] K. Łapiński, Umowa o pracę na czas określony w polskim i unijnym prawie pracy, https://sip-1lex-1pl-1004153yx0ff8.han3.lib.uni.lodz.pl/\#/monografia/369228055/60 (dostęp: 19.09.2017). Autorzy wskazują, że podstawą do skorzystania przez pracownika tymczasowego z dyspozycji art. $55 \S 1^{1}$ k.p. jest zarówno ciężkie naruszenie obowiązków pracodawcy przez agencję pracy tymczasowej, jak i przez pracodawcę użytkownika. 
zumieniu $\mathrm{z}$ agencją pracy tymczasowej, powinien przenieść pracownika tymczasowego do pracy odpowiedniej ze względu na jego stan zdrowia. Jeśli pracownik tymczasowy nie zostanie przeniesiony do innej pracy odpowiedniej ze względu na jego stan zdrowia, będzie mógł rozwiązać umowę o pracę tymczasową bez wypowiedzenia. W powyższym przypadku to brak działania uczestnika relacji zatrudnienia, nie zaś strony umowy o pracę, daje pracownikowi tymczasowemu uprawnienie do rozwiązania umowy bez wypowiedzenia. Takie rozłożenie obowiązków i uprawnień podmiotów zatrudnienia tymczasowego związane jest z trójpodmiotowością tej relacji, która z natury w sposób szczególny kształtuje wzajemne zobowiązania uczestników.

Rozwiązanie umowy o pracę bez wypowiedzenia może nastąpić jedynie w przypadku zaistnienia przesłanek wskazanych w kodeksie pracy, czyli:

a) ciężkiego naruszenia przez pracownika podstawowych obowiązków pracowniczych (art. $52 \$ 1$ pkt 1 )

b) popełnienia przez pracownika w czasie trwania umowy o pracę przestępstwa, które uniemożliwia dalsze zatrudnianie go na zajmowanym stanowisku, jeżeli przestępstwo jest oczywiste lub zostało stwierdzone prawomocnym wyrokiem (art. $52 \$ 1$ pkt 2)

c) zawinionej przez pracownika utraty uprawnień koniecznych do wykonywania pracy na zajmowanym stanowisku (art. $52 \$ 1$ pkt 3)

d) trwania niezdolności pracownika do pracy wskutek choroby:

- dłużej niż 3 miesiące - gdy pracownik był zatrudniony u danego pracodawcy krócej niż 6 miesięcy

- dłużej niż łączny okres pobierania z tego tytułu wynagrodzenia i zasiłku oraz pobierania świadczenia rehabilitacyjnego przez pierwsze 3 miesiące - gdy pracownik był zatrudniony u danego pracodawcy co najmniej 6 miesięcy lub jeżeli niezdolność do pracy została spowodowana wypadkiem przy pracy albo chorobą zawodową (art. $53 \$ 1$ pkt 1)

e) usprawiedliwionej nieobecności pracownika w pracy z innych przyczyn niż wymienione w pkt. 4, trwającej dłużej niż 1 miesiąc (art. $53 \$ 1$ pkt 2)

f) jeżeli zostanie wydane orzeczenie lekarskie stwierdzające szkodliwy wpływ wykonywanej pracy na zdrowie pracownika, a pracodawca nie przeniesie go w terminie wskazanym w orzeczeniu lekarskim do innej pracy, odpowiedniej ze względu na stan jego zdrowia i kwalifikacje zawodowe (art. $55 \$ 1$ )

g) gdy pracodawca dopuścił się ciężkiego naruszenia podstawowych obowiązków wobec pracownika (art. $55 \$ 1^{1}$ ).

W przypadku gdy rozwiązania umowy o pracę bez wypowiedzenia dokonuje pracodawca, musi, dla zachowania zgodności z prawem, zachować formę pisemną. W odniesieniu do konieczności zachowania tej formy przez pracownika kodeks pracy zawiera ustawowe superfluum. Najpierw bowiem w art. $30 \$ 3$ nakłada na każdą ze stron stosunku pracy obowiązek zachowania formy pisemnej przy rozwiązywaniu umowy o pracę bez wypowiedzenia, aby potem dodatkowo po- 
twierdzić ten obowiązek w stosunku do pracownika w art. $55 \$ 2$. Również na obu stronach stosunku pracy ciąży obowiązek uzasadnienia rozwiązania umowy o pracę bez wypowiedzenia (art. $30 \$ 4$ i art. $55 \$ 2$ k.p.).

Dodatkowym warunkiem umożliwiającym zgodne z prawem rozwiązanie umowy o pracę bez wypowiedzenia $\mathrm{z}$ winy pracownika bądź rozwiązania umowy przez pracownika w trybie art. $55 \$ 1^{1}$ k.p. jest konieczność zachowania terminu, w jakim należy złożyć oświadczenie woli o rozwiązaniu umowy o pracę. Jest to dla obu stron stosunku pracy termin jednego miesiąca od uzyskania wiadomości o okolicznościach uzasadniających rozwiązanie umowy (art. $52 \S 2$ i art. $55 \$ 2$ zd. 2 k.p.). Jest to termin zawity ${ }^{54}$. Istotnym warunkiem umożliwiającym pracodawcy rozwiązanie umowy o pracę bez wypowiedzenia $\mathrm{z}$ winy pracownika jest konieczność konsultacji tej decyzji z reprezentującą pracownika zakładową organizacją związkową (art. $52 \S 3$ k.p.). Pracodawca nie jest jednak tą opinią związany.

Omówione regulacje, poza wskazaną różnicą dotyczącą zatrudnienia tymczasowego, w sposób tożsamy kształtują sytuację osób zatrudnionych w ramach pracowniczego umownego zatrudnienia nietypowego. Status ten nie odbiega od tego, jaki posiadają pracownicy zatrudnieni typowo. W sposób odmienny jest natomiast ukształtowana sytuacja osób zatrudnionych w ramach umownego zatrudnienia niepracowniczego.

Możliwość rozwiązania umowy bez zachowania okresu wypowiedzenia ustanawia regulacja prawna dotycząca pracy nakładczej. Przepis $₫ 6$ rozp.pr.nakład. wskazuje zamknięty katalog przyczyn, które mogą stanowić podstawę rozwiązania umowy o pracę nakładczą bez wypowiedzenia z powodu przyczyny leżącej po stronie wykonawcy. Warto wskazać, że przyczyny te nie są tożsame $\mathrm{z}$ wskazanymi w kodeksie pracy, ale podobieństwo obu katalogów jest znacz$n \mathrm{e}^{55}$. Rozwiązanie umowy o pracę nakładczą bez wypowiedzenia może nastąpić w przypadku:

1. Ciężkiego naruszenia przez wykonawcę obowiązków wynikających z umowy, a w szczególności wadliwego wykonywania $\mathrm{z}$ jego winy powierzonej pracy, nieprzestrzegania przepisów i zasad bezpieczeństwa i higieny pracy, nierozliczania się $\mathrm{w}$ ustalonych terminach $\mathrm{z}$ pobranych surowców lub materiałów, niewykonywania bez uzasadnionych przyczyn przez okres 3 miesięcy minimalnej miesięcznej ilości pracy albo dokonania nadużyć w zakresie korzystania ze świadczeń z ubezpieczenia społecznego lub innych świadczeń socjalnych.

2. W razie popełnienia przez wykonawcę przestępstwa, które uniemożliwia dalsze powierzanie mu pracy nakładczej, jeżeli przestępstwo jest oczywiste lub zostało stwierdzone prawomocnym wyrokiem.

54 L. Florek, Rozwiq̨anie i wygaśnięcie..., s. 205.

55 F. Małysz, Chałupnictwo (1) umowa i wynagrodzenie, „Służba Pracownicza” 2006, nr 4, s. 13. 
3. W razie niewykonywania pracy przez wykonawcę $\mathrm{z}$ powodu:

a) niezdolności do pracy wskutek choroby lub odosobnienia ze względu na chorobę zakaźną przez okres dłuższy niż 3 miesiące

b) niezdolności do pracy wskutek choroby zawodowej lub spowodowanej wypadkiem przy pracy przez okres dłuższy niż 6 miesięcy

c) braku możności wykonywania pracy z przyczyn innych niż określone pod lit. a) i b) przez okres dłuższy niż 1 miesiąc, z zastrzeżeniem $₫ 5$ ust. 2 rozp. pr.nakł.

Odpowiednio, podobnie jak w przypadku regulacji zawartej w kodeksie pracy, rozwiązanie umowy musi nastąpić w terminie jednego miesiąca od uzyskania przez nakładcę wiadomości o okolicznościach uzasadniających rozwiązanie umowy. Rozporządzenie w sprawie uprawnień pracowniczych osób wykonujących pracę nakładczą nie ustanawia konieczności zachowania formy pisemnej takiego rozwiązania ani wskazania w jego treści przyczyny rozwiązania czy też pouczenia o możliwości odwołania do sądu, ani nie odsyła w przedmiocie konieczności wypełnienia wskazanych obowiązków do kodeksu pracy. Przyczyna rozwiązania umowy powinna jednak być wskazana w celu uniknięcia kwestionowania jego zasadności. Zachowanie formy pisemnej rozwiązania wynika natomiast ze wskazywanej już regulacji art. $77 \$ 2$ k.c.

Również wykonawca ma możliwość niezwłocznego rozwiązania umowy o pracę nakładczą ( $\$ 8$ rozp.pr.nakład.). Jest do tego uprawniony w przypadku odpowiednim do regulacji art. $55 \$ 1$ k.p. Normy przepisów $₫ 8$ rozp.pr.nakład. i art. $55 \$ 1$ k.p. różnią się w dwóch aspektach. Nakładca musi przydzielić wykonawcy inną pracę $\mathrm{w}$ terminie miesiąca od wydania orzeczenia lekarskiego stwierdzającego szkodliwy wpływ wykonywanej pracy na zdrowie wykonawcy. Pracodawca jest w odpowiednim stanie faktycznym związany terminem wskazanym w orzeczeniu lekarskim. Dodatkowo, w przypadku pracy nakładczej, która jest świadczona w domu wykonawcy, uprawnienie do rozwiązania umowy o pracę nakładczą przez wykonawcę daje stwierdzenie orzeczeniem lekarskim szkodliwego wpływu wykonywanej pracy na zdrowie jego współmieszkańców oraz brak dostarczenia przez nakładcę innej pracy w terminie miesiąca od wydania takiego orzeczenia ( $\$ 8$ ust. 2 rozp.pr.nakład.). Ta okoliczność związana jest $\mathrm{z}$ charakterem pracy nakładczej, której jednym z założeń systemowych jest możliwość świadczenia pracy w domu. Dlatego też wprowadzenie dodatkowej przesłanki umożliwiającej wykonawcy rozwiązanie umowy bez wypowiedzenia wydaje się w pełni uzasadnione.

Rozwiązanie umowy zlecenia następuje co do zasady w trybie natychmiastowym, ponieważ kodeks cywilny nie wymaga konieczności zachowania okresu wypowiedzenia. Przepis art. $746 \$ 1$ k.c. wskazuje wręcz, że dający zlecenie może je wypowiedzieć w każdym czasie. Wypowiedzenie ma skutek wygaśnięcia zobowiązania z chwilą złożenia oświadczenia o wypowiedzeniu, czyli jest równoznaczne $\mathrm{z}$ rozwiązaniem umowy bez zachowania okresu wypowiedze- 
nia ${ }^{56}$. Uprawnienie takie przysługuje również przyjmującemu zlecenie (art. 746 $\$ 2$ k.c. $)^{57}$.

Regulacja prawna umowy o dzieło również nie ustanawia konieczności zachowania okresu wypowiedzenia przy jej rozwiązywaniu. Zamawiający ma prawo odstąpienia ${ }^{58}$ od umowy w każdym czasie, aż do ukończenia dzieła (art. 644 k.c.). Zamawiający może odstąpić od umowy o dzieło również w przypadku zaistnienia okoliczności wskazanych w treści art. 631 k.c., czyli konieczności znacznego podwyższenia wynagrodzenia kosztorysowego, bądź art. 635 k.c., czyli w przypadku gdy przyjmujący zamówienie opóźnia się z rozpoczęciem lub wykończeniem dzieła tak dalece, że nie jest prawdopodobne, aby ukończył je w umówionym terminie. Opóźnienie to ma zatem charakter kwalifikowany. Kolejna okoliczność uprawniająca zamawiającego do odstąpienia od umowy o dzieło została określona $\mathrm{w}$ art. $636 \mathrm{k} . c$. Zgodnie $\mathrm{z}$ treścią tego przepisu w razie wadliwego albo sprzecznego $\mathrm{z}$ umową wykonywania dzieła, jeżeli nie doszło jeszcze do jego odbioru, zamawiający może wezwać przyjmującego zamówienie do zmiany sposobu wykonania umowy i wyznaczyć mu w tym celu odpowiedni termin. Po jego bezskutecznym upływie zamawiający może od umowy odstąpićs ${ }^{59}$. Brak wskazania możliwości odstąpienia od umowy o dzieło przez przyjmującego zamówienie świadczy o braku istnienia takiego prawa. Ustawowe prawo odstąpienia od umowy przysługuje jedynie w przypadkach wskazanych w odpowiednich przepisach ${ }^{60}$.

Umowa agencyjna może być rozwiązana bez zachowania terminu wypowiedzenia jedynie z powodu niewykonania obowiązków przez jedną ze stron w całości lub w znacznej części ${ }^{61}$ oraz w przypadku zaistnienia nadzwyczajnych okoliczności (art. $764^{2} \$ 1$ k.c.). Norma ta pozostaje zbieżna z art. 16 dyrektywy agencyjnej.

56 K. Kopaczyńska-Pieczniak, Art. 746, [w:] A. Kidyba (red.), Kodeks cywilny. Komentarz, t. 3: Zobowiq̨zania - część szczególna, https://sip-1lex-1pl-1004153yx0ff8.han3.lib.uni.lodz.pl/\#/ komentarz/587286629/462822 (dostęp: 19.09.2017).

57 Ł. Pisarczyk, Różne formy..., s. 91.

58 Odstąpienie od umowy, o czym była już mowa, nie jest tożsame z jej wypowiedzeniem.

59 Alternatywnym uprawnieniem zamawiającego jest powierzenie wykonania bądź poprawienia dzieła osobie trzeciej na koszt i niebezpieczeństwo przyjmującego zamówienie. Z prawa odstąpienia zamawiający powinien zatem korzystać w przypadku gdy ze względu na osobiste przymioty przyjmującego zamówienie nikt inny poza nim nie będzie w stanie poprawić lub dokończyć rozpoczętego dzieła. A. Olejniczak, Art. 356, [w:] A. Kidyba (red.), Kodeks cywilny. Komentarz. t. 3: Zobowiązania - część ogólna, https://sip-1lex-1pl-1004153yx0ff8. han3.lib.uni.lodz.pl/\#/komentarz/587264119/167840 (dostęp: 19.09.2017).

60 G. Tracz, Odstapienie, [w:] G. Tracz, Sposoby jednostronnej rezygnacji z zobowiq̨zań umownych, https://sip-1lex-1pl-1004153080077.han3.lib.uni.lodz.pl/\#/monografia/369164046/8 (dostęp: 19.09.2017).

61 Można zatem zauważyć pewną zbieżność konstrukcyjną z rozwiązaniem umowy o pracę bez wypowiedzenia w razie ciężkiego naruszenia przez pracownika podstawowych obowiązków (art. 52 § 1 pkt 1 k.p.) oraz ciężkiego naruszenia podstawowych obowiązków wobec pracownika (art. $55 \S 1^{1}$ k.p.). 
W kontekście omawianych zagadnień prawo cywilne w różny sposób kreuje status prawny osób świadczących pracę w ramach zatrudnienia umownego. Regulacje umowy o pracę nakładczą i umowy agencyjnej wskazują zamknięte katalogi przyczyn stanowiących podstawę rozwiązania umowy bez wypowiedzenia. Dzięki temu stabilizacja zatrudnienia jest względnie duża. Regulacja dotycząca umowy zlecenia nie wprowadza w tym zakresie ograniczeń, przez co status prawny osób świadczących pracę nie jest szczególnie chroniony. W ramach więzi umowy o dzieło ustawodawca co prawda wskazał konkretne okoliczności, w których strony mogą od umowy odstąpić, co stabilizuje więź zatrudnienia, w tym również status prawny wykonawców. Nie powoduje to jednak, że umowa nie może wskazywać innych podstaw do odstąpienia od niej. Takie zróżnicowanie wynika z odrębności konstrukcyjnych poszczególnych podstaw umownego zatrudnienia cywilnoprawnego. Zatrudnienie nakładcze, najbardziej zbliżone do konstrukcji prawnopracowniczych, również w zakresie możliwości rozwiązania umowy bez wypowiedzenia zapewnia stabilizację zatrudnienia. Zatrudnienie powstające w konsekwencji zawarcia umowy agencyjnej gwarantuje jej stronom, że rozwiązanie umowy bez wypowiedzenia może zostać zastosowane jedynie w nadzwyczajnych okolicznościach. W tym względzie najmniej korzystnie kształtuje się status prawny osób zatrudnionych na podstawie umów zlecenia, umów o świadczenie usług, do których stosuje się przepisy o zleceniu i umów o dzieło. Nie wydaje się jednak, by istniała potrzeba wzmożonej ochrony w tym zakresie osób świadczących pracę na ich podstawie.

Przepisy kodeksu cywilnego w regulacjach dotyczących poszczególnych umów nie zastrzegają dla trybu natychmiastowego rozwiązania umowy, czy - w przypadku umowy o dzieło - odstąpienia on niej, żadnych warunków co do formy. Strony mogą jednak zastrzec w umowie konieczność jej zachowania. Dodatkowo, dla celów dowodowych, rozwiązanie takie powinno nastąpić na piśmie z podaniem przyczyny w przypadku rozwiązywania umowy zlecenia $\mathrm{z}$ ważnych powodów czy też umowy agencyjnej z powodów wskazanych w art. $764^{2} \$ 1$ k.c. Zastosowanie znajduje również art. $77 \$ 2$ k.c., który dla ważności rozwiązania umowy wymaga formy, w jakiej została ona zawarta.

Kolejny sposób rozwiązania umowy o pracę przewidziany w art. $30 \$ 1$ k.p. jest bezpośrednio związany z terminowym charakterem umowy o pracę. Umowa o pracę zawarta na czas określony ulega rozwiązaniu z upływem czasu, na który była zawarta (art. $30 \$ 1$ pkt 4 k.p.). To samo dotyczy umowy o pracę nakładczą zawartej jako umowa na czas określony. Natomiast umowa o pracę nakładczą zawarta jako umowa na czas wykonania określonej pracy rozwiązuje się z chwilą ukończenia tej pracy. Wynika to $\mathrm{z}$ samej istoty tych umów ${ }^{62}$. Powyższe regulacje nie odbiegają od regulacji pozostałych umów, których przedmiotem jest zatrudnienie, a które są właściwe prawu cywilnemu. Takie umowy również rozwiązują

62 F. Małysz, Chałupnictwo...., s. 13. 
się w określonym przez strony czasie bądź w związku z określonymi okolicznościami - wypełnieniem zobowiązania przez jedną ze stron.

$\mathrm{Na}$ tym etapie rozważań niezbędne jest omówienie różnic w statusie prawnym osób świadczących pracę $\mathrm{w}$ ramach umownego zatrudnienia nietypowego w obrębie ochrony szczególnej przed wypowiedzeniem lub rozwiązaniem umowy. Mianem ochrony szczególnej przed wypowiedzeniem lub rozwiązaniem umowy określa się zbiór norm prawnych chroniących pracowników ze względu na ich szczególną sytuację osobistą bądź pełnioną funkcję czy też wykonywany zawód ${ }^{63}$. Ochrona ta jest bardzo rozbudowana, dlatego też należy skupić uwagę na tych jej przejawach, które dotyczą najliczniejszych grup pracowników.

Ochrona szczególna występuje na trzech płaszczyznach. Po pierwsze jest to całkowity zakaz wypowiedzenia lub rozwiązania bez wypowiedzenia umowy o pracę; po drugie jest to obowiązek uzyskania zgody właściwego przedstawicielstwa pracowniczego, organu państwowego lub społecznego na wypowiedzenie albo rozwiązanie bez wypowiedzenia umowy; po trzecie - ustawodawca ustanawia określony katalog przyczyn ${ }^{64}$, które mogą dopuszczać wypowiedzenie ${ }^{65}$. Poza wyjątkowymi przypadkami ochrona ta nie jest uzależniona od rodzaju umowy o pracę ${ }^{66}$. Pierwsza płaszczyzna ochrony szczególnej, polegająca na zakazie wypowiedzenia umowy o pracę, dotyczy pracowników w trakcie trwania urlopu oraz innej usprawiedliwionej nieobecności w pracy (np. choroby), o ile nie upłynął okres uprawniający do rozwiązania stosunku pracy bez wypowiedzenia (art. 41 k.p.). Zakaz ten dotyczy wszystkich pracowników, bez względu na podstawę świadczonej pracy. Ochrona ta jest właściwa dla prawa pracy, zatem osoby zatrudnione na podstawie umów cywilnoprawnych nie są nią objęte. Wyjątek stanowią wykonawcy pracy nakładczej, którym podczas trwania urlopu lub choroby, na mocy $\$ 5$ ust. 1 rozp.pr.nakład., nakładca nie może wypowiedzieć umowy ${ }^{67}$. Pracownicy są jedyną grupą osób zatrudnionych, którym nie można wypowiedzieć umowy w okresie 4 lat przed osiągnięciem wieku emerytalnego, jeżeli okres zatrudnienia umożliwi im uzyskanie prawa do emerytury $\mathrm{z}$ osiągnięciem tego wieku (art. 39 k.p.).

Sytuacja osobista pracownika związana z rodzicielstwem (ciąża, urlopy związane $\mathrm{z}$ rodzicielstwem) uniemożliwia pracodawcy zarówno wypowiedzenie,

63 A. Dubowik, Szczególna ochrona przed wypowiedzeniem stosunku pracy, „Praca i Zabezpieczenie Społeczne" 1997, nr 3, s. 24.

64 Przyczynami uchylającymi ochronę szczególną w stosunku do wszystkich pracowników szczególnie chronionych są upadłość pracodawcy lub likwidacja zakładu pracy. W razie wypowiedzenia umowy o pracę z pracownikiem szczególnie chronionym z innych przyczyn dotyczących pracodawcy ochrona ta zostaje uchylona lub ograniczona.

65 L. Florek, Rozwiq̨zanie i wygaśnięcie..., s. 184.

66 A. Dubowik, Szczególna ochrona....

67 Wyłączenie tej ochrony powoduje ogłoszenie upadłości, likwidacji bądź zaniechanie systemu pracy nakładczej. 
jak i rozwiązanie umowy o pracę (art. $177 \$ 1$ k.p.). Pracownik jest chroniony również przed rozwiązaniem umowy o pracę bez wypowiedzenia, chyba że reprezentująca go zakładowa organizacja związkowa wyrazi zgodę na rozwiązanie umowy o pracę bez wypowiedzenia (art. $177 \$ 1$ k.p. in fine). Wskazana ochrona nie dotyczy pracownika zatrudnionego na podstawie umowy na okres próbny, której okres nie przekracza jednego miesiąca (art. 177 \$ 2 k.p.). Zgodnie z dyspozycją art. $177 \$ 3$ k.p. umowa o pracę zawarta na czas określony albo na okres próbny przekraczający jeden miesiąc, która uległaby rozwiązaniu po upływie trzeciego miesiąca ciąży, ulega przedłużeniu do dnia porodu. Na mocy art. 13 ust. 3 z.p.t. przepis art. $177 \$ 3$ k.p. nie ma zastosowania do zatrudnienia tymczasowego $^{68}$. Z ochrony trwałości stosunku zatrudnienia w okresie ciąży i urlopu macierzyńskiego w zakresie zakazu wypowiadania i rozwiązywania bez wypowiedzenia korzystają natomiast kobiety zatrudnione ${ }^{69}$ na podstawie umowy o pracę nakładczą na czas nieokreślony ${ }^{70}$ ( $\$ 7$ ust. 1 rozp.pr.nakład.). Przesłanką wyłączającą tę ochronę, tak samo jak odpowiednio w przypadku stosunku pracy (art. 177 $\$ 4$ k.p.), jest stan upadłości lub likwidacji nakładcy ( $\$ 7$ ust. 2 rozp.pr.nakład.). Ochronę tę wyłącza również zaniechanie stosowania systemu pracy nakładczej przez nakładcę, co uzasadnia istota zatrudnienia nakładczego ${ }^{71}$. Rozporządzenie w sprawie uprawnień pracowniczych osób wykonujących pracę nakładczą zawiera również regulację odpowiednią do przepisu art. $177 \$ 3$ k.p. Zgodnie z $\$ 7$ ust. 3 rozp.pr.nakład. umowa o pracę nakładczą zawarta na czas określony albo na czas wykonania określonej pracy, która uległaby rozwiązaniu po upływie trzeciego miesiąca ciąży, ulega przedłużeniu do dnia porodu. Z powyższej ochrony nie korzystają natomiast, jak w przypadku zatrudnienia pracowniczego, osoby zatrudnione na podstawie umowy na okres próbny.

Ochrona szczególna trwałości stosunku pracy obejmuje swoim zakresem również pracowników od momentu złożenia przez nich wniosku o udzielenie urlopu wychowawczego do dnia zakończenia tego urlopu (art. $186^{8}$ k.p.). Powyższy zakaz aktywizuje się nie wcześniej niż na 21 dni przed rozpoczęciem korzystania z urlopu wychowawczego (art. $186^{8} \$ 3$ k.p.). Wobec braku ustawowego wyłączenia, ochroną tą objęci są również pracownicy tymczasowi. Nie dotyczy on natomiast osób świadczących pracę na podstawie umów prawa cywilnego.

Prawo pracy ustanawia rozbudowaną ochronę szczególną przed wypowiedzeniem lub rozwiązaniem umowy o pracę w stosunku do osób pełniących określone

68 Pozostała ochrona przewidziana w art. 177 k.p. pozostaje aktualna względem zatrudnienia tymczasowego.

69 Wydaje się, że zakres $\S 7$ ust. 1 rozp.pr.nakład. powinien obejmować, po uprzednim rozszerzeniu uprawnień wynikających z $\S 18$ rozp.pr.nakład., również mężczyzn wykonujących pracę nakładczą, którzy korzystaliby z urlopu macierzyńskiego.

70 M. Włodarczyk, Art. 177, [w:] K.W. Baran (red.), Kodeks pracy. Komentarz, https://sip-1lex-1pl1004153yx0ff8.han3.lib.uni.lodz.pl/\#/komentarz/587329247/490882 (dostęp: 19.09.2017).

71 Ł. Pisarczyk, Różne formy..., s. 121. 
funkcje bądź wykonujących określony zawód. Z punktu widzenia prowadzonych rozważań istotne wydaje się wskazanie, że pracodawca nie może, bez zgody zarządu zakładowej organizacji związkowej, wypowiedzieć ani rozwiązać umowy o pracę imiennie wskazanemu członkowi zakładowej organizacji związkowej lub innemu pracownikowi będącemu członkiem danej zakładowej organizacji związkowej, upoważnionemu do jej reprezentowania (art. 32 ust. 1 u.z.z.). Ograniczenie to, niemające charakteru zakazu, a jedynie wymagające uzyskania zgody, dotyczy również możliwości rozwiązania umowy o pracę bez zachowania okresu wypowiedzenia $^{72}$. Dla prawidłowości decyzji pracodawcy niezbędna jest zgoda odpowiedniego organu bądź brak jego sprzeciwu ${ }^{73}$. Inaczej kwestię tę normują regulacje dotyczące pracy nakładczej. Zgodnie z $\$ 5$ ust. 3 rozp.pr.nakład. nakładca nie może, bez zgody zakładowej organizacji związkowej, wypowiedzieć ani rozwiązać umowy z wykonawcą będącym członkiem zarządu tej organizacji ${ }^{74}$. Ochrona wykonawców pracy nakładczej jest zatem mniej intensywna aniżeli ochrona pracowników. W pierwszym przypadku dotyczy bowiem wyłącznie członków zarządu zakładowej organizacji związkowej; w drugim - imiennie wskazanego członka zakładowej organizacji związkowej lub innego pracownika będącego członkiem danej zakładowej organizacji związkowej, upoważnionych do jej reprezentowania. Wydaje się, że uzasadnieniem takiej regulacji jest ograniczone do wstępowania do związków zawodowych prawo koalicji przyznane osobom wykonującym pracę nakładczą. Gdyby osobom tym przyznać pełne prawo koalicji, powinny one korzystać również z pełnej ochrony przed wypowiedzeniem i rozwiązaniem stosunku pracy, przysługującej w związku z członkostwem w zakładowej organizacji związkowej.

Osoby wykonujące pracę na podstawie umowy agencyjnej, pomimo posiadania prawa koalicji (art. 2 ust. 1 u.z.z.), w ogóle nie zostały objęte ochroną szczególną przed wypowiedzeniem i rozwiązaniem stosunku zatrudnienia. Wydaje się, że istniejące w tym zakresie zróżnicowanie uprawnień osób zatrudnionych, uzależnione od rodzaju umownej podstawy zatrudnienia nietypowego, powinno zostać ujednolicone względem wszystkich osób świadczących pracę ${ }^{75}$.

Omówione różnice w możliwości wypowiadania oraz rozwiązywania bez wypowiedzenia stosunków prawnych, których przedmiotem jest umowne zatrud-

72 K. Rączka, Szczególna ochrona trwałości stosunku pracy działacza zwiq̨zkowego, [w:] A. Wypych-Żywicka, M. Tomaszewska, J. Stelina (red.), Zbiorowe prawo pracy XXI wieku, Gdańsk 2010. s. 199-200.

73 J. Piątkowski, op. cit., s. 143.

74 W tej sytuacji wskazaną ochronę wyłącza ogłoszenie upadłości nakładcy lub jego likwidacja, zaniechanie systemu pracy nakładczej, osiągnięcie wieku emerytalnego lub uzyskanie prawa do renty z tytułu zaliczenia do I lub II grupy inwalidzkiej (§ 5 ust. 3 rozp.pr.nakład.).

75 W tym zakresie istotne zmiany zakłada projekt zmiany ustawy o związkach zawodowych, wskazany na s. 216 (przypis 36). Odniesienie się do ich brzmienia będzie możliwe po wejściu projektowanej nowelizacji w życie. 
nienie nietypowe, prowadzą do wniosku, że ochrona przed wypowiedzeniem umów o pracę i ich rozwiązaniem bez wypowiedzenia jest szersza od właściwej prawu cywilnemu i nasycona w największym stopniu w przypadku umowy o pracę na czas nieokreślony (zatrudnienia typowego). Stronom umów cywilnoprawnych pozostawiono w tym zakresie większą dowolność, choć kwestie związane z możliwościami rozwiązania umów nie zostały do końca pozostawione ich swobodnemu uznaniu.

\subsection{Uprawnienia osób świadczących pracę nietypowo w przypadku wadliwego rozwiązania umowy}

Status prawny osób świadczących pracę w ramach umownego zatrudnienia nietypowego jest zróżnicowany w odniesieniu do regulacji ich uprawnienia w razie wadliwego rozwiązania umowy. Zróżnicowanie to obejmuje zarówno przypadki wadliwości wypowiedzenia, jak i rozwiązania umowy bez wypowiedzenia. W niniejszej części rozważań zostanie ono poddane analizie pod kątem systemowego uzasadnienia.

Różnice w statusie prawnym osób świadczących pracę w ramach umownego zatrudnienia nietypowego w przypadku wadliwego rozwiązania umowy zależą przede wszystkim od rodzaju zatrudnienia - typowego albo nietypowego, z odmiennościami dotyczącymi zarówno nietypowego umownego zatrudnienia pracowniczego, jak i cywilnoprawnego. Sankcjonowanie ochrony trwałości stosunku zatrudnienia dochodzi do skutku zawsze na wniosek osoby świadczącej pracę, zgodnie z zasadą, że prawo nie powinno wkraczać w sferę wolności jednostki. Uprawnienia przysługujące pracownikom w razie niezgodnego z prawem rozwiązania stosunku pracy uznać należy za przepisy sankcjonujące wobec unormowań dotyczących ochrony trwałości stosunku pracy ${ }^{76}$. Poniższa analiza obejmować będzie prezentację statusu prawnego osób świadczących pracę w ramach umownego zatrudnienia nietypowego w odniesieniu do wadliwego rozwiązania umowy za wypowiedzeniem oraz bez wypowiedzenia.

Punktem wyjścia będzie status prawny pracowników zatrudnionych typowo - na podstawie umowy o pracę na czas nieokreślony. W przypadku dokonania wypowiedzenia takiej umowy w sposób nieuzasadniony bądź z naruszeniem

76 W. Piotrowski, Roszczenia pracownika z tytułu niezgodnego z prawem rozwiq̨zania stosunku pracy w kodeksie pracy, 1974, „Państwo i Prawo” 1974, nr 10, s. 34. 
dyspozycji norm dotyczących trybu wypowiedzenia (np. bez zachowania trybu konsultacji związkowej czy formy pisemnej), pracownik ma prawo do uzyskania przed sądem wyroku stwierdzającego bezskuteczność wypowiedzenia, wyroku przywracającego go do pracy bądź odszkodowania (art. $45 \$ 1$ k.p.). Pierwsze orzeczenie, zdecydowanie preferowane przez ustawodawcę $e^{77}$, zapada w przypadku gdy okres wypowiedzenia umowy o pracę jeszcze trwa. Drugie - gdy okres wypowiedzenia umowy o pracę już się zakończył. Oba orzeczenia mają charakter konstytutywny, bowiem bezprawne wypowiedzenie nie jest czynnością bezskuteczną z mocy prawa ${ }^{78}$. Pracownik, decydując się na wybór wskazanych żądań, dąży do zachowania pracy, którą już utracił bądź którą ma dopiero utracić. Dodatkowo restytucja spełnia istotną rolę z punktu widzenia prawa do pracy oraz ochrony pracownika, dlatego właśnie jest rozwiązaniem preferowanym ${ }^{79}$. Jej nadrzędnym celem jest uzyskanie przez pracownika utraconego miejsca pracy ${ }^{80}$ przy jednoczesnym ograniczeniu poniesionej szkody majątkowej ${ }^{81}$.

$Z$ uprawnieniem do przywrócenia do pracy ściśle wiąże się uprawnienie do wynagrodzenia za czas pozostawania bez pracy. Spełniające funkcję kompensacyjną ${ }^{82}$, orzekane jest w wysokości określonej w art. 47 k.p.:

a) odpowiadającej całemu okresowi pozostawania bez pracy (w przypadku naruszenia przepisów o ochronie szczególnej)

b) odpowiadającej maksymalnie dwumiesięcznemu wynagrodzeniu, jeśli okres wypowiedzenia był krótszy niż trzy miesiące

c) odpowiadającej jednomiesięcznemu wynagrodzeniu, jeśli okres wypowiedzenia wynosił trzy miesiące.

Jeżeli pracownik nie ma woli zachowania bądź odzyskania utraconej pracy albo sąd uzna, że orzeczenie wymienionych środków jest niemożliwe ${ }^{83}$ lub niecelowe $^{84}$ (art. $45 \$ 2$ k.p.), pracownikowi przysługuje odszkodowanie za okres

77 A. Rycak, Roszczenia restytucyjne czy odszkodowawcze w zwiqzzku z nieuzasadnionym lub niezgodnym z prawem rozwiqzaniem umowy o pracę, [w:] G. Goździewicz (red.), Reprezentacja praw..., s. 280.

78 L. Florek, Rozwiązanie i wygaśnięcie..., s. 191.

79 A. Rycak, Roszczenia restytucyjne.., s. 283.

80 W. Piotrowski, op. cit., s. 39

81 Ł. Pisarczyk, Naprawienie szkody poniesionej przez pracownika wskutek wadliwego rozwiązania umowy o pracę przez pracodawcę, [w:] L. Florek, M. Latos-Mitkowska (red.), Prawo pracy a bezrobocie, Warszawa 2003, s. 175.

82 Tak jak odszkodowanie w prawie cywilnym. L. Florek, Rozwiqzanie i wygaśnięcie..., s. 192.

83 Przykładem sytuacji uniemożliwiającej powrót do pracy jest likwidacja stanowiska pracy. Ł. Pisarczyk, Naprawienie szkody..., s. 186.

84 Niecelowość może mieć miejsce, gdy kontynuacja zatrudnienia prowadzi do zakłócenia procesu pracy, na przykład w razie konfliktu pomiędzy pracownikiem i przełożonym. $九$. Pisarczyk, Naprawienie szkody..., s. 187-188. Przykładem niecelowości może być również utrata zaufania (Wyrok Sądu Najwyższego z dnia 5 czerwca 2008 r., III PK 5/08, LEX nr 494088), konflikt z pracodawcą (Wyrok Sądu Najwyższego z dnia 19 listopada 1997 r., I PKN 374/97, 
od 2 tygodni do 3 miesięcy, ale nie mniej niż wynosiło wynagrodzenie za okres wypowiedzenia (art. $47^{1}$ k.p.). Sąd może orzec inne roszczenie niż żądane przez pracownika jeszcze w jednym przypadku. Zgodnie z art. $477^{1}$ k.p.c., jeżeli pracownik dokonał wyboru jednego z przysługujących mu alternatywnie roszczeń, a zgłoszone roszczenie okaże się nieuzasadnione, sąd może z urzędu uwzględnić inne roszczenie alternatywne. Brak uzasadnienia ${ }^{85}$ wyboru dokonanego przez pracownika oceniany jest przez sąd na podstawie okoliczności sprawy ${ }^{86}$. W razie zastosowania dyspozycji art. $477^{1}$ k.p.c. sąd może zarówno orzec bezskuteczność wypowiedzenia zamiast żądanego odszkodowania, przywrócenie do pracy zamiast żądanego odszkodowania bądź odszkodowanie zamiast żądanych przez pracownika roszczeń o uznanie bezskuteczności wypowiedzenia albo o przywrócenie do pracy.

Przepis art. $47^{1}$ k.p. nie wskazuje kryteriów, za pomocą których należy ustalać wysokość odszkodowania w przypadku okresu wypowiedzenia krótszego niż 3 miesiące ${ }^{87}$, poza określeniem minimalnej wysokości odszkodowania, stanowiącej równowartość wynagrodzenia za okres wypowiedzenia. Możliwość zasądzenia (na podstawie art. $45 \$ 2$ k.p.) odszkodowania pomimo żądania pracownika uznania przywrócenia do pracy nie dotyczy pracowników objętych szczególną ochroną trwałości stosunku pracy wynikającą z art. 39 k.p., 177 k.p. oraz przepisów szczególnych, chyba że przywrócenie pracownika do pracy jest niemożliwe z powodu ogłoszenia upadłości lub likwidacji pracodawcy (art. $45 \$ 3$ k.p.). Tylko w razie ogłoszenia upadłości lub likwidacji pracodawcy sąd nie jest związany w zakresie żądania przywrócenia do pracy pracownika objętego wskazaną ochroną ${ }^{88}$.

Pracownicy zatrudnieni na podstawie umów terminowych mają jedynie roszczenie o odszkodowanie ${ }^{89}$. W tym zakresie unormowanie dotyczące umowy o pracę na okres próbny zawiera art. $50 \$ 1$ k.p. Odszkodowanie należne jest w wysokości wynagrodzenia za czas, do którego umowa miała trwać (art. $50 \$ 1$ zd. 2 k.p.). Z uwagi na maksymalny, trzymiesięczny okres trwania umowy o pracę na okres

LEX nr 33480) czy brak określonych kwalifikacji (Wyrok Sądu Najwyższego dnia 9 lutego 1999 r., I PKN 565/98, LEX nr 39348).

85 Brak zasadności dochodzonego roszczenia może być oceniany w szczególności poprzez sprzeczność z zasadami współżycia społecznego oraz społeczno-gospodarczym przeznaczeniem prawa. Wyrok Sądu Najwyższego z dnia 30 marca 1994 r., I PZP 40/94, LEX nr 13356.

86 J. Witkowski, Art. 477¹, [w:] K. Antonów, A. Jabłoński (red.), Kodeks postępowania cywilnego. Postępowanie odrębne w sprawach z zakresu prawa pracy i ubezpieczeń społecznych. Komentarz, https://sip-1lex-1pl-1004153yx0ff8.han3.lib.uni.lodz.pl/\#/komentarz/587514138/311578 (dostęp: 19.09.2017).

87 K. Jaśkowski, Art. $47^{1}$ k.p., [w:] K. Jaśkowski, E. Maniewska (red.), Komentarz aktualizowany do kodeksu pracy, https://sip-1lex-1pl-1004153yx0ff8.han3.lib.uni.lodz.pl/\#/komentarz/ 587260382/536354 (dostęp: 19.09.2017).

88 Z. Góral, Art. 45, [w:] K.W. Baran (red.), Kodeks pracy. Komentarz, https://sip-1lex-1pl-1004153yx0ff8.han3.lib.uni.lodz.pl/\#/komentarz/587329063/490697 (dostęp: 19.09.2017).

89 Z uwzględnieniem wyjątku przewidzianego w art. 50 § 5 k.p. 
próbny, odszkodowanie takie nie przewyższy kwoty trzymiesięcznego wynagrodzenia. Wysokość odszkodowania przysługującego w razie wypowiedzenia umów na czas określony z naruszeniem przepisów określa art. $50 \$ 4$ k.p. Odszkodowanie to przysługuje, tak jak w przypadku umowy o pracę na okres próbny, za czas, do którego miała trwać umowa, nie dłużej jednak niż za 3 miesiące. Górna granica odszkodowania została określona na takim samym poziomie jak w przypadku umów o pracę na czas nieokreślony. Tak jak w razie orzekania odszkodowania należnego na podstawie przepisu art. $47^{1}$ k.p., również w tym przypadku wysokość odszkodowania nie jest powiązana z rzeczywistą szkodą. Przysługuje ono niezależnie od tego, czy pracownik poniósł uszczerbek majątkowy ${ }^{90}$.

Wyjątek w zakresie roszczeń przysługujących pracownikowi w razie naruszenia przepisów o wypowiadaniu umów o pracę na czas określony ustanawia przepis art. $50 \$ 5$ k.p. Zgodnie z nim przepis art. 45 k.p. stosuje się odpowiednio w stosunku do pracownicy w okresie ciąży lub urlopu macierzyńskiego, pracownika - ojca wychowującego dziecko w okresie korzystania z urlopu macierzyńskiego, a także pracownika $\mathrm{w}$ okresie korzystania $\mathrm{z}$ ochrony stosunku pracy na podstawie przepisów ustawy o związkach zawodowych. W tych przypadkach może zostać orzeczona bezskuteczność wypowiedzenia, przywrócenie do pracy albo odszkodowanie. W stosunku do wymienionych kategorii osób odszkodowanie może zostać zasądzone również na podstawie art. $50 \$ 5$ in fine $\mathrm{w} \mathrm{zw} . \mathrm{z}$ art. $45 \$ 3$ in fine k.p., czyli w przypadku gdy w stosunku do pracownika objętego szczególną ochroną, pomimo żądania uznania wypowiedzenia za bezskuteczne lub przywrócenia do pracy, sąd zasądza odszkodowanie z powodu ogłoszenia upadłości lub likwidacji pracodawcy. W związku z tym, że przepis art. $45 \$ 3$ k.p. stosuje się odpowiednio do pracowników objętych zakresem podmiotowym art. $50 \$ 5$ k.p., to aby art. $45 \$ 3$ k.p. znalazł odpowiednie zastosowanie, jego zakres podmiotowy musi krzyżować się z zakresem podmiotowym art. $50 \S 5$ k.p. Brak możliwości zasądzenia przez sąd odszkodowania pomimo żądania uznania wypowiedzenia za bezskuteczne lub przywrócenia do pracy, wyłączony ogłoszeniem upadłości lub likwidacją pracodawcy, dotyczy pracownic w okresie ciąży lub osób przebywających na urlopie macierzyńskim. W stosunku do pozostałych osób objętych zakresem podmiotowym art. $50 \$ 5 \mathrm{k}$.p. sąd ma możliwość zasądzenia odszkodowania w razie uznania żądania o uznanie wypowiedzenia za bezskuteczne lub przywrócenia do pracy za niemożliwe lub niecelowe. Wysokość odszkodowania należnego pracownikom objętym hipotezą art. $50 \$ 5$ k.p. obliczana jest zgodnie z art. $47^{1}$ k.p. w zw. z art. 45 k.p. Nie znajduje do nich zastosowania sposób obliczania odszkodowania określony w art. $50 \$ 4$ k.p. Stanowisko to potwierdził Sąd Najwyższy w wyroku z dnia 3 grudnia 2009 r. ${ }^{91}$

90 Z. Góral, Art. 50, [w:] K.W. Baran (red.), Kodeks pracy. Komentarz, https://sip-1lex-1pl1004153yx0ff8.han3.lib.uni.lodz.pl/\#/komentarz/587329068/490702 (dostęp: 19.09.2017).

91 II PK 142/09, LEX nr 823871. 
Przed nowelizacją czerwcową z 2015 r. umowy o pracę na czas określony nieprzekraczający 6 miesięcy bądź przekraczający 6 miesięcy w sytuacji gdy strony nie przewidziały możliwości wypowiedzenia, były niewypowiadalne. $\mathrm{W}$ takich przypadkach trudno było mówić o naruszeniu przepisów o wypowiedzeniu zgodnie $z$ art. $50 \$ 3$ k.p. Zarówno w literaturze, jak i w orzecznictwie zarysowały się trzy poglądy dotyczące tego zagadnienia. Zgodnie z pierwszym, pomimo braku możliwości wypowiedzenia umowy o pracę, uznać należało, że doszło do naruszenia przepisów o wypowiedzeniu, zatem pracownik ma prawo do odszkodowania $^{92}$. Drugi pogląd zakładał, że w przypadku niewypowiadalnych umów o pracę na czas określony zastosowanie znajdzie art. 58 k.c. w zw. z art. 300 k.p. - wypowiedzenie takie nie będzie skuteczne ${ }^{93}$. Zgodnie z trzecim poglądem w przypadku wypowiedzenia umowy niewypowiadalnej stosowany powinien być art. 59 k.p. dotyczący roszczeń pracownika wynikających z dokonanego $\mathrm{z}$ naruszeniem prawa rozwiązania bez wypowiedzenia umowy terminowej ${ }^{94}$. Zwolennicy ostatniego stanowiska wskazywali, że wypowiedzenie umowy o pracę ujawniające wolę pracodawcy rozwiązania stosunku pracy jest po prostu wadliwym rozwiązaniem umowy bez wypowiedzenia. Wadliwość ta polegała na braku przesłanek do rozwiązania umowy bez wypowiedzenia. Jeśli przyjąć pierwszy z zaprezentowanych poglądów, którego nie podzielam, należałoby uznać, że doszło do naruszenia przepisów, które w ogóle nie znajdowały zastosowania ${ }^{95}$. Rozpatrzenie argumentacji dwóch kolejnych stanowisk uzależnione jest od tego, czy przyjmie się konieczność korzystania na podstawie art. 300 k.p. z przepisów kodeksu cywilnego. Przepisy prawa pracy regulowały możliwość rozwiązania umowy o pracę zawartej na czas określony nawet $\mathrm{w}$ przypadku gdy strony w umowie nie przewidziały możliwości jej wypowiedzenia lub gdy została ona zawarta na czas nieprzekraczający 6 miesięcy. Możliwość taką dawało rozwiązanie umowy bez wypowiedzenia. Odwołanie do przepisów kodeksu cywilnego znajduje zastosowanie jedynie w przypadkach nieuregulowanych przepisami prawa pracy. Dlatego też przychylam się do

92 Zgodnie ze wskazanym powyżej wyrokiem Sądu Najwyższego II PK 142/09.

93 T. Liszcz, Odpowiedzialność odszkodowawcza pracodawcy wobec pracownika, „Praca i Zabezpieczenie Społeczne" 2008, nr 12, s. 2 i nast.

94 Wyrok Sądu Najwyższego z dnia 5 listopada 1998 r., I PKN 414/98, LEX nr 36768.

95 A. Górnicz-Mulcahy i M. Lewandowicz-Machnikowska, analizując omawiane zagadnienie z punktu widzenia rozwiązania przez pracownika za wypowiedzeniem umowy o pracę na czas określony, która była umową niewypowiadaną, wskazują, że treść oświadczenia woli pracownika, w tym to, kiedy ma ono wywołać skutki prawne, powinna decydować o jego interpretacji. Autorki argumentują, że takie wypowiedzenie wywołuje skutki i powoduje rozwiązanie stosunku pracy po upływie okresu wypowiedzenia. Jednakże będąc czynnością bezprawną, skutkuje możliwością dochodzenia przez pracodawcę odszkodowania od pracownika. A. Górnicz-Mulcahy i M. Lewandowicz-Machnikowska, Skutki prawne wypowiedzenia przez pracownika umowy na czas określony nieprzewidującej prawa do wypowiedzenia, „Monitor Prawa Pracy” 2012, nr 12, s. 631, 633. 
ostatniego poglądu ${ }^{96}$. Zastosowanie przepisu art. 58 k.c. w zw. z art. 300 k.p. mogłoby mieć miejsce jedynie w przypadku braku jakiejkolwiek regulacji na gruncie prawa pracy. Nowelizacja czerwcowa kodeksu pracy z 2015 r. spowodowała, że powyższe wątpliwości nie są już aktualne względem umów o pracę na czas określony zawartych w wyniku stosowania kodeksu pracy, bowiem w nowym stanie prawnym wypowiadalna jest każda umowa zawarta na czas określony. Powyższe wątpliwości zachowają natomiast aktualność względem umów o pracę tymczasową, które w swojej treści nie będą zawierały postanowienia o możliwości ich rozwiązania za wypowiedzeniem.

Istotne znaczenie ma różnica w statusie prawnym pracowników zatrudnionych typowo i nietypowo, polegająca na tym, że tylko ci pierwsi mają roszczenia inne niż odszkodowawcze w przypadku wadliwego rozwiązania umowy o pracę za wypowiedzeniem. Pracownikom zatrudnionym nietypowo przysługuje wyłącznie odszkodowanie. Poprzez takie unormowanie ustawodawca wyraźnie rozgranicza trwałe zatrudnienie typowe od „z natury” czasowego pracowniczego umownego zatrudnienia terminowego, w sposób korzystniejszy kształtując status prawny pracowników zatrudnionych typowo.

Sytuacja prawna pracowników świadczących pracę na podstawie różnych rodzajów umów o pracę zróżnicowana jest również w odniesieniu do uprawnień z tytułu wadliwego rozwiązania umowy o pracę bez wypowiedzenia. W przypadku wadliwości takiego rozwiązania pracownikowi zatrudnionemu na podstawie umowy o pracę na czas nieokreślony przysługują zawsze dwa alternatywne roszczenia - restytucyjne oraz odszkodowawcze (art. 56 k.p.). Roszczenia te przysługują w przypadku jakichkolwiek wadliwości rozwiązania - zarówno formalnych, jak i materialnych ${ }^{97}$. Restytucja miejsca pracy ma, tak samo jak w przypadku wadliwości rozwiązania umowy o pracę za wypowiedzeniem, charakter ex nunc. Z przywróceniem do pracy związane jest prawo do wynagrodzenia za czas pozostawania bez pracy, którego wysokość stanowi równowartość nie mniejszą niż wysokość jednomiesięcznego wynagrodzenia i nie większą niż wysokość trzymiesięcznego wynagrodzenia za pracę (art. 57 \$ 1 k.p.). Wprowadzenie górnej granicy odszkodowania świadczy o braku jego elastyczności, stanowiąc próbę wyważenia interesów pracowniczych i pracodawczych ${ }^{98}$. W przypadku gdy wynagrodzenie za czas pozostawania bez pracy miałoby zostać wypłacone pracownikowi objętemu szczególną ochroną trwałości stosunku pracy, z którym w sposób wadliwy rozwiązano umowę o pracę bez wypowiedzenia, wynagrodzenie takie należne jest za cały okres pozostawania bez pracy (art. $57 \$ 2$ k.p.). Alternatywne roszczenie,

96 Stanowisko to aprobuje K. Łapiński, Uprawnienia pracownika w razie niezgodnego z prawem wypowiedzenia umowy o pracę na czas określony przez pracodawcę, [w:] K. Łapiński, Umowa o pracę na czas określony w polskim i unijnym prawie pracy, https://sip-1lex-1pl1004153yx0ff8.han3.lib.uni.lodz.pl/\#/monografia/369228055/38 (dostęp: 19.09.2017).

97 A. Sobczyk, Rozwiq̨zanie umowy o pracę bez wypowiedzenia, Gdańsk 2005, s. 141.

98 Ł. Pisarczyk, Naprawienie szkody..., 194, 198. 
czyli roszczenie odszkodowawcze, orzekane jest w trzech przypadkach. Po pierwsze, sąd orzeka o odszkodowaniu, a nie o przywróceniu do pracy, na wniosek pracownika. Po drugie, orzeczenie takie zapada, jeśli przywrócenie do pracy jest niemożliwe bądź niecelowe; ograniczenie to nie dotyczy pracowników objętych ochroną szczególną - w ich przypadku jedyną przyczyną orzeczenia odszkodowania, poza ich żądaniem, jest ogłoszenie upadłości bądź likwidacji pracodawcy (art. $56 \$ 2$ k.p.). Trzecim przypadkiem orzeczenia alternatywnego jest uznanie przez sąd, poprzez zastosowanie art. $477^{1}$ k.p.c., niezasadności alternatywnego roszczenia dochodzonego przez pracownika.

Odszkodowanie jest jedynym roszczeniem przysługującym pracownikom zatrudnionym na podstawie umów o pracę na czas określony, gdy upłynął już okres, do którego umowa miała trwać, bądź w przypadku gdy przywrócenie do pracy byłoby niewskazane ze względu na krótki czas, jaki pozostał do upływu tego terminu (art. 59 k.p.). Uzasadniony wydaje się przy tym pogląd, zgodnie z którym regulacja art. 59 k.p. powinna znaleźć zastosowanie również w stosunku do rozwiązania $z$ naruszeniem przepisów umów o pracę na okres próbny ${ }^{99}$.

Wysokość odszkodowania określa art. 58 k.p. Zgodnie z jego dyspozycją wynosi ono, w przypadku umowy o pracę na czas nieokreślony, równowartość wynagrodzenia należnego pracownikowi za okres wypowiedzenia. Odszkodowanie należne w razie wadliwego rozwiązania bez wypowiedzenia umowy o pracę na czas określony ustalane jest w odniesieniu do okresu, do którego miała trwać umowa, wynosi jednak nie więcej niż równowartość trzymiesięcznego wynagrodzenia (art. 58 zd. 2 k.p.). Powyższe odszkodowanie nie jest jedynym, którego może domagać się pracownik. Zgodnie z orzeczeniem Trybunału Konstytucyjnego ${ }^{100}$ dopuszczalne jest dochodzenie innych roszczeń niż wskazane w art. 58 k.p. w sytuacji gdy szkoda poniesiona przez pracownika przewyższa wartością odszkodowanie przyznane w oparciu o regulacje kodeksu pracy. Wyrok ten, w odniesieniu do odpowiedzialności z tytułu rozwiązania umowy o pracę bez wypowiedzenia, oddziela odpowiedzialność pracodawcy sankcjonowaną normami kodeksu pracy od odpowiedzialności sankcjonowanej przepisami kodeksu cywilnego ${ }^{101}$. Pomimo że od wydania wyroku upłynęło już kilka lat, nie nastąpiła wskazywana w doktrynie konieczność dostosowania zakresu odpowiedzialności stron stosunku pracy do jego treści ${ }^{102}$.

W odniesieniu do statusu prawnego pracowników w zakresie rozwiązania przez pracodawcę umowy bez wypowiedzenia w sposób niezgodny z prawem, je-

99 B. Wagner, Terminowe umowy o pracę, Warszawa 1980, s. 108. Przeciwnie: A. Sobczyk, Rozwiq̨zanie umowy..., s. 152.

100 Wyrok Trybunału Konstytucyjnego z dnia 27 listopada 2007 r., SK 18/05, Dz.U. Nr 225, poz. 1672.

101 M. Gersdorf, Odpowiedzialność odszkodowawcza pracodawcy w świetle ochrony trwałości stosunku pracy, [w:] G. Goździewicz (red.), Reprezentacja praw..., s. 104.

102 Ibidem, s. 95-107 i literatura tam wskazana. 
dynie pracownikom zatrudnionym typowo przysługuje prawo restytucji. Zatem również w tym przypadku status prawny pracowników zatrudnionych nietypowo jest ukształtowany w sposób odmienny, uwzględniający czasowy charakter pracowniczego zatrudnienia terminowego.

Uprawnienia wykonawców pracy nakładczej w zakresie roszczeń z tytułu niezgodnego z prawem wypowiedzenia bądź rozwiązania umowy bez wypowiedzenia są w obu przypadkach jednakowe. Wykonawcy przysługuje roszczenie o przywrócenie do pracy lub o odszkodowanie ( $\$ 9$ ust. 1 rozp.pr.nakład.). Roszczenie odszkodowawcze jest jedynym, jakiego może dochodzić wykonawca, z którym z naruszeniem przepisów rozwiązano umowę zawartą na okres próbny, na czas określony bądź na czas wykonania określonej pracy ( $\$ 9$ ust. 2 rozp.pr.nakład.). Sąd rozstrzygający o przysługujących wykonawcy roszczeniach może dodatkowo zasądzić odszkodowanie zamiast dochodzonej restytucji, w przypadku gdy uzna ją za sprzeczną z zasadami współżycia społecznego ( $\$ 9$ ust. 3 rozp.pr.nakład.). Odszkodowanie przyznane wykonawcy nie może być niższe niż równowartość jednomiesięcznego wynagrodzenia i nie może przekraczać jego trzykrotności ( $\$ 9$ ust. 4 rozp.pr.nakład.). W przypadku zasądzenia roszczenia restytucyjnego wykonawcy przysługuje wynagrodzenie za czas pozostawania bez pracy, nie więcej jednak niż w wysokości stanowiącej jego trzykrotność ( $\$ 9$ ust. 5 rozp.pr.nakład.). Zbliżona do pracowniczej regulacja wpisuje się w założenie mieszanego charakteru pracy nakładczej. Bezpośrednie zastosowanie rozwiązań właściwych dla prawa pracy, bez odpowiedniego odesłania do kodeksu pracy, pozwala uznać pracę nakładczą za cywilnoprawną podstawę świadczenia pracy o silnym związku z regulacjami prawnopracowniczymi. W przypadku pracy nakładczej prawodawca na pierwszym miejscu postawił roszczenie restytucyjne, które może być zastąpione odszkodowaniem tylko w ściśle określonych przypadkach.

Zbliżenie pozycji prawnej osób zatrudnionych na podstawie umów o pracę oraz pracy nakładczej znajduje swój wyraz w jeszcze jednej regulacji. Chodzi mianowicie o zaliczenie do stażu pracy okresów pozostawania bez pracy w przypadku niezgodnego z prawem wypowiedzenia bądź rozwiązania umowy o pracę lub umowy o pracę nakładczą. W obu przypadkach do stażu pracy zalicza się dwa okresy: pierwszy, za który przyznano wynagrodzenie z tytułu pozostawania bez pracy (art. $51 \S 1$ k.p. i $57 \$ 4$ k.p.; $\$ 9$ ust. 5 zdanie 2 rozp.pr.nakład.) i drugi, odpowiadający czasem okresowi, za który przyznano odszkodowanie (art. $51 \S 2$ k.p. i art. 61 k.p.; $\$ 9$ ust. 6 rozp.pr.nakład.).

W regulacjach dotyczących umów stanowiących przedmiot niniejszych rozważań (umowy zlecenia, umów o świadczenie usług, do których stosuje się przepisy o zleceniu, umowy agencyjnej i umowy o dzieło) kodeks cywilny ponad regulacje ogólne (deliktowe) statuuje dwa przypadki, w których osobom zatrudnionym należne jest odszkodowanie z tytułu rozwiązania umowy. Pierwszy z nich dotyczy umowy zlecenia. Zgodnie $\mathrm{z}$ art. $746 \$ 1$ k.c. in fine, jeśli dający zlecenie wypowiedział je bez ważnego powodu, a zlecenie jest odpłatne, powinien on naprawić 
powstałą szkodę. Zakres odpowiedzialności dającego zlecenie $\mathrm{w}$ tym przypadku obejmuje szkodę wyrządzoną na skutek wypowiedzenia umowy. Przesłankami odpowiedzialności są wypowiedzenie dokonane bez ważnego powodu, szkoda powstała $\mathrm{w}$ majątku przyjmującego zlecenie oraz związek przyczynowy między takim wypowiedzeniem a szkodą. Szkoda obejmuje ponadto zarówno rzeczywistą stratę, jak i utracone korzyści ${ }^{103}$. Drugi przypadek zobowiązujący do wypłaty odszkodowania normuje art. $764^{2} \$ 2$ k.c. W razie wypowiedzenia umowy agencyjnej na skutek okoliczności, za które odpowiedzialność ponosi druga strona, jest ona zobowiązana do naprawienia szkody powstałej w następstwie rozwiązania umowy. Wskazana regulacja dotyczy tylko szkody poniesionej przez wypowiadającego w następstwie rozwiązania umowy, czyli nie każdej szkody ${ }^{104}$. Konstrukcja ta nie wyłącza dochodzenia odszkodowania na zasadach ogólnych.

Z powyższej analizy wynika, że sytuacja osób świadczących pracę w ramach umownego zatrudnienia nietypowego różni się $\mathrm{w}$ zakresie związanym $\mathrm{z}$ wadliwym wypowiedzeniem i rozwiązaniem umowy bez wypowiedzenia. Różnice te dostrzegalne są zarówno wewnątrz samego zatrudnienia pracowniczego, jak i przy dokonywaniu porównania jego regulacji z regulacjami dotyczącymi zatrudnienia cywilnoprawnego. Osobom zatrudnionym na podstawie umowy o pracę na czas nieokreślony prawo przyznaje najszerszą gamę uprawnień. Sytuacja prawna pracowników kreowana przez regulacje dotyczące uprawnień przysługujących im $\mathrm{w}$ razie wadliwego wypowiedzenia umowy o pracę jest mniej korzystna od sytuacji osób świadczących pracę $\mathrm{w}$ ramach zatrudnienia cywilnoprawnego w jednym przypadku. W przypadku wadliwego wypowiedzenia umowy o pracę ${ }^{105}$ wysokość odszkodowania należnego pracownikowi na podstawie przepisów kodeksu pracy jest limitowana i nie musi być równa wysokości rzeczywiście poniesionej szkody. Szkoda poniesiona przez osobę zatrudnioną na podstawie umowy prawa cywilnego nie jest limitowana w zakresie odszkodowania, zatem podlega pełnej kompensacji ${ }^{106}$. Takie zróżnicowanie wynika z kilku okoliczności o społeczno-gospodar-

103 K. Kopaczyńska-Pieczniak, Art. 746, [w:] A. Kidyba (red.), Kodeks cywilny. Komentarz, t. 3: Zobowiq̨zania - część szczególna, https://sip-1lex-1pl-1004153yx0ff8.han3.lib.uni.lodz. pl/\#/komentarz/587286629/462822 (dostęp: 19.09.2017).

104 E. Rott-Pietrzyk, Art. 764², [w:] E. Rott-Pietrzyk, Komentarz do niektórych przepisów kodeksu cywilnego. Umowa agencyjna po nowelizacji. Art. 758-764(9) k.c. Komentarz, https:// sip-1lex-1pl-1004153yx0ff8.han3.lib.uni.lodz.pl/\#/komentarz/587241133/38573 (dostęp: 19.09.2017).

105 W związku z przedstawionym powyżej wyrokiem Trybunału Konstytucyjnego (SK 18/05) szkody ponad wartość orzeczoną na podstawie kodeksu pracy, wynikającą z niezgodnego z prawem rozwiązania umowy o pracę, pracownik może dochodzić na podstawie przepisów kodeksu cywilnego.

106 A. Sobczyk zwraca uwagę, że w tym zakresie sytuacja prawna pracownika jest mniej korzystna niż osoby zatrudnionej na podstawie umowy prawa cywilnego. Autor wskazuje dodatkowo, że w tej kwestii regulacje kodeksu pracy ograniczają konstytucyjne prawo do własności, pozbawiając pracownika możliwości pełnego pokrycia szkody. A. Sob- 
czym charakterze. Po pierwsze, w stosunkach prawnopracowniczych, zwłaszcza w odniesieniu do zatrudnienia typowego, określenie rozmiaru rzeczywistej szkody nie zawsze jest możliwe. Wiązałoby się ono w każdym przypadku z szacowaniem szkody poniesionej przez pracownika. Poza powyższym argumentem warto wskazać, że stosunki objęte prawem pracy kreowane są $\mathrm{w}$ innych realiach społecznych niż stosunki prawa cywilnego, gdzie pełna kompensacja poniesionej szkody jest zasadą. Prawo pracy normuje obszar, w którym wzajemne zależności pomiędzy podmiotami są bardzo silne. Obciążenie pracodawcy zbyt wysokim odszkodowaniem mogłoby powodować obniżenie jego wypłacalności względem pozostałych pracowników. Przyjęte w prawie pracy rozwiązania wydają się wyważać interesy partnerów społecznych w sposób odpowiedni.

\subsection{Szczególne uprawnienia i obowiązki osób zatrudnionych nietypowo związane z zakończeniem stosunku prawnego}

Status prawny osób zatrudnionych $w$ ramach umownego zatrudnienia nietypowego jest zróżnicowany w zakresie ich uprawnień i obowiązków związanych z ustaniem stosunku prawnego. Uprawnienia i obowiązki są różne w zależności od reżimu prawnego zatrudnienia. W ramach danego reżimu doznają one również pewnych odmienności, związanych głównie ze specyfiką wykonywania pracy w obrębie konkretnego stosunku prawnego. Omówienie tych odrębności pozwoli na dokonanie ich weryfikacji pod kątem zasadności i konieczności obowiązywania.

$\mathrm{Z}$ punktu widzenia osoby świadczącej pracę istotnym uprawnieniem jest prawo do otrzymania świadectwa pracy. Dokument ten potwierdza w szczególności staż pracy, którym można legitymować się, ubiegając się o nowe zatrudnienie. Świadectwo pracy umożliwia również nabycie uprawnień pracowniczych u kolejnego pracodawcy oraz uprawnień z ubezpieczenia społecznego ${ }^{107}$. Obowiązek pracodawcy wydania pracownikowi świadectwa pracy statuuje kodeks pracy (art. 97 k.p.), dlatego wobec braku stosownego odesłania nie znajduje on odpowiednika w kon-

czyk, Prawo i człowiek pracujący - między ochrona godności a równości, www.prawo.amu. edu.pl/__data/assets/pdf_file/0006/173499/Sobczyk-Prawo-i-czowiek-pracujcy-midzyochron-godnoci-a-rownoci.pdf, s. 5 (dostęp: 21.01.2017).

107 E. Wronikowska, Komentarz do rozporządzenia w sprawie szczegółowej treści świadectwa pracy oraz sposobu i trybu jego wydawania i prostowania, [w:] E. Wronikowska, Akty wykonawcze do kodeksu pracy. Komentarz, https://sip-1lex-1pl-1004153yx131d.han3.lib.uni. lodz.pl/\#/komentarz/587247456/44896 (dostęp: 19.09.2017). 
strukcji zatrudnienia cywilnoprawnego. Jedynymi zatrudnionymi w reżimie prawa cywilnego, którym przysługuje uprawnienie do otrzymania świadectwa pracy, są wykonawcy pracy nakładczej ( $\$ 10$ rozp.pr.nakład.). W świadectwie pracy nakładczej nakładca umieszcza jedynie te okresy pracy, w których wykonawca uzyskał wynagrodzenie co najmniej równe wysokości połowy najniższego wynagrodzenia $^{108}$ ( $\$ 10$ ust. 2 rozp.pr.nakład.). Istotne jest, że wykonawcy nie przysługuje roszczenie o sprostowanie świadectwa pracy, przysługujące pracownikowi na mocy art. $97 \$ 2^{1}$ k.p. Natomiast $\$ 10$ ust. 3 rozp.pr.nakład. odsyła do stosowania do zatrudnienia nakładczego odpowiednio art. 99 k.p., ustanawiającego możliwość dochodzenia roszczeń z tytułu naprawienia szkody wyrządzonej wskutek niewydania w terminie bądź wydania niewłaściwego świadectwa pracy. Zatem wykonawca pracy nakładczej nie może wnioskować o sprostowanie świadectwa pracy, ale wydanie świadectwa o niewłaściwej treści, pociągające za sobą szkodę, upoważnia go do dochodzenia odszkodowania.

Osoby wykonujące pracę w ramach umów zlecenia, umów agencyjnych oraz umów o dzieło mogą otrzymać od podmiotu zatrudniającego dokument potwierdzający fakt świadczenia przez nie pracy, jednak dokument taki nie ma charakteru świadectwa pracy. Brak istnienia obowiązku odpowiadającego właściwemu dla prawu pracy obowiązkowi wydania świadectwa pracy wynika z odmiennej konstrukcji zatrudnienia cywilnoprawnego. Osoby zatrudnione na podstawie wskazanych powyżej umów prawa cywilnego nie muszą dokumentować przebiegu swojego zatrudnienia, bowiem nie jest on istotny dla przysługujących im uprawnień. Co więcej, treść świadectwa pracy w przeważającej części determinowana jest warunkami świadczenia pracy w ramach stosunku pracy, z którym związane są uprawnienia pracownicze i uprawnienia z zakresu ubezpieczeń społecznych (art. $97 \$ 2$ k.p.). W warunkach formalnej równości stron w stosunkach cywilnoprawnych osoba świadcząca pracę samodzielnie dokumentuje swoje kwalifikacje, bez konieczności potwierdzania ich dokumentacją sporządzoną przez podmiot zatrudniający.

W stosunku pracy tymczasowej obowiązek wydania świadectwa pracy spoczywa na agencji pracy tymczasowej, co jednoznacznie wynika z treści art. 18a z.p.t. Jest to obowiązek pracodawczy o charakterze ewidencyjno-formalnym, którym co do zasady obarczona jest agencja pracy tymczasowej ${ }^{109}$. Agencja pracy tymczasowej zobowiązana jest do wydania pracownikowi tymczasowemu świadectwa pracy dotyczącego łącznego zakończonego okresu zatrudnienia w tej agencji, objętego kolejnymi umowami o pracę, nawiązanymi w okresie nie dłuższym niż dwanaście kolejnych miesięcy. Upływ dwunastego miesiąca powoduje aktualizację obowiązku agencji pracy tymczasowej do wydania świadectwa pracy, pod

108 W zakresie najniższego wynagrodzenia, o którym mowa w $\S 10$ ust. 2 rozp.pr.nakład., aktualne pozostają uwagi poczynione na s. 150-151.

109 M. Raczkowski, op. cit., s. 63. 
warunkiem że stosunek pracy ustał. Jeśli umowa zakończy się po upływie dwunastego miesiąca, agencja pracy tymczasowej wydaje świadectwo pracy w dniu jej rozwiązania lub wygaśnięcia ${ }^{110}$. Nie wyłącza to możliwości żądania pracownika tymczasowego w zakresie wydania świadectwa pracy za zakończone, częściowe okresy zatrudnienia w agencji pracy tymczasowej ${ }^{111}$. Odpowiednią do omówionej regulację zawiera art. 97 k.p. w odniesieniu do zatrudnienia terminowego. Osoby świadczące pracę u tego samego pracodawcy na podstawie umowy na okres próbny lub umowy na czas określony powinny otrzymać od pracodawcy świadectwo pracy obejmujące okres 24 miesięcy (art. $97 \$ 1^{1}$ k.p.). Jeżeli jednak rozwiązanie lub wygaśnięcie umowy o pracę zawartej przed upływem 24 miesięcy przypada po tym terminie, pracodawca wydaje świadectwo pracy w dniu rozwiązania bądź wygaśnięcia umowy o pracę (art. $97 \$ 1^{2}$ k.p.). Pracownik zatrudniony na podstawie umów terminowych może w każdym czasie żądać świadectwa pracy obejmującego jedną bądź wszystkie umowy, które łączyły go z pracodawcą (art. $97 \$ 1^{3}$ k.p.).

Ustanie stosunku zatrudnienia wiąże się nie tylko z powinnościami natury formalnej. Istotnym uprawnieniem pracowników, związanym $\mathrm{z}$ wypowiedzeniem umowy o pracę dokonanym przez pracodawcę, jest prawo do wykorzystania w okresie wypowiedzenia dni wolnych na poszukiwanie pracy (art. 37 k.p.). Uzależnione jest ono w pierwszej kolejności od dokonania wypowiedzenia przez pracodawcę. Po drugie, przysługuje jedynie tym pracownikom, których okres wypowiedzenia wynosi co najmniej dwa tygodnie. W stanie prawnym obowiązującym po wejściu w życie nowelizacji czerwcowej z 2015 r. nie przysługuje ono zatem jedynie pracownikom zatrudnionym na podstawie umowy na okres próbny, która trwa krócej niż 3 miesiące (art. 34 k.p.) oraz pracownikom tymczasowym (art. 13 ust. 2 z.p.t.). Jeśli strony umowy o pracę skróciły, na mocy dyspozycji art. $36 \S 6$ k.p., okres wypowiedzenia, który pierwotnie wynosił co najmniej dwa tygodnie, pracownik traci uprawnienie do otrzymania dni wolnych na poszukiwanie pracy ${ }^{112}$. Wymiar zwolnienia na poszukiwanie pracy wynosi 2 dni w przypadku dwutygodniowego i jednomiesięcznego okresu wypowiedzenia oraz 3 dni $\mathrm{w}$ okresie trzymiesięcznego wypowiedzenia. Wymiar zwolnienia na poszukiwanie pracy jest ściśle uzależniony od rodzaju zawartej umowy o pracę oraz stażu zakładowego danego pracownika, co różnicuje sytuację prawną osób zatrudnionych w zależności od podstawy zatrudnienia.

Strony ustającej umowy muszą dokonać wzajemnych rozliczeń. Jest to np. ekwiwalent za niewykorzystany urlop należny pracownikowi na mocy art. 171 k.p. Przepis ten, na podstawie $\$ 16$ ust. 2 rozp.pr.nakład., jest stosowa-

110 M. Paluszkiewicz, Treść stosunku prawnego, [w:] M. Paluszkiewicz, Zatrudnienie tymczasowe w polskim prawie pracy. Konstrukcja i charakter prawny, https://sip-1lex-1pl-1004153yx131d.han3.lib.uni.lodz.pl/\#/monografia/369234447/26 (dostęp: 19.09.2017).

111 M. Raczkowski, op. cit., s. 63-64.

112 A. Piszczek, K. Stefański, Dni wolne na poszukiwanie pracy - wybrane problemy, „Gdańsko-Łódzkie Roczniki Prawa Pracy i Prawa Socjalnego" 2012, nr 2, s. 28. 
ny do zatrudnienia nakładczego. Fakt nieprzyznania pozostałym grupom osób zatrudnionych powyższego uprawnienia wynika z tego, że osoby te (przyjmujący zlecenie, agenci i wykonawcy dzieła) nie posiadają ustawowego prawa do urlopu wypoczynkowego. W przypadku zatrudnienia pracowniczego, zgodnie $\mathrm{z}$ art. $92^{1}$ k.p., pracownikowi, którego stosunek pracy ustał w związku z przejściem na rentę lub emeryturę, przysługuje odprawa w wysokości jednomiesięcznego wynagrodzenia przy spełnieniu warunków uprawniających do renty z tytułu niezdolności do pracy lub emerytury (art. $92^{1} \$ 1$ k.p.). Prawo do odprawy rentowej i emerytalnej przysługuje wyłącznie raz (art. $92^{1} \$ 2$ k.p.). Pracownicy są jedyną grupą osób zatrudnionych, której przysługuje prawo do odprawy emerytalnej lub rentowej.

Na podstawie ustawy o szczególnych zasadach rozwiązywania z pracownikami stosunków pracy z przyczyn niedotyczących pracowników pracownikom przysługuje odprawa z tytułu rozwiązania stosunku pracy z przyczyn ich niedotyczących. Prawo to należy do podstawowych unormowań ochronnych współczesnego prawa pracy ${ }^{113}$. Przy spełnieniu określonych warunków umożliwiających zakwalifikowanie rozwiązania stosunku pracy do zwolnienia grupowego pracownik uprawiony jest do otrzymania odprawy w wysokości:

a) jednomiesięcznego wynagrodzenia, jeżeli był zatrudniony u danego pracodawcy krócej niż 2 lata

b) dwumiesięcznego wynagrodzenia, jeżeli był zatrudniony u danego pracodawcy od 2 do 8 lat

c) trzymiesięcznego wynagrodzenia, jeżeli był zatrudniony u danego pracodawcy ponad 8 lat (art. 8 ust. 1 u.zw.grup.).

Wykonawcom pracy nakładczej również przyznano prawo do odprawy w przypadku rozwiązania umowy z przyczyn niedotyczących wykonawcy ( $\$ 9 \mathrm{~b}$ rozp. pr.nakład.). Prawo to przysługuje im w przypadku gdy powodem rozwiązania umowy, dokonanego również za porozumieniem ( $\$ 9 c$ rozp.pr.nakład.), było ogłoszenie upadłości lub likwidacji nakładcy bądź dokonane przez niego zaniechanie lub ograniczenie stosowania systemu pracy nakładczej. W takiej sytuacji wysokość odprawy równa jest jednomiesięcznemu wynagrodzeniu, jeżeli łączny okres pracy wynosi dziesięć lat, dwumiesięcznemu wynagrodzeniu, jeżeli łączny okres pracy wynosi dwadzieścia lat oraz trzymiesięcznemu wynagrodzeniu, jeżeli łączny okres pracy wynosi 20 lat i więcej (\$9b ust. 2 rozp.pr.nakład.). Okres pracy nakładczej nie stanowi jedynej podstawy obliczenia wymiaru łącznego okresu pracy. Na wymiar ten składają się m.in. okresy zatrudnienia w ramach stosunku pracy, w ramach pracy nakładczej, gdy wykonawca osiągał wynagrodzenie w wysokości równej co najmniej najniższemu wynagrodzeniu za pracę czy też okres służby w Policji (\$32 w zw. z $\$ 9$ b ust. 3 rozp.pr.nakład.).

113 M. Gersdorf, Podstawowe dylematy zwiqzane z rozwojem prawa pracy w okresie transformacji ustrojowej, „Praca i Zabezpieczenie Społeczne” 2003, nr 5, s. 6. 
Ustawowe prawo do odprawy nie przysługuje pozostałym osobom świadczącym pracę $\mathrm{w}$ ramach umownego zatrudnienia cywilnoprawnego (przyjmującym zlecenie, agentom, wykonawcom dzieła). Tworzy ono bowiem więzi o innym przeznaczeniu gospodarczym, z którym nie współgra konieczność minimalizowania negatywnych skutków fiskalnych przedwczesnego zakończenia trwania stosunku zatrudnienia. Co więcej, w przypadku umów zleceń, umów agencyjnych i umów o dzieło, ograniczone możliwości ich przedwczesnej terminacji, połączone z możliwością dochodzenia odszkodowania na zasadach ogólnych, wyłączają konieczność stosowania konstrukcji prawnych zbliżonych do omówionych powyżej.

W związku z tym, że pracownikowi przy ustawaniu stosunku zatrudnienia należy się wynagrodzenie za czas rzeczywiście przepracowany, a nie za wykonane czynności, rozliczenie stron stosunku pracy następuje zgodnie z wysokością wynagrodzenia określoną $\mathrm{w}$ umowie o pracę do samego końca jej trwania ${ }^{114}$. Jeśli pracownik $\mathrm{w}$ trakcie trwania stosunku pracy poniósł dodatkowe koszty, może domagać się ich zwrotu na podstawie art. 742 k.c. w zw. z art. 300 k.p. ${ }^{115}$ Osoby zatrudnione na podstawie umów prawa cywilnego często w trakcie trwania umowy ponoszą wydatki, które przy jej zakończeniu muszą zostać rozliczone. W odniesieniu do umowy zlecenia kwestię rozliczenia wydatków normuje art. 742 k.c., stosowany również do rozliczeń stron zatrudnienia pracowniczego. Zwrotowi podlega nie tylko kwota równa poczynionym przez przyjmującego zlecenie wydatkom, ale również obliczane od niej ustawowe odsetki. Zwrot wydatków uzależniony jest rzeczywistą korzyścią, jaką z ich dokonania uzyskał dający zlecenie ${ }^{116}$. $\mathrm{W}$ odpowiedniej sytuacji agent, jeżeli nic innego nie wynika $\mathrm{z}$ treści umowy, może domagać się zwrotu wydatków związanych z wykonaniem zlecenia, o ile były uzasadnione, a ich wysokość nie przekracza zwykłej miary w danych stosunkach (art. 762 k.c. $)^{117}$. Wydatki przekraczające tę granicę należy traktować jako koszty agenta, które pokrywa $\mathrm{z}$ własnych dochodó $\mathrm{w}^{118}$.

W przypadku pracy świadczonej w formie organizacyjnej telepracy zakończenie stosunku prawnego związane jest ze szczególnymi okolicznościami. Istotne jest bowiem, w jaki sposób po zakończeniu świadczenia pracy sprzęt dostarczony telepracownikowi ma zostać od niego odebrany. Kodeks pracy nie ustanawia

114 Z uwzględnieniem uprawnienia do ekwiwalentu za niewykorzystany urlop i innych związanych ze stosunkiem pracy należności.

115 Wyrok Sądu Najwyższego z dnia 12 marca 2009 r., II PK 198/08, LEX nr 621545.

116 Wyrok Sądu Najwyższego z dnia 14 października 2009 r., V CSK 111/03, LEX nr 654430.

117 Szczegółowej analizy konstrukcji prawnej świadczenia wyrównawczego przysługującego agentowi dokonują E. Rott-Pietrzyk, W. Klyta, Świadczenie wyrównawcze przysługujace agentowi - nowa instytucja w prawie polskim, „Kwartalnik Prawa Prywatnego” 2004, nr 3(13), passim.

118 E. Rott-Pietrzyk, Art. 762, [w:] E. Rott-Pietrzyk, Komentarz do niektórych przepisów kodeksu cywilnego. Umowa agencyjna po nowelizacji. Art. 758-764(9) k.c. Komentarz, https:// sip-1lex-1pl-1004153yx131d.han3.lib.uni.lodz.pl/\#/komentarz/587241129/38569 (dostęp: 19.09.2017). 
w tym zakresie żadnych unormowań. Wydaje się, że kwestia ta może zostać zatem uregulowana $\mathrm{w}$ porozumieniu $\mathrm{w}$ sprawie telepracy albo $\mathrm{w}$ regulaminie telepracy. Wobec braku takich regulowań należałoby przyjąć, że skoro to pracodawca, zgodnie $z$ art. $67^{11}$ k.p., ma dostarczyć telepracownikowi sprzęt niezbędny do wykonywania pracy, jest on również zobowiązany do jego odbioru. Konieczność odebrania sprzętu jest bowiem konsekwencją jego dostarczenia. Natomiast bez wątpienia na telepracowniku ciąży obowiązek wydania sprzętu.

Konstrukcja prawna umowy o dzieło w sposób szczególny reguluje status prawny przyjmującego zamówienie w przypadku konieczności znacznego podwyższenia wynagrodzenia kosztorysowego. W takiej sytuacji zamawiający może od umowy odstąpić, płacąc przyjmującemu zamówienie odpowiednią część wynagrodzenia (art. 631 k.c.). Przyjmujący zamówienie ma roszczenie o zapłatę wynagrodzenia również w przypadku odstąpienia od umowy przez zamawiającego przed ukończeniem dzieła. Wysokość wynagrodzenia może być pomniejszona o to, co przyjmujący zamówienie zaoszczędził z powodu niewykonania dzieła (art. 644 k.c.). W obu przypadkach przyjmujący zamówienie ma dodatkowe roszczenie o odbiór dzieła ${ }^{119}$.

Szczególne unormowanie dotyczące wzajemnych rozliczeń pomiędzy stronami umowy ustanawia regulacja umowy agencyjnej. Zgodnie $\mathrm{z}$ dyspozycją zawartą w art. $761^{1}$ k.c. agentowi przysługuje prowizja nawet po rozwiązaniu umowy. Aby agent był uprawniony do takiej prowizji, skutek w postaci zawarcia umowy z klientem musi być spowodowany działaniami agenta podczas trwania umowy agencyjnej. Prowizja przysługuje wtedy w dwóch przypadkach. Pierwszy dotyczy sytuacji, kiedy umowa z klientem została zawarta po rozwiązaniu umowy agencyjnej, ale propozycja jej zawarcia nastąpiła w trakcie trwania umowy agencyjnej (art. $761^{1} \$ 1$ k.c.). Drugi - jeżeli umowa z klientem została zawarta w przeważającej mierze w wyniku działalności agenta w okresie trwania umowy agencyjnej i w rozsądnym czasie od rozwiązania umowy agencyjnej (art. $761^{1} \$ 2$ k.c.). W drugiej sytuacji bez znaczenia jest, czy zamówienie kontrahenta doszło do zainteresowanych przed wygaśnięciem umowy agencyjnej czy po jej wygaśnięciu ${ }^{120}$. Oba wskazane roszczenia stają się wymagalne zawsze po ustaniu stosunku prawnego - umowy agencyjnej. Implementują one do krajowego porządku prawnego regulację art. 8 dyrektywy agencyjnej. Agent, na zasadach określonych w art. $764^{3}-764^{5}$ k.c., ma prawo domagać się od dającego zlecenie świadczenia wyrównawczego po rozwiązaniu umowy. Przepisy normu-

119 Tak w odniesieniu do odstąpienia od umowy w warunkach określonych w art. 631 k.c. wypowiada się A. Sikorska, Uprawnienia zamawiajacego dzieło do odstapienia od umowy na podstawie przepisów kodeksu cywilnego, „Przegląd Sądowy” 2004, nr 10, s. 58.

120 E. Rott-Pietrzyk, Art. 761(1), Art. 761(2), [w:] E. Rott-Pietrzyk, Komentarz do niektórych przepisów kodeksu cywilnego. Umowa agencyjna po nowelizacji. Art. 758-764(9) k.c. Komentarz, https://sip-1lex-1pl-1004153yx131d.han3.lib.uni.lodz.pl/\#/komentarz/587241123/38563 (dostęp: 19.09.2017). 
jące zasady wypłaty świadczenia wyrównawczego przysługującego agentom realizują wymagania przewidziane $\mathrm{w}$ dyrektywie agencyjnej (art. 17). Przesłanki uzyskania tego świadczenia wskazuje art. $764^{3} \$ 1$ k.p. Jest ono należne agentowi w wysokości nieprzekraczającej rocznego wynagrodzenia ${ }^{121}$, jeśli w czasie trwania umowy pozyskał nowych klientów lub przyczynił się do istotnego wzrostu obrotów $\mathrm{z}$ dotychczasowymi klientami, a dający zlecenie czerpie $\mathrm{z}$ tego tytułu korzyści pomimo rozwiązania umowy agencyjnej ${ }^{122}$. Dodatkową przesłanką, jaka musi zostać spełniona kumulatywnie z przesłankami wymienionymi powyżej, aby agent otrzymał świadczenie wyrównawcze, są względy słuszności. Przy ich badaniu bierze się pod uwagę takie okoliczności jak to, czy i w jakim zakresie wysiłki i aktywność agenta zostały już wynagrodzone w postaci prowizji i innych świadczeń w czasie trwania umowy ${ }^{123}$. Wysokość świadczenia wyrównawczego limitowana jest zgodnie z art. $764^{3} \$ 2$ k.c. Nie może ono przekroczyć wysokości wynagrodzenia agenta ${ }^{124}$ za jeden rok, obliczonego na podstawie średniego rocznego wynagrodzenia uzyskanego w okresie ostatnich pięciu lat. Jeżeli umowa agencyjna trwała krócej niż pięć lat, wynagrodzenie to oblicza się z uwzględnieniem średniej z całego okresu jej trwania.

Okoliczności wyłączające możliwość ubiegania się przez agenta o omawiane świadczenie wyrównawcze określa art. $764^{4}$ k.c. Nie przysługuje ono agentowi, jeżeli:

a) dający zlecenie wypowiedział umowę na skutek okoliczności, za które odpowiedzialność ponosi agent, usprawiedliwiających wypowiedzenie umowy bez zachowania terminów wypowiedzenia

b) agent wypowiedział umowę, chyba że wypowiedzenie jest uzasadnione okolicznościami, za które odpowiada dający zlecenie, albo jest usprawiedliwione wiekiem, ułomnością lub chorobą agenta, a względy słuszności nie pozwalają domagać się od niego dalszego wykonywania czynności agenta

c) agent za zgodą dającego zlecenie przeniósł na inną osobę swoje prawa i obowiązki wynikające z umowy.

Przyznanie agentowi wskazanych uprawnień w zakresie należnej prowizji wynika z faktu, że efekty jego pracy często materializują się po zakończeniu stosunku prawnego. Wobec braku omówionej regulacji dający zlecenie czerpałby korzyści z pracy agenta, za którą ten nie zostałby odpowiednio wynagrodzony.

121 Wynagrodzenie oblicza się, uśredniając wynagrodzenie otrzymane w ciągu ostatnich pięciu lat trwania umowy albo, jeżeli trwała ona krócej niż pięć lat, uśredniając wynagrodzenie z całego jej trwania.

122 Ł. Pisarczyk, Różne formy..., s. 98-99.

123 T. Wiśniewski, Świadczenie wyrównawcze przysługujące agentowi, „Przegląd Sądowy” 2001, nr 10, s. 56.

124 Wynagrodzenie to oblicza się jako dochód uzyskiwany przez agenta po odliczeniu kosztów działalności. Wyrok Sądu Apelacyjnego w Lublinie z dnia 31 marca 2015 r., I Aca 823/14, LEX nr 1668621. 
Omówiony stan normatywny różnicuje status prawny osób świadczących pracę w ramach umownego zatrudnienia nietypowego związany z ich obowiązkami i uprawnieniami na etapie ustania stosunku zatrudnienia. Różnice te wynikają z odmiennych warunków świadczenia pracy, zamierzonych celów, jakie spełnia dany stosunek zatrudnienia oraz rozłożenia obowiązków pomiędzy jego strony. Wskazane różnice, jak choćby uprawnienia do ekwiwalentów, odpraw, zwrotu wydatków czy odebrania przedmiotów służących do świadczenia pracy bądź będących jej wynikiem, związane są z istotą poszczególnych podstaw umownego zatrudnienia nietypowego i w związku z tym ich obowiązywanie wydaje się w pełni uzasadnione. Gospodarcze powody zróżnicowania statusu prawnego osób świadczących pracę w omówionym zakresie uzasadnione są potrzebą współistnienia w obrocie prawnym stosunków, których przedmiotem jest świadczenie pracy, o charakterze zarówno podporządkowanym i socjalnie rozbudowanym, jak i o charakterze niezależnym, zapewniających mniejszą ilość uprawnień. Szczegółowe uregulowanie na gruncie przepisów prawa cywilnego kwestii związanych ze wzajemnym rozliczeniem stron na etapie ustawania stosunku prawnego związane jest $\mathrm{z}$ faktem, że wykonując pracę, osoba zatrudniona często samodzielnie zapewnia niezbędne narzędzia i inne przedmioty. W stosunkach pracy, których charakter jest odmienny, zapewnienie niezbędnych materiałów i sprzętu do świadczenia pracy jest obowiązkiem pracodawcy, stąd konieczność dokonywania wzajemnych rozliczeń jest w tym zakresie sporadyczna.

Wydaje się, że możliwość dokonania wyboru podstawy prawnej zatrudnienia spośród rodzajowo różnych konstrukcji prawnych (również w zakresie kreowania statusu prawnego osób świadczących pracę) jest warunkiem prawidłowo funkcjonującej gospodarki. Powyższe dotyczy również obowiązków i uprawnień osób zatrudnionych na etapie ustania stosunku prawnego.

\subsection{Podsumowanie}

Przeprowadzone rozważania ujawniły szereg różnic w statusie prawnym osób świadczących pracę w ramach umownego zatrudnienia nietypowego w fazie ustania stosunku prawnego. Różnice te występują w odniesieniu do uregulowań normujących rozwiązywanie umowy, w razie wadliwego rozwiązania umowy oraz w zakresie statusu prawnego osób zatrudnionych, związanego ze szczególnymi obowiązkami i uprawnieniami na etapie zakończenia stosunku prawnego. Zróżnicowanie uprawnień ochronnych w zakresie trwałości zatrudnienia od najpełniejszych (stosunek pracy, a zwłaszcza umowa o pracę na czas nieokreślony) poprzez te o charakterze mieszanym (praca nakładcza), do uprawnień o charakterze 
minimalnym i fragmentarycznym, najmniej ingerującym w wolę stron (umowa zlecenia, umowa agencyjna i umowa o dzieło) jest uzasadnione równoległym funkcjonowaniem konstrukcji prawnych kreujących odmienne sytuacje podmiotów, które je tworzą. Aktualnie obowiązująca koncepcja ochrony pracowników przed utratą pracy jest wynikiem kompromisów partnerów społecznych. Nie oznacza to, że pod jej adresem nie można formułować argumentów postulujących zmiany legislacyjne, jak choćby postulatu wprowadzenia konieczności uzasadniania i konsultacji związkowej wypowiedzenia umowy o pracę na czas określony. Nie wydaje się przy tym racjonalne całościowe rozszerzanie ochrony trwałości zatrudnienia na pozapracownicze umowne stosunki zatrudnienia. $\mathrm{Z}$ punktu widzenia prawidłowo funkcjonującej gospodarki konieczne jest bowiem, aby system prawny umożliwiał zawieranie umów, których przedmiotem jest świadczenie pracy, nieobjętych ochroną trwałości zatrudnienia. Natomiast z perspektywy ochrony socjalnej nie ulega wątpliwości, że zatrudnienie powstające w wyniku zawierania takich umów powinno mieć charakter incydentalny i względnie krótkotrwały. Przyznanie właściwej prawu pracy ochrony trwałości stosunku pracy osobom świadczącym pracę na podstawie umów prawa cywilnego pozostawałoby w sprzeczności z gospodarczym przeznaczeniem tych umów jako doraźnego, a nie trwałego, sposobu prowadzenia przez podmioty zatrudniające wewnętrznej polityki zatrudnienia.

W zakresie uprawnień osób świadczących pracę nietypowo w przypadku wadliwego rozwiązania umowy opisane różnice występują już na płaszczyźnie stosunków prawnopracowniczych. Uwaga ta odnosi się zwłaszcza do zarezerwowanego dla zatrudnienia typowego (umowy o pracę na czas nieokreślony) prawa restytucji. Wydaje się jednak, że posiadanie tego prawa wypełnia systemowe założenia zatrudnienia bezterminowego, nie pozostając w zbieżności z tymi, które dotyczą zatrudnienia terminowego.

W związku z odmiennym charakterem poszczególnych rodzajów umownego zatrudnienia nietypowego zakończenie stosunku prawnego wiąże się ze szczególnymi uprawnieniami i obowiązkami osób zatrudnionych. Uprawnienia w zakresie prawa do otrzymania świadectwa pracy, ekwiwalentu za niewykorzystany urlop wypoczynkowy czy dni wolnych na poszukiwanie pracy związane są z cechami zatrudnienia pracowniczego, dlatego też nie obejmują swoim zakresem zatrudnienia cywilnoprawnego. Ono z kolei wymaga od stron stosunku zatrudnienia dokonania wzajemnych rozliczeń. Potrzeba ta wynika z samodzielnego organizowania procesu pracy przez osobę zatrudnioną, która często ${ }^{125}$ ponosi dodatkowe koszty wykonania umowy, wymagające pokrycia przez podmiot zatrudniający w końcowym rozliczeniu.

125 Ponoszenie przez pracownika dodatkowych kosztów związanych ze świadczeniem pracy ma miejsce wyjątkowo, ale, o czym była mowa w treści rozdziału, również podlega konieczności dokonania rozliczenia pomiędzy stronami. 


\section{Zakończenie}

Uwagi podsumowujące opracowanie warto rozpocząć od dwóch wniosków. Po pierwsze należy mieć na względzie, że zrównywanie statusu prawnego wszystkich osób świadczących pracę $\mathrm{w}$ ramach zatrudnienia umownego spowodowałoby, iż wybór podstawy prawnej stosunku zatrudnienia stałby się w dużej mierze iluzoryczny. Jednym z czynników wpływających na ten wybór jest bowiem model statusu prawnego osób świadczących pracę, który aktualizuje się w chwili dokonywania kwalifikacji prawnej zatrudnienia. Jeśli model ten będzie jednolity, stosunki zatrudnienia umownego, wbrew potrzebom obrotu gospodarczego, zrównają status prawny osób świadczących pracę w różnych warunkach organizacyjnych i faktycznych. Stosunki społeczne wymagają, aby równolegle funkcjonowały różne podstawy prawne umownego zatrudnienia, w sposób odmienny kreujące status prawny osób świadczących pracę. Po drugie wskazać należy na aktualność społecznych i gospodarczych celów, które decydowały o wyodrębnieniu poszczególnych podstaw prawnych i form organizacyjnych umownego zatrudnienia nietypowego. Skoro zatem cele te zachowały swoją aktualność, słuszne jest zróżnicowanie kreowanych przez poszczególne podstawy prawne i formy organizacyjne umownego zatrudnienia nietypowego konstrukcji prawnych wpływających na status prawny osób świadczących pracę.

W toku prowadzonych w opracowaniu rozważań ujawniony został szereg różnic w statusie prawnym osób świadczących pracę w ramach umownego zatrudnienia nietypowego. Zdecydowaną większość z tych różnic uznaję za uzasadnione odrębnościami systemowymi rodzajów umownego zatrudnienia nietypowego bądź ich społeczno-gospodarczymi założeniami. Niemniej jednak prowadzone analizy niejednokrotnie wykazały, że istnieją obszary regulacji prawnych wymagające ingerencji ustawodawcy celem dokonania zmian w unormowaniach obejmujących swoim zakresem status prawny osób świadczących pracę. Ingerencja ta nie naruszałaby pierwotnych założeń systemowych poszczególnych rodzajów umownego zatrudnienia nietypowego.

Ograniczenia stosowania umownego zatrudnienia nietypowego wyznaczają ramy prawne, w których ustawodawca dopuszcza kwalifikowanie zatrudnienia 
jako jego określony rodzaj. W odniesieniu do powyższego założenia przedstawione w rozdziale pierwszym uwagi wykazały, że ograniczenia te pozwalają dookreślić istotę poszczególnych podstaw prawnych i form organizacyjnych umownego zatrudnienia nietypowego. Jeśli bowiem dla przykładu zatrudnienie tymczasowe, celem prawidłowej kwalifikacji, musi spełniać przesłanki pozytywne określone w ustawie o zatrudnianiu pracowników tymczasowych (art. 2 pkt 1 i 2 z.p.t.), przy jednoczesnym braku występowania przesłanek negatywnych (art. 2 pkt 3 z.p.t., art. 4 z.p.t., art. 8 z.p.t.), to ich analiza pozwala wykazać, kiedy ustawodawca dopuszcza stosowanie zatrudnienia tymczasowego. Tym samym umożliwia to określenie okoliczności, w których osoby świadczące pracę zostają objęte normami kreującymi status prawny pracowników tymczasowych. Powyższe uwagi mogą zostać odniesione również do zakresu swobody wyboru i kształtowania podstawy prawnej umownego zatrudnienia nietypowego w odniesieniu do wpływu, jaki wywiera ona na status prawny osób świadczących pracę. Granice tej swobody, wynikające ze społeczno-gospodarczego przeznaczenia poszczególnych rodzajów zatrudnienia, wyznaczają ramy prawne, które kształtują status prawny osób świadczących pracę.

W obrębie norm dotyczących statusu prawnego osób świadczących pracę w zakresie modelu ochrony danych osobowych $\mathrm{w}$ fazie zawierania umowy model ochrony danych osobowych kandydatów ubiegających się o umowne zatrudnienie niepracownicze ukształtowany jest w sposób nietypowy. Osoby te nie podlegają ochronie ustanowionej w prawie pracy, ale ogólnym regulacjom ustawy o ochronie danych osobowych. Nieobjęcie kandydatów ubiegających się o umowne zatrudnienie niepracownicze ochroną właściwą prawu pracy uzasadnione jest formalną równością stron stosunków podlegających prawu cywilnemu, z których żadna nie wymaga wzmożonej ochrony. W stosunku pracy ochrony takiej wymaga pracownik, dlatego też zostaje nią objęty już na etapie ubiegania się o zatrudnienie pracownicze. Z powyższego wynika, że obecnie obowiązujący stan prawny dotyczący ochrony danych osobowych osób zatrudnianych w ramach umownego zatrudnienia nietypowego wpisuje się w jego założenia systemowe.

Warunki dopuszczenia do pracy, wpływające na status prawny osób przyjmowanych do pracy $w$ ramach umownego zatrudnienia nietypowego, są unormowane $\mathrm{w}$ sposób nietypowy w odniesieniu do telepracy, pracy tymczasowej oraz zatrudnienia cywilnoprawnego. Przedstawione $\mathrm{w}$ rozdziale drugim unormowania dotyczące tego zagadnienia mają ścisły związek z charakterem prawnym podstaw i form organizacyjnych umownego zatrudnienia nietypowego. Istota pracy świadczonej wyłącznie bądź również poza zakładem pracy, jako jedna z cech telepracy, uzasadnia przeprowadzenie pierwszej kontroli w zakresie bhp w domu telepracownika przed dopuszczeniem go do pracy (art. $67^{14} \S 4$ k.p.). Druga z cech telepracy - wykorzystywanie $\mathrm{w}$ pracy środków porozumiewania na odległość - uzasadnia z kolei konieczność dostarczenia telepracownikowi sprzętu, o którym mowa $w$ art. $67^{11}$ k.p. Powyższe nietypowe cechy telepracy, wpływające na status 
prawny osób świadczących pracę, są racjonalne, bowiem pozostają nieodzownie związane z okolicznościami organizacyjnymi, w jakich jest ona świadczona. W zakresie warunków dopuszczenia do pracy szczególnie kształtuje się również status prawny osób mających świadczyć pracę tymczasową. Obowiązek przeszkolenia pracownika tymczasowego w zakresie bezpieczeństwa i higieny pracy, podobnie jak zapewnienia odzieży i obuwia roboczego, spoczywa na pracodawcy użytkowniku (art. 2a z.p.t.). Taka nietypowość jest uzasadniona i wynika z faktu, że to właśnie pracodawca użytkownik jest najlepiej zorientowany w kwestiach dotyczących organizacji procesu pracy pracownika tymczasowego.

Obowiązujący stan prawny nie wymaga, aby podmiot zatrudniający kierował osobę przyjmowaną do pracy na wstępne badania lekarskie i dokonywał wstępnego szkolenia z zakresu bhp. Takie uregulowanie nie jest korzystne, bowiem w sposób nieracjonalny różnicuje ochronę zdrowia i życia zależnie od podstawy świadczenia pracy. Podmiot zatrudniający na podstawie umowy cywilnoprawnej nie jest ustawowo zobligowany do zapewnienia sprzętu i materiałów niezbędnych do wykonania umówionej pracy. Pewien wyjątek w kwestii zapewnienia materiałów dotyczy pracy nakładczej. Co do zasady nakładca zobowiązany jest bowiem do zapewnienia wykonawcy surowców, materiałów lub innych przedmiotów oraz narzędzi, maszyn i urządzeń niezbędnych do wykonania pracy nakładczej ( $\$ 11$ ust. 1 rozp.pr.nakład.). Takie rozłożenie obowiązków pozostaje zbieżne z mieszanym charakterem pracy nakładczej jako zatrudnienia łączącego cechy stosunków prawnopracowniczych i cywilnoprawnych.

Rozważania dotyczące ochrony przed dyskryminacją osób nawiązujących stosunek prawny i tych, które już świadczą pracę w ramach umownego zatrudnienia nietypowego, omówione w końcowej części rozdziału drugiego, dowiodły, że istniejące w tym zakresie różnice wynikają ze szczególnych cech podstaw prawnych i form organizacyjnych umownego zatrudnienia nietypowego. $Z$ tej właśnie przyczyny art. $67^{15} \$ 1$ k.p. zakazuje mniej korzystnego traktowania telepracownika w porównaniu z pracownikami wykonującymi podobną lub taką samą pracę, a przepis art. $67^{15} \$ 2$ k.p. zakazuje dyskryminacji, której podstawą byłoby podjęcie pracy w formie organizacyjnej telepracy bądź odmowa podjęcia pracy w takiej formie. Z kolei art. 15 ust. 1 z.p.t. odnosi się do porównywania sytuacji pracownika tymczasowego oraz pracownika zatrudnionego przez pracodawcę użytkownika na takim samym lub podobnym stanowisku. W tym względzie pracownik tymczasowy nie może być traktowany mniej korzystnie niż pracownik zatrudniony przez pracodawcę użytkownika. Przepis art. 15 ust. 1 z.p.t. słusznie odwołuje się do zakazu mniej korzystnego traktowania, a nie do zakazu dyskryminacji. Warunki organizacyjne pracy świadczonej w ramach zatrudnienia tymczasowego ze swojej natury narzucają pewne różnice, które jednak nie mogą cechować się mniej korzystnym traktowaniem pracownika tymczasowego. W zakresie statusu prawnego pracowników tymczasowych, związanego z normami przeciwdziałającymi dyskryminacji, krytycznie oceniam regulację art. 15 ust. 2 z.p.t. Skoro bo- 
wiem systemowym założeniem zatrudnienia tymczasowego jest m.in. znalezienie zatrudnienia stałego, to kryterium czasu trwania zatrudnienia tymczasowego nie powinno różnicować sytuacji prawnej pracowników tymczasowych względem dostępu do szkoleń podnoszących kwalifikacje zawodowe, organizowanych przez pracodawcę użytkownika. W zakresie ochrony przed dyskryminacją w sposób odmienny od typowego ukształtowany jest również status prawny osób świadczących pracę $\mathrm{w}$ ramach umownego zatrudnienia cywilnoprawnego. Osoby takie nie podlegają regulacjom prawa pracy, lecz ustawie o wdrożeniu niektórych przepisów Unii Europejskiej w zakresie równego traktowania. Ustawa ta mniej korzystnie kreuje status prawny osób zatrudnionych na podstawie umów niepracowniczych od statusu pracowniczego, głównie poprzez ograniczenie zakresu działań, które uznane być mogą za dyskryminujące, wskazując zamknięty katalog przyczyn dyskryminacji. Przedstawione w treści pracy różnice uzasadnione są nie tylko słabszą z systemowego założenia pozycją pracownika względem pracodawcy, ale również samym charakterem zatrudnienia prawnopracowniczego, w którym wystąpienie zachowań o charakterze dyskryminacyjnym jest o wiele bardziej prawdopodobne niż w przypadku stosunków cywilnoprawnych. Z tego właśnie względu ochrona przyznana pracownikom jest szersza.

Status prawny osób świadczących pracę $\mathrm{w}$ ramach umownego zatrudnienia nietypowego doznaje szczególnych zróżnicowań w okresie realizacji stosunku prawnego. Początkowe rozważania rozdziału trzeciego dotyczyły obowiązków osób zatrudnionych względem podmiotów zatrudniających. Zróżnicowanie $\mathrm{w}$ tym zakresie wynika $\mathrm{z}$ uwarunkowanych założeniami systemowymi odmiennych warunków świadczenia pracy w ramach poszczególnych podstaw prawnych i form organizacyjnych zatrudnienia umownego. Szczególne obowiązki telepracowników (jak choćby obowiązek przestrzegania porozumienia, o którym mowa $\mathrm{w}$ art. $67^{6} \$ 1$ i 2 k.p., i regulaminu, o którym mowa w art. $67^{6} \$ 3$ i 4 k.p., czy szczególnie uregulowany obowiązek przestrzegania bhp - art. $67^{14}$ k.p.) związane są $\mathrm{z}$ istotą tej formy organizacyjnej świadczenia pracy. W sposób nietypowy została uregulowana sytuacja prawna pracowników tymczasowych, są oni bowiem zobowiązani do przestrzegania zdecydowanej większości obowiązków pracowniczych nie względem swojego pracodawcy ( $w$ rozumieniu art. 3 k.p.), a względem uczestnika trójpodmiotowej relacji zatrudnienia tymczasowego - pracodawcy użytkownika. Powyższe wynika $\mathrm{z}$ cech zatrudnienia tymczasowego jako więzi trzech podmiotów. W sposób najbardziej nietypowy, z racji podlegania innemu reżimowi prawnemu, unormowane są obowiązki osób świadczących pracę $\mathrm{w}$ ramach umownego zatrudnienia cywilnoprawnego. Doświadczają one również odmienności w zależności od konkretnej podstawy prawnej świadczenia pracy. Z tego względu osoby zatrudnione na podstawie umów właściwych prawu cywilnemu nie są zobowiązane np. do dbałości o dobro podmiotu zatrudniającego. Natomiast ciążą na nich inne obowiązki, związane $\mathrm{z}$ naturą danych stosunków prawnych, jak choćby obowiązek przyjmującego zlecenie do udzielania bieżących wiadomo- 
ści o jego realizacji (art. 740 k.c.) czy obowiązek lojalności obciążający agenta (art. 760 k.c.). W uwagach podsumowujących warto wskazać, że ustawodawca dał, mocą art. $304^{1}$ k.p., wyraz swojej szczególnej dbałości o bezpieczeństwo i higienę pracy wszystkich osób świadczących pracę, bez względu na reżim prawny, któremu ona podlega. Dlatego też wszystkie osoby świadczące pracę w ramach zatrudnienia umownego w różnym zakresie zobowiązane są do przestrzegania przepisów i zasad bhp. Jednakże celem lepszej realizacji postulatu zapewnienia bezpiecznych i higienicznych warunków pracy wszystkim osobom zatrudnionym warte rozważenia jest wprowadzenie szczegółowych sankcji za nieprzestrzeganie przepisów i zasad bhp przez osoby świadczące pracę w ramach umownego zatrudnienia cywilnoprawnego.

Z obowiązkami osób świadczących pracę związane są określone uprawnienia, które w przeważającej mierze w sposób uzasadniony różnicują ich status prawny. Szczególne znaczenie mają uprawnienia związane z ochroną wynagrodzenia za pracę oraz prawem do wypoczynku. Ochrona wynagrodzenia za pracę jest najszersza w zatrudnieniu prawnopracowniczym, natomiast nie znajduje pełnego odzwierciedlenia w stosunkach umownego zatrudnienia cywilnoprawnego. Nie jest jednak konieczne zapewnianie daleko idącej ochrony wynagrodzenia podmiotom mającym w obrocie gospodarczym pozycję formalnie równą z podmiotami zatrudniającymi. Nie byłoby również uzasadnione obejmowanie osób zatrudnionych na podstawie umów zlecenia, umów o świadczenie usług, do których stosuje się przepisy o zleceniu, umów agencyjnych i umów o dzieło regulacjami w zakresie zapewniania okresów odpoczynku, które aktualnie są właściwe prawu pracy. Skoro bowiem osoby te samodzielnie organizują proces swojej pracy, powinny również samodzielnie organizować okresy jej nieświadczenia - okresy odpoczynku. Tym samym brak możliwości wpływania przez podmiot zatrudniający na proces organizacji pracy uzasadnia brak konieczności zapewnienia odpoczynku osobom świadczącym pracę w ramach stosunków o niepodporządkowanym charakterze. W toku prowadzonej analizy wykazano, że w odniesieniu do prawa do wypoczynku ustawodawca w sposób nietypowy unormował status prawny pracowników tymczasowych. Ujawnione różnice (brak wpływu okresów zatrudnienia na wymiar urlopu, inny niż typowy wymiar urlopu czy udzielanie urlopu z dołu) nie są sprzeczne z interesami pracowników tymczasowych, wypełniając założenie systemowe zatrudnienia tymczasowego - krótkotrwałość stosunku prawnego. Wydaje się jednak, że mogłyby one budzić pewne wątpliwości z punktu widzenia zasady równego traktowania.

Prawodawca słusznie stara się chronić zdrowie i życie, nie różnicując ich na pracownicze i niepracownicze. Nie znaczy to jednak, że status wszystkich osób świadczących pracę jest w tym zakresie jednolity. Uprawnienie do pracy w warunkach bezpiecznych i higienicznych w sposób nietypowy kształtuje m.in. status prawny telepracowników. Poczynione w treści rozdziału trzeciego uwagi dowodzą, że podstawą istnienia tych odmienności jest charakter zatrudnienia w formie organizacyj- 
nej telepracy, czyli praca wyłącznie bądź również poza zakładem pracy. Natomiast szczególne cechy zatrudnienia tymczasowego wpływają na nietypowość statusu prawnego pracowników tymczasowych w zakresie prawa do pracy w warunkach bezpieczeństwa i higieny. Trójpodmiotowość więzi zatrudnienia tymczasowego uzasadnia regulację prawną, zgodnie $\mathrm{z}$ którą względem pracownika tymczasowego prawo do pracy w warunkach bezpiecznych i higienicznych aktualizuje się $\mathrm{w}$ stosunku do obowiązku ich zapewnienia przez pracodawcę użytkownika (art. 14 ust. 2 pkt 1 z.p.t.). Osoby świadczące pracę w ramach umownego zatrudnienia cywilnoprawnego mają ograniczone, względem pracowniczego, prawo do bezpiecznych i higienicznych warunków pracy. Wskazane $\mathrm{w}$ treści art. $304^{1}$ k.p., a omówione szczegółowo w rozdziale trzecim monografii różnice w prawie do bhp osób świadczących pracę, są uzasadnione. Wynikają one w przeważającej mierze z niepodporządkowanego charakteru świadczonej pracy, którego konsekwencją jest brak bieżącego nadzoru podmiotu powierzającego wykonanie pracy nad jej przebiegiem.

Dokonując podsumowania rozważań dotyczących statusu prawnego osób świadczących pracę $\mathrm{w}$ ramach umownego zatrudnienia nietypowego $\mathrm{w}$ zakresie ich uprawnień warto odnieść się jeszcze do tych związanych z rodzicielstwem. Ich trzon przysługuje wszystkim pracownikom, bez względu na podstawę prawną i formę organizacyjną świadczenia pracy. W zakresie ograniczonym uprawnienia związane z rodzicielstwem przysługują również wykonawcom pracy nakładczej. Ustawa z dnia 24 lipca 2015 r. o zmianie ustawy - Kodeks pracy oraz niektórych innych ustaw dokonała daleko idących zmian w standardach ochronnych związanych z uprawnieniami rodzicielskimi. Chociaż kierunek zmian legislacyjnych uznać należy za pożądany, wydaje się, że powinny one w szerszym stopniu objąć osoby świadczące pracę w ramach umów właściwych prawu cywilnemu. Nie ma bowiem społecznych i gospodarczych podstaw do rozgraniczania rodzicielstwa pracowniczego, cechującego się licznymi przywilejami, i rodzicielstwa niepracowniczego, uprzywilejowanego jedynie fragmentarycznie.

Odpowiedzialność osób świadczących pracę w ramach umownego zatrudnienia nietypowego, związana z zakresem nałożonych na nie obowiązków, bez wątpienia różnicuje status prawny osób świadczących pracę w ramach umownego zatrudnienia nietypowego. Podporządkowany charakter pracy świadczonej w ramach stosunku pracy uzasadnia podleganie przez pracowników odpowiedzialności porządkowej, która nie dotyczy osób zatrudnionych na podstawie umów prawa cywilnego uregulowanych $\mathrm{w}$ kodeksie cywilnym ${ }^{1}$. Z kolei ograniczenie odpowiedzialności materialnej pracowników jest konsekwencją przejęcia ryzyka związanego $\mathrm{z}$ organizowaniem procesu świadczenia pracy przez pracodawcę. W stosunkach właściwych prawu cywilnemu ryzyko takie ponosi osoba świadcząca pracę, dlatego też jej odpowiedzialność nie jest ograniczona na wzór odpowiedzialności pracowniczej.

1 E. Staszewska, Odpowiedzialność pracownicza, Warszawa 2013, s. 18. 
W zakresie wynikającym z charakteru trójpodmiotowej relacji nietypowość odpowiedzialności osoby świadczącej pracę dotyczy również pracowników tymczasowych. Zgodnie z art. 19 z.p.t. odpowiedzialnością za naprawienie szkody wyrządzonej przez pracownika tymczasowego pracodawcy użytkownikowi obciążona jest, w granicach odpowiedzialności pracowniczej, agencja pracy tymczasowej. Takie rozłożenie ryzyka związanego z organizowaniem procesu pracy uzasadnione jest występującym w zatrudnieniu tymczasowym podziałem przymiotów pracodawczych pomiędzy agencję pracy tymczasowej i pracodawcę użytkownika.

Zróżnicowanie sytuacji prawnej osób świadczących pracę w ramach umownego zatrudnienia nietypowego wynika również $\mathrm{z}$ odmiennej zakresowo odpowiedzialności podmiotów zatrudniających za wykroczenia i przestępstwa. W tym obszarze status prawny pracowników, jako podmiotów o słabszej - z założenia systemowego - pozycji, jest korzystniejszy aniżeli status prawny osób świadczących pracę w ramach umownego zatrudnienia cywilnoprawnego. Przepisy prawa pracy w sposób szczególny sankcjonują obowiązki pracodawców względem pracowników, przez co interesy pracownicze są lepiej chronione. Stosowanie, mocą przepisów kodeksu karnego, sankcji za popełnienie przestępstw przeciwko prawom osób wykonujących pracę zarobkową ma na celu ochronę wszystkich tych osób, chyba że konkretna norma ogranicza katalog podmiotów chronionych do pracowników. Takie ograniczenie występuje w dwóch przepisach (art. 218 k.k. i 220 k.k.), co uzasadnione jest powiązaniem hipotez tych norm $\mathrm{z}$ warunkami świadczenia pracy podporządkowanej o charakterze prawnopracowniczym.

Podleganie ubezpieczeniom społecznym przez osoby świadczące pracę w ramach umownego zatrudnienia nietypowego wpływa na ich status prawny, bowiem nie wszystkie one są objęte ubezpieczeniami społecznymi w takim samym zakresie. Zbliżony do pracowniczego status ubezpieczeniowy posiadają osoby zatrudnione na podstawie umowy o pracę nakładczą, umowy zlecenia, umów o świadczenie usług, do których stosuje się przepisy o zleceniu, oraz umowy agencyjnej. Odmienny status mają natomiast wykonawcy umów o dzieło, świadczący pracę na podstawie umowy zawartej z innym podmiotem niż ich pracodawca. Nie są oni objęci obowiązkowymi ubezpieczeniami emerytalnym i rentowym, mogąc przystąpić do nich dobrowolnie (art. 7 u.s.u.s.) $)^{2}$. Nieobligatoryjne podleganie ubezpieczeniom emerytalnemu i rentowemu wyłącza względem wykonawców umów o dzieło możliwość przystąpienia do ubezpieczenia chorobowego, co wynika z braku ciągłości zatrudnienia opartego na tej podstawie prawnej ${ }^{3}$. Jednakże zwiększenie popularności stosowania umów o dzieło, związane z gospodarczą

2 I. Sierocka, Ubezpieczenie społeczne osób świadczących pracę na podstawie umów prawa cywilnego, [w:] A. Bieliński, A. Giedrewicz-Niewińska, M. Szabłowska-Juckiewicz (red.), Elastyczne formy zatrudnienia i organizacji czasu pracy, Warszawa 2015, s. 103.

3 M. Krajewski, Dobrowolne ubezpieczenie emerytalne i rentowe na gruncie art. 7 i 10 ustawy o systemie ubezpieczeń społecznych, „Praca i Zabezpieczenie Społeczne” 2014, nr 5, s. 10. 
potrzebą świadczenia pracy w ramach jednorazowych usług, uzasadnia postulat przyznania wykonawcom umów o dzieło możliwości choćby dobrowolnego przystąpienia do ubezpieczeń społecznych w zakresie obecnie dla nich wyłączonym, celem przyznania im szerszej ochrony socjalnej. Wykonawcy umów o dzieło są jedynymi osobami, spośród tych, których status prawny był w niniejszej pracy omawiany, niepodlegającymi obowiązkowemu ubezpieczeniu zdrowotnemu. Jednak z uwagi na to, że mogą oni przystąpić do ubezpieczenia zdrowotnego dobrowolnie, ingerencja ustawodawcy w tym zakresie nie wydaje się konieczna.

Istotne różnice $\mathrm{w}$ zakresie statusu prawnego osób świadczących pracę zachodzą w obrębie zbiorowego prawa pracy. Są one w dużej mierze nieuzasadnione społecznym lub gospodarczym przeznaczeniem poszczególnych podstaw prawnych i form organizacyjnych zatrudnienia. Nie ma bowiem przesłanek dla ograniczania prawa koalicji w związkach zawodowych, jak ma to obecnie miejsce (art. 2 ust 1 i 2 u.z.z.), które wynikałoby ze społecznego lub gospodarczego celu poszczególnych rodzajów zatrudnienia umownego. Prawo do zrzeszania się w związkach zawodowych mają bowiem wszyscy ludzie pracy (zgodnie z definicją związku zawodowego - art. 1 u.z.z.), którzy, w odniesieniu do prawa koalicji, nie powinni być różnicowani ze względu na podstawę zatrudnienia. Dodatkowo zauważyć należy, że konsekwencją nieposiadania prawa tworzenia i przynależności do związków zawodowych przez osoby zatrudnione niewymienione w art. 2 u.z.z. jest pozbawienie ich reprezentacji związkowej w wielu aspektach ${ }^{4}$. Ani społeczno-gospodarcze przeznaczenie umów stanowiących podstawy prawne zatrudnienia cywilnoprawnego, ani ich niepodporządkowany charakter nie uzasadniają nieprzyznania wszystkim osobom świadczącym pracę pełni praw w zakresie zrzeszania się w związkach zawodowych.

Status prawny osób świadczących pracę $\mathrm{w}$ ramach umownego zatrudnienia nietypowego w zakresie prawa do zawierania układów zbiorowych pracy i podlegania ich postanowieniom również przejawia wewnętrzne zróżnicowanie. W przeważającej mierze jest ono konsekwencją braku prawa koalicji w związkach zawodowych. Dlatego też rozszerzenie prawa wstępowania i przynależności do związków zawodowych na wszystkie osoby świadczące pracę w ramach umownego zatrudnienia cywilnoprawnego powinno być zsynchronizowane $\mathrm{z}$ przyznaniem im pełnych bądź zbliżonych do pracowniczych uprawnień w zakresie zawierania układów zbiorowych pracy i podlegania ich postanowieniom. Zróżnicowanie statusu prawnego osób świadczących pracę występuje również na płaszczyźnie prawa do uczestnictwa w zarządzaniu przedsiębiorstwem. W tym zakresie warto wskazać, że pracownicy tymczasowi nie są uwzględniani w liczbie osób zatrudnionych u pracodawcy użytkownika, od której zależy obowiązek powołania

4 B. Cudowski, Reprezentacja zatrudnionych w sporach zbiorowych pracy (de lege lata $i$ de lege ferenda), [w:] A. Wypych-Żywicka, M. Tomaszewska, J. Stelina (red.), Zbiorowe prawo pracy XXI wieku, Gdańsk 2010, s. 241. 
rady pracowników oraz nie korzystają z czynnego i biernego prawa wyborczego do rady pracowników działającej u pracodawcy użytkownika ${ }^{5}$. Wydaje się, że uzasadnione byłyby, postulowane w rozdziale czwartym, zmiany w tym zakresie. Pracownicy tymczasowi są zainteresowani posiadaniem wiedzy odnoszącej się do pracodawcy użytkownika na temat stanu, struktury i przewidywanych zmian zatrudnienia oraz działań mających na celu utrzymanie poziomu zatrudnienia czy mogących powodować istotne zmiany w organizacji pracy lub w podstawach zatrudnienia (art. 13 ust. 1 pkt 2 i 3 u.ik.). Przyznanie pracownikom tymczasowym biernego i czynnego prawa wyborczego do rady pracowników działającej u pracodawcy użytkownika powinno być jednak uzależnione od minimalnego okresu świadczenia pracy przez pracownika tymczasowego na rzecz pracodawcy użytkownika. Nie jest przy tym konieczne rozszerzanie prawa do uczestnictwa $\mathrm{w}$ zarządzaniu przedsiębiorstwem na osoby świadczące pracę w ramach umownego zatrudnienia cywilnoprawnego niecechującego się trwałością (incydentalnie zawieranych umów zlecenia, umów o dzieło), którego niepodporządkowany charakter wyłącza zasadność współdziałania na poziomie zarządzania przedsiębiorstwem osoby świadczącej pracę z podmiotem zatrudniającym.

Przedstawienie zagadnień związanych ze statusem prawnym osób świadczących pracę $\mathrm{w}$ ramach umownego zatrudnienia nietypowego $\mathrm{w}$ fazie ustania stosunku prawnego ujawniło szereg nie zawsze uzasadnionych różnic w tym zakresie. Ochrona trwałości zatrudnienia jest najszersza w zatrudnieniu typowym. Leszek Mitrus wskazuje wręcz, że dotyczy ona jedynie umów o pracę na czas nieokreślony ${ }^{6}$. Tylko względem tej podstawy umownego zatrudnienia ustawodawca ustanowił obowiązek uzasadniania wypowiedzenia oraz jego konsultacji związkowej. Obowiązująca od 22 lutego 2016 r. możliwość wypowiedzenia każdej umowy o pracę zawartej na czas określony bez podawania przyczyny takiego wypowiedzenia ostatecznie niweczy stabilny charakter zatrudnienia terminowego, w sposób niekorzystny wpływając na status prawny osób świadczących pracę ${ }^{7}$. Pozytywnie oceniam natomiast występujący co do zasady brak możliwości wypowiedzenia umów o pracę tymczasową (art. 13 ust. 2 z.p.t.). Wypowiedzenie takiej umowy jest dopuszczalne w przypadku wprowadzenia do niej odpowiedniego postanowienia. W sposób korzystny wpływa to na status prawny pracowników tymczasowych w zakresie stabilizacji zatrudnienia, które z założenia powinno trwać przez umówiony czas. Podobna stabilizacja występuje w zatrudnieniu nakładczym. Mocą przepisu $₫ 4$ ust. 2 rozp.pr.nakład., stosowanego a contrario, nie

5 A. Reda, Pracodawca użytkownik jako podmiot prawa pracy, Poznań 2011, s. 118-119.

6 L. Mitrus, Czterdzieści lat obowiązywania kodeksu pracy oraz perspektywy jego rozwoju, „Kwartalnik Prawa Prywatnego”, 2015, vol. 24, z. 4, s. 780.

7 W obowiązującym przed nowelizacją stanie prawnym zastrzeżenia względem fragmentaryczności ochrony przed wypowiedzeniem wskazywały A. Górnicz-Mulcahy, M. Lewandowicz-Machnikowska, Skutki prawne wypowiedzenia przez pracownika umowy na czas określony nieprzewidujacej prawa do wypowiedzenia, „Monitor Prawa Pracy” 2012, nr 12, s. 633. 
można za wypowiedzeniem rozwiązać umowy o pracę nakładczą zawartej na czas określony i na czas wykonania określonej pracy. Taka regulacja pozostaje w zgodzie z naturą prawną umów terminowych jako trwających do określonego przez strony momentu.

Sytuacja prawna osób świadczących pracę w ramach umownego zatrudnienia nietypowego jest zróżnicowana również w odniesieniu do okresów wypowiedzenia. Nowelizacja czerwcowa z 2015 r. ujednoliciła przepisy związane z długością okresów wypowiedzenia umów o pracę $\mathrm{w}$ ramach zatrudnienia pracowniczego regulowanego kodeksem pracy, poza umową o pracę na okres próbny. W odmienny sposób ustalona pozostaje długość okresu wypowiedzenia umowy o pracę tymczasową. Spośród cywilnoprawnych podstaw zatrudnienia konieczność upływu okresu wypowiedzenia ustanawiają jedynie regulacje umowy o pracę nakładczą i umowy agencyjnej, dowodząc trwałego charakteru stosunków prawnych powstających w następstwie ich zawarcia. Powyższe uwagi łączą się ściśle z okolicznościami umożliwiającymi rozwiązanie badanych umów bez zachowania okresu wypowiedzenia. Obowiązujące w tym względzie regulacje właściwe prawu pracy związane są z podporządkowanym charakterem zatrudnienia pracowniczego i znacznym ograniczeniem woli pracodawcy w niezwłocznym rozwiązywaniu umowy o pracę. Powoduje to, że - zgodnie z założeniami systemowymi - zatrudnienie pracownicze jest trwalsze i szerzej chronione niż cywilnoprawne. Nie oznacza to jednak, o czym była mowa w rozdziale piątym, że każda umowa stanowiąca podstawę zatrudnienia cywilnoprawnego może zostać rozwiązana w trybie natychmiastowym bez względu na okoliczności. Osoby zatrudnione na podstawie umów prawa cywilnego (poza umową o pracę nakładczą) nie podlegają szczególnej ochronie trwałości stosunku pracy, przez co ich status prawny jest odmienny od pracowniczego. Nie byłoby uzasadnione rozszerzanie tej ochrony na stosunki podlegające reżimowi prawa cywilnego. Brak trwałości zatrudnienia $\mathrm{w}$ stopniu równym pracowniczemu jest bowiem uzasadniony, przemawiając za pozostawieniem w tym względzie obecnie obowiązujących różnic systemowych.

Wadliwe wypowiedzenie lub rozwiązanie bez wypowiedzenia umowy stanowiącej podstawę świadczenia pracy w ramach zatrudnienia nietypowego kształtuje status prawny osób świadczących pracę w sposób różnorodny, w przeważającej mierze wypełniając społeczno-gospodarcze założenia konieczności współistnienia odmiennych podstaw prawnych świadczenia pracy. Nietypowość umownego zatrudnienia pracowniczego przejawia się m.in. tym, że w przypadku wadliwego wypowiedzenia umowy o pracę na czas określony pracownik nie ma prawa restytucji. Podstawy prawne umownego zatrudnienia pracowniczego różnicują również wysokość dochodzonego przez pracowników odszkodowania należnego w razie wadliwego wypowiedzenia bądź rozwiązania bez wypowiedzenia umowy, co zostało opisane w rozdziale piątym. Zbliżona do pracowniczej regulacja zatrudnienia nakładczego w zakresie statusu prawnego osoby świadczącej pracę $\mathrm{w}$ razie wadliwego wypowiedzenia lub rozwiązania bez wypowiedzenia umowy wpisuje się $\mathrm{w}$ mie- 
szany charakter tej podstawy prawnej zatrudnienia, oscylujący pomiędzy prawnopracowniczym a cywilnoprawnym. Regulacje kodeksu cywilnego jedynie w dwóch przypadkach (art. $746 \$ 1$ k.c. in fine i art. $764^{2} \$ 2$ k.c.) ustanawiają obowiązek odszkodowawczy związany $\mathrm{z}$ wypowiedzeniem umowy. Jednoznacznie wskazuje to, że w odniesieniu do zatrudnienia cywilnoprawnego ustawodawca nie ustanawia, ponad ogólne przepisy dotyczące odszkodowania, szczególnych norm w zakresie roszczeń przysługujących osobom świadczącym pracę $\mathrm{w}$ razie wadliwego wypowiedzenia umowy bądź rozwiązania jej bez wypowiedzenia. Nie jest przy tym konieczne zrównywanie na omawianej płaszczyźnie statusu prawnego pracowników i osób świadczących pracę w ramach umów prawa cywilnego. Obecnie istniejące różnice $\mathrm{w}$ tym zakresie czynią zatrudnienie pracownicze trwalszym, wypełniając tym samym przypisane mu założenia systemowe.

Zakończenie stosunku prawnego umownego zatrudnienia nietypowego różnicuje status prawny osób świadczących pracę w zakresie ich uprawnień i obowiązków zależnie od reżimu prawnego świadczenia pracy i warunków organizacyjnych zatrudnienia. W związku z tym, ponieważ następstwem kwalifikacji zatrudnienia jako pracowniczego jest wiele uprawnień (prawo do urlopu wypoczynkowego czy uprawnienia w zakresie ubezpieczeń społecznych), pracodawca zobowiązany jest do wydania świadectwa pracy. Spośród cywilnoprawnych podstaw prawnych umownego zatrudnienia jedynie regulacja pracy nakładczej ustanawia obowiązek wydania świadectwa pracy. Brak istnienia w zatrudnieniu cywilnoprawnym obowiązku odpowiadającego właściwemu prawu pracy obowiązkowi wydania świadectwa pracy wynika $\mathrm{z}$ odmiennej konstrukcji zatrudnienia cywilnoprawnego. Osoby zatrudnione na podstawie umów prawa cywilnego (umowy zlecenia, umów o świadczenie usług, do których stosuje się przepisy o zleceniu, umowy agencyjnej i umowy o dzieło) nie muszą legitymować się dokumentami o przebiegu swojego zatrudnienia, bowiem nie jest on istotny dla przysługujących im uprawnień. Ponadto treść świadectwa pracy w przeważającej mierze związana jest $\mathrm{z}$ warunkami świadczenia pracy w ramach stosunku pracy, zatem zastosowanie go względem zatrudnienia cywilnoprawnego nie byłoby możliwe. Pozostałe omówione w końcowej części rozdziału piątego regulacje związane z zakończeniem stosunku umownego zatrudnienia nietypowego wynikają bądź z okoliczności, w których świadczona jest praca (np. obowiązek wypłaty ekwiwalentu za niewykorzystany urlop, obowiązek odebrania sprzętu od telepracownika, obowiązek wypłaty prowizji agentowi nawet po rozwiązaniu umowy), bądź ze szczególnej ochrony przyznanej pracownikom (np. obowiązek wypłaty odprawy na podstawie ustawy o szczególnych zasadach rozwiązywania z pracownikami stosunków pracy z przyczyn niedotyczących pracowników). Dlatego też ich obowiązywanie, różnicujące status prawny osób świadczących pracę, jest w pełni uzasadnione.

Wydaje się bezsporne, że prawidłowo funkcjonujący system prawny wymaga współistnienia w obrocie gospodarczym podstaw prawnych zatrudnienia umownego, które spełniają różne założenia, co wiąże się z tym, że status prawny osób 
świadczących pracę w konsekwencji zawarcia konkretnej umowy jest zróżnicowany. Różnice te charakteryzują dany stosunek prawny, dając podmiotom zatrudnienia możliwość dokonania realnego wyboru umownej podstawy świadczenia pracy. Przedstawione w niniejszej pracy rozważania potwierdzają tezę o aktualności społeczno-gospodarczych celów wyodrębnienia podstaw prawnych i form organizacyjnych umownego zatrudnienia nietypowego. Dowodzą one również, że istnieje konieczność, aby w sposób odmienny, choć nie na wszystkich płaszczyznach, kreowały one status prawny osób świadczących pracę. 


\section{Bibliografia}

\section{Publikacje}

Antonów K., Przedmiotowe, konstytucyjne i procesowe przesłanki uznania prawa zabezpieczenia społecznego za odrębna gałąź prawa, [w:] A. Patulski, K. Walczak (red.), Jedność w różnorodności. Studia z zakresu prawa pracy, zabezpieczenia społecznego i polityki społecznej. Księga pamiątkowa dedykowana Profesorowi Wojciechowi Muszalskiemu, Warszawa 2009.

Arendt Ł., Wykorzystanie umów terminowych w Polsce w kontekście skutków światowego kryzysu gospodarczego, „Polityka Społeczna” 2014, nr 9.

Balcerak W., Sytuacja prawna ajentów w gospodarce uspołecznionej, „Praca i Zabezpieczenie Społeczne" 1975, nr 2.

Banaszak B., Konstytucja Rzeczypospolitej Polskiej. Komentarz, Warszawa 2009.

Baran K.W., Komentarz do ustawy o zwiqzkach zawodowych, [w:] K.W. Baran, Zbiorowe prawo pracy. Komentarz, https://sip.lex.pl/\#/komentarz/587710503/507943 (dostęp: 19.09.2017).

Baran K.W., O systematyce i delimitacji niepracowniczych stosunków zatrudnienia. Z zagadnień prawa pracy i prawa socjalnego, [w:] Z. Kubot, T. Kuczyński (red.), Księga jubileuszowa Profesora Herberta Szurgacza, Warszawa 2011.

Baran K.W., O zakresie podmiotowym nauki prawa pracy na tle niepracowniczych stosunków zatrudnienia, [w:] L. Florek, Ł. Pisarczyk (red.), Wspótczesne problemy prawa pracy i ubezpieczeń społecznych. XVIII Zjazd Katedr i Zakładów Prawa Pracy i Ubezpieczeń Społecznych, Warszawa 2011.

Baran K.W., Refleksje o zakresie prawa koalicji w projekcie nowelizacji ustawy o zwiqzkach zawodowych, „Monitor Prawa Pracy” 2016, nr 6.

Baran K.W., Zatrudnienie tymczasowe a zbiorowe prawo pracy, [w:] A. Sobczyk (red.), Z problematyki zatrudnienia tymczasowego, https://sip.lex.pl/\#/monografia/369236017/5 (dostęp: 19.09.2017).

Baran K.W., Zbiorowe prawo pracy, Kraków 2002.

Baran K.W., Zbiorowe prawo pracy a zatrudnienie niepracownicze, [w:] K.W. Baran (red.), System prawa pracy, t. 7: Zatrudnienie niepracownicze, Warszawa 2015.

Baran K.W. (red.), Kodeks pracy. Komentarz, Warszawa 2012. 
Baran K.W. (red.), Kodeks pracy. Komentarz, Warszawa 2016.

Baran K.W. (red.), Zarys systemu prawa pracy, t. 1: Część ogólna prawa pracy, Warszawa 2010.

Barta J., Fajgielski P., Markiewicz R., Ochrona danych osobowych, Kraków 2004.

Bielak E., Lewandowski H. (red.), Granice liberalizacji prawa prac. Problemy zabezpieczenia spotecznego, Łódź 2003.

Bielak-Jomaa E., Ochrona danych osobowych bezrobotnych i poszukujqcych pracy, [w:] T. Wyka, A. Nerka (red.), Ochrona danych osobowych podmiotów objętych prawem pracy i prawem ubezpieczeń społecznych, Warszawa 2012.

Bieliński A., Giedrewicz-Niewińska A., Szabłowska-Juckiewicz M. (red.), Elastyczne formy zatrudnienia i organizacji czasu pracy, Warszawa 2015.

Bieniek G. (red.), Komentarz do kodeksu cywilnego. Księga trzecia. Zobowiq̨zania, t. 2, Warszawa 2007.

Bińczycka-Majewska T., Konstrukcja zabezpieczenia ryzyka starości w nowym systemie prawnym, [w:] T. Bińczycka-Majewska (red.), Konstrukcje prawa emerytalnego, Kraków 2004.

Bocianowski P., Konieczne zmiany w polskim kodeksie pracy w zakresie umów na czas określony - wyrok Trybunatu Sprawiedliwości UE z 13 marca 2014 r. w sprawie C-38/13, „Praca i Zabezpieczenie Społeczne" 2014, nr 4.

Boruta I., Podmioty prawa do urlopu wychowawczego i innych „rodzicielskich” praw pracowniczych, „Praca i Zabezpieczenie Społeczne” 1997, nr 2.

Boruta I., W sprawie przyszłości prawa pracy, „Praca i Zabezpieczenie Społeczne” 2003, nr 4.

Brzozowski A., Odpowiedzialność przyjmujq̨cego zamówienie za wady dzieła, Warszawa 1986.

Brzozowski A., Umowa o dzieło, [w:] J. Rajski (red.), Prawo zobowiq̨zań - część szczegółowa, t. 7, Warszawa 2003.

Brzozowski A., Safjan M., Skowrońska-Bocian E., Witold Czachórski. Zobowiqzzania. Zarys wykładu, Warszawa 2002.

Chobot A., Nowe formy zatrudnienia. Kierunki rozwoju i nowelizacji, Warszawa 1997.

Chobot A., Pachciarek K., Prawa i obowiqzki agencji pracy tymczasowej i pracodawcy użytkownika wobec pracownika tymczasowego, „Praca i Zabezpieczenie Społeczne” 2005, nr 1.

Ciepła H., Art. 829, [w:] H. Dolecki, T. Wiśniewski (red.), Kodeks postępowania cywilnego. Komentarz, t. 4, art. 730-1088, https://sip-1lex-1pl-1004153yx0674.han3.lib.uni.lodz.pl/\#/komentarz/587310133/171035 (dostęp: 19.09.2017).

Ciszewski J. (red.), Kodeks cywilny. Komentarz, Warszawa 2013.

Ciupa S.W., Umowa o pracę zawierana na czas nieobecności (zastępstwo) pracownika, „Monitor Prawniczy" 2002, nr 24.

Ciupa S.W., Umowa o teleprace, „Monitor Prawa Pracy” 2005, nr 3.

Ciupa S.W., Zatrudnienie pracowników w formie telepracy wedtug kodeksu pracy. Część 1, „Monitor Prawa Pracy" 2007, nr 11.

Cudowski B., Reprezentacja praw i interesów pracowniczych w sporach zbiorowych pracy, [w:] H. Lewandowski (red.), Polskie prawo pracy w okresie transformacji w oświetleniu prawa wspólnotowego, Warszawa 1997.

Cudowski B., Reprezentacja zatrudnionych w sporach zbiorowych pracy (de lege lata $i$ de lege ferenda), [w:] A. Wypych-Żywicka, M. Tomaszewska, J. Stelina (red.), Zbiorowe prawo pracy XXI wieku, Gdańsk 2010. 
Cudowski B., Iwulski J. (red.), Z aktualnych zagadnień prawa pracy i zabezpieczenia społecznego. Księga Jubileuszowa Profesora Waleriana Sanetry, Białystok 2013.

Czerniak-Swędzioł J., Pracowniczy obowiq̨zek ochrony interesów gospodarczych pracodawcy, Warszawa 2007.

Danieluk B., Zastosowanie regresji logistycznej w badaniach eksperymentalnych, „Psychologia Społeczna" 2010, nr 5.

Daszczyńska A., Prawo pracownika tymczasowego do wypoczynku, [w:] A. Sobczyk (red.), Z problematyki zatrudnienia tymczasowego, https://sip-1lex-1pl-100415308001a.han3.lib.uni. lodz.pl/\#/monografia/369236017/53 (dostęp: 19.09.2017).

Depta R., Teleworking jako alternatywna forma pracy w przyszłości, „Praca i Zabezpieczenie Społeczne" 1998, nr 4.

Dolecki H., Sokołowski T. (red.), Kodeks rodzinny i opiekuńczy. Komentarz, https://sip-1lex-1pl-1004153yx161d.han3.lib.uni.lodz.pl/\#/komentarz/587292531/152280 (dostęp: 19.09.2017).

Dörre-Nowak D., Zatrudnienie tymczasowe a regulacje dyskryminacyjne, [w:] A. Sobczyk (red.), Z problematyki zatrudnienia tymczasowego, https://sip-1lex-1pl-100415308001a.han3.lib. uni.lodz.pl/\#/monografia/369236017/41 (dostęp: 19.09.2017).

Dral A., Problemy liberalizacji, deregulacji i uelastyczniania ochrony trwałości stosunku pracy w polskim prawie, „Praca i Zabezpieczenie Społeczne” 2009, nr 5.

Driczynski S., Elastyczność pojęcia czas pracy, Szczecin 2002.

Drozd A., Ustawa o ochronie danych osobowych. Komentarz. Wzory pism i przepisy, Warszawa 2008.

Dubowik A., Rady pracowników i zwiq̨zki zawodowe jako reprezentanci zbiorowych interesów pracowników na szczeblu zakładowym, [w:] Z. Hajn (red.), Zwiq̨zkowe przedstawicielstwo pracowników zakładu pracy, Warszawa 2012.

Dubowik A., Szczególna ochrona przed wypowiedzeniem stosunku pracy, „Praca i Zabezpieczenie Społeczne" 1997, nr 3.

Duchna S., Paluszkiewicz M., Podporzq̨dkowanie telepracownika w stosunku pracy, „Zeszyty Prawnicze UKSW" 2013, nr 13.1.

Dyląg W., Prawo do odpoczynku jako przejaw funkcji ochronnej prawa pracy, [w:] M. Bosak (red.), Funkcja ochronna prawa pracy a wyzwania wspótczesności, Warszawa 2014.

Fajgielski P., Zgoda na przetwarzanie danych osobowych, [w:] G. Sibiga, X. Konarski (red.), Ochrona danych osobowych. Aktualne problemy i nowe wyzwania, Warszawa 2007.

Florek L. (red.), Czas pracy, https://sip-1lex-1pl-1004153yx161d.han3.lib.uni.lodz.pl/\#/monografia/369223854/4 (dostęp: 19.09.2017).

Florek L., Czas pracy i urlopy wypoczynkowe w prawie europejskim, „Praca i Zabezpieczenie Społeczne" 1999, nr 2.

Florek L., Europejskie prawo pracy i ubezpieczeń społecznych, Warszawa 1996.

Florek L., Granice liberalizacji prawa pracy, [w:] E. Bielak, H. Lewandowski (red.), Granice liberalizacji prawa pracy. Problemy zabezpieczenia społecznego. Materiały z XIV Zjazdu Katedr (Zakładów) Prawa Pracy i Ubezpieczeń Społecznych, Łódź 2003.

Florek L., Kodyfikacyjne problemy prawa pracy, „Państwo i Prawo” 2007, nr 11.

Florek L., Konstytucyjne gwarancje uprawnień pracowniczych, „Państwo i Prawo” 1997, nr 11/12. 
Florek L., Konstytucyjne i prawnomiędzynarodowe podstawy ochrony trwałości stosunku pracy, [w:] G. Goździewicz (red.), Ochrona trwałości stosunku pracy w społecznej gospodarce rynkowej, Warszawa 2010.

Florek L., Pojęcie i zakres wolności zwiq̨zkowej, [w:] A. Wypych-Żywicka, M. Tomaszewska, J. Stelina (red.), Zbiorowe prawo pracy XXI wieku, Gdańsk 2010.

Florek L., Prawna ochrona pracowników, Warszawa 1990.

Florek L., Prawne formy elastycznych form zatrudnienia, [w:] L. Machol-Zajda (red.), Elastyczne formy zatrudnienia sposobem na efektywność firm, Warszawa 2001.

Florek L., Rozwiq̨zanie i wygaśnięcie stosunku pracy, [w:] M. Matey-Tyrowicz, T. Zieliński (red.), Prawo pracy RP w obliczu przemian, Warszawa 2006.

Florek L., Swoboda umów w prawie pracy, [w:] M. Seweryński, J. Stelina (red.), Wolność i sprawiedliwość w zatrudnieniu. Księga pamiq̨tkowa poświęcona Prezydentowi Rzeczypospolitej Polskiej Profesorowi Lechowi Kaczyńskiemu, Gdańsk 2012.

Florek L., Ustawa i umowa w prawie pracy, Warszawa 2010.

Florek L., Znaczenie układów zbiorowych pracy, [w:] Z. Góral (red.), Układy zbiorowe pracy w stulecie urodzin Profesora Wacława Szuberta, Warszawa 2013.

Florek L. (red.), Kodeks pracy. Komentarz, Warszawa 2005.

Florek L., Seweryński M., Międzynarodowe prawo pracy, Warszawa 1988.

Frączek M., Łajeczko M., Praca tymczasowa - pytania i odpowiedzi, „Służba Pracownicza” 2005, nr 2.

Generalny Inspektor Danych Osobowych, Sprawozdanie z dziatalności Generalnego Inspektora Ochrony Danych Osobowych za rok 2004, www.giodo.gov.pl/plik/t/pdf/j/pl/id_p/727.pdf, s. 171-173 (dostęp: 2.01.2017).

Gersdorf M., Cechy charakterystyczne stosunku pracy po nowelizacji kodeksu pracy, „Praca i Zabezpieczenie Społeczne" 2002, nr 10.

Gersdorf M., O przyczynowości zawarcia i rozwiqzzania umowy na czas określony, [w:] A. Sobczyk (red.), Stosunki zatrudnienia w dwudziestoleciu społecznej gospodarki rynkowej, Warszawa 2010.

Gersdorf M., Podstawowe dylematy zwiqzane z rozwojem prawa pracy w okresie transformacji ustrojowej, „Praca i Zabezpieczenie Społeczne” 2003, nr 5.

Gersdorf M., Prawo zatrudnienia, Warszawa 2013.

Gersdorf M., Zatrudnienie pracowników w formie telepracy, „Praca i Zabezpieczenie Społeczne” 2008, nr 5.

Gersdorf M. (red.), Zatrudnieni i zatrudniający na aktualnym rynku pracy, Warszawa 2012.

Gersdorf M., Rączka K., Raczkowski M. (red.), Kodeks pracy. Komentarz, Warszawa 2012.

Gładoch M., Ustawa o informowaniu pracowników i przeprowadzaniu z nimi konsultacji. Komentarz, Toruń 2007.

Głogowska M., Dopuszczalność uzyskania informacji o karalności od kandydata na pracownika przez pracodawcę, [w:] A. Świątkowski (red.), Studia z zakresu prawa pracy i polityki społecznej, Kraków 2010.

Gniewek E. (red.), Kodeks cywilny. Komentarz. Księga trzecia: Zobowiq̨zania, Warszawa 2006.

Godlewska-Bujok B., Płaca minimalna - druga strona medalu, „Praca i Zabezpieczenie Społeczne" 2007, nr 4. 
Gołaczyński J. (red.), Ustawa o świadczeniu usług droga elektronicznq. Komentarz, https://sip-1lex-1pl-1004153yx161d.han3.lib.uni.lodz.pl/\#/komentarz/587247057/44497 (dostęp: 19.09.2017).

Goździewicz G., Przemiany w zakresie ochrony trwałości stosunku pracy w Polsce - wybrane zagadnienia, [w:] G. Goździewicz (red.), Ochrona trwałości stosunku pracy w społecznej gospodarce rynkowej, Warszawa 2010.

Goździewicz G., Charakter porozumień zbiorowych w prawie pracy, „Praca i Zabezpieczenie Społeczne" 1998, nr 3.

Goździewicz G., Pozycja prawna podmiotów w zbiorowym prawie pracy, [w:] A.M. Świątkowski (red.), Ochrona praw człowieka w świetle przepisów prawa pracy i zabezpieczenia społecznego. Referaty i wystapienia zgłoszone na XVII Zjazd Katedr/Zakładów Prawa Pracy i Zabezpieczenia Społecznego, Kraków 7-9 maja 2009 r., Warszawa 2009.

Goździewicz G., Układy zbiorowe pracy jako źródło prawa pracy, [w:] Z. Góral (red.), Układy zbiorowe pracy w stulecie urodzin Profesora Wactawa Szuberta, Warszawa 2013.

Goździewicz G., Wpływ działań zbiorowych na indywidualne stosunki pracy, [w:] H. Lewandowski (red.), Polskie prawo pracy w okresie transformacji w oświetleniu prawa wspólnotowego, Warszawa 1997.

Góra-Błaszczykowska A., Postępowanie w sprawach o ustalenie istnienia umowy o pracę - uwagi, „Monitor Prawa Pracy” 2005, nr 6.

Góral Z., Art. 411', [w:] K.W. Baran (red.), Kodeks pracy. Komentarz, https://sip.lex.pl/\#/komentarz/587329059/490693 (dostęp: 19.09.2017).

Góral Z., Art. 45 k.p., [w:] K.W. Baran (red.), Kodeks pracy. Komentarz, https://sip-1lex-1pl-1004153yx0ff8.han3.lib.uni.lodz.pl/\#/komentarz/587329063/490697 (dostęp: 19.09.2017).

Góral Z., Art. 50 k.p., [w:] K.W. Baran (red.), Kodeks pracy. Komentarz, https://sip-1lex-1pl-1004153yx0ff8.han3.lib.uni.lodz.pl/\#/komentarz/587329068/490702 (dostęp: 19.09.2017).

Góral Z., Art. 100 k.p., [w:] K.W. Baran (red.), Kodeks pracy. Komentarz, https://sip-1lex-1pl-1004153yx0674.han3.lib.uni.lodz.pl/\#/komentarz/587329143/490776 (dostęp: 19.09.2017).

Góral Z., Najnowsze tendencje w polskim prawie pracy na tle integracji europejskiej, „Prace Naukowe Wydziału Administracji. Szkoła Wyższa im. Pawła Włodkowica w Płocku. Zeszyty Naukowe" 2003.

Góral Z., Odpowiedzialność porzq̨dkowa pracowników w świetle najnowszego orzecznictwa sq̨dowego, „Praca i Zabezpieczenie Społeczne” 2002, nr 11.

Góral Z., O kodeksowym katalogu zasad indywidualnego prawa pracy, Warszawa 2011.

Góral Z., Swoboda doboru pracowników i wolność pracy, [w:] H. Lewandowski (red.), Polskie prawo pracy w okresie transformacji w oświetleniu prawa wspólnotowego, Warszawa 1997.

Góral Z., Swoboda nawiqzania stosunku pracy jako jedna z podstawowych zasad prawa pracy, [w:] Z. Niedbała, M. Skąpski (red.), Problemy zatrudnienia we współczesnym ustroju pracy. Księga jubileuszowa na 55-lecie pracy naukowej i dydaktycznej Profesora Włodzimierza Piotrowskiego, Poznań 2009.

Góral Z., Ustawa o promocji zatrudnienia i instytucjach rynku pracy. Komentarz, https://sip-1lex-1pl-1004153yx161d.han3.lib.uni.lodz.pl/\#/komentarz/587300338/508259 (dostęp: 19.09.2017). 
Góral Z. (red.), Z zagadnień wspótczesnego prawa pracy. Księga jubileuszowa Profesora Henryka Lewandowskiego, Warszawa 2009.

Górnicz-Mulcahy A., Lewandowicz-Machnikowska M., Skutki prawne wypowiedzenia przez pracownika umowy na czas określony nieprzewidującej prawa do wypowiedzenia, „Monitor Prawa Pracy" 2012, nr 12.

Grabowski M., Zając A., Dane, informacja, wiedza - próba definicji, www.uci.agh.edu.pl/uczelnia/ tad/PSI9/2.rtf (dostęp: 19.09.2017).

Grzebyk P., „Osoby wykonujqce pracę zarobkowq” a wolność koalicji. Uwagi na marginesie projektu zmieniajacego ustawę o zwiq̨zkach zawodowych z 22 marca 2016 r., „Praca i Zabezpieczenie Społeczne" 2016, nr 5.

Grzegorczyk T., Kodeks postępowania w sprawach o wykroczenia, Warszawa 2008.

Grzybowski S., O przepisach kodeksu cywilnego dotyczących zlecenia, „Nowe Prawo” 1967, nr 10. Grzybowski S., System prawa cywilnego, t. 1, Wrocław-Warszawa-Kraków-Gdańsk-Łódź 1985.

Grzymkowski R., Aktualne problemy oraz perspektywy rozwoju pracy nakładczej (I), „Praca i Zabezpieczenie Społeczne" 1970, nr 11.

Grzymkowski R., Aktualne problemy oraz perspektywy rozwoju pracy nakładczej (II), „Praca i Zabezpieczenie Społeczne" 1970, nr 12.

Gujski W., Jeszcze o art. 22 § $1^{1}$ k.p., „Prawo Pracy” 1996, nr 11.

Gujski W., Praca nakładcza (chałupnicza), „Prawo Pracy” 1996, nr 7.

Gujski W., Volenti non fit iniuria, „Prawo Pracy” 1996, nr 9.

Hajn Z., Aspekty prawne relacji: pracownik-pracodawca w procesie przemian społeczno-gospodarczych i integracji europejskiej, [w:] H. Lewandowski, J. Sokołowski (red.), Pracodawca-pracownik w procesie przemian gospodarki polskiej i integracji z Uniq Europejska, Łódź 2000.

Hajn Z., Prawo zrzeszania się w zwiq̨zkach zawodowych - prawo pracowników, czy prawo ludzi pracy?, [w:] A. Wypych-Żywicka, M. Tomaszewska, J. Stelina (red.), Zbiorowe prawo pracy XXI wieku, Gdańsk 2010.

Hajn Z., Regulacja pozycji prawnej pracownika i pracodawcy a funkcje prawa pracy, „Praca i Zabezpieczenie Społeczne" 2000, nr 10.

Iwulski J., Sanetra W. (red.), Kodeks pracy. Komentarz, Warszawa 2011.

Jabłoński A., Prawo do zasitku chorobowego osoby wykonującej równocześnie pracę w ramach kilku tytułów ubezpieczeniowych, [w:] Z. Kubot, T. Kuczyński (red.), Z zagadnień prawa pracy i prawa socjalnego. Księga jubileuszowa Profesora Herberta Szurgacza, Warszawa 2011.

Jackowiak U., Ochrona danych osobowych w prawie pracy, „Praca i Zabezpieczenie Społeczne” 1998, $\mathrm{nr} 7 / 8$.

Jackowiak U., Piankowski M., Stelina J., Uziak W., Wypych-Żywicka A., Zieleniecki M. (red.), Kodeks pracy z komentarzem, Gdynia 2004.

Jarzyński W., Rzońca A., Stolarczyk P., Wojciechowski W., Płaca minimalna zabija miejsca pracy, Analiza FOR 2011, nr 2, www.for.org.pl/pl/a/1861,Analiza-22011-Placa-minimalna-zabijamiejsca-pracy (dostęp: 19.09.2017).

Jasińska J., Fik P., O zmianie ustawy o minimalnym wynagrodzeniu za pracę, „Praca i Zabezpieczenie Społeczne” 2016, nr 9.

Jaśkiewicz W., Jackowiak C., Piotrowski W., Prawo pracy w zarysie, Warszawa 1984. 
Jaśkowski K., Art. 47¹, [w:] K. Jaśkowski, E. Maniewska (red.), Komentarz aktualizowany do kodeksu pracy, https://sip-1lex-1pl-1004153yx0ff8.han3.lib.uni.lodz.pl/\#/komentarz/587260382/536354 (dostęp: 19.09.2017).

Jaśkowski K., Nowa regulacja układów zbiorowych pracy, „Prawo Pracy” 1998, nr 1.

Jaśkowski K., Nowa umowa o pracę na czas określony, „Praca i Zabezpieczenie Społeczne” 2015, $\mathrm{nr} 11$.

Jaśkowski K., Układy zbiorowe pracy, Warszawa 1994.

Jaśkowski K., Maniewska E. (red.), Komentarz aktualizowany do kodeksu pracy, https://sip-1lex-1pl-1004153yx161d.han3.lib.uni.lodz.pl/\#/komentarz/587713884/536306 (dostęp: 19.09.2017).

Jerzak M., Deregulacja rynku pracy w Polsce i Unii Europejskiej, „Materiały i Studia NBP”, 2004, nr 176.

Jończyk J., Prawo pracy, Warszawa 1994.

Jończyk J., Promocja zatrudnienia i przeciwdziałanie bezrobociu, „Praca i Zabezpieczenie Spoteczne” 2004, nr 9.

Jończyk J., Rodzaje i formy zatrudnienia, „Praca i Zabezpieczenie Społeczne” 2012, nr 6.

Kamińska-Pietnoczko A., Dane osobowe w zatrudnieniu, „Monitor Prawa Pracy” 2015, nr 1.

Kasińska H., Rozwiq̨zanie terminowych umów o pracę, „Praca i Zabezpieczenie Społeczne” 1980, nr 6.

Kasprowicz Ł., Sens i znaczenie wynagrodzenia minimalnego, „Praca i Zabezpieczenie Społeczne" 2013, nr 5.

Kiersztyn A., Prekariat i postawy obywatelskie Polaków, „Polityka Społeczna” 2004, nr 4.

Koczur S., Differentia specifica „podporzq̨dkowania” właściwego dla stosunku pracy a umów cywilnoprawnych, „Monitor Prawa Pracy” 2015, nr 2.

Koczur S., Ustalenie istnienia stosunku pracy przez sq̨d karny - wokół zastrzeżeń interpretacyjnych na gruncie art. 220 KK, „Monitor Prawa Pracy” 2013, nr 11.

Koczur W., Zasiłek chorobowy jako świadczenie z tytułu czasowej niezdolności do pracy pracowników tymczasowych, [w:] A. Sobczyk (red.), Z problematyki zatrudnienia tymczasowego, https://sip-1lex-1pl-100415308001a.han3.lib.uni.lodz.pl/\#/monografia/369236017/67 (dostęp: 19.09.2017).

Kolasa A., Zdaniem Państwowej Inspekcji Pracy, „Praca i Zabezpieczenie Społeczne” 1999, nr 3.

Kolasiński K., Prawo pracy znowelizowane, Toruń 1996.

Kopaczyńska-Pieczniak K., Art. 734, [w:] A. Kidyba (red.), Kodeks cywilny. Komentarz, t. 3: Zobowiq̨zania - część szczególna, https://sip-1lex-1pl-1004153yx0674.han3.lib.uni.lodz.pl/\#/ komentarz/587286617/462810 (dostęp: 19.09.2017).

Kopaczyńska-Pieczniak K., Art. 746, [w:] A. Kidyba (red.), Kodeks cywilny. Komentarz, t. 3: Zobowiq̨zania - część szczególna, https://sip-1lex-1pl-1004153yx0ff8.han3.lib.uni.lodz.pl/\#/ komentarz/587286629/462822 (dostęp: 19.09.2017).

Kopaczyńska-Pieczniak K., Art. 760, [w:] A. Kidyba (red.), Kodeks cywilny. Komentarz, t. 3: Zobowiq̨zania - część szczególna, https://sip-1lex-1pl-1004153yx0674.han3.lib.uni.lodz.pl/\#/ komentarz/587286645/462838 (dostęp: 19.09.2017).

Kostrzewa P., Art. 12, [w:] P. Kostrzewa, Ustawa o systemie ubezpieczeń społecznych. Komentarz, https://sip-1lex-1pl-1004153yx0cd3.han3.lib.uni.lodz.pl/\#/komentarz/587704619/502059 (dostęp: 19.09.2017). 
Kostrzewa P., Ustawa o systemie ubezpieczeń społecznych. Komentarz, Komentarze https://sip-1lex-1pl-1004153yx161d.han3.lib.uni.lodz.pl/\#/komentarz/587704605/502045 (dostęp: 19.09.2017). Kotowski W., Kurzępa B., Wykroczenia pozakodeksowe. Komentarz, Warszawa 2008.

Krajewski M., Dobrowolne ubezpieczenie emerytalne i rentowe na gruncie art. 7 i 10 ustawy o systemie ubezpieczeń społecznych, „Praca i Zabezpieczenie Społeczne” 2014, nr 5.

Książek D., Telepraca, „Praca i Zabezpieczenie Społeczne” 2004, nr 7.

Kubot Z., Kierownictwo pracodawcy wobec pracowników wypożyczonych, „Praca i Zabezpieczenie Społeczne" 2002, nr 4.

Kubot Z., Szczególne formy zatrudnienia i samozatrudnienia, [w:] Z. Kubot (red.), Szczególne formy zatrudnienia, Wrocław 2000.

Kubot Z., Umowa o pracę na zastępstwo, „Praca i Zabezpieczenie Społeczne” 2003, nr 2.

Kubot Z., Urlop wypoczynkowy w zatrudnieniu niepracowniczym typu cywilnoprawnego, „Praca ¡ Zabezpieczenie Społeczne" 2002, nr 9.

Kuczyński T., O właściwościach pracowniczego obowiązku dbałości o dobro zakładu pracy, „Praca i Zabezpieczenie Społeczne" 2004, nr 7.

Kurzynoga M., Prawo do wszczęcia sporu zbiorowego oraz prawo do akcji zbiorowych osób zarobkowo wykonujacych pracę niebędących pracownikami, „Monitor Prawa Pracy” 2014, nr 12.

Lach D.E., Nowe formy zatrudnienia i zabezpieczenia społecznego w zakresie ochrony zdrowia, „Praca i Zabezpieczenie Społeczne” 2006, nr 5.

Latos-Miłkowska M., Art. 67 ${ }^{14}$, [w:] M. Derlacz-Wawrowska, M. Latos-Mitkowska, Kodeks pracy. Komentarz w perspektywie europejskiej i międzynarodowej, https://sip-1lex-1pl-1004153yx0674.han3.lib.uni.lodz.pl/\#/komentarz/587713118/510558 (dostęp: 19.09.2017).

Lewandowski H., Instytucja próby w prawie pracy, Warszawa 1968.

Lewandowski H., Uwagi o roli umowy we wspótczesnym prawie pracy, [w:] M. Matey-Tyrowicz, L. Nawacki, B. Wagner (red.), Prawo pracy a wyzwania XXI wieku. Księga Jubileuszowa Profesora Tadeusza Zielińskiego, Warszawa 2002.

Lewandowski H., Uwagi w sprawie podziału umowy o pracę na rodzaje, [w:] H. Lewandowski (red.), Studia z prawa pracy, Warszawa 1988.

Lewandowski H., Zbliżenie polskiego indywidualnego prawa pracy do prawa wspólnotowego (Unii Europejskiej), [w:] H. Lewandowski, J. Sokołowski (red.), Pracodawca-pracownik w procesie przemian gospodarki polskiej i integracji z Uniq Europejską, Łódź 2000.

Lewandowski H., Góral Z., Przeciwdziałanie stosowaniu umów cywilnoprawnych do zatrudnienia pracowniczego, „Praca i Zabezpieczenie Społeczne” 1996, nr 12.

Liszcz T., Nietypowe stosunki pracy w projekcie kodeksu pracy, [w:] Z. Niedbała, M. Skąpski (red.), Problemy zatrudnienia we wspótczesnym ustroju pracy. Księga jubileuszowa na 55-lecie pracy naukowej i dydaktycznej Profesora Włodzimierza Piotrowskiego, Poznań 2009.

Liszcz T., Odpowiedzialność odszkodowawcza pracodawcy wobec pracownika, „Praca i Zabezpieczenie Społeczne" 2008, nr 12.

Liszcz T., Prawna ochrona niepracowniczego zatrudnienia na podstawie umowy według projektu kodeksu pracy, [w:] A. Patulski, K. Walczak (red.), Jedność w różnorodności. Studia z zakresu prawa pracy, zabezpieczenia społecznego i polityki społecznej. Księga pamiątkowa dedykowana Profesorowi Wojciechowi Muszalskiemu, Warszawa 2009. 
Liszcz T., Prawo pracy, Warszawa 2008.

Liszcz T., Swoboda umów w prawie pracy, [w:] M. Seweryński, J. Stelina (red.), Wolność i sprawiedliwość w zatrudnieniu. Księga pamiątkowa poświęcona Prezydentowi Rzeczypospolitej Polskiej Profesorowi Lechowi Kaczyńskiemu, Gdańsk 2012.

Loga J., Formy ochrony trwałości stosunku pracy, [w:] H. Lewandowski (red.), Studia z prawa pracy, Warszawa 1988.

Loga J., Uwagi na tle projektu zmiany kodeksu pracy, „Praca i Zabezpieczenie Społeczne” 1981, nr 5/6. Longchamps de Berier R., Polskie prawo cywilne - zobowiqzania, Lwów 1939, Poznań 1999 (wydanie anastatyczne).

Ludera-Ruszel A., Ustawa z dnia 3 grudnia 2010 r. o wdrożeniu niektórych przepisów Unii Europejskiej w zakresie równego traktowania jako przykład realizacji przez Polskę polityki równości Unii Europejskiej, „Analizy i Studia Europejskie” 2011, nr 1(7).

Ludwiczak W., Umowa zlecenia, Poznań 1955.

Łapiński K., Godziwe wynagrodzenie za pracę, „Monitor Prawa Pracy” 2011, nr 12.

Łapiński K., Umowa o pracę na czas określony w polskim i unijnym prawie pracy, https://sip-1lex-1pl-1004153yx161d.han3.lib.uni.lodz.pl/\#/monografia/369228055/4 (dostęp: 19.09.2017).

Łapiński K., Uprawnienia pracownika w razie niezgodnego z prawem wypowiedzenia umowy o pracę na czas określony przez pracodawcę, [w:] K. Łapiński, Umowa o pracę na czas określony w polskim i unijnym prawie pracy, https://sip-1lex-1pl-1004153yx0ff8.han3.lib.uni.lodz. pl/\#/monografia/369228055/38 (dostęp: 19.09.2017).

Łętowska E., Podstawy prawa cywilnego, Warszawa 1997.

Łętowska E., Umowy - mitologia równości, [w:] S. Wronkowska, M. Zieliński (red.), Szkice z teorii prawa i szczegółowych nauk, Poznań 1990.

Machnikowski P., Swoboda umów według artykułu $353^{1}$ kodeksu cywilnego. Konstrukcja prawna, Warszawa 2005.

Machol-Zajda L., Telepraca - nowa forma zatrudnienia, [w:] K.W. Frieske (red.), Deregulacja polskiego rynku pracy, Warszawa 2003.

Makowski D., Nowa ustawa o Państwowej Inspekcji Pracy, „Praca i Zabezpieczenie Społeczne” 2007, nr 6.

Makowski D., Praca tymczasowa jako nietypowa forma zatrudnienia, Warszawa 2006.

Makowski D., Rozwój nietypowych form zatrudnienia w prawie państw Unii Europejskiej, [w:] H. Lewandowski, J. Sokołowski (red.), Pracodawca-pracownik w procesie przemian gospodarki polskiej i integracji z Uniq̨ Europejska, Łódź 2000.

Małysz F., Chałupnictwo. Umowa i wynagradzanie, „Służba Pracownicza” 2006, nr 4.

Małysz F., Treść i forma umowy o pracę, „Służba Pracownicza” 2009, nr 9.

Małysz F., Wybrane uprawnienia pracownicze osób wykonujących pracę nakładczą, „Polityka Społeczna" 2001, nr 8.

Matey-Tyrowicz M., Nietypowe formy zatrudnienia - dyrektywy i praktyka UE, [w:] K.W. Frieske (red.), Deregulacja polskiego rynku pracy, Warszawa 2003.

Matey-Tyrowicz M., Zieliński T. (red.), Prawo pracy RP w obliczu przemian, Warszawa 2006.

Matusiak-Wojnicz A., Wojnicz P., Egzekucyjne i nieegzekucyjne potrącenia z wynagrodzeń, Wrocław 2012. 
Mitrus L., Czterdzieści lat obowiq̨zywania kodeksu pracy oraz perspektywy jego rozwoju, „Kwartalnik Prawa Prywatnego", 2015, vol. 24(4).

Mitrus L., Kilka uwag o rozwiq̨zaniu za wypowiedzeniem umowy o pracę na czas określony, [w:] A. Sobczyk (red.), Stosunki zatrudnienia w dwudziestoleciu społecznej gospodarki rynkowej, Warszawa 2010.

Mitrus L., Ochrona pracowników tymczasowych w świetle prawa unijnego a prawo polskie, [w:] A. Sobczyk (red.), Z problematyki zatrudnienia tymczasowego, Warszawa 2011.

Mitrus L., Projekt nowelizacji kodeksu pracy dotyczący umów terminowych, „Monitor Prawa Pracy" 2015, nr 6.

Moszyński M., Praca tymczasowa - aspekty ekonomiczne i zatrudnieniowe, „Praca i Zabezpieczenie Społeczne" 2004, nr 10.

Mucha A., Telepraca jako nowoczesna forma i organizacja zatrudnienia, „Radca Prawny” 2000, nr 5.

Musiała A., Problematyka kwalifikacji umowy o zatrudnienie jako umowy o pracę bądź umowy cywilnoprawnej o świadczenie usług, „Monitor Prawa Pracy” 2015, nr 1.

Musiała A., Zatrudnienie niepracownicze, Warszawa 2011.

Musiała A., Jankowiak J., Kiedy zatrudniony ma status pracownika, „Służba Pracownicza” 2007, nr 4.

Muszalski W. (red.), Kodeks pracy. Komentarz, Warszawa 2001.

Mycko-Katner I., Umowa agencyjna, Warszawa 2012.

Myszka M., Glosa do wyroku Sądu Najwyższego z 7 września 2005 r. (II PK 29/04) w sprawie niedopuszczalności zawierania długoterminowych umów o pracę na czas określony z możliwościq ich wcześniejszego wypowiedzenia, „Praca i Zabezpieczenie Społeczne” 2006, nr 8.

Nasiłowski M., System rynkowy: podstawy mikro- i makroekonomii, Warszawa 2011.

Nerka A., Problematyka zgody pracownika na przetwarzanie danych osobowych, [w:] T. Wyka, A. Nerka (red.), Granice ochrony danych osobowych w stosunkach pracy, Warszawa 2009.

Niedbała Z. (red.), Prawo pracy, Warszawa 2010.

Nowacki J., Odpowiedzialność pracownika za naruszenie porzq̨dku i dyscypliny pracy, [w:] R. Korolec, J. Pacho (red.), Nowe prawo pracy, Warszawa 1975.

Nowak M., Wynagrodzenie za prace, https://sip-1lex-1pl-1004153yx161d.han3.lib.uni. lodz.pl/\#/ monografia/369288048/4 (dostęp: 19.09.2017).

Ogiegło L., Zlecenie, [w:] J. Rajski (red.), Prawo zobowiq̨zań - część szczegółowa, t. 7, Warszawa 2003.

OlejniczakA., Art. 353¹, [w:] A. Kidyba (red.), Kodeks cywilny. Komentarz, t3: Zobowiqzzania - częśćogólna, https://sip-1lex-1pl-1004153yx0674.han3.lib.uni.lodz.pl/\#/komentarz/587264116/167837 (dostęp: 19.09.2017).

OlejniczakA., Art. 355, [w:] A. Kidyba (red.), Kodeks cywilny. Komentarz, t. 3: Zobowiqzzania-część ogólna, https://sip-1lex-1pl-1004153yx0674.han3.lib.uni.lodz.pl/\#/komentarz/587264118/167839 (dostęp: 19.09.2017).

Opolski K., Społeczno-ekonomiczne aspekty dokształcania i doskonalenia zawodowego, „Praca i Zabezpieczenie Społeczne" 1981, nr 5/6.

Orłowski G., Umowa zlecenia a „miękkie domniemanie stosunku pracy”, „Monitor Prawa Pracy” 2007, nr 3. 
Pacho J., Stosunek pracy i jego podmioty, [w:] R. Korolec, J. Pacho (red.), Nowe prawo pracy, Warszawa 1975.

Paluszkiewicz M., Agencje zatrudnienia po nowelizacji ustawy o promocji zatrudnienia i instytucjach rynku pracy, „Praca i Zabezpieczenie Społeczne” 2014, nr 6.

Paluszkiewicz M., Art. 19(b), [w:] Z. Góral (red.), Ustawa o promocji zatrudnienia i instytucjach rynku pracy. Komentarz, https://sip-1lex-1pl-1004153yx0674.han3.lib.uni.lodz.pl/\#/komentarz/587300374/508298 (dostęp: 19.09.2017).

Paluszkiewicz M., Ogólna charakterystyka konstrukcji zatrudnienia tymczasowego w polskim prawie pracy, [w:] M. Paluszkiewicz, Zatrudnienie tymczasowe w polskim prawie pracy, https:// sip-1lex-1pl-1004153yx0674.han3.lib.uni.lodz.pl/\#/monografia/369234447/12 (dostęp: 19.09.2017).

Paluszkiewicz M., Podmioty stosunku prawnego, [w:] M. Paluszkiewicz, Zatrudnienie tymczasowe w polskim prawie pracy, https://sip-1lex-1pl-1004153yx0674.han3.lib.uni.lodz.pl/\#/monografia/369234447/15 (dostęp: 19.09.2017).

Paluszkiewicz M., Problem kwalifikacji prawnej pracy wykonywanej po uptywie terminu określonego w ustawie o zatrudnianiu pracowników tymczasowych, „Monitor Prawa Pracy” 2015, nr 11.

Paluszkiewicz M., Treść stosunku prawnego między agencja pracy tymczasowej a pracodawca użytkownikiem, [w:] M. Paluszkiewicz, Zatrudnienie tymczasowe w polskim prawie pracy, https://sip-1lex-1pl-1004153yx0674.han3.lib.uni.lodz.pl/\#/monografia/369234447/19 (dostęp: 19.09.2017).

Paluszkiewicz M., Układy zbiorowe pracy w zatrudnieniu tymczasowym, [w:] Z. Góral (red.), Układy zbiorowe pracy w stulecie urodzin Profesora Wacława Szuberta, Warszawa 2013.

Patulski A., Doktrynalne aspekty zatrudnienia tymczasowego (wybrane aspekty), [w:] A. Sobczyk (red.), Stosunki zatrudnienia w dwudziestoleciu społecznej gospodarki rynkowej, Warszawa 2010.

Patulski A., Koncepcja flexicurity a nietypowe formy zatrudnienia, czyli jak ograniczyć segmentyzację polskiego rynku pracy, [w:] A. Sobczyk (red.), Stosunki zatrudnienia w dwudziestoleciu społecznej gospodarki rynkowej, Warszawa 2010.

Patulski A., Orłowski G. (red.), Kodeks pracy 2012. Komentarz dla praktyków, Gdańsk 2012.

Pędziwiatr M., Uprawnienia kierownicze w stosunkach pracy tymczasowej, „Praca i Zabezpieczenie Społeczne" 2008, nr 5.

Piątkowski J., Udział związku zawodowego w rozwiązaniu stosunku pracy - niedoskonałości regulacji prawnej, [w:] G. Goździewicz (red.), Reprezentacja praw i interesów pracowniczych, Toruń 2001.

Pietraszewska-Macheta A., Ustawa o świadczeniach opieki zdrowotnej finansowanych ze środków publicznych. Komentarz, https://sip-1lex-1pl-1004153yx161d.han3.lib.uni.lodz.pl/\#/komentarz/587640954/521064 (dostęp: 19.09.2017).

Piotrowski W., Roszczenia pracownika z tytułu niezgodnego z prawem rozwiq̨zania stosunku pracy w kodeksie pracy, „Państwo i Prawo” 1974, nr 10.

Pisarczyk Ł., Konstrukcja i zakres ryzyka pracodawcy, „Praca i Zabezpieczenie Społeczne” 2003, nr 12. 
Pisarczyk Ł., Naprawienie szkody poniesionej przez pracownika wskutek wadliwego rozwiqzania umowy o pracę przez pracodawcę, [w:] L. Florek, M. Latos-Miłkowska (red.), Prawo pracy a bezrobocie, Warszawa 2003.

Pisarczyk Ł., Obowiqzek ułatwiania pracownikom podnoszenia kwalifikacji zawodowych, „Praca i Zabezpieczenie Społeczne" 2003, nr 4.

Pisarczyk Ł., Przejście zakładu pracy na innego pracodawcę, Warszawa 2002.

Pisarczyk Ł., Różne formy zatrudnienia, Warszawa 2003.

Pisarczyk Ł., Terminowe umowy o pracę - szansa czy zagrożenie, „Praca i Zabezpieczenie Spoteczne" 2006, nr 8.

Pisarczyk Ł., Praca tymczasowa a ryzyko pracodawcy, [w:] A. Sobczyk (red.), Z problematyki zatrudnienia tymczasowego, https://sip-1lex-1pl-1004153yx0674.han3.lib.uni.lodz.pl/\#/monografia/369236017/25 (dostęp: 19.09.2017).

Piszczek A., Odrębność podporządkowania pracownika w nietypowych umownych stosunkach pracy, Łódź 2016.

Piszczek A., Stefański K., Dni wolne na poszukiwanie pracy - wybrane problemy, „Gdańsko-Łódzkie Roczniki Prawa Pracy i Prawa Socjalnego" 2012, nr 2.

Podgórska-Rakiel E., Konieczność nowelizacji prawa polskiego w kwestii wolności zwiqzzkowych z perspektywy Międzynarodowej Organizacji Pracy, „Monitor Prawa Pracy” 2014, nr 10.

Prusinowski P., Umowne podstawy zatrudnienia, Warszawa 2012.

Raczkowski M., Ustawa o zatrudnianiu pracowników tymczasowych. Komentarz, Warszawa 2013. Radomski W., Umowa o pracę na okres próbny i wstępny jako warunek zawarcia umowy na czas nie określony, „Praca i Zabezpieczenie Społeczne” 1975, nr 7.

Radwański Z., Teoria umów, Warszawa 1977.

Radwański Z., Olejniczak A., Zobowiq̨zania - część ogólna, Warszawa 2005.

Rączka K., Szczególna ochrona trwałości stosunku pracy działacza zwiq̨zkowego, [w:] A. Wypych-Żywicka, M. Tomaszewska, J. Stelina (red.), Zbiorowe prawo pracy XXI wieku, Gdańsk 2010.

Reda A., Ochronne rozwiqzania prawa pracy w zatrudnieniu tymczasowym, [w:] M. Seweryński, J. Stelina (red.), Wolność i sprawiedliwość w zatrudnieniu. Księga pamiątkowa poświęcona Prezydentowi Rzeczypospolitej Polskiej Profesorowi Lechowi Kaczyńskiemu, Gdańsk 2012.

Reda A., Praca tymczasowa na podstawie umowy cywilnoprawnej, „Praca i Zabezpieczenie Spoteczne" 2012, nr 9.

Reda A., Pracodawca użytkownik jako podmiot prawa pracy, Poznań 2011.

Reda-Ciszewska A., Glosa do wyroku SN z dnia 1 kwietnia 2015 r., I PK 203/14, „Orzecznictwo Sądów Polskich" 2016, nr 1, poz. 8.

Romer T., Kodeks pracy. Komentarz, Warszawa 2012.

Romer T., Rozwiqzanie umowy o pracę (art. 30-61), „Prawo Pracy” 1996, nr 2.

Rott-Pietrzyk E., Art. 761(1), art. 761(2), [w:] E. Rott-Pietrzyk, Komentarz do niektórych przepisów kodeksu cywilnego. Umowa agencyjna po nowelizacji. Art. 758-764(9) k.c. Komentarz, https:// sip-1lex-1pl-1004153yx131d.han3.lib.uni.lodz.pl/\#/komentarz/587241123/38563 (dostęp: 19.09.2017).

Rott-Pietrzyk E., Art. 762, [w:] E. Rott-Pietrzyk, Komentarz do niektórych przepisów kodeksu cywilnego. Umowa agencyjna po nowelizacji. Art. 758-764(9) k.c. Komentarz, https://sip- 
-1lex-1pl-1004153yx131d.han3.lib.uni.lodz.pl/\#/komentarz/587241129/38569 (dostęp: 19.09.2017).

Rott-Pietrzyk E., Art. 764², [w:] E. Rott-Pietrzyk, Komentarz do niektórych przepisów kodeksu cywilnego. Umowa agencyjna po nowelizacji. Art. 758-764(9) k.c. Komentarz, https://sip-1lex-1pl-1004153yx0ff8.han3.lib.uni.lodz.pl/\#/komentarz/587241133/38573 (dostęp: 19.09.2017).

Rott-Pietrzyk E., Dopuszczalność zastrzeżenia wypowiedzenia umowy agencyjnej na czas oznaczony, „Przegląd Prawa Handlowego” 2003, nr 10.

Rott-Pietrzyk E., Umowa agencyjna, [w:] J. Rajski (red.), Prawo zobowiq̨zań - część szczegółowa, t. 7, Warszawa 2003.

Rott-Pietrzyk E., Umowa agencyjna po nowelizacji (art. 758-764(9) k.c.). Komentarz, https://sip-1lex-1pl-100415308001a.han3.lib.uni.lodz.pl/\#/komentarz/587241115/38555 (dostęp: 19.09.2017).

Rott-Pietrzyk E., Klyta W., Świadczenie wyrównawcze przysługujące agentowi - nowa instytucja w prawie polskim, „Kwartalnik Prawa Prywatnego” 2004, nr 3(13).

Róziewicz-Ładoń K., Instytucjonalna ochrona konkurencji, [w:] K. Róziewicz-Ładoń, Postępowanie przed Prezesem Urzędu Ochrony Konkurencji i Konsumentów w zakresie przeciwdziałania praktykom ograniczającym konkurencję, https://sip-1lex-1pl-1004153yx0cd3.han3.lib.uni. lodz.pl/\#/monografia/369228613/5 (dostęp: 19.09.2017).

Rycak A., Doktryna employment-at-will w prawie pracy w Stanach Zjednoczonych, „Praca i Zabezpieczenie Społeczne" 2008, nr 8.

Rycak A., Roszczenia restytucyjne czy odszkodowawcze w zwiq̨zku z nieuzasadnionym lub niezgodnym z prawem rozwiq̨zaniem umowy o pracę, [w:] G. Goździewicz (red.), Reprezentacja praw i interesów pracowniczych, Toruń 2001.

Rycak A., Zwiq̨zkowa reprezentacja uprawnień pracowniczych w rozwiq̨zaniu umów o praca, [w:] G. Goździewicz (red.), Reprezentacja praw i interesów pracowniczych, Toruń 2001.

Rylski M., Ochrona pracownika przed nadużywaniem terminowego zatrudnienia, „Praca i Zabezpieczenie Społeczne" 2014, nr 8.

Rylski M., O powszechnym rozumieniu okresów wypowiedzenia i sposobach ich obliczania - krytycznie. Część l, „Monitor Prawa Pracy” 2015, nr 6.

Rylski M., O powszechnym rozumieniu okresów wypowiedzenia i sposobach ich obliczania - krytycznie. Część II, „Monitor Prawa Pracy” 2015, nr 7.

Rylski M., Podnoszenie kwalifikacji zawodowych przez pracowników na gruncie kodeksu pracy teorie modelu legislacyjnego $i$ ich konsekwencje prawne, cz. 2, „Praca i Zabezpieczenie Spoteczne" 2015, nr 2.

Rzetecka-Gil A., Kodeks cywilny. Komentarz. Zobowiq̨zania - część ogólna, https://sip-1lex-1pl-1004153yx161d.han3.lib.uni.lodz.pl/\#/komentarz/587362220/159660 (dostęp: 19.09.2017).

Sadlik R., Obowiq̨zek dbałości o dobro zakładu pracy i skutki jego naruszenia, „Monitor Prawa Pracy" 2015, nr 7.

Sadlik R., Umowa o pracę na czas wykonania określonej pracy, „Prawo Pracy” 2004, nr 4.

Sadlik R., Uprawnienia Inspekcji Pracy w ustalaniu stosunku pracy, „Prawo Pracy” 2000, nr 12.

Salwa Z., Kształtowanie treści umowy o pracę, „Praca i Zabezpieczenie Społeczne” 1993, nr 12. 
Salwa Z., Podmioty odpowiedzialne za wykroczenia przeciwko prawom pracownika, „Praca i Zabezpieczenie Społeczne” 2001, nr 8.

Salwa Z., Prawo pracy w PRL, Warszawa 1989.

Salwa Z., Rola umowy o pracę w kształtowaniu stosunku pracy, „Państwo i Prawo” 1977, nr 11.

Salwa Z., W sprawie rodzajów umowy o pracę i sposobie rozwiqzania umowy zawartej na okres wykonania określonej roboty, „Praca i Zabezpieczenie Społeczne” 1965, nr 7.

Salwa Z., Wypowiedzenie umowy o pracę w kodeksie pracy, „Państwo i Prawo” 1974, nr 8/9.

Salwa Z., Zakres podmiotowy i przedmiotowy układów zbiorowych pracy, „Praca i Zabezpieczenie Społeczne" 1994, nr 12.

Sanetra W., Kilka uwag o pojęciu odpowiedzialności w prawie pracy, „Praca i Zabezpieczenie Społeczne" 2007, nr 11.

Sanetra W., Konstytucyjne prawo do rokowań, „Praca i Zabezpieczenie Społeczne” 1998, nr 12.

Sanetra W., Praca tymczasowa - zatrudnienie czy pośrednictwo pracy, [w:] Z. Góral (red.), Z zagadnień wspótczesnego prawa pracy. Księga jubileuszowa Profesora Henryka Lewandowskiego, Warszawa 2009.

Sanetra W., Prawo pracy. Zarys wykładów, Białystok 1994.

Sanetra W., Strony układu zbiorowego pracy po nowelizacji kodeksu pracy, „Praca i Zabezpieczenie Społeczne" 1995, nr 2.

Sanetra W., Zasada równego traktowania pracowników w kodeksie pracy, „Państwo i Prawo" $1977, \mathrm{nr} 9$.

Serwach M., Wina jako zasada odpowiedzialności cywilnej oraz okoliczność zwalniająca z obowiq̨zku naprawienia szkody, „Wiadomości Ubezpieczeniowe” 2009, nr 1.

Seweryński M., Ochrona pracowników przed rozwiq̨zaniem umowy o pracę według projektu kodeksu pracy, [w:] G. Goździewicz (red.), Reprezentacja praw i interesów pracowniczych, Toruń 2001.

Seweryński M., Uwagi o przyszłości układów zbiorowych pracy, [w:] Z. Góral (red.), Układy zbiorowe pracy w stulecie urodzin Profesora Wactawa Szuberta, Warszawa 2013.

Sidorko A., Art. 68, [w:] A. Pietraszewska-Macheta (red.), Ustawa o świadczeniach zdrowotnych finansowanych ze środków publicznych. Komentarz, https://sip-1lex-1pl-1004153yx0cd3. han3.lib.uni.lodz.pl/\#/komentarz/587259973/521174 (dostęp: 19.09.2017).

Sidorko A., Ubezpieczenie zdrowotne zleceniobiorców, „Służba Pracownicza” 2010, nr 4.

Sierocka I., Ubezpieczenie społeczne osób świadczących pracę na podstawie umów prawa cywilnego, [w:] A. Bieliński, A. Giedrewicz-Niewińska, M. Szabłowska-Juckiewicz (red.), Elastyczne formy zatrudnienia i organizacji czasu pracy, Warszawa 2015.

Sierocka I., Umowa zlecenia i umowa o dzieło w systemie ubezpieczeń społecznych, „Monitor Prawa Pracy" 2015, nr 7.

Sikorska A., Uprawnienia zamawiajacego dzieło do odstapienia od umowy na podstawie przepisów kodeksu cywilnego, „Przegląd Sądowy” 2004, nr 10.

Skąpski M., Funkcje prawnej regulacji podnoszenia kwalifikacji zawodowych pracowników z zakres ich realizacji w Polsce, [w:] L. Florek, Ł. Pisarczyk (red.), Wspótczesne problemy prawa pracy i ubezpieczeń społecznych. XVIII Zjazd Katedr i Zakładów Prawa Pracy i Ubezpieczeń Spotecznych, Warszawa 2011. 
Skąpski M., Funkcje regulacji czasu pracy wobec idei równości i sprawiedliwości, „Annales Universitatis Mariae Curie-Skłodowska Lublin - Polonia" 2015, vol. 62(2).

Skąpski M., Pracowniczy obowiq̨zek dbałości o dobro zakładu pracy (art. 100 § 2 pkt 4 k.p.), „Praca i Zabezpieczenie Społeczne", 2001, nr 2.

Skoczyński J., Ochrona wynagrodzenia za pracę, „Praca i Zabezpieczenie Społeczne” 1997, nr 3.

Skoczyński J., Reprezentacja praw i interesów pracowników służby publicznej, [w:] G. Goździewicz (red.), Reprezentacja praw i interesów pracowniczych, Toruń 2001.

Skoczyński J., Zmiany regulacji obowiq̨zku ubezpieczeń społecznych z tytułu świadczenia pracy na podstawie cywilnoprawnych umów o świadczenie usług, „Praca i Zabezpieczenie Społeczne" 2000, nr 2.

Skóra M., Minimalne wynagrodzenie za pracę jako przejaw funkcji ochronnej prawa pracy, [w:] M. Bosak (red.), Funkcja ochronna prawa pracy a wyzwania współczesności, Warszawa 2014.

Skwarczyński H., Inspektor pracy w nowym postępowaniu w sprawach o wykroczenia, „Praca i Zabezpieczenie Społeczne" 2003, nr 9.

Sobczyk A., Art. 4, [w:] A. Sobczyk, Ustawa o zatrudnianiu pracowników tymczasowych. Komentarz, https://sip-1lex-1pl-1004153yx0cd3.han3.lib.uni.lodz.pl/\#/komentarz/587241493/38933 (dostęp: 17.09.2017).

SobczykA., Art. 9, [w:] A. Sobczyk, Ustawa o zatrudnianiu pracowników tymczasowych. Komentarz, https://sip-1lex-1pl-1004153yx0cd3.han3.lib.uni.lodz.pl/\#/komentarz/587241498/38938 (dostęp: 19.09.2017).

Sobczyk A., Art. 10, [w:] A. Sobczyk, Ustawa o zatrudnianiu pracowników tymczasowych. Komentarz, https://sip-1lex-1pl-1004153yx0674.han3.lib.uni.lodz.pl/\#/komentarz/587241499/38939 (dostęp: 19.09.2017).

Sobczyk A., Art. 14, [w:] A. Sobczyk, Ustawa o zatrudnianiu pracowników tymczasowych. Komentarz, https://sip-1lex-1pl-1004153yx0674.han3.lib.uni.lodz.pl/\#/komentarz/587241503/38943 (dostęp: 19.09.2017).

Sobczyk A., Art. 67 ${ }^{14}$, [w:] A. Sobczyk (red.), Kodeks pracy. Komentarz, Warszawa 2012.

Sobczyk A., Art. 67 ${ }^{15}$, [w:] A. Sobczyk (red.), Kodeks pracy. Komentarz, Warszawa 2012.

Sobczyk A., Interes pracodawcy i pracownika w zatrudnieniu tymczasowym, „Monitor Prawa Pracy" 2011, nr 5.

Sobczyk A., Metody ograniczania umów cywilnoprawnych w stosunkach pracy - wątpliwości systemowe, „Praca i Zabezpieczenie Społeczne” 1997, nr 9.

Sobczyk A., Prawo dziecka do opieki rodziców jako uzasadnienie dla urlopu i zasitku macierzyńskiego, „Praca i Zabezpieczenie Społeczne” 2015, nr 9.

Sobczyk A., Prawo i człowiek pracujący - między ochroną godności a równości, www.prawo.amu. edu.pl/_data/assets/pdf_file/0006/173499/Sobczyk-Prawo-i-czowiek-pracujcy-midzyochron-godnoci-a-rownoci.pdf (dostęp: 21.01.2017).

Sobczyk A., Prawo pracy w świetle Konstytucji RP, t. 1: Teoria publicznego i prywatnego indywidualnego prawa pracy, Warszawa 2013.

Sobczyk A., Prawo pracy w świetle Konstytucji RP, t. 2: Wybrane problemy i instytucje prawa pracy a konstytucyjne prawa i wolności człowieka, Warszawa 2013.

Sobczyk A., Rozwiq̨zanie umowy o pracę bez wypowiedzenia, Gdańsk 2005. 
Sobczyk A., Różnicowanie praw (ochrony) zatrudnionych - wybrane kryteria i ich ocena, [w:] M. Bosak (red.), Funkcja ochronna prawa pracy a wyzwania wspótczesności, Warszawa 2014.

Sobczyk A., Telepraca w prawie polskim, Warszawa 2009.

Sobczyk A., Zatrudnienie pracowników tymczasowych, „Praca i Zabezpieczenie Społeczne” 2004, nr 4.

Sobczyk A., Zakres przedmiotowy negatywnych przyczyn wypowiedzenia umowy o pracę, [w:] A.M. Świątkowski (red.), Ochrona praw człowieka w świetle przepisów prawa pracy i zabezpieczenia społecznego. Referaty i wystapienia zgłoszone na XVII Zjazd Katedr/Zakładów Prawa Pracy i Zabezpieczenia Społecznego, Kraków 7-9 maja 2009 r., Warszawa 2009.

Sobczyk A. (red.), Kodeks pracy. Komentarz, Warszawa 2014.

Sobczyk A. (red.), Stosunki zatrudnienia w dwudziestoleciu społecznej gospodarki rynkowej. Księga pamiątkowa z okazji jubileuszu 40-lecia pracy naukowej Profesor Barbary Wagner, Warszawa 2010.

Soćko M., The Deduction from Remuneration for Work in the Polish Labour Code as One of Elements Remuneration-Protection System, „Praca i Zabezpieczenie Społeczne” 2014, nr 8.

Sośniak W., Umowy o świadczenie usług z artykułu 750 kodeksu cywilnego, „Państwo i Prawo" 1981, nr 5.

Spytek-Bandurska G., Wybrane problemy pracodawców ze stosowaniem przepisów o ochronie danych osobowych, [w:] T. Wyka, A. Nerka (red.), Granice ochrony danych osobowych w stosunkach pracy, Warszawa 2009.

Staszewska E., Odpowiedzialność pracownicza, Warszawa 2013.

Stefański K., Czas pracy, https://sip-1lex-1pl-1004153yx161d.han3.lib.uni.lodz.pl/\#/monografia/369276106/4 (dostęp: 19.09.2017).

Stefański K., Okresy odpoczynku w kodeksie pracy, „Praca i Zabezpieczenie Społeczne” 2006, $\mathrm{nr} 1$.

Stelina J., Nowa koncepcja umowy o pracę na czas określony, „Państwo i Prawo” 2015, nr 11.

Stelina J., Tradycyjna koncepcja stosunku pracy a stosunek pracy tymczasowej - potrzeba refleksji, [w:] A. Sobczyk (red.), Z problematyki zatrudnienia tymczasowego, Warszawa 2011.

Supiot A., Zatrudnienie pracownicze i zatrudnienie niezależne, [w:] M. Seweryński (red.), Referaty na VI Europejski Kongres Prawa Pracy i Zabezpieczenia Społecznego, Warszawa 1999.

Szewczyk H., Charakter prawny umowy na czas wykonania określonej pracy, „Monitor Prawa Pracy" 2004, nr 8.

Szewczyk H., Ochrona dóbr osobistych w zatrudnieniu, Warszawa 2007.

Szubert W., O charakterze prawnym stosunku pracy, „Państwo i Prawo” 1964, nr 7.

Szubert W., Ubezpieczenia społeczne. Zarys systemu, Warszawa 1987.

Szubert W., Układy zbiorowe pracy, Warszawa 1960.

Szubert W., Zakres podmiotowy i przedmiotowy kodeksu pracy, „Państwo i Prawo” 1974, nr 8/9.

Szubert W., Zarys prawa pracy, Warszawa 1980.

Szyburska-Walczak G., Ubezpieczenia społeczne. Repetytorium, Warszawa 2012.

Świątkowski A.M., Europejskie prawo socjalne, Warszawa 1999.

Świątkowski A.M., Kodeks pracy. Komentarz, Warszawa 2010.

Świątkowski A.M., Kodeks pracy. Komentarz, Warszawa 2012. 
Świątkowski A.M., Ochrona praw pracowniczych i socjalnych poprzez nawiq̨zanie stosunku pracy, [w:] A. Patulski, K. Walczak K. (red.), Jedność w różnorodności. Studia z zakresu prawa pracy, zabezpieczenia społecznego i polityki społecznej. Księga pamiątkowa dedykowana Profesorowi Wojciechowi Muszalskiemu, Warszawa 2009.

Świątkowski A.M., Prawo do wolności zrzeszania się i uprawnień pokrewnych, „Monitor Prawa Pracy" 2015, nr 9.

Świątkowski A.M., Przedmiot stosunku pracy. Rozważania de lege lata i de lege ferenda, [w:] L. Florek, Ł. Pisarczyk (red.), Współczesne problemy prawa pracy i ubezpieczeń społecznych. XVIII Zjazd Katedr i Zakładów Prawa Pracy i Ubezpieczeń Społecznych, Warszawa 2011.

Świątkowski A.M., Telepraca - specyfika zatrudnienia na odległość, „Monitor Prawa Pracy” 2006, nr 7.

Świerczyński M., Art. 2, [w:] J. Gołaczyński (red.), Ustawa o świadczeniu usług droga elektronicznq. Komentarz, https://sip-1lex-1pl-1004153yx0674.han3.lib.uni.lodz.pl/\#/komentarz/587247059/44499 (dostęp: 19.09.2017).

Święcicki M., Prawo pracy, Warszawa 1968.

Tiraboschi M., Rymkevitch O., The Regulation of Temporary Agency Work at European Union Level: Problems and Perspectives, [w:] T. Davulis, D. Petrylaitė (red.), Labour and Social Security Law in the XXI Century: Challenges and Perspectives, Wilno 2007, s. 295-299.

Tomanek A., Glosa do uchwały z 16 czerwca 1994 r., „Orzecznictwo Sądów Polskich” 1995, nr 9, poz. 184.

Tomaszewska M., Art. 25 k.p., pkt 10, [w:] K.W. Baran (red.), Kodeks pracy. Komentarz, https:// sip-1lex-1pl-1004153yx0674.han3.lib.uni.lodz.pl/\#/komentarz/587329041/490674 (dostęp: 19.09.2017).

Tracz G., Odstapienie, [w:] G. Tracz, Sposoby jednostronnej rezygnacji z zobowiq̨zań umownych, https://sip-1lex-1pl-1004153080077.han3.lib.uni.lodz.pl/\#/monografia/369164046/8 (dostęp: 19.09.2017)..

Trzaskowski R., Granice ksztattowania treści i celu umów obligacyjnych. Art. 353¹ KC, Kraków 2005. Unterschütz J., Karnoprawna ochrona praw osób wykonujących pracę zarobkowa, Warszawa 2010. Unterschütz J., Wybrane problemy ograniczenia swobody koalicji w świetle prawa międzynarodowego i konstytucji RP, „Praca i Zabezpieczenie Społeczne” 2013, nr 10.

Wagner B., Jednolitość, wielopostaciowość czy ewolucja funkcji ochronnej prawa pracy - zatrudnienie typowe versus tymczasowe, [w:] A. Sobczyk (red.), Z problematyki zatrudnienia tymczasowego, https://sip-1lex-1pl-1004153yx0674.han3.lib.uni.lodz.pl/\#/monografia/369236017/15 (dostęp: 19.09.2017).

Wagner B., Niektóre elementy regulacji stosunku pracy w projekcie kodeksu pracy, „Praca i Zabezpieczenie Społeczne" 2008, nr 9.

Wagner B., O swobodzie umowy o pracę raz jeszcze, [w:] M. Matey-Tyrowicz, L. Nawacki, B. Wagner (red.), Prawo pracy a wyzwania XXI wieku. Księga Jubileuszowa Profesora Tadeusza Zielińskiego, Warszawa 2002.

Wagner B., Prawo do zabezpieczenia społecznego w Konstytucji RP, [w:] A. Patulski, K. Walczak (red.), Jedność w różnorodności. Studia z zakresu prawa pracy, zabezpieczenia społecznego i polityki społecznej. Księga pamiq̨tkowa dedykowana Profesorowi Wojciechowi Muszalskiemu, Warszawa 2009. 
Wagner B., Terminowe umowy o pracę, Warszawa 1980.

Wagner B., Wynagrodzenie oraz inne świadczenia za pracę, „Prawo Pracy” 1997, nr 5.

Wagner B., Zagadnienia na tle umowy o pracę na czas określony, „Praca i Zabezpieczenie Spoteczne" 1975, nr 3.

Wagner B. (red.), Kodeks pracy. Komentarz, Gdańsk 2004.

Wagner B. (red.), Kodeks pracy 2011. Komentarz, Gdańsk 2011.

Walas A., Problemy ustawowego uregulowania stosunku pracy, „Praca i Zabezpieczenie Społeczne" 1963, nr 5.

Walczak K., Ochrona danych osobowych kandydata do pracy w trakcie rekrutacji, [w:] T. Wyka, A. Nerka (red.), Ochrona danych osobowych objętych prawem pracy i prawem ubezpieczeń społecznych. Stan obecny i perspektywy zmian, Warszawa 2012.

Walczak K., Równość czy równowaga w zbiorowych stosunkach pracy, [w:] A.M. Świątkowski (red.), Ochrona praw człowieka w świetle przepisów prawa pracy i zabezpieczenia społecznego. Referaty i wystąienia zgłoszone na XVII Zjazd Katedr/Zakładów Prawa Pracy i Zabezpieczenia Społecznego, Kraków 7-9 maja 2009 r., Warszawa 2009.

Walczak K., Umowa na zastępstwo - czy można ja kwestionować ze względu na niezgodność z prawem europejskim?, „Monitor Prawa Pracy” 2005, nr 3.

Walczak K., Wynagrodzenie minimalne w umowach zlecenia i o świadczenie usług - zagadnienia doktrynalne i praktyczne. Część 2, „Monitor Prawa Pracy” 2016, nr 9.

Wiśniewski J., Różnorodne formy zatrudnienia, Toruń 2012.

Wiśniewski J., Zatrudnienie pracowników w formie telepracy, Toruń 2007.

Wiśniewski T., Świadczenie wyrównawcze przysługujące agentowi, „Przegląd Sądowy” 2001, nr 10.

Witkowski J., Art. 477¹, [w:] K. Antonów, A. Jabłoński (red.), Kodeks postępowania cywilnego. Postępowanie odrębne w sprawach zzakresu prawa pracyiubezpieczeńspołecznych. Komentarz, https://sip-1lex-1pl-1004153yx0ff8.han3.lib.uni.lodz.pl/\#/komentarz/587514138/311578 (dostęp: 19.09.2017).

Włodarczyk M., Art. 102, [w:] K.W. Baran (red.), Kodeks pracy. Komentarz, https://sip-1lex-1pl-1004153yx0674.han3.lib.uni.lodz.pl/\#/komentarz/587329148/490781 (dostęp: 19.09.2017).

Włodarczyk M., Art. 177, [w:] K.W. Baran (red.), Kodeks pracy. Komentarz, https://sip-1lex-1pl-1004153yx0ff8.han3.lib.uni.lodz.pl/\#/komentarz/587329247/490882 (dostęp: 19.09.2017).

Włodarczyk M., Pośrednictwo pracy. Studium prawno-społeczne, Łódź 2002.

Wojciechowska D., Zwiq̨zki zawodowe w firmie, Gdańsk 2004.

Wojtyła J., Dylematy ochronnej funkcji prawa pracy w stosunkach prawnych zatrudnienia, [w:] M. Seweryński, J. Stelina (red.), Wolność i sprawiedliwość w zatrudnieniu. Księga pamiątkowa poświęcona Prezydentowi Rzeczypospolitej Polskiej Profesorowi Lechowi Kaczyńskiemu, Gdańsk 2012.

Wratny J., Kodeks pracy. Komentarz, Warszawa 2005.

Wratny J., Minimalne wynagrodzenie za pracę - nowe regulacje prawne, „Praca i Zabezpieczenie Społeczne" 2003, nr 6.

Wratny J., Problemy ochrony pracowników w elastycznych formach zatrudnienia, „Praca i Zabezpieczenie Społeczne" 2007, nr 7. 
Wratny J., Problemy regulacji wynagrodzenia za pracę de lege ferenda, „Praca i Zabezpieczenie Społeczne" 2013, nr 10.

Wratny J., Przemiany stosunku pracy w III RP, „Praca i Zabezpieczenie Społeczne” 2012, nr 5.

Wratny J., Zakres przedmiotowy układów zbiorowych pracy w świetle przepisów prawa pracy, [w:] J. Wratny (red.), Układy zbiorowe pracy w demokratycznym ustroju pracy. Studium z zakresu prawa pracy, Warszawa 1997.

Wratny J., Zwiq̨zki zawodowe i inne formy przedstawicielstwa pracowniczego, „Monitor Prawa Pracy" 2013, nr 12.

Wrocławska T., O znaczeniu wyroku sq̨du karnego w postępowaniu w sprawach z zakresu prawa pracy na przykładzie wybranych instytucji prawa pracy, [w:] G. Uścińska (red.), Prawo pracy. Refleksje i poszukiwania. Księga jubileuszowa Profesora Jerzego Wratnego, Warszawa 2013.

Wronikowska E., Komentarz do rozporządzenia w sprawie szczegółowej treści świadectwa pracy oraz sposobu i trybu jego wydawania i prostowania, [w:] E. Wronikowska, Akty wykonawcze do kodeksu pracy. Komentarz, https://sip-1lex-1pl-1004153yx131d.han3.lib.uni.lodz.pl/\#/ komentarz/587247456/44896 (dostęp: 19.09.2017).

Wronikowska E., Nowik P., Zbiorowe prawo pracy, Warszawa 2008.

Wronkowska S., Zieliński M. (red.), Szkice z teorii prawa i szczegółowych nauk prawnych, Poznań 1990. Wyka T., Art. 229, [w:] K.W. Baran (red.), Kodeks pracy. Komentarz, https://sip-1lex-1pl-1004153yx0674.han3.lib.uni.lodz.pl/\#/komentarz/587329321/490969 (dostęp: 19.09.2017).

Wyka T., Art. 237(3), [w:] K.W. Baran (red.), Kodeks pracy. Komentarz, https://sip-1lex-1pl-1004153yx0674.han3.lib.uni.lodz.pl/\#/komentarz/587329334/490982 (dostęp: 19.09.2017).

Wyka T., Bezpieczeństwo i ochrona zdrowia w zatrudnieniu niepracowniczym typu cywilnoprawnego, [w:] Z. Kubot (red.), Szczególne formy zatrudnienia, Wrocław 2000.

Wyka T., Granice pozyskiwania danych osobowych dotyczących zdrowia pracownika, [w:] T. Wyka, A. Nerka (red.), Ochrona danych osobowych objętych prawem pracy i prawem ubezpieczeń społecznych. Stan obecny i perspektywy zmian, Warszawa 2012.

Wyka T., Konstytucyjne prawo każdego do bezpiecznych i higienicznych warunków pracy a zatrudnienie na innej podstawie niż stosunek pracy oraz praca na własny rachunek - uwagi de lege ferenda, [w:] J. Stelina, A. Wypych-Żywicka (red.), Człowiek, obywatel, pracownik. Studia z zakresu prawa pracy. Księga jubileuszowa Profesor Urszuli Jackowiak, „Gdańskie Studia Prawnicze" 2007, t. 17.

Wyka T., Ochrona zdrowia i życia pracownika jako element treści stosunku pracy, Warszawa 2003, s. 70.

Wyka T., Prawna ochrona zdrowia pracownika, [w:] H. Lewandowski (red.), Polskie prawo pracy w okresie transformacji w oświetleniu prawa wspólnotowego, Warszawa 1997.

Wyka T., Propozycje zmian w prawie pracy w zakresie gromadzenia i przetwarzania danych osobowych kandydata na pracownika i pracownika, [w:] T. Wyka, A. Nerka (red.), Ochrona danych osobowych objętych prawem pracy i prawem ubezpieczeń społecznych. Stan obecny i perspektywy zmian, Warszawa 2012.

Wyka T., Regulacja umowy o pracę nakładczą na gruncie polskiego porządku prawnego, „Studia Prawno-Ekonomiczne" 1984, t. 33.

Zając T., Z doświadczeń kontrolnych Państwowej Inspekcji Pracy, „Praca i Zabezpieczenie Spoteczne" 2001, nr 1. 
Zakrzewska-Szczepańska K., Bhp zatrudnionych bez umowy o pracę, „Służba Pracownicza” 2006, nr 10.

Zakrzewska-Szczepańska K., Telepraca w Unii Europejskiej i w Polsce, „Służba Pracownicza” 2006, nr 4.

Zieliński M.J., Zasada równego traktowania a zakaz dyskryminacji w prawie pracy, „Praca i Zabezpieczenie Społeczne" 2013, nr 8.

Zieliński T., Prawo pracy. Zarys systemu. Cz. 2: Prawo stosunku pracy, Warszawa Kraków 1986.

\section{Akty prawne}

\subsection{Akty Organizacji Narodów Zjednoczonych}

Powszechna Deklaracja Praw Człowieka z dnia 10 grudnia 1948 r., www.un.org/en/universal-declaration-human-rights/index.html (dostęp: 19.09.2017).

\subsection{Akty Międzynarodowej Organizacji Pracy}

Konwencja MOP z dnia 29 października 1919 r. nr 1 dotycząca ograniczenia czasu pracy do ośmiu godzin dziennie i czterdziestu ośmiu godzin tygodniowo w zakładach przemysłowych, www. mop.pl/doc/html/konwencje/k001.html (dostęp: 19.09.2017).

Konwencja MOP z dnia 25 października 1921 r. nr 14 dotycząca odpoczynku tygodniowego w zakładach przemysłowych, Dz.U. z 1925 r., Nr 51, poz. 384.

Konwencja MOP z dnia 30 maja 1928 r. nr 26 dotyczącą ustanowienia metod ustalania płac minimalnych, www.mop.pl/doc/html/konwencje/ k026.html (dostęp: 19.09.2017).

Konwencja MOP z dnia 29 czerwca 1933 r. nr 39 dotycząca obowiązkowego ubezpieczenia na wypadek śmierci pracowników najemnych, zatrudnionych w przedsiębiorstwach przemystowych i handlowych, w wolnych zawodach, jak również chałupników i pracowników gospodarstw domowych, Dz.U. z 1949 r., Nr 31, poz. 231.

Konwencja MOP z dnia 14 czerwca 1935 r. nr 47 dotycząca minimalnych norm na statkach handlowych, Dz.U. z 1997 r., Nr 72, poz. 454.

Konwencja MOP z dnia 4 czerwca 1936 r. nr 52 dotycząca corocznych płatnych urlopów, www. mop.pl/doc/html/konwencje/k052.html (dostęp: 19.09.2017).

Konwencja MOP z dnia 17 czerwca 1948 r. nr 87 dotycząca wolności związkowej i ochrony praw związkowych, Dz.U. z 1958 r., Nr 29, poz. 125.

Konwencja MOP z dnia 8 czerwca 1949 r. nr 95 dotycząca ochrony płacy, Dz.U. z 1955 r., Nr 38, poz. 234.

Konwencja MOP z dnia 8 czerwca 1949 r. nr 98 dotycząca stosowania zasad prawa organizowania się i rokowań zbiorowych, Dz.U. z 1958 r., Nr 29, poz. 126. 
Konwencja MOP z dnia 6 czerwca 1951 r. nr 99 dotycząca metod ustalania płac minimalnych w rolnictwie, Dz.U. z 1977 r., Nr 39, poz. 176.

Konwencja MOP z dnia 6 czerwca 1951 r. nr 100 dotycząca jednakowego wynagrodzenia dla pracujących mężczyzn i kobiet za pracę jednakowej wartości, Dz.U. z 1955 r., Nr 38, poz. 238.

Konwencja MOP z dnia 5 czerwca 1957 r. nr 106 dotycząca cotygodniowego odpoczynku w handlu i w biurach, www.mop.pl/doc/html/ konwencje/k106.html (dostęp: 19.09.2017).

Konwencja MOP z dnia 4 czerwca 1958 r. nr 111 dotycząca dyskryminacji w zatrudnieniu oraz wykonywaniu zawodu, Dz.U. z 1961 r., Nr 42, poz. 218.

Konwencja MOP z dnia 3 czerwca 1970 r. nr 131 dotycząca ustalania płac minimalnych, zwłaszcza w odniesieniu do krajów rozwijających się, www.mop.pl/doc/html/konwencje/k131. html (dostęp: 19.09.2017).

Konwencja MOP z dnia 2 czerwca 1971 r. nr 135 dotycząca ochrony przedstawicieli pracowników w przedsiębiorstwach i przyznania im ułatwień, Dz.U. z 1977 r., Nr 39, poz. 178.

Konwencja z MOP z dnia 5 czerwca 1974 r. nr 140 dotycząca płatnego urlopu szkoleniowego, Dz.U. z 1979 r., Nr 16, poz. 100.

Konwencja MOP z dnia 4 czerwca 1975 r. nr 142 dotycząca roli poradnictwa i kształcenia zawodowego w rozwoju zasobów ludzkich, Dz.U. z 1979 r., Nr 29, poz. 164.

Konwencja MOP z dnia 7 czerwca 1978 r. nr 151 dotycząca ochrony prawa organizowania się i procedury określania warunków zatrudnienia w służbie publicznej, Dz.U. z 1977 r., Nr 39, poz. 178.

Konwencja MOP z dnia 3 czerwca 1981 r. nr 154 dotycząca popierania rokowań zbiorowych, www.mop.pl/doc/html/konwencje/k154.html (dostęp: 19.09.2017).

Konwencja MOP z dnia 3 czerwca 1981 r. nr 155 dotycząca bezpieczeństwa, zdrowia pracowników i środowiska pracy, www.mop.pl/doc/html/konwencje/ k155.html (dostęp: 19.09.2017).

Konwencja MOP z dnia 2 czerwca 1982 r. nr 158 dotycząca rozwiązania stosunku pracy z inicjatywy pracodawcy, www.mop.pl/doc/html/konwencje/ k158.html (dostęp: 19.09.2017).

Konwencja MOP z dnia 7 czerwca 1994 r. nr 175 dotycząca pracy w niepełnym wymiarze czasu, www.mop.pl/doc/html/konwencje/k175.html (dostęp: 19.09.2017).

Konwencja MOP z dnia 3 czerwca 1997 r. nr 181 dotycząca prywatnych biur pośrednictwa pracy, Dz.U. z 2008 r., Nr 222, poz. 1448.

Zalecenie MOP z dnia 6 czerwca 1951 r. nr 91 dotyczące układów zbiorowych pracy, www.mop. $\mathrm{pl} / \mathrm{doc} / \mathrm{html} / z a l e c e n i a / z 091 . h t m l$ (dostęp: 19.09.2017).

Zalecenie MOP z dnia 5 czerwca 1963 r. nr 119 dotyczące rozwiązania stosunku pracy z inicjatywy pracodawcy, www.mop.pl/doc/html/zalecenia/ z119.html (dostęp: 19.09.2017).

Zalecenie MOP z dnia 2 czerwca 1971 r. nr 143 dotyczące ochrony przedstawicieli pracowników w przedsiębiorstwach i przyznania im ułatwień, www.mop.pl/doc/html/zalecenia/z143. html (dostęp: 19.09.2017).

Zalecenie MOP z dnia 3 czerwca 1981 r. nr 163 dotyczące popierania rokowań zbiorowych, www. mop.pl/doc/html/zalecenia/z163.html (dostęp: 19.09.2017).

Zalecenie MOP z dnia 2 czerwca 1982 r. nr 166 dotyczące rozwiązania stosunku pracy z inicjatywy pracodawcy, www.mop.pl/doc/html/zalecenia/ z166.html (dostęp: 19.09.2017).

Zalecenie MOP z dnia 15 czerwca 2006 r. nr 198 dotyczące stosunku pracy, www.mop.pl/doc/ html/zalecenia/z198.html (dostęp: 19.09.2017). 


\subsection{Akty Rady Europy}

Europejska Karta Społeczna sporządzona w Turynie, 18 października 1961 r., Dz.U. z 1999 r., Nr 8 , poz. 67 ze zm.

Konwencja o ochronie praw człowieka i podstawowych wolności z dnia 4 listopada 1950 r., zmieniona następnie Protokołami nr 3, 5 i 8 oraz uzupełniona Protokołem nr 2, Dz.U. z 1993 r., $\mathrm{Nr} 61$, poz. 284 ze zm.

Konwencja Rady Europy nr 108 z dnia 28 stycznia 1981 r. dotycząca ochrony osób w związku z automatycznym przetwarzaniem danych osobowych, Dz.U. z 2003 r., Nr 3, poz. 25.

\subsection{Akty unijne (wspólnotowe)}

Dyrektywa Rady nr 75/117/EWG z dnia 10 lutego 1975 r. w sprawie zbliżenia ustawodawstw Państw Członkowskich dotyczących stosowania zasady równości wynagrodzeń dla mężczyzn i kobiet, Dz.Urz. EWG L 45 z dnia 19 lutego 1975 r., s. 19-20.

Dyrektywa Rady nr 76/207/EWG z dnia 9 lutego 1976 r. w sprawie wprowadzenia w życie zasady równego traktowania kobiet i mężczyzn w zakresie dostępu do zatrudnienia, kształcenia i awansu zawodowego oraz warunków pracy, Dz.Urz. EWG L 39 z dnia 14 lutego 1976 r., s. 4042.

Dyrektywa Rady nr 86/613/EWG z dnia 11 grudnia 1986 r. w sprawie stosowania zasady równego traktowania kobiet i mężczyzn pracujących na własny rachunek, w tym w rolnictwie, oraz w sprawie ochrony kobiet pracujących na własny rachunek w okresie ciąży i macierzyństwa, Dz.Urz. EWG L 359 z dnia 19 grudnia 1986 r., s. 56-58.

Dyrektywa Rady nr 86/653/EWG z dnia 18 grudnia 1986 r. w sprawie koordynacji ustawodawstw Państw Członkowskich odnoszących się do przedstawicieli handlowych działających na własny rachunek, Dz.Urz. EWG L 382 z dnia 31 grudnia 1986, s. 17-21.

Dyrektywa Rady nr 89/391/EWG z dnia 12 czerwca 1989 r. w sprawie wprowadzenia środków w celu poprawy bezpieczeństwa i zdrowia pracowników w miejscu pracy, Dz.Urz. EWG L 183 z dnia 29 czerwca 1989 r., s. 1-8.

Dyrektywa Rady nr 91/383/EWG z dnia 25 czerwca 1991 r. uzupełniająca środki mające wspierać poprawę bezpieczeństwa i zdrowia w pracy pracowników pozostających w stosunku pracy na czas określony lub w czasowym stosunku pracy, Dz.Urz. EWG L 206 z dnia 29 lipca 1991, s. $19-21$.

Dyrektywa Rady nr 93/104/WE z dnia 23 listopada 1993 r. dotycząca niektórych aspektów organizacji czasu pracy, Dz.Urz. WE L 307 z dnia 13 grudnia 1993 r., s. 18-24.

Dyrektywa Parlamentu Europejskiego i Rady nr 95/46/EC z dnia 24 października 1995 r. w sprawie ochrony osób fizycznych w zakresie przetwarzania danych osobowych oraz swobodnego przepływu tych danych, Dz.Urz. EC L 281 z dnia 23 listopada 1995, s. 31-50.

Dyrektywa Rady nr 97/81/WE z dnia 15 grudnia 1997 r. dotycząca Porozumienia ramowego dotyczącego pracy w niepełnym wymiarze godzin zawartego przez Europejską Unię Konfederacji Przemysłowych i Pracodawców (UNICE), Europejskie Centrum Przedsiębiorstw Publicznych 
(CEEP) oraz Europejską Konfederację Związków Zawodowych (ETUC), Dz.Urz. WE L 14 z dnia 20 stycznia 1998, s. 9-14.

Dyrektywa Rady nr 99/70/WE z dnia 28 czerwca 1999 r. dotycząca Porozumienia ramowego w sprawie pracy na czas określony, zawartego przez Europejską Unię Konfederacji Przemysłowych i Pracodawców (UNICE), Europejskie Centrum Przedsiębiorstw Publicznych (CEEP) oraz Europejską Konfederację Związków Zawodowych (ETUC), Dz.Urz. WE L 175/43, z dnia 10 lipca 1999 r., s. 368-373.

Dyrektywa Rady nr 2000/43/WE z dnia 29 czerwca 2000 r. wprowadzająca w życie zasadę równego traktowania osób bez względu na pochodzenie rasowe lub etniczne, Dz.Urz. WE L 180 z dnia 19 lipca 2000 r., s. 22-26.

Dyrektywa Rady nr 2000/78/WE z dnia 27 listopada 2000 r. ustanawiająca ogólne warunki ramowe równego traktowania w zakresie zatrudnienia i pracy, Dz.Urz. WE L 303 z dnia 2 grudnia 2000 r., s. 16-22.

Dyrektywa Parlamentu Europejskiego i Rady nr 2002/14/WE z dnia 11 marca 2002 r. ustanawiająca ogólne ramowe warunki informowania i przeprowadzania konsultacji z pracownikami we Wspólnocie Europejskiej, Dz.Urz. WE L 80 z dnia 23 marca 2002, s. 29-34.

Dyrektywa Parlamentu Europejskiego i Rady nr 2003/88/WE z dnia 4 listopada 2003 r. dotycząca niektórych aspektów organizacji czasu pracy, Dz.Urz. WE L 299 z dnia 18 listopada 2003 r., s. 9-19.

Dyrektywa Rady nr 2004/113/WE z dnia 13 grudnia 2004 r. wprowadzająca w życie zasadę równego traktowania mężczyzn i kobiet w zakresie dostępu do towarów i ustug oraz dostarczania towarów i usług, Dz.Urz. WE L 373 z dnia 21 grudnia 2004 r., s. 37-43.

Dyrektywa Parlamentu Europejskiego i Rady nr 2006/54/WE z dnia 5 lipca 2006 r. w sprawie wprowadzenia w życie zasady równości szans oraz równego traktowania kobiet i mężczyzn w dziedzinie zatrudnienia i pracy, Dz.Urz. WE L 204 z dnia 26 lipca 2006 r., s. 23-36.

Dyrektywa Parlamentu Europejskiego i Rady nr 2008/94/WE z dnia 22 października 2008 r. w sprawie ochrony pracowników na wypadek niewypłacalności pracodawcy, Dz.Urz. WE L 283 z 28 dnia października 2008 r., s. 36-42.

Dyrektywa Parlamentu Europejskiego i Rady nr 2008/104/WE z dnia 19 listopada 2008 r. w sprawie pracy tymczasowej, Dz.Urz. WE L. 327 z dnia 5 grudnia 2008 r., s. 9-14.

Dyrektywa Parlamentu Europejskiego i Rady nr 2009/38/WE z dnia 6 maja 2009 r. w sprawie ustanowienia europejskiej rady zakładowej lub trybu informowania pracowników i konsultowania się z nimi w przedsiębiorstwach lub w grupach przedsiębiorstw o zasięgu wspólnotowym, Dz.Urz. WE L 22 z dnia 16 maja 2009, s. 28-44.

Europejskie ramowe porozumienie w sprawie telepracy z dnia 16 lipca 2002 r., www.etuc.org/ signature-european-framework-agreement-telework-brussels-16072002 (dostęp: 19.09.2017).

Karta Praw Podstawowych Unii Europejskiej zatwierdzona dnia 2 października 2000 r. na szczycie w Nicei (OJ 2000/c 364 of 18.12.2000), przyjęta przez Kartę Praw Podstawowych Unii Europejskiej z dnia 12 grudnia 2007 r., Dz.Urz. UE 2007 C 303.

Traktat o funkcjonowaniu Unii Europejskiej z dnia 26 października 2012 r., Dz.Urz. UE C 326 z dnia 26 października 2012, s. 47-390. 


\subsection{Akty prawa krajowego}

Ustawa z dnia 18 stycznia 1951 r. o dniach wolnych od pracy, Dz.U. z 2015 r., poz. 90 - t.j. Ustawa z dnia 25 lutego 1964 r. Kodeks rodzinny i opiekuńczy, Dz.U. z 2015 r., poz. 2082 - t.j. Ustawa z dnia 23 kwietnia 1964 r. Kodeks cywilny, Dz.U. z 2014 r., poz. 121 - t.j. ze zm. Ustawa z dnia 17 listopada 1964 r. Kodeks postępowania cywilnego, Dz.U. z 2014 r., poz. 101 - t.j. ze zm.

Ustawa z dnia 20 maja 1971 r. Kodeks wykroczeń, Dz.U. z 2013 r., poz. 482 - t.j. ze zm. Ustawa z dnia 26 czerwca 1974 r. Kodeks pracy, Dz.U. z 2014 r., poz. 1502 - t.j. ze zm. Ustawa z dnia 6 marca 1981 r. o Państwowej Inspekcji Pracy, Dz.U. z 1981 r., Nr 6, poz. 23 ze zm. Ustawa z dnia 25 września 1981 r. o samorządzie załogi przedsiębiorstwa państwowego, Dz.U. z 1981 r., Nr 24, poz. 123 - t.j. ze zm.

Ustawa z dnia 23 maja 1991 r. o rozwiązywaniu sporów zbiorowych, Dz.U. z 1991 r., Nr 55, poz. 236 ze zm.

Ustawa z dnia 23 maja 1991 r. o związkach zawodowych, Dz.U. z 2015 r., poz. 1881 - t.j.

Ustawa z dnia 16 kwietnia 1993 r. o zwalczaniu nieuczciwej konkurencji, Dz.U. z 2003 r., Nr 153, poz. 1503 ze zm.

Ustawa z dnia 4 marca 1994 r. o zakładowym funduszu świadczeń socjalnych, Dz.U. z 2015 r., poz. $111-$ t.j.

Ustawa z dnia 2 lutego 1996 r. o zmianie ustawy - Kodeks pracy oraz o zmianie niektórych ustaw, Dz.U. z 1996 r., Nr 24, poz. 110.

Ustawa z dnia 2 kwietnia 1997 r. Konstytucja Rzeczypospolitej Polskiej, Dz. U.Dz.U. z 1997 r., $\mathrm{Nr} 78$, poz. 483 ze zm.

Ustawa z dnia 6 czerwca 1997 r., Kodeks karny, Dz.U. z 1997 r., Nr 88, poz. 553 ze zm.

Ustawa z dnia 6 czerwca 1997 r., Kodeks postępowania karnego, Dz.U. z 1997 r., Nr 89, poz. 555 ze zm.

Ustawa z dnia 29 sierpnia 1997 r. o ochronie danych osobowych, Dz.U. z 2014 r., poz. 1182 - t.j. ze zm.

Ustawa z dnia 13 października 1998 r. o systemie ubezpieczeń społecznych, Dz.U. z 2015 r., poz. $121-$ t.j.

Ustawa z dnia 25 czerwca 1999 r. o świadczeniach pieniężnych z ubezpieczenia społecznego w razie choroby i macierzyństwa, Dz.U. z 2014 r., poz. 159 - t.j.

Ustawa z dnia 9 listopada 2000 r. o zmianie ustawy - Kodeks pracy oraz niektórych innych ustaw, Dz.U. z 2000 r., Nr 107, poz. 1127.

Ustawa z dnia 27 lipca 2001 r. prawo o ustroju sądów powszechnych, Dz.U. z 2015 r., poz. 133 t.j. ze zm.

Ustawa z dnia 24 sierpnia 2001 r. Kodeks postępowania w sprawach o wykroczenia, Dz.U. z 2013 r., poz. 395 - t.j. ze zm.

Ustawa z dnia 5 kwietnia 2002 r. o europejskich radach zakładowych, Dz.U. z 2012 r., poz. 1146 - t.j. Ustawa z dnia 18 lipca 2002 r. o świadczeniu usług drogą elektroniczną, Dz.U. z 2013 r., poz. 1422 - t.j. Ustawa z dnia 26 lipca 2002 r. o zmianie ustawy - Kodeks pracy oraz o zmianie niektórych innych ustaw, Dz.U. z 2002 r., Nr 135, poz. 1146. 
Ustawa z dnia 10 października 2002 r. o minimalnym wynagrodzeniu za pracę, t.j. Dz.U. z 2017 r., poz. 847.

Ustawa z dnia 30 października 2002 r. o ubezpieczeniu społecznym z tytułu wypadków przy pracy i chorób zawodowych, Dz.U. z 2009 r., Nr 167, poz. 1322 - t.j. ze zm.

Ustawa z dnia 13 marca 2003 r. o szczególnych zasadach rozwiązywania z pracownikami stosunków pracy z przyczyn niedotyczących pracowników, Dz.U. z 2015 r., poz. 192 - t.j.

Ustawa z dnia 9 lipca 2003 r. o zatrudnianiu pracowników tymczasowych, Dz.U. z 2003 r., Nr 166, poz. 1608 ze zm.

Ustawa z dnia 14 listopada 2003 r. o zmianie ustawy - Kodeks pracy oraz o zmianie niektórych innych ustaw, Dz.U. z 2003 r., Nr 213, poz. 2081.

Ustawa z dnia 22 stycznia 2004 r. o zmianie ustawy o ochronie danych osobowych oraz ustawy o wynagrodzeniu osób zajmujących kierownicze stanowiska państwowe, Dz.U. z 2004 r., Nr 33, poz. 285.

Ustawa z dnia 20 kwietnia 2004 r. o promocji zatrudnienia i instytucjach rynku pracy, Dz.U. z 2015 r., poz. 149 - t.j. ze zm.

Ustawa z dnia z dnia 27 sierpnia 2004 r. o świadczeniach z opieki zdrowotnej finansowanych ze środków publicznych, Dz.U. z 2015 r., poz. 581 - t.j. ze zm.

Ustawa z dnia 7 kwietnia 2006 r. o informowaniu pracowników i przeprowadzaniu z nimi konsultacji, Dz.U. z 2006 r., Nr 79, poz. 550 ze zm.

Ustawa z dnia 13 lipca 2006 r. o ochronie roszczeń pracowniczych w razie niewypłacalności pracodawcy, Dz.U. z 2014 r., poz. 272 - t.j. ze zm.

Ustawa z dnia 13 kwietnia 2007 r. o Państwowej Inspekcji Pracy (t.j. Dz.U. z 2017 r. poz. 786 z późn. zm.).

Ustawa z dnia 24 sierpnia 2007 r. o zmianie ustawy - Kodeks pracy oraz niektórych innych ustaw, Dz.U. z 2007 r., Nr 181, poz. 1288.

Ustawa z dnia 3 grudnia 2010 r. o wdrożeniu niektórych przepisów Unii Europejskiej w zakresie równego traktowania, Dz.U. z 2010 r., Nr 254, poz. 1700 ze zm.

Ustawa z dnia 23 października 2014 r. o zmianie ustawy o systemie ubezpieczeń społecznych oraz niektórych innych ustaw, Dz.U. z 2014, poz. 1831.

Ustawa z dnia 7 listopada 2014 r. o ułatwianiu wykonywania działalności gospodarczej, Dz.U. z 2014 r., poz. 1662.

Ustawa z dnia 25 czerwca 2015 r. o zmianie ustawy - Kodeks pracy oraz niektórych innych ustaw, Dz.U. z 2015 r., poz. 1220.

Ustawa z dnia 24 lipca 2015 r. o zmianie ustawy - Kodeks pracy oraz niektórych innych ustaw, Dz.U. z 2015 r., poz. 1268.

Rozporządzenie Ministra Pracy i Polityki Socjalnej z dnia 15 maja 1996 r. w sprawie sposobu usprawiedliwiania nieobecności w pracy oraz udzielania pracownikom zwolnień od pracy, Dz.U. z 2014 r., poz. 1632 - t.j.

Rozporządzenie Ministra Pracy Polityki Socjalnej z dnia 1 grudnia 1998 r. w sprawie bezpieczeństwa i higieny pracy na stanowiskach wyposażonych w monitory ekranowe, Dz.U. z 1998 r., Nr 148, poz. 973.

Rozporządzenie Ministra Zdrowia i Opieki Społecznej z dnia 30 maja 1996 r. w sprawie przeprowadzania badań lekarskich pracowników, zakresu profilaktycznej opieki zdrowotnej nad 
pracownikami oraz orzeczeń lekarskich wydawanych do celów przewidzianych w kodeksie pracy, Dz.U. z 1996 r., Nr 69, poz. 332 - t.j. ze zm.

Rozporządzenie Ministra Pracy i Polityki Społecznej z dnia 5 grudnia 2002 r. w sprawie przypadków, w których wyjątkowo jest dopuszczalne zatrudnianie młodocianych, którzy nie ukończyli gimnazjum, osób niemających 16 lat, które ukończyły gimnazjum, oraz osób niemających 16 lat, które nie ukończyły gimnazjum, Dz.U. z 2002 r., Nr 214, poz. 1808.

Rozporządzenie Ministra Gospodarki i Pracy z dnia 27 lipca 2004 r. w sprawie szkolenia w dziedzinie bezpieczeństwa i higieny pracy, Dz.U. z 2004 r., Nr 180, poz. 1860 ze zm.

Rozporządzenie Ministra Edukacji Narodowej z dnia 15 grudnia 2010 r. w sprawie praktycznej nauki zawodu, Dz.U. z 2010 r., Nr 244, poz. 1626.

Rozporządzenie Ministra Edukacji Narodowej z dnia 23 grudnia 2011 r. w sprawie klasyfikacji zawodów szkolnictwa zawodowego, Dz.U. z 2012 r., poz. 7.

Rozporządzenie Przewodniczącego Komitetu Drobnej Wytwórczości z dnia 14 maja 1966 r. w sprawie określenia istotnych cech pracy nakładczej jako zatrudnienia wyłączonego spod działania prawa przemysłowego, Dz.U. z 1966 r., Nr 18, poz. 117.

Rozporządzenie Rady Ministrów z dnia 28 maja 1996 r. zmieniające rozporządzenie w sprawie uprawnień pracowniczych osób wykonujących pracę nakładczą, Dz.U. z 1996 r., Nr 60, poz. 280.

Rozporządzenie Rady Ministrów z dnia 28 maja 1996 r. w sprawie przygotowania zawodowego młodocianych i ich wynagradzania, Dz.U. z 2014 r., poz. 232 - t.j.

Rozporządzenie z dnia 31 grudnia 1975 r. w sprawie uprawnień pracowniczych osób wykonujących pracę nakładczą, Dz.U. z 1976 r., Nr 3, poz. 19 ze zm.

Rozporządzenie Rady Ministrów z dnia 20 sierpnia 2002 r. w sprawie utworzenia Komisji Kodyfikacyjnej Prawa Pracy, Dz.U. z 2002 r., Nr 139, poz. 1167.

Rozporządzenie Rady Ministrów z dnia 24 sierpnia 2004 r. w sprawie wykazu prac wzbronionych młodocianym i warunków ich zatrudniania przy niektórych z tych prac, Dz.U. z 2004 r., Nr 200, poz. 2047.

Rozporządzenie z dnia 28 maja 1996 r. w sprawie zakresu prowadzenia przez pracodawców dokumentacji w sprawach związanych ze stosunkiem pracy oraz sposobu prowadzenia akt osobowych pracownika, Dz.U. z 1996 r., Nr 62, poz. 286 ze zm. 


\section{Orzeczenia}

\subsection{Orzeczenia Trybunału Sprawiedliwości Unii Europejskiej}

Wyrok Europejskiego Trybunału Sprawiedliwości z dnia 4 lipca 2006 r., C 212/04, Zb. Orz. 2006, 2. I-6057, pkt 84-85.

Wyrok Trybunału Sprawiedliwości Unii Europejskiej z dnia 13 marca 2014 r., C 38/13, Dz.Urz. UE C 135 z 5 maja 2014, s. 13.

\subsection{Orzeczenia Trybunału Konstytucyjnego}

Wyrok Trybunału Konstytucyjnego z dnia 27 listopada 2007 r., SK 18/05, Dz.U. z 2007 r., Nr 225, poz. 1672.

Wyrok Trybunału Konstytucyjnego z dnia 2 grudnia 2008 r., P 48/07, Dz.U. z 2008 r., Nr 219, poz. 1409.

Wyrok Trybunału Konstytucyjnego z dnia 2 czerwca 2015 r., K 1/13, Dz.U. z 2015 r., poz. 791.

\subsection{Orzeczenia Sądu Najwyższego}

Orzeczenie Sądu Najwyższego z dnia 16 lutego 1952 r., C 773/51, LEX nr 1673877.

Orzeczenie Sądu Najwyższego z dnia 15 grudnia 1956 r., IV CR 35/56, LEX nr 118855.

Uchwała Sądu Najwyższego z dnia 11 maja 1976 r., I PZP 18/76, LEX nr 12404.

Uchwała Sądu Najwyższego z dnia 10 września 1976 r., I PZP 48/76, OSNC 1977, Nr 4, poz. 65.

Uchwała Sądu Najwyższego z dnia 21 listopada 1978 r., I PZP 28/78, OSNC 1979, Nr 5, poz. 92.

Uchwała Sądu Najwyższego z dnia 17 grudnia 1981 r., III CZP 32/81, LEX nr 2746.

Uchwała Sądu Najwyższego z dnia 14 czerwca 1994 r., I PZP 26/94, LEX nr 11847.

Uchwała Sądu Najwyższego z dnia 7 września 1994 r., I PZP 35/94, LEX nr 11877.

Uchwała Sądu Najwyższego z dnia 15 grudnia 2005 r., I KZP 34/05, LEX nr 164200.

Uchwała Sądu Najwyższego z dnia 2 września 2009 r., II UZP 6/09, LEX nr 514221.

Uchwała Sądu Najwyższego z dnia 12 grudnia 2011 r., I UZP 6/11, LEX nr 951414.

Wyrok Sądu Najwyższego z dnia 10 września 1963 r., Rw 915/63, LEX nr 1674067.

Wyrok Sądu Najwyższego z dnia 2 grudnia 1975 r., I PRN 42/75, LEX nr 14292.

Wyrok Sądu Najwyższego z dnia 12 sierpnia 1977 r., I PRN 97/77, LEX nr 14411.

Wyrok Sądu Najwyższego z dnia 16 stycznia 1979 r., I CR 440/78, LEX nr 5107.

Wyrok Sądu Najwyższego z dnia 1 kwietnia 1985 r., I PR 19/85, LEX nr 13556.

Wyrok Sądu Najwyższego z dnia 3 kwietnia 1986 r., II URN 20/86, LEX nr 15944.

Wyrok Sądu Najwyższego z dnia 15 lipca 1987 r., I PRN 25/87, LEX nr 13048.

Wyrok Sądu Najwyższego z dnia 30 marca 1994 r., I PZP 40/94, LEX nr 13356.

Wyrok Sądu Najwyższego z dnia 10 września 1997 r., I PKN 246/97, LEX nr 32795. 
Wyrok Sądu Najwyższego z dnia 19 listopada 1997 r., I PKN 374/97, LEX nr 33480. Wyrok Sądu Najwyższego z dnia 25 listopada 1997 r., I PKN 385/97, LEX nr 33569. Wyrok Sądu Najwyższego z dnia 4 grudnia 1997 r., I PKN 419/97, LEX nr 33895. Wyrok Sądu Najwyższego z dnia 24 lutego 1998 r., I PKN 538/97, LEX nr 34664. Wyrok Sądu Najwyższego z dnia 2 kwietnia 1998 r., I PKN 521/97, LEX nr 35307. Wyrok Sądu Najwyższego z dnia 16 kwietnia 1998 r., III ZP 52/97, LEX nr 32575. Wyrok Sądu Najwyższego z dnia 18 czerwca 1998 r., I PKN 191/98, LEX nr 36702. Wyrok Sądu Najwyższego z dnia 23 września 1998 r., II UKN 229/98, LEX nr 37516. Wyrok Sądu Najwyższego z dnia 5 listopada 1998 r., I PKN 414/98, LEX nr 36768. Wyrok Sądu Najwyższego z dnia 29 grudnia 1998 r., I PKN 494/98, LEX nr 36562. Wyrok Sądu Najwyższego dnia 9 lutego 1999 r., I PKN 565/98, LEX nr 39348. Wyrok Sądu Najwyższego z dnia 21 kwietnia 1999 r., I PKN 36/99, LEX nr 37100. Wyrok Sądu Najwyższego z dnia 15 października 1999 r., I PKN 307/99, LEX nr 39667. Wyrok Sądu Najwyższego z dnia 4 października 2000 r., I PKN 61/00, LEX nr 46823. Wyrok Sądu Najwyższego z dnia 3 listopada 2000 r., IV CKN 152/00, LEX nr 45451. Wyrok Sądu Najwyższego z dnia 23 stycznia 2002 r., I PKN 786/00, LEX nr 54890. Wyrok Sądu Najwyższego z dnia 14 października 2004 r., I PK 697/03, LEX nr 149347. Wyrok Sądu Najwyższego z dnia 7 września 2005 r., II PK 29/04, LEX nr 145435. Wyrok Sądu Najwyższego z dnia 22 września 2005 r., IV CK 100/05, LEX nr 187120. Wyrok Sądu Najwyższego z dnia 9 lutego 2006 r., II PK 160/05, LEX nr 212491. Wyrok Sądu Najwyższego z dnia 25 października 2007 r., II PK 49/07, LEX nr 464877. Wyrok Sądu Najwyższego z dnia 11 grudnia 2007 r., II CSK 370/07. LEX nr 492169. Wyrok Sądu Najwyższego z dnia 9 stycznia 2008 r., III UK 73/07, LEX nr 356045. Wyrok Sądu Najwyższego z dnia 9 stycznia 2008 r., III UK 76/07, LEX nr 465905. Wyrok Sądu Najwyższego z dnia 5 czerwca 2008 r., III PK 5/08, LEX nr 494088. Wyrok Sądu Najwyższego z dnia 17 czerwca 2008 r., I UK 402/07, OSNP 2009, nr 21-22, poz. 297. Wyrok Sądu Najwyższego z dnia 9 lipca 2008 r., I PK 2/08, LEX nr 531844. Wyrok Sądu Najwyższego z dnia 4 grudnia 2008 r., II PK 137/08, LEX nr 469931. Wyrok Sądu Najwyższego z dnia 3 lutego 2009 r., I PK 156/2008, Lexis.pl nr 2082101. Wyrok Sądu Najwyższego z dnia 12 marca 2009 r., II PK 198/08, LEX nr 621545. Wyrok Sądu Najwyższego z dnia 30 września 2009 r., II PK 88/09, LEX nr 559938. Wyrok Sądu Najwyższego z dnia 14 października 2009 r., V CSK 111/03, LEX nr 654430. Wyrok Sądu Najwyższego z dnia 3 grudnia 2009 r., II PK 142/09, LEX nr 823871. Wyrok Sądu Najwyższego z dnia 27 maja 2010 r., II PK 354/09, LEX nr 598002. Wyrok Sądu Najwyższego z dnia 2 marca 2011 r., II PK 204/10, LEX nr 817517. Wyrok Sądu Najwyższego z dnia 28 czerwca 2011 r., II PK 9/11, LEX nr 1044012. Wyrok Sądu Najwyższego z dnia 4 października 2011 r., I PK 56/11, LEX nr 1107213. Wyrok Sądu Najwyższego z dnia 2 października 2012 r., II PK 56/12, LEX nr 1243024. Wyrok Sądu Najwyższego z dnia 2 października 2012 r., II PK 82/12, LEX nr 1365774. Wyrok Sądu Najwyższego z dnia 26 marca 2013 r., II UK 201/12, LEX nr 1341964. Wyrok Sądu Najwyższego z dnia 27 sierpnia 2013 r., II UK 26/13, LEX nr 1379926. Wyrok Sądu Najwyższego z dnia 11 września 2013 r., II PK 372/12, LEX nr 1474905. 
Wyrok Sądu Najwyższego z dnia 18 września 2013 r., II UK 39/13, LEX nr 1378531.

Wyrok Sądu Najwyższego z dnia 5 czerwca 2014 r., I PK 308/13, LEX nr 1475061.

Wyrok Sądu Najwyższego z dnia 24 marca 2015 r., II UK 184/14, LEX nr 1710359.

Wyrok Sądu Najwyższego z dnia 1 kwietnia 2015 r., I PK 203/14, LEX nr 1710344.

\subsection{Pozostate orzeczenia}

Wyrok Sądu Apelacyjnego w Gdańsku z dnia 15 marca 1996 r., I Acr 33/96, LEX nr 25507.

Wyrok Naczelnego Sądu Administracyjnego z dnia 30 stycznia 2002 r., II SA 1098/01, LEX nr 50816.

Wyrok Naczelnego Sądu Administracyjnego z dnia 28 listopada 2002 r., II SA 3389/01, LEX nr 74596.

Wyrok Sądu Apelacyjnego w Gdańsku z dnia 27 czerwca 2013 r., III AUa 2027/12, LEX nr 1342233.

Wyrok Sądu Apelacyjnego w Gdańsku z dnia 16 lipca 2013 r., III AUa 379/13, LEX nr 1353683.

Wyrok Sądu Apelacyjnego w Białymstoku z dnia 1 lipca 2014 r., III AUa 13/14, LEX nr 1493712.

Wyrok Sądu Apelacyjnego w Lublinie z dnia 31 marca 2015 r., I Aca 823/14, LEX nr 1668621. 
